\title{
Estimates of Recharge from Runoff at the Hanford Site, Washington
}

By Richard S. Dinicola

\section{U.S. GEOLOGICAL SURVEY}

Water-Resources Investigations Report 97-4038

Prepared in cooperation with

U.S. DEPARTMENT OF ENERGY

Tacoma, Washington 


\section{U.S. DEPARTMENT OF THE INTERIOR \\ BRUCE BABBITT, Secretary}

U.S. GEOLOGICAL SURVEY

Gordon P. Eaton, Director

Any use of trade, product, or firm names is for descriptive purposes only and does not imply endorsement by the U.S. Geological Survey.

For additional information write to:

District Chief

U.S. Geological Survey

1201 Pacific Avenue, Suite 600

Tacoma, Washington 98402
Copies of this report may be purchased from:

U.S. Geological Survey

Branch of Information Services

Box 25286

Denver, Colorado 80225 


\section{CONTENTS}

Abstract----1

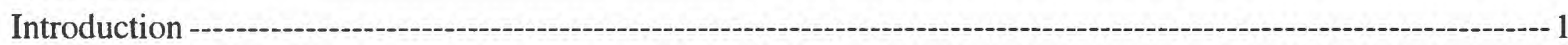

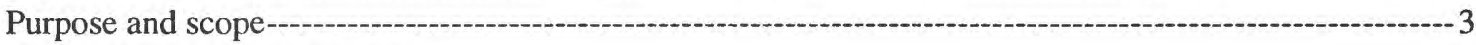

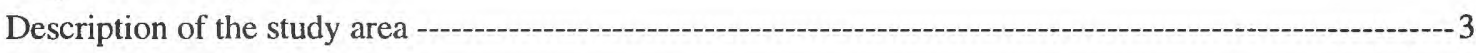

Approach ---

Climatic and hydrologic data ---

Climatic data----

Hydrologic data----

Conceptual model of runoff and recharge from runoff---

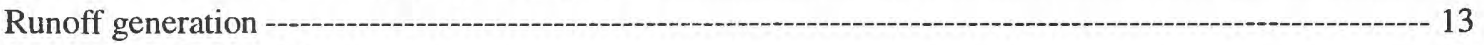

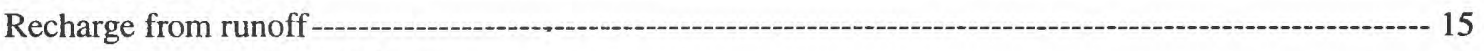

Recharge from spring discharge--

Numerical models of runoff and recharge from runoff -

The Hydrological Simulation Program - FORTRAN (HSPF) ---

Simulation of frozen soils -- 18

Model construction--- 19

Land segments --o-_- 19

Reaches ------ 21

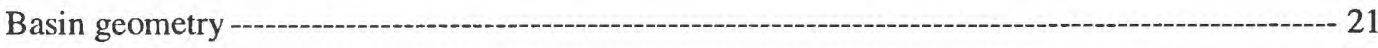

Estimation and calibration of parameter values -

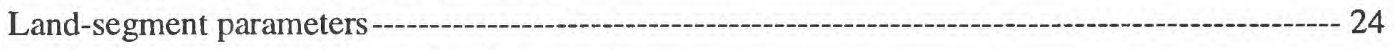

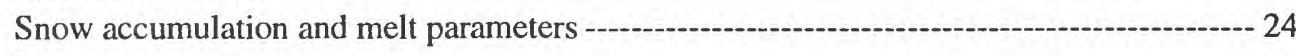

Evapotranspiration parameters --- 24

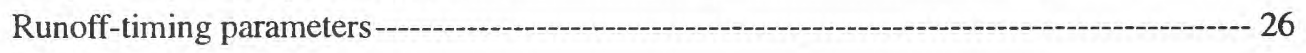

Infiltration parameters --- 26

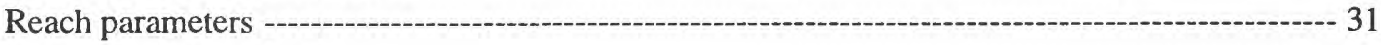

Synthesis of long-term climate data --

Estimates of runoff and recharge from runoff--- 32

Comparison to other recharge estimates -- 35

References cited --o 37

Appendices

1. Final HSPF input file for Upper Cold Creek model --

2. Final HSPF input file for Lower Cold Creek model---

3. Final HSPF input file for combined Cold Creek model--

4. Final HSPF input file for Upper Dry Creek model ---

5. Final HSPF input file for Middle Dry Creek model -

6. Final HSPF input file for Lower Dry Creek model -

7. Final HSPF input file for combined Dry Creek model -- 


\section{FIGURES}

1. Map showing location of study area and weather stations -

2. Map showing location of data collection sites and subbasins in the study area--

3. Graph showing soil moisture at site C2 before and after the June 29, 1991, runoff event in lower Cold Creek ---- 12

4. Schematic diagram showing linkages between land segments and reaches in the numerical model for Cold Creek Basin

5. Schematic diagram showing linkages between land segments and reaches in the numerical model for Dry Creek Basin

6. Graphs showing observed and simulated snow depth at the Hanford Meteorological Station for (a) November 1978 - February 1979, and (b) December 1988 - March 1989 -..-- 25

7. Graphs showing simulated and calculated evapotranspiration estimates for (a) Snively Basin Bowen-ratio site, and (b) the Benson Springs grass lysimeter site

8. Graphs showing observed and simulated daily mean discharge for October 1990 - May 1993 , for (a) upper Cold Creek Basin and (b) lower Cold Creek Basin

9. Graphs showing observed and simulated daily mean discharge for October 1990 - May 1993 , for (a) upper Dry Creek Basin and (b) lower Dry Creek Basin

\section{TABLES}

1. Precipitation data collection stations $-7$

2. Summary of precipitation data collected in and near the study area for the period

September 26, 1990, through June 21, 1993 - 8

3. Summary of monthly mean climatic data for the study area---

4. Monthly and annual peak-discharge and total-streamflow data for the study area,

October 1990 - May 1993--- 10

5. Stream-gaging stations in or near the study area --...- 11

6. Total streamflow at selected stream-gaging stations in the Esquatzel Coulee Basin for water years 1958-93 - 14

7. Definitions and descriptions of process-related parameters in the HSPF program --

8. Soil categories and their average depth, average available water capacity, and areal extents in the study area --.- 20

9. Vegetation categories and their areal extents in the study area-

10. Slope and aspect categories and their areal extents in the study area--

11. Altitude categories and their areal extent in the study area -.. 20

12. Subbasin drainage areas in the study area-- 21

13. Observed data and simulated peak discharges and runoff volumes from the calibrated numerical models --- 28

14. Simulated annual runoff for delineated subbasins in the study area for water years 1958-93 --------- 33

15. Simulated annual recharge from runoff for delineated subbasins in the study area for water years 1958-93 -- 34

16. Simulated annual peak discharge and total streamflow for the study area for water years 1958-93 ----- 36 
CONVERSION FACTORS AND VERTICAL DATUM

\begin{tabular}{rcl} 
Multiply & By & To obtain \\
\hline inch (in.) & 25.4 & millimeter \\
foot $(\mathrm{ft})$ & 0.3048 & meter \\
mile $(\mathrm{mi})$ & 1.609 & kilometer \\
$\mathrm{acre}$ & 4,047 & square meter \\
square mile $\left(\mathrm{mi}^{2}\right)$ & 2.590 & square kilometer \\
acre-foot $(\mathrm{acre}-\mathrm{ft})$ & 1,233 & cubic meter \\
inch per hour $(\mathrm{in} / \mathrm{hr})$ & 1,233 & cubic meter per year \\
inch per year $(\mathrm{in} / \mathrm{yr})$ & 2.54 & centimeter per hour \\
acre-foot per year (acre- & 2.54 & centimeter per year \\
miles per hour $(\mathrm{mi} / \mathrm{hr})$ & 0.02832 & cubic meter per second \\
& 0.477 & meters per second \\
\hline
\end{tabular}

Temperature: To correct temperature given in this report in degrees Fahrenheit $\left({ }^{\circ} \mathrm{F}\right)$ to degrees Celsius $\left({ }^{\circ} \mathrm{C}\right)$, use the following equation: ${ }^{\circ} \mathrm{C}=5 / 9\left({ }^{\circ} \mathrm{F}-32\right)$.

Sea Level: In this report "sea level" refers to the National Geodetic Vertical Datum of 1929 (NGVD of 1929)--a geodetic datum derived from a general adjustment of the first-order level nets of both the United States and Canada, formerly called Sea Level Datum of 1929.

Altitude: In this report "altitude" is measured in feet above or below sea level. 


\title{
Estimates of Recharge from Runoff at the Hanford Site, Washington
}

\author{
By Richard S. Dinicola
}

\begin{abstract}
Recharge from runoff was estimated using a short-term data collection effort in combination with a numerical simulation model of runoff and recharge. The hydrologic data collected during October 1990 through May 1993 was used to construct and test numerical models with the Hydrological Simulation Program-FORTRAN (HSPF) computer code. The numerical models were then used to estimate long-term average rates of runoff and recharge using 36 years of historical climate data.
\end{abstract}

HSPF parameter values were estimated from physiographic data, channel geometry data, theoretical hydraulic formulas, and information derived from other investigations. Selected parameter values were calibrated to observed hydrologic data--including both recent streamflow data and historical peak-discharge estimates--but many other parameter values, as well as the complete numerical models, could not be fully calibrated and tested because no substantial runoff occurred during the investigation. It was determined through trial and error that no combination of model parameters could accurately simulate both the recent streamflow data and the historical peak-flow data, so the final values were set to simulate a plausible upper limit for runoff and recharge.

Average annual runoff simulated for the 74.5-squaremile Cold Creek Basin and the 148-square-mile Dry Creek Basin was 517 acre-feet and 976 acre-feet, respectively. Average annual recharge from runoff simulated for Cold Creek Basin and Dry Creek Basin were 429 acre-feet and 829 acre-feet, respectively. Sixteen percent of the runoff was infiltrated but subsequently lost to evapotranspiration from channel sediments and from runout-zone soils. Simulated recharge from runoff within the boundaries of the Hanford Site was 868 acre-feet per year, and simulated recharge from runoff for all areas that likely contribute water directly to the uppermost unconfined aquifer beneath the Hanford Site was 1,175 acre-feet per year. The latter estimate is 160 percent greater than the previously published recharge from runoff estimate. Estimated recharge from runoff at the Hanford Site is 16 percent, 13 percent, and 6 percent as large as three previously published estimates of direct recharge from precipitation over the area. The accuracy of the recharge from runoff estimates could not be quantified with available data, but a qualitative assessment indicates that the runoff estimates are reasonable and of the correct order of magnitude.

\section{INTRODUCTION}

A variety of radioactive and other hazardous wastes have been released into the environment at the U.S. Department of Energy's Hanford Site in south-central Washington (fig. 1). Some of those wastes have migrated to ground water in the uppermost unconfined aquifer underlying the site (U.S. Congress, Office of Technology Assessment, 1991), which discharges primarily to the Columbia River (Delaney and others, 1991). The rate at which ground water and its contaminants are transported from the aquifer to the Columbia River is greatly influenced by the west to east head gradient in the aquifer, which itself is influenced by the quantity and spatial distribution of ground-water recharge. 


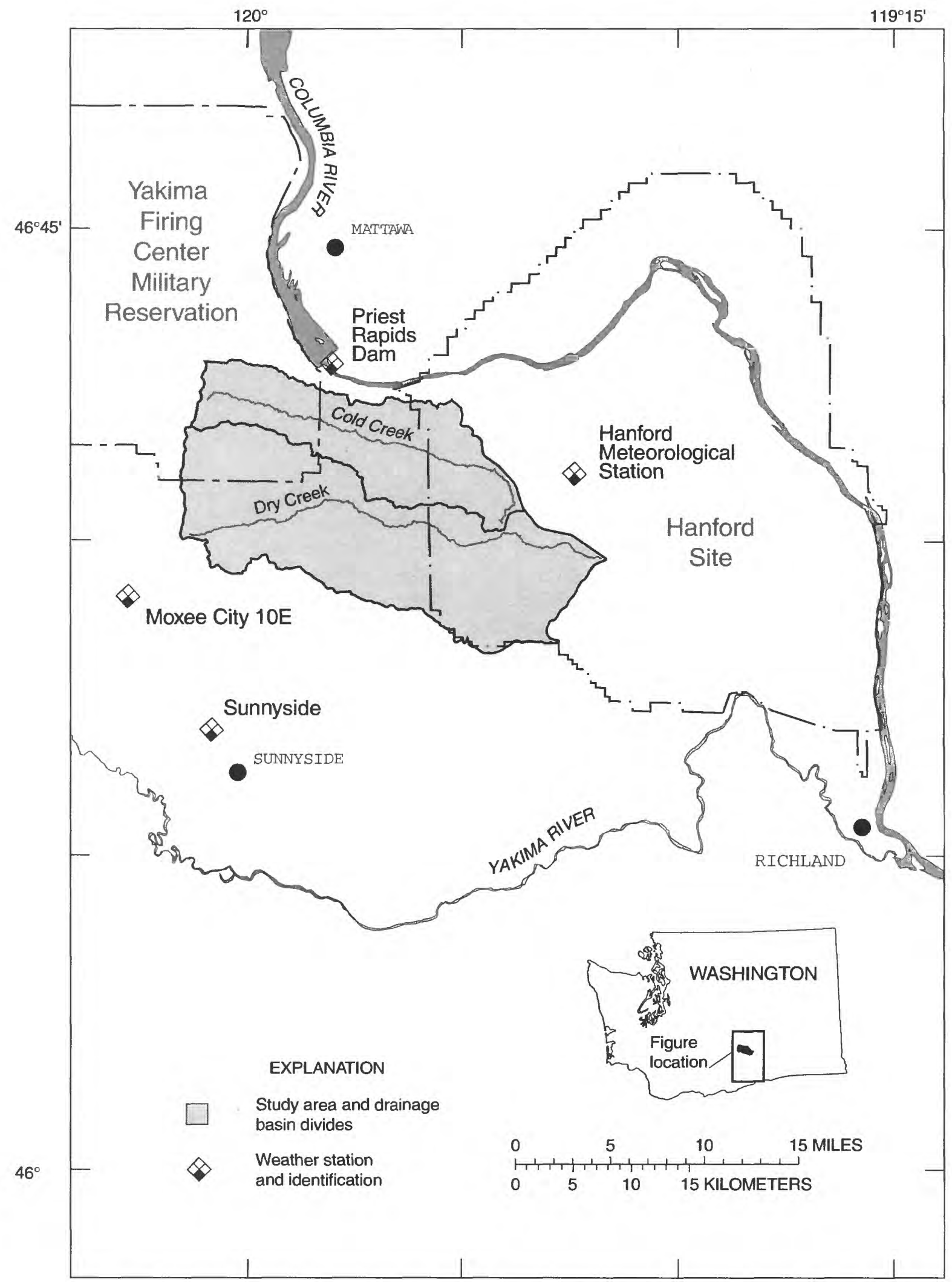

Figure 1. Location of study area and weather stations. 
Recharge to the uppermost unconfined aquifer is from both artificial and natural sources. Artificial recharge, which is primarily from industrial wastewater, is well documented (Jacobson and Freshley, 1990). Natural recharge from direct infiltration and percolation of rainfall and snowmelt has been estimated for several specific locations on the Hanford Site (Gee and others, 1992; Gee, 1987; Prych, 1994; Rockhold and others, 1995) and for the Hanford Site as a whole (Bauer and Vaccaro, 1990; Jacobson and Freshley, 1990; Fayer and Walters, 1995). A second source of natural recharge--referred to in this report as recharge from runoff--is not well documented and has been only coarsely approximated at 450 acre-feet per year (Newcomb and others, 1972).

Recharge from runoff is ground-water recharge that results from infiltration and percolation of surface runoff. Recharge from runoff that contributes to the uppermost unconfined aquifer beneath the Hanford Site is thought to result primarily from infiltration and percolation of storm runoff generated in nearby Cold Creek and Dry Creek drainage basins. Such recharge may be of particular importance with regard to contaminant transport to the Columbia River because it occurs to the west of the Hanford Site and helps maintain the head gradient that slopes towards the river.

There is a need to better estimate the amount of recharge from runoff at the Hanford Site. There are many technical difficulties in measuring such recharge directly, so improved recharge estimates will likely result from improved estimates of runoff. There is essentially no historic runoff data for the Hanford Site. Historic peak discharges measured in nearby streams provide little indication of associated runoff volumes. It is unknown whether historic runoff volumes measured in nearby Esquatzel Coulee Basin (located about 40 miles to the east of the Hanford Site) are representative of runoff at the Hanford Site because of differences in climate, physiography, and land-use. Because the annual variation in runoff in the semiarid study area is extreme, it would require tens of years to obtain the runoff data needed to improve the current published estimate of recharge from runoff.

For this investigation, recharge from runoff was estimated using a short-term data collection effort, long-term historic climate data, and a numerical simulation model of runoff and recharge. The short-term hydrologic data was used to construct and test a numerical model, which in turn was used to estimate long-term average rates of runoff and recharge using historical climate data.

\section{Purpose and Scope}

The purpose of this investigation was to estimate the long-term average runoff from Cold Creek and Dry Creek Basins, and to estimate the long-term average recharge from runoff at the Hanford Site. This report documents the construction and application of the numerical models used to simulate runoff and recharge, and presents estimates of recharge from runoff for the period 1958 through 1993. Unfortunately, no substantial runoff occurred in the study area during the period of this investigation, so the numerical models were calibrated and tested with only limited data. However, the runoff and recharge estimates presented are thought to be improvements over the existing estimates and their accuracy, although not quantifiable, is discussed in qualitative terms in this report.

\section{Description of the Study Area}

The 222-square-mile study area is located in south-central Washington (fig. 1). The physiography is characterized by two synclinal basins bordered by three narrow east-trending anticlines. The basins open to the east onto a broad plain composed of sediments from the Columbia River. The entire area is underlain by basalt. The basalt is exposed or at a shallow depth on ridges in the western parts of Cold Creek Basin, but it is blanketed by a deep layer of loess and alluvial or glaciofluvial sediments in Dry Creek valley and in the lowland plain of the Hanford Site. Altitudes range from below 600 feet on the eastern plain to over 4,000 feet on the western ridge tops. Slopes are gentle in the valleys and on the plain, but they are often steeper than 45 degrees on the ridges.

Most soils in the area formed in loess, although some soils on the ridges formed in residuum and colluvium derived from basalt. Soils are deep to very deep on moderate or gentle slopes in the lowlands and grade to very shallow on the steep ridges. The deeper soils are predominately silt loams, with some fine sands or loamy fine sands, and the shallower soils are predominately gravelly or cobbly loams. The soils in the area are generally well drained and have moderately high water-holding capacities.

The semiarid climate in the area is characterized by hot, dry summers and cold, moist winters. Average annual precipitation for 1912 through 1980 ranges from 6.3 inches at the Hanford Meteorological Station (HMS) (Stone and others, 1983) to greater than 11 inches at high 
elevations. Over 50 percent of the precipitation falls from November through February, and about 40 percent of that falls as snow. Only 10 percent of the annual precipitation falls from July through September. On average, daily precipitation at the HMS equals or exceeds 0.10 inches only 23 days per year, and it exceeds 1.00 inch only about once every 18 years. Average annual air temperature at the HMS is $53^{\circ} \mathrm{F}$; it is coldest during January $\left(29^{\circ} \mathrm{F}\right)$ and is hottest during July $\left(64^{\circ} \mathrm{F}\right)$. Relative humidity at the HMS is low during the summer months (32 to 42 percent), and moderate during the winter months (56 to 80 percent). Windspeeds at the HMS are highest during the spring months ( 9 miles per hour), and lowest during the winter months (7 miles per hour). Daily average total solar radiation at the HMS ranges from 89 langleys in December to 647 langleys in July.

Natural vegetation in the study area consists of shrub-steppe plant communities composed of winter and summer annual grasses and perennial grasses and shrubs (Rickard and Vaughn, 1988). Because of the mixture of shallow-rooted grasses, such as poa and cheatgrass, and deep-rooted shrubs, such as sagebrush and rabbitbrush, this desert vegetation is efficient in utilizing soil water. All of the vegetation suffers summer water stress, but with the exception of the winter annuals, it generally survives the summer months by utilizing summer rains and water stored at depth from winter precipitation. There are also some small, natural riparian communities near perennial springs and seeps. Approximately 86 percent of the study area is covered with natural vegetation, and the remainder has been converted to dryland wheat (13 percent) and irrigated grapes, apples, or alfalfa (1 percent).

As is typical for semiarid environments, the majority of precipitation falling on the study area is lost to evapotranspiration. Bauer and Vaccaro (1990) estimated about 81 to 94 percent of average annual precipitation in the study area is lost through evapotranspiration. The lower value is for areas with thin and stony soils. Gee (1992) found that nearly 100 percent of precipitation was evapotranspired from sites with fine-textured soils and deeprooted shrubs, but only 65 percent was evapotranspired from a site with sandy soil and shallow-rooted grasses.

Cold Creek and Dry Creek are ephemeral streams that drain the two synclinal valleys in the study area. During periods of runoff, which are uncommon, these streams flow eastward onto the alluvium underlying the Hanford Site where they eventually disappear from the surface by infiltration into the sediments. Topographically, the Cold Creek Valley continues south-eastwardly to the Yakima River, and Dry Creek drains to the Cold Creek Valley.
Historically, however, streamflow in Cold Creek has been entirely infiltrated before reaching the mouth of Dry Creek Valley, and streamflow in Dry Creek has been entirely infiltrated soon after reaching the Cold Creek Valley and well upslope from the Yakima River. There are many small, perennial springs and seeps throughout the study area whose discharges are quickly lost to infiltration and evaporation. The most significant of these is Rattlesnake Springs near the mouth of Dry Creek Valley, and the unnamed valley-bottom seeps along the upper two-thirds of Cold Creek. Dry Creek flows perennially for a few miles below Rattlesnake Springs. The upper reach of Cold Creek does not flow perennially in most years, but the established, lush riparian zone suggests that water is usually available at shallow depth.

\section{Approach}

The approach used to estimate recharge from runoff was to construct numerical models to simulate rainfallrunoff and recharge processes and to apply those models using historical climate data as input. Specific tasks included (1) collect short-term and assemble long-term climatic and hydrologic data, (2) develop a conceptual model of study area hydrology to guide the construction of numerical models, (3) construct numerical models with the Hydrological Simulation Program - FORTRAN (HSPF) computer code, (4) estimate or calibrate numerical model parameters, (5) synthesize long-term climate records for the study basins by adjusting long-term data observed at nearby weather stations to represent study area climate, and (6) apply the numerical models to estimate long-term average values for runoff and recharge from runoff. The resulting runoff estimates were compared to historic streamflow data from Esquatzel Coulee Basin as a qualitative check for reasonableness, and the resulting recharge estimates were compared to other recharge estimates for the aquifer of interest to demonstrate the relative importance of recharge from runoff.

\section{CLIMATIC AND HYDROLOGIC DATA}

Short-term climatic data were collected by the U.S. Geological Survey in the study area during the period October 1990 through May 1993, and long-term data were obtained from the Hanford Meteorological Station (HMS) and three National Weather Service stations for the period October 1957 through May 1993. Those data were used to synthesize long-term climate records for the study basins by correlating the short-term, study-area data with the 
long-term data from nearby sites. Additional climatic data--including soil temperature and snow depth--were obtained from the HMS and the National Weather Service site at Pullman, Washington. Those data were used to calibrate and assess the frozen-ground and the snow accumulation and melt components of the numerical models.

Hydrologic data--including streamflow and soil moisture--were collected by the USGS in the study area from October 1990 through May 1993. Those data were used to calibrate the streamflow generation and channel infiltration components of the numerical models. Additional hydrologic data--including evapotranspiration and streamflow data--from sites both within and near the study area were obtained from various published reports. Those data were used to calibrate the evapotranspiration component of the numerical models and to assess the simulation results.

\section{Climatic Data}

Within the study area, 15-minute increment precipitation data were collected at five sites (fig. 2) using weighing-bucket type recording gages with a rated accuracy of $+/-0.06$ inches. All five gages were fitted with alter-type wind screens. Total precipitation data were collected approximately monthly at 17 sites using storage-type precipitation gages; those gages were not fitted with wind screens. Both the recording and storage gages were maintained for winter operation. A list of precipitation data collection stations and their locations is in table 1. A summary of the precipitation data collected from September 1990 through June 1993 is in table 2.

Other 15-minute increment meteorological data were collected in the study area at the Cold Creek micrometeorological station (MET in fig. 2). Air temperature, relative humidity, solar radiation, windspeed, and soil temperature data were collected using a thermistor, a relative humidity sensor, a button-type pyranometer, a 3-cup anemometer, and buried thermistors, respectively. A summary of the meteorological data collected for the period October 1990 through May 1993 is in table 3.

Climatic data were obtained for stations outside the study area for October 1957 through May 1993. They include hourly-increment precipitation, air temperature, dew-point temperature, solar radiation, and windspeed data from the HMS, and daily precipitation data from National Weather Service stations at Sunnyside, Moxee City 10 E, and Priest Rapids Dam (table 1 and fig. 1). A summary of the meteorological data is included in table 3, and monthly precipitation data for the period September 1990 through June 1993 is in table 2.

Daily soil temperature and snow depth data for January 1970 through May 1993 were obtained from the National Weather Service station at Pullman, Washington, located about 120 miles west of the study area, and daily snow depth data for water years 1977-90 were obtained for the HMS. Those data are described in the "Numerical Models of Runoff and Recharge from Runoff' section of this report.

\section{Hydrologic Data}

Fifteen-minute increment streamflow data were collected at four gaging stations (fig. 2 and tables 4 and 5) in Cold Creek and Dry Creek Basins. Water-measurement structures were built at three of the stations to allow for more accurate discharge calculations. Broad-crested v-notch weirs (Brakensiek and others, 1979) were constructed for the sites in upper Cold Creek (12510618) and lower Dry Creek (12510655), and an 8-foot trapezoidal supercritical-flow flume (Kilpatrick and Schneider, 1983) was constructed for the site in lower Cold Creek (12510625). Existing culverts under a state highway were used as control structures for the measurement of discharge at the upper Dry Creek site (12510650). Monthly and annual peak-discharge and total streamflow data for the period October 1990 through May 1993 are in table 4. Daily streamflow data have been published elsewhere (Miles and others, 1992, 1993, and 1994).

Miscellaneous soil moisture measurements were made at four sites in Cold Creek and Dry Creek stream channels; all the sites were located in downstream reaches underlain by alluvium (fig. 2). Vertical profiles of soilmoisture were made by lowering a neutron soil-moisture probe into 15 - to 30 -foot-deep access tubes. Measurements were initially made in 2 -inch diameter steel tubes installed in augered holes, but data collected during runoff suggested that most of the downward water flux was due to preferential flow in the backfilled zones around the tubes. A second set of 5-inch diameter steel tubes was installed with an air-percussion drill-rig (the technique did not require backfilling) that greatly reduced preferential flow problems. Data from the 2 -inch tubes were considered unreliable and are not presented. Applicable soilmoisture data from one of the 5-inch tubes (C2) are presented in figure 3 and the "Conceptual Model of Runoff and Recharge from Runoff" section of this report. 


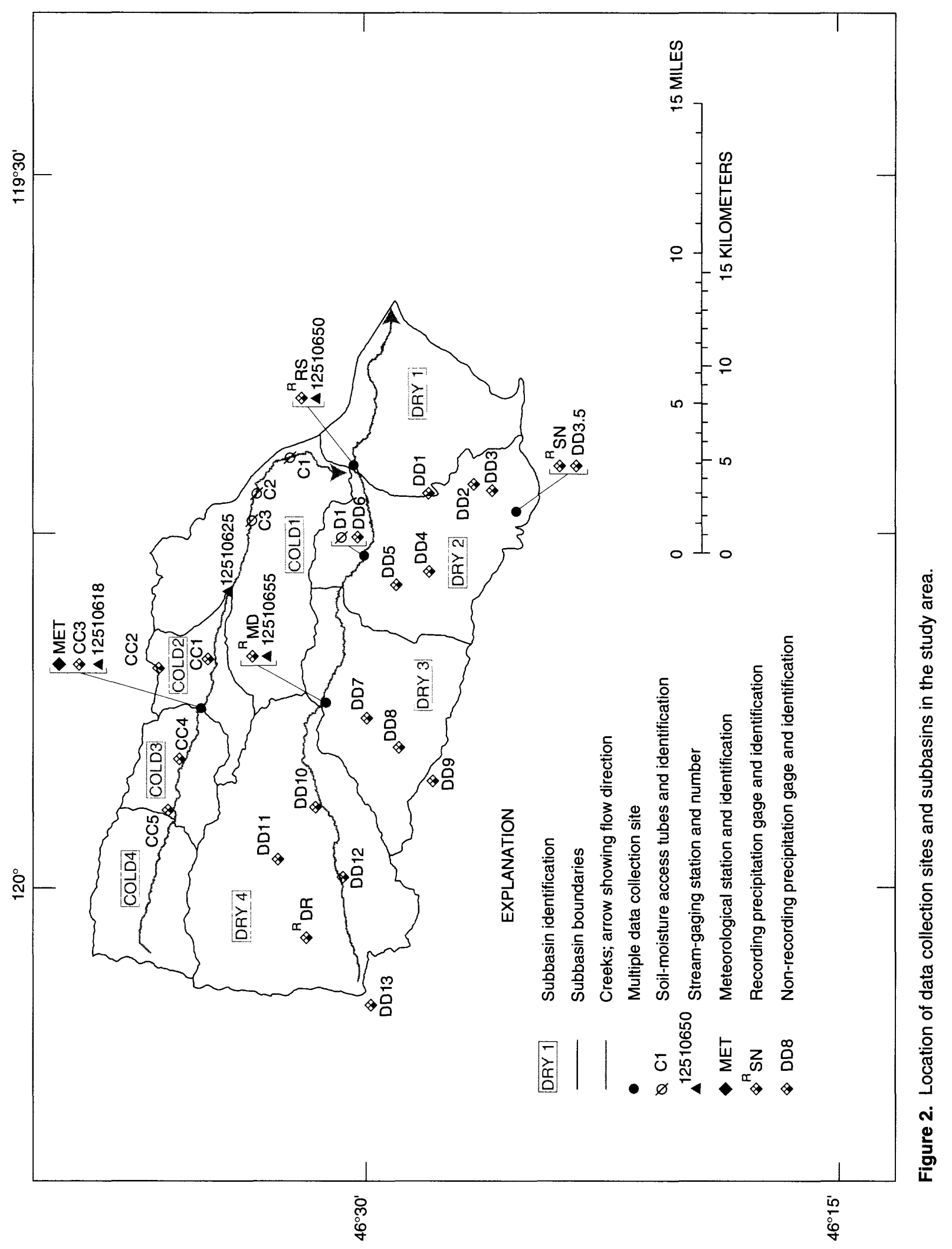


Table 1.--Precipitation data collection stations

[Gage operators: USGS, United States Geological Survey; PNL, Pacific Northwest Laboratory; NWS, National Weather Service]

\begin{tabular}{|c|c|c|c|c|}
\hline $\begin{array}{l}\text { Station } \\
\text { code }\end{array}$ & Station name & Gage operator and type & $\begin{array}{l}\text { Station location } \\
\text { (latitude - longitude) }\end{array}$ & $\begin{array}{l}\text { Altitude } \\
\text { (feet) }\end{array}$ \\
\hline DD1 & Old Field & USGS non-recording & $46^{\circ} 28^{\prime} 15^{\prime \prime} \quad 119^{\circ} 43^{\prime} 13^{\prime \prime}$ & 1,060 \\
\hline DD2 & Snively1 & USGS non-recording & $46^{\circ} 26^{\prime} 56^{\prime \prime} \quad 119^{\circ} 42^{\prime} 52^{\prime \prime}$ & 1,600 \\
\hline DD3 & Snively2 & USGS non-recording & $46^{\circ} 26^{\prime} 06^{\prime \prime} \quad 119^{\circ} 43^{\prime} 00^{\prime \prime}$ & 1,920 \\
\hline DD3.5 & Check & USGS non-recording & $46^{\circ} 25^{\prime} 30^{\prime \prime} \quad 119^{\circ} 44^{\prime} 04^{\prime \prime}$ & 2,600 \\
\hline DD4 & Bennett & USGS non-recording & $46^{\circ} 28^{\prime} 19^{\prime \prime} \quad 119^{\circ} 46^{\prime} 35^{\prime \prime}$ & 1,200 \\
\hline DD5 & Boundary & USGS non-recording & $46^{\circ} 29^{\prime} 12^{\prime \prime} \quad 119^{\circ} 47^{\prime} 05^{\prime \prime}$ & 1,020 \\
\hline DD6 & Neutron & USGS non-recording & $46^{\circ} 30^{\prime} 04^{\prime \prime} \quad 119^{\circ} 45^{\prime} 54^{\prime \prime}$ & 820 \\
\hline DD7 & Roberts & USGS non-recording & $46^{\circ} 30^{\prime} 16^{\prime \prime} \quad 119^{\circ} 53^{\prime} 03^{\prime \prime}$ & 1,280 \\
\hline DD8 & Midway & USGS non-recording & $46^{\circ} 29^{\prime} 24^{\prime \prime} \quad 119^{\circ} 54^{\prime} 27^{\prime \prime}$ & 1,700 \\
\hline DD9 & Pass & USGS non-recording & $46^{\circ} 28^{\prime} 22^{\prime \prime} \quad 119^{\circ} 55^{\prime} 52^{\prime \prime}$ & 2,300 \\
\hline DD10 & Bus & USGS non-recording & $46^{\circ} 31^{\prime} 34^{\prime \prime} \quad 119^{\circ} 56^{\prime} 48^{\prime \prime}$ & 1,440 \\
\hline DD12 & Meeboer & USGS non-recording & $46^{\circ} 31^{\prime} 11^{\prime \prime} 119^{\circ} 59^{\prime} 50^{\prime \prime}$ & 1,640 \\
\hline DD13 & Apples & USGS non-recording & $46^{\circ} 30^{\prime} 22^{\prime \prime} \quad 120^{\circ} 05^{\prime} 21^{\prime \prime}$ & 1,800 \\
\hline $\mathrm{CCl}$ & Grapes & USGS non-recording & $46^{\circ} 34^{\prime} 51^{\prime \prime} \quad 119^{\circ} 50^{\prime} 12^{\prime \prime}$ & 1,280 \\
\hline $\mathrm{CC} 2$ & Emerson & USGS non-recording & $46^{\circ} 36^{\prime} 32^{\prime \prime} \quad 119^{\circ} 50^{\prime} 40^{\prime \prime}$ & 2,100 \\
\hline $\mathrm{CC} 3$ & Met & USGS non-recording & $46^{\circ} 35^{\prime} 11^{\prime \prime} \quad 119^{\circ} 52^{\prime} 26^{\prime \prime}$ & 1,460 \\
\hline $\mathrm{CC} 4$ & Gate & USGS non-recording & $46^{\circ} 35^{\prime} 52^{\prime \prime} \quad 119^{\circ} 54^{\prime} 52^{\prime \prime}$ & 1,760 \\
\hline RS & Rattlesnake & USGS recording & $46^{\circ} 30^{\prime} 23^{\prime \prime} \quad 119^{\circ} 41^{\prime} 54^{\prime \prime}$ & 690 \\
\hline $\mathrm{SN}$ & Snively & USGS recording & $46^{\circ} 25^{\prime} 30^{\prime \prime} \quad 119^{\circ} 44^{\prime} 04^{\prime \prime}$ & 2,600 \\
\hline MD & Middle Dry & USGS recording & $46^{\circ} 31^{\prime} 29^{\prime \prime} 119^{\circ} 52^{\prime} 19^{\prime \prime}$ & 1,130 \\
\hline $\mathrm{DR}$ & Desert Rose & USGS recording & $46^{\circ} 32^{\prime} 14^{\prime \prime} \quad 120^{\circ} 02^{\prime} 28^{\prime \prime}$ & 2,040 \\
\hline HMS & Hanford Met. Station & PNL recording & $46^{\circ} 34^{\prime} 00^{\prime \prime} \quad 119^{\circ} 36^{\prime} 00^{\prime \prime}$ & 733 \\
\hline MOX & Moxee City $10 \mathrm{E}$ & NWS recording & $46^{\circ} 31^{\prime} 00^{\prime \prime} \quad 120^{\circ} 10^{\prime} 00^{\prime \prime}$ & 1,551 \\
\hline PRD & Priest Rapids Dam & NWS recording & $46^{\circ} 39^{\prime} 00^{\prime \prime} \quad 119^{\circ} 54^{\prime} 00^{\prime \prime}$ & 459 \\
\hline SUN & Sunnyside & NWS recording & $46^{\circ} 19^{\prime} 00^{\prime \prime} \quad 120^{\circ} 00^{\prime} 00^{\prime \prime}$ & 747 \\
\hline
\end{tabular}




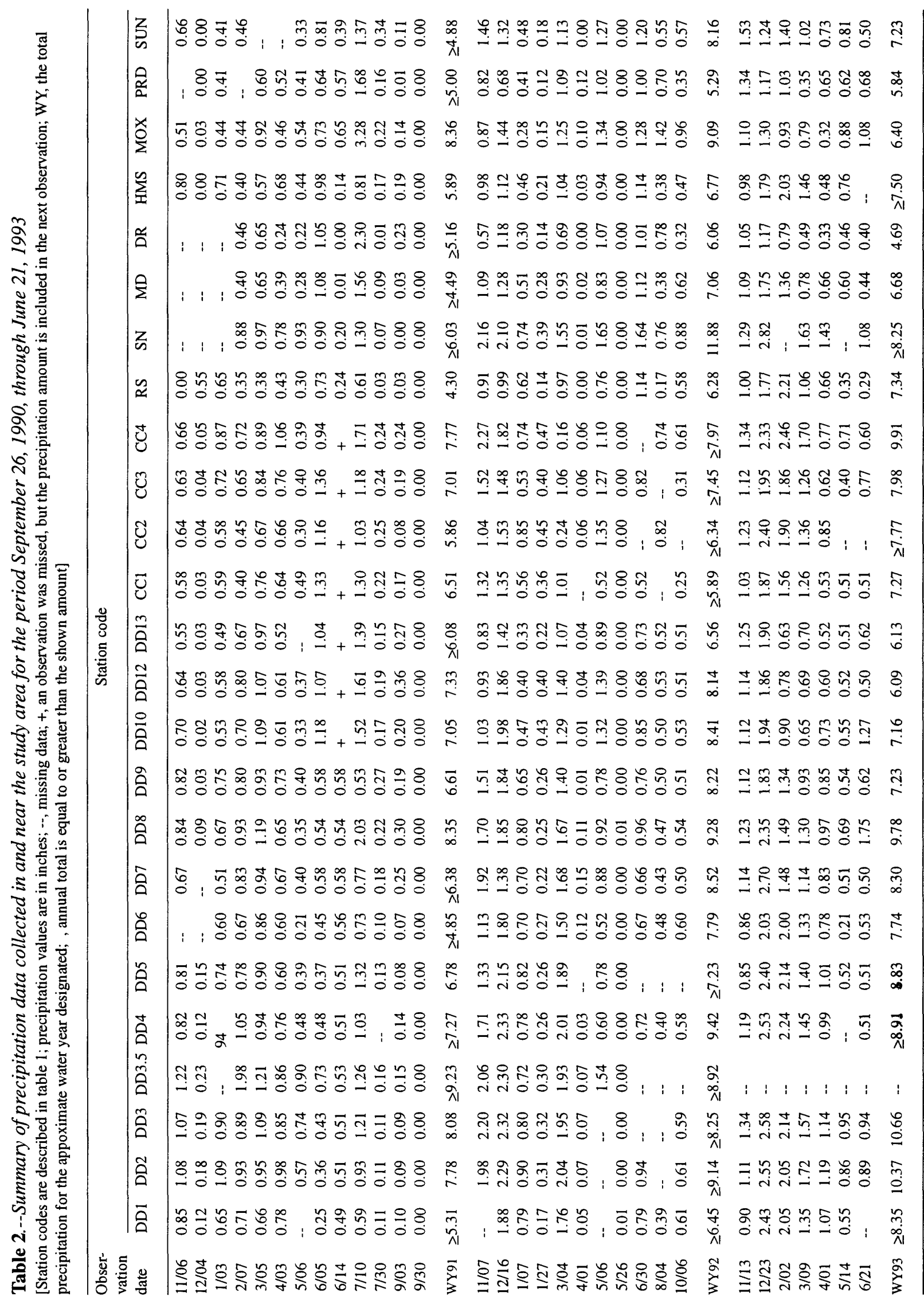


Table 3.--Summary of monthly mean climatic data for the study area

[CCMS, Cold Creek Meteorological Station; HMS, Hanford Meteorological Station; HMS-LT, Long-Term averages for the Hanford Meteorological Station for period of record shown; --, long-term averages are shown in the rows for water year 1991 only]

\begin{tabular}{|c|c|c|c|c|c|c|c|c|c|c|c|c|}
\hline \multirow[b]{2}{*}{ Date } & \multicolumn{2}{|c|}{$\begin{array}{l}\text { Air Temperature } \\
\text { (degrees F) }\end{array}$} & \multicolumn{4}{|c|}{$\begin{array}{l}\text { Windspeed } \\
\text { (miles per hour) }\end{array}$} & \multicolumn{2}{|c|}{$\begin{array}{l}\text { Dew Point } \\
\text { (degrees F) }\end{array}$} & \multirow[b]{2}{*}{$\begin{array}{l}\text { HMS-LT } \\
1950-80\end{array}$} & \multicolumn{2}{|c|}{$\begin{array}{l}\text { Solar Radiation } \\
\text { (langleys) }\end{array}$} & \multirow[b]{2}{*}{$\begin{array}{l}\text { HMS-LT } \\
1955-80\end{array}$} \\
\hline & CCMS & HMS & $\begin{array}{l}\text { HMS-LT } \\
1912-80\end{array}$ & CCMS & HMS & $\begin{array}{l}\text { HMS-LT } \\
1945-80\end{array}$ & CCMS & HMS & & CCMS & HMS & \\
\hline OCT 1990 & 50.6 & 52.4 & 53.0 & 6.4 & 8.8 & 6.6 & 33.8 & 35.3 & 36 & 238 & 240 & 262 \\
\hline NOV 1990 & 44.8 & 46.3 & 39.8 & 5.8 & 10.6 & 6.1 & 33.3 & 33.6 & 31 & 143 & 132 & 129 \\
\hline DEC 1990 & 24.2 & 24.7 & 32.7 & 5.0 & 7.3 & 6.1 & 17.2 & 17.2 & 27 & 101 & 88 & 89 \\
\hline JAN 1991 & 29.4 & 28.9 & 29.3 & 4.6 & 5.4 & 6.4 & 22.7 & 22.4 & 23 & 122 & 114 & 115 \\
\hline FEB 1991 & 44.5 & 44.6 & 36.3 & 5.5 & 6.8 & 7.1 & 34.2 & 33.5 & 28 & 207 & 184 & 195 \\
\hline MAR 1991 & 42.0 & 44.1 & 45.1 & 6.3 & 8.0 & 8.5 & 30.0 & 29.2 & 28 & 303 & 302 & 333 \\
\hline APR 1991 & 52.2 & 54.6 & 53.1 & 7.3 & 10.5 & 9.0 & 29.0 & 31.0 & 31 & 479 & 447 & 464 \\
\hline MAY 1991 & 58.3 & 60.9 & 61.5 & 7.3 & 9.8 & 8.9 & 34.3 & 37.4 & 36 & 493 & 482 & 566 \\
\hline JUNE 1991 & 62.6 & 65.7 & 69.3 & 7.0 & 9.0 & 9.2 & 40.7 & 43.2 & 41 & 540 & 521 & 629 \\
\hline JULY 1991 & 76.1 & 78.6 & 76.4 & 7.6 & 9.6 & 8.7 & 38.1 & 45.9 & 43 & 661 & 635 & 647 \\
\hline AUG 1991 & 77.2 & 78.3 & 74.3 & 6.8 & 8.8 & 8.0 & 38.8 & 47.4 & 43 & 547 & 537 & 549 \\
\hline SEP 1991 & 69.9 & 70.0 & 65.2 & 7.3 & 7.9 & 7.5 & 28.9 & 40.2 & 40 & 457 & 432 & 414 \\
\hline OCT 1991 & 53.0 & 53.0 & -- & 6.2 & 7.3 & -- & 23.3 & 31.0 & -. & 275 & 262 & -- \\
\hline NOV 1991 & 36.9 & 41.2 & -- & 4.4 & 6.7 & -- & 31.1 & 34.3 & -- & 102 & 96 & -- \\
\hline DEC 1991 & 36.7 & 37.9 & -- & 4.6 & 6.3 & -- & 30.6 & 32.3 & -- & 93 & 80 & -- \\
\hline JAN 1992 & 35.9 & 37.6 & -- & 4.2 & 6.0 & -- & 30.7 & 31.8 & -- & 91 & 84 & -- \\
\hline FEB 1992 & 40.6 & 42.1 & -- & 4.5 & 5.8 & -- & 35.6 & 36.7 & -- & 147 & 139 & -- \\
\hline MAR 1992 & 50.6 & 51.6 & -- & 6.3 & 6.7 & -- & 34.0 & 35.3 & -- & 338 & 341 & -- \\
\hline APR 1992 & 52.8 & 56.3 & -- & 6.2 & 8.9 & -- & 34.9 & 37.1 & -- & 428 & 416 & -- \\
\hline MAY 1992 & 66.2 & 68.4 & -- & 7.5 & 9.3 & -- & 25.9 & 35.1 & -- & 627 & 607 & -- \\
\hline JUNE 1992 & 74.6 & 77.0 & -. & 7.1 & 9.6 & -. & 32.8 & 44.2 & -- & 626 & 596 & -- \\
\hline JULY 1992 & 74.6 & 76.8 & -. & 7.2 & 9.0 & -- & 38.4 & 48.6 & -- & 568 & 546 & -- \\
\hline AUG 1992 & 76.0 & 77.3 & -- & 6.7 & 8.4 & -- & 28.8 & 44.1 & -- & 540 & 508 & -- \\
\hline SEP 1992 & 63.0 & 64.6 & -- & 7.0 & 9.0 & -- & 31.4 & 41.0 & -- & 393 & 365 & -- \\
\hline OCT 1992 & 54.6 & 55.5 & -- & 5.8 & 6.5 & -- & 31.3 & 37.6 & -- & 234 & 217 & -- \\
\hline NOV 1992 & 38.0 & 41.0 & -- & 4.3 & 5.8 & -- & 31.6 & 34.3 & -- & 111 & 107 &.- \\
\hline DEC 1992 & 29.1 & 30.1 & -- & 5.9 & 6.9 & -- & 22.5 & 24.0 & -- & 100 & 88 & -- \\
\hline JAN 1993 & 24.2 & 25.3 & -- & 5.1 & 6.0 & .- & 19.0 & 20.9 & -. & 113 & 101 & -- \\
\hline FEB 1993 & 29.5 & 31.0 & -- & 5.3 & 5.9 & -- & 20.6 & 23.4 & -- & 199 & 172 & -. \\
\hline MAR 1993 & 40.8 & 42.9 & -. & 5.1 & 6.7 & -- & 29.7 & 32.2 & -- & 277 & 250 & -. \\
\hline APR 1993 & 49.7 & 52.6 & -- & 5.6 & 8.9 & -- & 33.4 & 36.4 & -- & 406 & 380 & -- \\
\hline MAY 1993 & 64.5 & 66.7 & -- & 6.2 & 9.3 & -- & 33.4 & 43.1 & -- & 561 & 509 & -- \\
\hline Average & 50.7 & 52.4 & -. & 6.0 & 7.9 & -- & 30.6 & 35.1 & -- & 330 & 313 & -- \\
\hline
\end{tabular}


Table 4.--Monthly and annual peak-discharge and total-streamflow data for the study area, October 1990-May 1993 [Max.Q, maximum instantaneous discharge; Total, monthly or annual total volume of streamflow; $\mathrm{ft}^{3} / \mathrm{s}$, cubic feet per second; ac-ft, acre-feet; e, estimated]

\begin{tabular}{|c|c|c|c|c|c|c|c|c|}
\hline \multirow[b]{3}{*}{ Date } & \multicolumn{8}{|c|}{ Discharge } \\
\hline & \multicolumn{2}{|c|}{$\begin{array}{l}\text { Upper Cold Creek } \\
\text { Station } 12510618\end{array}$} & \multicolumn{2}{|c|}{$\begin{array}{l}\text { Lower Cold Creek } \\
\text { Station } 12510625\end{array}$} & \multicolumn{2}{|c|}{$\begin{array}{l}\text { Upper Dry Creek } \\
\text { Station } 12510650\end{array}$} & \multicolumn{2}{|c|}{$\begin{array}{l}\text { Lower Dry Creek } \\
\text { Station } 12510655\end{array}$} \\
\hline & $\begin{array}{l}\text { Max.Q } \\
\text { (cfs) }\end{array}$ & $\begin{array}{l}\text { Total } \\
\text { (ac-ft) }\end{array}$ & $\begin{array}{l}\text { Max.Q } \\
\text { (cfs) }\end{array}$ & $\begin{array}{l}\text { Total } \\
\text { (ac-ft) }\end{array}$ & $\begin{array}{l}\text { Max.Q } \\
\text { (cfs) }\end{array}$ & $\begin{array}{l}\text { Total } \\
\text { (ac-ft) }\end{array}$ & $\begin{array}{l}\text { Max.Q } \\
\text { (cfs) }\end{array}$ & $\begin{array}{l}\text { Total } \\
\text { (ac-ft) }\end{array}$ \\
\hline 1990 OCT & 0 & 0 & 0 & 0 & 0 & 0 & 0.46 & 23 \\
\hline $1990 \mathrm{NOV}$ & 0 & 0 & 0 & 0 & 0 & 0 & 0.55 & 29 \\
\hline $1990 \mathrm{DEC}$ & 0 & 0 & 0 & 0 & 0 & 0 & $0.56 \mathrm{e}$ & $32 \mathrm{e}$ \\
\hline 1991 JAN & 0 & 0 & 0 & 0 & 0 & 0 & 74 & 41 \\
\hline 1991 FEB & 0 & 0 & 0 & 0 & 0 & 0 & 0.62 & 29 \\
\hline $1991 \mathrm{MAR}$ & 0 & 0 & 0 & 0 & 0 & 0 & 0.53 & 26 \\
\hline 1991 APR & 0 & 0 & 0 & 0 & 0 & 0 & 0.51 & 26 \\
\hline $1991 \mathrm{MAY}$ & 0 & 0 & 0 & 0 & 0 & 0 & 0.49 & 26 \\
\hline 1991 JUN & 0 & 0 & 170 & 5.7 & $5.0 \mathrm{e}$ & $9.9 \mathrm{e}$ & 12 & 32 \\
\hline 1991 JUL & 0 & 0 & 0 & 0 & 0 & 0 & 0.62 & 30 \\
\hline 1991 AUG & 0 & 0 & 0 & 0 & 0 & 0 & 0.46 & 26 \\
\hline 1991 SEP & 0 & 0 & 0 & 0 & 0 & 0 & 0.44 & 24 \\
\hline WY 1991 & 0 & 0 & 170 & 5.7 & $5.0 \mathrm{e}$ & $9.9 \mathrm{e}$ & 74 & 345 e \\
\hline 1991 OCT & 0 & 0 & 0 & 0 & 0 & 0 & 0.48 & 24 \\
\hline $1991 \mathrm{NOV}$ & 0 & 0 & 2.6 & 0.20 & 0 & 0 & 0.43 & 24 \\
\hline $1991 \mathrm{DEC}$ & 0 & 0 & 0 & 0 & 0 & 0 & $0.46 \mathrm{e}$ & $27 \mathrm{e}$ \\
\hline 1992 JAN & 0 & 0 & 0 & 0 & 0 & 0 & $0.49 \mathrm{e}$ & $29 \mathrm{e}$ \\
\hline 1992 FEB & 0 & 0 & 0 & 0 & 0 & 0 & 0.49 & 26 \\
\hline 1992 MAR & 0 & 0 & 0 & 0 & 0 & 00 & 0.49 & 27 \\
\hline 1992 APR & 10 & 0.30 & 0.75 & 0.02 & 0 & 0 & 0.52 & 28 \\
\hline 1992 MAY & 0 & 0 & 0 & 0 & 0 & 0 & 0.50 & 27 \\
\hline 1992 JUN & 0 & 0 & 0.01 & 0.02 & 0 & 0 & 0.46 & 21 \\
\hline 1992 JUL & 0 & 0 & 0 & 0 & 0 & 0 & 0.49 & 28 \\
\hline 1992 AUG & 0 & 0 & 0 & 0 & 0 & 0 & $0.43 \mathrm{e}$ & $23 \mathrm{e}$ \\
\hline 1992 SEP & 0 & 0 & 0 & 0 & 0 & 0 & $0.41 \mathrm{e}$ & $23 \mathrm{e}$ \\
\hline WY 1992 & 10 & 0.30 & 2.6 & 0.24 & 0 & 0 & 0.52 & $308 \mathrm{e}$ \\
\hline 1992 OCT & 0 & 0 & 0 & 0 & 0 & 0 & $0.43 \mathrm{e}$ & $24 \mathrm{e}$ \\
\hline 1992 NOV & 0 & 0 & 0 & 0 & 0 & 0 & 0.43 & 23 \\
\hline 1992 DEC & 0 & 0 & $0 \mathrm{e}$ & $0 \mathrm{e}$ & 0 & 0 & 0.44 & 24 \\
\hline 1993 JAN & 0 & 0 & $0 \mathrm{e}$ & $0 \mathrm{e}$ & 0 & 0 & 0.44 & 20 \\
\hline 1993 FEB & 0 & 0 & 5.3 & $0.60 \mathrm{e}$ & 0 & 0 & $0.40 \mathrm{e}$ & $21 \mathrm{e}$ \\
\hline 1993 MAR & 15 & 38 & 4.2 & 0.90 & 0 & 0 & 0.49 & 28 \\
\hline 1993 APR & 0.69 & 27 & 0 & 0 & 0 & 0 & 0.49 & 27 \\
\hline 1993 MAY & 0.48 & 18 & 0 & 0 & 0 & 0 & 0.50 & 28 \\
\hline OCT-MAY 1993 & 15 & 84.1 & $5.3 \mathrm{e}$ & $1.50 \mathrm{e}$ & 0 & 0 & 0.50 & $195 \mathrm{e}$ \\
\hline
\end{tabular}




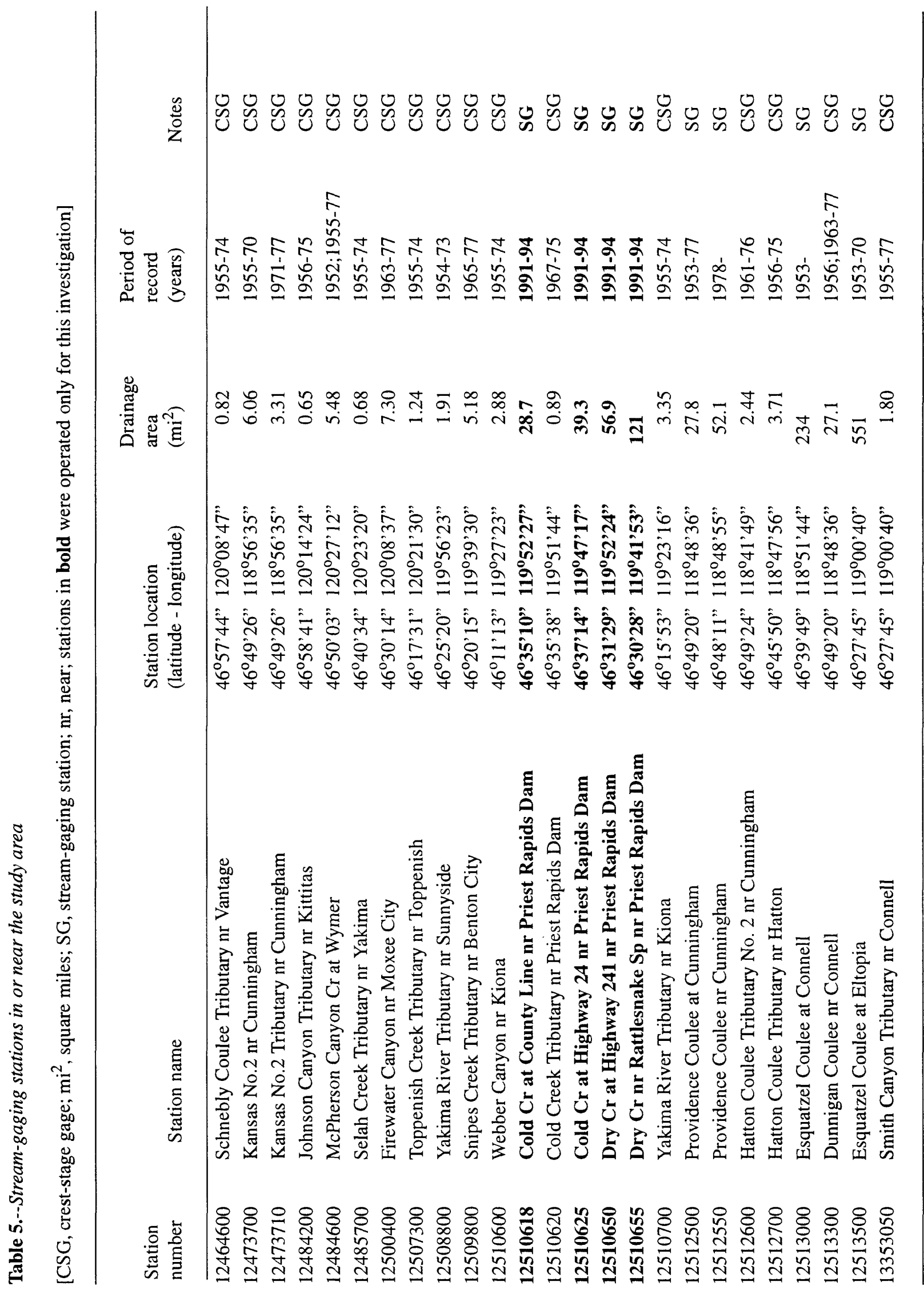




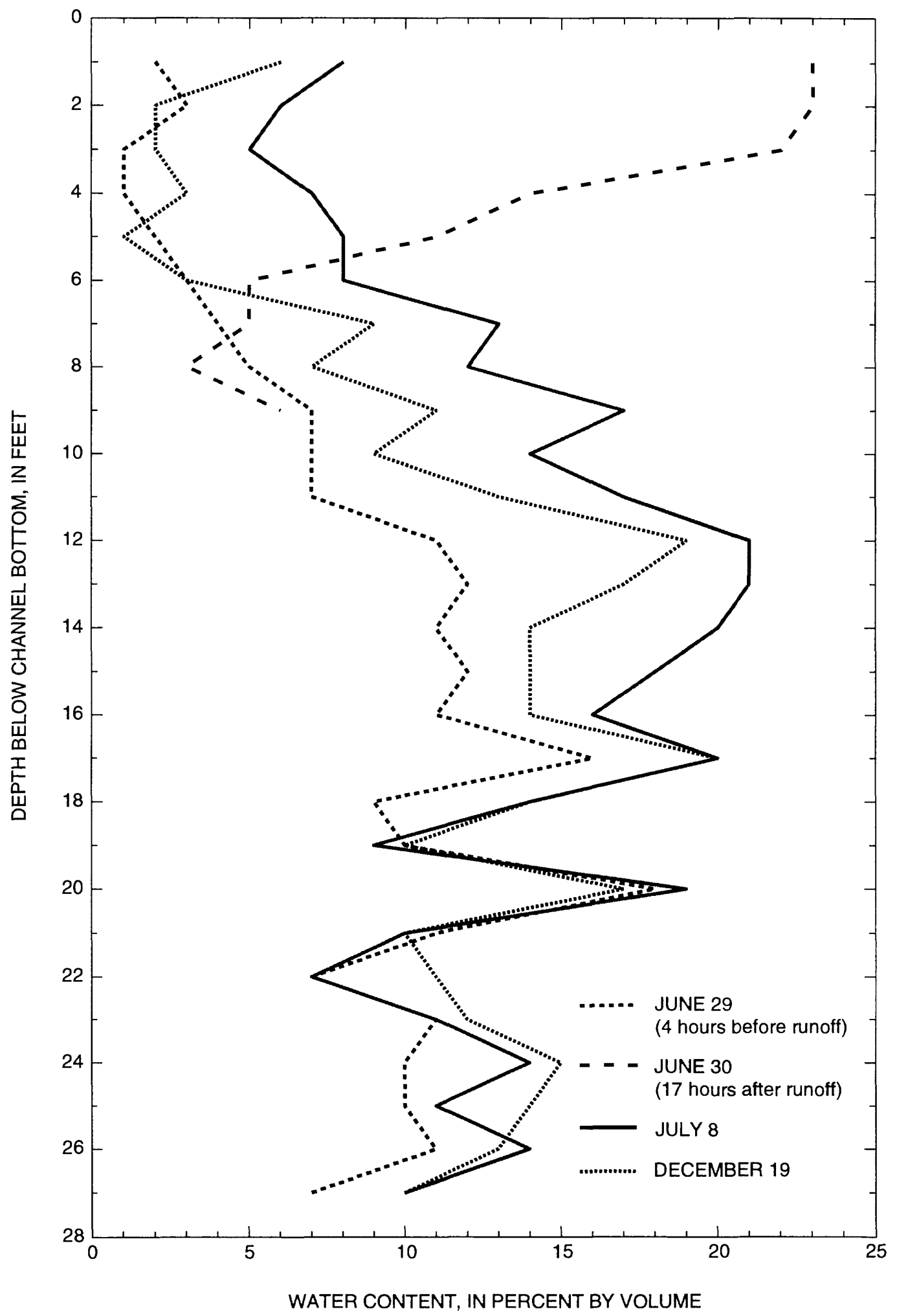

Figure 3. Soil moisture at site C2 before and after the June 29, 1991 runoff in lower Cold Creek. 
Evapotranspiration data collected by Tomlinson (1994) and Gee and others (1992) during June 1990 through September 1991 at two sites in the study area were obtained. Both sites were located on the lower slopes of the Rattlesnake Hills in the eastern portion of Dry Creek Basin. At Tomlinson's Snively Basin site, daily evapotranspiration from a mixed-grass-covered plot was calculated using micrometeorological data and the Bowen-ratio method. At Gee and others' Benson Springs site, daily evapotranspiration from a bunchgrass-covered plot was calculated using data from a weighing-type monolith lysimeter. The evapotranspiration data are presented in the "Estimation and Calibration of Parameter Values" section of this report.

Streamflow data collected since 1957 at 21 stations in and around the study area (table 5) were assembled (Williams and Pearson, 1985). Seventeen of the stations gaged small tributary basins ( 0.65 to 7.30 square miles) where only instantaneous peak-flows were determined. The remaining four stations gaged larger areas (27.8 to 551 square miles) in the Esquatzel Coulee Basin where both peak-flow and daily streamflow data were collected with recording stream gages. Annual streamflow data from three of the recording stream-gaging stations in the Esquatzel Coulee Basin are summarized in table 6.

\section{CONCEPTUAL MODEL OF RUNOFF AND RECHARGE FROM RUNOFF}

This conceptual model describes, in general terms, runoff generation and recharge from runoff in the study area. It was used to guide the construction of numerical models and the estimation of parameter values. The conceptual model was devised from hydrologic and climatic data collected for this study, as well as from previously published data and results from this and other semiarid areas.

\section{Runoff Generation}

Runoff in the study area is uncommon and is primarily generated by winter precipitation, often augmented with snowmelt and probably enhanced by frozen ground. Nearly all runoff recorded at the stations listed in table 5 occurred from late December through March. Probable causes of selected winter runoff are presented in the literature. Peak streamflows of 350 and 190 cubic feet per second $\left(\mathrm{ft}^{3} / \mathrm{s}\right)$ at Rattlesnake Springs in Dry Creek Basin in January of 1969 and 1970 were both attributed to rapid snowmelt on frozen soil (Harr, 1971). Substantial runoff at unspecified locations on the Hanford Site in February 1985 were attributed to a warm "chinook" wind, gusting to 43 miles per hour, which melted most of an 8-inch snowpack in less than one day (Gee and others, 1992). Floods of January 1974 in southern Washington were attributed to rapid melting of above-normal snowpacks, rainfall, and frozen soils (Longfield, 1974), and the floods of 1956 in the Esquatzel Coulee area (Anderson and Bodhaine, 1956) were attributed to heavy rain falling on frozen soils covered by varying amounts of snow.

The effect that frozen soils have on runoff generation in the study area is not well documented. The frozen-soils information presented in the previously referenced runoff reports was anecdotal, and it is possible that high rainfall and snowmelt intensities may have been the sole cause of runoff. Soil freezing was monitored at the meteorological station in Cold Creek Basin during this investigation, but the paucity of runoff precluded an assessment of the effects of frozen soils on runoff generation. Many reports documenting the hydrologic significance of frozen soils in other seasonally cold regions are summarized by Fox (1992) and by Gray and Prowse (1992). Infiltration into dry, frozen soils or soils frozen to depths less than about 6 inches may not be significantly different from infiltration into unfrozen soils, but infiltration may be greatly impaired in soils that have a high moisture content when frozen or in soils that are frozen at depths greater than 12 inches. The moisture and thermal regimes of soils in the study area during past periods of runoff is largely unknown. In general, soil-moisture contents during winter presumably range from very low to very high, and subsoil temperatures below freezing have been recorded at the HMS many times during December, January, and February.

Although there were periods of heavy rainfall, melting snowpacks, and frozen soils during the data collection period for this investigation, the combination of these factors needed to generate large volumes of runoff did not occur. Record snowfall in the region during the winter of 1992-93 did result in sustained runoff from snowmelt in the upper Cold Creek Basin (table 4), but the volume of runoff was minor in relation to probable historic runoff. Those data and historical data support the hypothesis that runoff generation in the study area is not well correlated to annual precipitation. Comparison of peak-discharge data for stations listed in table 5 with annual precipitation at the HMS showed poor correlation between above average precipitation and widespread runoff in the region. 
Table 6.--Total streamflow at selected stream-gaging stations in the Esquatzel Coulee Basin for water years 1958-93 [ac-ft, acre-feet; ac-ft/mi ${ }^{2}$, acre-feet per square mile of drainage area; missing record denoted by “.”; Average, average annual runoff for period of record shown]

Total streamflow

\begin{tabular}{|c|c|c|c|c|c|c|}
\hline \multirow{2}{*}{$\begin{array}{l}\text { Water } \\
\text { year }\end{array}$} & \multicolumn{2}{|c|}{ Station 12513000} & \multicolumn{2}{|c|}{ Station 12512500} & \multicolumn{2}{|c|}{ Station 12512550} \\
\hline & $\mathrm{ac}-\mathrm{ft}$ & $\mathrm{ac}-\mathrm{ft} / \mathrm{mi}^{2}$ & $\mathrm{ac}-\mathrm{ft}$ & $\mathrm{ac}-\mathrm{ft} / \mathrm{mi}^{2}$ & & $\mathrm{ac}-\mathrm{ft} / \mathrm{mi}^{2}$ \\
\hline 1958 & 0 & 0 & 0 & 0 & . & . \\
\hline 1959 & 19 & 0.01 & 54 & 1.9 & . & . \\
\hline 1960 & 0 & 0 & 0 & 0 & . & . \\
\hline 1961 & 0 & 0 & 0 & 0 & . & . \\
\hline 1962 & 0 & 0 & 0 & 0 & . & . \\
\hline 1963 & 102 & 0.44 & 21 & 0.76 & . & . \\
\hline 1964 & 0 & 0 & 3 & 0.11 & . & . \\
\hline 1965 & 218 & 0.93 & 47 & 1.7 & . & . \\
\hline 1966 & 0 & 0 & 0 & 0 & . & . \\
\hline 1967 & 0 & 0 & 0 & 0 & . & . \\
\hline 1968 & 0 & 0 & 0 & 0 & . & . \\
\hline 1969 & 7,260 & 31 & 1,360 & 49 & . & . \\
\hline 1970 & 3,710 & 16 & 789 & 28 & . & . \\
\hline 1971 & 999 & 4.3 & 275 & 9.9 & . & . \\
\hline 1972 & 168 & 0.72 & 39 & 1.4 & . & . \\
\hline 1973 & 43 & 0.18 & 66 & 2.4 & . & . \\
\hline 1974 & 143 & 0.61 & 44 & 1.6 & . & . \\
\hline 1975 & 459 & 2.0 & 89 & 3.2 & . & . \\
\hline 1976 & 36 & 0.15 & 8.9 & 0.32 & . & . \\
\hline 1977 & 0.10 & 0 & . & 0 & . & $\cdot$ \\
\hline 1978 & 0.40 & 0 & . & . & 4.4 & 0.08 \\
\hline 1979 & 3,460 & 14.8 & . & . & 1,150 & 22 \\
\hline 1980 & 2,950 & 12.6 & . & . & 823 & 16 \\
\hline 1981 & 0 & 0 & . & . & 0 & 0 \\
\hline 1982 & 1,036 & 4.4 & . & . & 437 & 8.4 \\
\hline 1983 & 7.5 & 0.03 & . & . & 5.1 & 0.10 \\
\hline 1984 & 2,210 & 9.46 & . & . & 898 & 17 \\
\hline 1985 & 7,650 & 33 & . & . & 1,837 & 35 \\
\hline 1986 & 281 & 1.2 & . & . & 235 & 4.5 \\
\hline 1987 & 71 & 0.30 & . & . & 21 & 0.40 \\
\hline 1988 & 175 & 0.75 & . & . & 159 & 3.0 \\
\hline 1989 & 1,770 & 7.6 & . & . & 411 & 7.9 \\
\hline 1990 & 0 & 0 & . & . & 0 & 0 \\
\hline 1991 & 0 & 0 & . & . & 19 & 0.37 \\
\hline 1992 & 0 & 0 & . & . & 0 & 0 \\
\hline 1993 & 2,560 & 11 & . & . & 583 & 11 \\
\hline Average & 982 & 4.2 & 140 & 5.0 & 411 & 7.9 \\
\hline
\end{tabular}


As is typical of many arid to semiarid regions, runoff is infrequent in the study area. The historical peakdischarge data shows that for water years 1957 through 1977--the period when most of the stream-gaging stations were operational--runoff occurred, on average, about once every two years. Relatively substantial runoff was observed about once every four years. Runoff was also uncommon for the duration of this investigation; it was recorded four times from October 1990 through May 1993 (table 4), and it was relatively insubstantial. The largest peak discharge per unit area was $1.6 \mathrm{ft}^{3} / \mathrm{s} / \mathrm{mi}^{2}$ at station 12510625 during June 1991, and the largest annual runoff volume per unit area (excluding spring-fed discharge at station 12510655 ) was $3.5 \mathrm{acre}-\mathrm{ft} / \mathrm{mi}^{2}$ at station 12510618 during the 1993 water year. For comparison, unit-area peak discharges and annual runoff volumes of greater than $10 \mathrm{ft}^{3} / \mathrm{s} / \mathrm{mi}^{2}$ and 10 acre- $\mathrm{ft} / \mathrm{mi}^{2}$, respectively, are not uncommon in the region (Williams and Pearson, 1985).

\section{Recharge from Runoff}

All runoff in the study area is ultimately lost to evaporation or infiltration. Cold Creek and Dry Creek channels decrease in size downstream from the lower streamgaging stations until they eventually become indistinct in terminal runout zones. Although there are no topographic barriers between the runout zones and the Yakima River, there is no geomorphic or botanical evidence to indicate that unchannelized flow from Cold and Dry Creek Basins proceeds downstream beyond these zones. Given that runoff is primarily generated during winter months when evaporation rates are low, it is unlikely that much runoff is lost to evaporation.

It is likely that most of the runoff that infiltrates into alluvial channels eventually percolates and recharges the uppermost unconfined aquifer beneath the Hanford Site.

The alluvial channels in the study area are mostly nonvegetated and are underlain by coarse sediments with low water-holding capacity. Thus, transpiration is negligible, and little water is held near the surface for evaporation. Soil moisture data from before and after minor runoff in lower Cold Creek (fig. 3) suggest that even during summer, rapid percolation through channel sediments does indeed occur. Evapotranspiration of infiltrated runoff is likely greater in the terminal runout zones that are vegetated and are underlain by fine sands and redeposited silt loams, than in the nonvegetated channels. Although Gee and others (1992) found no evidence for direct recharge from precipitation alone in vegetated areas underlain by silt loams at the Hanford Site, the addition of large volumes of runoff water over such sites would likely lead to percolation below the zone of active evapotranspiration. Contrary to that conclusion, Scanlon (1994) found that percolated water from episodic infiltration in Hueco Bolson, Texas, did not necessarily recharge ground water, even after percolating to depths greater than 40 feet. Under west Texas climate conditions, the water was subjected to long-term upward liquid and vapor flow. However, Scanlon hypothesized that downward flow is more prevalent at the Hanford Site because underlying sediments are coarser and infiltration is common during winter, when temperatures and evapotranspiration are lowest.

Runoff and recharge characteristics differ between upper Cold Creek and upper Dry Creek Basins because of differences in basin physiography. Upper Cold Creek Basin is v-shaped with steep slopes covered by thin, stony soils, and the narrow valley is nearly devoid of alluvial fill. Thus, runoff flows quickly downstream and does not infiltrate into the channel bottom until it reaches a point approximately 1 mile upstream from the lower Cold Creek stream gage (station 12510625) where the alluvial valley begins. Upper Dry Creek Basin is wide, the steep sides are separated from the main stream channel by gentle slopes with deep soils, and the valley is underlain with alluvium. Thus, runoff can infiltrate into both the tributary and the mainstream channel bottoms. The lower sections of Cold Creek and Dry Creek Basins are similar--steep slopes with shallow soils drain to gentler slopes with deeper soils and valleys underlain by extensive alluvial deposits.

\section{Recharge from Spring Discharge}

Some discharge from ephemeral springs along upper Cold Creek and perennial springs along lower Dry Creek is subsequently infiltrated and probably contributes to recharge at the Hanford Site. A shallow ground-water flow system in the bedrock underlying upper Cold Creek Basin is the likely source of ephemeral spring discharge. Springs and seeps along the upper Cold Creek channel were observed to discharge to the stream from March through July of 1993, and anecdotal information from area residents suggest that such discharges are common following particularly wet winters. The springs did not discharge to the surface during the previous two drier years, but the established, lush riparian vegetation growing along upper Cold Creek indicates that shallow ground water is regularly available. The 1993 spring-fed discharge disappeared from the surface soon after flowing onto the alluvial fill in lower Cold Creek valley, which is also where the lush riparian zone abruptly ends. 
No such springs or riparian zones are present along upper Dry Creek, but it is believed that the discharge from Rattlesnake Springs in lower Dry Creek Basin is from a localized perched aquifer (Price and Harr, 1970; and Brown, 1970). The perennial springs discharge into Dry Creek immediately upstream from the lower stream gage (station 12510655). Annual average discharges from Rattlesnake Springs for the 1991-93 water years were relatively constant at $0.48,0.42$, and $0.41 \mathrm{ft}^{3} / \mathrm{s}$, respectively; Price and Harr (1970) reported an annual average discharge of $0.47 \mathrm{ft}^{3} / \mathrm{s}$. Discharge was not well correlated with annual precipitation. Monthly mean discharges varied from 0.58 to $0.33 \mathrm{ft}^{3} / \mathrm{s}$, but the seasonal variation was not consistent from year to year. These data suggest that discharge from Rattlesnake Springs does not vary with recent ground-water recharge; Price and Harr (1970) reached the same conclusion. Surface water in Dry Creek was visible in the channel for 0.9 to 1.7 miles downstream of the springs, depending on discharge. The lush riparian zone below Rattlesnake Springs thins out abruptly between 1 and 2 miles downstream of the springs, indicating that shallow ground water is not present outside of the immediate vicinity of the springs.

\section{NUMERICAL MODELS OF RUNOFF AND RECHARGE FROM RUNOFF}

Numerical models were used to estimate long-term average runoff and recharge for the study area. The models, one for Cold Creek Basin and one for Dry Creek Basin, were constructed using the Hydrological Simulation Program - FORTRAN (HSPF-Version 9) computer program.

\section{The Hydrological Simulation Program - FORTRAN (HSPF)}

HSPF was selected because it could simulate most of the important hydrologic processes in the conceptual model of runoff and recharge, including snow accumulation and melt, infiltration of runoff into channel bottoms and runout zones, evapotranspiration and percolation of infiltrated runoff, and ephemeral or perennial discharge of ground water. HSPF could not directly simulate frozen ground or its effect on runoff. However, a separate procedure was used to estimate the times of frozen ground, and an HSPF routine allowed adjustment of infiltration-related parameter values to account for frozen-ground effects.
HSPF is a continuous-type precipitation-runoff program; it simulates and updates hydrologic fluxes and storages during each user-specified time step ( 1 hour for this investigation) over the entire time span of a simulation. The program is documented in the HSPF users manual (U.S. Environmental Protection Agency, 1984).

HSPF represents a drainage basin with land segments and reaches; the former represent land areas and the latter represent stream channels. Land segments and reaches are connected with a network routine in HSPF to represent the geometry of a drainage basin as a whole.

HSPF uses a mass-balance approach, or water budget, to account for all inflows, outflows and changes in storage for both land segments and reaches. Inflows may be precipitation; snowmelt; and overland flow, interflow, ground-water flow, or streamflow from other land segments or reaches. Outflows may be evapotranspiration (including sublimation of snow); overland flow, interflow, ground-water flow, or streamflow; and recharge to regional ground-water systems (inactive ground water). Changes in storage can be in any of the numerous defined storage components of the water budget, such as a snowpack, soil moisture, or ground water. HSPF requires records of precipitation and estimates of potential evapotranspiration (PET) to drive the nonsnow-related water budget computations, and it requires additional records of air temperature, dew point, solar radiation, and wind speed to simulate snow accumulation and melt.

A land segment in HSPF represents a parcel of land that has distinct and relatively uniform hydrologic characteristics and climate. Those characteristics are commonly inferred from soil type, vegetation, and topography. HSPF represents the hydrologic characteristics of land segments with process-related parameters in the water-budget formulations. The process-related parameters represent properties relevant to the movement or storage of water in land segments (table 7). Many of the process-related parameters cannot be measured directly, so their values are estimated from available physiographic data and then refined through calibration. The water-budget formulation for land segments is described in detail in the HSPF users manual (U.S. Environmental Protection Agency, 1984, pages 158-176).

A reach in HSPF represents a segment of a surfacewater drainage network that has relatively uniform hydraulic properties. HSPF represents the hydraulic characteristics of a given reach of stream channel or any other 
Table 7.--Definitions and descriptions of process-related parameters in the HSPF program

\begin{tabular}{ll}
\hline Parameter & Definition and Description \\
\hline AGWETP & $\begin{array}{l}\text { Active ground-water evapotranspiration (ET) index; represents the fraction of PET that can be met from } \\
\text { plants transpiring water directly from the saturated zone. }\end{array}$
\end{tabular}

AGWRC Active ground-water recession coefficient; governs the rate at which ground water is discharged from a land segment. When there is no inflow to ground-water storage, it is equal to the ratio of the rate of discharge 'today' to the rate of discharge 'yesterday'.

BASETP Baseflow evapotranspiration index; represents the fraction of PET that can be met from riparian plants transpiring discharged ground water.

CEPSC Interception storage capacity; represents the maximum amount of intercepted precipitation that can be stored on vegetation.

DEEPFR Deep fraction of ground-water index; represents the fraction of ground-water recharge that will enter the deep (inactive) ground-water system and be lost from the basin of interest.

INFEXP Infiltration equation exponent; it is the exponent in the infiltration equation that governs the rate of decrease of infiltration with increasing soil moisture.

INFILD Infiltration difference; the ratio of the maximum to the mean infiltration rates within a land segment. It is used to represent the amount of variation in soil properties within a land-segment type.

INFILT Infiltration index; governs the partitioning of water incident on the soil surface into either potential direct runoff or lower-zone soil moisture.

INTFW Interflow index; governs the partitioning of potential direct runoff into either interflow (shallowsubsurface flow), overland flow, or upper-zone soil moisture storage.

IRC Interflow recession coefficient; governs the rate at which interflow is discharged from a land segment.

KVARY "K" variation; governs, in combination with AGWRC, the rate at which ground water is discharged from a land segment. It affects this discharge when there is inflow to ground-water storage.

LSUR Length of the surface overland-flow plane; represents the average length of the overland flow plane for a land segment.

LZETP Lower-zone evapotranspiration; represents the fraction of PET that can be met by plants transpiring water from the lower soil zone.

LZSN Lower-zone storage - nominal; represents the soil-moisture storage ability of the lower soil zone.

NSUR "N" value of the surface; represents the average Manning's roughness coefficient of a land segment.

SLSUR Slope of the surface; represents the average slope of a land segment.

UZSN Upper-zone storage - nominal; represents the storage ability in depressions and surface layers of a land segment. 
conveyance feature in flow tables (FTABLES), which define the discharge from the downstream end of a reach as a function of the volume in the reach. These FTABLES can generally be derived using various theoretical flow equations in combination with some measurable reach characteristics, such as cross section, roughness, slope, and length. A water budget for a reach is calculated by first adding the inflows to the storage of a reach, and then apportioning stored water to channel infiltration or downstream flow according to the FTABLE.

HSPF represents drainage basin geometry as a connected series of land segments and reaches. For this investigation, individual land segments with similar characteristics but different locations in a basin were grouped into land-segment types and a single set of process-related parameter values was determined for each land-segment type. For example, all moderately sloping, north-facing, sagebrush-covered parcels with deep silt-loam soils were included in a single land-segment type. A complex mosaic of slopes, aspects, vegetation, and soils was thus represented with relatively few land-segment types.

Reaches were not grouped, so a separate FTABLE was calculated for each reach. The land area draining to a given reach was defined as a subbasin, and the areal extent of land segments within each subbasin was specified in the network routine of HSPF.

The connections between land segments and reaches are also specified in the network routine of HSPF. Outflows calculated for any land segment or reach--such as overland flow or stream discharge--can be routed to any other land segment or reach so a variety of connections between land segments and reaches can be represented. For this investigation, it was necessary to represent the alluvium beneath stream channels as land segments so storage and evaporation of infiltrated water could be simulated. Infiltration of runoff into the alluvium was simulated by routing some streamflow to the underlying land segment where the water was then apportioned between storage, evaporation, and percolation according to the water-budget calculations.

\section{Simulation of Frozen Soils}

Simulation of the occurrence and infiltration properties of frozen ground were critical for realistic simulation of runoff, but HSPF does not explicitly simulate soil freezing and thawing. Therefore, estimated dates of soil freezing and thawing were determined using a separate procedure, and the effects that freezing had on infiltration was simulated by adjusting and resetting the value of the INFILT parameter in HSPF, a parameter that directly controls the simulation of infiltration and runoff.
Dates of soil freezing and thawing were estimated using a method developed and tested by Cary and others (1978) in eastern Washington. The method considers only the net daily heat flow across the soil surface. It is applicable when the top foot of soil has cooled to near $0^{\circ} \mathrm{C}$; at that time, almost all further heat loss comes from freezing water because the latent heat of freezing is much greater than the heat capacity of soil. Thus, the daily heat flow into or out of the soil may be interpreted as freezing or thawing of water. When the sum of the daily heat flows is negative, ice must be present in the soil, and when it is positive, the soil is unfrozen. This concept may be stated as

$$
M=\left(\sum_{n=1}^{n} G_{n}+u p_{n}\right)
$$

where $M$ is the net daily heat flow in watts per square meter, $\mathrm{n}$ indicates the day beginning with the soil temperature near $0^{\circ} \mathrm{C}, G_{n}$ is the daily average soil heat flux downward across the soil surface, and $u p_{n}$ is daily average soil heat flux upward from subsoil layers into the zone susceptible to freezing. When $M$ is less than zero, it is assumed that the soil is frozen, and when $M$ is equal to or greater than zero, it is assumed that the soil is not frozen.

Values of $u p_{n}$, which are typically small, are estimated by the empirical relation

$$
u p_{n}=2.5 \sin (J+80)
$$

where J is the Julian date. Cary and others (1978) report that the equation gave values of mean daily upward soil heat flux that followed the experimental measurements reasonably well. Values of $G n$ are estimated by the semiempirical relation

$$
G_{n}=\frac{k}{l}\left(T_{a}-\frac{T_{a-1}}{B}\right)\left(1-\frac{I_{2}}{I_{2}+N}\right),
$$

where $k$ is the average soil thermal conductivity (watts per meter per degree Celsius) over length $l$ (meters), $T a$ is the average daily air temperature (degrees Celsius), $\mathrm{Ta}-1$ is the average daily air temperature of the previous day, $B$ is a proportionality constant, $I_{2}$ is the depth of snow cover in meters, and $N$ is a calibration constant. The summation calculation for $M$ begins approximately with the autumn day when the soil temperature is near $0^{\circ} \mathrm{C}$. For each 
consecutive day through the winter, values for $u p_{n}$ are calculated from equation (2) and values for $G n$ are calculated from equation (3) using average daily air temperature and snow cover data. Approximate values for the quantity $k / l$ and the coefficients $B$ and $N$ are presented in Cary and others (1978), although those values can be refined through calibration to observed data. A snowpack cannot have a temperature greater than $0^{\circ} \mathrm{C}$, so the upper limit of $\mathrm{Ta}$ is set equal to $0^{\circ} \mathrm{C}$ when snow cover is present.

Because the method assumes the soil is always near $0^{\circ} \mathrm{C}$ when it is not frozen, the upper limit of $T a-1$, which is a surrogate for average soil temperature in equation (3), is also set to $0^{\circ} \mathrm{C}$.

Daily values of air temperature and snow cover--as well as parameter-value estimates of the quantity $k /$ and the coefficients $B$ and $N$--are required to obtain daily solutions for equations (1) and (3). For this investigation, the necessary parameter values were calibrated by starting with a set of values from Cary and others (1978) and adjusting those values using observed daily air temperature, snow depth, and soil temperature data from the National Weather Service station at Pullman, Washington, for 1970 through 1993. The Pullman data were used for calibration because no equivalent data sets were available for sites within the study area. The resulting parameter values were considered to be transferrable to the study area because the silt-loam soils at the Pullman station are similar to the predominant soil type in the study area. The calibration involved calculation of daily values of $M$ from the observed air temperature and snow depth data according to the procedure previously described and adjustment of parameter values to get good agreement between simulated and observed frozen soil. Observed frozen soil was indicated when the soil temperature at 2-inch depth was less than $0^{\circ} \mathrm{C}$, and simulated frozen soil (at a 2-inch depth) was indicated when $M$ was less than -25 watts per square meter.

The final calibrated parameter values $(k / l=25, B=1$, and $N=0.025$ ) resulted in correct frozen-soil predictions for the Pullman site 83 percent of the time. The method incorrectly predicted frozen soil 5 percent of the days when the soil temperature was greater than $0^{\circ} \mathrm{C}$, and it incorrectly predicted thawed soil 12 percent of the days when the soil temperature was less than or equal to $0^{\circ} \mathrm{C}$.

The calibrated method was tested for study area conditions using observed air and soil temperature data, and HSPF simulated snow depth for the Cold Creek meteorological station. The method correctly predicted frozen soil 92 percent of the time for the winter months (November through March) of 1990 through 1993, but the method predicted the final 1993 thaw 4 days after the thaw was observed. Although such results are reasonable, the few days with incorrect simulations may have resulted in large errors in the simulation of runoff. Frozen ground generally has a significant effect on runoff during only a few days each winter when rainfall and snowmelt intensities are great enough to produce significant runoff. Thus, if frozen-soil conditions were incorrectly simulated on those few critical days, runoff simulation errors could be large.

\section{Model Construction}

To construct numerical models for Cold Creek and Dry Creek Basins, physiographic data was used to apportion land area to land-segment types and to divide surfacewater drainage networks into reaches; basin geometry was defined by establishing links between land segments and reaches; parameter values for land segments and reaches were estimated from physiographic data, channel geometry data, and theoretical hydraulic formulas; and selected parameter values were calibrated to observed data.

\section{Land Segments}

Land segments were defined on the basis of soil type, vegetation type, slope, aspect, altitude, and geographic location. Land-segment types were defined as a group of land segments with the same soils and vegetation, but subject to different climate. A unique set of HSPF parameter values was determined for each land-segment type, so the spatial distribution of land-segment types represented the spatial distribution of study area physiography. Likewise, unique climatic data were assigned to all land segments with a given slope, aspect, altitude and general geographic location, thus representing the spatial distribution of climatic data. It was not computationally feasible to represent the entire continuum of physical and climatic characteristics found in the study area, so simplified classification schemes for soil, vegetation, topography, and geography were utilized.

All soils in the study area were classified into one of four categories, based on total depth and available water capacity (AWC). The original soils data--obtained from T.A. Zimmerman (Pacific Northwest Laboratory, written commun., 1985)--were classified into five depth-AWC groups for coarsely-mapped areas on the Yakima Firing Range, and into 17 groups for all other areas. All of those groups were combined to create the four categories for this investigation. Those categories, their areally-weighted average depths and AWCs, and their areal extent in the study area are shown in table 8 . 
Table 8.--Soil categories and their average depth, average available water capacity, and areal extents in the study area [AWC, available water capacity]

\begin{tabular}{lccc}
\hline Soil category & $\begin{array}{c}\text { Average depth } \\
\text { (feet) }\end{array}$ & $\begin{array}{c}\text { Average AWC } \\
\text { (inches per inch) }\end{array}$ & $\begin{array}{c}\text { Areal extent (percent of } \\
\text { total study area) }\end{array}$ \\
\hline Shallow-low AWC & 1.5 & 0.13 & 36 \\
Shallow-high AWC & 1.7 & 0.20 & 8 \\
Deep-low AWC & 4.4 & 0.12 & 14 \\
Deep-high AWC & 4.0 & 0.19 & 42 \\
\hline
\end{tabular}

Five vegetation types--or land uses--were defined for the study area. The original land use data--also obtained from T.A. Zimmerman (Pacific Northwest Laboratory, written commun., 1985)--were classified into five suitable categories. Because a sixth category, commercial, included less than one-tenth of one percent of the study area, those areas were reclassified as grasslands. The vegetation categories and their areal extent in the study area are shown in table 9.

Table 9.--Vegetation categories and their areal extents in the study area

$[<$, less than]

\begin{tabular}{lc}
\hline Vegetation category & $\begin{array}{c}\text { Areal extent (percent of } \\
\text { total study area) }\end{array}$ \\
\hline Sagebrush & 35 \\
Bare sand & $<1$ \\
Irrigated agriculture & $<1$ \\
Grasslands & 51 \\
Dryland wheat & 13 \\
\hline
\end{tabular}

Topographic classification was based on slope, aspect, and altitude. Three slope categories, two aspect categories, and four altitude categories were defined from digital elevation model data with a grid spacing of 30 by 30 meters. Slope and aspect categories and their areal extents in the study area are shown in table 10; altitude categories and their areal extents in the study area are shown in table 11.
Combining the 13 defined soil-vegetation groups with 84 defined climate zones--based on slope, aspect, altitude and geographic location--resulted in a total of 274 land-segment types for the study area. A few additional land segments were defined to represent the alluvium beneath stream channels.

Table 10.--Slope and aspect categories and their areal extent in the study area [>, greater than]

\begin{tabular}{lccc}
$\begin{array}{l}\text { Slope/ } \\
\text { aspect } \\
\text { category }\end{array}$ & $\begin{array}{l}\text { Slope range } \\
\text { (degrees) }\end{array}$ & Aspect & $\begin{array}{l}\text { Areal extent } \\
\text { (percent of } \\
\text { total study area) }\end{array}$ \\
\hline Mild & $0-4$ & north & 19 \\
Mild & $0-4$ & south & 17 \\
Moderate & $>4-10$ & north & 19 \\
Moderate & $>4-10$ & south & 22 \\
Steep & $>10$ & north & 15 \\
Steep & $>10$ & south & 8 \\
\hline
\end{tabular}

Table 11.--Altitude categories and their areal extent in the study area

\begin{tabular}{crc}
$\begin{array}{l}\text { Altitude } \\
\text { category }\end{array}$ & \multicolumn{1}{c}{$\begin{array}{c}\text { Altitude range } \\
\text { (feet) }\end{array}$} & $\begin{array}{c}\text { Areal extent (percent of } \\
\text { total study area) }\end{array}$ \\
\hline 1 & $512-1,312$ & 19 \\
2 & $1,313-2,297$ & 42 \\
3 & $2,298-3,281$ & 31 \\
4 & $3,282-4,193$ & 8 \\
\hline
\end{tabular}


Geographic location was characterized by defining eight subbasins for the study area, four each in Cold Creek and Dry Creek Basins. Subbasin boundaries are shown on figure 2, and subbasin sizes are shown in table 12.

Table 12.--Subbasin drainage areas in the study area

Drainage area
(square miles)

\begin{tabular}{ll}
\hline COLD4 & 17.0 \\
COLD3 & 11.6 \\
COLD2 & 10.7 \\
COLD1 & 35.2
\end{tabular}

Cold Creek Basin total

DRY4

56.9

DRY3

29.6

DRY2

34.7

DRY 1

26.7

Dry Creek Basin total

147.9

\section{Reaches}

The reaches defined for the study basins represent only the general hydraulic characteristics of the drainage networks; small-scale variations in characteristics were not represented. The beginning and end points of reaches, called nodes in HSPF, were defined at all points where specific flow information was desired, such as at the four stream-gaging station sites and at the point where Dry Creek crosses the Hanford Site boundary. Those nodes were required because inflows and outflows from reaches are calculated only at defined nodes in the HSPF program. Nodes were also defined at the upstream boundary of the alluvial channel deposits in Cold Creek to delineate that location where channel infiltration begins, at the Rattlesnake Springs location to allow simulation of ground-water discharge to Dry Creek, and at two points that delineate a reach where dispersed seeps and springs discharge to upper Cold Creek.

A total of 10 surface-water reaches, five in each basin, were defined for the study area. One additional reach was defined to represent the shallow ground-water flow system beneath upper Cold Creek Basin.

\section{Basin Geometry}

Basin geometry was represented by defining the hydraulic links between land segments and reaches, including links representing channel infiltration areas and terminal runout zones. The geometry of Cold Creek and Dry Creek Basins, as represented in the numerical models, is shown as schematic diagrams in figures 4 and 5 .

Runoff from land segments was routed to the nearest surface-water reach, and direct recharge from land segments was routed either to the regional ground-water flow system or to a ground-water reach representing the shallow ground-water flow system underlying the upper Cold Creek Basin (subbasins COLD4, COLD3, and COLD2). In those subbasins, direct recharge was routed to the ground-water reach so it could be allocated between the regional ground-water flow system and ephemeral ground-water discharge into stream channels; this was done because the standard ground-water algorithms in HSPF do not allow simulation of ephemeral ground-water discharge. Also, in the Dry Creek Basin model, a constant amount of ground-water discharge was routed to the reach that represents Rattlesnake Springs (D4)--the actual source of ground water to Rattlesnake Springs is not known, so no specific source was identified in the model. Discharge to those springs was assumed to be constant throughout the period of simulation and not affected by seasonal variations in ground-water recharge, so a separate groundwater reach was not needed to represent the source of the spring water. For all other areas represented in the models, direct recharge from land segments was assumed to recharge the regional ground-water system and was not routed to any channel reaches in the study area.

Streamflow in all channel reaches was routed either downstream or to below-channel land segments as infiltrated runoff. All streamflow in upper Cold Creek Basin (reaches $\mathrm{C} 1, \mathrm{C} 2$, and $\mathrm{C} 3$ ) was routed to the next downstream reach; no infiltration was simulated for those nonalluvial channels. All streamflow from reach D4 in the Dry Creek model was also routed downstream; no infiltration was simulated because ground water is discharged to Rattlesnake Springs in this reach. Streamflow in all other reaches was first apportioned to meet the channel infiltration demand, and any remaining flow was routed downstream. Water apportioned to channel infiltration was routed to below-channel land segments. Those segments were used to simulate the storage and evapotranspiration of infiltrated runoff from alluvial sediments, which the standard HSPF channel-routing algorithms do not 


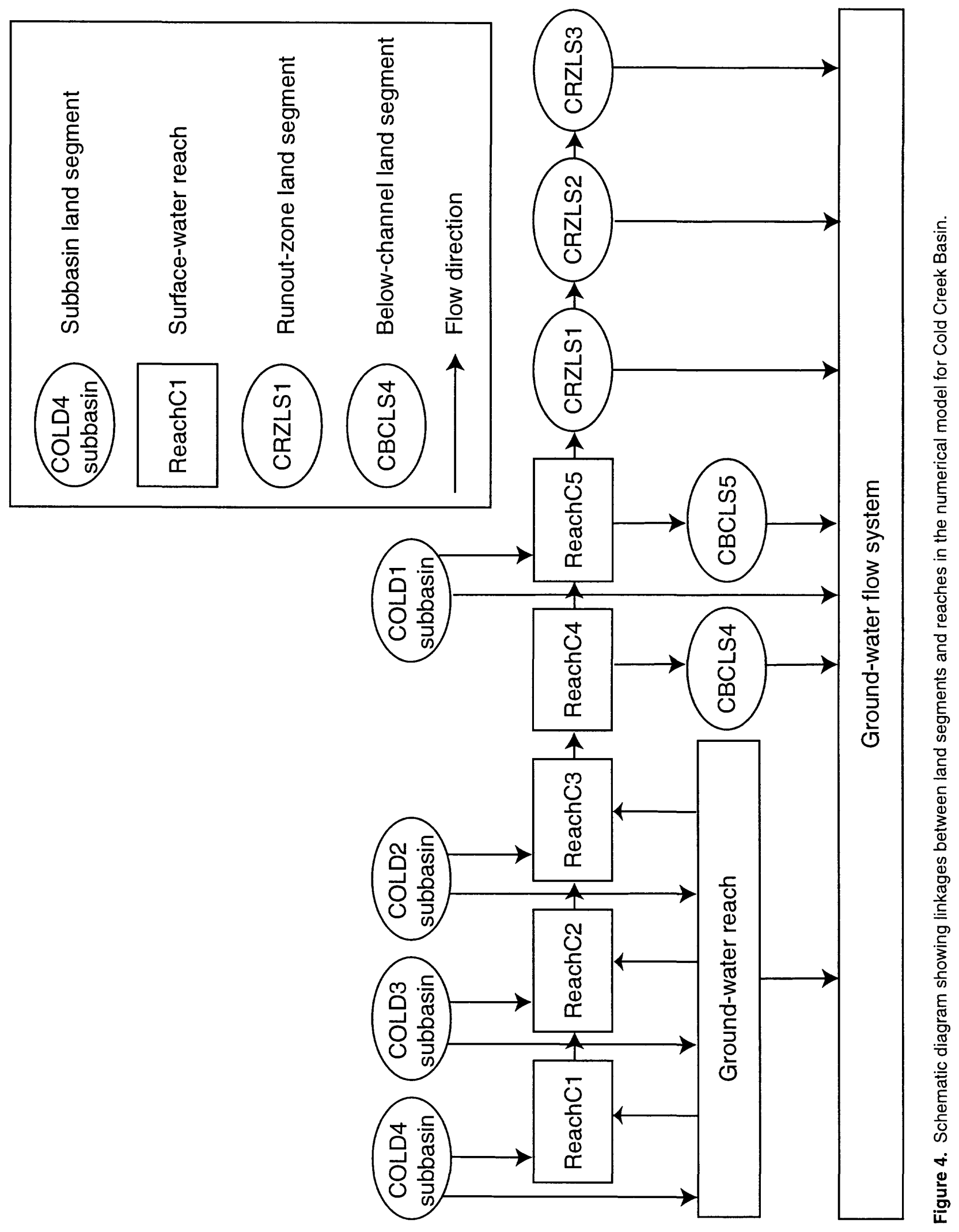




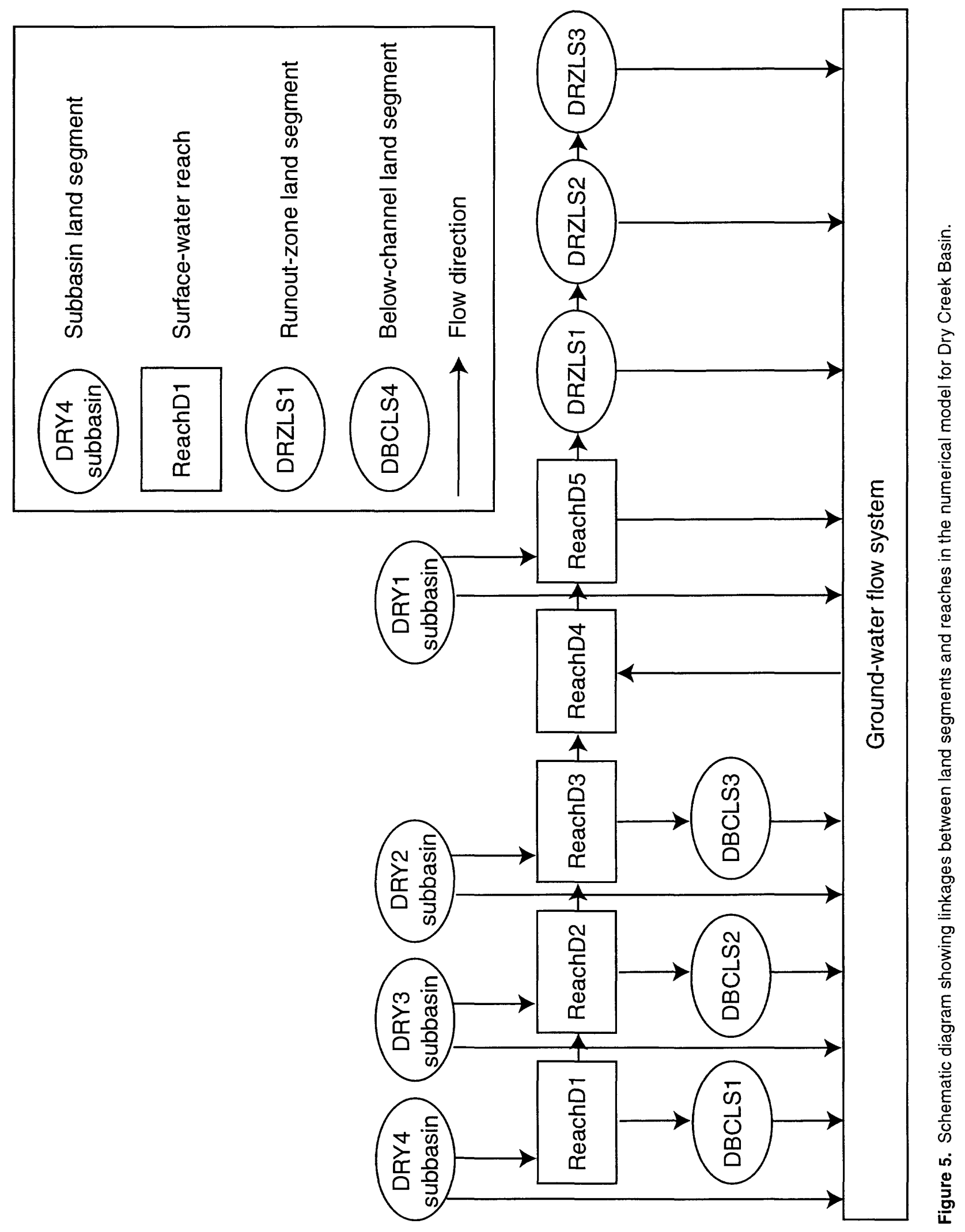


simulate. Water that was neither stored in nor evapotranspired from below-channel land segments was considered a source of recharge from runoff.

All streamflow remaining in the furthest downstream reaches defined for Cold Creek and Dry Creek (C5 and D5, respectively) was routed to a series of runout-zone land segments designed to simulate variable areas of inundation that would result from variable volumes of runoff. The runout zones for Cold Creek and Dry Creek were each represented by a series of three land segments. Streamflow onto the first segment was first apportioned to infiltration, and any remaining flow was routed downstream to the second segment. Streamflow onto the second segment was treated likewise, but streamflow onto the third and final segment was all apportioned to infiltration. For all segments, the infiltrated water was further apportioned between evapotranspiration and percolation, and the latter was considered to be a source of recharge from runoff.

\section{Estimation and Calibration of Parameter Values}

Parameter values were estimated from physiographic data, channel geometry data, theoretical hydraulic formulas, and information derived from other investigations. Selected values were calibrated to observed hydrologic data, but many other parameter values--as well as the complete numerical models--could not be calibrated and tested over the full range of expected climate conditions.

Because it is not technically sound to quantify calibration errors on the basis of limited available data, a qualitative discussion of model sensitivity and errors is presented. Additional hydrologic data would be needed to further assess model calibration and performance.

\section{Land-Segment Parameters}

Land-segment parameters are related to snow accumulation and melt, evapotranspiration, runoff timing, and infiltration. All parameter values for the various landsegment types are listed in the HSPF input files in Appendixes 1 through 7.

\section{Snow accumulation and melt parameters}

Most parameter values related to snow accumulation and melt on land segments were estimated from published reports on snow hydrology. A sensitivity analysis showed that simulated snow accumulation and melt was most sensitive to the coefficient that adjusts measured snowfall to account for undercatch of snow by the gage (SNOWCF), and to two empirical parameters--the sublimation adjustment coefficient (SNOEVP) and the condensation/convection melt coefficient (CCFACT). The value for SNOWCF was set at 1.25, which assumes the precipitation gages catch only 80 percent of actual snowfall. That value was estimated from a graph of windspeed and snowfall catch efficiency (Goodison and McKay, 1978) using the average winter windspeeds at the HMS of about 2 meters per second. The values for SNOEVP and CCFACT were calibrated to daily snow depth data from the HMS for water years 1977-90. The simulated and observed snow depths for two selected winters with above average snowfall (figure 6) are indicative of the calibration results. The model simulated the ephemeral occurrence of snowcover quite well, but it simulated the absolute snowdepth less accurately. Snow-water equivalent data were not available for the calibration.

\section{Evapotranspiration parameters}

Parameter values related to evapotranspiration from land segments were estimated using information from previous investigations in the study area. Monthly values for interception storage capacity (CEPSC) and lower zone evapotranspiration index (LZETP) were extracted from Bauer and Vaccaro's Deep Percolation Model for eastern Washington (1987) and from an unpublished recharge model produced for the Basalt Waste Isolation Project (C.R. Cole, Pacific Northwest Laboratory, written commun., 1984). Values for the lower soil-zone storage capacity indices (LZSN) were estimated from soil-water storage capacity data compiled by T.A. Zimmerman (Pacific Northwest Laboratory, written commun., 1985). Parameter values related to evapotranspiration from belowchannel land segments were set to represent sand and cobble materials with sparse vegetal cover on the basis of the author's experience with HSPF.

Simulation of total evapotranspiration from grass covered land segments was assessed using calculated evapotranspiration data for the period June 1990September 1991 from two experimental sites in Dry Creek Basin (Tomlinson, 1994; G.W. Gee, Pacific Northwest Laboratory, written commun., 1993; S.A. Tomlinson, U.S. Geological Survey, written commun., 1995). Instrumentation that allowed estimation of evapotranspiration using the Bowen-ratio method was in place at one site, and a weighing lysimeter was in place at the second site. Both sites were grass covered. Total ET was simulated with HSPF for the two sites using appropriate climate data for 


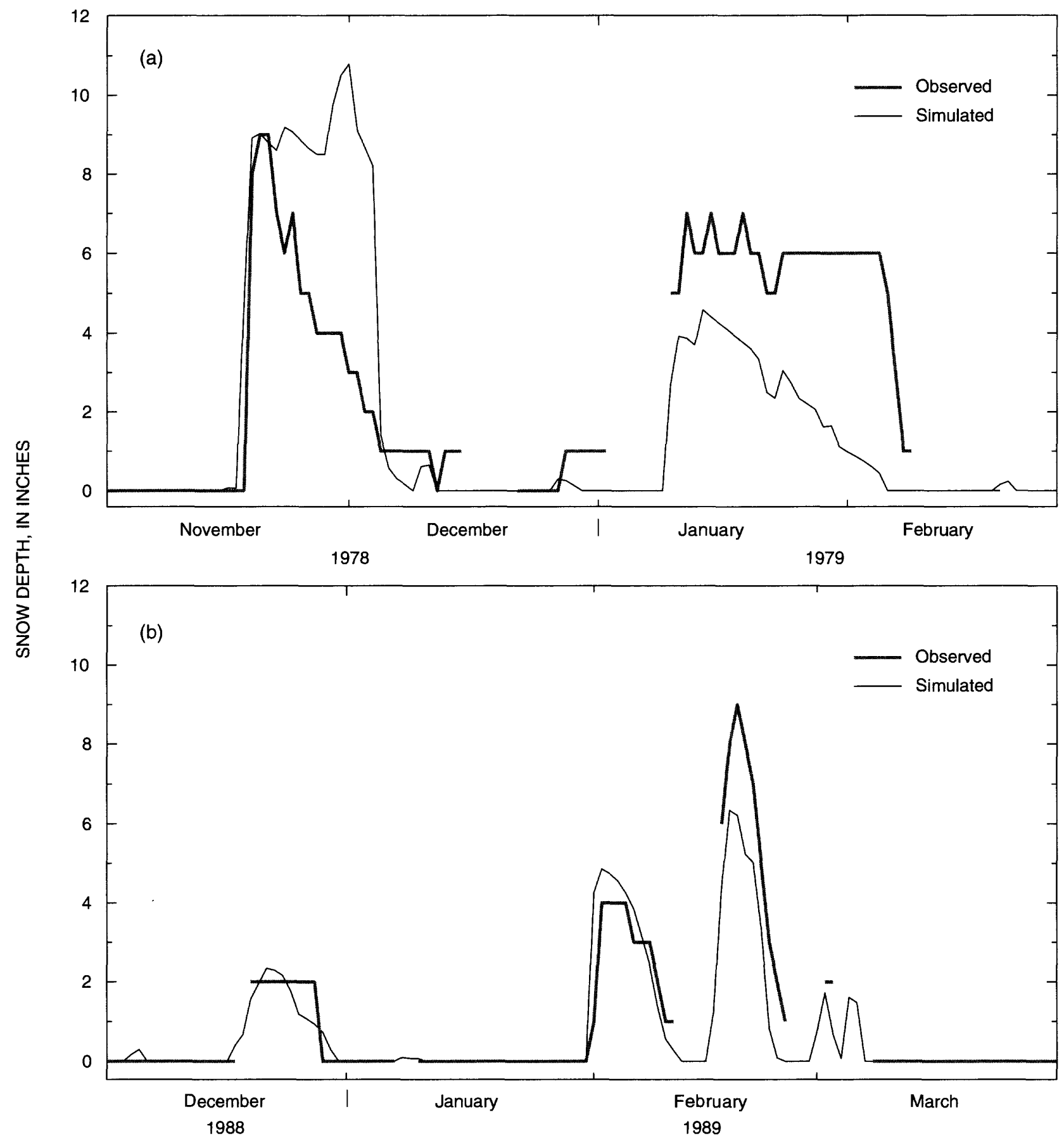

Figure 6. Observed and simulated snow depth at the Hanford Meteorological Station for (a) November 1978 to February 1979, and (b) December 1988 to March 1989. 
the defined climate zones of the experimental sites. The calculated data and the HSPF simulation results from three different values for the LZSN parameter are shown in figure 7. The three parameter values included the original estimated value for grass-covered land segments underlain by deep soils with high available-water capacities, and values reflecting soil available-moisture capacities 20 percent greater than and less than the original estimated value. All three parameter values resulted in reasonable evapotranspiration simulations at both sites. Runoff-particularly winter runoff--is only slightly affected by evapotranspiration through the influence of ET on antecedent soil-moisture conditions, so the original estimates for all three evapotranspiration parameter values (LZSN, CEPSC, and LZETP) for grass-covered land segments appeared to be fully adequate for this investigation. Data were not available to assess the adequacy of parameter values for other land segment types.

\section{Runoff-timing parameters}

Parameter values that primarily control only the timing of runoff--average length, slope, and roughness of overland flow planes (LSUR, SLSUR, and NSUR respectively), the interflow index (INTFW), and upper soil-zone storage capacity index (UZSN)-- were estimated directly from field or map measurements or from the author's experience. There were no available data to calibrate or assess the validity of those values, but their influence on simulated runoff and recharge volumes is minor.

\section{Infiltration parameters}

Parameter values related to infiltration into both frozen and thawed soils (the infiltration index INFILT and the infiltration-equation exponent INFEXP) were determined through calibration to available streamflow data after all other model parameter values were either estimated or calibrated. A sensitivity analysis, wherein changes in simulated runoff relative to changes in model parameter values were assessed, showed that simulated runoff is most sensitive to the values for INFILT and INFEXP. Continuous records of streamflow observed during October 1990 through May 1993 (table 4) and four instantaneous peak-discharge estimates of historic flows (table 13) were used for calibration. The available data were not ideal for calibration; no substantial runoff occurred during the period October 1990-May 1993, when continuous records of streamflow were collected and no runoff volume data were available with the historic peak-discharge data. However, the peak discharge data were used anyway because they are somewhat indicative of the magnitude of historic runoff.

The same values for INFILT and INFEXP were assigned to all land segment types. This simplification was justified because actual infiltration characteristics are likely similar for the fine-textured soils that cover most of the study area and because the observed streamflow data were not adequate to realistically ascertain subtle differences. Simulated infiltration still did vary between land segments because of the variation in previously assigned available-water capacity and evapotranspiration related parameter values.

To calibrate INFILT and INFEXP, values were adjusted for thawed conditions to simulate no significant runoff during the October 1990-May 1993 (as was observed). Then, values were adjusted for frozen-soil conditions to simulate substantial runoff to coincide with the four historical peak discharges while still simulating little or no runoff for October 1991-May 1993. Accurate simulation of 1990-93 runoff volumes was given much greater emphasis than accurate simulation of historical peak flows because peak flows in the study area are not well correlated with runoff volumes. For example, peak discharges associated with recent runoff were greatly affected by sudden releases of runoff from temporary storage behind tumbleweed-and sediment-choked culverts and channels. Thus, a small volume of runoff often resulted in a large peak discharge. The observed data were not available to simulate those random storages and releases of runoff.

The final calibrated parameters resulted in simulated historical peak discharges that were consistently less than observed (table 13). No storm runoff was simulated for January 13, 1969, when runoff was observed in lower Dry Creek. The model did predict frozen ground throughout the basin, but air temperatures were below freezing from January 12 through February 3 , so all precipitation was simulated as snowfall and essentially no snow was melted. A peak discharge of only $31 \mathrm{ft}^{3} / \mathrm{s}$ was simulated for January 14, 1970, when runoff was observed in lower Dry Creek. Rapid snowmelt was simulated for that day, but most of that was held in the deep, dry snowpack and was not available for runoff. Sustained, above freezing temperatures and rainfall did result in significant simulated runoff for the following week; a peak discharge of $345 \mathrm{ft}^{3} / \mathrm{s}$ was simulated for January 24,1970 . A peak discharge of only $156 \mathrm{ft}^{3} / \mathrm{s}$ was simulated for January 16 , 1971 , in upper Dry Creek; the observed peak discharge was $2,280 \mathrm{ft}^{3} / \mathrm{s}$. The model predicted frozen ground 

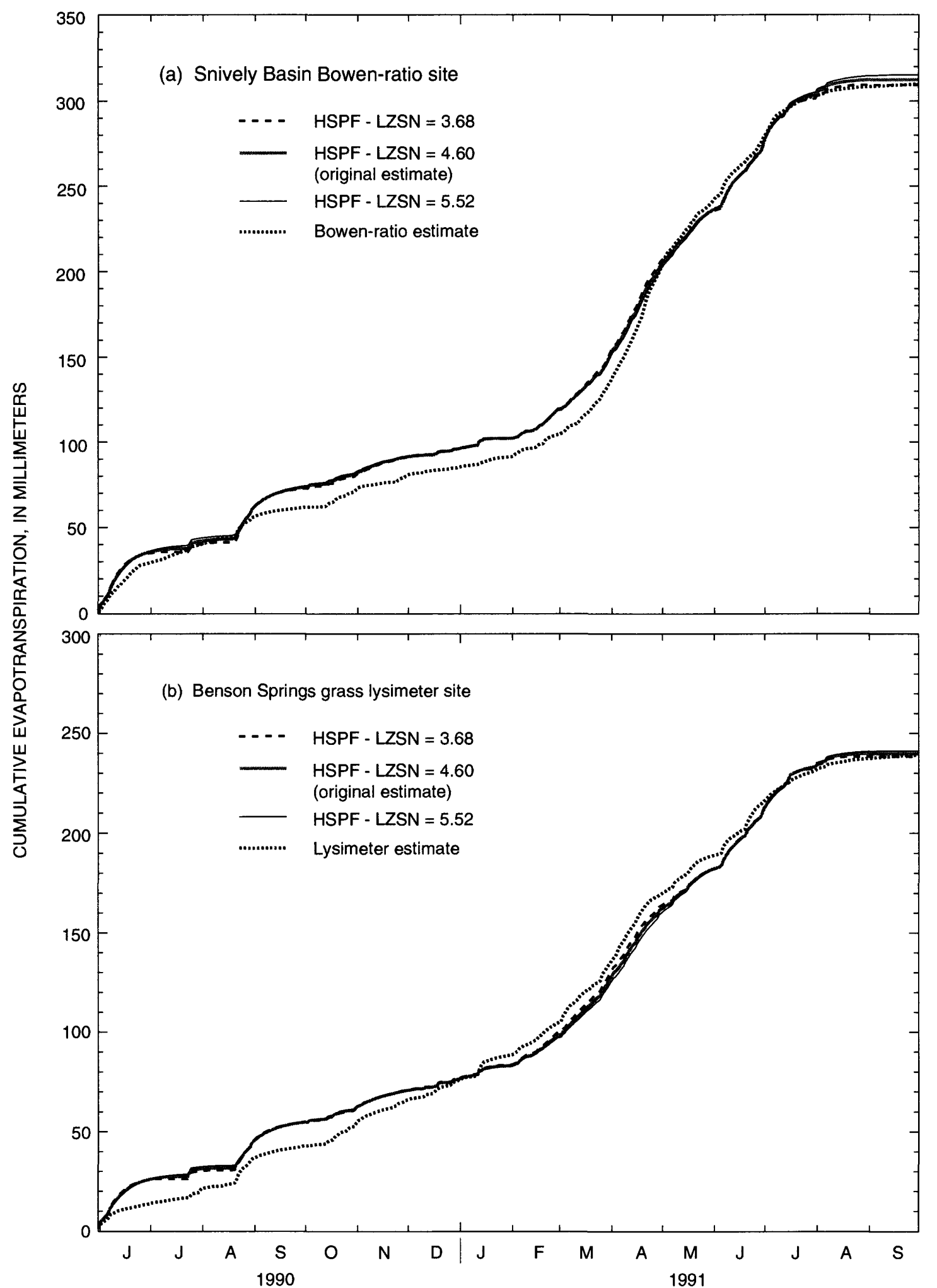

Figure 7. Simulated and calculated evapotranspiration estimates for (a) the Snively Basin Bowen-ratio site, and (b) the Benson Springs grass lysimeter site. HSPF - LZSN refers to the value of the lower-zone nominal storage capacity parameter used to get these results from the HSPF simulation model. 
Table 13.--Observed data and simulated peak discharges and runoff volumes from the calibrated numerical models

[Max.Q, maximum instantaneous discharge; $\mathrm{ft}^{3} / \mathrm{s}$, cubic feet per second; acre-ft, acre-feet; e, estimated; missing data denoted by “.”; na, not applicable]

\begin{tabular}{|c|c|c|c|c|c|c|c|c|c|}
\hline \multirow[b]{2}{*}{ Date } & \multicolumn{2}{|c|}{$\begin{array}{l}\text { Upper Cold Creek } \\
\text { Station } 12510618\end{array}$} & \multicolumn{2}{|c|}{$\begin{array}{l}\text { Lower Cold Creek } \\
\text { Station } 12510625\end{array}$} & \multicolumn{2}{|c|}{$\begin{array}{l}\text { Upper Dry Creek } \\
\text { Station } 12510650\end{array}$} & \multicolumn{3}{|c|}{$\begin{array}{l}\text { Lower Dry Creek } \\
\text { Station } 12510655\end{array}$} \\
\hline & $\begin{array}{l}\text { Max.Q } \\
\left(\mathrm{ft}^{3} / \mathrm{s}\right)\end{array}$ & $\begin{array}{l}\text { Total } \\
\text { (acre-ft) }\end{array}$ & $\begin{array}{l}\operatorname{Max} . Q \\
\left(\mathrm{ft}^{3} / \mathrm{s}\right)\end{array}$ & $\begin{array}{c}\text { Total } \\
\text { (acre-ft) }\end{array}$ & $\begin{array}{l}\text { Max.Q } \\
\left(\mathrm{ft}^{3} / \mathrm{s}\right)\end{array}$ & $\begin{array}{l}\text { Total } \\
\text { (acre-ft) }\end{array}$ & $\begin{array}{l}\text { Max.Q } \\
\left(\mathrm{ft}^{3} / \mathrm{s}\right)\end{array}$ & $\begin{array}{c}\text { Total } \\
\text { (acre- } \mathrm{ft}\end{array}$ & \\
\hline \multicolumn{10}{|c|}{ Observed Discharge } \\
\hline $01 / 13 / 1969$ & . & & . & . & & . & 190 & . & \\
\hline $01 / 14 / 1970$ & . & . & . & . & & . & 350 & . & \\
\hline $01 / 16 / 1971$ & . & . & . & . & 2,280 & . & . & . & \\
\hline 03/06/1989 & . & . & 244 & . & & . & . & . & \\
\hline WY 1991 & 0 & 0 & 170 & 5.7 & $5.0 \mathrm{e}$ & $9.9 \mathrm{e}$ & 74.0 & 345 & $\mathrm{e}$ \\
\hline WY 1992 & 10.0 & 0.30 & 2.6 & 0.24 & 0 & 0 & 0.52 & 308 & $\mathrm{e}$ \\
\hline Oct-May 1993 & 14.6 & 83.8 & $5.3 \mathrm{e}$ & $1.50 \mathrm{e}$ & 0 & 0 & 0.50 & 195 & $\mathrm{e}$ \\
\hline 1991-93 Total & na & 101 & na & $7.5 \mathrm{e}$ & na & $9.9 \mathrm{e}$ & na & 848 & e \\
\hline \multicolumn{10}{|c|}{ Simulated Discharge } \\
\hline $01 / 13 / 1969$ & na & na & na & na & na & na & 0.45 & na & \\
\hline $01 / 14 / 1970$ & na & na & na & na & na & na & $31 .^{1}$ & na & \\
\hline $01 / 16 / 1971$ & na & na & na & na & 156 & na & na & na & \\
\hline 03/06/1989 & na & na & 103 & na & na & na & na & na & \\
\hline WY 1991 & 7.8 & 13.9 & 0 & 0 & 0.61 & 0.10 & 0.45 & 309 & \\
\hline WY 1992 & 3.0 & 14.0 & 0 & 0 & 0 & 0 & 0.45 & 309 & \\
\hline Oct-May 1993 & 41.1 & 160 & 51.6 & 54.5 & 0 & 0 & 205 & 341 & \\
\hline 1991-93 Total & na & 188 & na & 54.5 & na & 0.10 & na & 957 & \\
\hline
\end{tabular}

${ }^{1}$ A peak discharge of $345 \mathrm{ft}^{3} / \mathrm{s}$ was simulated for January $24,1970$.

throughout most of the basin, but the input precipitation and simulated snowmelt were not enough to generate a peak discharge as large as the observed peak. Even when model parameter values were adjusted so that infiltration was essentially zero, the simulated peak discharge was still an order of magnitude less than the observed value; such results indicate that the actual precipitation that led to runoff during that time was not represented in the input climatic data. The model correctly simulated frozen ground and snowmelt runoff for March 6, 1989, but the simulated peak discharge in lower Cold Creek was 58 percent less than that observed. When parameter values were adjusted to simulate essentially no infiltration, the peak discharge was still 25 percent less than observed.
Although most of the observed low-volume runoff for water years 1991-93 was poorly simulated (figs. 8-9 and table 13), the final calibrated parameters correctly simulated the lack of substantial runoff during the period. No storm runoff was simulated for January 12 or June 20 , 1991, in lower Dry Creek (fig. 9). The January 12 runoff resulted from the rapid melting of snow that had accumulated as drifts in the incised stream channels. Redistribution of snow by wind was not considered in the models, so they simulated the melting of a thin, dispersed snowpack that did not result in runoff. The June 20 runoff was a result of a localized intense precipitation that was not represented in the precipitation data used for the simulations. No runoff was simulated for June 29, 1991, in lower Cold 


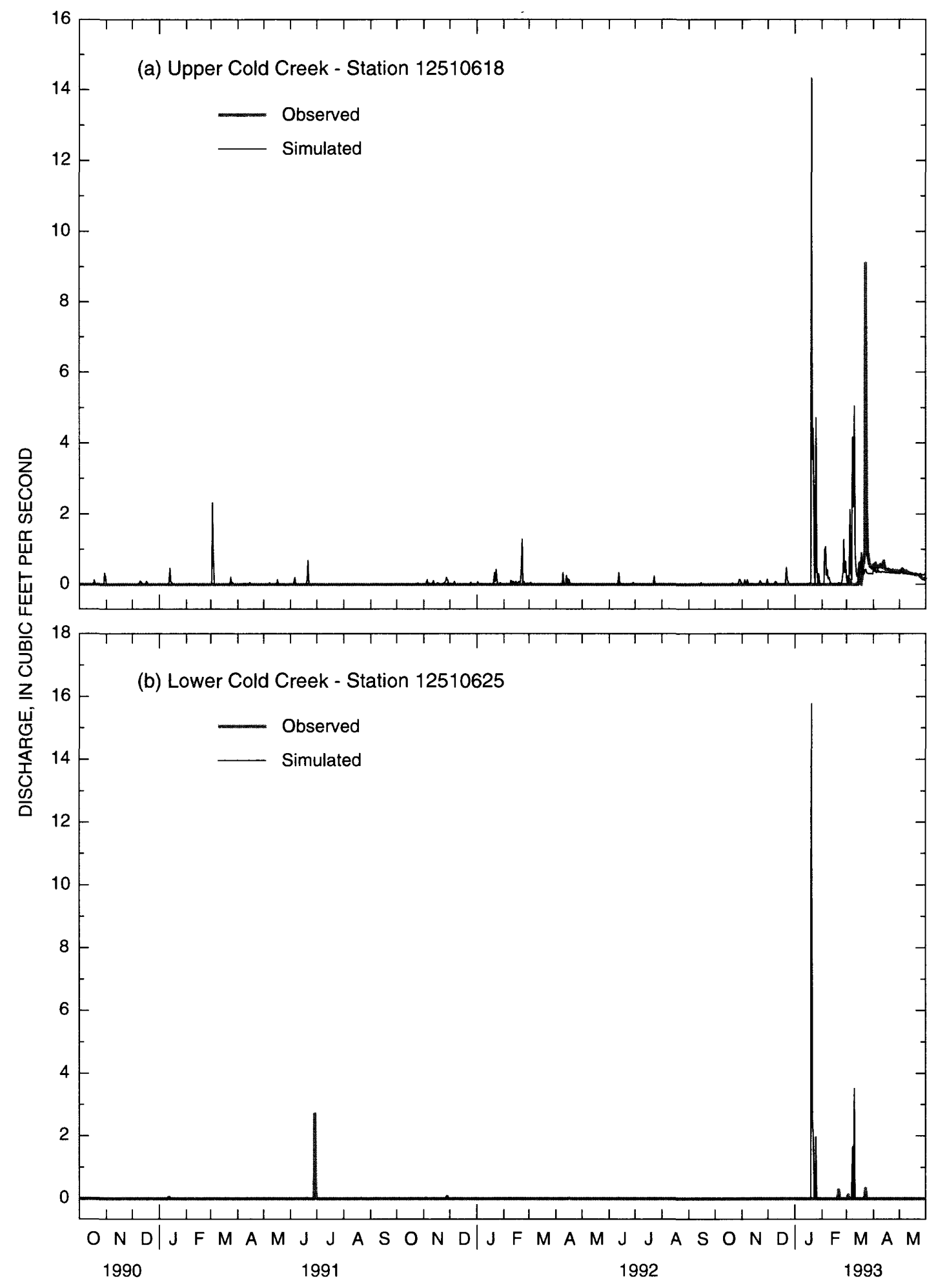

Figure 8. Observed and simulated daily mean discharge for October 1990 to May 1993, for (a) Upper Cold Creek Basin, and (b) Lower Cold Creek Basin. 


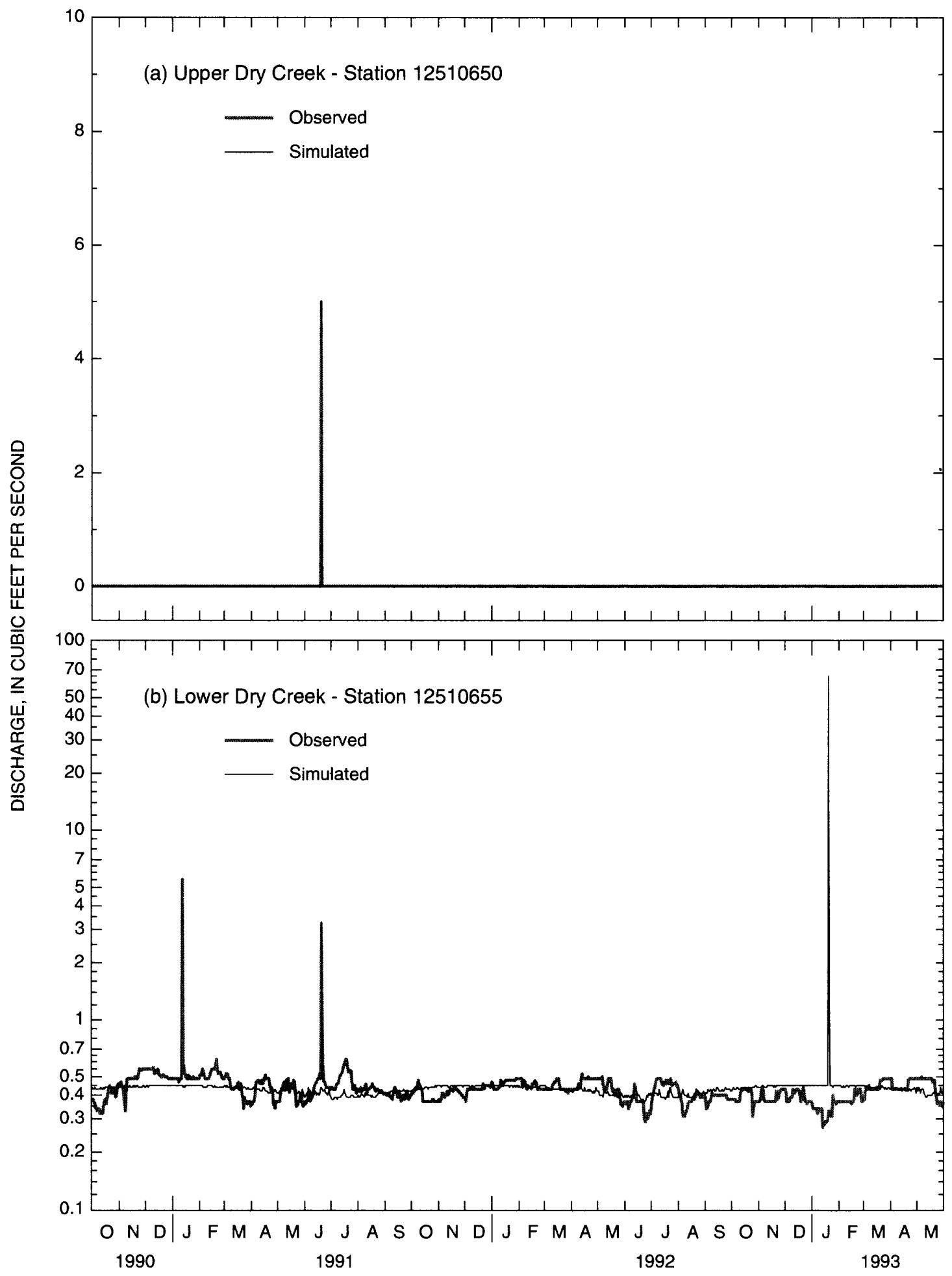

Figure 9. Observed and simulated daily mean discharge for October 1990 to May 1993, for (a) Upper Dry Creek Basin and (b) Lower Dry creek Basin. 
Creek (fig. 8) for similar reasons. The observed runoff was a result of localized intense precipitation that was not represented in the precipitation data used for the simulations. The relatively large observed peak discharge of $61 \mathrm{ft}^{3} / \mathrm{s}$ from that runoff was also a result of rapidly released waters that were ponded behind a temporarily plugged culvert. Minor volumes of streamflow were simulated for upper Cold Creek during 1991-92, when none were recorded at the streamflow-gaging station. Minor runoff was observed in the upper basin during this period, but it was infiltrated into tributary channel bottoms before it reached the streamflow-gaging station. In the Cold Creek model, infiltration into channel deposits was not simulated in the upper basin because the alluvial channel deposits are either absent or only a few feet thick. Excess streamflow was simulated in upper Cold Creek and in lower Dry and Cold Creeks during snowmelt periods in January and March, 1993. The models correctly simulated snowmelt over frozen soils that was observed in January, but the actual snowmelt was stored in the snowpack itself, whereas the simulated snowmelt saturated the snowpack and resulted in streamflow. The models simulated snowmelt over some frozen and some thawed soils in March, as was observed, but they simulated too much melt early in the month when the ground was still frozen, so simulated streamflows were greater than observed.

Through trial and error, no combination of INFILT and INFEXP parameter values could accurately simulate all observed data--historical peak discharges were consistently underestimated, and 1990-93 streamflow was consistently overestimated. Given the likely poor correlation between the historical peak discharges and the unknown associated runoff volumes, the 1990-93 simulation results were assumed to be more indicative of overall model performance. Thus, the final parameter values were set to simulate a plausible upper limit for runoff and recharge primarily on the basis of 1990-93 simulation results.

Parameter values were assigned to make infiltration capacities moderately high when soils were not frozen and very low when soils were frozen, and the models were constructed to instantaneously switch from one parameter value to the other during a freeze or thaw. In reality, infiltration capacities of frozen soils vary greatly from storm to storm, primarily as a function of the water content of the upper soil layer and of the depth, duration, and rapidity of frost formation. Also, the actual transition from thawed to frozen conditions is gradual rather than instantaneous. The assigned parameter values represent little infiltration into frozen soils for all instances, so they may oversimulate runoff from some periods, as was seen for January and
March of 1993. Given that errors in almost all other components of the numerical models--including inaccuracies in the input climate data--are reflected in the calibration results, much uncertainty remains regarding how well the calibrated values represent the actual infiltration characteristics of the study area.

\section{Reach Parameters}

The important reach parameter values are in FTABLES, which define the discharge from the downstream end of a reach or a channel bottom as a function of the volume in the reach. The FTABLES for all reaches are listed in the HSPF input files in Appendixes 1 through 7. Values in all standard FTABLES were not calibrated; they were estimated directly from field and map measurements. The volumes of water in a reach for selected flow depths were determined from field measurements of representative channel cross sections and map measurements of channel length; the corresponding downstream discharges were estimated using Manning's equation. An estimate of total wetted-channel area was also made for each flow depth. Storage and discharge values for the FTABLE used to represent the ground-water reach in upper Cold Creek Basin were calibrated to match the observed 1990-93 baseflow discharge in upper Cold Creek.

The discharges representing channel infiltration were estimated for a reach by multiplying the corresponding wetted-channel area by an average infiltration rate of 4 inches per hour. That average infiltration capacity was estimated using the few observed runoff data from the basins. Soil-moisture measurements were made in access tube $\mathrm{C} 2$ immediately before and 17 hours after runoff flowed over the site (fig. 3). Water was still ponded around the tube when the second measurement was made, and the wetting front had moved downward at a rate of about 4 inches per hour. Also, the downstream extent of surface flow was noted for the few flood waves that passed the streamflow-gaging stations. From those data, the average unit-area infiltration rate was estimated by dividing the peak discharge by the total downstream wettedchannel area. The resulting estimates are likely larger than the actual infiltration rates because the calculation assumes that attenuation of the runoff peak was from channel infiltration only. The estimated loss rates were 2 and 5 inches per hour for events observed in Cold Creek Basin, and were 5 and 8 inches per hour for events observed in Dry Creek Basin. 


\section{SYNTHESIS OF LONG-TERM CLIMATE DATA}

Synthesized long-term (October 1957 through May 1993) data sets of hourly precipitation, air temperature, dew point, solar radiation, and potential evapotranspiration--in addition to observed windspeed and solar radiation data--were used to estimate long-term average values for runoff and recharge. The climate data were synthesized by adjusting long-term data observed at nearby weather stations to account for location and altitude variability across the study area.

Seventeen precipitation data sets were synthesized from daily data observed at the HMS, Moxee City $10 \mathrm{E}$, Priest Rapids Dam, and Sunnyside weather stations. The study basins were first divided into five precipitation regions on the basis of correlation of precipitation totals to data from the four long-term stations (table 2). The UCOLD precipitation region contained subbasin COLD4; the LCOLD region contained subbasins COLD3, COLD2, and COLD1; the UDRY region contained subbasin DRY4; the MDRY region contained subbasin DRY3; and the LDRY region contained subbasins DRY2 and DRY1. Daily precipitation data from the long-term stations located outside of the study area were then multiplied by adjustment factors to represent study-area precipitation. The adjustment factors accounted for precipitation variation due to location and altitude. Variation due to location was accounted for by using different long-term station data for different precipitation regions in the study area; Priest Rapids Dam data were used for the UCOLD region, HMS data were used for the LCOLD and LDRY regions, Moxee City $10 \mathrm{E}$ data were used for the UDRY region, and Sunnyside data were used for the MDRY region. The location components of the adjustment factors were determined by comparing monthly precipitation totals from the long-term stations to data from USGS recording precipitation stations located within the study basins. Precipitation variation with altitude within a given region was calculated using data from all of the USGS precipitation stations in the study area. The resulting increases in precipitation with altitude ranged from 0.24 inches per thousand feet in Cold Creek Basin to 0.79 inches per thousand feet in Dry Creek Basin. Finally, the adjusted daily values for all regions and altitudes were disaggregated into hourly values according to the hourly distribution of precipitation recorded at the HMS, which were the only observed hourly data available.

Four air temperature and dew-point temperature datasets, one for each of the four altitude categories (table 11 ), were synthesized from hourly data observed at the
HMS. The HMS air temperature data were adjusted for the average altitude within each zone using dry and wet lapse rates. The dry lapse rate of $5^{\circ} \mathrm{F}$ per 1,000 feet was used when no precipitation was recorded, and the wet lapse rate of $3.5^{\circ} \mathrm{F}$ per 1,000 feet was used when precipitation was recorded. The HMS dew point data were adjusted by estimating the decrease in vapor pressure with altitude (Reitan, 1963) and then calculating an adjusted dew point using the lapsed temperature and vapor pressure data.

Four solar radiation datasets, one for each of the moderate and steep slope/aspect categories (table 10), were synthesized from hourly data observed at the HMS; the HMS data were used directly for the two mild-slope categories. The HMS data--representing solar radiation on a horizontal plane--were adjusted for the different slopes and aspects using an algorithm that considers latitude, day of year, and land-surface slope and aspect (Kaufman and Weatherred, 1982).

Windspeed data from the HMS were used directly for all areas in the study basins. Windspeed does vary across the basins, but the data needed to accurately adjust for that variation were not available.

Twenty potential evapotranspiration data sets--one for each unique altitude/slope/aspect zone--were synthesized from the previously adjusted air temperature and solar radiation data using a method from Jensen (1973). Daily PET was computed as a function of daily incident solar radiation, average daily air temperature, and land-surface altitude. Hourly PET was estimated by disaggregating the daily values according to the hourly distribution of solar radiation.

\section{ESTIMATES OF RUNOFF AND RECHARGE FROM RUNOFF}

The synthesized long-term climate data were input to the calibrated numerical models to simulate runoff and recharge from runoff for the 1958-93 water years (tables 14 and 15). The runoff estimates in table 14 represent simulated surface-water flows in the study area and include storm-generated runoff, discharge from Rattlesnake Springs, and discharge from the unnamed ephemeral springs along upper Cold Creek. The recharge estimates in table 15 represent the amount of simulated runoff that was infiltrated and percolated below the zone of active evapotranspiration; the recharge from runoff estimates do not include recharge from direct infiltration and 
Table 14.--Simulated annual runoff for delineated subbasins in the study area for water years 1958-93

[Avg., average annual runoff for water years 1958-93]

Runoff, in acre-feet per year

\begin{tabular}{|c|c|c|c|c|c|c|c|c|c|c|}
\hline $\begin{array}{l}\text { Water } \\
\text { year }\end{array}$ & COLD4 & COLD3 & COLD2 & COLD1 & $\begin{array}{l}\text { COLD } \\
\text { TOTAL }\end{array}$ & DRY4 & DRY3 & DRY2 & DRY 1 & $\begin{array}{l}\text { DRY } \\
\text { TOTAL }\end{array}$ \\
\hline 1958 & 686 & 240 & 58 & 20 & 1,000 & 188 & 112 & 426 & 464 & 1,190 \\
\hline 1959 & 892 & 484 & 208 & 154 & 1,740 & 152 & 343 & 729 & 623 & 1,850 \\
\hline 1960 & 32 & 11 & 5 & 5 & 53 & 25 & 90 & 7 & 312 & 435 \\
\hline 1961 & 191 & 110 & 23 & 9 & 334 & 214 & 34 & 355 & 440 & 1,040 \\
\hline 1962 & 45 & 13 & 5 & 8 & 71 & 50 & 25 & 44 & 330 & 449 \\
\hline 1963 & 178 & 178 & 90 & 95 & 541 & 330 & 15 & 500 & 544 & 1,390 \\
\hline 1964 & 83 & 6 & 3 & 6 & 98 & 9 & 127 & 32 & 327 & 496 \\
\hline 1965 & 2,140 & 109 & 23 & 21 & 2,290 & 787 & 1,530 & 137 & 380 & 2,840 \\
\hline 1966 & 41 & 4 & 3 & 6 & 53 & 31 & 46 & 15 & 317 & 410 \\
\hline 1967 & 363 & 17 & 7 & 8 & 394 & 26 & 121 & 19 & 317 & 482 \\
\hline 1968 & 97 & 2 & 1 & 3 & 103 & 7 & 4 & 6 & 311 & 328 \\
\hline 1969 & 219 & 100 & 31 & 20 & 371 & 62 & 112 & 92 & 344 & 611 \\
\hline 1970 & 1,530 & 242 & 102 & 86 & 1,960 & 218 & 638 & 373 & 489 & 1,720 \\
\hline 1971 & 237 & 30 & 9 & 7 & 283 & 156 & 19 & 88 & 348 & 611 \\
\hline 1972 & 5 & 2 & 2 & 6 & 16 & 25 & 10 & 10 & 314 & 359 \\
\hline 1973 & 3 & 152 & 27 & 14 & 197 & 186 & 158 & 483 & 475 & 1,300 \\
\hline 1974 & 977 & 294 & 95 & 52 & 1,420 & 320 & 596 & 368 & 442 & 1,730 \\
\hline 1975 & 109 & 155 & 47 & 11 & 322 & 37 & 141 & 31 & 319 & 527 \\
\hline 1976 & 13 & 7 & 4 & 7 & 32 & 8 & 7 & 13 & 315 & 343 \\
\hline 1977 & 2 & 2 & 2 & 4 & 10 & 7 & 3 & 5 & 311 & 326 \\
\hline 1978 & 107 & 188 & 87 & 66 & 447 & 1,150 & 372 & 334 & 455 & 2,310 \\
\hline 1979 & 8 & 6 & 3 & 4 & 22 & 31 & 80 & 6 & 311 & 427 \\
\hline 1980 & 243 & 151 & 82 & 321 & 798 & 801 & 1,060 & 399 & 631 & 2,880 \\
\hline 1981 & 945 & 52 & 16 & 10 & 1,020 & 164 & 288 & 55 & 328 & 836 \\
\hline 1982 & 71 & 84 & 12 & 7 & 175 & 125 & 290 & 224 & 373 & 1,010 \\
\hline 1983 & 967 & 485 & 208 & 162 & 1,820 & 862 & 517 & 197 & 381 & 1,960 \\
\hline 1984 & 249 & 313 & 206 & 201 & 969 & 27 & 15 & 913 & 686 & 1,640 \\
\hline 1985 & 35 & 42 & 17 & 8 & 103 & 11 & 13 & 18 & 315 & 357 \\
\hline 1986 & 165 & 489 & 166 & 134 & 954 & 57 & 71 & 1,060 & 664 & 1,850 \\
\hline 1987 & 41 & 25 & 10 & 7 & 82 & 35 & 6 & 9 & 314 & 364 \\
\hline 1988 & 320 & 28 & 10 & 9 & 368 & 52 & 30 & 88 & 352 & 522 \\
\hline 1989 & 46 & 52 & 18 & 20 & 137 & 138 & 51 & 37 & 323 & 548 \\
\hline 1990 & 4 & 3 & 2 & 6 & 14 & 11 & 4 & 7 & 313 & 335 \\
\hline 1991 & 11 & 3 & 3 & 7 & 23 & 22 & 5 & 10 & 314 & 352 \\
\hline 1992 & 8 & 6 & 3 & 9 & 26 & 15 & 123 & 32 & 321 & 492 \\
\hline $1993^{1}$ & 66 & 110 & 59 & 148 & 382 & 17 & 117 & 234 & 463 & 830 \\
\hline Avg. & 308 & 117 & 46 & 46 & 517 & 177 & 199 & 204 & 396 & 976 \\
\hline
\end{tabular}

${ }^{1}$ Values for June-September 1993 were estimated, not modeled. 
Table 15.--Simulated annual recharge from runoff for delineated subbasins the study area for water years 1958-93 [Avg., average annual recharge from runoff for the 1958-93 water years]

Recharge from runoff, in acre-feet per year

\begin{tabular}{|c|c|c|c|c|c|c|c|c|}
\hline $\begin{array}{l}\text { Water } \\
\text { year }\end{array}$ & COLD2 & COLD1 & $\begin{array}{l}\text { COLD } \\
\text { TOTAL }\end{array}$ & DRY4 & DRY3 & DRY2 & DRY1 & $\begin{array}{l}\text { DRY } \\
\text { TOTAL }\end{array}$ \\
\hline 1958 & 427 & 424 & 851 & 106 & 114 & 184 & 574 & 978 \\
\hline 1959 & 649 & 940 & 1,589 & 116 & 255 & 320 & 870 & 1,560 \\
\hline 1960 & 37 & 2 & 39 & 20 & 76 & 7 & 277 & 381 \\
\hline 1961 & 161 & 117 & 278 & 161 & 62 & 172 & 480 & 876 \\
\hline 1962 & 44 & 4 & 48 & 40 & 18 & 34 & 292 & 384 \\
\hline 1963 & 163 & 294 & 457 & 204 & 105 & 167 & 674 & 1,149 \\
\hline 1964 & 40 & 27 & 67 & 5 & 79 & 47 & 300 & 431 \\
\hline 1965 & 252 & 1,381 & 1,633 & 169 & 270 & 177 & 1,826 & 2,443 \\
\hline 1966 & 27 & 5 & 32 & 24 & 37 & 9 & 282 & 352 \\
\hline 1967 & 130 & 190 & 320 & 19 & 110 & 13 & 282 & 424 \\
\hline 1968 & 41 & 31 & 71 & 2 & 0 & 2 & 276 & 280 \\
\hline 1969 & 225 & 97 & 322 & 55 & 101 & 82 & 310 & 548 \\
\hline 1970 & 523 & 1,154 & 1,677 & 190 & 424 & 275 & 637 & 1,526 \\
\hline 1971 & 114 & 113 & 228 & 90 & 60 & 52 & 313 & 515 \\
\hline 1972 & 4 & 1 & 5 & 19 & 3 & 5 & 278 & 304 \\
\hline 1973 & 49 & 99 & 147 & 91 & 148 & 130 & 641 & 1,011 \\
\hline 1974 & 532 & 722 & 1,254 & 191 & 433 & 161 & 661 & 1,447 \\
\hline 1975 & 215 & 60 & 275 & 26 & 117 & 35 & 286 & 464 \\
\hline 1976 & 20 & 1 & 21 & 4 & 2 & 7 & 285 & 299 \\
\hline 1977 & 0 & 0 & 1 & 1 & 0 & 0 & 277 & 278 \\
\hline 1978 & 230 & 156 & 385 & 514 & 542 & 211 & 764 & 2,030 \\
\hline 1979 & 14 & 0 & 15 & 24 & 68 & 3 & 276 & 372 \\
\hline 1980 & 272 & 375 & 647 & 140 & 468 & 202 & 1,733 & 2,543 \\
\hline 1981 & 249 & 557 & 806 & 142 & 159 & 71 & 363 & 735 \\
\hline 1982 & 82 & 50 & 132 & 88 & 176 & 73 & 473 & 811 \\
\hline 1983 & 548 & 1,022 & 1,570 & 354 & 522 & 161 & 663 & 1,700 \\
\hline 1984 & 399 & 439 & 838 & 20 & 8 & 143 & 1,140 & 1,312 \\
\hline 1985 & 82 & 5 & 86 & 4 & 7 & 13 & 284 & 309 \\
\hline 1986 & 330 & 512 & 842 & 49 & 58 & 218 & 1,148 & 1,474 \\
\hline 1987 & 65 & 1 & 66 & 29 & 3 & 5 & 280 & 317 \\
\hline 1988 & 115 & 188 & 302 & 43 & 24 & 37 & 322 & 426 \\
\hline 1989 & 55 & 41 & 96 & 71 & 89 & 35 & 290 & 486 \\
\hline 1990 & 3 & 0 & 3 & 5 & 0 & 2 & 278 & 285 \\
\hline 1991 & 9 & 0 & 9 & 14 & 0 & 4 & 281 & 299 \\
\hline 1992 & 10 & 1 & 11 & 8 & 100 & 36 & 287 & 431 \\
\hline $1993^{1}$ & 169 & 164 & 333 & 12 & 103 & 99 & 455 & 669 \\
\hline Avg. & 175 & 255 & 430 & 85 & 132 & 89 & 524 & 830 \\
\hline
\end{tabular}

${ }^{1}$ Values for June-September 1993 were estimated, not modeled. 
percolation of precipitation. Simulated annual peak discharges and total streamflows are presented in table 16; those estimates represent streamflow at the four recording stream-gaging stations in the study area.

The average annual runoff simulated for Cold Creek Basin (517 acre-ft) was about half as much as that simulated for Dry Creek Basin (976 acre-ft), but the average annual runoff per square mile of drainage area was similar for the two basins $\left(6.94\right.$ and 6.60 acre- $\mathrm{ft} / \mathrm{mi}^{2}$ for Cold Creek and Dry Creek, respectively). Simulated average annual ground-water discharges into Cold Creek and Dry Creek were 68 acre-ft and 310 acre-ft, respectively, so storm-generated runoff per square mile was actually greater in Cold Creek Basin $\left(6.03 \mathrm{acre}-\mathrm{ft} / \mathrm{mi}^{2}\right)$ than in Dry Creek Basin (4.50 acre-ft/mi ${ }^{2}$ ). Those results are consistent with the conceptual model, wherein storm-generated runoff from in Cold Creek Basin with its steep slopes and thin, stony soils was expected to be greater than stormgenerated runoff in Dry Creek Basin.

The average annual recharge from runoff simulated for Cold Creek Basin (430 acre-ft) was also about half as much as that simulated for Dry Creek Basin (830 acre-ft). The greatest amount of recharge from runoff was simulated for the most downstream subbasin in the Dry Creek Basin (524 acre- $\mathrm{ft}$ for DRY1), and about 276 acre- $\mathrm{ft}$ of that amount was due to recharge of spring-water from Rattlesnake Springs. No recharge from runoff was simulated for the two upper Cold Creek subbasins (COLD4 and COLD3) because, as was described in the conceptual model, there is essentially no alluvial fill in those areas. Given that there were no surface-water outflows from the study area, the difference between average annual runoff for the entire study area $(1,493$ acre-ft) and recharge from runoff for the study area $(1,260 \mathrm{acre}-\mathrm{ft})$ reflects that 16 percent of the runoff (237. acre-ft) was infiltrated but subsequently lost to evapotranspiration from channel sediments and from runout-zone soils.

Simulated average annual recharge from runoff for subbasins located primarily within the boundaries of the Hanford Site (subbasins DRY2, DRY1, and COLD1) was 868 acre-ft, and simulated recharge from runoff for all areas that likely contribute water directly to the uppermost unconfined aquifer beneath the Hanford Site (subbasins COLD2, COLD1, DRY3, DRY2, and DRY1) was 1,175 acre-ft/yr. The latter estimate probably best represents recharge from runoff in areas where the underlying water table is in unconsolidated sediments. Recharge from runoff in the DRY4 subbasin most likely percolates directly into basalt, and it is unknown how much of that recharge flows to the uppermost unconfined aquifer.
The uncertainty in the long-term runoff and recharge from runoff estimates could not be quantified with available data. There were few data to compare with simulated long-term runoff, and there were no data to compare with simulated recharge from runoff. As described previously, the numerical models were calibrated to simulate a plausible upper limit for runoff and recharge, and as was shown in table 13 , the models simulated too much streamflow for the 1991-93 water years.

However, in a qualitative assessment of the 1958-93 runoff estimates, the runoff estimates appear to be quite reasonable; when considered with the previously presented calibration results, the estimates are certainly of the correct order of magnitude. A comparison was made between simulated streamflow at the four stream-gaging stations in the study area (table 16) and historic streamflow data from nearby Esquatzel Coulee Basin (table 6). Esquatzel Coulee is not similar enough to the study area to validly compare observed and simulated runoff for individual storms, but it is similar enough to compare observed and simulated long-term average runoff. The average annual runoff observed for water years 1958-93 at station 12513000 (Esquatzel Coulee at Connell, a $234-\mathrm{mi}^{2}$ drainage basin located about 40 miles east of the study area) was $4.20 \mathrm{acre}-\mathrm{ft} / \mathrm{mi}^{2}$. Comparable values simulated for the study-area stations ranged from 1.50 to 14.9 acre- $\mathrm{ft} / \mathrm{mi}^{2}$. Likewise, the maximum recorded annual-runoff volume at station 12513000 was $32.7 \mathrm{acre}-\mathrm{ft} / \mathrm{mi}^{2}$; comparable values simulated for the study-area stations ranged from 11.4 to $78.6 \mathrm{acre}-\mathrm{ft} / \mathrm{mi}^{2}$. Thus, the observed average annual runoff data from Esquatzel Coulee is bracketed by the simulated runoff for the study area. Dry Creek Basin, which receives relatively little precipitation, had less simulated runoff than Esquatzel Coulee, and Cold Creek Basin, which receives relatively more precipitation, had more simulated runoff than Esquatzel Coulee.

\section{Comparison to Other Recharge Estimates}

From this investigation, estimated recharge from runoff for areas within the Hanford Site boundaries is $868 \mathrm{acre}-\mathrm{ft} / \mathrm{yr}$, and estimated recharge from runoff for all areas that likely contribute water directly to the uppermost unconfined aquifer beneath the Hanford Site is $1,175 \mathrm{acre}-\mathrm{ft} / \mathrm{yr}$. These estimates are approximately 90 and 160 percent greater, respectively, than the only other known published estimate of annual recharge from runoff (450 acre-ft/yr; Newcomb and others, 1972). 
Table 16.--Simulated annual peak discharge and total streamflow for the study area for water years 1958-93

[Max.Q, maximum hourly discharge for the year; $\mathrm{ft}^{3} / \mathrm{s}$, cubic feet per second; acre-ft, acre feet; Average, average annual total streamflow for 1958-93 water years; Average per $\mathrm{mi}^{2}$, average annual total streamflow per square mile of drainage area upstream of stream-gaging station for water years 1958-93; <, less than]

\begin{tabular}{|c|c|c|c|c|c|c|c|c|}
\hline \multirow[b]{4}{*}{$\begin{array}{l}\text { Water } \\
\text { year }\end{array}$} & \multicolumn{8}{|c|}{ Simulated discharge } \\
\hline & \multirow{2}{*}{\multicolumn{2}{|c|}{$\begin{array}{l}\text { Upper Cold Creek } \\
\text { Station } 12510618\end{array}$}} & \multirow{2}{*}{\multicolumn{2}{|c|}{$\begin{array}{l}\text { Lower Cold Creek } \\
\text { Station } 12510625\end{array}$}} & \multirow{2}{*}{\multicolumn{2}{|c|}{$\begin{array}{l}\text { Upper Dry Creek } \\
\text { Station } 12510650\end{array}$}} & \multirow{2}{*}{\multicolumn{2}{|c|}{$\begin{array}{l}\text { Lower Dry Creek } \\
\text { Station } 12510655\end{array}$}} \\
\hline & & & & & & & & \\
\hline & $\begin{array}{l}\operatorname{Max} . Q \\
\left(\mathrm{ft}^{3} / \mathrm{s}\right)\end{array}$ & $\begin{array}{l}\text { Total } \\
\text { (acre-ft) }\end{array}$ & $\begin{array}{l}\text { Max.Q } \\
\left(\mathrm{ft}^{3} / \mathrm{s}\right)\end{array}$ & $\begin{array}{l}\text { Total } \\
\text { (acre-ft) }\end{array}$ & $\begin{array}{l}\text { Max.Q } \\
\left(\mathrm{ft}^{3} / \mathrm{s}\right)\end{array}$ & $\begin{array}{l}\text { Total } \\
\text { (acre-ft) }\end{array}$ & $\begin{array}{l}\operatorname{Max} . Q \\
\left(\mathrm{ft}^{3} / \mathrm{s}\right)\end{array}$ & $\begin{array}{l}\text { Total } \\
\text { (acre-ft) }\end{array}$ \\
\hline 1958 & 986 & 929 & 756 & 535 & 243 & 71 & 544 & 593 \\
\hline 1959 & 517 & 1,380 & 428 & 917 & 69 & 25 & 362 & 805 \\
\hline 1960 & 42 & 43 & 21 & 7 & $<1$ & $<1$ & $<1$ & 309 \\
\hline 1961 & 141 & 302 & 98 & 148 & 118 & 42 & 332 & 483 \\
\hline 1962 & 47 & 58 & 25 & 12 & 2 & $<1$ & 7 & 310 \\
\hline 1963 & 248 & 357 & 225 & 268 & 233 & 115 & 332 & 646 \\
\hline 1964 & 109 & 89 & 72 & 46 & 0 & 0 & 60 & 325 \\
\hline 1965 & 3,750 & 2,250 & 3,380 & 2,010 & 1,600 & 609 & 3,130 & 2,120 \\
\hline 1966 & 39 & 45 & 21 & 14 & 0 & 0 & $<1$ & 309 \\
\hline 1967 & 601 & 380 & 293 & 244 & 0 & 0 & $<1$ & 308 \\
\hline 1968 & 74 & 98 & 51 & 52 & 0 & 0 & $<1$ & 309 \\
\hline 1969 & 110 & 320 & 75 & 110 & 0 & 0 & 2 & 308 \\
\hline 1970 & 1,640 & 1,780 & 1,410 & 1,340 & 69 & 19 & 347 & 618 \\
\hline 1971 & 261 & 267 & 184 & 151 & 156 & 56 & 116 & 338 \\
\hline 1972 & 1 & 7 & 0 & 0 & 0 & 0 & $<1$ & 308 \\
\hline 1973 & 193 & 155 & 155 & 126 & 290 & 86 & 532 & 736 \\
\hline 1974 & 883 & 1,270 & 736 & 814 & 265 & 118 & 676 & 767 \\
\hline 1975 & 130 & 266 & 121 & 83 & 6 & 1 & 2 & 309 \\
\hline 1976 & 5 & 21 & 0 & 0 & 0 & 0 & $<1$ & 311 \\
\hline 1977 & 1 & 4 & 0 & 0 & 0 & 0 & $<1$ & 308 \\
\hline 1978 & 117 & 297 & 158 & 136 & 727 & 622 & 423 & 863 \\
\hline 1979 & $<1$ & 15 & 0 & 0 & 0 & 0 & $<1$ & 308 \\
\hline 1980 & 325 & 395 & 246 & 187 & 1,320 & 651 & 1,990 & 1,720 \\
\hline 1981 & 1,500 & 999 & 1,260 & 755 & 29 & 12 & 225 & 416 \\
\hline 1982 & 158 & 155 & 119 & 75 & 97 & 29 & 467 & 584 \\
\hline 1983 & 1,220 & 1,460 & 1,020 & 1,090 & 600 & 497 & 613 & 810 \\
\hline 1984 & 291 & 565 & 379 & 355 & 0 & 0 & 1,060 & 1,070 \\
\hline 1985 & 24 & 78 & 20 & 8 & 0 & 0 & $<1$ & 309 \\
\hline 1986 & 541 & 655 & 393 & 473 & 1 & $<1$ & 1,030 & 1,140 \\
\hline 1987 & 16 & 66 & $<1$ & $<1$ & $<1$ & $<1$ & $<1$ & 309 \\
\hline 1988 & 442 & 348 & 268 & 235 & 6 & 1 & 137 & 352 \\
\hline 1989 & 123 & 99 & 103 & 52 & 208 & 58 & 17 & 312 \\
\hline 1990 & 1 & 7 & 0 & 0 & 0 & 0 & $<1$ & 308 \\
\hline 1991 & 8 & 14 & 0 & 0 & $<1$ & $<1$ & $<1$ & 309 \\
\hline 1992 & 3 & 14 & 0 & 0 & 0 & 0 & $<1$ & 309 \\
\hline 1993 & 41 & 176 & 52 & 55 & 0 & 0 & 205 & 440 \\
\hline Average & na & 427 & na & 286 & na & 84 & na & 558 \\
\hline Average per $\mathrm{mi}^{2}$ & na & 14.9 & na & 7.3 & na & 1.5 & na & 3.8 \\
\hline
\end{tabular}


The recharge from runoff estimates indicate that such recharge is a significant source of water to the uppermost unconfined aquifer beneath the Hanford Site. The estimate of recharge from runoff to the aquifer $(1,175 \mathrm{acre}-\mathrm{ft} / \mathrm{yr})$ is equal to 41 percent of Bauer and Vaccaro's (1990) estimate of direct recharge from precipitation over the same portion of the study area, and is equal to 13 percent of their estimate of direct recharge from precipitation to the aquifer. The estimate of recharge from runoff for the Hanford Site ( 868 acre-ft/yr) is equal to 16 percent, 13 percent, and 6 percent of Bauer and Vaccaro's (1990), Fayer and Walters' (1995), and Jacobsen and Freshley's (1990) estimates of direct recharge from precipitation over the Hanford Site, respectively. The estimated recharge from runoff to the aquifer is also equal to about 40 percent of Jacobsen and Freshley's (1990) estimate of ground-water input to the aquifer at the western boundary. Their estimate is for "water contributed...from Cold Creek valley...from Dry Creek valley and Rattlesnake Mountain Springs," so it presumably includes at least some of the recharge from runoff in those areas.

\section{REFERENCES CITED}

Anderson, D.G., and Bodhaine, G.L., 1956, Floods of 1956 in the Esquatzel Coulee area in Washington: U.S. Geological Survey Open-File Report, 51 p.

Bauer, H.H., and Vaccaro, J.J., 1987, Documentation of a deep percolation model for estimating ground-water recharge: U.S. Geological Survey Open-File Report $86-536,180 \mathrm{p}$.

, 1990, Estimates of ground-water recharge to the Columbia Plateau regional aquifer system, Washington, Oregon, and Idaho, for predevelopment and current land-use conditions: U.S. Geological Survey Water- Resources Investigations Report $88-4108,37 \mathrm{p}$.

Brakensiek, D.L., Osborn, H.B., and Rawls, W.J., 1979, Field manual for research in agricultural hydrology: Washington, D.C., U.S. Department of Agriculture, Agriculture Handbook no. 224, 547 p.

Brown, R.E., 1970, Pacific Northwest Laboratory annual report for 1970 to the USAEC division of biology and medicine, v. 1 life sciences, part 2 ecological: Richland, Washington, Pacific Northwest Laboratory, BNWL-1306, 108 p.
Carey, J.W., Campbell, G.S., and Papendick, R.I., 1978, Is the soil frozen or not--an algorithm using weather records: Water Resources Research, v. 14, no. 6, p. $1,117-1,122$.

Delaney, C.D., Lindsey, K.A., and Reidel, S.P., 1991, Geology and hydrology of the Hanford Site--A standardized text for use in Westinghouse Company documents and reports: Richland, Washington, Westinghouse Hanford Company Report, WHC-SD-ER-TI-003.

Fayer, M.J., and Walters, T.B., 1995, Estimated recharge rates at the Hanford Site: Richland, Washington, Pacific Northwest Laboratory, PNL-10285, [about 75 p.].

Fox, J.D., 1992, Incorporating freeze-thaw calculations into a water balance model: Water Resources Research, v. 28 , no. 9, p. 2,229-2,244.

Gee, G.W., 1987, Recharge at the Hanford Site--Status report: Richland, Washington, Pacific Northwest Laboratory, PNL-6403, [about 30 p.].

Gee, G.W., Fayer, M.J., Rockhold, M.L., and Campbell, M.D., 1992, Variations in recharge at the Hanford Site: Northwest Science, v. 66, no. 4, p. 237-249.

Goodison, B.E., and McKay, D.J., 1978, Canadian snowfall measurements--Some implications for the collection and analysis of data from remote stations; in, Proceedings of the Western Snow Conference, Otter Rock, Oregon, April 18-20, 1978, p. 48-57.

Gray, D.M., and Prowse, T.D., 1992, Snow and floating ice; in, Maidment, D.R., ed., Handbook of Hydrology, McGraw-Hill, New York, p. 7.27-7.30.

Harr, R.D., 1971, Pacific Northwest Laboratory annual report for 1970 to the USAEC division of biology and medicine, v. 1 life sciences, part 2 ecological: Richland, Washington, Pacific Northwest Laboratory, BNWL-1550, $108 \mathrm{p}$.

Jacobson, E.A. and Freshley, M.D., 1990, An initial inverse calibration of the ground-water flow model for the Hanford unconfined aquifer: Richland, Washington, Pacific Northwest Laboratory, PNL $7144,45 \mathrm{p}$. 
Jensen, M.E., 1973, Consumptive use of water and irrigation water requirements: New York, NY, American Society of Civil Engineers., Irrigation and Drainage Division, 215 p.

Kaufman, M.R., and Weatherred, J.D., 1982, Determination of potential direct beam solar irradiance: Rocky Mountain Forest and Range Experiment Station, U.S. Forest Service, Research Paper RM-242, 23 p.

Kilpatrick, F.A., and Schneider, V.R., 1983, Use of flumes in measuring discharge: U.S. Geological Survey Techniques of Water-Resources Investigations, Book 3, chap. A14, $46 \mathrm{p}$.

Longfield, R.J., 1974, Floods of January 1974 in Washington: U.S. Geological Survey Open-File Report, $13 \mathrm{p}$.

Miles, M.B., Wiggins, W.D., Ruppert, G.P., Smith, R.R., Reed, L.L., and Hubbard, L.E., 1992, Water Resources Data Washington Water Year 1991: U.S. Geological Survey Water Data Report WA-91-1, 439 p.

1993, Water Resources Data Washington Water Year 1992: U.S. Geological Survey Water Data Report WA-92-1, 459 p.

Miles, M.B., Wiggins, W.D., Ruppert, G.P., Smith, R.R., Reed, L.L., Hubbard, L.E., and Courts, M.L., 1994, Water Resources Data Washington Water Year 1993: U.S. Geological Survey Water Data Report WA-93-1, 408 p.

Newcomb, R.C., Strand, J.R., and Frank, F.J., 1972, Geology and ground-water characteristics of the Hanford Reservation of the U.S. Atomic Energy Commission, Washington: U.S. Geological Survey Professional Paper 717, $78 \mathrm{p}$.

Price, K.R., and Harr, R.D., 1970, Pacific Northwest Laboratory annual report for 1970 to the USAEC division of biology and medicine, v. 1 life sciences, part 2 ecological: Richland, Washington, Pacific Northwest Laboratory, BNWL-1306, 108 p.

Prych, E.A., 1994, Using chloride and chlorine-36 as soil-water tracers to estimate deep percolation at selected locations on the U.S. Department of Energy Hanford Site, Washington: U.S. Geological Survey Open-file Report 94-514, 125 p.
Reitan, C.H., 1963, Surface dew point and water vapor aloft: Journal of Applied Meteorology, v. 2, no. 6, p. $776-779$.

Rickard, W.H., and Vaughn, B.E., 1988, Plant community characteristics and responses, in Rickard and others, eds., Shrub-Steppe, Balance, and Change in a Semiarid Terrestrial Ecosystem--Developments in Agricultural and Managed Forest Ecology: Amsterdam, Elsevier, v. 20, p. 109-179.

Rockhold, M.L., Fayer, M.J., Kincaid, C.T., and Gee, G.W., 1995, Estimation of natural ground water recharge for the performance assessment of a low-level waste disposal facility at the Hanford Site: Richland, Washington, Pacific Northwest Laboratory, PNL-10508, [about 50 p.].

Scanlon, B.R., 1994, Water and heat flux in desert soils: Water Resources Research, v. 30, no. 3, p. 709-719.

Stone, W.A., Thorp, J.M., Gifford, O.P., and Hoitink, D.J., 1983, Climatological summary for the Hanford area: Richland, Washington, Pacific Northwest Laboratory, PNL-4622, [about 300 p.].

Tomlinson, S.A., 1994, Instrumentation, methods and preliminary evaluation of evapotranspiration for a grasslands in the Arid Lands Ecology Reserve, Benton, County, Washington, May-October 1990: U.S. Geological Survey Water-Resources Investigations Report 93-4081, 32 p.

U.S. Congress, Office of Technology Assessment, 1991, Complex cleanup--the environmental legacy of nuclear weapons production: Washington, D.C., U.S. Government Printing Office, OTA-O-484, $212 \mathrm{p}$.

U.S. Environmental Protection Agency, 1984, Hydrological simulation program-FORTRAN (HSPF)--users manual for release 9.0 (draft): Washington, D.C., U.S. Environmental Protection Agency, EPA 600/3-84-066, 767 p.

Williams, J.R., and Pearson, H.E., 1985, Streamflow statistics and drainage-basin characteristics for the southwestern and eastern regions, Washington, Volume II, Eastern Washington: U.S. Geological Survey Open-File Report 84-145-B, 662 p. 
APPENDIXES 
Appendix 1.--Final HSPF input file for Upper Cold Creek model. For brevity, the "SPECIAL ACTIONS" portion of the model input, where the dates of soil freezing and thawing are represented by changes in the INFILT parameter values, is not included. Complete input files may be obtained by contacting the District Chief at the address shown on page ii of this report

RUN

GLOBAL

Cold4 final model - hms.wdm data

START 1957/10/01 00:00 END 1993/05/31 24:00

RUN INTERP OUTPUT LEVEL 0

$\begin{array}{llllll}\text { RESUME } & 0 & \text { RUN } & 1 & \text { TSSFL } & 15 \\ \text { WDMSFL } & 16\end{array}$

END GLOBAL

OPN SEQUENCE

INGRP

INDELT 01:00

PERLND 207

PERLND 227

PERLND 247

PERLND 287

PERLND 301

PERLND $\quad 307$

PERLND 309

PERIND 321

PERLND 323

PERLND 327

PERLND 341

PERLND $\quad 343$

PERLND 347

PERLND $\quad 348$

PERLND $\quad 349$

PERLND 361

PERLND $\quad 367$

PERLND $\quad 368$

PERLND 381

PERLND 387

PERLND 389

PERLND 401

PERLND $\quad 407$

PERLND 421

PERLND $\quad 422$

PERLND 427

PERLND 461

PERLND 467

COPY 1

DISPLY 1

END INGRP

END OPN SEQUENCE

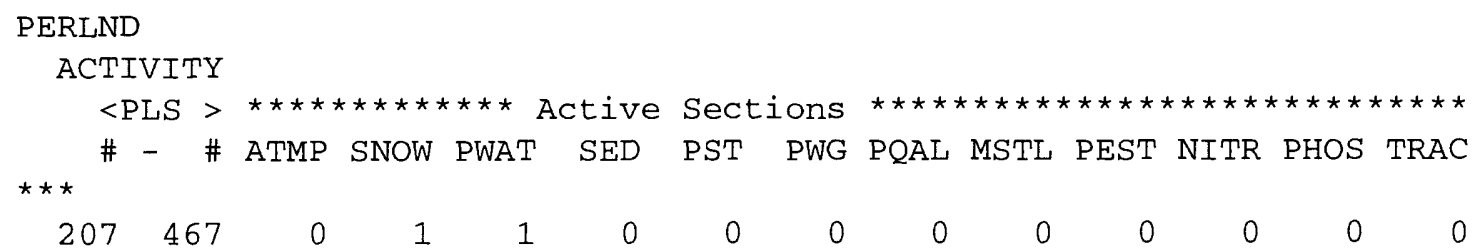




\section{END ACTIVITY}

PRINT-INFO

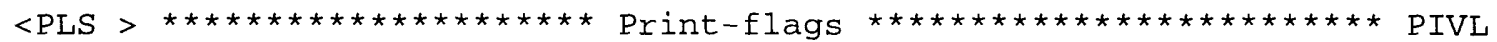

PYR

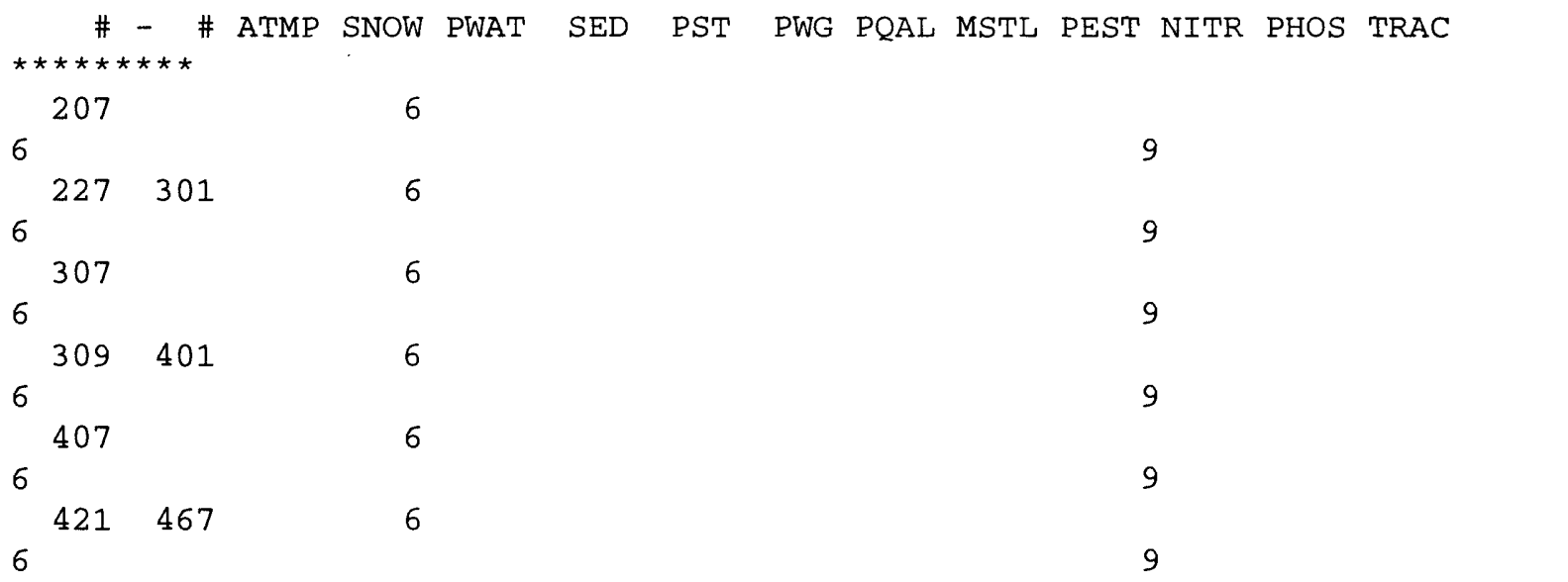

END PRINT-INFO

GEN-INFO

$<$ PLS ><---Name------>NBLKS Unit-systems Printer

\# \# User $t$-series Engl Metr

$\star \star \star$

in out

$\star \star \star$

$\star \star \star$ Grouped by elevation zone $* \star \star$

207

227

247

287

301

307

309

321

323

327

341

343

347

348

349

361

367

368

381

387

389

401

407

421

422

427

461

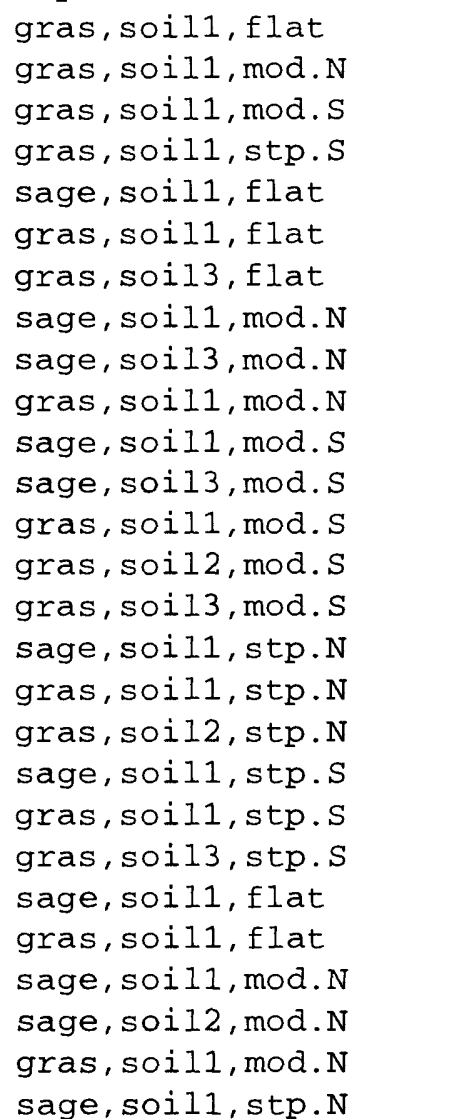

$\begin{array}{llllll}1 & 1 & 1 & 1 & 6 & 0 \\ 1 & 1 & 1 & 1 & 6 & 0 \\ 1 & 1 & 1 & 1 & 6 & 0 \\ 1 & 1 & 1 & 1 & 6 & 0 \\ 1 & 1 & 1 & 1 & 6 & 0 \\ 1 & 1 & 1 & 1 & 6 & 0 \\ 1 & 1 & 1 & 1 & 6 & 0 \\ 1 & 1 & 1 & 1 & 6 & 0 \\ 1 & 1 & 1 & 1 & 6 & 0 \\ 1 & 1 & 1 & 1 & 6 & 0 \\ 1 & 1 & 1 & 1 & 6 & 0 \\ 1 & 1 & 1 & 1 & 6 & 0 \\ 1 & 1 & 1 & 1 & 6 & 0 \\ 1 & 1 & 1 & 1 & 6 & 0 \\ 1 & 1 & 1 & 1 & 6 & 0 \\ 1 & 1 & 1 & 1 & 6 & 0 \\ 1 & 1 & 1 & 1 & 6 & 0 \\ 1 & 1 & 1 & 1 & 6 & 0 \\ 1 & 1 & 1 & 1 & 6 & 0 \\ 1 & 1 & 1 & 1 & 6 & 0 \\ 1 & 1 & 1 & 1 & 6 & 0 \\ 1 & 1 & 1 & 1 & 6 & 0 \\ 1 & 1 & 1 & 1 & 6 & 0 \\ 1 & 1 & 1 & 1 & 6 & 0 \\ 1 & 1 & 1 & 1 & 6 & 0 \\ 1 & 1 & 1 & 1 & 6 & 0 \\ 1 & 1 & 1 & 1 & 6 & 0\end{array}$




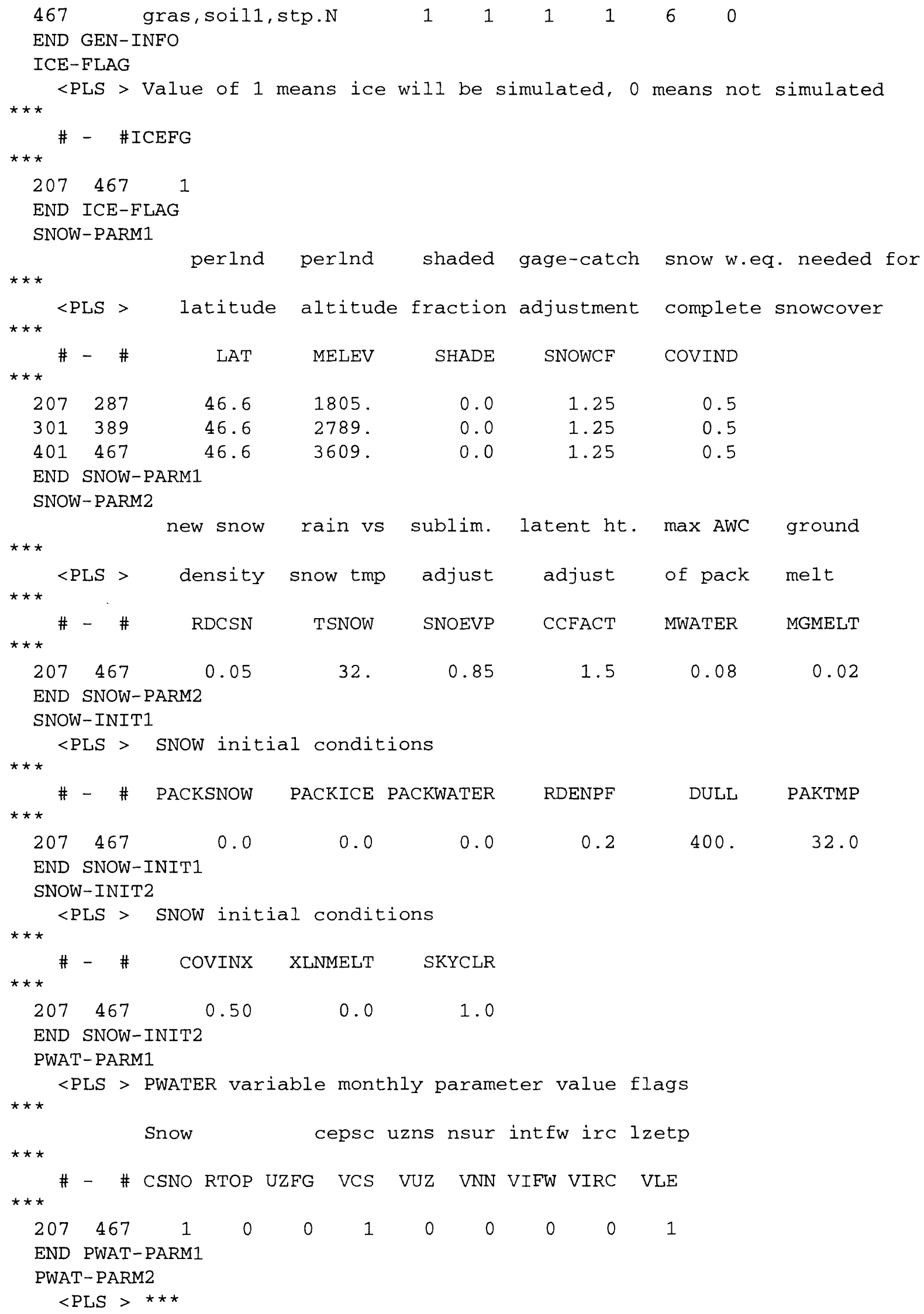




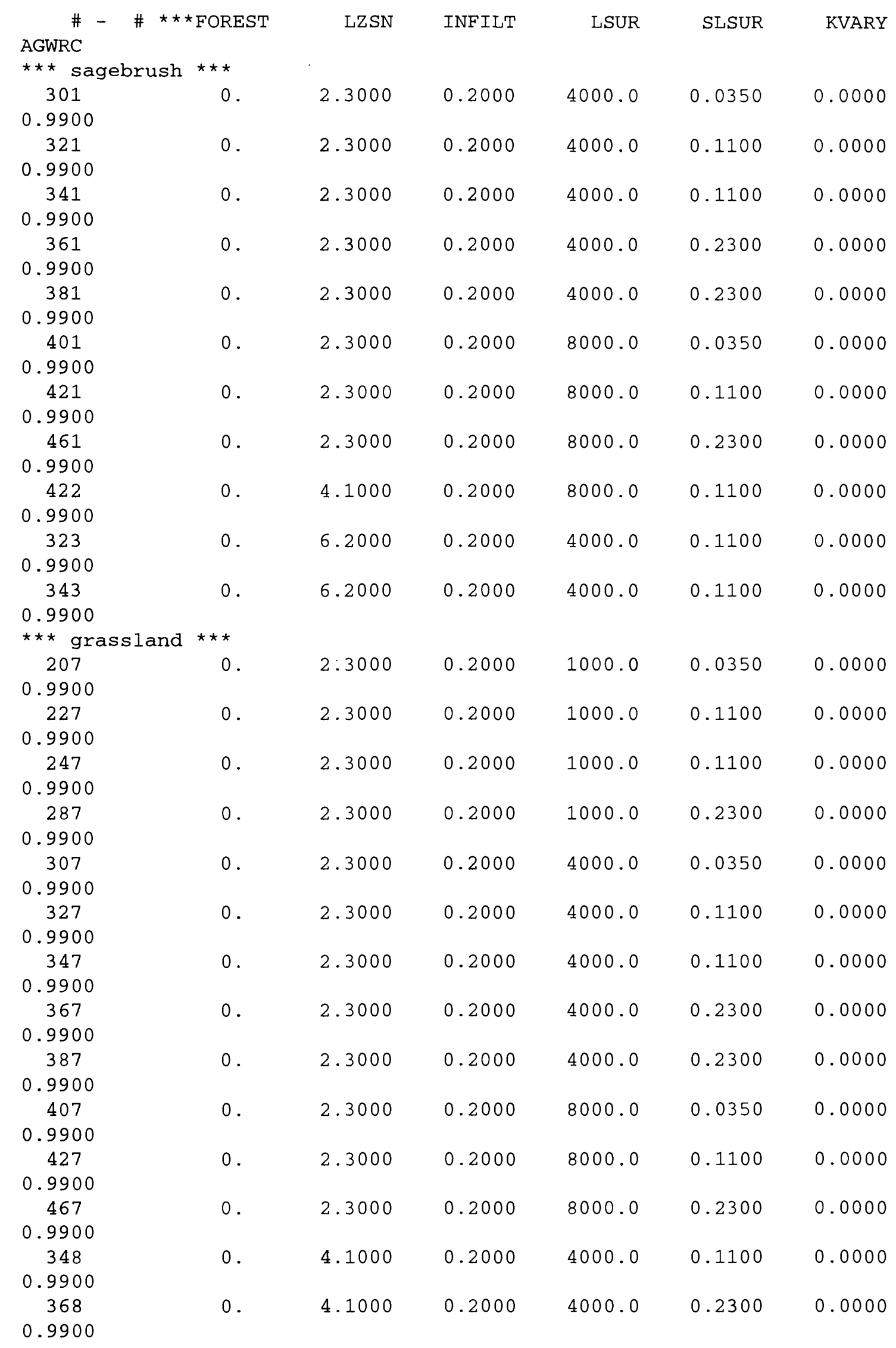




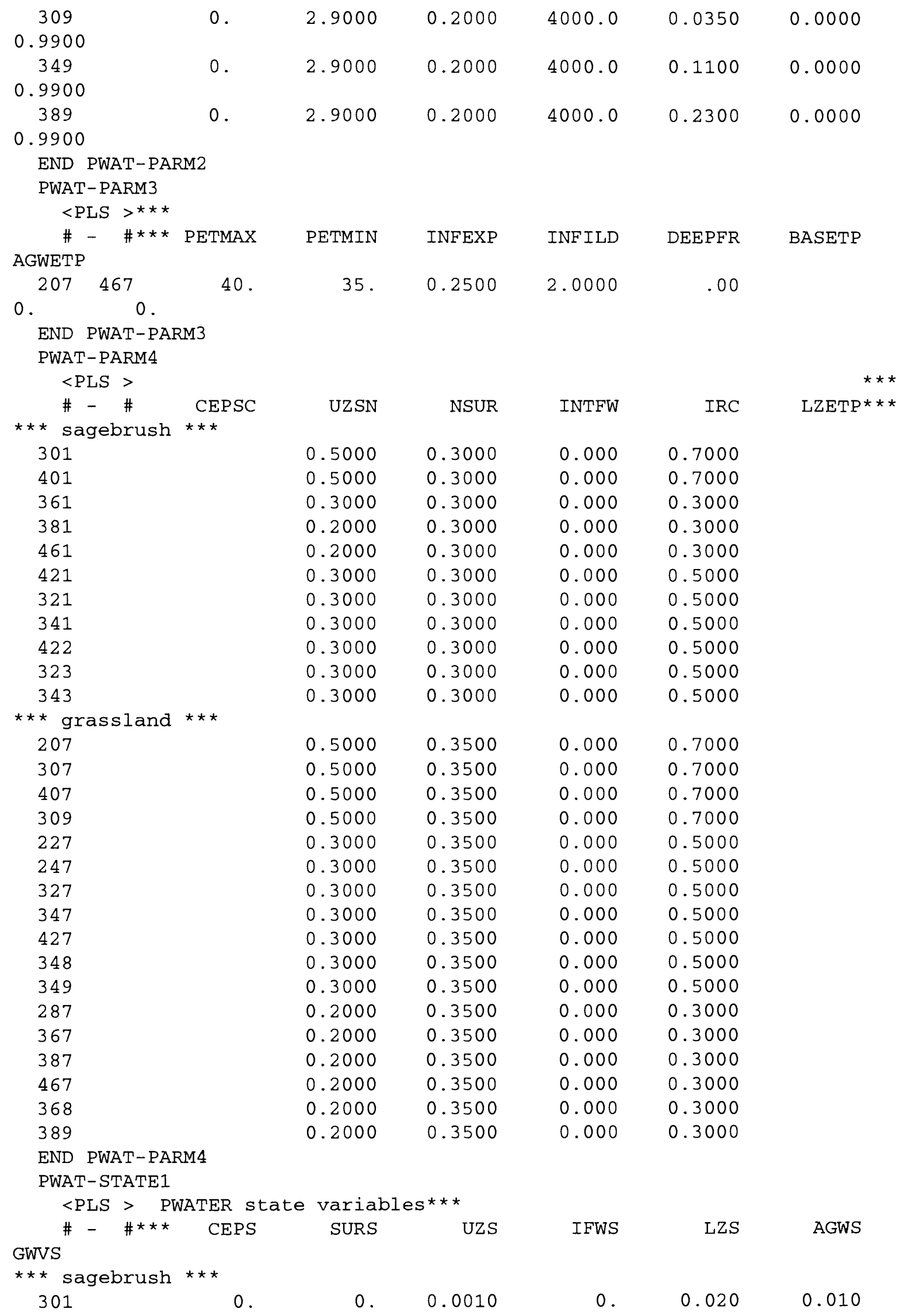




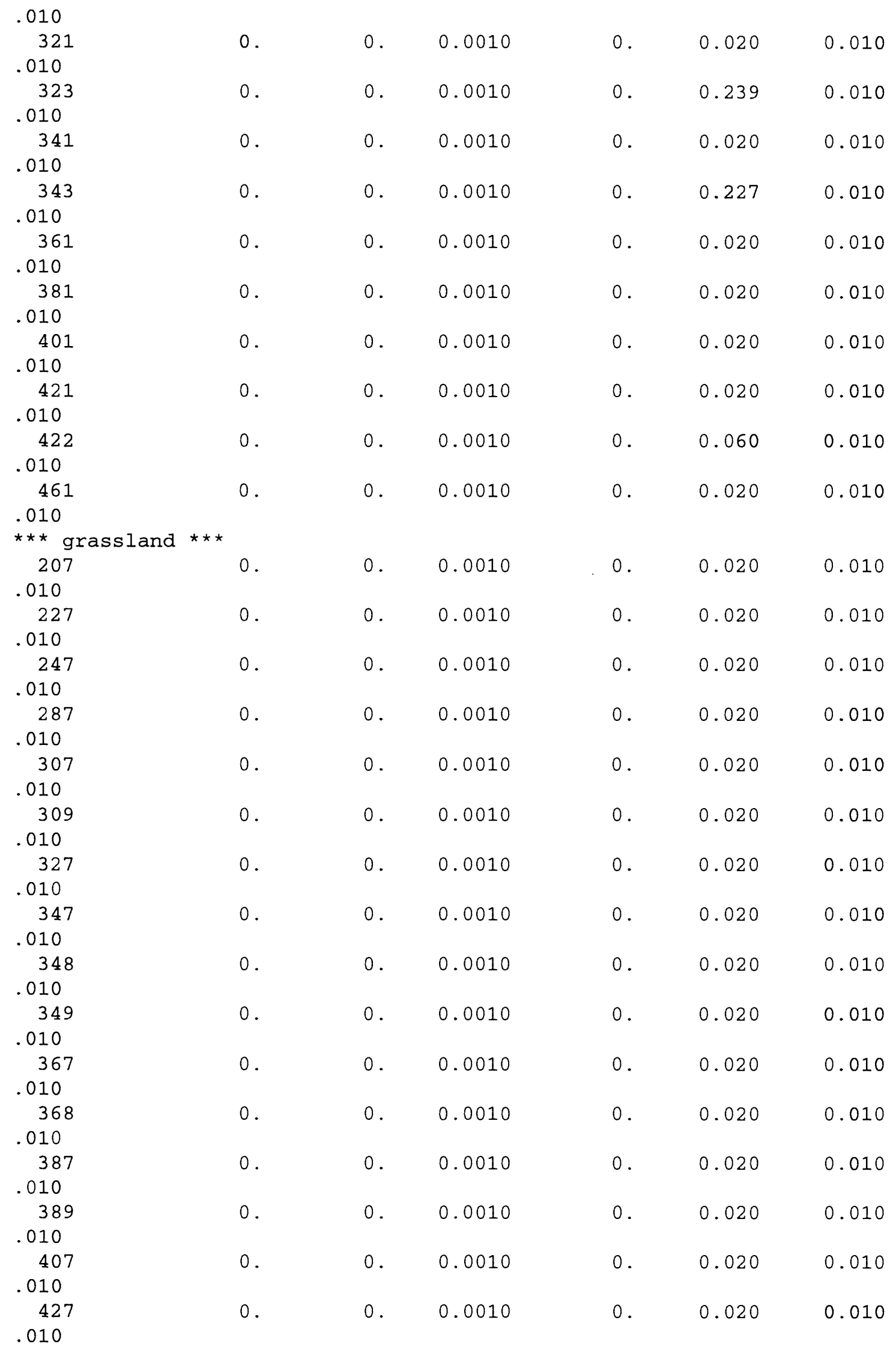




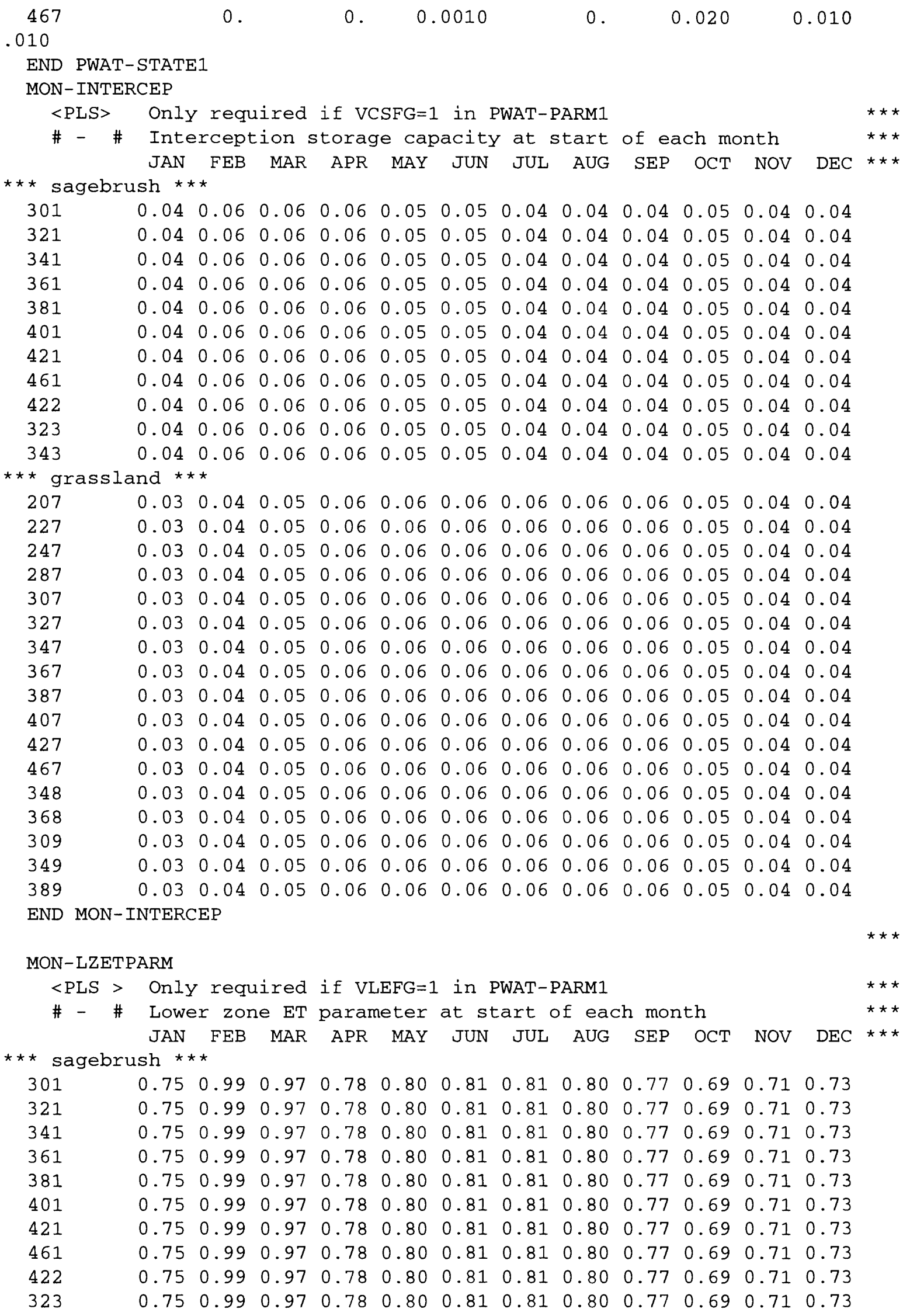




$\begin{array}{lllllllllllll}* * * \text { grassland *** } & & & \\ 207 & 0.45 & 0.52 & 0.65 & 0.76 & 0.80 & 0.81 & 0.81 & 0.80 & 0.77 & 0.69 & 0.58 & 0.48 \\ 227 & 0.45 & 0.52 & 0.65 & 0.76 & 0.80 & 0.81 & 0.81 & 0.80 & 0.77 & 0.69 & 0.58 & 0.48 \\ 247 & 0.45 & 0.52 & 0.65 & 0.76 & 0.80 & 0.81 & 0.81 & 0.80 & 0.77 & 0.69 & 0.58 & 0.48 \\ 287 & 0.45 & 0.52 & 0.65 & 0.76 & 0.80 & 0.81 & 0.81 & 0.80 & 0.77 & 0.69 & 0.58 & 0.48 \\ 307 & 0.45 & 0.52 & 0.65 & 0.76 & 0.80 & 0.81 & 0.81 & 0.80 & 0.77 & 0.69 & 0.58 & 0.48 \\ 327 & 0.45 & 0.52 & 0.65 & 0.76 & 0.80 & 0.81 & 0.81 & 0.80 & 0.77 & 0.69 & 0.58 & 0.48 \\ 347 & 0.45 & 0.52 & 0.65 & 0.76 & 0.80 & 0.81 & 0.81 & 0.80 & 0.77 & 0.69 & 0.58 & 0.48 \\ 367 & 0.45 & 0.52 & 0.65 & 0.76 & 0.80 & 0.81 & 0.81 & 0.80 & 0.77 & 0.69 & 0.58 & 0.48 \\ 387 & 0.45 & 0.52 & 0.65 & 0.76 & 0.80 & 0.81 & 0.81 & 0.80 & 0.77 & 0.69 & 0.58 & 0.48 \\ 407 & 0.45 & 0.52 & 0.65 & 0.76 & 0.80 & 0.81 & 0.81 & 0.80 & 0.77 & 0.69 & 0.58 & 0.48 \\ 427 & 0.45 & 0.52 & 0.65 & 0.76 & 0.80 & 0.81 & 0.81 & 0.80 & 0.77 & 0.69 & 0.58 & 0.48 \\ 467 & 0.45 & 0.52 & 0.65 & 0.76 & 0.80 & 0.81 & 0.81 & 0.80 & 0.77 & 0.69 & 0.58 & 0.48 \\ 348 & 0.45 & 0.52 & 0.65 & 0.76 & 0.80 & 0.81 & 0.81 & 0.80 & 0.77 & 0.69 & 0.58 & 0.48 \\ 368 & 0.45 & 0.52 & 0.65 & 0.76 & 0.80 & 0.81 & 0.81 & 0.80 & 0.77 & 0.69 & 0.58 & 0.48 \\ 309 & 0.45 & 0.52 & 0.65 & 0.76 & 0.80 & 0.81 & 0.81 & 0.80 & 0.77 & 0.69 & 0.58 & 0.48 \\ 349 & 0.45 & 0.52 & 0.65 & 0.76 & 0.80 & 0.81 & 0.81 & 0.80 & 0.77 & 0.69 & 0.58 & 0.48 \\ 389 & 0.45 & 0.52 & 0.65 & 0.76 & 0.80 & 0.81 & 0.81 & 0.80 & 0.77 & 0.69 & 0.58 & 0.48 \\ \text { END MON-LZETPARM } & & & & & & & & & & & & \end{array}$

END PERLND

EXT SOURCES

\begin{tabular}{|c|c|c|c|c|c|c|c|c|c|}
\hline \multicolumn{2}{|c|}{$\begin{array}{l}<- \text { Volume }-> \\
\star \star \star\end{array}$} & $<$ Member $>$ & \multicolumn{2}{|c|}{ SsysSgap<--Mult-->Tran } & \multicolumn{3}{|c|}{$<-$ Target vols $>$} & \multirow[t]{2}{*}{$<-\mathrm{Grp}>$} & $<-$ Member-> \\
\hline $\begin{array}{l}<\text { Name }> \\
\star \star \star\end{array}$ & \# & $<$ Name $>\#$ & tem & strg<-factor->strg & $<$ Name $>$ & \# & \# & & $<$ Name $>\# \#$ \\
\hline WDM & 3 & PREC & ENGI & 1.29 & PERLND & 207 & 287 & EXTNL & PREC \\
\hline WDM & 3 & PREC & ENGI & 1.45 & PERLND & 301 & 389 & EXTNL & PREC \\
\hline WDM & 3 & PREC & ENGI & 1.61 & PERLND & 401 & 467 & EXTNL & PREC \\
\hline WDM & 5 & WIND & ENGI & & PERLND & 207 & 467 & EXTNL & WINMOV \\
\hline WDM & 6 & SOLR & ENGI & & PERLND & 207 & & EXTNL & SOLRAD \\
\hline WDM & 7 & SOLR & ENGI & & PERLND & 227 & & EXTNL & SOLRAD \\
\hline WDM & 8 & SOLR & ENGI & & PERLND & 247 & & EXTNL & SOLRAD \\
\hline WDM & 10 & SOLR & ENGI & & PERLND & 287 & & EXTNL & SOLRAD \\
\hline WDM & 6 & SOLR & ENGI & & PERLND & 301 & 309 & EXTNL & SOLRAD \\
\hline WDM & 7 & SOLR & ENGI & & PERLND & 321 & 327 & EXTNL & SOLRAD \\
\hline WDM & 8 & SOLR & ENGI & & PERLND & 341 & 349 & EXTNL & SOLRAD \\
\hline WDM & 9 & SOLR & ENGI & & PERLND & 361 & 368 & EXTNL & SOLRAD \\
\hline WDM & 10 & SOLR & ENGI & & PERLND & 381 & 389 & EXTNL & SOLRAD \\
\hline WDM & 6 & SOLR & ENGI & & PERLND & 401 & 407 & EXTNL & SOLRAD \\
\hline WDM & 7 & SOLR & ENGI & & PERLND & 421 & 427 & EXTNL & SOLRAD \\
\hline WDM & 9 & SOLR & ENGI & & PERLND & 461 & 467 & EXTNL & SOLRAD \\
\hline WDM & 15 & TEMP & ENGI & & PERLND & 207 & 287 & ATEMP & AIRTMP \\
\hline WDM & 25 & DEWP & ENGI & & PERLND & 207 & 287 & EXTNL & DTMPG \\
\hline WDM & 18 & TEMP & ENGI & & PERLND & 301 & 389 & ATEMP & AIRTMP \\
\hline WDM & 28 & DEWP & ENGI & & PERLND & 301 & 389 & EXTNL & DTMPG \\
\hline WDM & 20 & TEMP & ENGI & & PERLND & 401 & 467 & ATEMP & AIRTMP \\
\hline WDM & 30 & DEWP & ENGI & & PERLND & 401 & 467 & EXTNL & DTMPG \\
\hline WDM & 35 & PET & ENGI & & PERLND & 207 & & EXTNL & PETINP \\
\hline WDM & 45 & PET & ENGI & & PERLND & 227 & & EXTNL & PETINP \\
\hline WDM & 55 & PET & ENGI & & PERLND & 247 & & EXTNL & PETINP \\
\hline
\end{tabular}




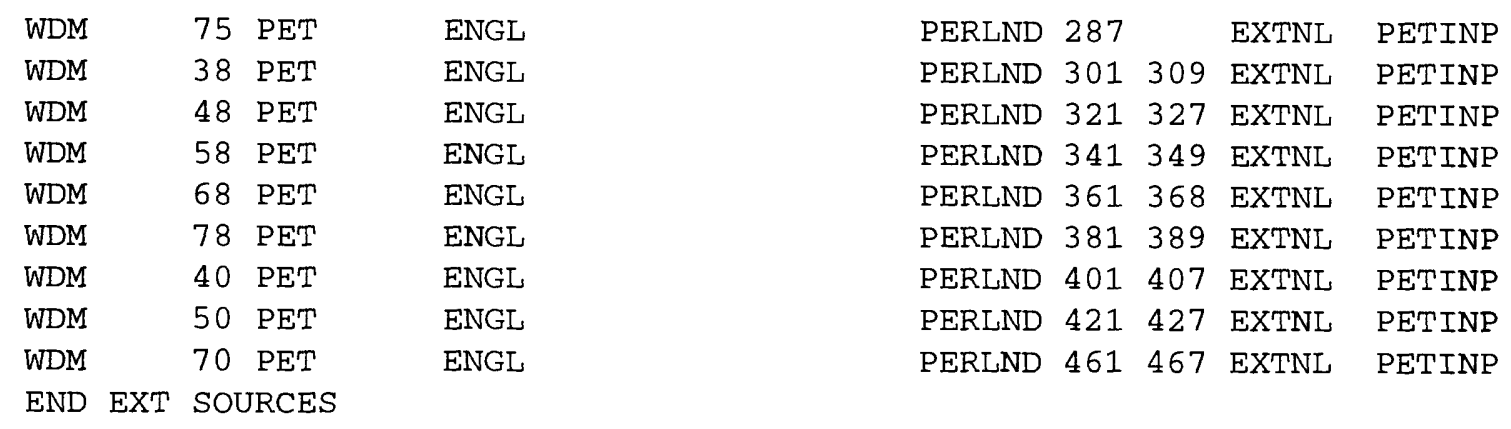

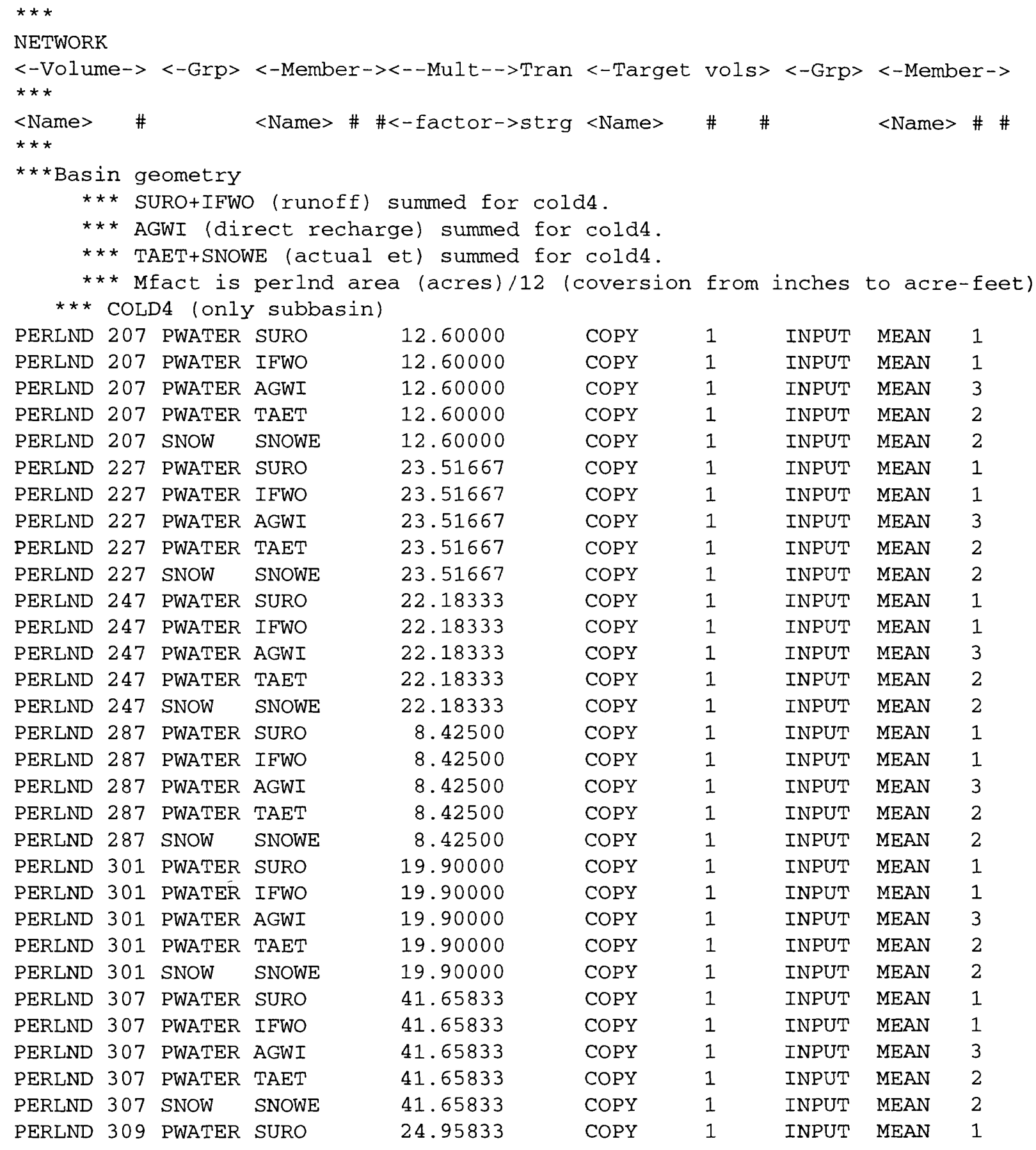




\begin{tabular}{|c|c|c|c|c|c|c|c|c|}
\hline PERLND & 309 & PWATER & IFWO & 24.95833 & COPY & 1 & INPUT & MEAN \\
\hline PERLND & 309 & PWATER & AGWI & 24.95833 & COPY & 1 & INPUT & MEAN \\
\hline PERLND & 309 & PWATER & TAET & 24.95833 & COPY & 1 & INPUT & MEAN \\
\hline PERLND & 309 & SNOW & SNOWE & 24.95833 & COPY & 1 & INPUT & MEAN \\
\hline PERLND & 321 & PWATER & SURO & 29.57500 & COPY & 1 & INPUT & MEAN \\
\hline PERLND & 321 & PWATER & IFWO & 29.57500 & COPY & 1 & INPUT & MEAN \\
\hline PERLND & 321 & PWATER & AGWI & 29.57500 & COPY & 1 & INPUT & MEAN \\
\hline PERLND & 321 & PWATER & TAET & 29.57500 & COPY & 1 & INPUT & MEAN \\
\hline PERLND & 321 & SNOW & SNOWE & 29.57500 & COPY & 1 & INPUT & MEAN \\
\hline PERLND & 323 & PWATER & SURO & 7.75000 & COPY & 1 & INPUT & MEAN \\
\hline PERLND & 323 & PWATER & IFWO & 7.75000 & COPY & 1 & INPUT & MEAN \\
\hline PERLND & 323 & PWATER & AGWI & 7.75000 & COPY & 1 & INPUT & MEAN \\
\hline PERLND & 323 & PWATER & TAET & 7.75000 & COPY & 1 & INPUT & MEAN \\
\hline PERLND & 323 & SNOW & SNOWE & 7.75000 & COPY & 1 & INPUT & MEAN \\
\hline PERLND & 327 & PWATER & SURO & 92.76666 & COPY & 1 & INPUT & MEAN \\
\hline PERLND & 327 & PWATER & IFWO & 92.76666 & COPY & 1 & INPUT & MEAN \\
\hline PERLND & 327 & PWATER & AGWI & 92.76666 & COPY & 1 & INPUT & MEAN \\
\hline PERLND & 327 & PWATER & TAET & 92.76666 & COPY & 1 & INPUT & MEAN \\
\hline PERLND & 327 & SNOW & SNOWE & 92.76666 & COPY & 1 & INPUT & MEAN \\
\hline PERLND & 341 & PWATER & SURO & 56.95833 & COPY & 1 & INPUT & MEAN \\
\hline PERLND & 341 & PWATER & IFWO & 56.95833 & COPY & 1 & INPUT & MEAN \\
\hline PERLND & 341 & PWATER & AGWI & 56.95833 & COPY & 1 & INPUT & MEAN \\
\hline PERLND & 341 & PWATER & TAET & 56.95833 & COPY & 1 & INPUT & MEAN \\
\hline PERLND & 341 & SNOW & SNOWE & 56.95833 & COPY & 1 & INPUT & MEAN \\
\hline PERLND & 343 & PWATER & SURO & 29.20833 & COPY & 1 & INPUT & MEAN \\
\hline PERLND & 343 & PWATER & IFWO & 29.20833 & COPY & 1 & INPUT & MEAN \\
\hline PERLND & 343 & PWATER & AGWI & 29.20833 & COPY & 1 & INPUT & MEAN \\
\hline PERLND & 343 & PWATER & TAET & 29.20833 & COPY & 1 & INPUT & MEAN \\
\hline PERLND & 343 & SNOW & SNOWE & 29.20833 & COPY & 1 & INPUT & MEAN \\
\hline PERLND & 347 & PWATER & SURO & 156.45833 & COPY & 1 & INPUT & MEAN \\
\hline PERLND & 347 & PWATER & IFWO & 156.45833 & COPY & 1 & INPUT & MEAN \\
\hline PERLND & 347 & PWATER & AGWI & 156.45833 & COPY & 1 & INPUT & MEAN \\
\hline PERLND & 347 & PWATER & TAET & 156.45833 & COPY & 1 & INPUT & MEAN \\
\hline PERLND & 347 & SNOW & SNOWE & 156.45833 & COPY & 1 & INPUT & MEAN \\
\hline PERLND & 348 & PWATER & SURO & 7.40833 & COPY & 1 & INPUT & MEAN \\
\hline PERLND & 348 & PWATER & IFWO & 7.40833 & COPY & 1 & INPUT & MEAN \\
\hline PERLND & 348 & PWATER & AGWI & 7.40833 & COPY & 1 & INPUT & MEAN \\
\hline PERLND & 348 & PWATER & TAET & 7.40833 & COPY & 1 & INPUT & MEAN \\
\hline PERLND & 348 & SNOW & SNOWE & 7.40833 & COPY & 1 & INPUT & MEAN \\
\hline PERLND & 349 & PWATER & SURO & 70.55000 & COPY & 1 & INPUT & MEAN \\
\hline PERLND & 349 & PWATER & IFWO & 70.55000 & COPY & 1 & INPUT & MEAN \\
\hline PERLND & 349 & PWATER & AGWI & 70.55000 & COPY & 1 & INPUT & MEAN \\
\hline PERLND & 349 & PWATER & TAET & 70.55000 & COPY & 1 & INPUT & MEAN \\
\hline PERLND & 349 & SNOW & SNOWE & 70.55000 & COPY & 1 & INPUT & MEAN \\
\hline PERLND & 361 & PWATER & SURO & 46.83333 & COPY & 1 & INPUT & MEAN \\
\hline PERLND & 361 & PWATER & IFWO & 46.83333 & COPY & 1 & INPUT & MEAN \\
\hline PERLND & 361 & PWATER & AGWI & 46.83333 & COPY & 1 & INPUT & MEAN \\
\hline PERLND & 361 & PWATER & TAET & 46.83333 & COPY & 1 & INPUT & MEAN \\
\hline PERLND & 361 & SNOW & SNOWE & 46.83333 & COPY & 1 & INPUT & MEAN \\
\hline PERLND & 367 & PWATER & SURO & 82.54166 & COPY & 1 & INPUT & MEAN \\
\hline PERLND & 367 & PWATER & IFWO & 82.54166 & COPY & 1 & INPUT & MEAN \\
\hline PERLND & 367 & PWATER & AGWI & 82.54166 & COPY & 1 & INPUT & MEAN \\
\hline PERLND & 367 & PWATER & TAET & 82.54166 & COPY & 1 & INPUT & MEAN \\
\hline PERLND & 367 & SNOW & SNOWE & 82.54166 & COPY & 1 & INPUT & MEAN \\
\hline
\end{tabular}




\begin{tabular}{|c|c|c|c|c|c|c|c|c|}
\hline PERLND & 368 & PWATER & SURO & 7.17500 & COPY & 1 & INPUT & MEAN \\
\hline PERLND & 368 & PWATER & IFWO & 7.17500 & COPY & 1 & INPUT & MEAN \\
\hline PERLND & 368 & PWATER & AGWI & 7.17500 & COPY & 1 & INPUT & MEAN \\
\hline PERLND & 368 & PWATER & TAET & 7.17500 & COPY & 1 & INPUT & MEAN \\
\hline PERLND & 368 & SNOW & SNOWE & 7.17500 & COPY & 1 & INPUT & MEAN \\
\hline PERLND & 381 & PWATER & SURO & 11.02500 & COPY & 1 & INPUT & MEAN \\
\hline PERLND & 381 & PWATER & IFWO & 11.02500 & COPY & 1 & INPUT & MEAN \\
\hline PERLND & 381 & PWATER & AGWI & 11.02500 & COPY & 1 & INPUT & MEAN \\
\hline PERLND & 381 & PWATER & TAET & 11.02500 & COPY & 1 & INPUT & MEAN \\
\hline PERLND & 381 & SNOW & SNOWE & 11.02500 & COPY & 1 & INPUT & MEAN \\
\hline PERLND & 387 & PWATER & SURO & 35.67500 & COPY & 1 & INPUT & MEAN \\
\hline PERLND & 387 & PWATER & IFWO & 35.67500 & COPY & 1 & INPUT & MEAN \\
\hline PERLND & 387 & PWATER & AGWI & 35.67500 & COPY & 1 & INPUT & MEAN \\
\hline PERLND & 387 & PWATER & TAET & 35.67500 & COPY & 1 & INPUT & MEAN \\
\hline PERLND & 387 & SNOW & SNOWE & 35.67500 & COPY & 1 & INPUT & MEAN \\
\hline PERLND & 389 & PWATER & SURO & 13.42500 & COPY & 1 & INPUT & MEAN \\
\hline PERLND & 389 & PWATER & IFWO & 13.42500 & COPY & 1 & INPUT & MEAN \\
\hline PERLND & 389 & PWATER & AGWI & 13.42500 & COPY & 1 & INPUT & MEAN \\
\hline PERLND & 389 & PWATER & TAET & 13.42500 & COPY & 1 & INPUT & MEAN \\
\hline PERLND & 389 & SNOW & SNOWE & 13.42500 & COPY & 1 & INPUT & MEAN \\
\hline PERLND & 401 & PWATER & SURO & 5.55833 & COPY & 1 & INPUT & MEAN \\
\hline PERLND & 401 & PWATER & IFWO & 5.55833 & COPY & 1 & INPUT & MEAN \\
\hline PERLND & 401 & PWATER & AGWI & 5.55833 & COPY & 1 & INPUT & MEAN \\
\hline PERLND & 401 & PWATER & TAET & 5.55833 & COPY & 1 & INPUT & MEAN \\
\hline PERLND & 401 & SNOW & SNOWE & 5.55833 & COPY & 1 & INPUT & MEAN \\
\hline PERLND & 407 & PWATER & SURO & 4.99167 & COPY & 1 & INPUT & MEAN \\
\hline PERLND & 407 & PWATER & IFWO & 4.99167 & COPY & 1 & INPUT & MEAN \\
\hline PERLND & 407 & PWATER & AGWI & 4.99167 & COPY & 1 & INPUT & MEAN \\
\hline PERLND & 407 & PWATER & TAET & 4.99167 & COPY & 1 & INPUT & MEAN \\
\hline PERLND & 407 & SNOW & SNOWE & 4.99167 & COPY & 1 & INPUT & MEAN \\
\hline PERLND & 421 & PWATER & SURO & 15.30000 & COPY & 1 & INPUT & MEAN \\
\hline PERLND & 421 & PWATER & IFWO & 15.30000 & COPY & 1 & INPUT & MEAN \\
\hline PERLND & 421 & PWATER & AGWI & 15.30000 & COPY & 1 & INPUT & MEAN \\
\hline PERLND & 421 & PWATER & TAET & 15.30000 & COPY & 1 & INPUT & MEAN \\
\hline PERLND & 421 & SNOW & SNOWE & 15.30000 & COPY & 1 & INPUT & MEAN \\
\hline PERLND & 422 & PWATER & SURO & 1.81667 & COPY & 1 & INPUT & MEAN \\
\hline PERLND & 422 & PWATER & IFWO & 1.81667 & COPY & 1 & INPUT & MEAN \\
\hline PERLND & 422 & PWATER & AGWI & 1.81667 & COPY & 1 & INPUT & MEAN \\
\hline PERLND & 422 & PWATER & TAET & 1.81667 & COPY & 1 & INPUT & MEAN \\
\hline PERLND & 422 & SNOW & SNOWE & 1.81667 & COPY & 1 & INPUT & MEAN \\
\hline PERLND & 427 & PWATER & SURO & 17.42500 & COPY & 1 & INPUT & MEAN \\
\hline PERLND & 427 & PWATER & IFWO & 17.42500 & COPY & 1 & INPUT & MEAN \\
\hline PERLND & 427 & PWATER & AGWI & 17.42500 & COPY & 1 & INPUT & MEAN \\
\hline PERLND & 427 & PWATER & TAET & 17.42500 & COPY & 1 & INPUT & MEAN \\
\hline PERLND & 427 & SNOW & SNOWE & 17.42500 & COPY & 1 & INPUT & MEAN \\
\hline PERLND & 461 & PWATER & SURO & 31.05833 & COPY & 1 & INPUT & MEAN \\
\hline PERLND & 461 & PWATER & IFWO & 31.05833 & COPY & 1 & INPUT & MEAN \\
\hline PERLND & 461 & PWATER & AGWI & 31.05833 & COPY & 1 & INPUT & MEAN \\
\hline PERLND & 461 & PWATER & TAET & 31.05833 & COPY & 1 & INPUT & MEAN \\
\hline PERLND & 461 & SNOW & SNOWE & 31.05833 & COPY & 1 & INPUT & MEAN \\
\hline PERLND & 467 & PWATER & SURO & 31.00833 & COPY & 1 & INPUT & MEAN \\
\hline PERLND & 467 & PWATER & IFWO & 31.00833 & COPY & 1 & INPUT & MEAN \\
\hline PERLND & 467 & PWATER & AGWI & 31.00833 & COPY & 1 & INPUT & MEAN \\
\hline PERLND & 467 & PWATER & TAET & 31.00833 & COPY & 1 & INPUT & MEAN \\
\hline
\end{tabular}




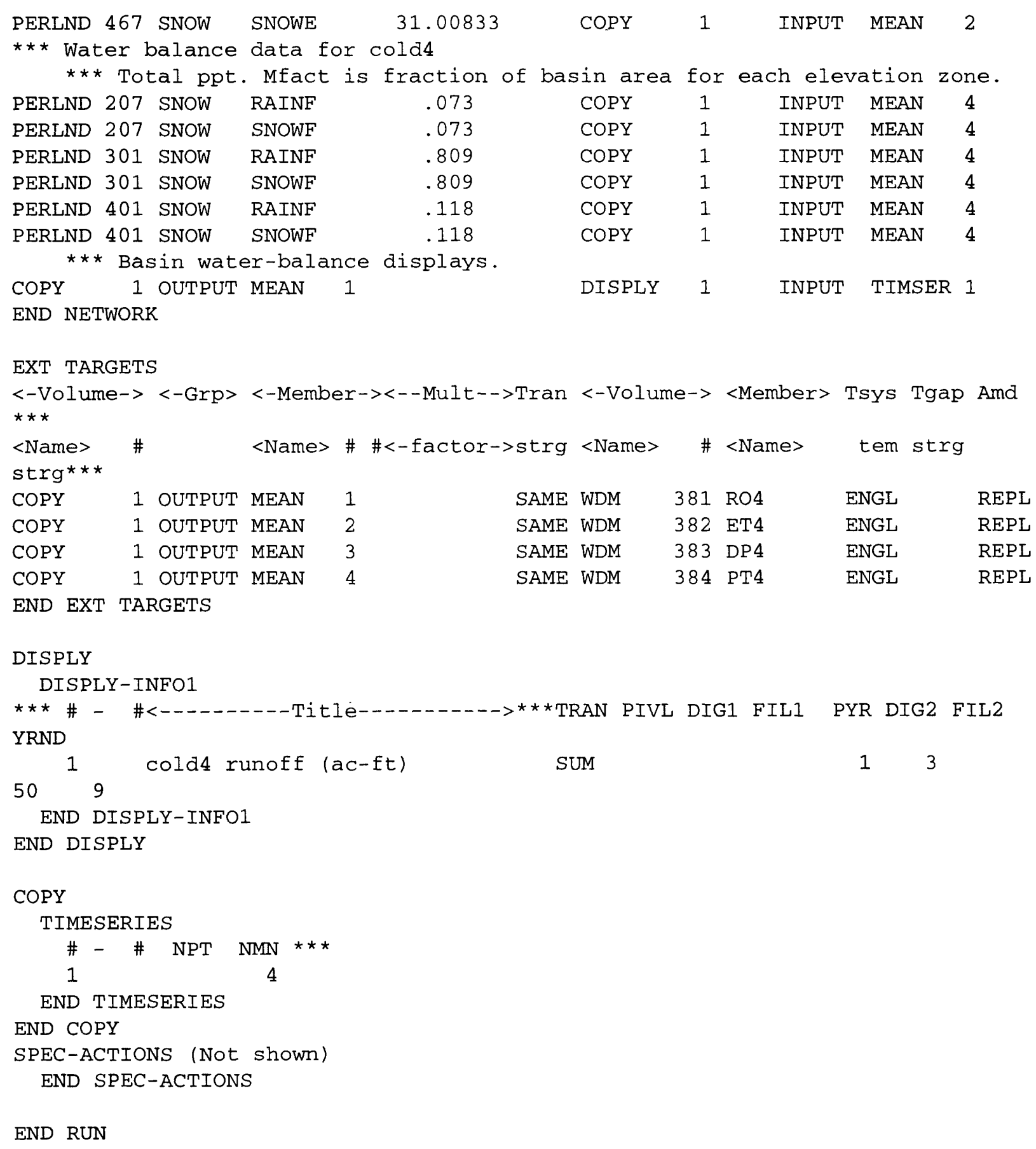

SAME WDM

SAME WDM

SAME WDM

SAME WDM

$\begin{array}{ll}381 & \text { RO4 } \\ 382 & \text { ET4 } \\ 383 & \text { DP4 } \\ 384 & \text { PT4 }\end{array}$

384 PT4

ENGL

ENGL

ENGL

ENGL

DISPLY

DISPLY-INFO1 
Appendix 2.--Final HSPF input file for Lower Cold Creek model. For brevity, the "SPECIAL ACTIONS" portion of the model input, where the dates of soil freezing and thawing are represented by changes in the INFILT parameter values, is not included. Complete input files may be obtained by contacting the District Chief at the address shown on page ii of this report

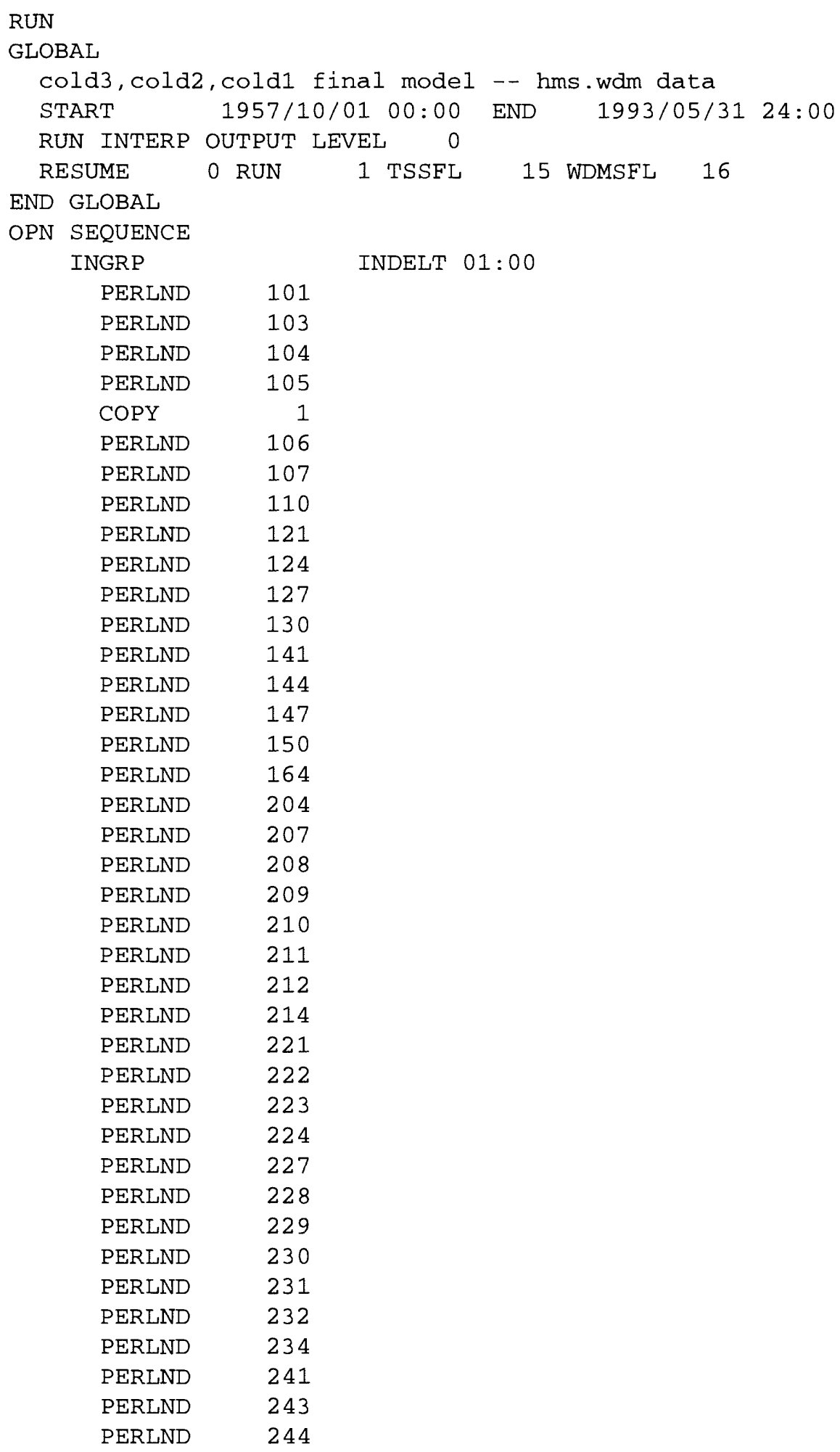




\begin{tabular}{|c|c|}
\hline PERLND & 247 \\
\hline PERLND & 248 \\
\hline PERLND & 249 \\
\hline PERLND & 250 \\
\hline PERLND & 252 \\
\hline PERLND & 253 \\
\hline PERLND & 254 \\
\hline PERLND & 261 \\
\hline PERLND & 264 \\
\hline PERLND & 267 \\
\hline PERLND & 268 \\
\hline PERLND & 269 \\
\hline PERLND & 281 \\
\hline PERLND & 287 \\
\hline PERLND & 289 \\
\hline PERLND & 308 \\
\hline PERLND & 321 \\
\hline PERLND & 341 \\
\hline PERLND & 347 \\
\hline PERLND & 361 \\
\hline PERLND & 367 \\
\hline PERLND & 381 \\
\hline PERLND & 387 \\
\hline COPY & 2 \\
\hline COPY & 3 \\
\hline DISPLY & 1 \\
\hline DISPLY & 2 \\
\hline DISPLY & 3 \\
\hline
\end{tabular}

END INGRP

END OPN SEQUENCE

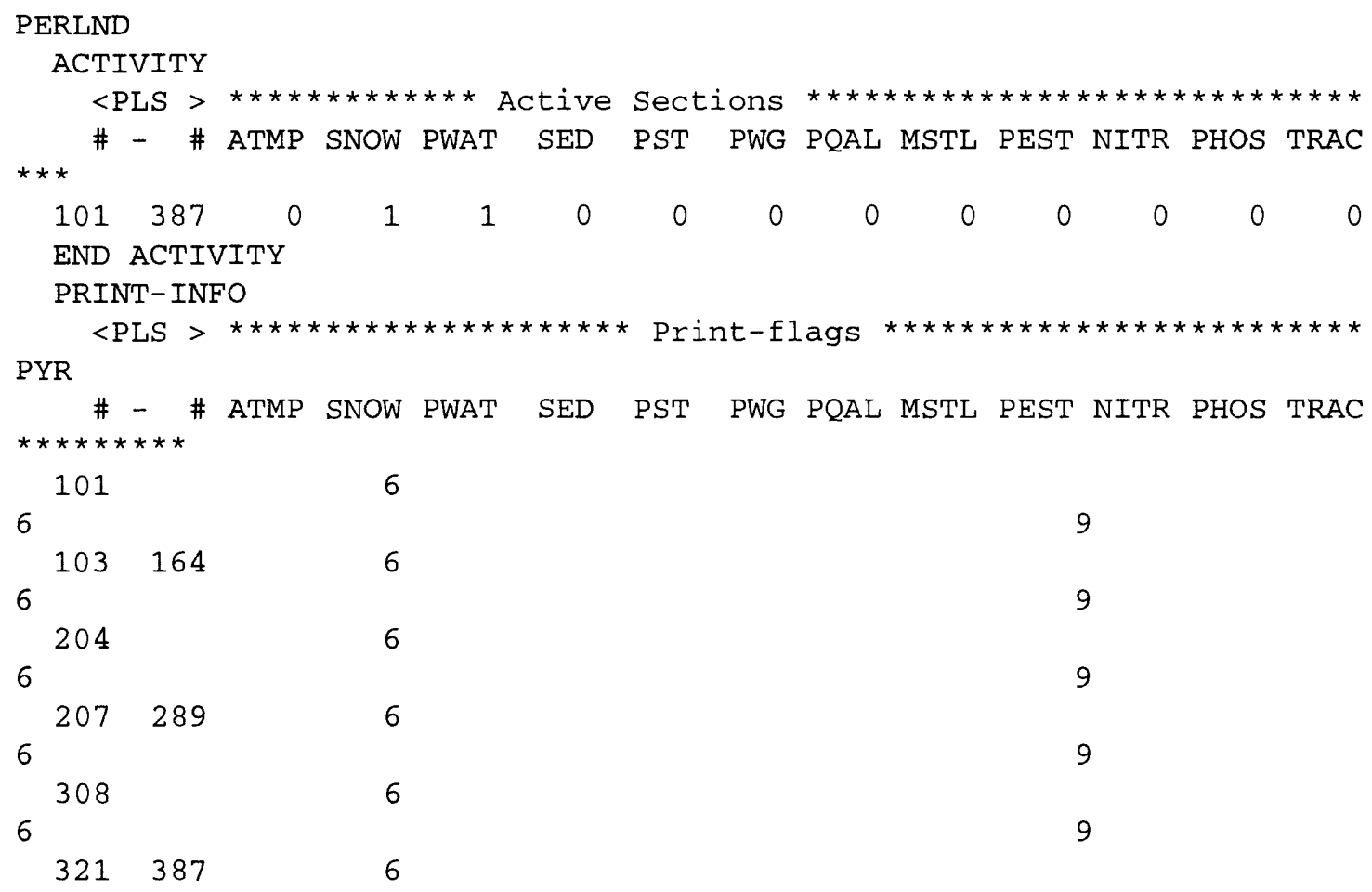

$308 \quad 6$

9

9

6 
END PRINT-INFO

GEN-INFO

$<$ PLS ><-----Name-------> NBLKS

Unit-systems Printer

$\star \star \star \star *-\#$

User $t$-series Engl Metr

$\star \star \star *$

in out

*** Grouped by elevation zone $* \star *$

101

103

104

105

106

107

110

121

124

127

130

141

144

147

150

164

204

207

208

209

210

211

212

214

221

222

223

224

227

228

229

230

231

232

234

241

243

244

247

248

249

250

252

253 sage, soil1, flat

sage, soil3, flat

sage, soil4, flat

bare, soill, flat

irri, soil4, flat

gras, soil1, flat

gras, soil4, flat

sage, soil1, mod.N

sage, soil , mod.N

gras, soil1, mod. N

gras, soil4, mod.N

sage, soil1, mod.s

sage, soil4, mod.s

gras, soil1, mod.s

gras, soil4, mod.S

sage, soil4, stp.N

sage, soil4, flat

gras, soill, flat

gras, soil2, flat

gras, soil3, flat

gras, soil4, flat

dwht, soil1, flat

dwht, soil2, flat

dwht, soil4, flat

sage, soil1, mod.N

sage, soil2, mod.N

sage, soil3, mod. $N$

sage, soil4, mod.N

gras, soil1, mod.N

gras, soil2, mod.N

gras, soil $3, \bmod . N$

gras, soil4, mod. N

dwht, soil1, mod. N

dwht, soil2, mod. N

dwht, soil 4, mod. N

sage, soil1, mod.s

sage, soil3, mod. S

sage, soil 4 mod. $S$

gras, soil1, mod.s

gras, soil2, mod.s

gras, soil3, mod.s

gras, soil4, mod. $\mathrm{S}$

dwht, soil2, mod.s

dwht, soil3, mod.s

$\begin{array}{llllll}1 & 1 & 1 & 1 & 6 & 0 \\ 1 & 1 & 1 & 1 & 6 & 0 \\ 1 & 1 & 1 & 1 & 6 & 0 \\ 1 & 1 & 1 & 1 & 6 & 0 \\ 1 & 1 & 1 & 1 & 6 & 0 \\ 1 & 1 & 1 & 1 & 6 & 0 \\ 1 & 1 & 1 & 1 & 6 & 0 \\ 1 & 1 & 1 & 1 & 6 & 0 \\ 1 & 1 & 1 & 1 & 6 & 0 \\ 1 & 1 & 1 & 1 & 6 & 0 \\ 1 & 1 & 1 & 1 & 6 & 0 \\ 1 & 1 & 1 & 1 & 6 & 0 \\ 1 & 1 & 1 & 1 & 6 & 0 \\ 1 & 1 & 1 & 1 & 6 & 0 \\ 1 & 1 & 1 & 1 & 6 & 0 \\ 1 & 1 & 1 & 1 & 6 & 0 \\ 1 & 1 & 1 & 1 & 6 & 0 \\ 1 & 1 & 1 & 1 & 6 & 0 \\ 1 & 1 & 1 & 1 & 6 & 0 \\ 1 & 1 & 1 & 1 & 6 & 0 \\ 1 & 1 & 1 & 1 & 6 & 0 \\ 1 & 1 & 1 & 1 & 6 & 0 \\ 1 & 1 & 1 & 1 & 6 & 0 \\ 1 & 1 & 1 & 1 & 6 & 0 \\ 1 & 1 & 1 & 1 & 6 & 0 \\ 1 & 1 & 1 & 1 & 6 & 0 \\ 1 & 1 & 1 & 1 & 6 & 0 \\ 1 & 1 & 1 & 1 & 6 & 0 \\ 1 & 1 & 1 & 1 & 6 & 0 \\ 1 & 1 & 1 & 1 & 6 & 0 \\ 1 & 1 & 1 & 1 & 6 & 0 \\ 1 & 1 & 1 & 1 & 6 & 0 \\ 1 & 1 & 1 & 1 & 6 & 0 \\ 1 & 1 & 1 & 1 & 6 & 0 \\ 1 & 1 & 1 & 1 & 6 & 0 \\ 1 & 1 & 1 & 1 & 6 & 0 \\ 1 & 1 & 1 & 1 & 6 & 0 \\ 1 & 1 & 1 & 1 & 6 & 0 \\ 1 & 1 & 1 & 1 & 6 & 0 \\ 1 & 1 & 1 & 1 & 6 & 0 \\ 1 & 1 & 1 & 1 & 6 & 0 \\ 1 & 1 & 1 & 1 & 6 & 0 \\ 1 & 1 & 1 & 1 & 6 & 0 \\ 1 & 1 & 1 & 1 & 6 & 0\end{array}$




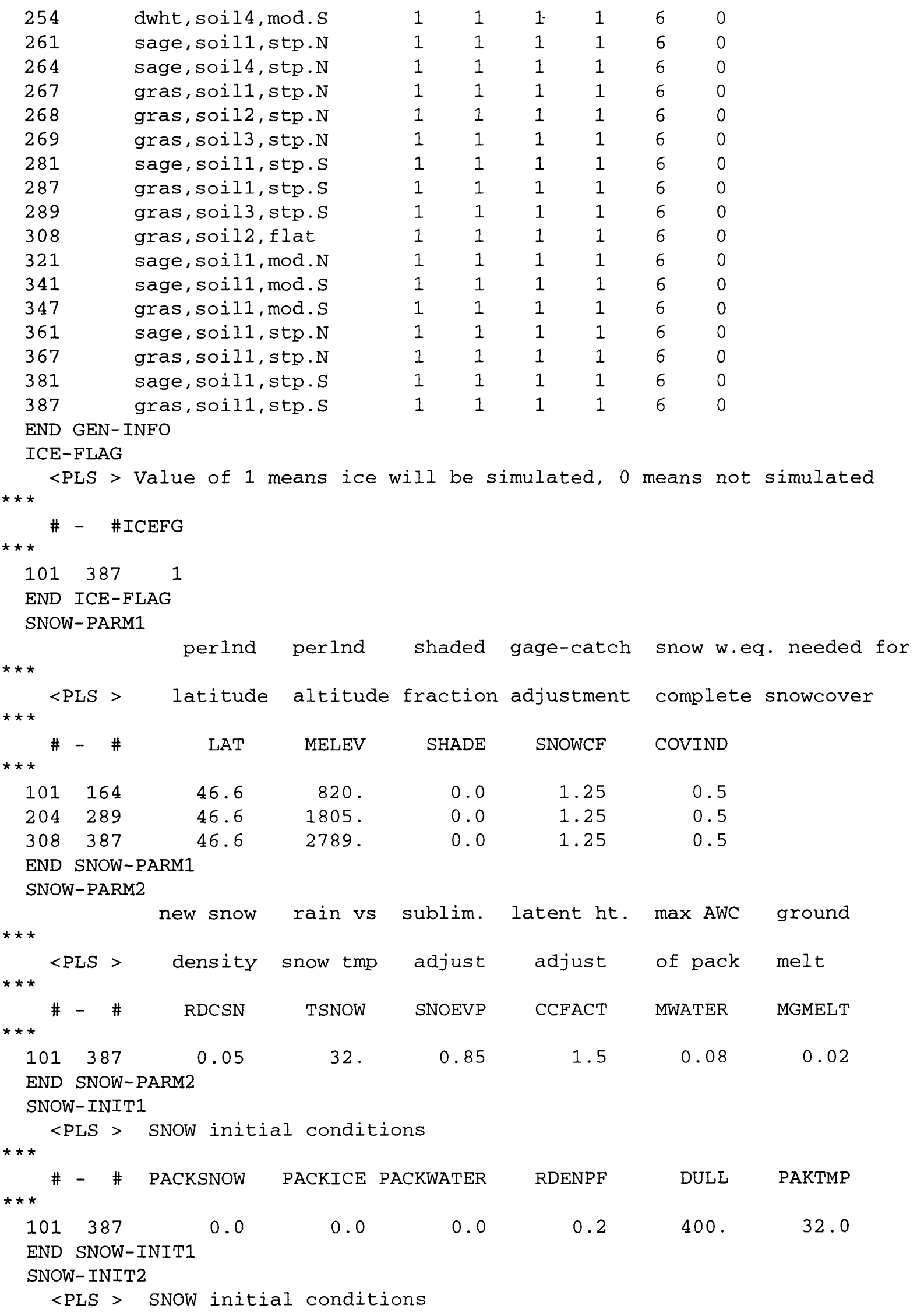


\# - \# COVINX XLNMELT SKYCLR
$101 \quad 387$
0.50
0.0
1.0
END SNOW-INIT2

PWAT-PARM 1

<PLS > PWATER variable monthly parameter value flags

Snow cepsc uzns nsur intfw irc lzetp

\# - \# CSNO RTOP UZFG VCS VUZ VNN VIFW VIRC VLE

$\begin{array}{lllllllllll}101 & 387 & 1 & 0 & 0 & 1 & 0 & 0 & 0 & 0 & 1\end{array}$

END PWAT-PARM1

PWAT-PARM2

$<$ PLS $>\star \star *$

\#- \#***FOREST LZSN INFILT ISUR SLSUR KVARY

AGWRC

** sagebrush $* \star *$

\begin{tabular}{|c|c|c|c|c|c|c|}
\hline 101 & 0. & 2.3000 & 0.2000 & 2000.0 & 0.0350 & 0.0000 \\
\hline \multicolumn{7}{|l|}{0.9900} \\
\hline 121 & 0 . & 2.3000 & 0.2000 & 2000.0 & 0.1100 & 0.0000 \\
\hline \multicolumn{7}{|l|}{0.9900} \\
\hline 221 & 0 . & 2.3000 & 0.2000 & 4000.0 & 0.1100 & 0.0000 \\
\hline \multicolumn{7}{|l|}{0.9900} \\
\hline 321 & 0 & 2.3000 & 0.2000 & 2000.0 & 0.1100 & 0.0000 \\
\hline \multicolumn{7}{|l|}{0.9900} \\
\hline 141 & 0 . & 2.3000 & 0.2000 & 2000.0 & 0.1100 & 0.0000 \\
\hline \multicolumn{7}{|l|}{0.9900} \\
\hline 241 & 0. & 2.3000 & 0.2000 & 4000.0 & 0.1100 & 0.0000 \\
\hline \multicolumn{7}{|l|}{0.9900} \\
\hline 341 & 0. & 2.3000 & 0.2000 & 8000.0 & 0.1100 & 0.0000 \\
\hline \multicolumn{7}{|l|}{0.9900} \\
\hline 261 & 0 . & 2.3000 & 0.2000 & 4000.0 & 0.2300 & 0.0000 \\
\hline \multicolumn{7}{|l|}{0.9900} \\
\hline 361 & 0. & 2.3000 & 0.2000 & 8000.0 & 0.2300 & 0.0000 \\
\hline \multicolumn{7}{|l|}{0.9900} \\
\hline 281 & 0 . & 2.3000 & 0.2000 & 4000.0 & 0.2300 & 0.0000 \\
\hline \multicolumn{7}{|l|}{0.9900} \\
\hline 381 & 0. & 2.3000 & 0.2000 & 4000.0 & 0.2300 & 0.0000 \\
\hline \multicolumn{7}{|l|}{0.9900} \\
\hline 222 & 0 & 4.1000 & 0.2000 & 4000.0 & 0.1100 & 0.0000 \\
\hline \multicolumn{7}{|l|}{0.9900} \\
\hline 103 & 0. & 6.2000 & 0.2000 & 2000.0 & 0.0350 & 0.0000 \\
\hline \multicolumn{7}{|l|}{0.9900} \\
\hline 223 & 0. & 6.2000 & 0.2000 & 4000.0 & 0.1100 & 0.0000 \\
\hline \multicolumn{7}{|l|}{0.9900} \\
\hline 243 & 0. & 6.2000 & 0.2000 & 4000.0 & 0.1100 & 0.0000 \\
\hline \multicolumn{7}{|l|}{0.9900} \\
\hline 104 & 0 . & 9.2000 & 0.2000 & 2000.0 & 0.0350 & 0.0000 \\
\hline \multicolumn{7}{|l|}{0.9900} \\
\hline 204 & 0 & 9.2000 & 0.2000 & 4000.0 & 0.0350 & 0.0000 \\
\hline \multicolumn{7}{|l|}{0.9900} \\
\hline 124 & 0. & 9.2000 & 0.2000 & 2000.0 & 0.1100 & 0.0000 \\
\hline
\end{tabular}




\begin{tabular}{|c|c|c|c|c|c|c|}
\hline \multicolumn{7}{|l|}{0.9900} \\
\hline 224 & 0 . & 9.2000 & 0.2000 & 4000.0 & 0.1100 & 0.0000 \\
\hline \multicolumn{7}{|l|}{0.9900} \\
\hline 144 & 0 . & 9.2000 & 0.2000 & 2000.0 & 0.1100 & 0.0000 \\
\hline \multicolumn{7}{|l|}{0.9900} \\
\hline 244 & 0. & 9.2000 & 0.2000 & 4000.0 & 0.1100 & 0.0000 \\
\hline \multicolumn{7}{|l|}{0.9900} \\
\hline 164 & 0 . & 9.2000 & 0.2000 & 2000.0 & 0.2300 & 0.0000 \\
\hline \multicolumn{7}{|l|}{0.9900} \\
\hline 264 & 0 . & 9.2000 & 0.2000 & 4000.0 & 0.2300 & 0.0000 \\
\hline \multicolumn{7}{|c|}{0.9900} \\
\hline \multicolumn{7}{|c|}{$\star * *$ grassland $* * *$} \\
\hline 107 & 0 & 2.3000 & 0.2000 & 2000.0 & 0.0350 & 0.0000 \\
\hline \multicolumn{7}{|l|}{0.9900} \\
\hline 207 & 0 . & 2.3000 & 0.2000 & 4000.0 & 0.0350 & 0.0000 \\
\hline \multicolumn{7}{|l|}{0.9900} \\
\hline 127 & 0 . & 2.3000 & 0.2000 & 2000.0 & 0.1100 & 0.0000 \\
\hline \multicolumn{7}{|l|}{0.9900} \\
\hline 227 & 0 . & 2.3000 & 0.2000 & 4000.0 & 0.1100 & 0.0000 \\
\hline \multicolumn{7}{|l|}{0.9900} \\
\hline 147 & 0. & 2.3000 & 0.2000 & 2000.0 & 0.1100 & 0.0000 \\
\hline \multicolumn{7}{|l|}{0.9900} \\
\hline 247 & 0. & 2.3000 & 0.2000 & 4000.0 & 0.1100 & 0.0000 \\
\hline \multicolumn{7}{|l|}{0.9900} \\
\hline 347 & 0. & 2.3000 & 0.2000 & 8000.0 & 0.1100 & 0.0000 \\
\hline \multicolumn{7}{|l|}{0.9900} \\
\hline 267 & 0 . & 2.3000 & 0.2000 & 4000.0 & 0.2300 & 0.0000 \\
\hline \multicolumn{7}{|l|}{0.9900} \\
\hline 367 & 0. & 2.3000 & 0.2000 & 8000.0 & 0.2300 & 0.0000 \\
\hline \multicolumn{7}{|l|}{0.9900} \\
\hline 287 & 0. & 2.3000 & 0.2000 & 4000.0 & 0.2300 & 0.0000 \\
\hline \multicolumn{7}{|l|}{0.9900} \\
\hline 387 & 0. & 2.3000 & 0.2000 & 8000.0 & 0.2300 & 0.0000 \\
\hline \multicolumn{7}{|l|}{0.9900} \\
\hline 208 & 0. & 4.1000 & 0.2000 & 4000.0 & 0.0350 & 0.0000 \\
\hline \multicolumn{7}{|l|}{0.9900} \\
\hline 308 & 0. & 4.1000 & 0.2000 & 8000.0 & 0.0350 & 0.0000 \\
\hline 0.9900 & & & & & & \\
\hline 228 & 0. & 4.1000 & 0.2000 & 4000.0 & 0.1100 & 0.0000 \\
\hline 0.9900 & & & & & & \\
\hline 248 & 0. & 4.1000 & 0.2000 & 4000.0 & 0.1100 & 0.0000 \\
\hline 0.9900 & & & & & & \\
\hline 268 & 0 . & 4.1000 & 0.2000 & 4000.0 & 0.2300 & 0.0000 \\
\hline 0.9900 & & & & & & \\
\hline 209 & 0. & 2.9000 & 0.2000 & 4000.0 & 0.0350 & 0.0000 \\
\hline 0.9900 & & & & & & \\
\hline 229 & 0. & 2.9000 & 0.2000 & 4000.0 & 0.1100 & 0.0000 \\
\hline 0.9900 & & & & & & \\
\hline 249 & 0 . & 2.9000 & 0.2000 & 4000.0 & 0.1100 & 0.0000 \\
\hline 0.9900 & & & & & & \\
\hline 269 & 0 . & 2.9000 & 0.2000 & 4000.0 & 0.2300 & 0.0000 \\
\hline 0.9900 & & & & & & \\
\hline 289 & 0 . & 2.9000 & 0.2000 & 4000.0 & 0.2300 & 0.0000 \\
\hline 0.9900 & & & & & & \\
\hline
\end{tabular}




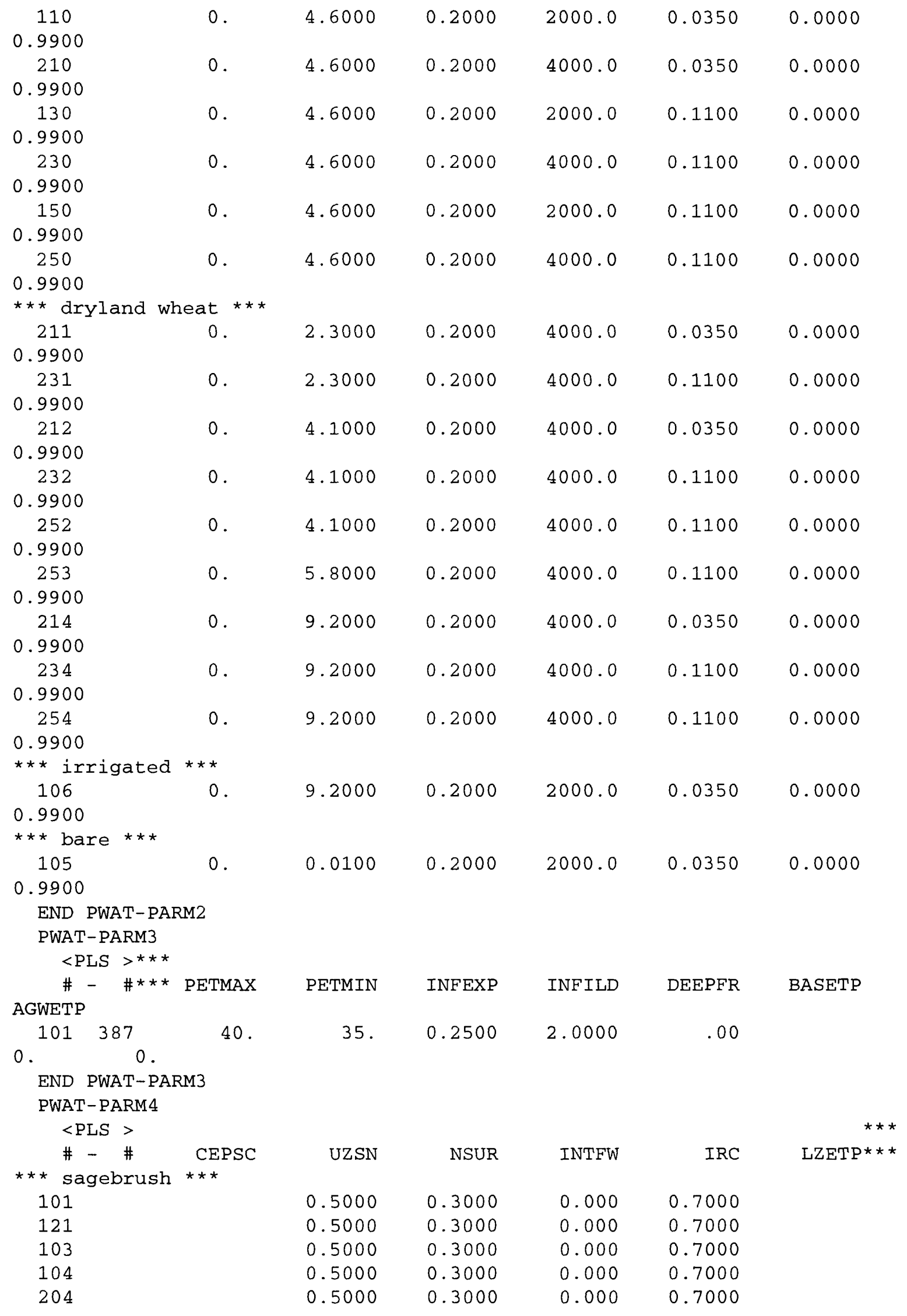




\begin{tabular}{|c|c|c|c|c|}
\hline 221 & 0.3000 & 0.3000 & 0.000 & 0.5000 \\
\hline 321 & 0.3000 & 0.3000 & 0.000 & 0.5000 \\
\hline 141 & 0.3000 & 0.3000 & 0.000 & 0.5000 \\
\hline 241 & 0.3000 & 0.3000 & 0.000 & 0.5000 \\
\hline 341 & 0.3000 & 0.3000 & 0.000 & 0.5000 \\
\hline 222 & 0.3000 & 0.3000 & 0.000 & 0.5000 \\
\hline 223 & 0.3000 & 0.3000 & 0.000 & 0.5000 \\
\hline 243 & 0.3000 & 0.3000 & 0.000 & 0.5000 \\
\hline 124 & 0.3000 & 0.3000 & 0.000 & 0.5000 \\
\hline 224 & 0.3000 & 0.3000 & 0.000 & 0.5000 \\
\hline 144 & 0.3000 & 0.3000 & 0.000 & 0.5000 \\
\hline 244 & 0.3000 & 0.3000 & 0.000 & 0.5000 \\
\hline 261 & 0.2000 & 0.3000 & 0.000 & 0.3000 \\
\hline 361 & 0.2000 & 0.3000 & 0.000 & 0.3000 \\
\hline 281 & 0.2000 & 0.3000 & 0.000 & 0.3000 \\
\hline 381 & 0.2000 & 0.3000 & 0.000 & 0.3000 \\
\hline 164 & 0.2000 & 0.3000 & 0.000 & 0.3000 \\
\hline 264 & 0.2000 & 0.3000 & 0.000 & 0.3000 \\
\hline$\star \star \star$ grassland $\star \star \star *$ & & & & \\
\hline 107 & 0.5000 & 0.3000 & 0.000 & 0.7000 \\
\hline 207 & 0.5000 & 0.3000 & 0.000 & 0.7000 \\
\hline 208 & 0.5000 & 0.3000 & 0.000 & 0.7000 \\
\hline 308 & 0.5000 & 0.3000 & 0.000 & 0.7000 \\
\hline 209 & 0.5000 & 0.3000 & 0.000 & 0.7000 \\
\hline 110 & 0.5000 & 0.3000 & 0.000 & 0.7000 \\
\hline 210 & 0.5000 & 0.3000 & 0.000 & 0.7000 \\
\hline 127 & 0.3000 & 0.3000 & 0.000 & 0.5000 \\
\hline 227 & 0.3000 & 0.3000 & 0.000 & 0.5000 \\
\hline 147 & 0.3000 & 0.3000 & 0.000 & 0.5000 \\
\hline 247 & 0.3000 & 0.3000 & 0.000 & 0.5000 \\
\hline 347 & 0.3000 & 0.3000 & 0.000 & 0.5000 \\
\hline 228 & 0.3000 & 0.3000 & 0.000 & 0.5000 \\
\hline 248 & 0.3000 & 0.3000 & 0.000 & 0.5000 \\
\hline 229 & 0.3000 & 0.3000 & 0.000 & 0.5000 \\
\hline 249 & 0.3000 & 0.3000 & 0.000 & 0.5000 \\
\hline 130 & 0.3000 & 0.3000 & 0.000 & 0.5000 \\
\hline 230 & 0.3000 & 0.3000 & 0.000 & 0.5000 \\
\hline 150 & 0.3000 & 0.3000 & 0.000 & 0.5000 \\
\hline 250 & 0.3000 & 0.3000 & 0.000 & 0.5000 \\
\hline 267 & 0.2000 & 0.3000 & 0.000 & 0.3000 \\
\hline 367 & 0.2000 & 0.3000 & 0.000 & 0.3000 \\
\hline 287 & 0.2000 & 0.3000 & 0.000 & 0.3000 \\
\hline 387 & 0.2000 & 0.3000 & 0.000 & 0.3000 \\
\hline 268 & 0.2000 & 0.3000 & 0.000 & 0.3000 \\
\hline 269 & 0.2000 & 0.3000 & 0.000 & 0.3000 \\
\hline 289 & 0.2000 & 0.3000 & 0.000 & 0.3000 \\
\hline *** dryland wheat & $\star \star * *$ & & & \\
\hline 211 & 0.5000 & 0.3000 & 0.000 & 0.7000 \\
\hline 212 & 0.5000 & 0.3000 & 0.000 & 0.7000 \\
\hline 214 & 0.5000 & 0.3000 & 0.000 & 0.7000 \\
\hline 231 & 0.3000 & 0.3000 & 0.000 & 0.5000 \\
\hline 232 & 0.3000 & 0.3000 & 0.000 & 0.5000 \\
\hline 252 & 0.3000 & 0.3000 & 0.000 & 0.5000 \\
\hline 253 & 0.3000 & 0.3000 & 0.000 & 0.5000 \\
\hline
\end{tabular}




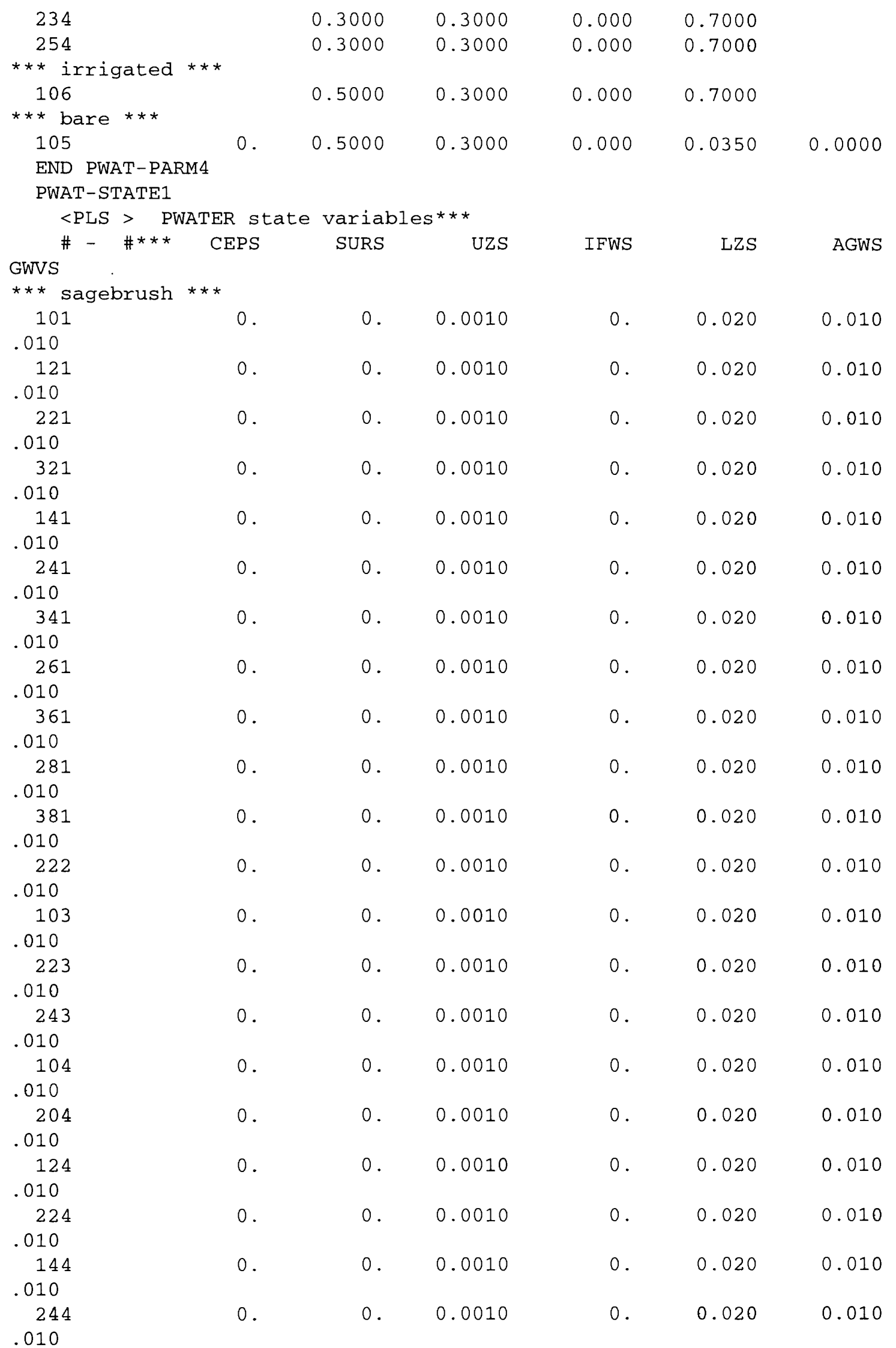




\begin{tabular}{|c|c|c|c|c|c|c|}
\hline \multirow{2}{*}{\multicolumn{7}{|c|}{$\begin{array}{c}164 \\
.010\end{array}$}} \\
\hline & & & & & & \\
\hline 264 & 0 . & 0 . & 0.0010 & 0 . & 0.020 & 0.010 \\
\hline \multicolumn{7}{|l|}{.010} \\
\hline \multicolumn{7}{|c|}{ *** grassland $* * *$} \\
\hline 107 & 0 & 0 . & 0.0010 & 0 . & 0.020 & 0.010 \\
\hline \multicolumn{7}{|l|}{.010} \\
\hline 207 & 0 . & 0 . & 0.0010 & 0 . & 0.020 & 0.010 \\
\hline \multicolumn{7}{|l|}{.010} \\
\hline 127 & 0 . & 0 . & 0.0010 & 0 . & 0.020 & 0.010 \\
\hline \multicolumn{7}{|l|}{.010} \\
\hline 227 & 0 . & 0 . & 0.0010 & 0 . & 0.020 & 0.010 \\
\hline \multicolumn{7}{|l|}{.010} \\
\hline 147 & 0 . & 0 . & 0.0010 & 0 . & 0.020 & 0.010 \\
\hline \multicolumn{7}{|l|}{.010} \\
\hline 247 & 0 . & 0 . & 0.0010 & 0 . & 0.020 & 0.010 \\
\hline \multicolumn{7}{|l|}{.010} \\
\hline 347 & 0 . & 0 . & 0.0010 & 0 . & 0.020 & 0.010 \\
\hline \multicolumn{7}{|l|}{.010} \\
\hline 267 & 0 . & 0 . & 0.0010 & 0 . & 0.020 & 0.010 \\
\hline \multicolumn{7}{|l|}{.010} \\
\hline 367 & 0 . & 0 . & 0.0010 & 0 . & 0.020 & 0.010 \\
\hline \multicolumn{7}{|l|}{.010} \\
\hline 287 & 0 . & 0 . & 0.0010 & 0 . & 0.020 & 0.010 \\
\hline \multicolumn{7}{|l|}{.010} \\
\hline 387 & 0 . & 0 . & 0.0010 & 0 . & 0.020 & 0.010 \\
\hline \multicolumn{7}{|l|}{.010} \\
\hline 208 & 0 . & 0 . & 0.0010 & 0 . & 0.020 & 0.010 \\
\hline \multicolumn{7}{|l|}{.010} \\
\hline 308 & 0 . & 0 . & 0.0010 & 0 . & 0.020 & 0.010 \\
\hline \multicolumn{7}{|l|}{.010} \\
\hline 228 & 0 . & 0 . & 0.0010 & 0 . & 0.020 & 0.010 \\
\hline \multicolumn{7}{|l|}{.010} \\
\hline 248 & 0 . & 0 . & 0.0010 & 0 . & 0.020 & 0.010 \\
\hline \multicolumn{7}{|l|}{.010} \\
\hline 268 & 0 . & 0 . & 0.0010 & 0 . & 0.020 & 0.010 \\
\hline \multicolumn{7}{|l|}{.010} \\
\hline 209 & 0 . & 0. & 0.0010 & 0 . & 0.020 & 0.010 \\
\hline .010 & & & & & & \\
\hline 229 & 0 . & 0 . & 0.0010 & 0 . & 0.020 & 0.010 \\
\hline .010 & & & & & & \\
\hline 249 & 0 . & 0 . & 0.0010 & 0 . & 0.020 & 0.010 \\
\hline .010 & & & & & & \\
\hline 269 & 0 . & 0 . & 0.0010 & 0 . & 0.020 & 0.010 \\
\hline .010 & & & & & & \\
\hline 289 & 0 . & 0 . & 0.0010 & 0 . & 0.020 & 0.010 \\
\hline .010 & & & & & & \\
\hline 110 & 0. & 0 . & 0.0010 & 0 . & 0.020 & 0.010 \\
\hline .010 & & & & & & \\
\hline 210 & 0. & 0. & 0.0010 & 0 . & 0.020 & 0.010 \\
\hline .010 & & & & & & \\
\hline 130 & 0. & 0. & 0.0010 & 0 . & 0.020 & 0.010 \\
\hline .010 & & & & & & \\
\hline 230 & 0 . & 0 . & 0.0010 & 0 . & 0.020 & 0.010 \\
\hline
\end{tabular}




\begin{tabular}{|c|c|c|c|c|c|c|}
\hline \multicolumn{7}{|l|}{.010} \\
\hline 150 & 0 . & 0 . & 0.0010 & 0 . & 0.020 & 0.010 \\
\hline \multicolumn{7}{|l|}{.010} \\
\hline 250 & 0 . & 0. & 0.0010 & 0 . & 0.020 & 0.010 \\
\hline \multicolumn{7}{|c|}{.010} \\
\hline *** dryland wheat & $\star * \star$ & & & & & \\
\hline 211 & 0 & 0 . & 0.0010 & 0 . & 0.020 & 0.010 \\
\hline \multicolumn{7}{|l|}{.010} \\
\hline 231 & 0 . & 0 . & 0.0010 & 0 . & 0.020 & 0.010 \\
\hline \multicolumn{7}{|l|}{.010} \\
\hline 212 & 0 . & 0 . & 0.0010 & 0 . & 0.020 & 0.010 \\
\hline \multicolumn{7}{|l|}{.010} \\
\hline 232 & 0 . & 0 . & 0.0010 & 0 . & 0.020 & 0.010 \\
\hline \multicolumn{7}{|l|}{.010} \\
\hline 252 & 0. & 0 . & 0.0010 & 0 . & 0.020 & 0.010 \\
\hline \multicolumn{7}{|l|}{.010} \\
\hline 253 & 0 . & 0. & 0.0010 & 0 . & 0.020 & 0.010 \\
\hline \multicolumn{7}{|l|}{.010} \\
\hline 214 & 0 . & 0 . & 0.0010 & 0. & 0.020 & 0.010 \\
\hline \multicolumn{7}{|l|}{.010} \\
\hline 234 & 0 . & 0 . & 0.0010 & 0 . & 0.020 & 0.010 \\
\hline \multicolumn{7}{|l|}{.010} \\
\hline 254 & 0 . & 0 . & 0.0010 & 0 . & 0.020 & 0.010 \\
\hline \multicolumn{7}{|l|}{.010} \\
\hline \multicolumn{7}{|c|}{$\star \star \star$ irrigated $\star \star \star *$} \\
\hline 106 & 0 . & 0 . & 0.0010 & 0 . & 0.020 & 0.010 \\
\hline \multicolumn{7}{|l|}{.010} \\
\hline$\star \star \star$ bare $\star \star \star *$ & & & & & & \\
\hline $\begin{array}{l}105 \\
.010\end{array}$ & 0 . & 0 . & 0.0010 & 0 & 0.020 & 0.010 \\
\hline
\end{tabular}

END PWAT-STATE1

MON-INTERCEP

$<$ PLS> Only required if $\mathrm{VCSFG}=1$ in PWAT-PARM1

\# - \# Interception storage capacity at start of each month

sagebrush

JAN FEB MAR APR MAY JUN JUL AUG SEP OCT NOV DEC *

$\begin{array}{llllllllllllll}1.01 & 0.04 & 0.06 & 0.06 & 0.06 & 0.05 & 0.05 & 0.04 & 0.04 & 0.04 & 0.05 & 0.04 & 0.04\end{array}$

$121 \quad \begin{array}{llllllllllllll}0.04 & 0.06 & 0.06 & 0.06 & 0.05 & 0.05 & 0.04 & 0.04 & 0.04 & 0.05 & 0.04 & 0.04\end{array}$

$\begin{array}{llllllllllllll}221 & 0.04 & 0.06 & 0.06 & 0.06 & 0.05 & 0.05 & 0.04 & 0.04 & 0.04 & 0.05 & 0.04 & 0.04\end{array}$

$\begin{array}{llllllllllllll}321 & 0.04 & 0.06 & 0.06 & 0.06 & 0.05 & 0.05 & 0.04 & 0.04 & 0.04 & 0.05 & 0.04 & 0.04\end{array}$

$1410 \quad \begin{array}{lllllllllllll}0.04 & 0.06 & 0.06 & 0.06 & 0.05 & 0.05 & 0.04 & 0.04 & 0.04 & 0.05 & 0.04 & 0.04\end{array}$

$\begin{array}{llllllllllllll}241 & 0.04 & 0.06 & 0.06 & 0.06 & 0.05 & 0.05 & 0.04 & 0.04 & 0.04 & 0.05 & 0.04 & 0.04\end{array}$

$\begin{array}{llllllllllllll}341 & 0.04 & 0.06 & 0.06 & 0.06 & 0.05 & 0.05 & 0.04 & 0.04 & 0.04 & 0.05 & 0.04 & 0.04\end{array}$

$\begin{array}{llllllllllllll}261 & 0.04 & 0.06 & 0.06 & 0.06 & 0.05 & 0.05 & 0.04 & 0.04 & 0.04 & 0.05 & 0.04 & 0.04\end{array}$

$\begin{array}{lllllllllllll}361 & 0.04 & 0.06 & 0.06 & 0.06 & 0.05 & 0.05 & 0.04 & 0.04 & 0.04 & 0.05 & 0.04 & 0.04\end{array}$

$\begin{array}{llllllllllllll}281 & 0.04 & 0.06 & 0.06 & 0.06 & 0.05 & 0.05 & 0.04 & 0.04 & 0.04 & 0.05 & 0.04 & 0.04\end{array}$

$\begin{array}{lllllllllllll}381 & 0.04 & 0.06 & 0.06 & 0.06 & 0.05 & 0.05 & 0.04 & 0.04 & 0.04 & 0.05 & 0.04 & 0.04\end{array}$

$\begin{array}{lllllllllllll}222 & 0.04 & 0.06 & 0.06 & 0.06 & 0.05 & 0.05 & 0.04 & 0.04 & 0.04 & 0.05 & 0.04 & 0.04\end{array}$

$\begin{array}{llllllllllllll}103 & 0.04 & 0.06 & 0.06 & 0.06 & 0.05 & 0.05 & 0.04 & 0.04 & 0.04 & 0.05 & 0.04 & 0.04\end{array}$

$\begin{array}{lllllllllllll}223 & 0.04 & 0.06 & 0.06 & 0.06 & 0.05 & 0.05 & 0.04 & 0.04 & 0.04 & 0.05 & 0.04 & 0.04\end{array}$

$\begin{array}{lllllllllllll}243 & 0.04 & 0.06 & 0.06 & 0.06 & 0.05 & 0.05 & 0.04 & 0.04 & 0.04 & 0.05 & 0.04 & 0.04\end{array}$

$\begin{array}{llllllllllllll}104 & 0.04 & 0.06 & 0.06 & 0.06 & 0.05 & 0.05 & 0.04 & 0.04 & 0.04 & 0.05 & 0.04 & 0.04\end{array}$

$\begin{array}{llllllllllllll}204 & 0.04 & 0.06 & 0.06 & 0.06 & 0.05 & 0.05 & 0.04 & 0.04 & 0.04 & 0.05 & 0.04 & 0.04\end{array}$

$124 \quad \begin{array}{llllllllllllll}0.04 & 0.06 & 0.06 & 0.06 & 0.05 & 0.05 & 0.04 & 0.04 & 0.04 & 0.05 & 0.04 & 0.04\end{array}$ 
$\begin{array}{llllllllllllll}224 & 0.04 & 0.06 & 0.06 & 0.06 & 0.05 & 0.05 & 0.04 & 0.04 & 0.04 & 0.05 & 0.04 & 0.04\end{array}$ $\begin{array}{lllllllllllll}144 & 0.04 & 0.06 & 0.06 & 0.06 & 0.05 & 0.05 & 0.04 & 0.04 & 0.04 & 0.05 & 0.04 & 0.04\end{array}$ $\begin{array}{lllllllllllll}244 & 0.04 & 0.06 & 0.06 & 0.06 & 0.05 & 0.05 & 0.04 & 0.04 & 0.04 & 0.05 & 0.04 & 0.04\end{array}$ $\begin{array}{lllllllllllll}164 & 0.04 & 0.06 & 0.06 & 0.06 & 0.05 & 0.05 & 0.04 & 0.04 & 0.04 & 0.05 & 0.04 & 0.04\end{array}$ $\begin{array}{lllllllllllllll}264 & 0.04 & 0.06 & 0.06 & 0.06 & 0.05 & 0.05 & 0.04 & 0.04 & 0.04 & 0.05 & 0.04 & 0.04\end{array}$ $\star * *$ grassland $* * *$

$\begin{array}{llllllllllllll}107 & 0.03 & 0.04 & 0.05 & 0.06 & 0.06 & 0.06 & 0.06 & 0.06 & 0.06 & 0.05 & 0.04 & 0.04\end{array}$ $\begin{array}{lllllllllllll}207 & 0.03 & 0.04 & 0.05 & 0.06 & 0.06 & 0.06 & 0.06 & 0.06 & 0.06 & 0.05 & 0.04 & 0.04\end{array}$ $\begin{array}{lllllllllllll}127 & 0.03 & 0.04 & 0.05 & 0.06 & 0.06 & 0.06 & 0.06 & 0.06 & 0.06 & 0.05 & 0.04 & 0.04\end{array}$ $\begin{array}{lllllllllllllll}227 & 0.03 & 0.04 & 0.05 & 0.06 & 0.06 & 0.06 & 0.06 & 0.06 & 0.06 & 0.05 & 0.04 & 0.04\end{array}$ $\begin{array}{llllllllllllll}147 & 0.03 & 0.04 & 0.05 & 0.06 & 0.06 & 0.06 & 0.06 & 0.06 & 0.06 & 0.05 & 0.04 & 0.04\end{array}$ $\begin{array}{llllllllllllll}247 & 0.03 & 0.04 & 0.05 & 0.06 & 0.06 & 0.06 & 0.06 & 0.06 & 0.06 & 0.05 & 0.04 & 0.04\end{array}$ $\begin{array}{lllllllllllllll}347 & 0.03 & 0.04 & 0.05 & 0.06 & 0.06 & 0.06 & 0.06 & 0.06 & 0.06 & 0.05 & 0.04 & 0.04\end{array}$ $\begin{array}{llllllllllllll}267 & 0.03 & 0.04 & 0.05 & 0.06 & 0.06 & 0.06 & 0.06 & 0.06 & 0.06 & 0.05 & 0.04 & 0.04\end{array}$ $\begin{array}{lllllllllllll}367 & 0.03 & 0.04 & 0.05 & 0.06 & 0.06 & 0.06 & 0.06 & 0.06 & 0.06 & 0.05 & 0.04 & 0.04\end{array}$ $\begin{array}{lllllllllllll}287 & 0.03 & 0.04 & 0.05 & 0.06 & 0.06 & 0.06 & 0.06 & 0.06 & 0.06 & 0.05 & 0.04 & 0.04\end{array}$ $\begin{array}{llllllllllllll}387 & 0.03 & 0.04 & 0.05 & 0.06 & 0.06 & 0.06 & 0.06 & 0.06 & 0.06 & 0.05 & 0.04 & 0.04\end{array}$ $\begin{array}{lllllllllllll}208 & 0.03 & 0.04 & 0.05 & 0.06 & 0.06 & 0.06 & 0.06 & 0.06 & 0.06 & 0.05 & 0.04 & 0.04\end{array}$ $\begin{array}{lllllllllllll}308 & 0.03 & 0.04 & 0.05 & 0.06 & 0.06 & 0.06 & 0.06 & 0.06 & 0.06 & 0.05 & 0.04 & 0.04\end{array}$ $\begin{array}{lllllllllllll}228 & 0.03 & 0.04 & 0.05 & 0.06 & 0.06 & 0.06 & 0.06 & 0.06 & 0.06 & 0.05 & 0.04 & 0.04\end{array}$ $\begin{array}{lllllllllllll}248 & 0.03 & 0.04 & 0.05 & 0.06 & 0.06 & 0.06 & 0.06 & 0.06 & 0.06 & 0.05 & 0.04 & 0.04\end{array}$ $\begin{array}{llllllllllllll}268 & 0.03 & 0.04 & 0.05 & 0.06 & 0.06 & 0.06 & 0.06 & 0.06 & 0.06 & 0.05 & 0.04 & 0.04\end{array}$ $\begin{array}{lllllllllllll}209 & 0.03 & 0.04 & 0.05 & 0.06 & 0.06 & 0.06 & 0.06 & 0.06 & 0.06 & 0.05 & 0.04 & 0.04\end{array}$ $\begin{array}{lllllllllllllll}229 & 0.03 & 0.04 & 0.05 & 0.06 & 0.06 & 0.06 & 0.06 & 0.06 & 0.06 & 0.05 & 0.04 & 0.04\end{array}$ $\begin{array}{lllllllllllll}249 & 0.03 & 0.04 & 0.05 & 0.06 & 0.06 & 0.06 & 0.06 & 0.06 & 0.06 & 0.05 & 0.04 & 0.04\end{array}$ $\begin{array}{llllllllllllll}269 & 0.03 & 0.04 & 0.05 & 0.06 & 0.06 & 0.06 & 0.06 & 0.06 & 0.06 & 0.05 & 0.04 & 0.04\end{array}$ $\begin{array}{lllllllllllll}289 & 0.03 & 0.04 & 0.05 & 0.06 & 0.06 & 0.06 & 0.06 & 0.06 & 0.06 & 0.05 & 0.04 & 0.04\end{array}$ $\begin{array}{lllllllllllll}110 & 0.03 & 0.04 & 0.05 & 0.06 & 0.06 & 0.06 & 0.06 & 0.06 & 0.06 & 0.05 & 0.04 & 0.04\end{array}$ $\begin{array}{lllllllllllll}210 & 0.03 & 0.04 & 0.05 & 0.06 & 0.06 & 0.06 & 0.06 & 0.06 & 0.06 & 0.05 & 0.04 & 0.04\end{array}$ $\begin{array}{llllllllllllll}130 & 0.03 & 0.04 & 0.05 & 0.06 & 0.06 & 0.06 & 0.06 & 0.06 & 0.06 & 0.05 & 0.04 & 0.04\end{array}$ $\begin{array}{lllllllllllll}230 & 0.03 & 0.04 & 0.05 & 0.06 & 0.06 & 0.06 & 0.06 & 0.06 & 0.06 & 0.05 & 0.04 & 0.04\end{array}$ $\begin{array}{lllllllllllllll}150 & 0.03 & 0.04 & 0.05 & 0.06 & 0.06 & 0.06 & 0.06 & 0.06 & 0.06 & 0.05 & 0.04 & 0.04\end{array}$ $\begin{array}{lllllllllllllll}250 & 0.03 & 0.04 & 0.05 & 0.06 & 0.06 & 0.06 & 0.06 & 0.06 & 0.06 & 0.05 & 0.04 & 0.04\end{array}$ *** dryland wheat ***

$\begin{array}{llllllllllllll}211 & 0.16 & 0.16 & 0.16 & 0.16 & 0.16 & 0.08 & 0.00 & 0.00 & 0.06 & 0.16 & 0.16 & 0.16\end{array}$ $\begin{array}{llllllllllllllll}231 & 0.16 & 0.16 & 0.16 & 0.16 & 0.16 & 0.08 & 0.00 & 0.00 & 0.06 & 0.16 & 0.16 & 0.16\end{array}$ $\begin{array}{lllllllllllllll}212 & 0.16 & 0.16 & 0.16 & 0.16 & 0.16 & 0.08 & 0.00 & 0.00 & 0.06 & 0.16 & 0.16 & 0.16\end{array}$ $\begin{array}{llllllllllllllll}232 & 0.16 & 0.16 & 0.16 & 0.16 & 0.16 & 0.08 & 0.00 & 0.00 & 0.06 & 0.16 & 0.16 & 0.16\end{array}$ $\begin{array}{lllllllllllllll}252 & 0.16 & 0.16 & 0.16 & 0.16 & 0.16 & 0.08 & 0.00 & 0.00 & 0.06 & 0.16 & 0.16 & 0.16\end{array}$ $\begin{array}{llllllllllllll}253 & 0.16 & 0.16 & 0.16 & 0.16 & 0.16 & 0.08 & 0.00 & 0.00 & 0.06 & 0.16 & 0.16 & 0.16\end{array}$ $\begin{array}{llllllllllllll}214 & 0.16 & 0.16 & 0.16 & 0.16 & 0.16 & 0.08 & 0.00 & 0.00 & 0.06 & 0.16 & 0.16 & 0.16\end{array}$ $\begin{array}{lllllllllllll}234 & 0.16 & 0.16 & 0.16 & 0.16 & 0.16 & 0.08 & 0.00 & 0.00 & 0.06 & 0.16 & 0.16 & 0.16\end{array}$ $\begin{array}{llllllllllllllll}254 & 0.16 & 0.16 & 0.16 & 0.16 & 0.16 & 0.08 & 0.00 & 0.00 & 0.06 & 0.16 & 0.16 & 0.16\end{array}$ *** irrigated vineyards and orchards ***

$\begin{array}{lllllllllllllll}106 & 0.02 & 0.02 & 0.03 & 0.05 & 0.06 & 0.07 & 0.07 & 0.08 & 0.08 & 0.03 & 0.02 & 0.02\end{array}$ END MON-INTERCEP

\section{MON-LZETPARM}

$<$ PLS > Only required if $\mathrm{VLEFG}=1$ in PWAT-PARM1

\# - \# Lower zone ET parameter at start of each month

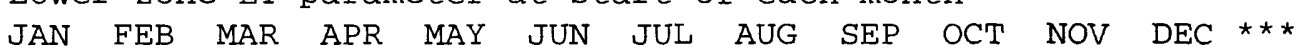

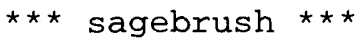

$\begin{array}{lllllllllllll}101 & 0.75 & 0.99 & 0.97 & 0.78 & 0.80 & 0.81 & 0.81 & 0.80 & 0.77 & 0.69 & 0.71 & 0.73\end{array}$

$\begin{array}{lllllllllllllll}121 & 0.75 & 0.99 & 0.97 & 0.78 & 0.80 & 0.81 & 0.81 & 0.80 & 0.77 & 0.69 & 0.71 & 0.73\end{array}$ 
$\begin{array}{llllllllllllll}221 & 0.75 & 0.99 & 0.97 & 0.78 & 0.80 & 0.81 & 0.81 & 0.80 & 0.77 & 0.69 & 0.71 & 0.73 \\ 321 & 0.75 & 0.99 & 0.97 & 0.78 & 0.80 & 0.81 & 0.81 & 0.80 & 0.77 & 0.69 & 0.71 & 0.73 \\ 141 & 0.75 & 0.99 & 0.97 & 0.78 & 0.80 & 0.81 & 0.81 & 0.80 & 0.77 & 0.69 & 0.71 & 0.73 \\ 241 & 0.75 & 0.99 & 0.97 & 0.78 & 0.80 & 0.81 & 0.81 & 0.80 & 0.77 & 0.69 & 0.71 & 0.73 \\ 341 & 0.75 & 0.99 & 0.97 & 0.78 & 0.80 & 0.81 & 0.81 & 0.80 & 0.77 & 0.69 & 0.71 & 0.73 \\ 261 & 0.75 & 0.99 & 0.97 & 0.78 & 0.80 & 0.81 & 0.81 & 0.80 & 0.77 & 0.69 & 0.71 & 0.73 \\ 361 & 0.75 & 0.99 & 0.97 & 0.78 & 0.80 & 0.81 & 0.81 & 0.80 & 0.77 & 0.69 & 0.71 & 0.73 \\ 281 & 0.75 & 0.99 & 0.97 & 0.78 & 0.80 & 0.81 & 0.81 & 0.80 & 0.77 & 0.69 & 0.71 & 0.73 \\ 381 & 0.75 & 0.99 & 0.97 & 0.78 & 0.80 & 0.81 & 0.81 & 0.80 & 0.77 & 0.69 & 0.71 & 0.73 \\ 222 & 0.75 & 0.99 & 0.97 & 0.78 & 0.80 & 0.81 & 0.81 & 0.80 & 0.77 & 0.69 & 0.71 & 0.73 \\ 103 & 0.75 & 0.99 & 0.97 & 0.78 & 0.80 & 0.81 & 0.81 & 0.80 & 0.77 & 0.69 & 0.71 & 0.73 \\ 223 & 0.75 & 0.99 & 0.97 & 0.78 & 0.80 & 0.81 & 0.81 & 0.80 & 0.77 & 0.69 & 0.71 & 0.73 \\ 243 & 0.75 & 0.99 & 0.97 & 0.78 & 0.80 & 0.81 & 0.81 & 0.80 & 0.77 & 0.69 & 0.71 & 0.73 \\ 104 & 0.75 & 0.99 & 0.97 & 0.78 & 0.80 & 0.81 & 0.81 & 0.80 & 0.77 & 0.69 & 0.71 & 0.73 \\ 204 & 0.75 & 0.99 & 0.97 & 0.78 & 0.80 & 0.81 & 0.81 & 0.80 & 0.77 & 0.69 & 0.71 & 0.73 \\ 124 & 0.75 & 0.99 & 0.97 & 0.78 & 0.80 & 0.81 & 0.81 & 0.80 & 0.77 & 0.69 & 0.71 & 0.73 \\ 224 & 0.75 & 0.99 & 0.97 & 0.78 & 0.80 & 0.81 & 0.81 & 0.80 & 0.77 & 0.69 & 0.71 & 0.73 \\ 144 & 0.75 & 0.99 & 0.97 & 0.78 & 0.80 & 0.81 & 0.81 & 0.80 & 0.77 & 0.69 & 0.71 & 0.73 \\ 244 & 0.75 & 0.99 & 0.97 & 0.78 & 0.80 & 0.81 & 0.81 & 0.80 & 0.77 & 0.69 & 0.71 & 0.73 \\ 164 & 0.75 & 0.99 & 0.97 & 0.78 & 0.80 & 0.81 & 0.81 & 0.80 & 0.77 & 0.69 & 0.71 & 0.73 \\ 264 & 0.75 & 0.99 & 0.97 & 0.78 & 0.80 & 0.81 & 0.81 & 0.80 & 0.77 & 0.69 & 0.71 & 0.73 \\ \star \star * \\ \text { grassland } & \star \star * & & & & & & & & & & \end{array}$

$\begin{array}{lllllllllllll}107 & 0.45 & 0.52 & 0.65 & 0.76 & 0.80 & 0.81 & 0.81 & 0.80 & 0.77 & 0.69 & 0.58 & 0.48\end{array}$ $\begin{array}{llllllllllllll}207 & 0.45 & 0.52 & 0.65 & 0.76 & 0.80 & 0.81 & 0.81 & 0.80 & 0.77 & 0.69 & 0.58 & 0.48\end{array}$ $\begin{array}{lllllllllllll}127 & 0.45 & 0.52 & 0.65 & 0.76 & 0.80 & 0.81 & 0.81 & 0.80 & 0.77 & 0.69 & 0.58 & 0.48\end{array}$ $\begin{array}{lllllllllllll}227 & 0.45 & 0.52 & 0.65 & 0.76 & 0.80 & 0.81 & 0.81 & 0.80 & 0.77 & 0.69 & 0.58 & 0.48\end{array}$ $\begin{array}{llllllllllllll}147 & 0.45 & 0.52 & 0.65 & 0.76 & 0.80 & 0.81 & 0.81 & 0.80 & 0.77 & 0.69 & 0.58 & 0.48\end{array}$ $\begin{array}{llllllllllllll}247 & 0.45 & 0.52 & 0.65 & 0.76 & 0.80 & 0.81 & 0.81 & 0.80 & 0.77 & 0.69 & 0.58 & 0.48\end{array}$ $\begin{array}{llllllllllllll}347 & 0.45 & 0.52 & 0.65 & 0.76 & 0.80 & 0.81 & 0.81 & 0.80 & 0.77 & 0.69 & 0.58 & 0.48\end{array}$ $\begin{array}{lllllllllllllll}267 & 0.45 & 0.52 & 0.65 & 0.76 & 0.80 & 0.81 & 0.81 & 0.80 & 0.77 & 0.69 & 0.58 & 0.48\end{array}$ $\begin{array}{lllllllllllll}367 & 0.45 & 0.52 & 0.65 & 0.76 & 0.80 & 0.81 & 0.81 & 0.80 & 0.77 & 0.69 & 0.58 & 0.48\end{array}$ $\begin{array}{llllllllllllll}287 & 0.45 & 0.52 & 0.65 & 0.76 & 0.80 & 0.81 & 0.81 & 0.80 & 0.77 & 0.69 & 0.58 & 0.48\end{array}$ $\begin{array}{llllllllllllll}387 & 0.45 & 0.52 & 0.65 & 0.76 & 0.80 & 0.81 & 0.81 & 0.80 & 0.77 & 0.69 & 0.58 & 0.48\end{array}$ $\begin{array}{llllllllllllll}208 & 0.45 & 0.52 & 0.65 & 0.76 & 0.80 & 0.81 & 0.81 & 0.80 & 0.77 & 0.69 & 0.58 & 0.48\end{array}$ $\begin{array}{llllllllllllll}308 & 0.45 & 0.52 & 0.65 & 0.76 & 0.80 & 0.81 & 0.81 & 0.80 & 0.77 & 0.69 & 0.58 & 0.48\end{array}$ $\begin{array}{lllllllllllllll}228 & 0.45 & 0.52 & 0.65 & 0.76 & 0.80 & 0.81 & 0.81 & 0.80 & 0.77 & 0.69 & 0.58 & 0.48\end{array}$ $\begin{array}{lllllllllllllll}248 & 0.45 & 0.52 & 0.65 & 0.76 & 0.80 & 0.81 & 0.81 & 0.80 & 0.77 & 0.69 & 0.58 & 0.48\end{array}$ $\begin{array}{llllllllllllll}268 & 0.45 & 0.52 & 0.65 & 0.76 & 0.80 & 0.81 & 0.81 & 0.80 & 0.77 & 0.69 & 0.58 & 0.48\end{array}$ $\begin{array}{lllllllllllllll}209 & 0.45 & 0.52 & 0.65 & 0.76 & 0.80 & 0.81 & 0.81 & 0.80 & 0.77 & 0.69 & 0.58 & 0.48\end{array}$ $\begin{array}{llllllllllllll}229 & 0.45 & 0.52 & 0.65 & 0.76 & 0.80 & 0.81 & 0.81 & 0.80 & 0.77 & 0.69 & 0.58 & 0.48\end{array}$ $\begin{array}{lllllllllllll}249 & 0.45 & 0.52 & 0.65 & 0.76 & 0.80 & 0.81 & 0.81 & 0.80 & 0.77 & 0.69 & 0.58 & 0.48\end{array}$ $\begin{array}{lllllllllllll}269 & 0.45 & 0.52 & 0.65 & 0.76 & 0.80 & 0.81 & 0.81 & 0.80 & 0.77 & 0.69 & 0.58 & 0.48\end{array}$ $\begin{array}{llllllllllllll}289 & 0.45 & 0.52 & 0.65 & 0.76 & 0.80 & 0.81 & 0.81 & 0.80 & 0.77 & 0.69 & 0.58 & 0.48\end{array}$ $\begin{array}{lllllllllllll}110 & 0.45 & 0.52 & 0.65 & 0.76 & 0.80 & 0.81 & 0.81 & 0.80 & 0.77 & 0.69 & 0.58 & 0.48\end{array}$ $\begin{array}{llllllllllllll}210 & 0.45 & 0.52 & 0.65 & 0.76 & 0.80 & 0.81 & 0.81 & 0.80 & 0.77 & 0.69 & 0.58 & 0.48\end{array}$ $\begin{array}{lllllllllllll}130 & 0.45 & 0.52 & 0.65 & 0.76 & 0.80 & 0.81 & 0.81 & 0.80 & 0.77 & 0.69 & 0.58 & 0.48\end{array}$ $\begin{array}{lllllllllllll}230 & 0.45 & 0.52 & 0.65 & 0.76 & 0.80 & 0.81 & 0.81 & 0.80 & 0.77 & 0.69 & 0.58 & 0.48\end{array}$ $\begin{array}{lllllllllllll}150 & 0.45 & 0.52 & 0.65 & 0.76 & 0.80 & 0.81 & 0.81 & 0.80 & 0.77 & 0.69 & 0.58 & 0.48\end{array}$ $\begin{array}{lllllllllllll}250 & 0.45 & 0.52 & 0.65 & 0.76 & 0.80 & 0.81 & 0.81 & 0.80 & 0.77 & 0.69 & 0.58 & 0.48\end{array}$ $\star \star \star$ dryland wheat $* \star *$

$\begin{array}{lllllllllllll}211 & 0.99 & 0.99 & 0.99 & 0.99 & 0.99 & 0.50 & 0.00 & 0.00 & 0.37 & 0.99 & 0.99 & 0.99\end{array}$ $\begin{array}{llllllllllllll}231 & 0.99 & 0.99 & 0.99 & 0.99 & 0.99 & 0.50 & 0.00 & 0.00 & 0.37 & 0.99 & 0.99 & 0.99\end{array}$ $\begin{array}{llllllllllllll}212 & 0.99 & 0.99 & 0.99 & 0.99 & 0.99 & 0.50 & 0.00 & 0.00 & 0.37 & 0.99 & 0.99 & 0.99\end{array}$ $\begin{array}{lllllllllllllll}232 & 0.99 & 0.99 & 0.99 & 0.99 & 0.99 & 0.50 & 0.00 & 0.00 & 0.37 & 0.99 & 0.99 & 0.99\end{array}$ 


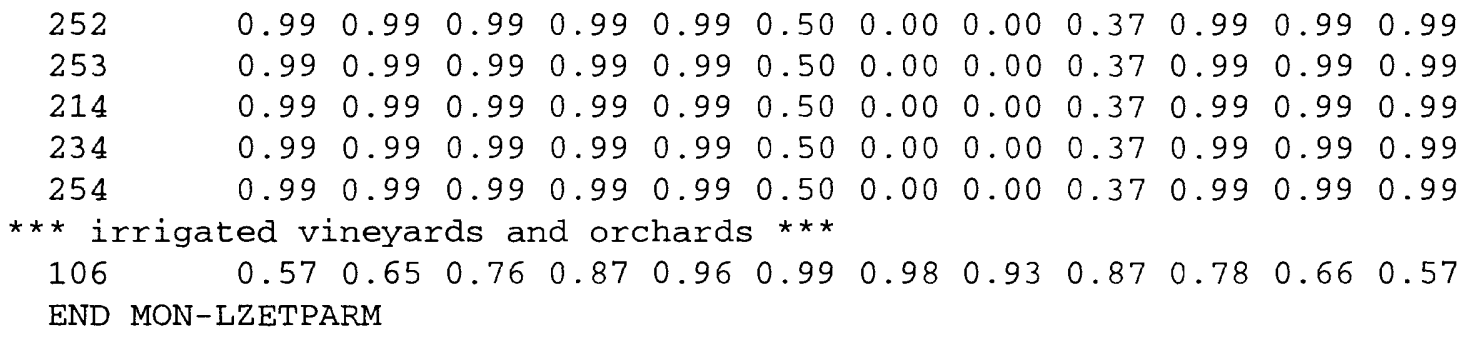




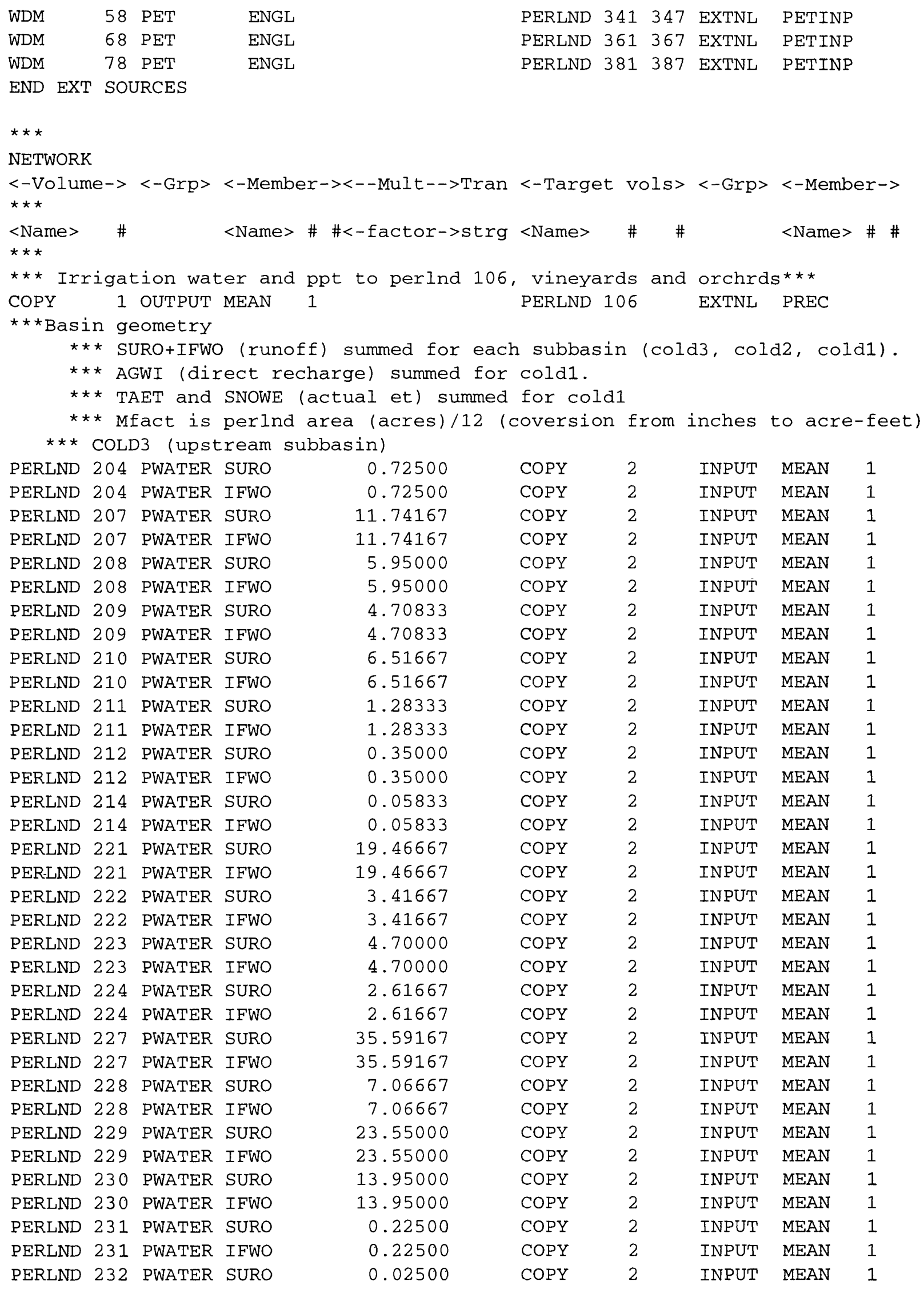




\begin{tabular}{|c|c|c|c|c|c|c|c|c|}
\hline PERLND & 232 & PWATER & IFWO & 0.02500 & COPY & 2 & INPUT & MEAN \\
\hline PERLND & 241 & PWATER & SURO & 20.35000 & COPY & 2 & INPUT & MEAN \\
\hline PERLND & 241 & PWATER & IFWO & 20.35000 & COPY & 2 & INPUT & MEAN \\
\hline PERLND & 243 & PWATER & SURO & 2.93333 & COPY & 2 & INPUT & MEAN \\
\hline PERLND & 243 & PWATER & IFWO & 2.93333 & COPY & 2 & INPUT & MEAN \\
\hline PERLND & 244 & PWATER & SURO & 6.59167 & COPY & 2 & INPUT & MEAN \\
\hline PERLND & 244 & PWATER & IFWO & 6.59167 & COPY & 2 & INPUT & MEAN \\
\hline PERLND & 247 & PWATER & SURO & 68.49167 & COPY & 2 & INPUT & MEAN \\
\hline PERLND & 247 & PWATER & IFWO & 68.49167 & COPY & 2 & INPUT & MEAN \\
\hline PERLND & 248 & PWATER & SURO & 6.85833 & COPY & 2 & INPUT & MEAN \\
\hline PERLND & 248 & PWATER & IFWO & 6.85833 & COPY & 2 & INPUT & MEAN \\
\hline PERLND & 249 & PWATER & SURO & 10.23333 & COPY & 2 & INPUT & MEAN \\
\hline PERLND & 249 & PWATER & IFWO & 10.23333 & COPY & 2 & INPUT & MEAN \\
\hline PERLND & 250 & PWATER & SURO & 28.48333 & COPY & 2 & INPUT & MEAN \\
\hline PERLND & 250 & PWATER & IFWO & 28.48333 & COPY & 2 & INPUT & MEAN \\
\hline PERLND & 253 & PWATER & SURO & 0.60833 & COPY & 2 & INPUT & MEAN \\
\hline PERLND & 253 & PWATER & IFWO & 0.60833 & COPY & 2 & INPUT & MEAN \\
\hline PERLND & 254 & PWATER & SURO & 0.84167 & COPY & 2 & INPUT & MEAN \\
\hline PERLND & 254 & PWATER & IFWO & 0.84167 & COPY & 2 & INPUT & MEAN \\
\hline PERLND & 261 & PWATER & SURO & 18.20833 & COPY & 2 & INPUT & MEAN \\
\hline PERLND & 261 & PWATER & IFWO & 18.20833 & COPY & 2 & INPUT & MEAN \\
\hline PERLND & 264 & PWATER & SURO & 7.21667 & COPY & 2 & INPUT & MEAN \\
\hline PERLND & 264 & PWATER & IFWO & 7.21667 & COPY & 2 & INPUT & MEAN \\
\hline PERLND & 267 & PWATER & SURO & 29.65000 & COPY & 2 & INPUT & MEAN \\
\hline PERLND & 267 & PWATER & IFWO & 29.65000 & COPY & 2 & INPUT & MEAN \\
\hline PERLND & 268 & PWATER & SURO & 0.88333 & COPY & 2 & INPUT & MEAN \\
\hline PERLND & 268 & PWATER & IFWO & 0.88333 & COPY & 2 & INPUT & MEAN \\
\hline PERLND & 269 & PWATER & SURO & 6.71667 & COPY & 2 & INPUT & MEAN \\
\hline PERLND & 269 & PWATER & IFWO & 6.71667 & COPY & 2 & INPUT & MEAN \\
\hline PERLND & 281 & PWATER & SURO & 18.05000 & COPY & 2 & INPUT & MEAN \\
\hline PERLND & 281 & PWATER & IFWO & 18.05000 & COPY & 2 & INPUT & MEAN \\
\hline PERLND & 287 & PWATER & SURO & 38.87500 & COPY & 2 & INPUT & MEAN \\
\hline PERLND & 287 & PWATER & IFWO & 38.87500 & COPY & 2 & INPUT & MEAN \\
\hline PERLND & 289 & PWATER & SURO & 6.34167 & COPY & 2 & INPUT & MEAN \\
\hline PERLND & 289 & PWATER & IFWO & 6.34167 & COPY & 2 & INPUT & MEAN \\
\hline PERLND & 308 & PWATER & SURO & 10.65000 & COPY & 2 & INPUT & MEAN \\
\hline PERLND & 308 & PWATER & IFWO & 10.65000 & COPY & 2 & INPUT & MEAN \\
\hline PERLND & 321 & PWATER & SURO & 28.70000 & COPY & 2 & INPUT & MEAN \\
\hline PERLND & 321 & PWATER & IFWO & 28.70000 & COPY & 2 & INPUT & MEAN \\
\hline PERLND & 341 & PWATER & SURO & 21.43333 & COPY & 2 & INPUT & MEAN \\
\hline PERLND & 341 & PWATER & IFWO & 21.43333 & COPY & 2 & INPUT & MEAN \\
\hline PERLND & 347 & PWATER & SURO & 23.31667 & COPY & 2 & INPUT & MEAN \\
\hline PERLND & 347 & PWATER & IFWO & 23.31667 & $\mathrm{COPY}$ & 2 & INPUT & MEAN \\
\hline PERLND & 361 & PWATER & SURO & 37.83333 & $\mathrm{COPY}$ & 2 & INPUT & MEAN \\
\hline PERLND & 361 & PWATER & IFWO & 37.83333 & COPY & 2 & INPUT & MEAN \\
\hline PERLND & 367 & PWATER & SURO & 29.24167 & COPY & 2 & INPUT & MEAN \\
\hline PERLND & 367 & PWATER & IFWO & 29.24167 & COPY & 2 & INPUT & MEAN \\
\hline PERLND & 381 & PWATER & SURO & 25.04167 & COPY & 2 & INPUT & MEAN \\
\hline PERLND & 381 & PWATER & IFWO & 25.04167 & COPY & 2 & INPUT & MEAN \\
\hline PERLND & 387 & PWATER & SURO & 28.76667 & COPY & 2 & INPUT & MEAN \\
\hline PERLND & 387 & PWATER & IFWO & 28.76667 & COPY & 2 & INPUT & MEAN \\
\hline \multicolumn{9}{|c|}{$\star \star \star$ COLD2 (Middle subbasin) } \\
\hline PERLND & 103 & PWATER & SURO & 12.13333 & COPY & 2 & INPUT & MEAN \\
\hline PERLND & 103 & PWATER & IFWO & 12.13333 & COPY & 2 & INPUT & MEAN \\
\hline
\end{tabular}


PERLND 104 PWATER SURO PERLND 104 PWATER IFWO PERLND 106 PWATER SURO PERLND 106 PWATER IFWO PERLND 110 PWATER SURO PERLND 110 PWATER IFWO PERLND 124 PWATER SURO PERLND 124 PWATER IFWO PERLND 130 PWATER SURO PERLND 130 PWATER IFWO PERLND 144 PWATER SURO PERLND 144 PWATER IFWO PERLND 150 PWATER SURO PERLND 150 PWATER IFWO PERLND 164 PWATER SURO PERLND 164 PWATER IFWO PERLND 204 PWATER SURO PERLND 204 PWATER IFWO PERLND 207 PWATER SURO PERLND 207 PWATER IFWO PERLND 208 PWATER SURO PERLND 208 PWATER IFWO PERLND 209 PWATER SURO PERLND 209 PWATER IFWO PERLND 210 PWATER SURO PERLND 210 PWATER IFWO PERLND 212 PWATER SURO PERLND 212 PWATER IFWO PERLND 214 PWATER SURO PERLND 214 PWATER IFWO PERLND 221 PWATER SURO PERLND 221 PWATER IFWO PERLND 222 PWATER SURO PERLND 222 PWATER IFWO PERLND 223 PWATER SURO PERLND 223 PWATER IFWO PERLND 224 PWATER SURO PERLND 224 PWATER IFWO PERLND 227 PWATER SURO PERLND 227 PWATER IFWO PERLND 228 PWATER SURO PERLND 228 PWATER IFWO PERLND 229 PWATER SURO PERLND 229 PWATER IFWO PERLND 230 PWATER SURO PERLND 230 PWATER IFWO PERLND 232 PWATER SURO PERLND 232 PWATER IFWO PERLND 234 PWATER SURO PERLND 234 PWATER IFWO PERLND 241 PWATER SURO PERLND 241 PWATER IFWO PERLND 243 PWATER SURO PERLND 243 PWATER IFWO

\begin{tabular}{|c|c|c|c|c|}
\hline 2.55000 & COPY & 2 & INPUT & MEAN \\
\hline 2.55000 & COPY & 2 & INPUT & MEAN \\
\hline 28.96667 & COPY & 2 & INPUT & MEAN \\
\hline 28.96667 & COPY & 2 & INPUT & MEAN \\
\hline 19.95000 & COPY & 2 & INPUT & MEAN \\
\hline 19.95000 & COPY & 2 & INPUT & MEAN \\
\hline 2.50000 & COPY & 2 & INPUT & MEAN \\
\hline 2.50000 & COPY & 2 & INPUT & MEAN \\
\hline 10.54167 & COPY & 2 & INPUT & MEAN \\
\hline 10.54167 & COPY & 2 & INPUT & MEAN \\
\hline 0.03333 & COPY & 2 & INPUT & MEAN \\
\hline 0.03333 & COPY & 2 & INPUT & MEAN \\
\hline 9.93333 & COPY & 2 & INPUT & MEAN \\
\hline 9.93333 & COPY & 2 & INPUT & MEAN \\
\hline 0.06667 & COPY & 2 & INPUT & MEAN \\
\hline 0.06667 & COPY & 2 & INPUT & MEAN \\
\hline 4.11667 & COPY & 2 & INPUT & MEAN \\
\hline 4.11667 & COPY & 2 & INPUT & MEAN \\
\hline 1.31667 & COPY & 2 & INPUT & MEAN \\
\hline 1.31667 & COPY & 2 & INPUT & MEAN \\
\hline 10.30833 & COPY & 2 & INPUT & MEAN \\
\hline 10.30833 & COPY & 2 & INPUT & MEAN \\
\hline 10.88333 & COPY & 2 & INPUT & MEAN \\
\hline 10.88333 & COPY & 2 & INPUT & MEAN \\
\hline 12.41667 & COPY & 2 & INPUT & MEAN \\
\hline 12.41667 & COPY & 2 & INPUT & MEAN \\
\hline 8.42500 & COPY & 2 & INPUT & MEAN \\
\hline 8.42500 & COPY & 2 & INPUT & MEAN \\
\hline 4.95000 & COPY & 2 & INPUT & MEAN \\
\hline 4.95000 & COPY & 2 & INPUT & MEAN \\
\hline 3.70000 & COPY & 2 & INPUT & MEAN \\
\hline 3.70000 & COPY & 2 & INPUT & MEAN \\
\hline 12.97500 & COPY & 2 & INPUT & MEAN \\
\hline 12.97500 & COPY & 2 & INPUT & MEAN \\
\hline 9.75000 & COPY & 2 & INPUT & MEAN \\
\hline 9.75000 & COPY & 2 & INPUT & MEAN \\
\hline 11.85833 & COPY & 2 & INPUT & MEAN \\
\hline 11.85833 & COPY & 2 & INPUT & MEAN \\
\hline 9.69167 & COPY & 2 & INPUT & MEAN \\
\hline 9.69167 & COPY & 2 & INPUT & MEAN \\
\hline 18.46667 & COPY & 2 & INPUT & MEAN \\
\hline 18.46667 & COPY & 2 & INPUT & MEAN \\
\hline 7.94167 & COPY & 2 & INPUT & MEAN \\
\hline 7.94167 & COPY & 2 & INPUT & MEAN \\
\hline 28.90833 & COPY & 2 & INPUT & MEAN \\
\hline 28.90833 & COPY & 2 & INPUT & MEAN \\
\hline 2.09167 & COPY & 2 & INPUT & MEAN \\
\hline 2.09167 & COPY & 2 & INPUT & MEAN \\
\hline 7.02500 & COPY & 2 & INPUT & MEAN \\
\hline 7.02500 & COPY & 2 & INPUT & MEAN \\
\hline 2.67500 & COPY & 2 & INPUT & MEAN \\
\hline 2.67500 & COPY & 2 & INPUT & MEAN \\
\hline 22.58333 & COPY & 2 & INPUT & MEAN \\
\hline 22.58333 & COPY & 2 & INPUT & MEAN \\
\hline
\end{tabular}




\begin{tabular}{|c|c|c|c|c|c|c|c|c|}
\hline PERLND & 244 & PWATER & SURO & 12.77500 & COPY & 2 & INPUT & MEAN \\
\hline PERLND & 244 & PWATER & IFWO & 12.77500 & COPY & 2 & INPUT & MEAN \\
\hline PERLND & 247 & PWATER & SURO & 4.66667 & COPY & 2 & INPUT & MEAN \\
\hline PERLND & 247 & PWATER & IFWO & 4.66667 & COPY & 2 & INPUT & MEAN \\
\hline PERLND & 248 & PWATER & SURO & 9.95833 & COPY & 2 & INPUT & MEAN \\
\hline PERLND & 248 & PWATER & IFWO & 9.95833 & COPY & 2 & INPUT & MEAN \\
\hline PERLND & 249 & PWATER & SURO & 35.18333 & COPY & 2 & INPUT & MEAN \\
\hline PERLND & 249 & PWATER & IFWO & 35.18333 & COPY & 2 & INPUT & MEAN \\
\hline PERLND & 250 & PWATER & SURO & 56.16667 & COPY & 2 & INPUT & MEAN \\
\hline PERLND & 250 & PWATER & IFWO & 56.16667 & COPY & 2 & INPUT & MEAN \\
\hline PERLND & 252 & PWATER & SURO & 13.75000 & COPY & 2 & INPUT & MEAN \\
\hline PERLND & 252 & PWATER & IFWO & 13.75000 & COPY & 2 & INPUT & MEAN \\
\hline PERLND & 253 & PWATER & SURO & 15.94167 & COPY & 2 & INPUT & MEAN \\
\hline PERLND & 253 & PWATER & IFWO & 15.94167 & COPY & 2 & INPUT & MEAN \\
\hline PERLND & 254 & PWATER & SURO & 35.32500 & COPY & 2 & INPUT & MEAN \\
\hline PERLND & 254 & PWATER & IFWO & 35.32500 & COPY & 2 & INPUT & MEAN \\
\hline PERLND & 261 & PWATER & SURO & 1.10000 & COPY & 2 & INPUT & MEAN \\
\hline PERLND & 261 & PWATER & IFWO & 1.10000 & COPY & 2 & INPUT & MEAN \\
\hline PERLND & 264 & PWATER & SURO & 14.12500 & COPY & 2 & INPUT & MEAN \\
\hline PERLND & 264 & PWATER & IFWO & 14.12500 & COPY & 2 & INPUT & MEAN \\
\hline PERLND & 267 & PWATER & SURO & 1.82500 & COPY & 2 & INPUT & MEAN \\
\hline PERLND & 267 & PWATER & IFWO & 1.82500 & COPY & 2 & INPUT & MEAN \\
\hline PERLND & 268 & PWATER & SURO & 20.68333 & COPY & 2 & INPUT & MEAN \\
\hline PERLND & 268 & PWATER & IFWO & 20.68333 & COPY & 2 & INPUT & MEAN \\
\hline PERLND & 269 & PWATER & SURO & 4.57500 & COPY & 2 & INPUT & MEAN \\
\hline PERLND & 269 & PWATER & IFWO & 4.57500 & COPY & 2 & INPUT & MEAN \\
\hline PERLND & 281 & PWATER & SURO & 2.70833 & COPY & 2 & INPUT & MEAN \\
\hline PERLND & 281 & PWATER & IFWO & 2.70833 & COPY & 2 & INPUT & MEAN \\
\hline PERLND & 287 & PWATER & SURO & 1.10000 & COPY & 2 & INPUT & MEAN \\
\hline PERLND & 287 & PWATER & IFWO & 1.10000 & COPY & 2 & INPUT & MEAN \\
\hline PERLND & 289 & PWATER & SURO & 29.10833 & COPY & 2 & INPUT & MEAN \\
\hline PERLND & 289 & PWATER & IFWO & 29.10833 & COPY & 2 & INPUT & MEAN \\
\hline PERLND & 308 & PWATER & SURO & 8.91667 & COPY & 2 & INPUT & MEAN \\
\hline PERLND & 308 & PWATER & IFWO & 8.91667 & COPY & 2 & INPUT & MEAN \\
\hline PERLND & 321 & PWATER & SURO & 5.99167 & COPY & 2 & INPUT & MEAN \\
\hline PERLND & 321 & PWATER & IFWO & 5.99167 & COPY & 2 & INPUT & MEAN \\
\hline PERLND & 341 & PWATER & SURO & 4.63333 & COPY & 2 & INPUT & MEAN \\
\hline PERLND & 341 & PWATER & IFWO & 4.63333 & COPY & 2 & INPUT & MEAN \\
\hline PERLND & 347 & PWATER & SURO & 7.76667 & COPY & 2 & INPUT & MEAN \\
\hline PERLND & 347 & PWATER & IFWO & 7.76667 & COPY & 2 & INPUT & MEAN \\
\hline PERLND & 361 & PWATER & SURO & 0.24167 & COPY & 2 & INPUT & MEAN \\
\hline PERLND & 361 & PWATER & IFWO & 0.24167 & COPY & 2 & INPUT & MEAN \\
\hline PERLND & 367 & PWATER & SURO & 0.47500 & COPY & 2 & INPUT & MEAN \\
\hline PERLND & 367 & PWATER & IFWO & 0.47500 & COPY & 2 & INPUT & MEAN \\
\hline PERLND & 381 & PWATER & SURO & 3.87500 & COPY & 2 & INPUT & MEAN \\
\hline PERLND & 381 & PWATER & IFWO & 3.87500 & COPY & 2 & INPUT & MEAN \\
\hline PERLND & 387 & PWATER & SURO & 1.70000 & COPY & 2 & INPUT & MEAN \\
\hline PERLND & 387 & PWATER & IFWO & 1.70000 & COPY & 2 & INPUT & MEAN \\
\hline \multicolumn{9}{|c|}{$\star \star \star$ COLD1 subbasin (downstream subbasin) } \\
\hline PERLND & 101 & PWATER & SURO & 98.92500 & COPY & 2 & INPUT & MEAN \\
\hline PERLND & 101 & PWATER & IFWO & 98.92500 & COPY & 2 & INPUT & MEAN \\
\hline PERLND & 101 & PWATER & AGWI & 98.92500 & COPY & 2 & INPUT & MEAN \\
\hline PERLND & 101 & PWATER & TAET & 98.92500 & COPY & 2 & INPUT & MEAN \\
\hline PERLND & 101 & SNOW & SNOWE & 98.92500 & COPY & 2 & INPUT & MEAN \\
\hline
\end{tabular}




\begin{tabular}{|c|c|c|c|c|c|c|c|c|}
\hline PERLND & 103 & PWATER & SURO & 13.51667 & COPY & 2 & INPUT & MEAN \\
\hline PERLND & 103 & PWATER & IFWO & 13.51667 & COPY & 2 & INPUT & MEAN \\
\hline PERLND & 103 & PWATER & AGWI & 13.51667 & COPY & 2 & INPUT & MEAN \\
\hline PERLND & 103 & PWATER & TAET & 13.51667 & COPY & 2 & INPUT & MEAN \\
\hline PERLND & 103 & SNOW & SNOWE & 13.51667 & COPY & 2 & INPUT & MEAN \\
\hline PERLND & 104 & PWATER & SURO & 270.27499 & COPY & 2 & INPUT & MEAN \\
\hline PERLND & 104 & PWATER & IFWO & 270.27499 & COPY & 2 & INPUT & MEAN \\
\hline PERLND & 104 & PWATER & AGWI & 270.27499 & COPY & 2 & INPUT & MEAN \\
\hline PERLND & 104 & PWATER & TAET & 270.27499 & COPY & 2 & INPUT & MEAN \\
\hline PERLND & 104 & SNOW & SNOWE & 270.27499 & COPY & 2 & INPUT & MEAN \\
\hline PERLND & 105 & PWATER & SURO & 31.89167 & COPY & 2 & INPUT & MEAN \\
\hline PERLND & 105 & PWATER & IFWO & 31.89167 & COPY & 2 & INPUT & MEAN \\
\hline PERLND & 105 & PWATER & AGWI & 31.89167 & COPY & 2 & INPUT & MEAN \\
\hline PERLND & 105 & PWATER & TAET & 31.89167 & COPY & 2 & INPUT & MEAN \\
\hline PERLND & 105 & SNOW & SNOWE & 31.89167 & COPY & 2 & INPUT & MEAN \\
\hline PERLND & 106 & PWATER & SURO & 72.98333 & COPY & 2 & INPUT & MEAN \\
\hline PERLND & 106 & PWATER & IFWO & 72.98333 & COPY & 2 & INPUT & MEAN \\
\hline PERLND & 106 & PWATER & AGWI & 72.98333 & COPY & 2 & INPUT & MEAN \\
\hline PERLND & 106 & PWATER & TAET & 72.98333 & COPY & 2 & INPUT & MEAN \\
\hline PERLND & 106 & SNOW & SNOWE & 72.98333 & COPY & 2 & INPUT & MEAN \\
\hline PERLND & 107 & PWATER & SURO & 35.50834 & COPY & 2 & INPUT & MEAN \\
\hline PERLND & 107 & PWATER & IFWO & 35.50834 & COPY & 2 & INPUT & MEAN \\
\hline PERLND & 107 & PWATER & AGWI & 35.50834 & COPY & 2 & INPUT & MEAN \\
\hline PERLND & 107 & PWATER & TAET & 35.50834 & COPY & 2 & INPUT & MEAN \\
\hline PERLND & 107 & SNOW & SNOWE & 35.50834 & COPY & 2 & INPUT & MEAN \\
\hline PERLND & 110 & PWATER & SURO & 511.64999 & COPY & 2 & INPUT & MEAN \\
\hline PERLND & 110 & PWATER & IFWO & 511.64999 & COPY & 2 & INPUT & MEAN \\
\hline PERLND & 110 & PWATER & AGWI & 511.64999 & COPY & 2 & INPUT & MEAN \\
\hline PERLND & 110 & PWATER & TAET & 511.64999 & COPY & 2 & INPUT & MEAN \\
\hline PERLND & 110 & SNOW & SNOWE & 511.64999 & COPY & 2 & INPUT & MEAN \\
\hline PERLND & 121 & PWATER & SURO & 86.91666 & COPY & 2 & INPUT & MEAN \\
\hline PERLND & 121 & PWATER & IFWO & 86.91666 & COPY & 2 & INPUT & MEAN \\
\hline PERLND & 121 & PWATER & AGWI & 86.91666 & COPY. & 2 & INPUT & MEAN \\
\hline PERLND & 121 & PWATER & TAET & 86.91666 & COPY & 2 & INPUT & MEAN \\
\hline PERLND & 121 & SNOW & SNOWE & 86.91666 & COPY & 2 & INPUT & MEAN \\
\hline PERLND & 124 & PWATER & SURO & 53.05000 & COPY & 2 & INPUT & MEAN \\
\hline PERLND & 124 & PWATER & IFWO & 53.05000 & COPY & 2 & INPUT & MEAN \\
\hline PERLND & 124 & PWATER & AGWI & 53.05000 & COPY & 2 & INPUT & MEAN \\
\hline PERLND & 124 & PWATER & TAET & 53.05000 & COPY & 2 & INPUT & MEAN \\
\hline PERLND & 124 & SNOW & SNOWE & 53.05000 & COPY & 2 & INPUT & MEAN \\
\hline PERLND & 127 & PWATER & SURO & 34.75834 & COPY & 2 & INPUT & MEAN \\
\hline PERLND & 127 & PWATER & IFWO & 34.75834 & COPY & 2 & INPUT & MEAN \\
\hline PERLND & 127 & PWATER & AGWI & 34.75834 & COPY & 2 & INPUT & MEAN \\
\hline PERLND & 127 & PWATER & TAET & 34.75834 & COPY & 2 & INPUT & MEAN \\
\hline PERLND & 127 & SNOW & SNOWE & 34.75834 & COPY & 2 & INPUT & MEAN \\
\hline PERLND & 130 & PWATER & SURO & 20.59167 & COPY & 2 & INPUT & MEAN \\
\hline PERLND & 130 & PWATER & IFWO & 20.59167 & COPY & 2 & INPUT & MEAN \\
\hline PERLND & 130 & PWATER & AGWI & 20.59167 & COPY & 2 & INPUT & MEAN \\
\hline PERLND & 130 & PWATER & TAET & 20.59167 & COPY & 2 & INPUT & MEAN \\
\hline PERLND & 130 & SNOW & SNOWE & 20.59167 & COPY & 2 & INPUT & MEAN \\
\hline PERLND & 141 & PWATER & SURO & 14.00000 & COPY & 2 & INPUT & MEAN \\
\hline PERLND & 141 & PWATER & IFWO & 14.00000 & COPY & 2 & INPUT & MEAN \\
\hline PERLND & 141 & PWATER & AGWI & 14.00000 & COPY & 2 & INPUT & MEAN \\
\hline PERLND & 141 & PWATER & TAET & 14.00000 & COPY & 2 & INPUT & MEAN \\
\hline
\end{tabular}




\begin{tabular}{|c|c|c|c|c|c|c|c|c|}
\hline PERLND & 141 & SNOW & SNOWE & 14.00000 & COPY & 2 & INPUT & MEAN \\
\hline PERLND & 144 & PWATER & SURO & 13.35833 & COPY & 2 & INPUT & MEAN \\
\hline PERLND & 144 & PWATER & IFWO & 13.35833 & COPY & 2 & INPUT & MEAN \\
\hline PERLND & 144 & PWATER & AGWI & 13.35833 & COPY & 2 & INPUT & MEAN \\
\hline PERLND & 144 & PWATER & TAET & 13.35833 & COPY & 2 & INPUT & MEAN \\
\hline PERLND & 144 & SNOW & SNOWE & 13.35833 & COPY & 2 & INPUT & MEAN \\
\hline PERLND & 147 & PWATER & SURO & 19.33333 & COPY & 2 & INPUT & MEAN \\
\hline PERLND & 147 & PWATER & IFWO & 19.33333 & COPY & 2 & INPUT & MEAN \\
\hline PERLND & 147 & PWATER & AGWI & 19.33333 & COPY & 2 & INPUT & MEAN \\
\hline PERLND & 147 & PWATER & TAET & 19.33333 & COPY & 2 & INPUT & MEAN \\
\hline PERLND & 147 & SNOW & SNOWE & 19.33333 & COPY & 2 & INPUT & MEAN \\
\hline PERLND & 150 & PWATER & SURO & 62.13333 & COPY & 2 & INPUT & MEAN \\
\hline PERLND & 150 & PWATER & IFWO & 62.13333 & COPY & 2 & INPUT & MEAN \\
\hline PERLND & 150 & PWATER & AGWI & 62.13333 & COPY & 2 & INPUT & MEAN \\
\hline PERLND & 150 & PWATER & TAET & 62.13333 & COPY & 2 & INPUT & MEAN \\
\hline PERLND & 150 & SNOW & SNOWE & 62.13333 & COPY & 2 & INPUT & MEAN \\
\hline PERLND & 164 & PWATER & SURO & 14.21667 & COPY & 2 & INPUT & MEAN \\
\hline PERLND & 164 & PWATER & IFWO & 14.21667 & COPY & 2 & INPUT & MEAN \\
\hline PERLND & 164 & PWATER & AGWI & 14.21667 & COPY & 2 & INPUT & MEAN \\
\hline PERLND & 164 & PWATER & TAET & 14.21667 & COPY & 2 & INPUT & MEAN \\
\hline PERLND & 164 & SNOW & SNOWE & 14.21667 & COPY & 2 & INPUT & MEAN \\
\hline PERLND & 204 & PWATER & SURO & 15.19167 & COPY & 2 & INPUT & MEAN \\
\hline PERLND & 204 & PWATER & IFWO & 15.19167 & COPY & 2 & INPUT & MEAN \\
\hline PERLND & 204 & PWATER & AGWI & 15.19167 & COPY & 2 & INPUT & MEAN \\
\hline PERLND & 204 & PWATER & TAET & 15.19167 & COPY & 2 & INPUT & MEAN \\
\hline PERLND & 204 & SNOW & SNOWE & 15.19167 & COPY & 2 & INPUT & MEAN \\
\hline PERLND & 207 & PWATER & SURO & 7.03333 & COPY & 2 & INPUT & MEAN \\
\hline PERLND & 207 & PWATER & IFWO & 7.03333 & COPY & 2 & INPUT & MEAN \\
\hline PERLND & 207 & PWATER & AGWI & 7.03333 & COPY & 2 & INPUT & MEAN \\
\hline PERLND & 207 & PWATER & TAET & 7.03333 & COPY & 2 & INPUT & MEAN \\
\hline PERLND & 207 & SNOW & SNOWE & 7.03333 & COPY & 2 & INPUT & MEAN \\
\hline PERLND & 208 & PWATER & SURO & 20.30000 & COPY & 2 & INPUT & MEAN \\
\hline PERLND & 208 & PWATER & IFWO & 20.30000 & COPY & 2 & INPUT & MEAN \\
\hline PERLND & 208 & PWATER & AGWI & 20.30000 & COPY & 2 & INPUT & MEAN \\
\hline PERLND & 208 & PWATER & TAET & 20.30000 & COPY & 2 & INPUT & MEAN \\
\hline PERLND & 208 & SNOW & SNOWE & 20.30000 & COPY & 2 & INPUT & MEAN \\
\hline PERLND & 209 & PWATER & SURO & 1.63333 & COPY & 2 & INPUT & MEAN \\
\hline PERLND & 209 & PWATER & IFWO & 1.63333 & COPY & 2 & INPUT & MEAN \\
\hline PERLND & 209 & PWATER & AGWI & 1.63333 & COPY & 2 & INPUT & MEAN \\
\hline PERLND & 209 & PWATER & TAET & 1.63333 & COPY & 2 & INPUT & MEAN \\
\hline PERLND & 209 & SNOW & SNOWE & 1.63333 & COPY & 2 & INPUT & MEAN \\
\hline PERLND & 210 & PWATER & SURO & 24.47500 & COPY & 2 & INPUT & MEAN \\
\hline PERLND & 210 & PWATER & IFWO & 24.47500 & COPY & 2 & INPUT & MEAN \\
\hline PERLND & 210 & PWATER & AGWI & 24.47500 & COPY & 2 & INPUT & MEAN \\
\hline PERLND & 210 & PWATER & TAET & 24.47500 & COPY & 2 & INPUT & MEAN \\
\hline PERLND & 210 & SNOW & SNOWE & 24.47500 & COPY & 2 & INPUT & MEAN \\
\hline PERLND & 211 & PWATER & SURO & 11.83333 & COPY & 2 & INPUT & MEAN \\
\hline PERLND & 211 & PWATER & IFWO & 11.83333 & COPY & 2 & INPUT & MEAN \\
\hline PERLND & 211 & PWATER & AGWI & 11.83333 & COPY & 2 & INPUT & MEAN \\
\hline PERLND & 211 & PWATER & TAET & 11.83333 & COPY & 2 & INPUT & MEAN \\
\hline PERLND & 211 & SNOW & SNOWE & 11.83333 & COPY & 2 & INPUT & MEAN \\
\hline PERLND & 212 & PWATER & SURO & 12.65000 & COPY & 2 & INPUT & MEAN \\
\hline PERLND & 212 & PWATER & IFWO & 12.65000 & COPY & 2 & INPUT & MEAN \\
\hline PERLND & 212 & PWATER & AGWI & 12.65000 & COPY & 2 & INPUT & MEAN \\
\hline
\end{tabular}




\begin{tabular}{|c|c|c|c|c|c|c|c|c|}
\hline PERLND & 212 & PWATER & TAET & 12.65000 & COPY & 2 & INPUT & MEAN \\
\hline PERLND & 212 & SNOW & SNOWE & 12.65000 & COPY & 2 & INPUT & MEAN \\
\hline PERLND & 214 & PWATER & SURO & 37.60833 & COPY & 2 & INPUT & MEAN \\
\hline PERLND & 214 & PWATER & IFWO & 37.60833 & COPY & 2 & INPUT & MEAN \\
\hline PERLND & 214 & PWATER & AGWI & 37.60833 & COPY & 2 & INPUT & MEAN \\
\hline PERLND & 214 & PWATER & TAET & 37.60833 & COPY & 2 & INPUT & MEAN \\
\hline PERLND & 214 & SNOW & SNOWE & 37.60833 & COPY & 2 & INPUT & MEAN \\
\hline PERLND & 221 & PWATER & SURO & 2.21667 & COPY & 2 & INPUT & MEAN \\
\hline PERLND & 221 & PWATER & IFWO & 2.21667 & COPY & 2 & INPUT & MEAN \\
\hline PERLND & 221 & PWATER & AGWI & 2.21667 & COPY & 2 & INPUT & MEAN \\
\hline PERLND & 221 & PWATER & TAET & 2.21667 & COPY & 2 & INPUT & MEAN \\
\hline PERLND & 221 & SNOW & SNOWE & 2.21667 & COPY & 2 & INPUT & MEAN \\
\hline PERLND & 222 & PWATER & SURO & 8.16667 & COPY & 2 & INPUT & MEAN \\
\hline PERLND & 222 & PWATER & IFWO & 8.16667 & COPY & 2 & INPUT & MEAN \\
\hline PERLND & 222 & PWATER & AGWI & 8.16667 & COPY & 2 & INPUT & MEAN \\
\hline PERLND & 222 & PWATER & TAET & 8.16667 & COPY & 2 & INPUT & MEAN \\
\hline PERLND & 222 & SNOW & SNOWE & 8.16667 & COPY & 2 & INPUT & MEAN \\
\hline PERLND & 223 & PWATER & SURO & 0.15000 & COPY & 2 & INPUT & MEAN \\
\hline PERLND & 223 & PWATER & IFWO & 0.15000 & COPY & 2 & INPUT & MEAN \\
\hline PERLND & 223 & PWATER & AGWI & 0.15000 & COPY & 2 & INPUT & MEAN \\
\hline PERLND & 223 & PWATER & TAET & 0.15000 & COPY & 2 & INPUT & MEAN \\
\hline PERLND & 223 & SNOW & SNOWE & 0.15000 & COPY & 2 & INPUT & MEAN \\
\hline PERLND & 224 & PWATER & SURO & 16.99167 & COPY & 2 & INPUT & MEAN \\
\hline PERLND & 224 & PWATER & IFWO & 16.99167 & COPY & 2 & INPUT & MEAN \\
\hline PERLND & 224 & PWATER & AGWI & 16.99167 & COPY & 2 & INPUT & MEAN \\
\hline PERLND & 224 & PWATER & TAET & 16.99167 & COPY & 2 & INPUT & MEAN \\
\hline PERLND & 224 & SNOW & SNOWE & 16.99167 & COPY & 2 & INPUT & MEAN \\
\hline PERLND & 227 & PWATER & SURO & 15.14167 & COPY & 2 & INPUT & MEAN \\
\hline PERLND & 227 & PWATER & IFWO & 15.14167 & COPY & 2 & INPUT & MEAN \\
\hline PERLND & 227 & PWATER & AGWI & 15.14167 & COPY & 2 & INPUT & MEAN \\
\hline PERLND & 227 & PWATER & TAET & 15.14167 & COPY & 2 & INPUT & MEAN \\
\hline PERLND & 227 & SNOW & SNOWE & 15.14167 & COPY & 2 & INPUT & MEAN \\
\hline PERLND & 228 & PWATER & SURO & 42.04167 & COPY & 2 & INPUT & MEAN \\
\hline PERLND & 228 & PWATER & IFWO & 42.04167 & COPY & 2 & INPUT & MEAN \\
\hline PERLND & 228 & PWATER & AGWI & 42.04167 & COPY & 2 & INPUT & MEAN \\
\hline PERLND & 228 & PWATER & TAET & 42.04167 & COPY & 2 & INPUT & MEAN \\
\hline PERLND & 228 & SNOW & SNOWE & 42.04167 & COPY & 2 & INPUT & MEAN \\
\hline PERLND & 229 & PWATER & SURO & 4.98333 & COPY & 2 & INPUT & MEAN \\
\hline PERLND & 229 & PWATER & IFWO & 4.98333 & COPY & 2 & INPUT & MEAN \\
\hline PERLND & 229 & PWATER & AGWI & 4.98333 & COPY & 2 & INPUT & MEAN \\
\hline PERLND & 229 & PWATER & TAET & 4.98333 & COPY & 2 & INPUT & MEAN \\
\hline PERLND & 229 & SNOW & SNOWE & 4.98333 & COPY & 2 & INPUT & MEAN \\
\hline PERLND & 230 & PWATER & SURO & 34.27500 & COPY & 2 & INPUT & MEAN \\
\hline PERLND & 230 & PWATER & IFWO & 34.27500 & COPY & 2 & INPUT & MEAN \\
\hline PERLND & 230 & PWATER & AGWI & 34.27500 & COPY & 2 & INPUT & MEAN \\
\hline PERLND & 230 & PWATER & TAET & 34.27500 & COPY & 2 & INPUT & MEAN \\
\hline PERLND & 230 & SNOW & SNOWE & 34.27500 & COPY & 2 & INPUT & MEAN \\
\hline PERLND & 231 & PWATER & SURO & 14.95833 & COPY & 2 & INPUT & MEAN \\
\hline PERLND & 231 & PWATER & IFWO & 14.95833 & COPY & 2 & INPUT & MEAN \\
\hline PERLND & 231 & PWATER & AGWI & 14.95833 & COPY & 2 & INPUT & MEAN \\
\hline PERLND & 231 & PWATER & TAET & 14.95833 & COPY & 2 & INPUT & MEAN \\
\hline PERLND & 231 & SNOW & SNOWE & 14.95833 & COPY & 2 & INPUT & MEAN \\
\hline PERLND & 232 & PWATER & SURO & 14.49167 & COPY & 2 & INPUT & MEAN \\
\hline PERLND & 232 & PWATER & IFWO & 14.49167 & COPY & 2 & INPUT & MEAN \\
\hline
\end{tabular}




\begin{tabular}{|c|c|c|c|c|c|c|c|c|}
\hline PERLND & 232 & PWATER & AGWI & 14.49167 & COPY & 2 & INPUT & MEAN \\
\hline PERLND & 232 & PWATER & TAET & 14.49167 & COPY & 2 & INPUT & MEAN \\
\hline PERLND & 232 & SNOW & SNOWE & 14.49167 & COPY & 2 & INPUT & MEAN \\
\hline PERLND & 234 & PWATER & SURO & 17.07500 & COPY & 2 & INPUT & MEAN \\
\hline PERLND & 234 & PWATER & IFWO & 17.07500 & COPY & 2 & INPUT & MEAN \\
\hline PERLND & 234 & PWATER & AGWI & 17.07500 & COPY & 2 & INPUT & MEAN \\
\hline PERLND & 234 & PWATER & TAET & 17.07500 & COPY & 2 & INPUT & MEAN \\
\hline PERLND & 234 & SNOW & SNOWE & 17.07500 & COPY & 2 & INPUT & MEAN \\
\hline PERLND & 241 & PWATER & SURO & 0.82500 & COPY & 2 & INPUT & MEAN \\
\hline PERLND & 241 & PWATER & IFWO & 0.82500 & COPY & 2 & INPUT & MEAN \\
\hline PERLND & 241 & PWATER & AGWI & 0.82500 & COPY & 2 & INPUT & MEAN \\
\hline PERLND & 241 & PWATER & TAET & 0.82500 & COPY & 2 & INPUT & MEAN \\
\hline PERLND & 241 & SNOW & SNOWE & 0.82500 & COPY & 2 & INPUT & MEAN \\
\hline PERLND & 243 & PWATER & SURO & 1.87500 & COPY & 2 & INPUT & MEAN \\
\hline PERLND & 243 & PWATER & IFWO & 1.87500 & COPY & 2 & INPUT & MEAN \\
\hline PERLND & 243 & PWATER & AGWI & 1.87500 & COPY & 2 & INPUT & MEAN \\
\hline PERLND & 243 & PWATER & TAET & 1.87500 & COPY & 2 & INPUT & MEAN \\
\hline PERLND & 243 & SNOW & SNOWE & 1.87500 & COPY & 2 & INPUT & MEAN \\
\hline PERLND & 244 & PWATER & SURO & 20.73333 & COPY & 2 & INPUT & MEAN \\
\hline PERLND & 244 & PWATER & IFWO & 20.73333 & COPY & 2 & INPUT & MEAN \\
\hline PERLND & 244 & PWATER & AGWI & 20.73333 & COPY & 2 & INPUT & MEAN \\
\hline PERLND & 244 & PWATER & TAET & 20.73333 & COPY & 2 & INPUT & MEAN \\
\hline PERLND & 244 & SNOW & SNOWE & 20.73333 & COPY & 2 & INPUT & MEAN \\
\hline PERLND & 247 & PWATER & SURO & 18.77500 & COPY & 2 & INPUT & MEAN \\
\hline PERLND & 247 & PWATER & IFWO & 18.77500 & COPY & 2 & INPUT & MEAN \\
\hline PERLND & 247 & PWATER & AGWI & 18.77500 & COPY & 2 & INPUT & MEAN \\
\hline PERLND & 247 & PWATER & TAET & 18.77500 & COPY & 2 & INPUT & MEAN \\
\hline PERLND & 247 & SNOW & SNOWE & 18.77500 & COPY & 2 & INPUT & MEAN \\
\hline PERLND & 248 & PWATER & SURO & 43.18333 & COPY & 2 & INPUT & MEAN \\
\hline PERLND & 248 & PWATER & IFWO & 43.18333 & COPY & 2 & INPUT & MEAN \\
\hline PERLND & 248 & PWATER & AGWI & 43.18333 & COPY & 2 & INPUT & MEAN \\
\hline PERLND & 248 & PWATER & TAET & 43.18333 & COPY & 2 & INPUT & MEAN \\
\hline PERLND & 248 & SNOW & SNOWE & 43.18333 & COPY & 2 & INPUT & MEAN \\
\hline PERLND & 249 & PWATER & SURO & 8.29167 & COPY & 2 & INPUT & MEAN \\
\hline PERLND & 249 & PWATER & IFWO & 8.29167 & COPY & 2 & INPUT & MEAN \\
\hline PERLND & 249 & PWATER & AGWI & 8.29167 & COPY & 2 & INPUT & MEAN \\
\hline PERLND & 249 & PWATER & TAET & 8.29167 & COPY & 2 & INPUT & MEAN \\
\hline PERLND & 249 & SNOW & SNOWE & 8.29167 & COPY & 2 & INPUT & MEAN \\
\hline PERLND & 250 & PWATER & SURO & 58.85833 & COPY & 2 & INPUT & MEAN \\
\hline PERLND & 250 & PWATER & IFWO & 58.85833 & COPY & 2 & INPUT & MEAN \\
\hline PERLND & 250 & PWATER & AGWI & 58.85833 & COPY & 2 & INPUT & MEAN \\
\hline PERLND & 250 & PWATER & TAET & 58.85833 & COPY & 2 & INPUT & MEAN \\
\hline PERLND & 250 & SNOW & SNOWE & 58.85833 & COPY & 2 & INPUT & MEAN \\
\hline PERLND & 252 & PWATER & SURO & 4.37500 & COPY & 2 & INPUT & MEAN \\
\hline PERLND & 252 & PWATER & IFWO & 4.37500 & COPY & 2 & INPUT & MEAN \\
\hline PERLND & 252 & PWATER & AGWI & 4.37500 & COPY & 2 & INPUT & MEAN \\
\hline PERLND & 252 & PWATER & TAET & 4.37500 & COPY & 2 & INPUT & MEAN \\
\hline PERLND & 252 & SNOW & SNOWE & 4.37500 & COPY & 2 & INPUT & MEAN \\
\hline PERLND & 253 & PWATER & SURO & 0.74167 & COPY & 2 & INPUT & MEAN \\
\hline PERLND & 253 & PWATER & IFWO & 0.74167 & COPY & 2 & INPUT & MEAN \\
\hline PERLND & 253 & PWATER & AGWI & 0.74167 & COPY & 2 & INPUT & MEAN \\
\hline PERLND & 253 & PWATER & TAET & 0.74167 & COPY & 2 & INPUT & MEAN \\
\hline PERLND & 253 & SNOW & SNOWE & 0.74167 & COPY & 2 & INPUT & MEAN \\
\hline PERLND & 254 & PWATER & SURO & 7.38333 & COPY & 2 & INPUT & MEAN \\
\hline
\end{tabular}




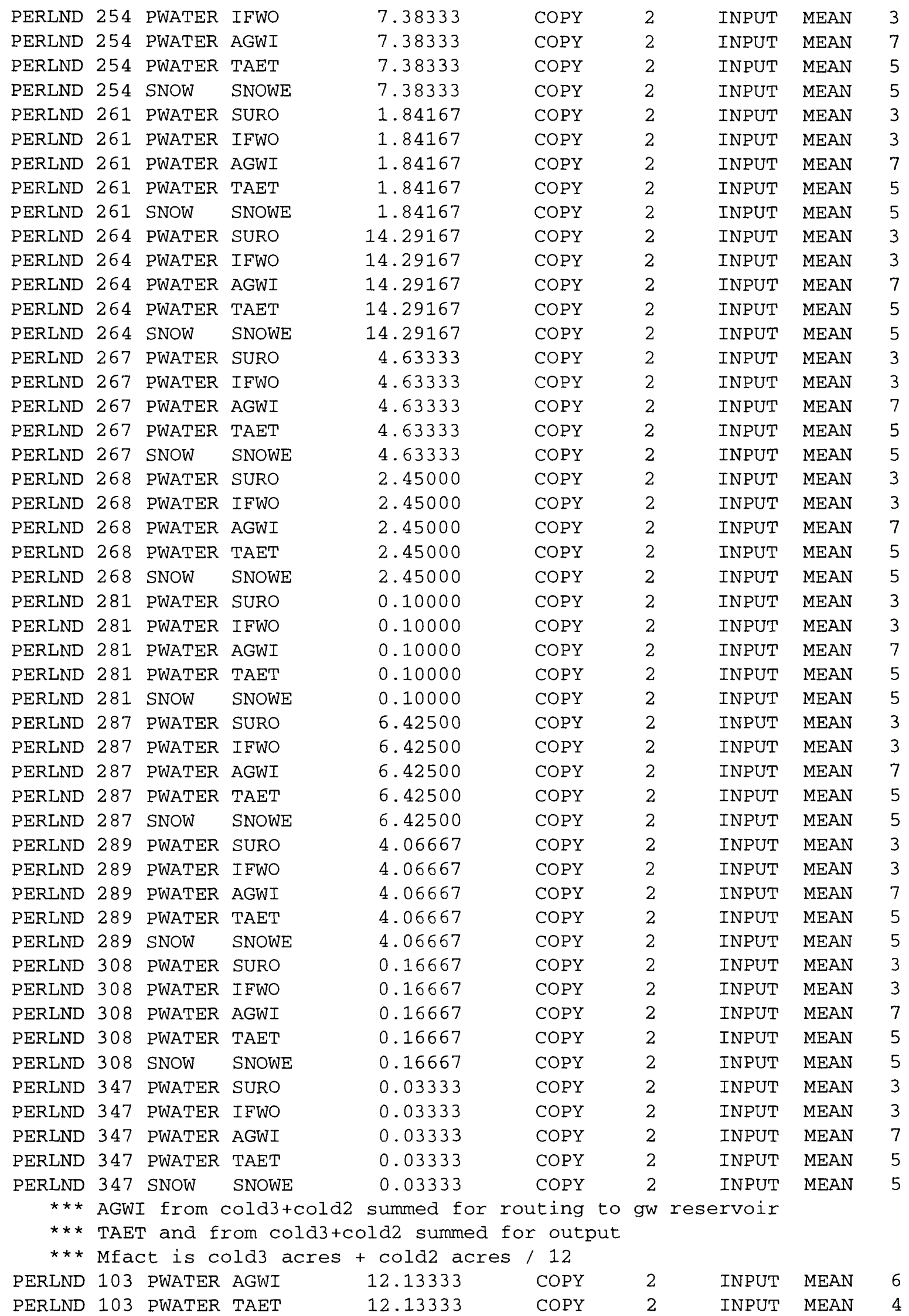


PERLND 104 PWATER AGWI PERLND 104 PWATER TAET PERLND 106 PWATER AGWI PERLND 106 PWATER TAET PERLND 110 PWATER AGWI PERLND 110 PWATER TAET PERLND 124 PWATER AGWI PERLND 124 PWATER TAET PERLND 130 PWATER AGWI PERLND 130 PWATER TAET PERLND 144 PWATER AGWI PERLND 144 PWATER TAET PERLND 150 PWATER AGWI PERLND 150 PWATER TAET PERLND 164 PWATER AGWI PERLND 164 PWATER TAET PERLND 204 PWATER AGWI PERLND 204 PWATER TAET PERLND 207 PWATER AGWI PERLND 207 PWATER TAET PERLND 208 PWATER AGWI PERLND 208 PWATER TAET PERLND 209 PWATER AGWI PERLND 209 PWATER TAET PERLND 210 PWATER AGWI PERLND 210 PWATER TAET PERLND 211 PWATER AGWI PERLND 211 PWATER TAET PERLND 212 PWATER AGWI PERLND 212 PWATER TAET PERLND 214 PWATER AGWI PERLND 214 PWATER TAET PERLND 221 PWATER AGWI PERLND 221 PWATER TAET PERLND 222 PWATER AGWI PERLND 222 PWATER TAET PERLND 223 PWATER AGWI PERLND 223 PWATER TAET PERLND 224 PWATER AGWI PERLND 224 PWATER TAET PERLND 227 PWATER AGWI PERLND 227 PWATER TAET PERLND 228 PWATER AGWI PERLND 228 PWATER TAET PERLND 229 PWATER AGWI PERLND 229 PWATER TAET PERLND 230 PWATER AGWI PERLND 230 PWATER TAET PERLND 231 PWATER AGWI PERLND 231 PWATER TAET PERLND 232 PWATER AGWI PERLND 232 PWATER TAET PERLND 234 PWATER AGWI PERLND 234 PWATER TAET

\begin{tabular}{|c|c|c|c|c|}
\hline 2.55000 & COPY & 2 & INPUT & MEAN \\
\hline 2.55000 & COPY & 2 & INPUT & MEAN \\
\hline 28.96667 & COPY & 2 & INPUT & MEAN \\
\hline 28.96667 & COPY & 2 & INPUT & MEAN \\
\hline 19.95000 & COPY & 2 & INPUT & MEAN \\
\hline 19.95000 & COPY & 2 & INPUT & MEAN \\
\hline 2.50000 & COPY & 2 & INPUT & MEAN \\
\hline 2.50000 & COPY & 2 & INPUT & MEAN \\
\hline 10.54167 & COPY & 2 & INPUT & MEAN \\
\hline 10.54167 & COPY & 2 & INPUT & MEAN \\
\hline 0.03333 & COPY & 2 & INPUT & MEAN \\
\hline 0.03333 & COPY & 2 & INPUT & MEAN \\
\hline 9.93333 & COPY & 2 & INPUT & MEAN \\
\hline 9.93333 & COPY & 2 & INPUT & MEAN \\
\hline 0.06667 & COPY & 2 & INPUT & MEAN \\
\hline 0.06667 & COPY & 2 & INPUT & MEAN \\
\hline 4.84167 & COPY & 2 & INPUT & MEAN \\
\hline 4.84167 & COPY & 2 & INPUT & MEAN \\
\hline 13.05827 & COPY & 2 & INPUT & MEAN \\
\hline 13.05827 & COPY & 2 & INPUT & MEAN \\
\hline 16.25833 & COPY & 2 & INPUT & MEAN \\
\hline 16.25833 & COPY & 2 & INPUT & MEAN \\
\hline 15.59166 & COPY & 2 & INPUT & MEAN \\
\hline 15.59166 & COPY & 2 & INPUT & MEAN \\
\hline 18.93334 & COPY & 2 & INPUT & MEAN \\
\hline 18.93334 & COPY & 2 & INPUT & MEAN \\
\hline 1.28333 & COPY & 2 & INPUT & MEAN \\
\hline 1.28333 & COPY & 2 & INPUT & MEAN \\
\hline 8.77500 & COPY & 2 & INPUT & MEAN \\
\hline 8.77500 & COPY & 2 & INPUT & MEAN \\
\hline 5.00833 & COPY & 2 & INPUT & MEAN \\
\hline 5.00833 & COPY & 2 & INPUT & MEAN \\
\hline 23.16667 & COPY & 2 & INPUT & MEAN \\
\hline 23.16667 & COPY & 2 & INPUT & MEAN \\
\hline 16.39167 & COPY & 2 & INPUT & MEAN \\
\hline 16.39167 & COPY & 2 & INPUT & MEAN \\
\hline 14.45000 & COPY & 2 & INPUT & MEAN \\
\hline 14.45000 & COPY & 2 & INPUT & MEAN \\
\hline 14.47500 & COPY & 2 & INPUT & MEAN \\
\hline 14.47500 & COPY & 2 & INPUT & MEAN \\
\hline 45.28334 & COPY & 2 & INPUT & MEAN \\
\hline 45.28334 & COPY & 2 & INPUT & MEAN \\
\hline 25.53334 & COPY & 2 & INPUT & MEAN \\
\hline 25.53334 & COPY & 2 & INPUT & MEAN \\
\hline 31.49167 & COPY & 2 & INPUT & MEAN \\
\hline 31.49167 & COPY & 2 & INPUT & MEAN \\
\hline 42.85833 & COPY & 2 & INPUT & MEAN \\
\hline 42.85833 & COPY & 2 & INPUT & MEAN \\
\hline 0.22500 & COPY & 2 & INPUT & MEAN \\
\hline 0.22500 & COPY & 2 & INPUT & MEAN \\
\hline 2.11667 & COPY & 2 & INPUT & MEAN \\
\hline 2.11667 & COPY & 2 & INPUT & MEAN \\
\hline 7.02500 & COPY & 2 & INPUT & MEAN \\
\hline 7.02500 & COPY & 2 & INPUT & MEAN \\
\hline
\end{tabular}




\begin{tabular}{|c|c|c|c|c|c|c|c|c|}
\hline PERLND & 241 & PWATER & AGWI & 23.02500 & COPY & 2 & INPUT & MEAN \\
\hline PERLND & 241 & PWATER & TAET & 23.02500 & COPY & 2 & INPUT & MEAN \\
\hline PERLND & 243 & PWATER & AGWI & 25.51663 & COPY & 2 & INPUT & MEAN \\
\hline PERLND & 243 & PWATER & TAET & 25.51663 & COPY & 2 & INPUT & MEAN \\
\hline PERLND & 244 & PWATER & AGWI & 19.36667 & COPY & 2 & INPUT & MEAN \\
\hline PERLND & 244 & PWATER & TAET & 19.36667 & COPY & 2 & INPUT & MEAN \\
\hline PERLND & 247 & PWATER & AGWI & 73.15834 & COPY & 2 & INPUT & MEAN \\
\hline PERLND & 247 & PWATER & TAET & 73.15834 & COPY & 2 & INPUT & MEAN \\
\hline PERLND & 248 & PWATER & AGWI & 16.81666 & COPY & 2 & INPUT & MEAN \\
\hline PERLND & 248 & PWATER & TAET & 16.81666 & COPY & 2 & INPUT & MEAN \\
\hline PERLND & 249 & PWATER & AGWI & 45.41666 & COPY & 2 & INPUT & MEAN \\
\hline PERLND & 249 & PWATER & TAET & 45.41666 & COPY & 2 & INPUT & MEAN \\
\hline PERLND & 250 & PWATER & AGWI & 84.65000 & COPY & 2 & INPUT & MEAN \\
\hline PERLND & 250 & PWATER & TAET & 84.65000 & COPY & 2 & INPUT & MEAN \\
\hline PERLND & 252 & PWATER & AGWI & 13.75000 & COPY & 2 & INPUT & MEAN \\
\hline PERLND & 252 & PWATER & TAET & 13.75000 & COPY & 2 & INPUT & MEAN \\
\hline PERLND & 253 & PWATER & AGWI & 16.55000 & COPY & 2 & INPUT & MEAN \\
\hline PERLND & 253 & PWATER & TAET & 16.55000 & COPY & 2 & INPUT & MEAN \\
\hline PERLND & 254 & PWATER & AGWI & 36.16667 & COPY & 2 & INPUT & MEAN \\
\hline PERLND & 254 & PWATER & TAET & 36.16667 & COPY & 2 & INPUT & MEAN \\
\hline PERLND & 261 & PWATER & AGWI & 19.30833 & COPY & 2 & INPUT & MEAN \\
\hline PERLND & 261 & PWATER & TAET & 19.30833 & COPY & 2 & INPUT & MEAN \\
\hline PERLND & 264 & PWATER & AGWI & 21.34167 & COPY & 2 & INPUT & MEAN \\
\hline PERLND & 264 & PWATER & TAET & 21.24167 & COPY & 2 & INPUT & MEAN \\
\hline PERLND & 267 & PWATER & AGWI & 31.47500 & COPY & 2 & INPUT & MEAN \\
\hline PERLND & 267 & PWATER & TAET & 31.47500 & COPY & 2 & INPUT & MEAN \\
\hline PERLND & 268 & PWATER & AGWI & 21.56666 & COPY & 2 & INPUT & MEAN \\
\hline PERLND & 268 & PWATER & TAET & 21.56666 & COPY & 2 & INPUT & MEAN \\
\hline PERLND & 269 & PWATER & AGWI & 11.29167 & COPY & 2 & INPUT & MEAN \\
\hline PERLND & 269 & PWATER & TAET & 11.29167 & COPY & 2 & INPUT & MEAN \\
\hline PERLND & 281 & PWATER & AGWI & 20.75833 & COPY & 2 & INPUT & MEAN \\
\hline PERLND & 281 & PWATER & TAET & 20.75833 & COPY & 2 & INPUT & MEAN \\
\hline PERLND & 287 & PWATER & AGWI & 39.97500 & COPY & 2 & INPUT & MEAN \\
\hline PERLND & 287 & PWATER & TAET & 39.97500 & COPY & 2 & INPUT & MEAN \\
\hline PERLND & 289 & PWATER & AGWI & 35.45000 & COPY & 2 & INPUT & MEAN \\
\hline PERLND & 289 & PWATER & TAET & 35.45000 & COPY & 2 & INPUT & MEAN \\
\hline PERLND & 308 & PWATER & AGWI & 19.56667 & COPY & 2 & INPUT & MEAN \\
\hline PERLND & 308 & PWATER & TAET & 19.56667 & COPY & 2 & INPUT & MEAN \\
\hline PERLND & 321 & PWATER & AGWI & 34.69167 & COPY & 2 & INPUT & MEAN \\
\hline PERLND & 321 & PWATER & TAET & 34.69167 & COPY & 2 & INPUT & MEAN \\
\hline PERLND & 341 & PWATER & AGWI & 26.06666 & COPY & 2 & INPUT & MEAN \\
\hline PERLND & 341 & PWATER & TAET & 26.06666 & COPY & 2 & INPUT & MEAN \\
\hline PERLND & 347 & PWATER & AGWI & 31.08334 & COPY & 2 & INPUT & MEAN \\
\hline PERLND & 347 & PWATER & TAET & 31.08334 & COPY & 2 & INPUT & MEAN \\
\hline PERLND & 361 & PWATER & AGWI & 38.07500 & COPY & 2 & INPUT & MEAN \\
\hline PERLND & 361 & PWATER & TAET & 38.07500 & COPY & 2 & INPUT & MEAN \\
\hline PERLND & 367 & PWATER & AGWI & 29.71667 & COPY & 2 & INPUT & MEAN \\
\hline PERLND & 367 & PWATER & TAET & 29.71667 & COPY & 2 & INPUT & MEAN \\
\hline PERLND & 381 & PWATER & AGWI & 28.91667 & COPY & 2 & INPUT & MEAN \\
\hline PERLND & 381 & PWATER & TAET & 28.91667 & COPY & 2 & INPUT & MEAN \\
\hline PERLND & 387 & PWATER & AGWI & 30.46667 & COPY & 2 & INPUT & MEAN \\
\hline PERLND & 387 & PWATER & TAET & 30.46667 & COPY & 2 & INPUT & MEAN \\
\hline
\end{tabular}

*** SNOWE from cold3+cold2 elevation/slope/aspect zones added to TAET $* \star *$ mfact is total acres in elev/slope/aspect zone / 12 . 


\begin{tabular}{|c|c|c|c|c|c|c|c|c|c|}
\hline PERLND & 103 & SNOW & SNOWE & & 63.60000 & COPY & 2 & INPUT & MEAN \\
\hline PERLND & 124 & SNOW & SNOWE & & 13.04167 & COPY & 2 & INPUT & MEAN \\
\hline PERLND & 144 & SNOW & SNOWE & & 9.96667 & COPY & 2 & INPUT & MEAN \\
\hline PERLND & 164 & SNOW & SNOWE & & 0.06667 & COPY & 2 & INPUT & MEAN \\
\hline PERLND & 204 & SNOW & SNOWE & & 83.74993 & COPY & 2 & INPUT & MEAN \\
\hline PERLND & 221 & SNOW & SNOWE & & 223.01669 & COPY & 2 & INPUT & MEAN \\
\hline PERLND & 241 & SNOW & SNOWE & & 356.41633 & COPY & 2 & INPUT & MEAN \\
\hline PERLND & 261 & SNOW & SNOWE & & 104.98333 & COPY & 2 & INPUT & MEAN \\
\hline PERLND & 281 & SNOW & SNOWE & & 100.18333 & COPY & 2 & INPUT & MEAN \\
\hline PERLND & 308 & SNOW & SNOWE & & 19.56667 & COPY & 2 & INPUT & MEAN \\
\hline PERLND & 321 & SNOW & SNOWE & & 34.69167 & COPY & 2 & INPUT & MEAN \\
\hline PERLND & 341 & SNOW & SNOWE & & 57.15000 & COPY & 2 & INPUT & MEAN \\
\hline PERLND & 361 & SNOW & SNOWE & & 67.79167 & COPY & 2 & INPUT & MEAN \\
\hline PERLND & 381 & SNOW & SNOWE & & 59.38334 & COPY & 2 & INPUT & MEAN \\
\hline$\star \star \star$ Wa & ater & balance & e data & for & $\operatorname{cold} 3+\operatorname{col} c$ & d cold1 & & & \\
\hline$\star * \star \mathrm{TO}$ & otal & ppt. Mf & fact is & fr & action of $b$ & area $f$ & & elevati & on zone. \\
\hline PERLND & 101 & SNOW & RAINF & & .049 & COPY & 2 & INPUT & MEAN \\
\hline PERLND & 101 & SNOW & SNOWF & & .049 & COPY & 2 & INPUT & MEAN \\
\hline PERLND & 106 & SNOW & RAINF & & .024 & COPY & 2 & INPUT & MEAN \\
\hline PERLND & 106 & SNOW & SNOWF & & .024 & COPY & 2 & INPUT & MEAN \\
\hline PERLND & 204 & SNOW & RAINF & & .726 & COPY & 2 & INPUT & MEAN \\
\hline PERLND & 204 & SNOW & SNOWF & & .726 & COPY & 2 & INPUT & MEAN \\
\hline PERLND & 308 & SNOW & RAINF & & .201 & COPY & 2 & INPUT & MEAN \\
\hline PERLND & 308 & SNOW & SNOWF & & .201 & COPY & 2 & INPUT & MEAN \\
\hline PERLND & 101 & SNOW & RAINF & & .694 & COPY & 3 & INPUT & MEAN \\
\hline PERLND & 101 & SNOW & SNOWF & & .694 & COPY & 3 & INPUT & MEAN \\
\hline PERLND & 106 & SNOW & RAINF & & .039 & COPY & 3 & INPUT & MEAN \\
\hline PERLND & 106 & SNOW & SNOWF & & .039 & COPY & 3 & INPUT & MEAN \\
\hline PERLND & 204 & SNOW & RAINF & & .267 & COPY & 3 & INPUT & MEAN \\
\hline PERLND & 204 & SNOW & SNOWF & & .267 & COPY & 3 & INPUT & MEAN \\
\hline \multicolumn{10}{|c|}{$\star \star \star$ Basin water-balance displays } \\
\hline COPY & 2 & OUTPUT & MEAN & 1 & & DISPLY & 1 & INPUT & TIMSER \\
\hline COPY & 2 & OUTPUT & MEAN & 2 & & DISPLY & 2 & INPUT & TIMSER \\
\hline COPY & 2 & OUTPUT & MEAN & 3 & & DISPLY & 3 & INPUT & TIMSER \\
\hline
\end{tabular}

END NETWORK

EXT TARGETS

\begin{tabular}{|c|c|c|c|c|c|c|c|c|c|c|c|}
\hline \multicolumn{2}{|c|}{$\begin{array}{l}<- \text { Volume-> } \\
\star \star \star\end{array}$} & $<-G r p>$ & \multicolumn{3}{|c|}{$<-$ Member $-><--$ Mult $-->$ Tran } & \multicolumn{2}{|l|}{$<-$ Voll } & & \multicolumn{2}{|r|}{ Tgap } & \multirow[t]{2}{*}{ And } \\
\hline $\begin{array}{l}<\text { Name }> \\
\text { strg*** }\end{array}$ & $\#$ & & $<$ Name $>$ & \# & $\#<-$ factor->strg & $<$ Name $>$ & \# & $<$ Name $>$ & tem & strg & \\
\hline COPY & 2 & OUTPUT & MEAN & 1 & SAME & WDM & 391 & RO3 & ENGL & & REPL \\
\hline COPY & 2 & OUTPUT & MEAN & 2 & SAME & WDM & 385 & $\mathrm{RO} 2$ & ENGL & & REPL \\
\hline COPY & 2 & OUTPUT & MEAN & 3 & SAME & WDM & 393 & RO1 & ENGL & & REPL \\
\hline COPY & 2 & OUTPUT & MEAN & 4 & SAME & WDM & 394 & ЕT32 & ENGL & & REPL \\
\hline COPY & 2 & OUTPUT & MEAN & 5 & SAME & WDM & 395 & ET1 & ENGL & & REPL \\
\hline COPY & 2 & OUTPUT & MEAN & 6 & SAME & WDM & 396 & DP3 2 & ENGL & & REPL \\
\hline COPY & 2 & OUTPUT & MEAN & 7 & SAME & WDM & 387 & DP1 & ENGL & & REPL \\
\hline COPY & 2 & OUTPUT & MEAN & 8 & SAME & WDM & 388 & РT32 & ENGL & & REPL \\
\hline COPY & 3 & OUTPUT & MEAN & 1 & SAME & WDM & 386 & PT1 & ENGL & & REPL \\
\hline
\end{tabular}




\section{DISPLY-INFO1}

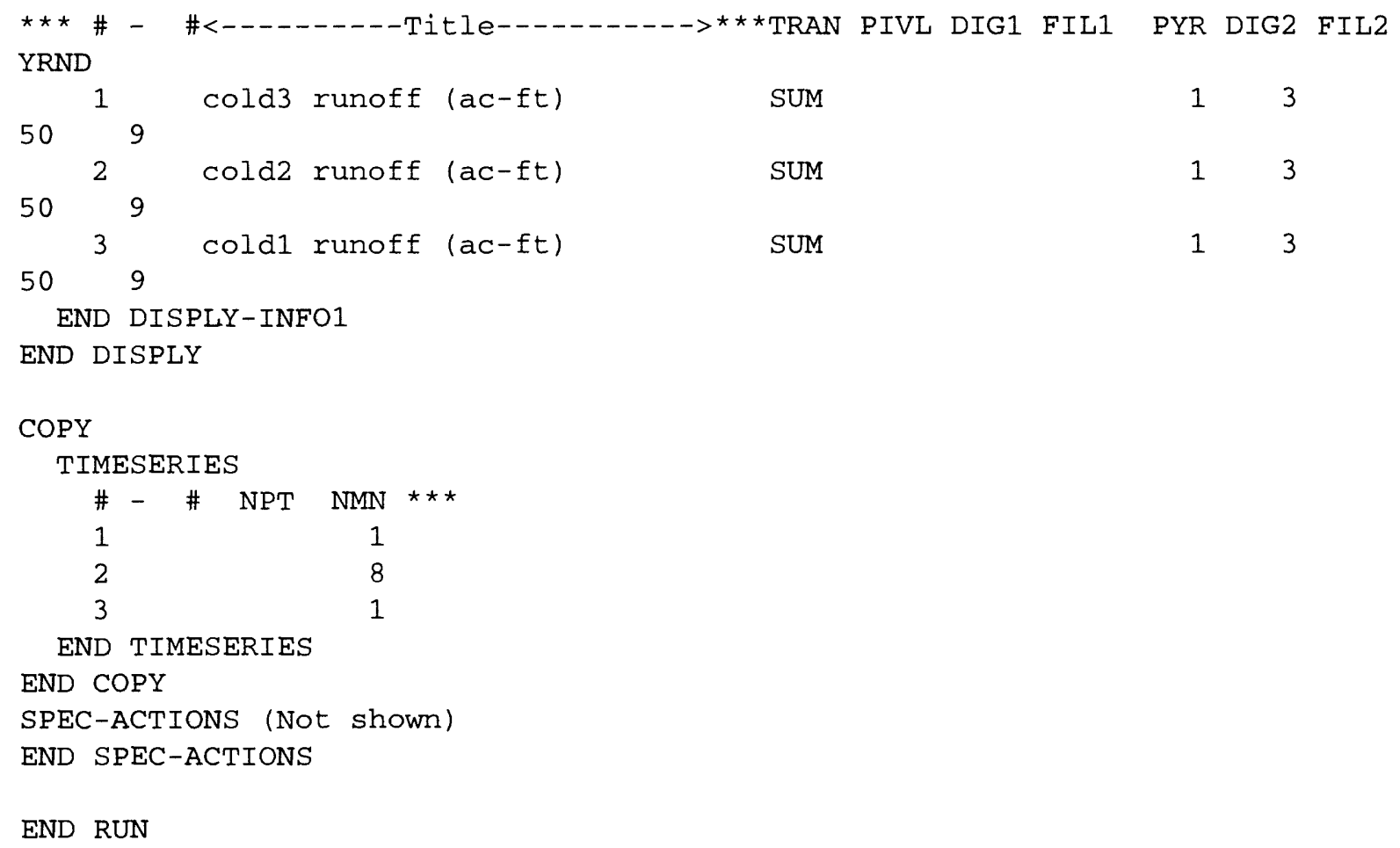


Appendix 3.--Final HSPF input file for combined Cold Creek model

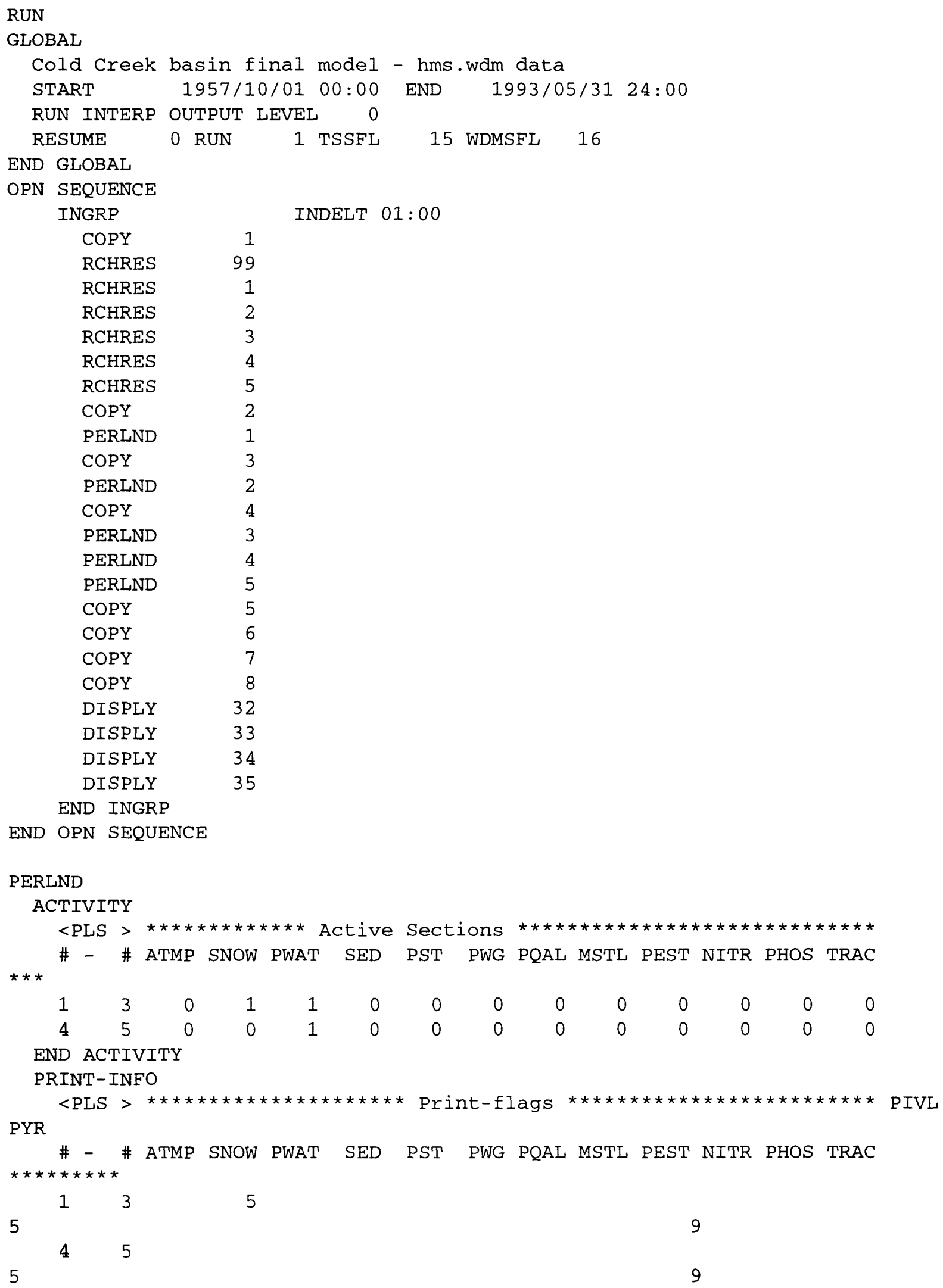




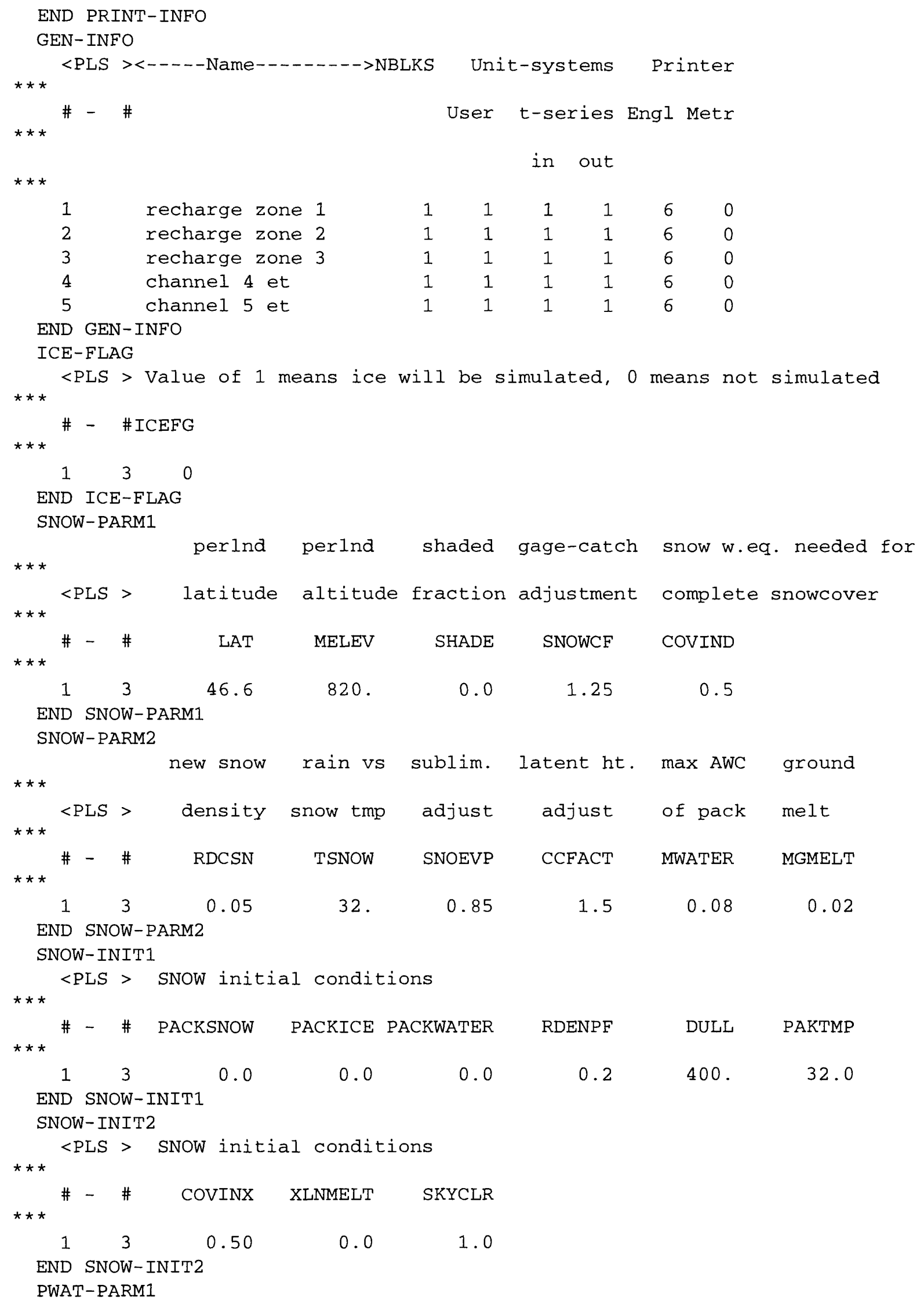




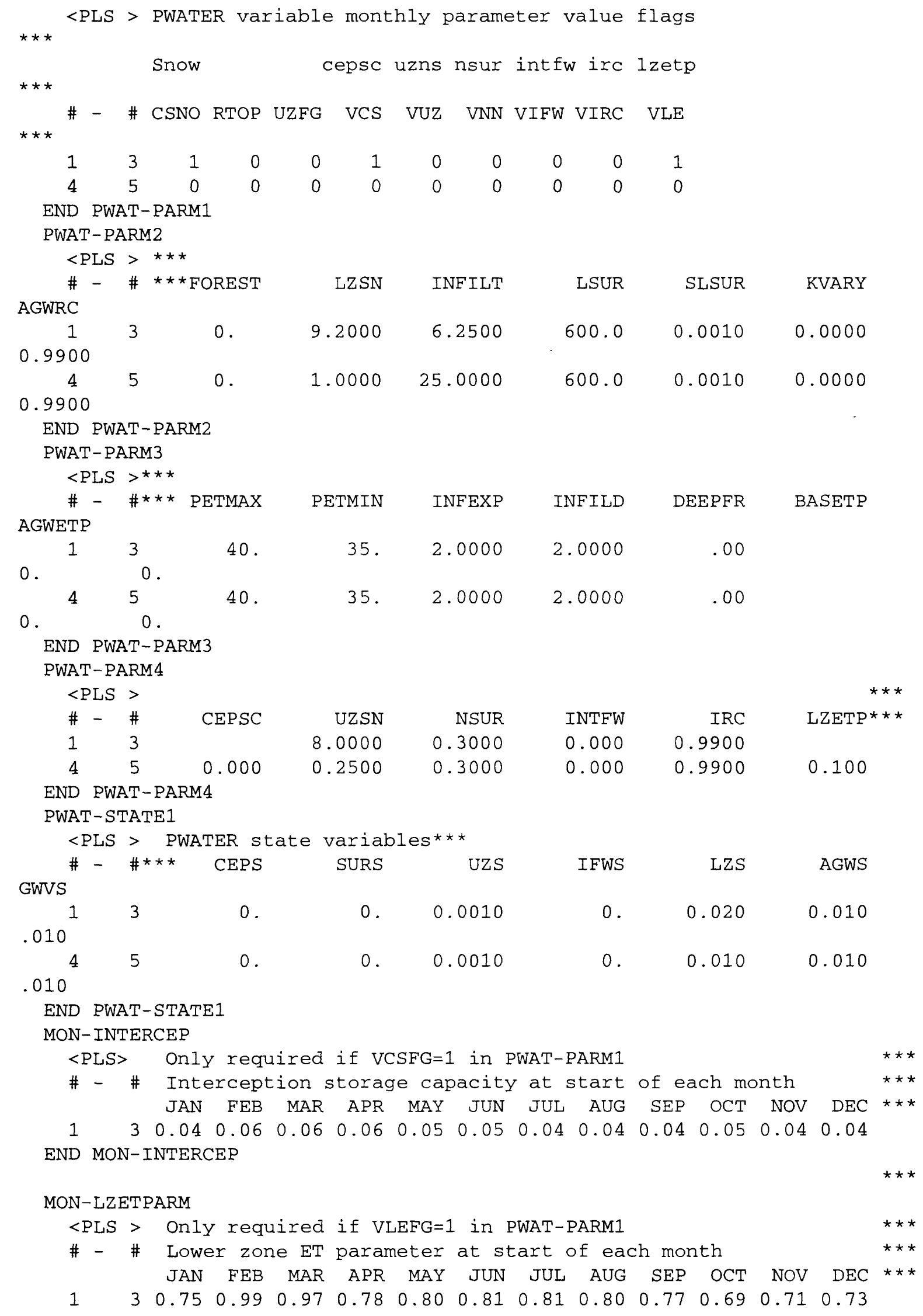


END MON-LZETPARM

END PERLND

EXT SOURCES

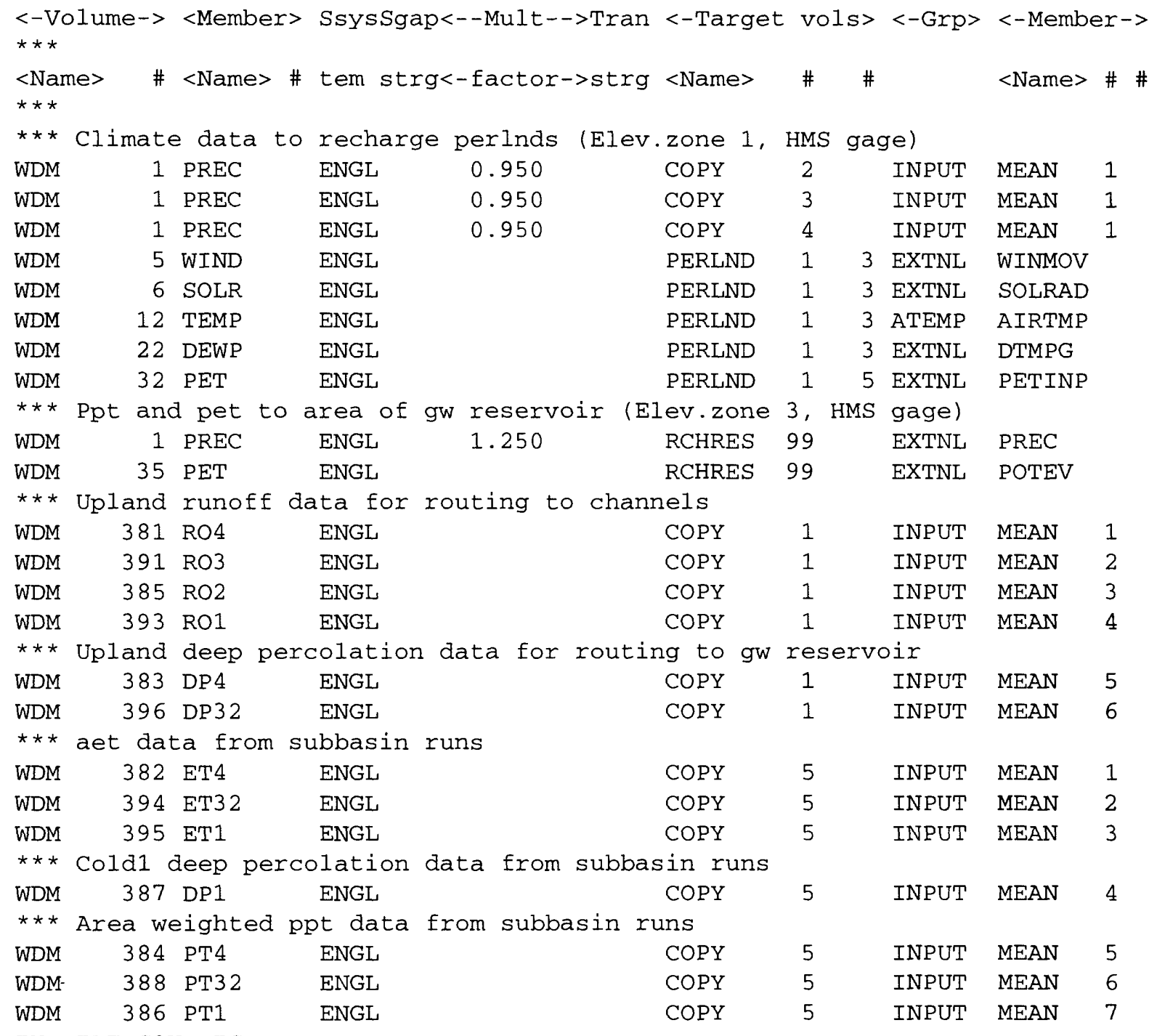

END EXT SOURCES

NETWORK

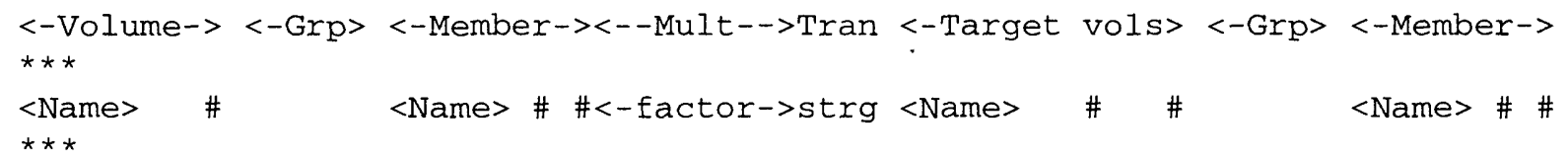

***Basin geometry (all units are ac-ft)

** Channel inflows from direct runoff in cold4, cold3, cold2, cold1

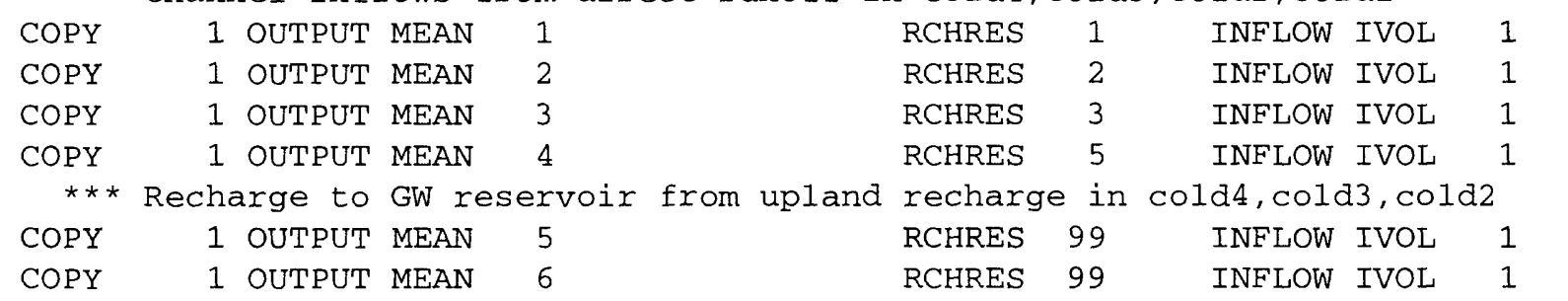


*** Discharge from GW reservoir to channels in cold4, cold3, cold2

\begin{tabular}{|c|c|c|c|c|c|c|c|c|c|}
\hline RCHRES & 99 & HYDR & OVOL & 2 & RCHRES & 1 & INFLOW & IVOL & 1 \\
\hline RCHRES & 99 & HYDR & OVOL & 3 & RCHRES & 2 & INFLOW & IVOL & 1 \\
\hline RCHRES & 99 & HYDR & OVOL & 4 & RCHRES & 3 & INFLOW & IVOL & 1 \\
\hline$* * *$ & han & nel cc & nectior & to cold3 & to $\operatorname{cold} 2 \mathrm{u}$ & & La2low $t$ & $=0 \mathrm{co}$. & \\
\hline RCHRES & 1 & HYDR & ROVOL & & RCHRES & 2 & INFLOW & IVOL & 1 \\
\hline RCHRES & 2 & HYDR & ROVOL & & RCHRES & 3 & INFLOW & IVOL & \\
\hline RCHRES & 3 & HYDR & ROVOL & & RCHRES & 4 & INFLOW & IVOL & \\
\hline RCHRES & 4 & HYDR & OVOL & 2 & RCHRES & 5 & INFLOW & IVOL & \\
\hline
\end{tabular}

*** Channel discharge+ppt to recharge zone perlnds

*** mfact for ovol to copy converts acft to inches

$* * *$ mfact for suro to copy is the ratio of source area to target area

*** recharge zone perlnd areas are 19.4, 147, 104 acres

*** Channel discharge to subsurface perlnd for channel et losses (applied

$\star \star *$ over 'average' channel area for rchres $4+5$ of 33 and 129 acres)

\begin{tabular}{|c|c|c|c|c|c|c|c|c|c|}
\hline RCHRES & 5 & HYDR & OVOL & 2 & 0.61856 & COPY & 2 & INPUT & MEAN \\
\hline COPY & 2 & OUTPUT & MEAN & 1 & & PERLND & 1 & EXTNL & PREC \\
\hline PERLND & 1 & PWATER & SURO & & 0.13197 & COPY & 3 & INPUT & MEAN \\
\hline COPY & 3 & OUTPUT & MEAN & 1 & & PERLND & 2 & EXTNL & PREC \\
\hline PERLND & 2 & PWATER & SURO & & 1.41346 & COPY & 4 & INPUT & MEAN \\
\hline COPY & 4 & OUTPUT & MEAN & 1 & & PERLND & 3 & EXTNL & PREC \\
\hline RCHRES & 4 & HYDR & OVOL & 1 & 0.36364 & PERLND & 4 & EXTNL & PREC \\
\hline RCHRES & 5 & HYDR & OVOL & 1 & 0.09302 & PERLND & 5 & EXTNL & PREC \\
\hline
\end{tabular}

*** End Basin Geometry

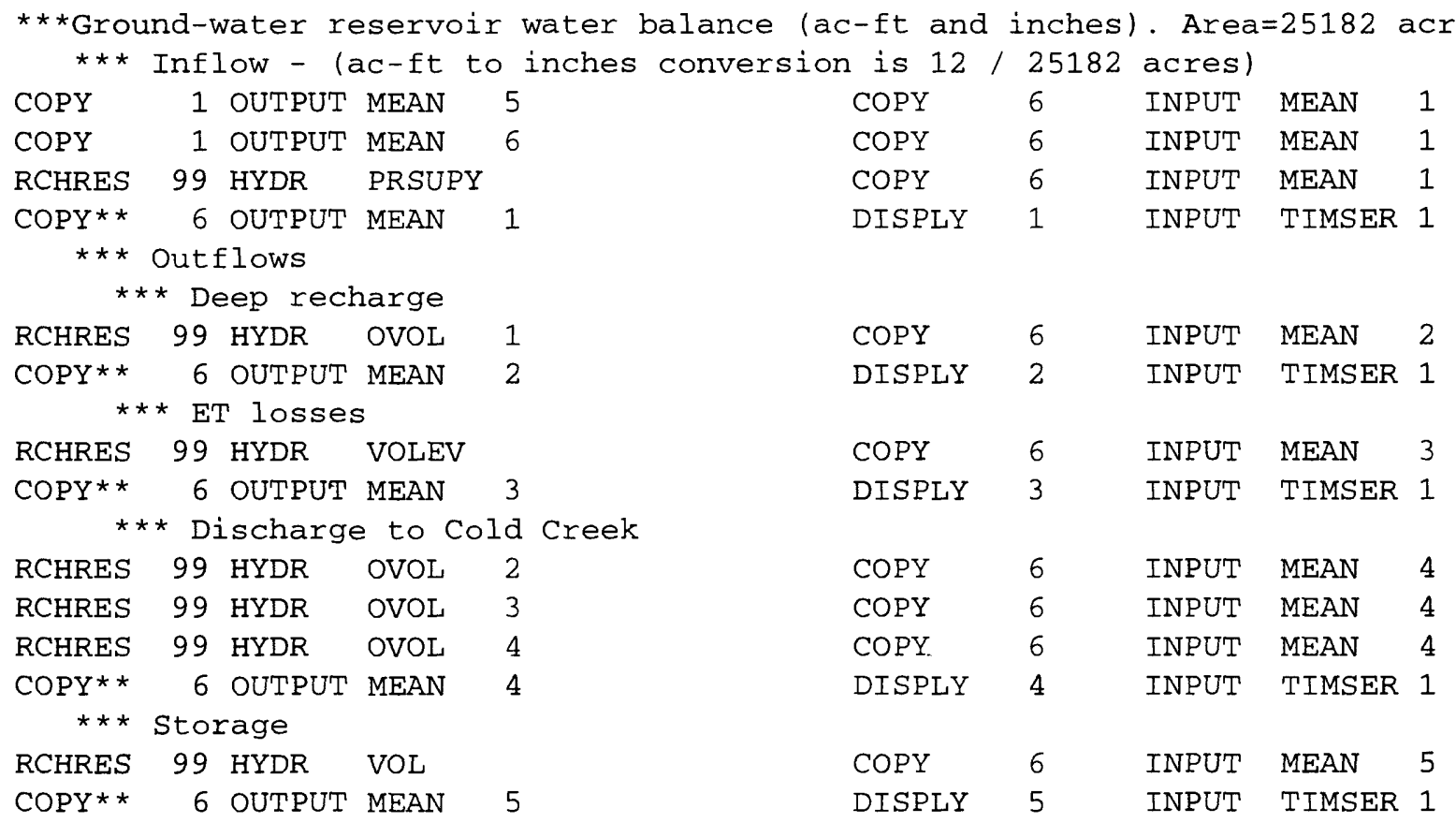

***Upper basin (cold4-cold2) water balance (ac-ft and inches).

Areas $=10908,14274$

$* * *$ The short losing reach above the flume is NOT included here.

*** Precip - areally weighted because it was stored as inches

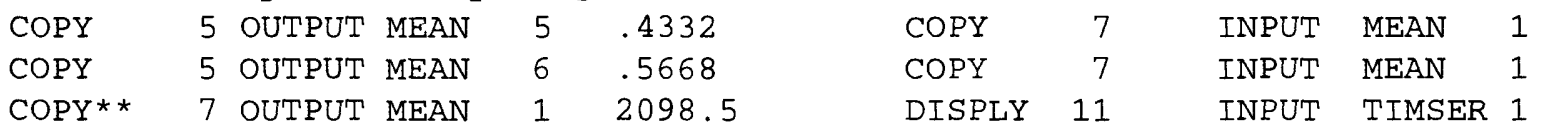




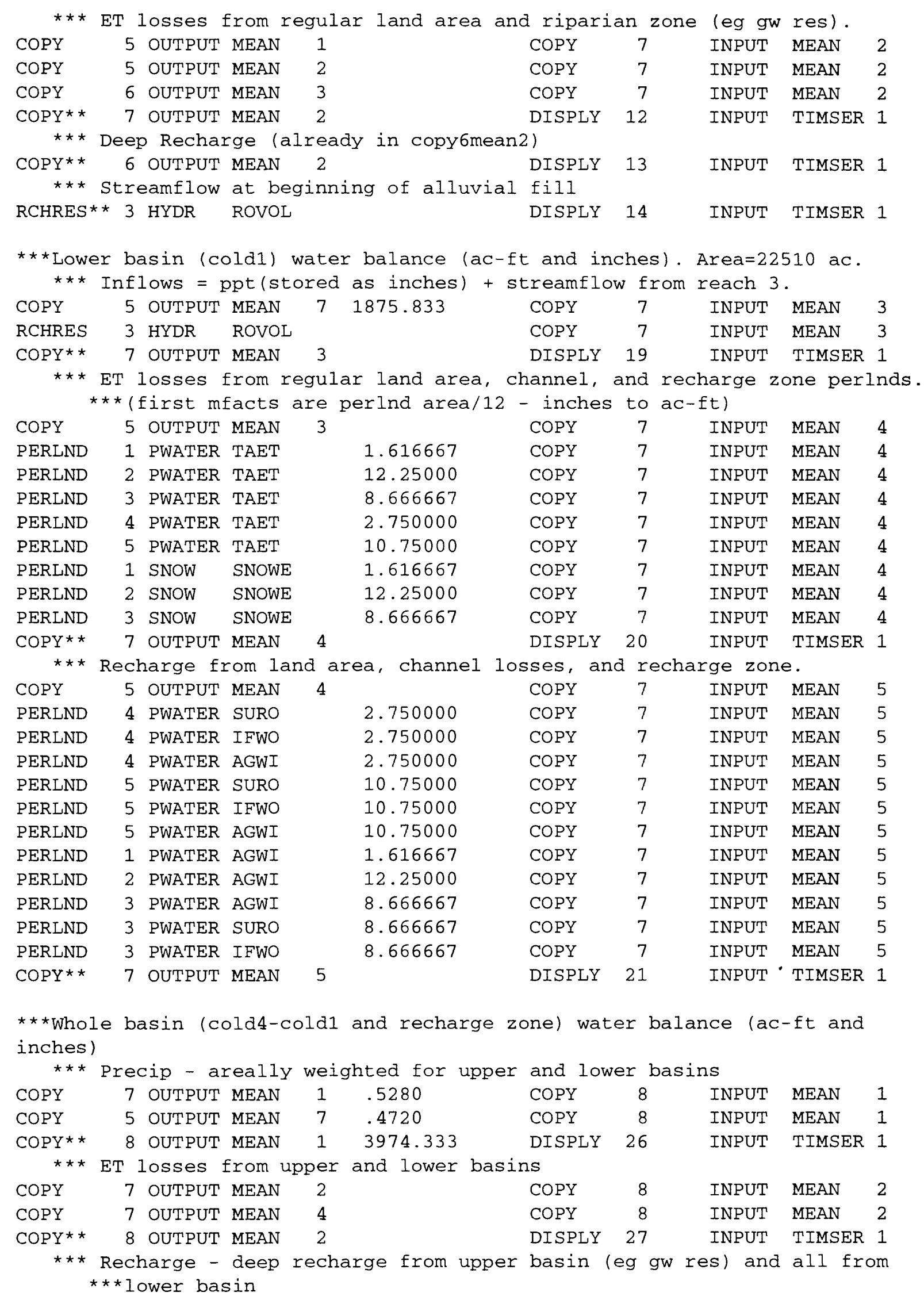




\begin{tabular}{|c|c|c|c|c|c|c|c|c|}
\hline COPY & 6 & OUTPUT & MEAN & 2 & COPY & 8 & INPUT & MEAN \\
\hline COPY & 7 & OUTPUT & MEAN & 5 & COPY & 8 & INPUT & MEAN \\
\hline $\mathrm{COPY} * \star$ & 8 & OUTPUT & MEAN & 3 & DISPLY & 28 & INPUT & TIMSER \\
\hline
\end{tabular}

\begin{tabular}{|c|c|c|c|c|c|c|c|c|c|}
\hline RCHRES & 2 & HYDR & ROVOL & & 12.1 & COPY & 8 & INPUT & MEAN \\
\hline RCHRES & 2 & HYDR & ROVOL & & & COPY & 8 & INPUT & MEAN \\
\hline RCHRES & 4 & HYDR & OVOL & 2 & 12.1 & COPY & 8 & INPUT & MEAN \\
\hline RCHRES & 4 & HYDR & OVOL & 2 & & COPY & 8 & INPUT & MEAN \\
\hline COPY & 8 & OUTPUT & MEAN & 4 & & DISPLY & 32 & INPUT & TIMSEF \\
\hline COPY & 8 & OUTPUT & MEAN & 5 & & DISPLY & 34 & INPUT & TIMSEF \\
\hline COPY & 8 & OUTPUT & MEAN & 6 & & DISPLY & 33 & INPUT & TIMSEF \\
\hline COPY & 8 & OUTPUT & MEAN & 7 & & DISPIY & 35 & INPUT & TIMSEF \\
\hline
\end{tabular}

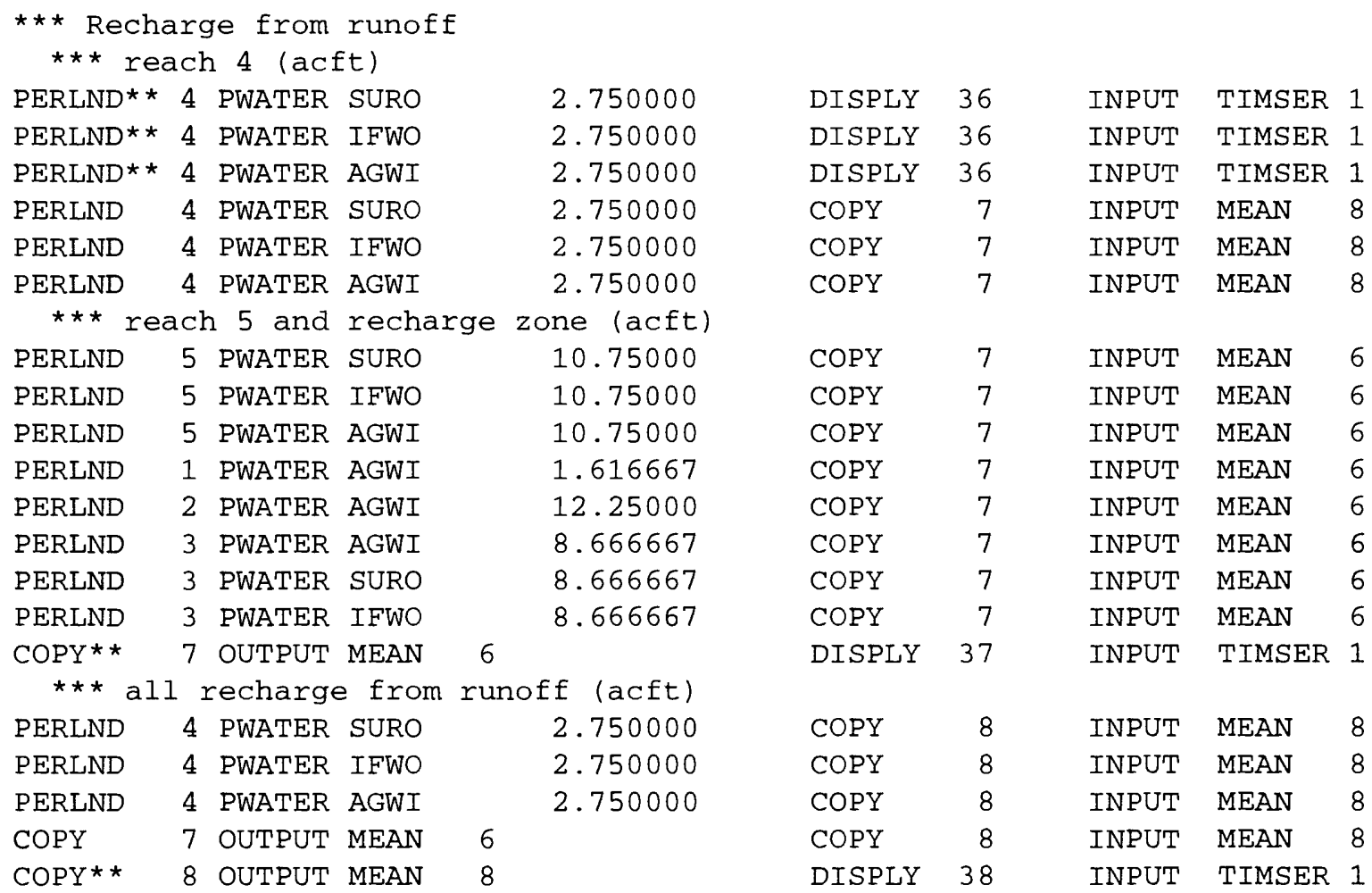

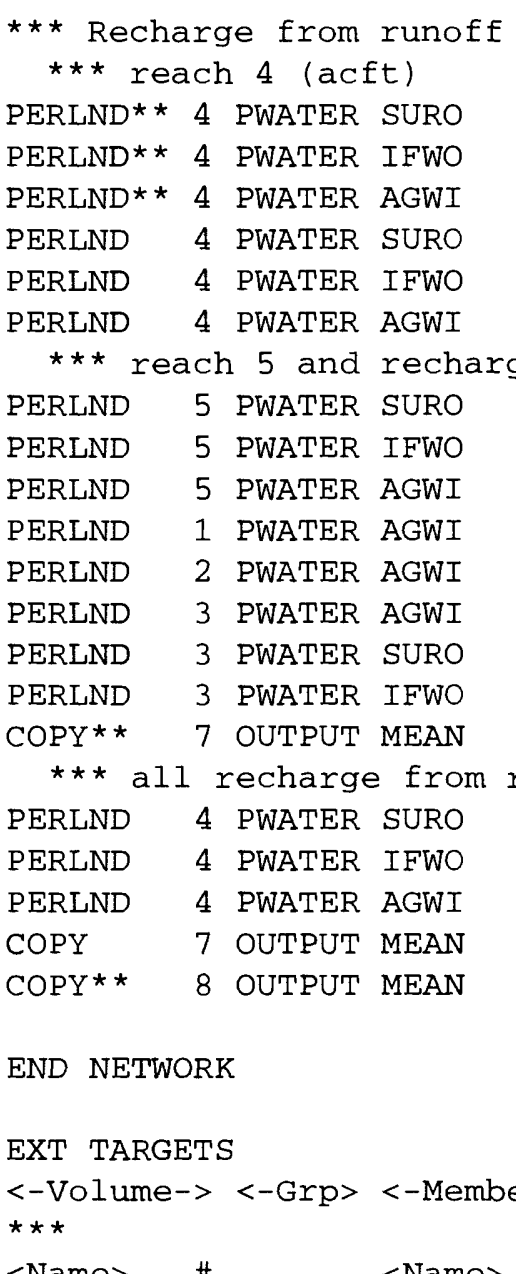

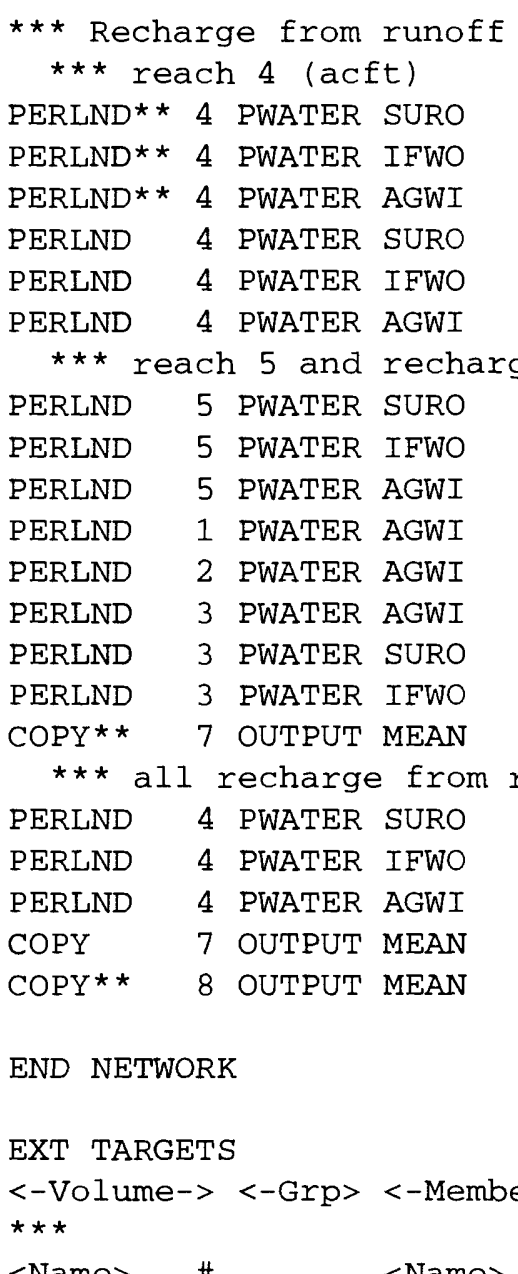

$<-$ Volume-> <-Grp> <-Member-><--Mult-->Tran <-Volume-> <Member> Tsys Tgap Amd

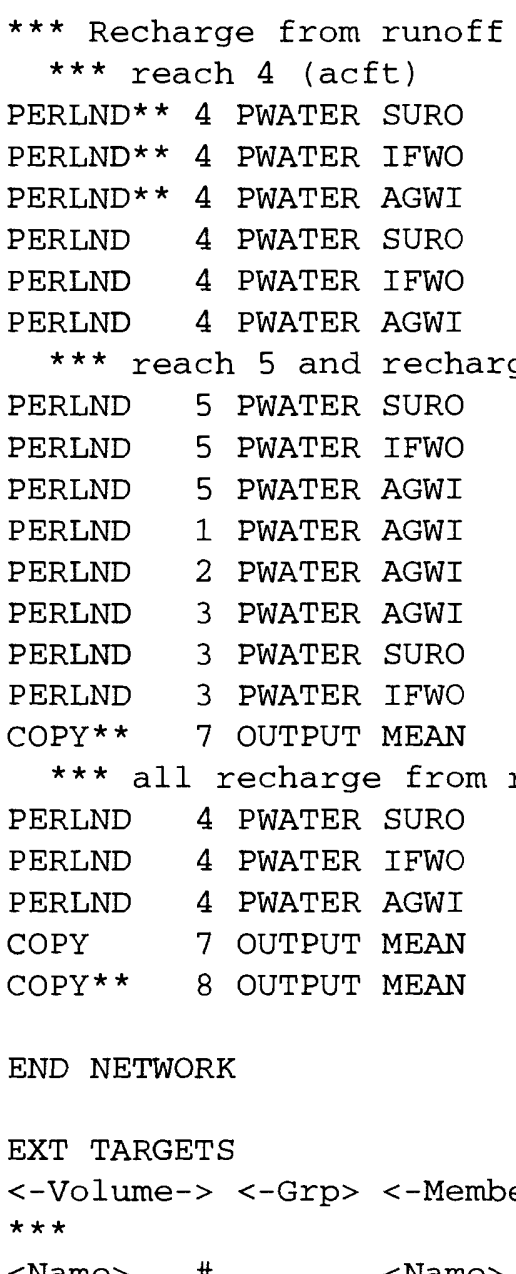

$<$ Name
strg*** $\quad$ <Name $\# \#<$-factor->strg $<$ Name $\quad \#<$ Name $>$ tem strg

$\star \star \star$ Ground-water reservoir water balance (ac-ft and inches).

$\star \star \star$ Inflow

SAME WDM 401 GWIA ENGL REPL

$\star \star \star$ Outflows

$\star \star \star$ Deep recharge

COPY 6 OUTPUT MEAN 2 SAME WDM 402 GWDA ENGL REPL $\star \star \star$ ET losses 


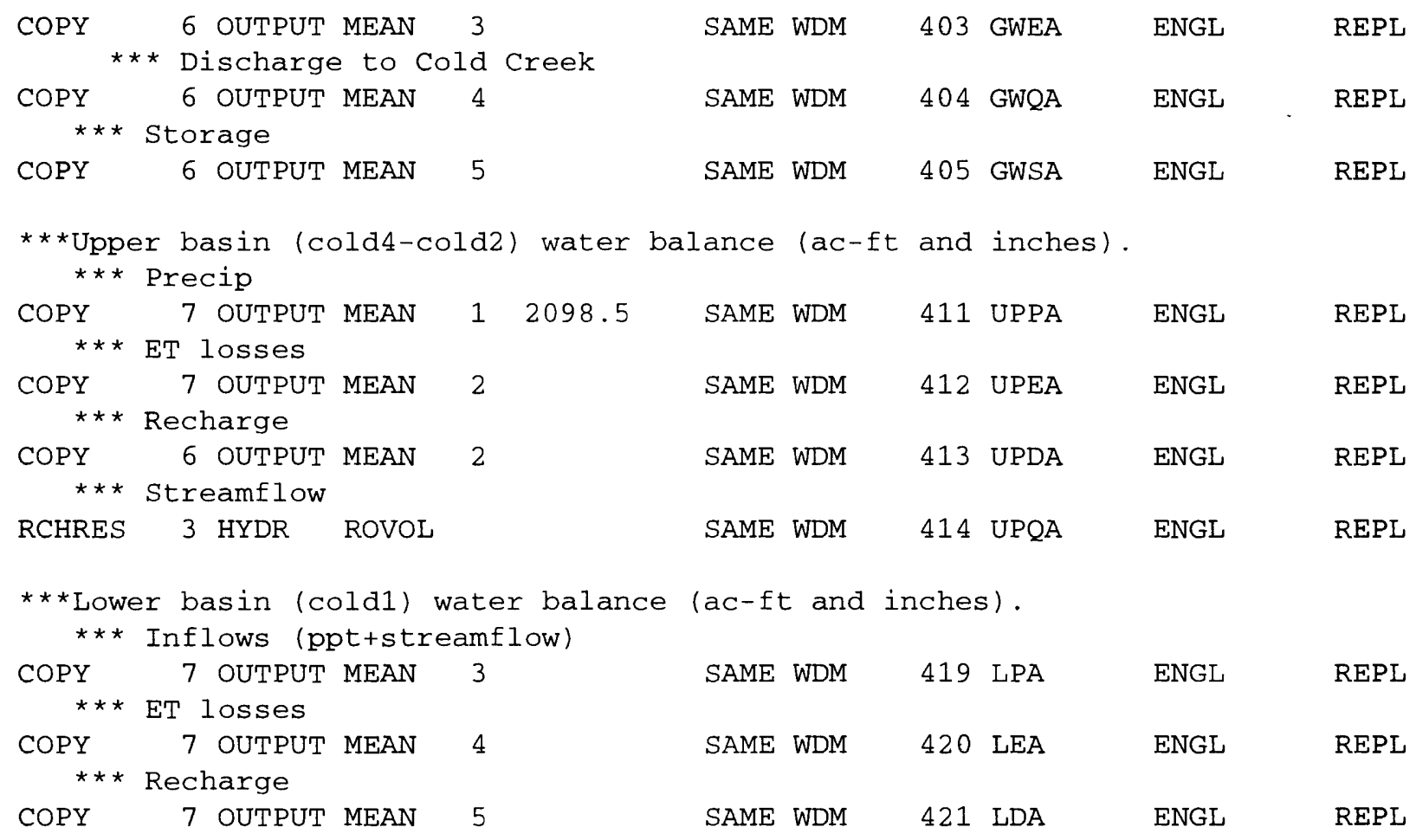

***Whole basin (cold4-cold1 and recharge zone) water balance (ac-ft and inches)

$\star \star *$ Precip

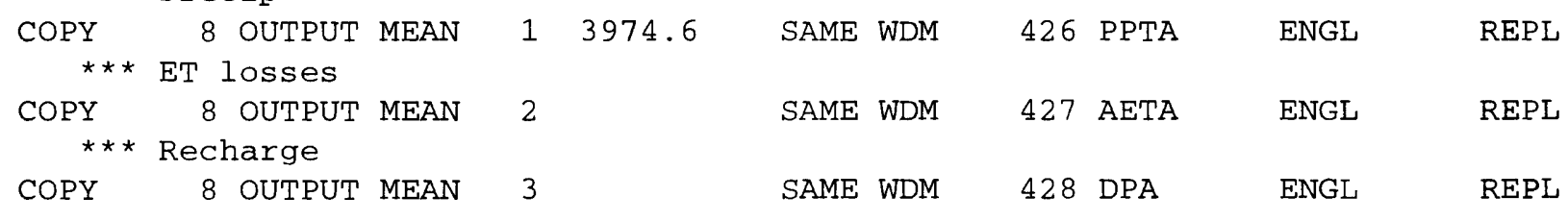

*** Simulated flow at gages (cfs and ac-ft)

\begin{tabular}{|c|c|c|c|c|c|c|c|c|c|c|}
\hline COPY & 8 & OUTPUT & MEAN & 4 & SAME & WDM & 432 & QWA & ENGL & REPL \\
\hline COPY & 8 & OUTPUT & MEAN & 5 & SAME & WDM & 434 & QWI & ENGL & REPI \\
\hline COPY & 8 & OUTPUT & MEAN & 6 & SAME & WDM & 433 & QFA & ENGL & $\mathrm{REF}$ \\
\hline COPY & 8 & OUTPUT & MEAN & 7 & SAME & WDM & 435 & QFI & ENGL & REF \\
\hline \multicolumn{11}{|c|}{$\star * *$ Recharge from runoff (ac-ft) } \\
\hline COPY & 7 & OUTPUT & MEAN & 8 & SAME & WDM & 610 & TL2 & ENGL & RE \\
\hline COPY & 7 & OUTPUT & MEAN & 6 & SAME & WDM & 611 & TL1 & ENGL & $\mathrm{RE}$ \\
\hline COPY & 8 & OUTPUT & MEAN & 8 & SAME & WDM & 612 & TL21 & ENGL & \\
\hline
\end{tabular}

END EXT TARGETS

RCHRES

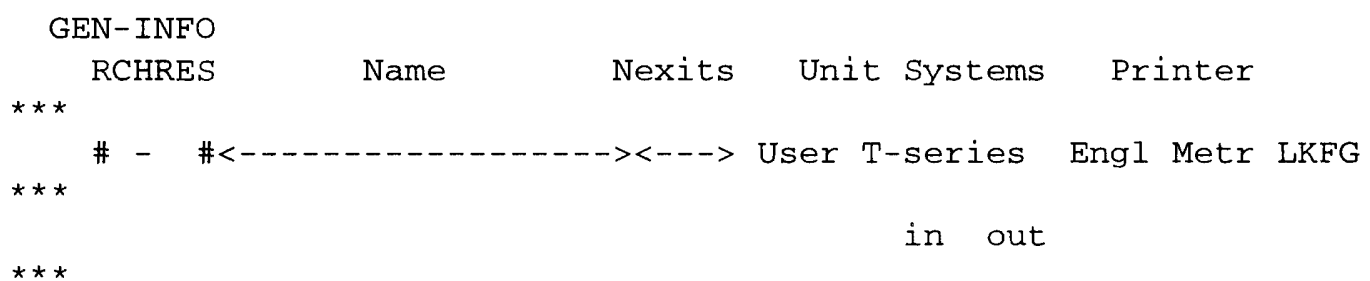

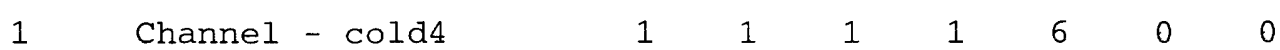




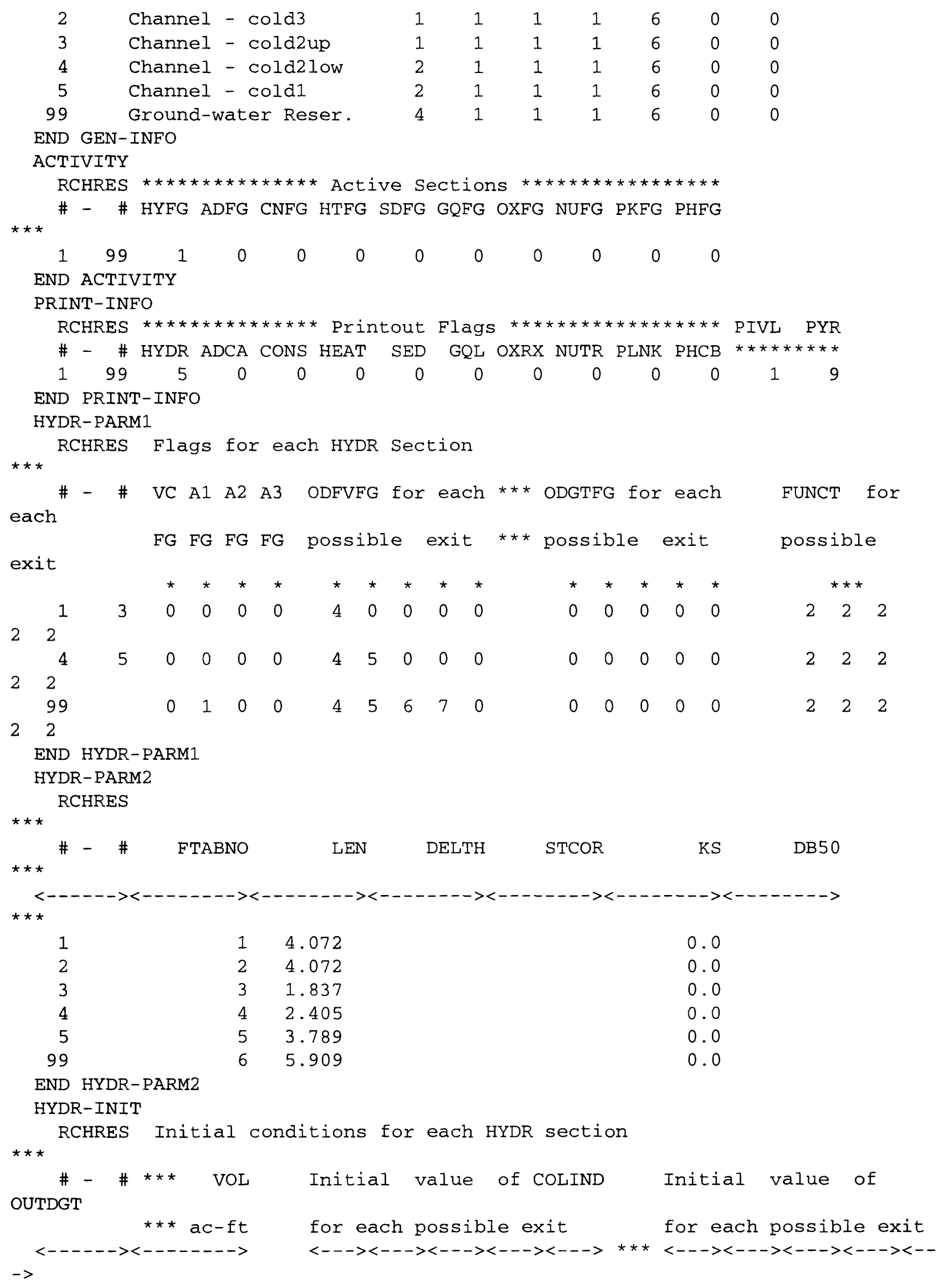




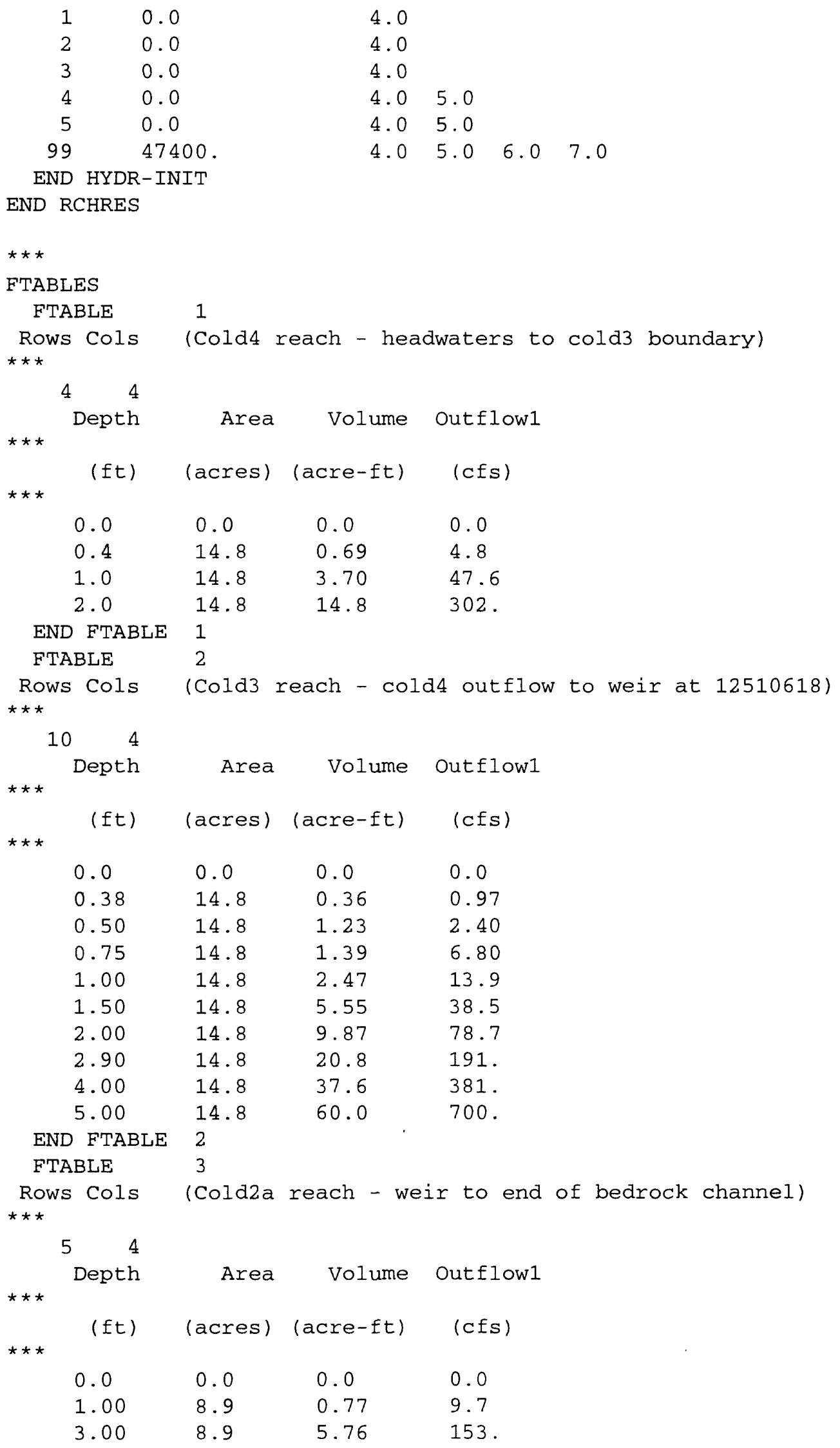




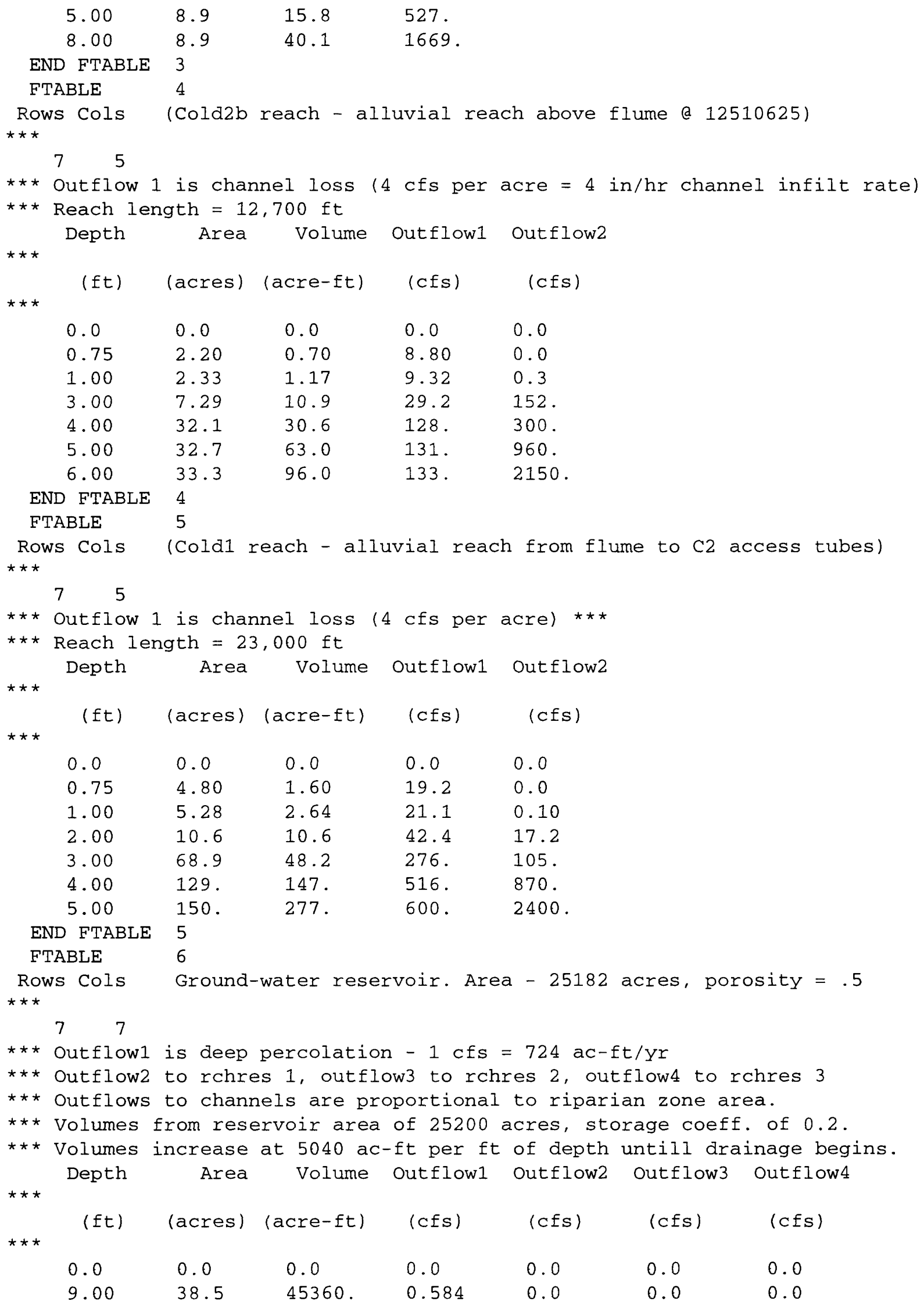




$\begin{array}{rllllll}9.42 & 38.5 & 47480 . & 2.920 & 0.0 & 0.0 & 0.0 \\ 9.65 & 38.5 & 48640 . & 5 . & 0.10 & 0.10 & 0.03 \\ 10.0 & 38.5 & 50400 . & 10 . & 0.20 & 0.20 & 0.06 \\ 11.0 & 38.5 & 55440 . & 40 . & 0.25 & 0.25 & 0.07 \\ 12.0 & 38.5 & 60440 . & 70 . & 0.40 & 0.40 & 0.13\end{array}$

END FTABLE 6

END FTABLES

\section{DISPLY}

DISPLY-INFO1

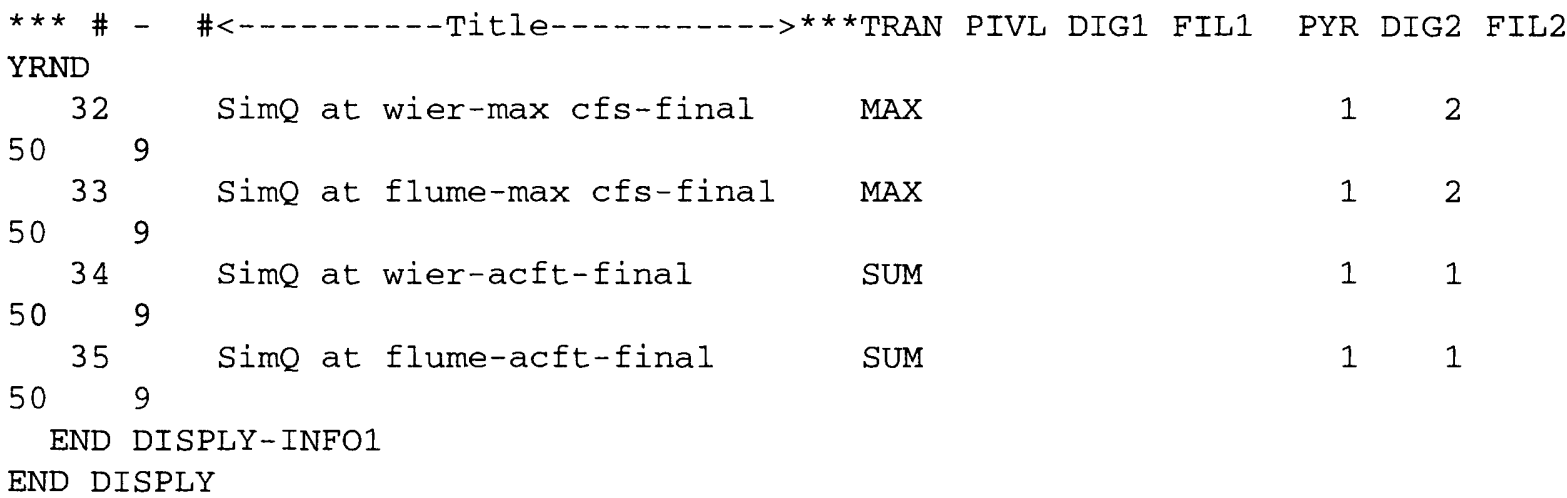

COPY

TIMESERIES

$\begin{array}{rrrr}\# & -\# & \text { NPT } & \text { NMN } \\ 1 & & 6 * * \\ 2 & 4 & 1 \\ 5 & & 7 \\ 6 & & 5 \\ 7 & & 8 \\ 8 & & 8\end{array}$

END TIMESERIES

END COPY

END RUN 
Appendix 4.--Final HSPF input file for Upper Dry Creek model. For brevity, the "SPECIAL ACTIONS" portion of the model input, where the dates of soil freezing and thawing are represented by changes in the INFILT parameter values, is not included. Complete input files may be obtained by contacting the District Chief at the address shown on page ii of this report

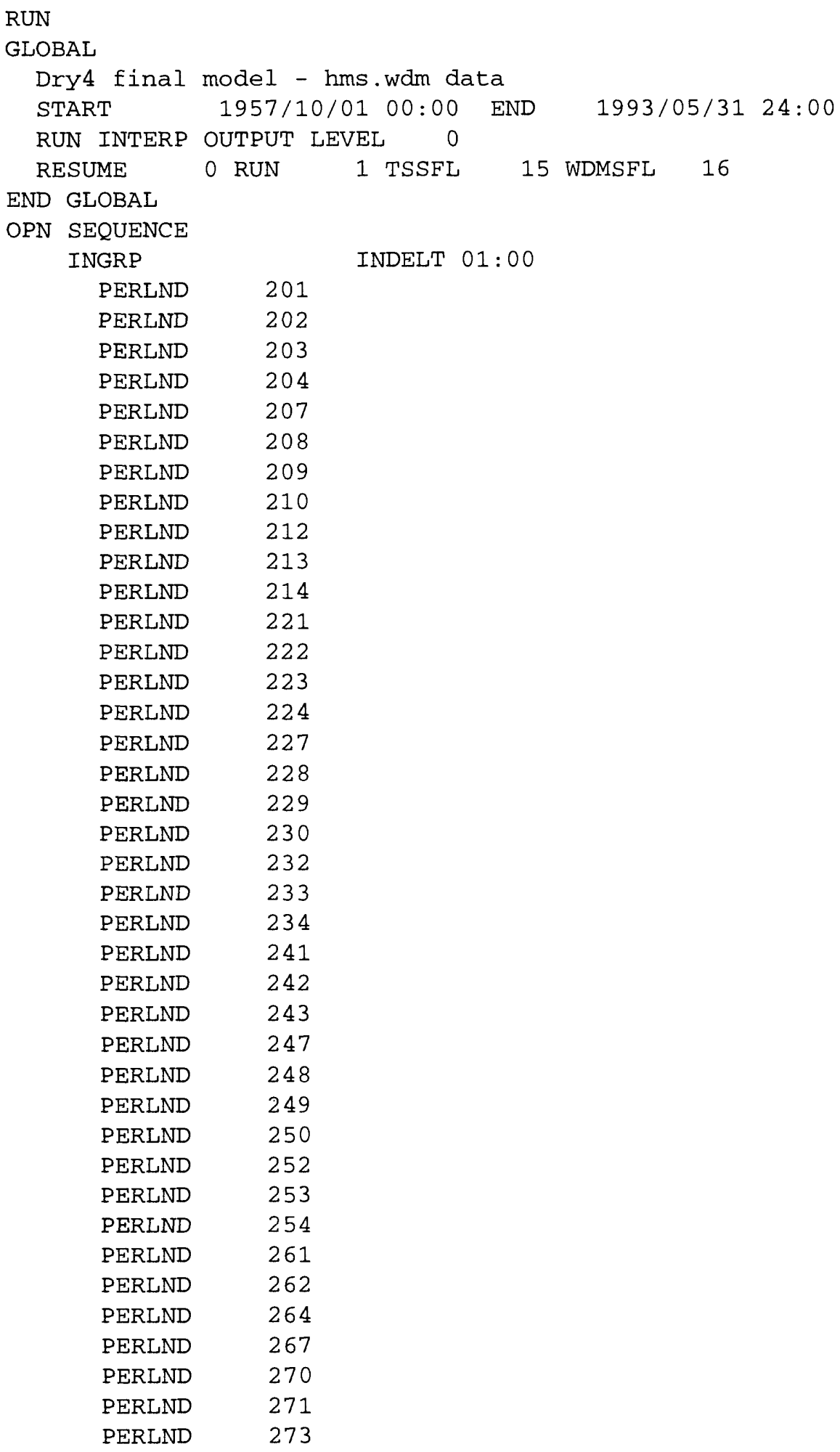




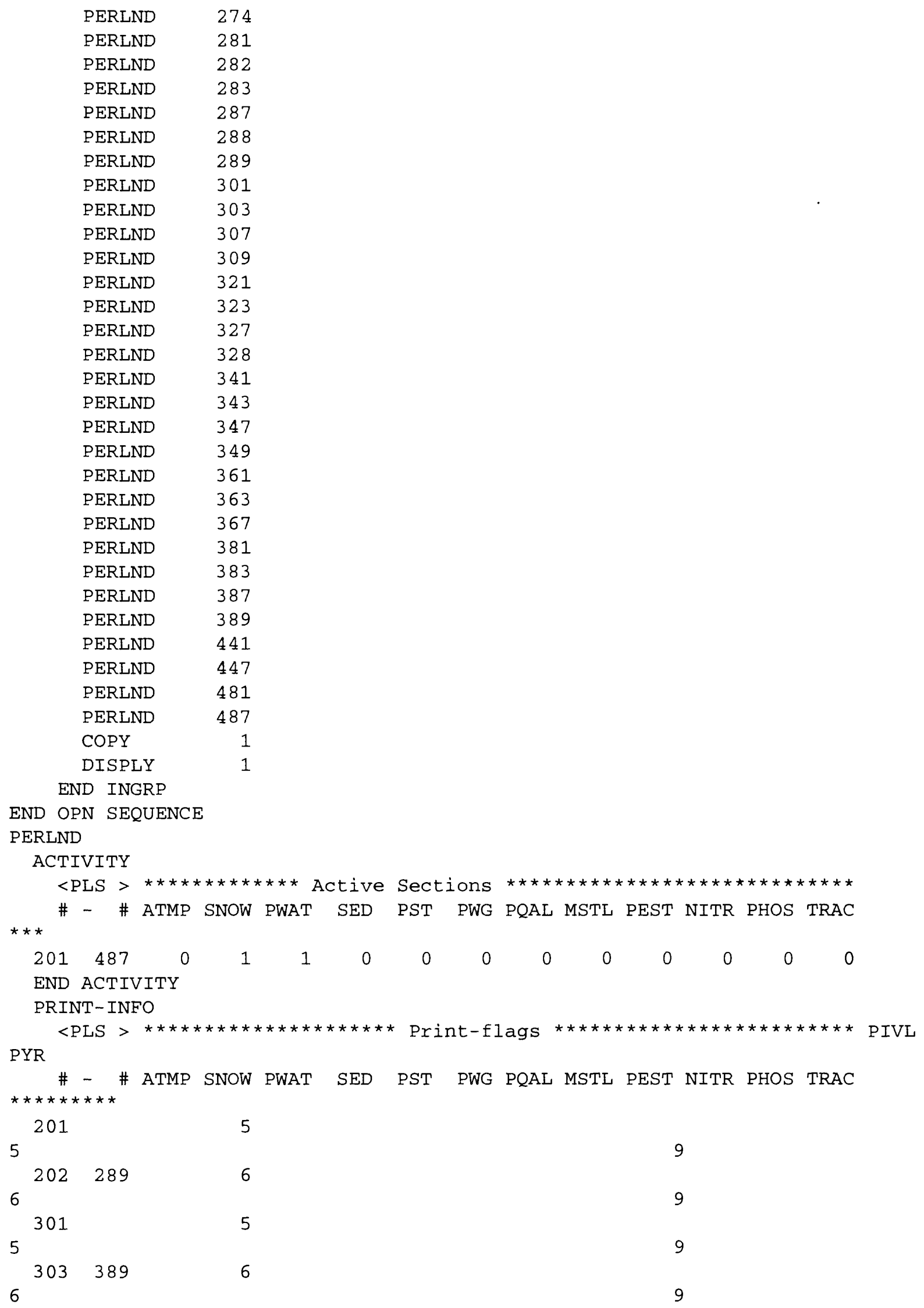


6

END PRINT-INFO

GEN-INFO

$<$ PLS ><---- NAME---.--> NBLKS

Unit-systems Printer

User t-series Engl Metr

in out

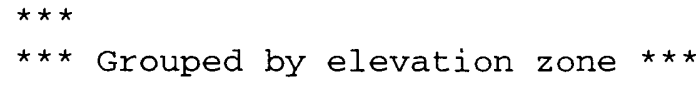

201

202

203

204

207

208

209

210

212

213

214

221

222

223

224

227

228

229

230

232

233

234

241

242

243

247

248

249

250

252

253

254

261

262

264

267

270

271

273

274

281 sage, soil2, flat

sage, soil3, flat

sage, soil4, flat

gras, soill, flat

gras, soil2, flat

gras, soil3, flat

gras, soil4, flat

dryw, soil2, mod. $N$

dryw, soil3, mod. $N$

dryw, soil4, mod. N

sage, soil1, mod. N

sage, soil2, mod. N

sage, soil $3, \bmod . \mathrm{N}$

sage, soil 4 , mod. $N$

gras, soil1, mod. N

gras, soil2, mod. N

gras, soil3, mod. N

gras, soil4, mod. N

dryw, soil2, mod. $N$

dryw, soil3, mod. $N$

dryw, soil4, mod.N

sage, soill, mod. S

sage, soil2, mod. $S$

sage, soil3, mod. S

gras, soill, mod.s

gras, soill, mod.s

gras, soil3, mod.s

gras, soil4, mod.s

dryw, soil2, mod.s

dryw, soil3, mod.s

dryw, soil4, mod.s

sage, soill, stp.N

sage, soil2, stp.N

sage, soil4, stp.N

gras, soil1, stp.N

gras, soil4, stp.N

dryw, soill, stp. N

dryw, soil3, stp. N

dryw, soil4, stp.N

sage, soill, stp.N

$\begin{array}{llllll}1 & 1 & 1 & 1 & 6 & 0 \\ 1 & 1 & 1 & 1 & 6 & 0 \\ 1 & 1 & 1 & 1 & 6 & 0 \\ 1 & 1 & 1 & 1 & 6 & 0 \\ 1 & 1 & 1 & 1 & 6 & 0 \\ 1 & 1 & 1 & 1 & 6 & 0 \\ 1 & 1 & 1 & 1 & 6 & 0 \\ 1 & 1 & 1 & 1 & 6 & 0 \\ 1 & 1 & 1 & 1 & 6 & 0 \\ 1 & 1 & 1 & 1 & 6 & 0 \\ 1 & 1 & 1 & 1 & 6 & 0 \\ 1 & 1 & 1 & 1 & 6 & 0 \\ 1 & 1 & 1 & 1 & 6 & 0 \\ 1 & 1 & 1 & 1 & 6 & 0 \\ 1 & 1 & 1 & 1 & 6 & 0 \\ 1 & 1 & 1 & 1 & 6 & 0 \\ 1 & 1 & 1 & 1 & 6 & 0 \\ 1 & 1 & 1 & 1 & 6 & 0 \\ 1 & 1 & 1 & 1 & 6 & 0 \\ 1 & 1 & 1 & 1 & 6 & 0 \\ 1 & 1 & 1 & 1 & 6 & 0 \\ 1 & 1 & 1 & 1 & 6 & 0 \\ 1 & 1 & 1 & 1 & 6 & 0 \\ 1 & 1 & 1 & 1 & 6 & 0 \\ 1 & 1 & 1 & 1 & 6 & 0 \\ 1 & 1 & 1 & 1 & 6 & 0 \\ 1 & 1 & 1 & 1 & 6 & 0 \\ 1 & 1 & 1 & 1 & 6 & 0 \\ 1 & 1 & 1 & 1 & 6 & 0 \\ 1 & 1 & 1 & 1 & 6 & 0 \\ 1 & 1 & 1 & 1 & 6 & 0 \\ 1 & 1 & 1 & 1 & 6 & 0 \\ 1 & 1 & 1 & 1 & 6 & 0 \\ 1 & 1 & 1 & 1 & 6 & 0 \\ 1 & 1 & 1 & 1 & 6 & 0 \\ 1 & 1 & 1 & 1 & 6 & 0 \\ 1 & 1 & 1 & 1 & 6 & 0 \\ 1 & 1 & 1 & 1 & 6 & 0 \\ 1 & 1 & 1 & 1 & 6 & 0 \\ 1 & 1 & 1 & 1 & 6 & 0 \\ 1 & 1 & 1 & 1 & 6 & 0\end{array}$




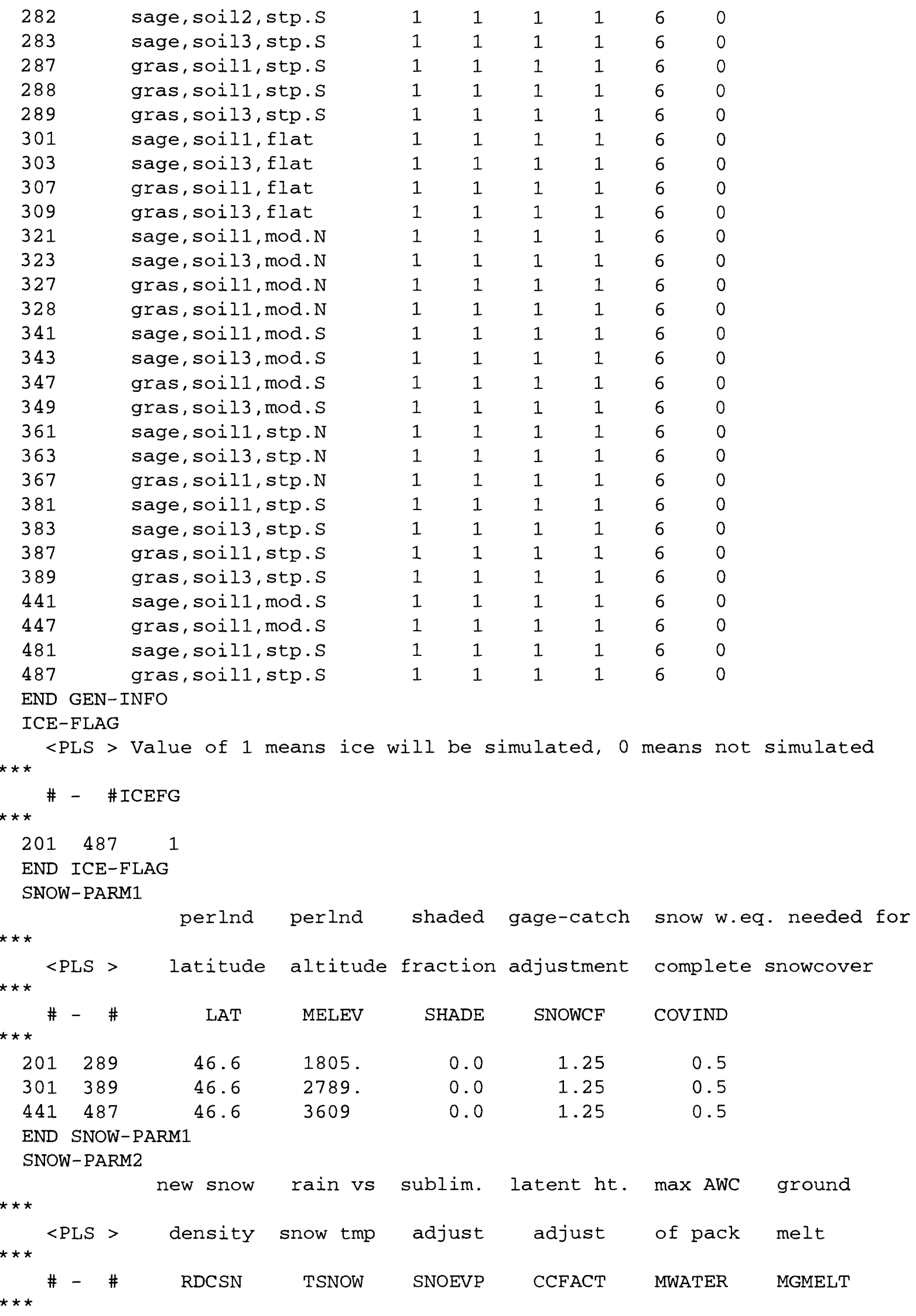



$201 \quad 487$
0.05
32 .
0.85
1.5
0.08
0.02
END SNOW-PARM2

SNOW-INIT1

$<$ PLS > SNOW initial conditions

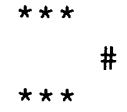

\# - \# PACKSNOW PACKICE PACKWATER RDENPF DULL PAKTMP

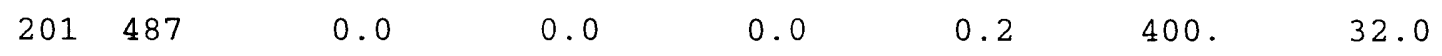

END SNOW-INIT1

SNOW-INIT2

$<$ PLS > SNOW initial conditions

$\#$ - \# COVINX XLNMELT SKYCLR

$\begin{array}{lllll}201 & 487 & 0.50 & 0.0 & 1.0\end{array}$

END SNOW-INIT2

PWAT-PARM1

$<$ PLS > PWATER variable monthly parameter value flags

Snow cepsc uzns nsur intfw irc lzetp

\# - \# CSNO RTOP UZFG VCS VUZ VNN VIFW VIRC VLE

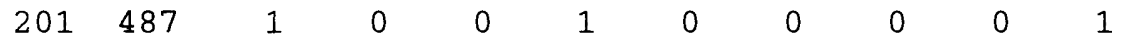

END PWAT-PARM1

PWAT-PARM2

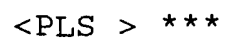

$\#$ - \# $* * *$ FOREST LZSN INFILT LSUR SLSUR KVARY

AGWRC

** sagebrush *

201

0.9900

221

0.9900

241

0.9900

261

0.9900

281

0.9900

301

0.9900

321

0.9900

341

0.9900

361

0.9900

381

0.9900

441

0.9900

481

0.9900
0

0 .

2.3000

0.2000

1000.0

0.0350

0.0000

2.3000

0.2000

2000.0

0.1100

0.0000

0 .

2.3000

0.2000

10000.0

0.1100

0.0000

0 .

2.3000

0.2000

2000.0

0.2300

0.0000

0 .

2.3000

0.2000

10000.0

0.2300

0.0000

0.

2.3000

0.2000

1000.0

0.0350

0.0000

0 .

2.3000

0.2000

2000.0

0.1100

0.0000

0 .

2.3000

0.2000

10000.0

0.1100

0.0000

0 .

2.3000

0.2000

2000.0

0.2300

0.0000

0 .

2.3000

$0.2000 \quad 10000.0$

0.2300

0.0000

0 .

2.3000

0.2000

25000.0

0.1100

0.0000

0 .

2.3000

0.2000

25000.0

0.2300

0.0000 


\begin{tabular}{|c|c|c|c|c|c|c|}
\hline $\begin{array}{r}202 \\
0.9900\end{array}$ & 0 . & 4.1000 & 0.2000 & 1000.0 & 0.0350 & 0.0000 \\
\hline 222 & 0 . & 4.1000 & 0.2000 & 2000.0 & 0.1100 & 0.0000 \\
\hline \multicolumn{7}{|l|}{0.9900} \\
\hline 242 & 0 . & 4.1000 & 0.2000 & 10000.0 & 0.1100 & 0.0000 \\
\hline \multicolumn{7}{|l|}{0.9900} \\
\hline 262 & 0 . & 4.1000 & 0.2000 & 2000.0 & 0.2300 & 0.0000 \\
\hline \multicolumn{7}{|l|}{0.9900} \\
\hline 282 & 0 . & 4.1000 & 0.2000 & 10000.0 & 0.2300 & 0.0000 \\
\hline \multicolumn{7}{|l|}{0.9900} \\
\hline 203 & 0 . & 6.2000 & 0.2000 & 1000.0 & 0.0350 & 0.0000 \\
\hline \multicolumn{7}{|l|}{0.9900} \\
\hline 223 & 0 . & 6.2000 & 0.2000 & 2000.0 & 0.1100 & 0.0000 \\
\hline \multicolumn{7}{|l|}{0.9900} \\
\hline 243 & 0 . & 6.2000 & 0.2000 & 10000.0 & 0.1100 & 0.0000 \\
\hline \multicolumn{7}{|l|}{0.9900} \\
\hline 283 & 0 . & 6.2000 & 0.2000 & 10000.0 & 0.2300 & 0.0000 \\
\hline \multicolumn{7}{|l|}{0.9900} \\
\hline 303 & 0 . & 6.2000 & 0.2000 & 1000.0 & 0.0350 & 0.0000 \\
\hline \multicolumn{7}{|l|}{0.9900} \\
\hline 323 & 0 . & 6.2000 & 0.2000 & 2000.0 & 0.1100 & 0.0000 \\
\hline \multicolumn{7}{|l|}{0.9900} \\
\hline 343 & 0 . & 6.2000 & 0.2000 & 10000.0 & 0.1100 & 0.0000 \\
\hline \multicolumn{7}{|l|}{0.9900} \\
\hline 363 & 0 . & 6.2000 & 0.2000 & 2000.0 & 0.2300 & 0.0000 \\
\hline \multicolumn{7}{|l|}{0.9900} \\
\hline 383 & 0 . & 6.2000 & 0.2000 & 10000.0 & 0.2300 & 0.0000 \\
\hline \multicolumn{7}{|l|}{0.9900} \\
\hline 204 & 0 . & 9.2000 & 0.2000 & 1000.0 & 0.0350 & 0.0000 \\
\hline \multicolumn{7}{|l|}{0.9900} \\
\hline 224 & 0 . & 9.2000 & 0.2000 & 2000.0 & 0.1100 & 0.0000 \\
\hline \multicolumn{7}{|l|}{0.9900} \\
\hline 264 & 0 . & 9.2000 & 0.2000 & 2000.0 & 0.2300 & 0.0000 \\
\hline \multicolumn{7}{|l|}{0.9900} \\
\hline \multicolumn{7}{|c|}{ 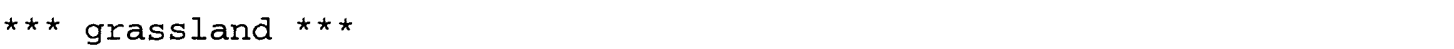 } \\
\hline 207 & 0 & 2.3000 & 0.2000 & 1000.0 & 0.0350 & 0.0000 \\
\hline \multicolumn{7}{|l|}{0.9900} \\
\hline 227 & 0 . & 2.3000 & 0.2000 & 2000.0 & 0.1100 & 0.0000 \\
\hline \multicolumn{7}{|l|}{0.9900} \\
\hline 247 & 0 . & 2.3000 & 0.2000 & 10000.0 & 0.1100 & 0.0000 \\
\hline 0.9900 & & & & & & \\
\hline 267 & 0 . & 2.3000 & 0.2000 & 2000.0 & 0.2300 & 0.0000 \\
\hline 0.9900 & & & & & & \\
\hline 287 & 0 . & 2.3000 & 0.2000 & 10000.0 & 0.2300 & 0.0000 \\
\hline 0.9900 & & & & & & \\
\hline 307 & 0 . & 2.3000 & 0.2000 & 1000.0 & 0.0350 & 0.0000 \\
\hline 0.9900 & & & & & & \\
\hline 327 & 0 . & 2.3000 & 0.2000 & 2000.0 & 0.1100 & 0.0000 \\
\hline 0.9900 & & & & & & \\
\hline 347 & 0 . & 2.3000 & 0.2000 & 10000.0 & 0.1100 & 0.0000 \\
\hline 0.9900 & & & & & & \\
\hline 367 & 0 . & 2.3000 & 0.2000 & 2000.0 & 0.2300 & 0.0000 \\
\hline 0.9900 & & & & & & \\
\hline 387 & 0. & 2.3000 & 0.2000 & 2000.0 & 0.2300 & 0.0000 \\
\hline
\end{tabular}


0.9900

447

0.9900

487

0.9900

208

0.9900

228

0.9900

248

0.9900

288

0.9900

328

0.9900

209

0.9900

229

0.9900

249

0.9900

289

0.9900

309

0.9900

349

0.9900

389

0.9900

210

0.9900

230

0.9900

250

0.9900

270

0.9900

*** dry. wheat

271

0.9900

212

0.9900

232

0.9900

252

0.9900

213

0.9900

233

0.9900

253

0.9900

273

0.9900
0.

2.3000

0.2000

25000.0

0.1100

0.0000

0.

2.3000

0.2000

25000.0

0.2300

0.0000

0 .

4.1000

0.2000

1000.0

0.0350

0.0000

0 .

4.1000

0.2000

2000.0

0.1100

0.0000

0.

4.1000

0.2000

10000.0

0.1100

0.0000

0.

4.1000

0.2000

10000.0

0.2300

0.0000

0.

4.1000

0.2000

2000.0

0.1100

0.0000

0.

2.9000

$0.2000 \quad 1000.0$

0.0350

0.0000

0 .

2.9000

0.2000

2000.0

0.1100

0.0000

0 .

2.9000

0.2000

10000.0

0.1100

0.0000

0 .

2.9000

$0.2000 \quad 10000.0$

0.2300

0.0000

0.

2.9000

0.2000

1000.0

0.0350

0.0000

0.

2.9000

$0.2000 \quad 10000.0$

0.1100

0.0000

0 .

2.9000

$0.2000 \quad 10000.0$

0.2300

0.0000

0.

4.6000

$0.2000 \quad 1000.0$

0.0350

0.0000

0 .

4.6000

$0.2000 \quad 2000.0$

0.1100

0.0000

0 .

4.6000

$0.2000 \quad 10000.0$

0.1100

0.0000

0.

4.6000

$0.2000 \quad 2000.0$

0.2300

0.0000

0 .

2.3000

0.2000

2000.0

0.2300

0.0000

4.1000

0.2000

1000.0

0.0350

0.0000

4.1000

0.2000

2000.0

0.1100

0.0000

0 .

4.1000

$0.2000 \quad 10000.0$

0.1100

0.0000

0 .

5.8000

$0.2000 \quad 1000.0$

0.0350

0.0000

0 .

5.8000

0.2000

2000.0

0.1100

0.0000

0 .

5.8000

$0.2000 \quad 10000.0$

0.1100

0.0000

0 .

5.8000

$0.2000 \quad 2000.0$

0.2300

0.0000 


\begin{tabular}{|c|c|c|c|c|c|c|}
\hline \multirow{2}{*}{\multicolumn{7}{|c|}{$\begin{array}{c}214 \\
0.9900\end{array}$}} \\
\hline & & & & & & \\
\hline 234 & 0 . & 9.2000 & 0.2000 & 2000.0 & 0.1100 & 0.0000 \\
\hline \multicolumn{7}{|l|}{0.9900} \\
\hline 254 & 0 . & 9.2000 & 0.2000 & 10000.0 & 0.1100 & 0.0000 \\
\hline \multicolumn{7}{|l|}{0.9900} \\
\hline 274 & 0 . & 9.2000 & 0.2000 & 2000.0 & 0.2300 & 0.0000 \\
\hline \multicolumn{7}{|l|}{0.9900} \\
\hline \multicolumn{7}{|c|}{ END PWAT-PARM2 } \\
\hline \multicolumn{7}{|c|}{ PWAT-PARM3 } \\
\hline \multicolumn{7}{|l|}{$<\operatorname{PLS}>\star \star \star$} \\
\hline 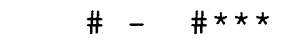 & PETMAX & PETMIN & INFEXP & INFILD & DEEPFR & BASETP \\
\hline \multicolumn{7}{|c|}{ AGWETP } \\
\hline 201487 & 40 & 35. & 0.2500 & 2.0000 & .00 & \\
\hline \multicolumn{7}{|c|}{$0 . \quad 0$} \\
\hline \multicolumn{7}{|c|}{ END PWAT-PARM3 } \\
\hline \\
\hline$<$ PLS $>$ & & & & & & 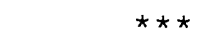 \\
\hline$\#-\#$ & CEPSC & UZSN & NSUR & INTFW & IRC & LZETP $* \star *$ \\
\hline \multicolumn{7}{|c|}{$\star \star \star$ sagebrush $\star \star \star$} \\
\hline 201 & & 0.5000 & 0.3000 & 0.000 & 0.7000 & \\
\hline 301 & & 0.5000 & 0.3000 & 0.000 & 0.7000 & \\
\hline 202 & & 0.5000 & 0.3000 & 0.000 & 0.7000 & \\
\hline 203 & & 0.5000 & 0.3000 & 0.000 & 0.7000 & \\
\hline 303 & & 0.5000 & 0.3000 & 0.000 & 0.7000 & \\
\hline 204 & & 0.5000 & 0.3000 & 0.000 & 0.7000 & \\
\hline 221 & & 0.3000 & 0.3000 & 0.000 & 0.5000 & \\
\hline 241 & & 0.3000 & 0.3000 & 0.000 & 0.5000 & \\
\hline 321 & & 0.3000 & 0.3000 & 0.000 & 0.5000 & \\
\hline 341 & & 0.3000 & 0.3000 & 0.000 & 0.5000 & \\
\hline 441 & & 0.3000 & 0.3000 & 0.000 & 0.5000 & \\
\hline 222 & & 0.3000 & 0.3000 & 0.000 & 0.5000 & \\
\hline 242 & & 0.3000 & 0.3000 & 0.000 & 0.5000 & \\
\hline 223 & & 0.3000 & 0.3000 & 0.000 & 0.5000 & \\
\hline 243 & & 0.3000 & 0.3000 & 0.000 & 0.5000 & \\
\hline 323 & & 0.3000 & 0.3000 & 0.000 & 0.5000 & \\
\hline 343 & & 0.3000 & 0.3000 & 0.000 & 0.5000 & \\
\hline 224 & & 0.3000 & 0.3000 & 0.000 & 0.5000 & \\
\hline 261 & & 0.2000 & 0.3000 & 0.000 & 0.3000 & \\
\hline 281 & & 0.2000 & 0.3000 & 0.000 & 0.3000 & \\
\hline 361 & & 0.2000 & 0.3000 & 0.000 & 0.3000 & \\
\hline 381 & & 0.2000 & 0.3000 & 0.000 & 0.3000 & \\
\hline 481 & & 0.2000 & 0.3000 & 0.000 & 0.3000 & \\
\hline 262 & & 0.2000 & 0.3000 & 0.000 & 0.3000 & \\
\hline 282 & & 0.2000 & 0.3000 & 0.000 & 0.3000 & \\
\hline 283 & & 0.2000 & 0.3000 & 0.000 & 0.3000 & \\
\hline 363 & & 0.2000 & 0.3000 & 0.000 & 0.3000 & \\
\hline 383 & & 0.2000 & 0.3000 & 0.000 & 0.3000 & \\
\hline 264 & & 0.2000 & 0.3000 & 0.000 & 0.3000 & \\
\hline ** grassland & $\star \star \star$ & & & & & \\
\hline 207 & & 0.5000 & 0.3000 & 0.000 & 0.7000 & \\
\hline 307 & & 0.5000 & 0.3000 & 0.000 & 0.7000 & \\
\hline 208 & & 0.5000 & 0.3000 & 0.000 & 0.7000 & \\
\hline 209 & & 0.5000 & 0.3000 & 0.000 & 0.7000 & \\
\hline
\end{tabular}




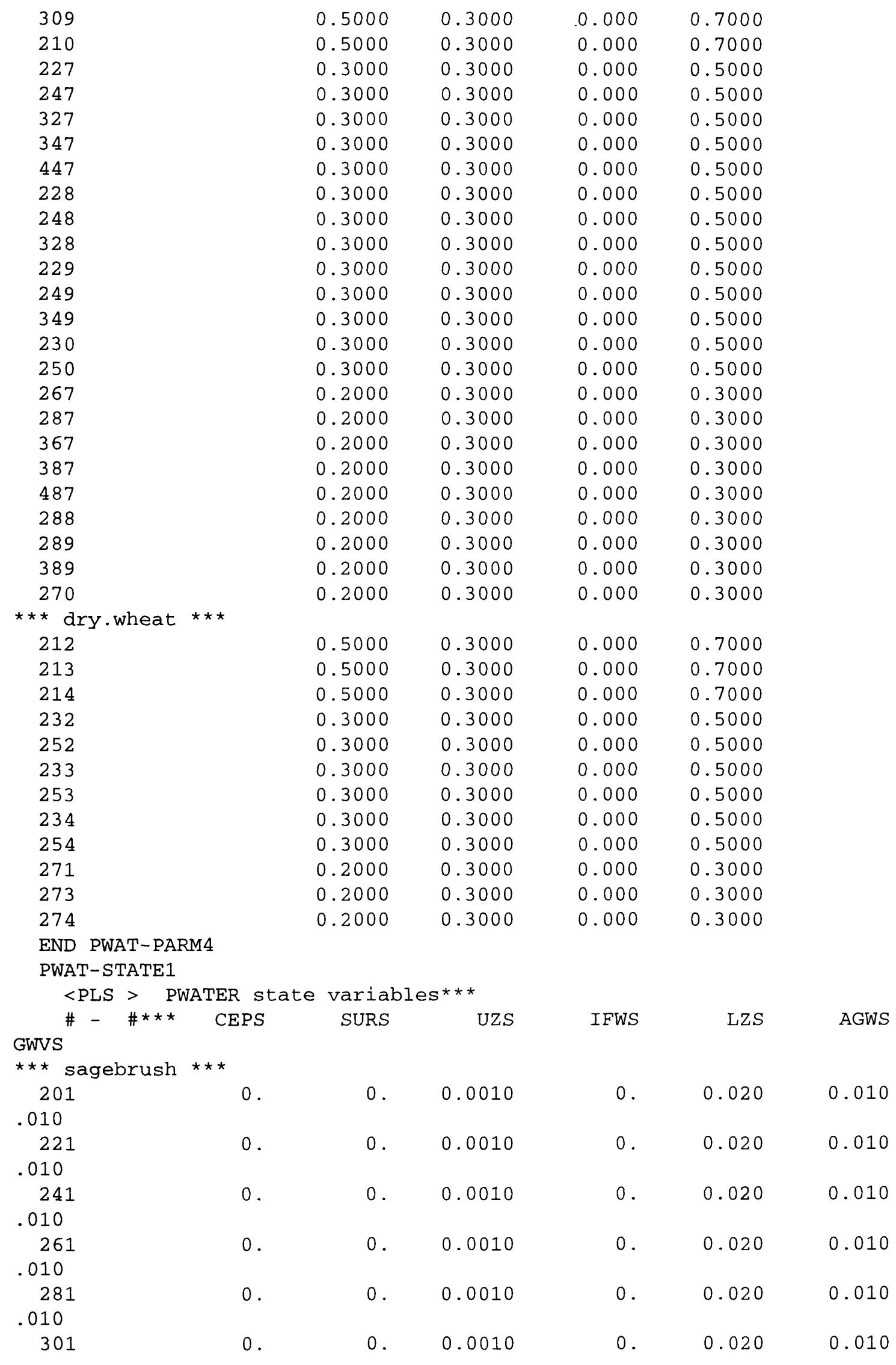




\begin{tabular}{|c|c|c|c|c|c|c|}
\hline .010 & & & & & & \\
\hline 321 & 0. & 0 . & 0.0010 & 0. & 0.020 & 0.010 \\
\hline .010 & & & & & & \\
\hline 341 & 0 . & 0 . & 0.0010 & 0 . & 0.020 & 0.010 \\
\hline .010 & & & & & & \\
\hline 361 & 0 . & 0. & 0.0010 & 0 . & 0.020 & 0.010 \\
\hline .010 & & & & & & \\
\hline 381 & 0 . & 0 . & 0.0010 & 0 . & 0.020 & 0.010 \\
\hline .010 & & & & & & \\
\hline 441 & 0. & 0 & 0.0010 & 0. & 0.020 & 0.010 \\
\hline .010 & & & & & & \\
\hline 481 & 0 . & 0 & 0.0010 & 0. & 0.020 & 0.010 \\
\hline .010 & & & & & & \\
\hline 202 & 0 . & 0 & 0.0010 & 0. & 0.020 & 0.010 \\
\hline .010 & & & & & & \\
\hline 222 & 0 . & 0 . & 0.0010 & 0 . & 0.020 & 0.010 \\
\hline .010 & & & & & & \\
\hline 242 & 0 . & 0 . & 0.0010 & 0. & 0.020 & 0.010 \\
\hline .010 & & & & & & \\
\hline 262 & 0. & 0 . & 0.0010 & 0 . & 0.020 & 0.010 \\
\hline .010 & & & & & & \\
\hline 282 & 0. & 0. & 0.0010 & 0. & 0.020 & 0.010 \\
\hline .010 & & & & & & \\
\hline 203 & 0 . & 0. & 0.0010 & 0. & 0.020 & 0.010 \\
\hline .010 & & & & & & \\
\hline 223 & 0 & 0. & 0.0010 & 0 & 0.020 & 0.010 \\
\hline .010 & & & & & & \\
\hline 243 & 0. & 0. & 0.0010 & 0 . & 0.020 & 0.010 \\
\hline .010 & & & & & & \\
\hline 283 & 0 . & 0 . & 0.0010 & 0 & 0.020 & 0.010 \\
\hline .010 & & & & & & \\
\hline 303 & 0. & 0 . & 0.0010 & 0. & 0.020 & 0.010 \\
\hline .010 & & & & & & \\
\hline 323 & 0 . & 0. & 0.0010 & 0. & 0.020 & 0.010 \\
\hline .010 & & & & & & \\
\hline 343 & 0. & 0. & 0.0010 & 0. & 0.020 & 0.010 \\
\hline .010 & & & & & & \\
\hline 363 & 0 . & 0. & 0.0010 & 0. & 0.020 & 0.010 \\
\hline .010 & & & & & & \\
\hline 383 & 0. & 0. & 0.0010 & 0. & 0.020 & 0.010 \\
\hline .010 & & & & & & \\
\hline 204 & 0 & 0. & 0.0010 & 0. & 0.020 & 0.010 \\
\hline .010 & & & & & & \\
\hline 224 & 0. & 0. & 0.0010 & 0. & 0.020 & 0.010 \\
\hline .010 & & & & & & \\
\hline 264 & 0. & 0. & 0.0010 & 0. & 0.020 & 0.010 \\
\hline .010 & & & & & & \\
\hline ***gra & & & & & & \\
\hline 207 & 0 & 0. & 0.0010 & 0. & 0.020 & 0.010 \\
\hline .010 & & & & & & \\
\hline 227 & 0 . & 0 . & 0.0010 & 0 & 0.020 & 0.010 \\
\hline .010 & & & & & & \\
\hline 247 & 0. & 0 . & 0.0010 & 0 . & 0.020 & 0.010 \\
\hline .010 & & & & & & \\
\hline
\end{tabular}




\begin{tabular}{|c|c|c|c|c|c|c|}
\hline \multirow{2}{*}{\multicolumn{7}{|c|}{$\begin{array}{r}267 \\
.010\end{array}$}} \\
\hline & & & & & & \\
\hline 287 & 0 & 0 . & 0.0010 & 0 & 0.020 & 0.010 \\
\hline \multicolumn{7}{|l|}{.010} \\
\hline 307 & 0 . & 0 . & 0.0010 & 0 & 0.020 & 0.010 \\
\hline \multicolumn{7}{|l|}{.010} \\
\hline 327 & 0. & 0 & 0.0010 & 0 & 0.020 & 0.010 \\
\hline \multicolumn{7}{|l|}{.010} \\
\hline 347 & 0. & 0. & 0.0010 & 0 . & 0.020 & 0.010 \\
\hline \multicolumn{7}{|l|}{.010} \\
\hline 367 & 0. & 0 & 0.0010 & 0 & 0.020 & 0.010 \\
\hline \multicolumn{7}{|l|}{.010} \\
\hline 387 & 0. & 0 & 0.0010 & 0. & 0.020 & 0.010 \\
\hline \multicolumn{7}{|l|}{.010} \\
\hline 447 & 0 . & 0. & 0.0010 & 0 . & 0.020 & 0.010 \\
\hline \multicolumn{7}{|l|}{.010} \\
\hline 487 & 0 . & 0 . & 0.0010 & 0 . & 0.020 & 0.010 \\
\hline \multicolumn{7}{|l|}{.010} \\
\hline 208 & 0 & 0 & 0.0010 & 0 . & 0.020 & 0.010 \\
\hline \multicolumn{7}{|l|}{.010} \\
\hline 228 & 0 . & 0 & 0.0010 & 0 & 0.020 & 0.010 \\
\hline \multicolumn{7}{|l|}{.010} \\
\hline 248 & 0 & 0 & 0.0010 & 0 . & 0.020 & 0.010 \\
\hline \multicolumn{7}{|l|}{.010} \\
\hline 288 & 0. & 0 & 0.0010 & 0 & 0.020 & 0.010 \\
\hline \multicolumn{7}{|l|}{.010} \\
\hline 328 & 0 & 0 & 0.0010 & 0 . & 0.020 & 0.010 \\
\hline \multicolumn{7}{|l|}{.010} \\
\hline 209 & 0 . & 0 & 0.0010 & 0 & 0.020 & 0.010 \\
\hline \multicolumn{7}{|l|}{.010} \\
\hline 229 & 0 . & 0. & 0.0010 & 0 & 0.020 & 0.010 \\
\hline \multicolumn{7}{|l|}{.010} \\
\hline 249 & 0 . & 0 . & 0.0010 & 0. & 0.020 & 0.010 \\
\hline \multicolumn{7}{|l|}{.010} \\
\hline 289 & 0 . & 0 . & 0.0010 & 0 . & 0.020 & 0.010 \\
\hline \multicolumn{7}{|l|}{.010} \\
\hline 309 & 0 . & 0 . & 0.0010 & 0 . & 0.020 & 0.010 \\
\hline \multicolumn{7}{|l|}{.010} \\
\hline 349 & 0 . & 0 . & 0.0010 & 0 . & 0.020 & 0.010 \\
\hline .010 & & & & & & \\
\hline 389 & 0 . & 0 . & 0.0010 & 0 . & 0.020 & 0.010 \\
\hline .010 & & & & & & \\
\hline 210 & 0 . & 0 . & 0.0010 & 0 . & 0.020 & 0.010 \\
\hline .010 & & & & & & \\
\hline 230 & 0 . & 0 . & 0.0010 & 0. & 0.020 & 0.010 \\
\hline .010 & & & & & & \\
\hline 250 & 0 . & 0 & 0.0010 & 0 . & 0.020 & 0.010 \\
\hline .010 & & & & & & \\
\hline 270 & 0 & 0 . & 0.0010 & 0 . & 0.020 & 0.010 \\
\hline .010 & & & & & & \\
\hline$* * * d r y$ & ** & & & & & \\
\hline 271 & 0 . & 0 . & 0.0010 & 0 . & 0.020 & 0.010 \\
\hline .010 & & & & & & \\
\hline 212 & 0 . & 0 . & 0.0010 & 0 . & 0.020 & 0.010 \\
\hline
\end{tabular}




\begin{tabular}{|c|c|c|c|c|c|c|}
\hline .010 & & & & & & \\
\hline 232 & 0 . & 0 . & 0.0010 & 0 . & 0.020 & 0.010 \\
\hline .010 & & & & & & \\
\hline 252 & 0 . & 0 . & 0.0010 & 0 . & 0.020 & 0.010 \\
\hline .010 & & & & & & \\
\hline 213 & 0 . & 0 . & 0.0010 & 0. & 0.020 & 0.010 \\
\hline .010 & & & & & & \\
\hline 233 & 0 . & 0 . & 0.0010 & 0 . & 0.020 & 0.010 \\
\hline .010 & & & & & & \\
\hline 253 & 0 . & 0 . & 0.0010 & 0 . & 0.020 & 0.010 \\
\hline .010 & & & & & & \\
\hline 273 & 0 . & 0 . & 0.0010 & 0. & 0.020 & 0.010 \\
\hline .010 & & & & & & \\
\hline 214 & 0 . & 0 . & 0.0010 & 0 . & 0.020 & 0.010 \\
\hline .010 & & & & & & \\
\hline 234 & 0 . & 0 . & 0.0010 & 0. & 0.020 & 0.010 \\
\hline .010 & & & & & & \\
\hline 254 & 0 . & 0 . & 0.0010 & 0 . & 0.020 & 0.010 \\
\hline .010 & & & & & & \\
\hline 274 & 0 . & 0 . & 0.0010 & 0. & 0.020 & 0.010 \\
\hline
\end{tabular}

.010

END PWAT-STATE1

MON-INTERCEP

$<$ PLS> Only required if $\mathrm{VCSFG}=1$ in PWAT-PARM1

\# - \# Interception storage capacity at start of each month JAN FEB MAR APR MAY JUN JUL AUG SEP OCT NOV DEC *** $\star * *$ sagebrush $* * *$

$\begin{array}{llllllllllllll}201 & 0.04 & 0.06 & 0.06 & 0.06 & 0.05 & 0.05 & 0.04 & 0.04 & 0.04 & 0.05 & 0.04 & 0.04\end{array}$

$\begin{array}{lllllllllllll}202 & 0.04 & 0.06 & 0.06 & 0.06 & 0.05 & 0.05 & 0.04 & 0.04 & 0.04 & 0.05 & 0.04 & 0.04\end{array}$

$\begin{array}{llllllllllllll}203 & 0.04 & 0.06 & 0.06 & 0.06 & 0.05 & 0.05 & 0.04 & 0.04 & 0.04 & 0.05 & 0.04 & 0.04\end{array}$

$\begin{array}{lllllllllllll}204 & 0.04 & 0.06 & 0.06 & 0.06 & 0.05 & 0.05 & 0.04 & 0.04 & 0.04 & 0.05 & 0.04 & 0.04\end{array}$

$\begin{array}{lllllllllllll}221 & 0.04 & 0.06 & 0.06 & 0.06 & 0.05 & 0.05 & 0.04 & 0.04 & 0.04 & 0.05 & 0.04 & 0.04\end{array}$

$\begin{array}{lllllllllllll}222 & 0.04 & 0.06 & 0.06 & 0.06 & 0.05 & 0.05 & 0.04 & 0.04 & 0.04 & 0.05 & 0.04 & 0.04\end{array}$

$\begin{array}{llllllllllllll}223 & 0.04 & 0.06 & 0.06 & 0.06 & 0.05 & 0.05 & 0.04 & 0.04 & 0.04 & 0.05 & 0.04 & 0.04\end{array}$

$\begin{array}{lllllllllllll}224 & 0.04 & 0.06 & 0.06 & 0.06 & 0.05 & 0.05 & 0.04 & 0.04 & 0.04 & 0.05 & 0.04 & 0.04\end{array}$

$\begin{array}{lllllllllllllll}241 & 0.04 & 0.06 & 0.06 & 0.06 & 0.05 & 0.05 & 0.04 & 0.04 & 0.04 & 0.05 & 0.04 & 0.04\end{array}$

$\begin{array}{lllllllllllllll}242 & 0.04 & 0.06 & 0.06 & 0.06 & 0.05 & 0.05 & 0.04 & 0.04 & 0.04 & 0.05 & 0.04 & 0.04\end{array}$

$\begin{array}{llllllllllllll}243 & 0.04 & 0.06 & 0.06 & 0.06 & 0.05 & 0.05 & 0.04 & 0.04 & 0.04 & 0.05 & 0.04 & 0.04\end{array}$

$\begin{array}{llllllllllllll}261 & 0.04 & 0.06 & 0.06 & 0.06 & 0.05 & 0.05 & 0.04 & 0.04 & 0.04 & 0.05 & 0.04 & 0.04\end{array}$

$\begin{array}{lllllllllllllll}262 & 0.04 & 0.06 & 0.06 & 0.06 & 0.05 & 0.05 & 0.04 & 0.04 & 0.04 & 0.05 & 0.04 & 0.04\end{array}$

$\begin{array}{lllllllllllllll}264 & 0.04 & 0.06 & 0.06 & 0.06 & 0.05 & 0.05 & 0.04 & 0.04 & 0.04 & 0.05 & 0.04 & 0.04\end{array}$

$\begin{array}{lllllllllllllll}281 & 0.04 & 0.06 & 0.06 & 0.06 & 0.05 & 0.05 & 0.04 & 0.04 & 0.04 & 0.05 & 0.04 & 0.04\end{array}$

$\begin{array}{lllllllllllllll}282 & 0.04 & 0.06 & 0.06 & 0.06 & 0.05 & 0.05 & 0.04 & 0.04 & 0.04 & 0.05 & 0.04 & 0.04\end{array}$

$\begin{array}{lllllllllllllll}283 & 0.04 & 0.06 & 0.06 & 0.06 & 0.05 & 0.05 & 0.04 & 0.04 & 0.04 & 0.05 & 0.04 & 0.04\end{array}$

$\begin{array}{lllllllllllll}301 & 0.04 & 0.06 & 0.06 & 0.06 & 0.05 & 0.05 & 0.04 & 0.04 & 0.04 & 0.05 & 0.04 & 0.04\end{array}$

$\begin{array}{llllllllllllll}303 & 0.04 & 0.06 & 0.06 & 0.06 & 0.05 & 0.05 & 0.04 & 0.04 & 0.04 & 0.05 & 0.04 & 0.04\end{array}$

$\begin{array}{lllllllllllllll}321 & 0.04 & 0.06 & 0.06 & 0.06 & 0.05 & 0.05 & 0.04 & 0.04 & 0.04 & 0.05 & 0.04 & 0.04\end{array}$

$\begin{array}{lllllllllllllll}323 & 0.04 & 0.06 & 0.06 & 0.06 & 0.05 & 0.05 & 0.04 & 0.04 & 0.04 & 0.05 & 0.04 & 0.04\end{array}$

$\begin{array}{lllllllllllllll}341 & 0.04 & 0.06 & 0.06 & 0.06 & 0.05 & 0.05 & 0.04 & 0.04 & 0.04 & 0.05 & 0.04 & 0.04\end{array}$

$\begin{array}{lllllllllllllll}343 & 0.04 & 0.06 & 0.06 & 0.06 & 0.05 & 0.05 & 0.04 & 0.04 & 0.04 & 0.05 & 0.04 & 0.04\end{array}$

$\begin{array}{llllllllllllll}361 & 0.04 & 0.06 & 0.06 & 0.06 & 0.05 & 0.05 & 0.04 & 0.04 & 0.04 & 0.05 & 0.04 & 0.04\end{array}$

$\begin{array}{llllllllllllll}363 & 0.04 & 0.06 & 0.06 & 0.06 & 0.05 & 0.05 & 0.04 & 0.04 & 0.04 & 0.05 & 0.04 & 0.04\end{array}$

$\begin{array}{lllllllllllll}381 & 0.04 & 0.06 & 0.06 & 0.06 & 0.05 & 0.05 & 0.04 & 0.04 & 0.04 & 0.05 & 0.04 & 0.04\end{array}$

$\begin{array}{lllllllllllllll}383 & 0.04 & 0.06 & 0.06 & 0.06 & 0.05 & 0.05 & 0.04 & 0.04 & 0.04 & 0.05 & 0.04 & 0.04\end{array}$ 


\begin{tabular}{|c|c|c|c|c|c|c|c|c|c|c|c|c|}
\hline 441 & .04 & 0.06 & 0.06 & 0.06 & 0.05 & 0.05 & 0.04 & & 0.04 & & & \\
\hline 481 & & 0.06 & 0.06 & 0.06 & 0.05 & 0.05 & 0.04 & 0.04 & 0.04 & 0.05 & 0.04 & \\
\hline \multicolumn{13}{|c|}{ * grassland $* \star *$} \\
\hline 207 & 0.03 & 0.04 & 0.05 & 0.06 & 06 & 0.06 & 0.06 & 0.06 & 0.06 & 05 & 0.04 & \\
\hline 08 & & 0.04 & 0.05 & 0.06 & 0.06 & 0.06 & 0.06 & 0.06 & 0.06 & & 0.04 & \\
\hline 99 & 03 & .04 & 0.05 & .06 & .06 & 0.06 & 0.06 & 0.06 & 0.06 & .05 & 0.04 & \\
\hline 10 & 03 & 0.04 & 0.05 & .06 & .06 & 0.06 & 0.06 & 0.06 & 0.06 & .05 & 0.04 & 0.04 \\
\hline 27 & 03 & .04 & 0.05 & .06 & .06 & 0.06 & 0.06 & 0.06 & 0.06 & & 0.04 & 0.04 \\
\hline 228 & 03 & .04 & 0.05 & .06 & .06 & 0.06 & 0.06 & 0.06 & 0.06 & & 04 & 0.04 \\
\hline 229 & 03 & 0.04 & 0.05 & .06 & .06 & 0.06 & 0.06 & 0.06 & 0.06 & & & 0.04 \\
\hline 230 & .03 & 0.04 & 0.05 & 0.06 & .06 & 0.06 & 0.06 & 0.06 & 0.06 & 05 & 04 & 0.04 \\
\hline 247 & .03 & 0.04 & 0.05 & .06 & .06 & 0.06 & 0.06 & 0.06 & 0.06 & 0.05 & .04 & 0.04 \\
\hline 248 & 0.03 & 0.04 & 0.05 & 0.06 & 0.06 & 0.06 & 0.06 & 0.06 & 0.06 & 0.05 & 04 & 0.04 \\
\hline 249 & 0.03 & 0.04 & 0.05 & 0.06 & 0.06 & 0.06 & 0.06 & 0.06 & 0.06 & 0.05 & 04 & 0.04 \\
\hline 250 & 0.03 & 0.04 & 0.05 & 0.06 & 0.06 & 0.06 & 0.06 & 0.06 & 0.06 & 0.05 & 0.04 & 0.04 \\
\hline 267 & 0.03 & 0.04 & 0.05 & 0.06 & 0.06 & 0.06 & 0.06 & 0.06 & 0.06 & 0.05 & 0.04 & 0.04 \\
\hline 270 & 0.03 & 0.04 & 0.05 & 0.06 & 0 . & 0.06 & 0.06 & 0.06 & 0.06 & 0.05 & 0 . & 0.04 \\
\hline 287 & 0.03 & 0.04 & 0.05 & 0.06 & 0.06 & 0.06 & 0.06 & 0.06 & 0.06 & & 0.04 & 0.0 \\
\hline 288 & 0.03 & 0.04 & 0.05 & 0.06 & 0.06 & 0.06 & 0.06 & 0.06 & 0.06 & 0.05 & 0.04 & 0.0 \\
\hline 289 & 0.03 & 0.04 & 0.05 & 0.06 & 0.06 & 0.06 & 0.06 & 0.06 & 0.06 & 0.05 & 0.04 & 0.0 \\
\hline 307 & 0.03 & 0.04 & 0.05 & 0.06 & 0.06 & 0.06 & 0.06 & 0.06 & 0.06 & 0.05 & 0.04 & 0.04 \\
\hline 309 & 0.03 & 0.04 & 0.05 & 0.06 & .06 & 0.06 & 0.06 & 0.06 & 0.06 & 0.05 & 0.04 & 0.0 \\
\hline 327 & 0.03 & 0.04 & 0.05 & 0.06 & .06 & 0.06 & 0.06 & 0.06 & 0.06 & 0.05 & 0.04 & 0.0 \\
\hline 328 & 0.03 & 0.04 & 0.05 & 0.06 & .06 & 0.06 & 0.06 & 0.06 & 0.06 & 0.05 & 0.04 & 0.04 \\
\hline 347 & 0.03 & 0.04 & 0.05 & 0.06 & .06 & 0.06 & 0.06 & 0.06 & 0.06 & 0. & 0.04 & 0.0 \\
\hline 349 & 0.03 & 0.04 & 0.05 & 0.06 & .06 & 0.06 & 0.06 & 0.06 & 0.06 & 0.05 & 0.04 & 0.0 \\
\hline 367 & 0.03 & 0.04 & 0.05 & 0.06 & 0.06 & 0.06 & 0.06 & 0.06 & 0.06 & 0.05 & 0.04 & 0.0 \\
\hline 387 & 0.03 & 0.04 & 0.05 & 0.06 & 0.06 & 0.06 & 0.06 & 0.06 & 0.06 & 0.05 & 0.04 & 0.0 \\
\hline 389 & 0.03 & 0.04 & 0.05 & 0.06 & 0.06 & 0.06 & 0.06 & 0.06 & 0.06 & 0.05 & 0.04 & 0.0 \\
\hline 447 & 0.03 & 0.04 & 0.05 & 0.06 & 0.06 & 0.06 & 0.06 & 0.06 & 0.06 & 0.05 & 0.04 & 0.0 \\
\hline 487 & 0.03 & 0.04 & 0.05 & 0.06 & 0.06 & 0.06 & 0.06 & 0.06 & 0.06 & 0.05 & 0.04 & 0. \\
\hline
\end{tabular}
$\star * *$ dry. wheat

$\begin{array}{llllllllllllll}212 & 0.16 & 0.16 & 0.16 & 0.16 & 0.16 & 0.08 & 0.00 & 0.00 & 0.06 & 0.16 & 0.16 & 0.16\end{array}$

$\begin{array}{lllllllllllllll}213 & 0.16 & 0.16 & 0.16 & 0.16 & 0.16 & 0.08 & 0.00 & 0.00 & 0.06 & 0.16 & 0.16 & 0.16\end{array}$

$\begin{array}{llllllllllllll}214 & 0.16 & 0.16 & 0.16 & 0.16 & 0.16 & 0.08 & 0.00 & 0.00 & 0.06 & 0.16 & 0.16 & 0.16\end{array}$

$\begin{array}{lllllllllllllll}232 & 0.16 & 0.16 & 0.16 & 0.16 & 0.16 & 0.08 & 0.00 & 0.00 & 0.06 & 0.16 & 0.16 & 0.16\end{array}$

$\begin{array}{llllllllllllll}233 & 0.16 & 0.16 & 0.16 & 0.16 & 0.16 & 0.08 & 0.00 & 0.00 & 0.06 & 0.16 & 0.16 & 0.16\end{array}$

$\begin{array}{lllllllllllllll}234 & 0.16 & 0.16 & 0.16 & 0.16 & 0.16 & 0.08 & 0.00 & 0.00 & 0.06 & 0.16 & 0.16 & 0.16\end{array}$

$\begin{array}{lllllllllllllll}252 & 0.16 & 0.16 & 0.16 & 0.16 & 0.16 & 0.08 & 0.00 & 0.00 & 0.06 & 0.16 & 0.16 & 0.16\end{array}$

$\begin{array}{lllllllllllllll}253 & 0.16 & 0.16 & 0.16 & 0.16 & 0.16 & 0.08 & 0.00 & 0.00 & 0.06 & 0.16 & 0.16 & 0.16\end{array}$

$\begin{array}{llllllllllllll}254 & 0.16 & 0.16 & 0.16 & 0.16 & 0.16 & 0.08 & 0.00 & 0.00 & 0.06 & 0.16 & 0.16 & 0.16\end{array}$

$\begin{array}{llllllllllllll}271 & 0.16 & 0.16 & 0.16 & 0.16 & 0.16 & 0.08 & 0.00 & 0.00 & 0.06 & 0.16 & 0.16 & 0.16\end{array}$

$\begin{array}{llllllllllllll}273 & 0.16 & 0.16 & 0.16 & 0.16 & 0.16 & 0.08 & 0.00 & 0.00 & 0.06 & 0.16 & 0.16 & 0.16\end{array}$

$\begin{array}{lllllllllllllll}274 & 0.16 & 0.16 & 0.16 & 0.16 & 0.16 & 0.08 & 0.00 & 0.00 & 0.06 & 0.16 & 0.16 & 0.16\end{array}$

END MON-INTERCEP

MON-LZETPARM

$\angle$ PLS > Only required if $\mathrm{VLEFG}=1$ in PWAT-PARM1

\# - \# Lower zone ET parameter at start of each month

JAN FEB MAR APR MAY JUN JUL AUG SEP OCT NOV DEC ***

$\star \star *$ sagebrush $* \star *$

$\begin{array}{llllllllllllll}201 & 0.75 & 0.99 & 0.97 & 0.78 & 0.80 & 0.81 & 0.81 & 0.80 & 0.77 & 0.69 & 0.71 & 0.73\end{array}$

$\begin{array}{llllllllllllllll}202 & 0.75 & 0.99 & 0.97 & 0.78 & 0.80 & 0.81 & 0.81 & 0.80 & 0.77 & 0.69 & 0.71 & 0.73\end{array}$

$\begin{array}{lllllllllllllll}203 & 0.75 & 0.99 & 0.97 & 0.78 & 0.80 & 0.81 & 0.81 & 0.80 & 0.77 & 0.69 & 0.71 & 0.73\end{array}$

$\begin{array}{lllllllllllllll}204 & 0.75 & 0.99 & 0.97 & 0.78 & 0.80 & 0.81 & 0.81 & 0.80 & 0.77 & 0.69 & 0.71 & 0.73\end{array}$ 
$\begin{array}{lllllllllllllll}221 & 0.75 & 0.99 & 0.97 & 0.78 & 0.80 & 0.81 & 0.81 & 0.80 & 0.77 & 0.69 & 0.71 & 0.73\end{array}$

$\begin{array}{llllllllllllllll}222 & 0.75 & 0.99 & 0.97 & 0.78 & 0.80 & 0.81 & 0.81 & 0.80 & 0.77 & 0.69 & 0.71 & 0.73\end{array}$

$\begin{array}{lllllllllllllll}223 & 0.75 & 0.99 & 0.97 & 0.78 & 0.80 & 0.81 & 0.81 & 0.80 & 0.77 & 0.69 & 0.71 & 0.73\end{array}$

224

241

$\begin{array}{lllllllllllll}0.75 & 0.99 & 0.97 & 0.78 & 0.80 & 0.81 & 0.81 & 0.80 & 0.77 & 0.69 & 0.71 & 0.73\end{array}$

242

243

$\begin{array}{lllllllllllll}0.75 & 0.99 & 0.97 & 0.78 & 0.80 & 0.81 & 0.81 & 0.80 & 0.77 & 0.69 & 0.71 & 0.73\end{array}$

$\begin{array}{lllllllllllll}0.75 & 0.99 & 0.97 & 0.78 & 0.80 & 0.81 & 0.81 & 0.80 & 0.77 & 0.69 & 0.71 & 0.73\end{array}$

261

$\begin{array}{lllllllllllll}0.75 & 0.99 & 0.97 & 0.78 & 0.80 & 0.81 & 0.81 & 0.80 & 0.77 & 0.69 & 0.71 & 0.73\end{array}$

262

$\begin{array}{llllllllllll}0.75 & 0.99 & 0.97 & 0.78 & 0.80 & 0.81 & 0.81 & 0.80 & 0.77 & 0.69 & 0.71 & 0.73\end{array}$

264

$\begin{array}{llllllllllll}0.75 & 0.99 & 0.97 & 0.78 & 0.80 & 0.81 & 0.81 & 0.80 & 0.77 & 0.69 & 0.71 & 0.73\end{array}$

281

$\begin{array}{llllllllllll}0.75 & 0.99 & 0.97 & 0.78 & 0.80 & 0.81 & 0.81 & 0.80 & 0.77 & 0.69 & 0.71 & 0.73\end{array}$

282

$\begin{array}{llllllllllll}0.75 & 0.99 & 0.97 & 0.78 & 0.80 & 0.81 & 0.81 & 0.80 & 0.77 & 0.69 & 0.71 & 0.73\end{array}$

$\begin{array}{llllllllllll}0.75 & 0.99 & 0.97 & 0.78 & 0.80 & 0.81 & 0.81 & 0.80 & 0.77 & 0.69 & 0.71 & 0.73\end{array}$

283

$\begin{array}{lllllllllllll}0.75 & 0.99 & 0.97 & 0.78 & 0.80 & 0.81 & 0.81 & 0.80 & 0.77 & 0.69 & 0.71 & 0.73\end{array}$

301

303

$\begin{array}{llllllllllll}0.75 & 0.99 & 0.97 & 0.78 & 0.80 & 0.81 & 0.81 & 0.80 & 0.77 & 0.69 & 0.71 & 0.73\end{array}$

321

323

$\begin{array}{llllllllllll}0.75 & 0.99 & 0.97 & 0.78 & 0.80 & 0.81 & 0.81 & 0.80 & 0.77 & 0.69 & 0.71 & 0.73\end{array}$

$\begin{array}{lllllllllllll}0.75 & 0.99 & 0.97 & 0.78 & 0.80 & 0.81 & 0.81 & 0.80 & 0.77 & 0.69 & 0.71 & 0.73\end{array}$

341

$\begin{array}{llllllllllll}0.75 & 0.99 & 0.97 & 0.78 & 0.80 & 0.81 & 0.81 & 0.80 & 0.77 & 0.69 & 0.71 & 0.73\end{array}$

343

$\begin{array}{llllllllllll}0.75 & 0.99 & 0.97 & 0.78 & 0.80 & 0.81 & 0.81 & 0.80 & 0.77 & 0.69 & 0.71 & 0.73\end{array}$

361

363

$\begin{array}{llllllllllll}0.75 & 0.99 & 0.97 & 0.78 & 0.80 & 0.81 & 0.81 & 0.80 & 0.77 & 0.69 & 0.71 & 0.73\end{array}$

381

$\begin{array}{lllllllllllll}0.75 & 0.99 & 0.97 & 0.78 & 0.80 & 0.81 & 0.81 & 0.80 & 0.77 & 0.69 & 0.71 & 0.73\end{array}$

383

$\begin{array}{lllllllllllll}0.75 & 0.99 & 0.97 & 0.78 & 0.80 & 0.81 & 0.81 & 0.80 & 0.77 & 0.69 & 0.71 & 0.73\end{array}$

$\begin{array}{lllllllllllll}0.75 & 0.99 & 0.97 & 0.78 & 0.80 & 0.81 & 0.81 & 0.80 & 0.77 & 0.69 & 0.71 & 0.73\end{array}$

441

$\begin{array}{lllllllllllll}0.75 & 0.99 & 0.97 & 0.78 & 0.80 & 0.81 & 0.81 & 0.80 & 0.77 & 0.69 & 0.71 & 0.73\end{array}$

481

$\begin{array}{llllllllllll}0.75 & 0.99 & 0.97 & 0.78 & 0.80 & 0.81 & 0.81 & 0.80 & 0.77 & 0.69 & 0.71 & 0.73\end{array}$

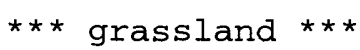

$\begin{array}{lllllllllllllll}207 & 0.45 & 0.52 & 0.65 & 0.76 & 0.80 & 0.81 & 0.81 & 0.80 & 0.77 & 0.69 & 0.58 & 0.48\end{array}$

$\begin{array}{llllllllllllll}208 & 0.45 & 0.52 & 0.65 & 0.76 & 0.80 & 0.81 & 0.81 & 0.80 & 0.77 & 0.69 & 0.58 & 0.48\end{array}$

$\begin{array}{lllllllllllllll}209 & 0.45 & 0.52 & 0.65 & 0.76 & 0.80 & 0.81 & 0.81 & 0.80 & 0.77 & 0.69 & 0.58 & 0.48\end{array}$

$\begin{array}{lllllllllllllll}210 & 0.45 & 0.52 & 0.65 & 0.76 & 0.80 & 0.81 & 0.81 & 0.80 & 0.77 & 0.69 & 0.58 & 0.48\end{array}$

227

228

229

230

247

248

249

250

267

270

287

288

289

307

309

$\begin{array}{llllllllllll}0.45 & 0.52 & 0.65 & 0.76 & 0.80 & 0.81 & 0.81 & 0.80 & 0.77 & 0.69 & 0.58 & 0.48\end{array}$

$\begin{array}{llllllllllll}0.45 & 0.52 & 0.65 & 0.76 & 0.80 & 0.81 & 0.81 & 0.80 & 0.77 & 0.69 & 0.58 & 0.48\end{array}$

$\begin{array}{llllllllllll}0.45 & 0.52 & 0.65 & 0.76 & 0.80 & 0.81 & 0.81 & 0.80 & 0.77 & 0.69 & 0.58 & 0.48\end{array}$

$\begin{array}{llllllllllll}0.45 & 0.52 & 0.65 & 0.76 & 0.80 & 0.81 & 0.81 & 0.80 & 0.77 & 0.69 & 0.58 & 0.48\end{array}$

$\begin{array}{lllllllllllll}0.45 & 0.52 & 0.65 & 0.76 & 0.80 & 0.81 & 0.81 & 0.80 & 0.77 & 0.69 & 0.58 & 0.48\end{array}$

$\begin{array}{llllllllllll}0.45 & 0.52 & 0.65 & 0.76 & 0.80 & 0.81 & 0.81 & 0.80 & 0.77 & 0.69 & 0.58 & 0.48\end{array}$

$\begin{array}{llllllllllll}0.45 & 0.52 & 0.65 & 0.76 & 0.80 & 0.81 & 0.81 & 0.80 & 0.77 & 0.69 & 0.58 & 0.48\end{array}$

$\begin{array}{llllllllllll}0.45 & 0.52 & 0.65 & 0.76 & 0.80 & 0.81 & 0.81 & 0.80 & 0.77 & 0.69 & 0.58 & 0.48\end{array}$

$\begin{array}{llllllllllll}0.45 & 0.52 & 0.65 & 0.76 & 0.80 & 0.81 & 0.81 & 0.80 & 0.77 & 0.69 & 0.58 & 0.48\end{array}$

$\begin{array}{llllllllllll}0.45 & 0.52 & 0.65 & 0.76 & 0.80 & 0.81 & 0.81 & 0.80 & 0.77 & 0.69 & 0.58 & 0.48\end{array}$

$\begin{array}{llllllllllll}0.45 & 0.52 & 0.65 & 0.76 & 0.80 & 0.81 & 0.81 & 0.80 & 0.77 & 0.69 & 0.58 & 0.48\end{array}$

$\begin{array}{llllllllllll}0.45 & 0.52 & 0.65 & 0.76 & 0.80 & 0.81 & 0.81 & 0.80 & 0.77 & 0.69 & 0.58 & 0.48\end{array}$

$\begin{array}{llllllllllll}0.45 & 0.52 & 0.65 & 0.76 & 0.80 & 0.81 & 0.81 & 0.80 & 0.77 & 0.69 & 0.58 & 0.48\end{array}$

$\begin{array}{llllllllllll}0.45 & 0.52 & 0.65 & 0.76 & 0.80 & 0.81 & 0.81 & 0.80 & 0.77 & 0.69 & 0.58 & 0.48\end{array}$

327

328

$\begin{array}{llllllllllll}0.45 & 0.52 & 0.65 & 0.76 & 0.80 & 0.81 & 0.81 & 0.80 & 0.77 & 0.69 & 0.58 & 0.48\end{array}$

$\begin{array}{lllllllllllll}0.45 & 0.52 & 0.65 & 0.76 & 0.80 & 0.81 & 0.81 & 0.80 & 0.77 & 0.69 & 0.58 & 0.48\end{array}$

$\begin{array}{lllllllllllll}0.45 & 0.52 & 0.65 & 0.76 & 0.80 & 0.81 & 0.81 & 0.80 & 0.77 & 0.69 & 0.58 & 0.48\end{array}$

347

349

$\begin{array}{llllllllllll}0.45 & 0.52 & 0.65 & 0.76 & 0.80 & 0.81 & 0.81 & 0.80 & 0.77 & 0.69 & 0.58 & 0.48\end{array}$

367

$\begin{array}{llllllllllll}0.45 & 0.52 & 0.65 & 0.76 & 0.80 & 0.81 & 0.81 & 0.80 & 0.77 & 0.69 & 0.58 & 0.48\end{array}$

387

$\begin{array}{llllllllllll}0.45 & 0.52 & 0.65 & 0.76 & 0.80 & 0.81 & 0.81 & 0.80 & 0.77 & 0.69 & 0.58 & 0.48\end{array}$

389

447

$\begin{array}{lllllllllllll}0.45 & 0.52 & 0.65 & 0.76 & 0.80 & 0.81 & 0.81 & 0.80 & 0.77 & 0.69 & 0.58 & 0.48\end{array}$

$\begin{array}{lllllllllllll}0.45 & 0.52 & 0.65 & 0.76 & 0.80 & 0.81 & 0.81 & 0.80 & 0.77 & 0.69 & 0.58 & 0.48\end{array}$

$\begin{array}{lllllllllllll}0.45 & 0.52 & 0.65 & 0.76 & 0.80 & 0.81 & 0.81 & 0.80 & 0.77 & 0.69 & 0.58 & 0.48\end{array}$

487

$\begin{array}{llllllllllll}0.45 & 0.52 & 0.65 & 0.76 & 0.80 & 0.81 & 0.81 & 0.80 & 0.77 & 0.69 & 0.58 & 0.48\end{array}$ 


\begin{tabular}{|c|c|c|c|c|c|c|c|c|c|c|c|c|}
\hline 212 & 0.99 & 0.99 & 0.99 & 0.99 & 0.99 & 0.50 & 0.00 & 0.00 & 0.37 & 0.99 & 0.99 & 0.99 \\
\hline 213 & 0.99 & 0.99 & 0.99 & 0.99 & 0.99 & 0.50 & 0.00 & 0.00 & 0.37 & 0.99 & 0.99 & 0.99 \\
\hline 214 & 0.99 & 0.99 & 0.99 & 0.99 & 0.99 & 0.50 & 0.00 & 0.00 & 0.37 & 0.99 & 0.99 & 0.99 \\
\hline 232 & 0.99 & 0.99 & 0.99 & 0.99 & 0.99 & 0.50 & 0.00 & 0.00 & 0.37 & 0.99 & 0.99 & 0.99 \\
\hline 233 & 0.99 & 0.99 & 0.99 & 0.99 & 0.99 & 0.50 & 0.00 & 0.00 & 0.37 & 0.99 & 0.99 & 0.99 \\
\hline 234 & 0.99 & 0.99 & 0.99 & 0.99 & 0.99 & 0.50 & 0.00 & 0.00 & 0.37 & 0.99 & 0.99 & 0.99 \\
\hline 252 & 0.99 & 0.99 & 0.99 & 0.99 & 0.99 & 0.50 & 0.00 & 0.00 & 0.37 & 0.99 & 0.99 & 0.99 \\
\hline 253 & 0.99 & 0.99 & 0.99 & 0.99 & 0.99 & 0.50 & 0.00 & 0.00 & 0.37 & 0.99 & 0.99 & 0.99 \\
\hline 254 & 0.99 & 0.99 & 0.99 & 0.99 & 0.99 & 0.50 & 0.00 & 0.00 & 0.37 & 0.99 & 0.99 & 0.99 \\
\hline 271 & 0.99 & 0.99 & 0.99 & 0.99 & 0.99 & 0.50 & 0.00 & 0.00 & 0.37 & 0.99 & 0.99 & 0.99 \\
\hline 273 & 0.99 & 0.99 & 0.99 & 0.99 & 0.99 & 0.50 & 0.00 & 0.00 & 0.37 & 0.99 & 0.99 & 0.99 \\
\hline 274 & 0.99 & 0.99 & 0.99 & 0.99 & 0.99 & 0.50 & 0.00 & 0.00 & 0.37 & 0.99 & 0.99 & 0.99 \\
\hline
\end{tabular}

END PERLND

EXT SOURCES

<-Volume-> <Member> SsysSgap<--Mult-->Tran <-Target vols> <-Grp> <-Member-> ***

$\star$ Name
$\star \star \star$

\# $<$ Name>

WDM

WDM

2 PREC

$\#$

tem strg<-factor->strg $<$

WDM

2 PREC

ENGL

.890

ENGL

1.150

WDM

2 PREC

ENGL

1.320

WDM

5 WIND

ENGL

6 SOLR ENGL

WDM 7 SOLR ENGL

WDM 8 SOLR ENGL

WDM 9 SOLR ENGL

WDM 10 SOLR ENGL

WDM 6 SOLR ENGL

WDM 7 SOLR ENGL

WDM 8 SOLR ENGL

WDM 9 SOLR ENGL

WDM 10 SOLR ENGL

WDM 8 SOLR ENGL

WDM 10 SOLR ENGL

WDM 15 TEMP ENGL

WDM 25 DEWP ENGL

WDM 18 TEMP ENGL

WDM 28 DEWP ENGL

WDM 20 TEMP ENGL

WDM 30 DEWP ENGL

WDM 35 PET ENGL

WDM 45 PET ENGL

WDM 55 PET ENGL

WDM 65 PET ENGL

WDM 75 PET ENGL

WDM 38 PET ENGL

WDM 48 PET ENGL

WDM 58 PET ENGL

WDM 68 PET ENGL

WDM 78 PET ENGL

WDM 60 PET ENGL

WDM 80 PET ENGL

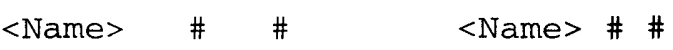

PERLND 201289 EXTNL PREC

PERLND 301389 EXTNL PREC

PERLND 441487 EXTNL PREC

PERLND 201487 EXTNL WINMOV

PERLND 201214 EXTNL SOLRAD

PERLND 221234 EXTNL SOLRAD

PERLND 241254 EXTNL SOLRAD

PERLND 261274 EXTNL SOLRAD

PERLND 281289 EXTNL SOLRAD

PERLND 301309 EXTNL SOLRAD

PERLND 321328 EXTNL SOLRAD

PERLND 341349 EXTNL SOLRAD

PERLND 361367 EXTNL SOLRAD

PERLND 381389 EXTNL SOLRAD

PERLND 441447 EXTNL SOLRAD

PERLND 481487 EXTNL SOLRAD

PERLND 201289 ATEMP AIRTMP

PERLND 201289 EXTNL DTMPG

PERLND 301389 ATEMP AIRTMP

PERLND 301389 EXTNL DTMPG

PERLND 441487 ATEMP AIRTMP

PERLND 441487 EXTNL DTMPG

PERLND 201214 EXTNL PETINP

PERLND 221234 EXTNL PETINP

PERLND 241254 EXTNL PETINP

PERLND 261274 EXTNL PETINP

PERLND 281289 EXTNL PETINP

PERLND 301309 EXTNL PETINP

PERLND 321328 EXTNL PETINP

PERLND 341349 EXTNL PETINP

PERLND 361367 EXTNL PETINP

PERLND 381389 EXTNL PETINP

PERLND 441447 EXTNL PETINP

PERLND 481487 EXTNL PETINP 
END EXT SOURCES

NETWORK

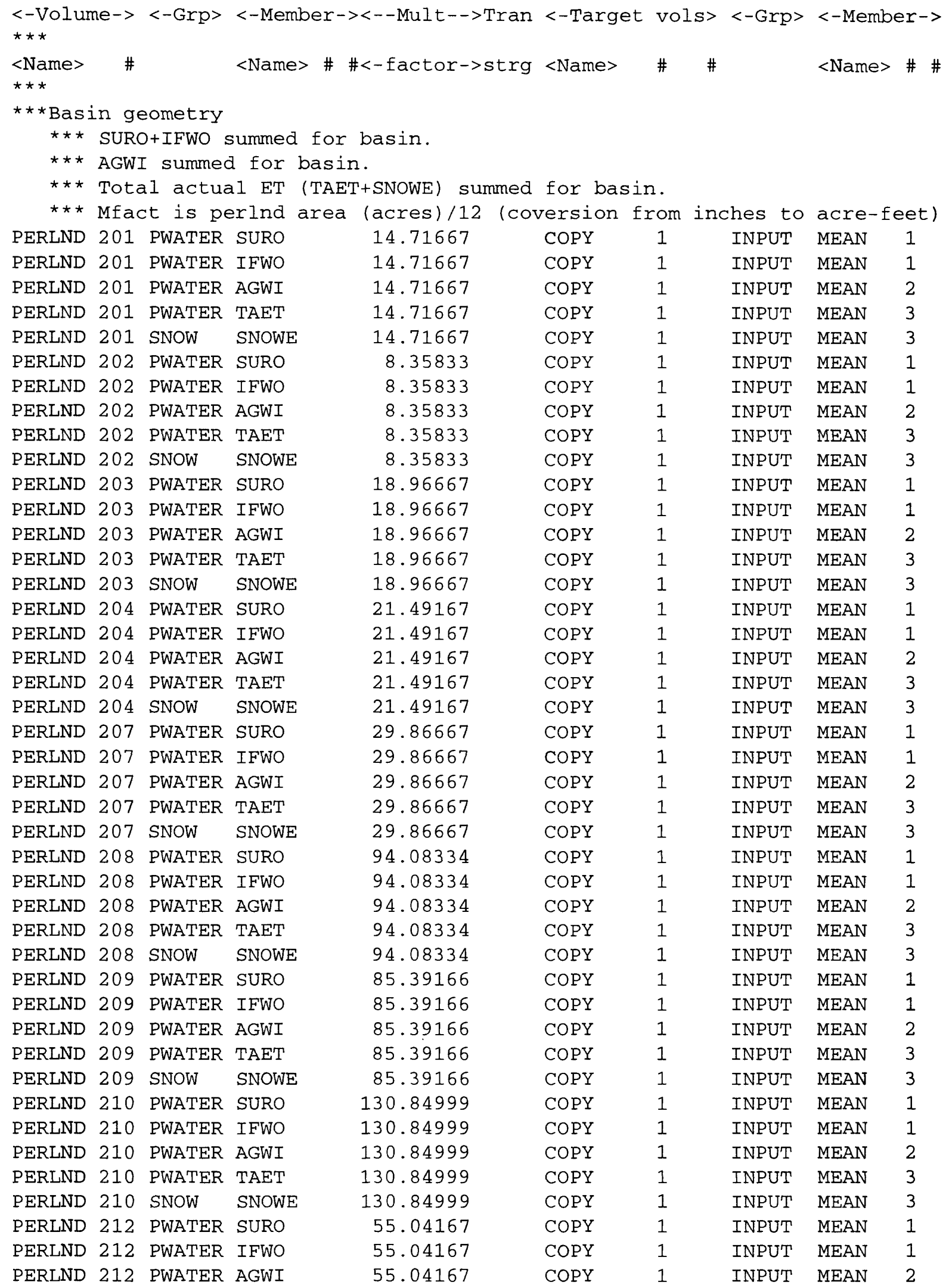




\begin{tabular}{|c|c|c|c|c|c|c|c|c|}
\hline PERLND & 212 & PWATER & TAET & 55.04167 & COPY & 1 & INPUT & MEAN \\
\hline PERLND & 212 & SNOW & SNOWE & 55.04167 & COPY & 1 & INPUT & MEAN \\
\hline PERLND & 213 & PWATER & SURO & 184.83333 & COPY & 1 & INPUT & MEAN \\
\hline PERLND & 213 & PWATER & IFWO & 184.83333 & COPY & 1 & INPUT & MEAN \\
\hline PERLND & 213 & PWATER & AGWI & 184.83333 & COPY & 1 & INPUT & MEAN \\
\hline PERLND & 213 & PWATER & TAET & 184.83333 & COPY & 1 & INPUT & MEAN \\
\hline PERLND & 213 & SNOW & SNOWE & 184.83333 & COPY & 1 & INPUT & MEAN \\
\hline PERLND & 214 & PWATER & SURO & 241.32500 & COPY & 1 & INPUT & MEAN \\
\hline PERLND & 214 & PWATER & IFWO & 241.32500 & COPY & 1 & INPUT & MEAN \\
\hline PERLND & $214^{\circ}$ & PWATER & AGWI & 241.32500 & COPY & 1 & INPUT & MEAN \\
\hline PERLND & 214 & PWATER & TAET & 241.32500 & COPY & 1 & INPUT & MEAN \\
\hline PERLND & 214 & SNOW & SNOWE & 241.32500 & COPY & 1 & INPUT & MEAN \\
\hline PERLND & 221 & PWATER & SURO & 14.12500 & COPY & 1 & INPUT & MEAN \\
\hline PERLND & 221 & PWATER & IFWO & 14.12500 & COPY & 1 & INPUT & MEAN \\
\hline PERLND & 221 & PWATER & AGWI & 14.12500 & COPY & 1 & INPUT & MEAN \\
\hline PERLND & 221 & PWATER & TAET & 14.12500 & COPY & 1 & INPUT & MEAN \\
\hline PERLND & 221 & SNOW & SNOWE & 14.12500 & COPY & 1 & INPUT & MEAN \\
\hline PERLND & 222 & PWATER & SURO & 8.70833 & COPY & 1 & INPUT & MEAN \\
\hline PERLND & 222 & PWATER & IFWO & 8.70833 & COPY & 1 & INPUT & MEAN \\
\hline PERLND & 222 & PWATER & AGWI & 8.70833 & COPY & 1 & INPUT & MEAN \\
\hline PERLND & 222 & PWATER & TAET & 8.70833 & COPY & 1 & INPUT & MEAN \\
\hline PERLND & 222 & SNOW & SNOWE & 8.70833 & COPY & 1 & INPUT & MEAN \\
\hline PERLND & 223 & PWATER & SURO & 21.39167 & COPY & 1 & INPUT & MEAN \\
\hline PERLND & 223 & PWATER & IFWO & 21.39167 & COPY & 1 & INPUT & MEAN \\
\hline PERLND & 223 & PWATER & AGWI & 21.39167 & COPY & 1 & INPUT & MEAN \\
\hline PERLND & 223 & PWATER & TAET & 21.39167 & COPY & 1 & INPUT & MEAN \\
\hline PERLND & 223 & SNOW & SNOWE & 21.39167 & COPY & 1 & INPUT & MEAN \\
\hline PERLND & 224 & PWATER & SURO & 18.59167 & COPY & 1 & INPUT & MEAN \\
\hline PERLND & 224 & PWATER & IFWO & 18.59167 & COPY & 1 & INPUT & MEAN \\
\hline PERLND & 224 & PWATER & AGWI & 18.59167 & COPY & 1 & INPUT & MEAN \\
\hline PERLND & 224 & PWATER & TAET & 18.59167 & COPY & 1 & INPUT & MEAN \\
\hline PERLND & 224 & SNOW & SNOWE & 18.59167 & COPY & 1 & INPUT & MEAN \\
\hline PERLND & 227 & PWATER & SURO & 17.24167 & COPY & 1 & INPUT & MEAN \\
\hline PERLND & 227 & PWATER & IFWO & 17.24167 & COPY & 1 & INPUT & MEAN \\
\hline PERLND & 227 & PWATER & AGWI & 17.24167 & COPY & 1 & INPUT & MEAN \\
\hline PERLND & 227 & PWATER & TAET & 17.24167 & COPY & 1 & INPUT & MEAN \\
\hline PERLND & 227 & SNOW & SNOWE & 17.24167 & COPY & 1 & INPUT & MEAN \\
\hline PERLND & 228 & PWATER & SURO & 32.16667 & COPY & 1 & INPUT & MEAN \\
\hline PERLND & 228 & PWATER & IFWO & 32.16667 & COPY & 1 & INPUT & MEAN \\
\hline PERLND & 228 & PWATER & AGWI & 32.16667 & COPY & 1 & INPUT & MEAN \\
\hline PERLND & 228 & PWATER & TAET & 32.16667 & COPY & 1 & INPUT & MEAN \\
\hline PERLND & 228 & SNOW & SNOWE & 32.16667 & COPY & 1 & INPUT & MEAN \\
\hline PERLND & 229 & PWATER & SURO & 32.95000 & COPY & 1 & INPUT & MEAN \\
\hline PERLND & 229 & PWATER & IFWO & 32.95000 & COPY & 1 & INPUT & MEAN \\
\hline PERLND & 229 & PWATER & AGWI & 32.95000 & COPY & 1 & INPUT & MEAN \\
\hline PERLND & 229 & PWATER & TAET & 32.95000 & COPY & 1 & INPUT & MEAN \\
\hline PERLND & 229 & SNOW & SNOWE & 32.95000 & COPY & 1 & INPUT & MEAN \\
\hline PERLND & 230 & PWATER & SURO & 46.60000 & COPY & 1 & INPUT & MEAN \\
\hline PERLND & 230 & PWATER & IFWO & 46.60000 & COPY & 1 & INPUT & MEAN \\
\hline PERLND & 230 & PWATER & AGWI & 46.60000 & COPY & 1 & INPUT & MEAN \\
\hline PERLND & 230 & PWATER & TAET & 46.60000 & COPY & 1 & INPUT & MEAN \\
\hline PERLND & 230 & SNOW & SNOWE & 46.60000 & COPY & 1 & INPUT & MEAN \\
\hline PERLND & 232 & PWATER & SURO & 22.17500 & COPY & 1 & INPUT & MEAN \\
\hline PERLND & 232 & PWATER & IFWO & 22.17500 & COPY & 1 & INPUT & MEAN \\
\hline
\end{tabular}




\begin{tabular}{|c|c|c|c|c|c|c|c|c|}
\hline PERLND & 232 & PWATER & AGWI & 22.17500 & COPY & 1 & INPUT & MEAN \\
\hline PERLND & 232 & PWATER & TAET & 22.17500 & COPY & 1 & INPUT & MEAN \\
\hline PERLND & 232 & SNOW & SNOWE & 22.17500 & COPY & 1 & INPUT & MEAN \\
\hline PERLND & 233 & PWATER & SURO & 26.00000 & COPY & 1 & INPUT & MEAN \\
\hline PERLND & 233 & PWATER & IFWO & 26.00000 & COPY & 1 & INPUT & MEAN \\
\hline PERLND & 233 & PWATER & AGWI & 26.00000 & COPY & 1 & INPUT & MEAN \\
\hline PERLND & 233 & PWATER & TAET & 26.00000 & COPY & 1 & INPUT & MEAN \\
\hline PERLND & 233 & SNOW & SNOWE & 26.00000 & COPY & 1 & INPUT & MEAN \\
\hline PERLND & 234 & PWATER & SURO & 67.42500 & COPY & 1 & INPUT & MEAN \\
\hline PERLND & 234 & PWATER & IFWO & 67.42500 & COPY & 1 & INPUT & MEAN \\
\hline PERLND & 234 & PWATER & AGWI & 67.42500 & COPY & 1 & INPUT & MEAN \\
\hline PERLND & 234 & PWATER & TAET & 67.42500 & COPY & 1 & INPUT & MEAN \\
\hline PERLND & 234 & SNOW & SNOWE & 67.42500 & COPY & 1 & INPUT & MEAN \\
\hline PERLND & 241 & PWATER & SURO & 49.21666 & COPY & 1 & INPUT & MEAN \\
\hline PERLND & 241 & PWATER & IFWO & 49.21666 & COPY & 1 & INPUT & MEAN \\
\hline PERLND & 241 & PWATER & AGWI & 49.21666 & COPY & 1 & INPUT & MEAN \\
\hline PERLND & 241 & PWATER & TAET & 49.21666 & COPY & 1 & INPUT & MEAN \\
\hline PERLND & 241 & SNOW & SNOWE & 49.21666 & COPY & 1 & INPUT & MEAN \\
\hline PERLND & 242 & PWATER & SURO & 15.63333 & COPY & 1 & INPUT & MEAN \\
\hline PERLND & 242 & PWATER & IFWO & 15.63333 & COPY & 1 & INPUT & MEAN \\
\hline PERLND & 242 & PWATER & AGWI & 15.63333 & COPY & 1 & INPUT & MEAN \\
\hline PERLND & 242 & PWATER & TAET & 15.63333 & COPY & 1 & INPUT & MEAN \\
\hline PERLND & 242 & SNOW & SNOWE & 15.63333 & COPY & 1 & INPUT & MEAN \\
\hline PERLND & 243 & PWATER & SURO & 39.30000 & COPY & 1 & INPUT & MEAN \\
\hline PERLND & 243 & PWATER & IFWO & 39.30000 & COPY & 1 & INPUT & MEAN \\
\hline PERLND & 243 & PWATER & AGWI & 39.30000 & COPY & 1 & INPUT & MEAN \\
\hline PERLND & 243 & PWATER & TAET & 39.30000 & COPY & 1 & INPUT & MEAN \\
\hline PERLND & 243 & SNOW & SNOWE & 39.30000 & COPY & 1 & INPUT & MEAN \\
\hline PERLND & 247 & PWATER & SURO & 85.25833 & COPY & 1 & INPUT & MEAN \\
\hline PERLND & 247 & PWATER & IFWO & 85.25833 & COPY & 1 & INPUT & MEAN \\
\hline PERLND & 247 & PWATER & AGWI & 85.25833 & COPY & 1 & INPUT & MEAN \\
\hline PERLND & 247 & PWATER & TAET & 85.25833 & COPY & 1 & INPUT & MEAN \\
\hline PERLND & 247 & SNOW & SNOWE & 85.25833 & COPY & 1 & INPUT & MEAN \\
\hline PERLND & 248 & PWATER & SURO & 130.00833 & COPY & 1 & INPUT & MEAN \\
\hline PERLND & 248 & PWATER & IFWO & 130.00833 & COPY & 1 & INPUT & MEAN \\
\hline PERLND & 248 & PWATER & AGWI & 130.00833 & COPY & 1 & INPUT & MEAN \\
\hline PERLND & 248 & PWATER & TAET & 130.00833 & COPY & 1 & INPUT & MEAN \\
\hline PERLND & 248 & SNOW & SNOWE & 130.00833 & COPY & 1 & INPUT & MEAN \\
\hline PERLND & 249 & PWATER & SURO & 142.04167 & COPY & 1 & INPUT & MEAN \\
\hline PERLND & 249 & PWATER & IFWO & 142.04167 & COPY & 1 & INPUT & MEAN \\
\hline PERLND & 249 & PWATER & AGWI & 142.04167 & COPY & 1 & INPUT & MEAN \\
\hline PERLND & 249 & PWATER & TAET & 142.04167 & COPY & 1 & INPUT & MEAN \\
\hline PERLND & 249 & SNOW & SNOWE & 142.04167 & COPY & 1 & INPUT & MEAN \\
\hline PERLND & 250 & PWATER & SURO & 41.96667 & COPY & 1 & INPUT & MEAN \\
\hline PERLND & 250 & PWATER & IFWO & 41.96667 & COPY & 1 & INPUT & MEAN \\
\hline PERLND & 250 & PWATER & AGWI & 41.96667 & COPY & 1 & INPUT & MEAN \\
\hline PERLND & 250 & PWATER & TAET & 41.96667 & COPY & 1 & INPUT & MEAN \\
\hline PERLND & 250 & SNOW & SNOWE & 41.96667 & COPY & 1 & INPUT & MEAN \\
\hline PERLND & 252 & PWATER & SURO & 29.98333 & COPY & 1 & INPUT & MEAN \\
\hline PERLND & 252 & PWATER & IFWO & 29.98333 & COPY & 1 & INPUT & MEAN \\
\hline PERLND & 252 & PWATER & AGWI & 29.98333 & COPY & 1 & INPUT & MEAN \\
\hline PERLND & 252 & PWATER & TAET & 29.98333 & COPY & 1 & INPUT & MEAN \\
\hline PERLND & 252 & SNOW & SNOWE & 29.98333 & COPY & 1 & INPUT & MEAN \\
\hline PERLND & 253 & PWATER & SURO & 69.99167 & COPY & 1 & INPUT & MEAN \\
\hline
\end{tabular}




\begin{tabular}{|c|c|c|c|c|c|c|c|c|}
\hline PERLND & 253 & PWATER & IFWO & 69.99167 & COPY & 1 & INPUT & MEAN \\
\hline PERLND & 253 & PWATER & AGWI & 69.99167 & COPY & 1 & INPUT & MEAN \\
\hline PERLND & 253 & PWATER & TAET & 69.99167 & COPY & 1 & INPUT & MEAN \\
\hline PERLND & 253 & SNOW & SNOWE & 69.99167 & COPY & 1 & INPUT & MEAN \\
\hline PERLND & 254 & PWATER & SURO & 22.06667 & COPY & 1 & INPUT & MEAN \\
\hline PERLND & 254 & PWATER & IFWO & 22.06667 & COPY & 1 & INPUT & MEAN \\
\hline PERLND & 254 & PWATER & AGWI & 22.06667 & COPY & 1 & INPUT & MEAN \\
\hline PERLND & 254 & PWATER & TAET & 22.06667 & COPY & 1 & INPUT & MEAN \\
\hline PERLND & 254 & SNOW & SNOWE & 22.06667 & COPY & 1 & INPUT & MEAN \\
\hline PERLND & 261 & PWATER & SURO & 32.05000 & COPY & 1 & INPUT & MEAN \\
\hline PERLND & 261 & PWATER & IFWO & 32.05000 & COPY & 1 & INPUT & MEAN \\
\hline PERLND & 261 & PWATER & AGWI & 32.05000 & COPY & 1 & INPUT & MEAN \\
\hline PERLND & 261 & PWATER & TAET & 32.05000 & COPY & 1 & INPUT & MEAN \\
\hline PERLND & 261 & SNOW & SNOWE & 32.05000 & COPY & 1 & INPUT & MEAN \\
\hline PERLND & 262 & PWATER & SURO & 14.90000 & COPY & 1 & INPUT & MEAN \\
\hline PERLND & 262 & PWATER & IFWO & 14.90000 & COPY & 1 & INPUT & MEAN \\
\hline PERLND & 262 & PWATER & AGWI & 14.90000 & COPY & 1 & INPUT & MEAN \\
\hline PERLND & 262 & PWATER & TAET & 14.90000 & COPY & 1 & INPUT & MEAN \\
\hline PERLND & 262 & SNOW & SNOWE & 14.90000 & COPY & 1 & INPUT & MEAN \\
\hline PERLND & 264 & PWATER & SURO & 39.85833 & COPY & 1 & INPUT & MEAN \\
\hline PERLND & 264 & PWATER & IFWO & 39.85833 & COPY & 1 & INPUT & MEAN \\
\hline PERLND & 264 & PWATER & AGWI & 39.85833 & COPY & 1 & INPUT & MEAN \\
\hline PERLND & 264 & PWATER & TAET & 39.85833 & COPY & 1 & INPUT & MEAN \\
\hline PERLND & 264 & SNOW & SNOWE & 39.85833 & COPY & 1 & INPUT & MEAN \\
\hline PERLND & 267 & PWATER & SURO & 12.02500 & COPY & 1 & INPUT & MEAN \\
\hline PERLND & 267 & PWATER & IFWO & 12.02500 & COPY & 1 & INPUT & MEAN \\
\hline PERLND & 267 & PWATER & AGWI & 12.02500 & COPY & 1 & INPUT & MEAN \\
\hline PERLND & 267 & PWATER & TAET & 12.02500 & COPY & 1 & INPUT & MEAN \\
\hline PERLND & 267 & SNOW & SNOWE & 12.02500 & COPY & 1 & INPUT & MEAN \\
\hline PERLND & 270 & PWATER & SURO & 19.80000 & COPY & 1 & INPUT & MEAN \\
\hline PERLND & 270 & PWATER & IFWO & 19.80000 & COPY & 1 & INPUT & MEAN \\
\hline PERLND & 270 & PWATER & AGWI & 19.80000 & COPY & 1 & INPUT & MEAN \\
\hline PERLND & 270 & PWATER & TAET & 19.80000 & COPY & 1 & INPUT & MEAN \\
\hline PERLND & 270 & SNOW & SNOWE & 19.80000 & COPY & 1 & INPUT & MEAN \\
\hline PERLND & 271 & PWATER & SURO & 11.00000 & COPY & 1 & INPUT & MEAN \\
\hline PERLND & 271 & PWATER & IFWO & 11.00000 & COPY & 1 & INPUT & MEAN \\
\hline PERLND & 271 & PWATER & AGWI & 11.00000 & COPY & 1 & INPUT & MEAN \\
\hline PERLND & 271 & PWATER & TAET & 11.00000 & COPY & 1 & INPUT & MEAN \\
\hline PERLND & 271 & SNOW & SNOWE & 11.00000 & COPY & 1 & INPUT & MEAN \\
\hline PERLND & 273 & PWATER & SURO & 8.95833 & COPY & 1 & INPUT & MEAN \\
\hline PERLND & 273 & PWATER & IFWO & 8.95833 & COPY & 1 & INPUT & MEAN \\
\hline PERLND & 273 & PWATER & AGWI & 8.95833 & COPY & 1 & INPUT & MEAN \\
\hline PERLND & 273 & PWATER & TAET & 8.95833 & COPY & 1 & INPUT & MEAN \\
\hline PERLND & 273 & SNOW & SNOWE & 8.95833 & COPY & 1 & INPUT & MEAN \\
\hline PERLND & 274 & PWATER & SURO & 13.14167 & COPY & 1 & INPUT & MEAN \\
\hline PERLND & 274 & PWATER & I FWO & 13.14167 & COPY & 1 & INPUT & MEAN \\
\hline PERLND & 274 & PWATER & AGWI & 13.14167 & COPY & 1 & INPUT & MEAN \\
\hline PERLND & 274 & PWATER & TAET & 13.14167 & COPY & 1 & INPUT & MEAN \\
\hline PERLND & 274 & SNOW & SNOWE & 13.14167 & COPY & 1 & INPUT & MEAN \\
\hline PERLND & 281 & PWATER & SURO & 17.67500 & COPY & 1 & INPUT & MEAN \\
\hline PERLND & 281 & PWATER & IFWO & 17.67500 & COPY & 1 & INPUT & MEAN \\
\hline PERLND & 281 & PWATER & AGWI & 17.67500 & COPY & 1 & INPUT & MEAN \\
\hline PERLND & 281 & PWATER & TAET & 17.67500 & COPY & 1 & INPUT & MEAN \\
\hline PERLND & 281 & SNOW & SNOWE & 17.67500 & COPY & 1 & INPUT & MEAN \\
\hline
\end{tabular}




\begin{tabular}{|c|c|c|c|c|c|c|c|c|}
\hline PERLND & 282 & PWATER & SURO & 12.34167 & COPY & 1 & INPUT & MEAN \\
\hline PERLND & 282 & PWATER & IFWO & 12.34167 & COPY & 1 & INPUT & MEAN \\
\hline PERLND & 282 & PWATER & AGWI & 12.34167 & COPY & 1 & INPUT & MEAN \\
\hline PERLND & 282 & PWATER & TAET & 12.34167 & COPY & 1 & INPUT & MEAN \\
\hline PERLND & 282 & SNOW & SNOWE & 12.34167 & COPY & 1 & INPUT & MEAN \\
\hline PERLND & 283 & PWATER & SURO & 17.18333 & COPY & 1 & INPUT & MEAN \\
\hline PERLND & 283 & PWATER & IFWO & 17.18333 & COPY & 1 & INPUT & MEAN \\
\hline PERLND & 283 & PWATER & AGWI & 17.18333 & COPY & 1 & INPUT & MEAN \\
\hline PERLND & 283 & PWATER & TAET & 17.18333 & COPY & 1 & INPUT & MEAN \\
\hline PERLND & 283 & SNOW & SNOWE & 17.18333 & COPY & 1 & INPUT & MEAN \\
\hline PERLND & 287 & PWATER & SURO & 17.38333 & COPY & 1 & INPUT & MEAN \\
\hline PERLND & 287 & PWATER & IFWO & 17.38333 & COPY & 1 & INPUT & MEAN \\
\hline PERLND & 287 & PWATER & AGWI & 17.38333 & COPY & 1 & INPUT & MEAN \\
\hline PERLND & 287 & PWATER & TAET & 17.38333 & COPY & 1 & INPUT & MEAN \\
\hline PERLND & 287 & SNOW & SNOWE & 17.38333 & COPY & 1 & INPUT & MEAN \\
\hline PERLND & 288 & PWATER & SURO & 15.50833 & COPY & 1 & INPUT & MEAN \\
\hline PERLND & 288 & PWATER & IFWO & 15.50833 & COPY & 1 & INPUT & MEAN \\
\hline PERLND & 288 & PWATER & AGWI & 15.50833 & COPY & 1 & INPUT & MEAN \\
\hline PERLND & 288 & PWATER & TAET & 15.50833 & COPY & 1 & INPUT & MEAN \\
\hline PERLND & 288 & SNOW & SNOWE & 15.50833 & COPY & 1 & INPUT & MEAN \\
\hline PERLND & 289 & PWATER & SURO & 25.54167 & COPY & 1 & INPUT & MEAN \\
\hline PERLND & 289 & PWATER & IFWO & 25.54167 & COPY & 1 & INPUT & MEAN \\
\hline PERLND & 289 & PWATER & AGWI & 25.54167 & COPY & 1 & INPUT & MEAN \\
\hline PERLND & 289 & PWATER & TAET & 25.54167 & COPY & 1 & INPUT & MEAN \\
\hline PERLND & 289 & SNOW & SNOWE & 25.54167 & COPY & 1 & INPUT & MEAN \\
\hline PERLND & 301 & PWATER & SURO & 29.51667 & COPY & 1 & INPUT & MEAN \\
\hline PERLND & 301 & PWATER & IFWO & 29.51667 & COPY & 1 & INPUT & MEAN \\
\hline PERLND & 301 & PWATER & AGWI & 29.51667 & COPY & 1 & INPUT & MEAN \\
\hline PERLND & 301 & PWATER & TAET & 29.51667 & COPY & 1 & INPUT & MEAN \\
\hline PERLND & 301 & SNOW & SNOWE & 29.51667 & COPY & 1 & INPUT & MEAN \\
\hline PERLND & 303 & PWATER & SURO & 13.80833 & COPY & 1 & INPUT & MEAN \\
\hline PERLND & 303 & PWATER & IFWO & 13.80833 & COPY & 1 & INPUT & MEAN \\
\hline PERLND & 303 & PWATER & AGWI & 13.80833 & COPY & 1 & INPUT & MEAN \\
\hline PERLND & 303 & PWATER & TAET & 13.80833 & COPY & 1 & INPUT & MEAN \\
\hline PERLND & 303 & SNOW & SNOWE & 13.80833 & COPY & 1 & INPUT & MEAN \\
\hline PERLND & 307 & PWATER & SURO & 44.43333 & COPY & 1 & INPUT & MEAN \\
\hline PERLND & 307 & PWATER & IFWO & 44.43333 & COPY & 1 & INPUT & MEAN \\
\hline PERLND & 307 & PWATER & AGWI & 44.43333 & COPY & 1 & INPUT & MEAN \\
\hline PERLND & 307 & PWATER & TAET & 44.43333 & COPY & 1 & INPUT & MEAN \\
\hline PERLND & 307 & SNOW & SNOWE & 44.43333 & COPY & 1 & INPUT & MEAN \\
\hline PERLND & 309 & PWATER & SURO & 20.00000 & COPY & 1 & INPUT & MEAN \\
\hline PERLND & 309 & PWATER & IFWO & 20.00000 & COPY & 1 & INPUT & MEAN \\
\hline PERLND & 309 & PWATER & AGWI & 20.00000 & COPY & 1 & INPUT & MEAN \\
\hline PERLND & 309 & PWATER & TAET & 20.00000 & COPY & 1 & INPUT & MEAN \\
\hline PERLND & 309 & SNOW & SNOWE & 20.00000 & COPY & 1 & INPUT & MEAN \\
\hline PERLND & 321 & PWATER & SURO & 18.95833 & COPY & 1 & INPUT & MEAN \\
\hline PERLND & 321 & PWATER & IFWO & 18.95833 & COPY & 1 & INPUT & MEAN \\
\hline PERLND & 321 & PWATER & AGWI & 18.95833 & COPY & 1 & INPUT & MEAN \\
\hline PERLND & 321 & PWATER & TAET & 18.95833 & COPY & 1 & INPUT & MEAN \\
\hline PERLND & 321 & SNOW & SNOWE & 18.95833 & COPY & 1 & INPUT & MEAN \\
\hline PERLND & 323 & PWATER & SURO & 8.05833 & COPY & 1 & INPUT & MEAN \\
\hline PERLND & 323 & PWATER & IFWO & 8.05833 & COPY & 1 & INPUT & MEAN \\
\hline PERLND & 323 & PWATER & AGWI & 8.05833 & COPY & 1 & INPUT & MEAN \\
\hline PERLND & 323 & PWATER & TAET & 8.05833 & COPY & 1 & INPUT & MEAN \\
\hline
\end{tabular}




\begin{tabular}{|c|c|c|c|c|c|c|c|c|}
\hline PERLND & 323 & SNOW & SNOWE & 8.05833 & COPY & 1 & INPUT & MEAN \\
\hline PERLND & 327 & PWATER & SURO & 24.15000 & COPY & 1 & INPUT & MEAN \\
\hline PERLND & 327 & PWATER & IFWO & 24.15000 & COPY & 1 & INPUT & MEAN \\
\hline PERLND & 327 & PWATER & AGWI & 24.15000 & COPY & 1 & INPUT & MEAN \\
\hline PERLND & 327 & PWATER & TAET & 24.15000 & COPY & 1 & INPUT & MEAN \\
\hline PERLND & 327 & SNOW & SNOWE & 24.15000 & COPY & 1 & INPUT & MEAN \\
\hline PERLND & 328 & PWATER & SURO & 8.79167 & COPY & 1 & INPUT & MEAN \\
\hline PERLND & 328 & PWATER & IFWO & 8.79167 & COPY & 1 & INPUT & MEAN \\
\hline PERLND & 328 & PWATER & AGWI & 8.79167 & COPY & 1 & INPUT & MEAN \\
\hline PERLND & 328 & PWATER & TAET & 8.79167 & COPY & 1 & INPUT & MEAN \\
\hline PERLND & 328 & SNOW & SNOWE & 8.79167 & COPY & 1 & INPUT & MEAN \\
\hline PERLND & 341 & PWATER & SURO & 96.05000 & COPY & 1 & INPUT & MEAN \\
\hline PERLND & 341 & PWATER & IFWO & 96.05000 & COPY & 1 & INPUT & MEAN \\
\hline PERLND & 341 & PWATER & AGWI & 96.05000 & COPY & 1 & INPUT & MEAN \\
\hline PERLND & 341 & PWATER & TAET & 96.05000 & COPY & 1 & INPUT & MEAN \\
\hline PERLND & 341 & SNOW & SNOWE & 96.05000 & COPY & 1 & INPUT & MEAN \\
\hline PERLND & 343 & PWATER & SURO & 49.64167 & COPY & 1 & INPUT & MEAN \\
\hline PERLND & 343 & PWATER & IFWO & 49.64167 & COPY & 1 & INPUT & MEAN \\
\hline PERLND & 343 & PWATER & AGWI & 49.64167 & COPY & 1 & INPUT & MEAN \\
\hline PERLND & 343 & PWATER & TAET & 49.64167 & COPY & 1 & INPUT & MEAN \\
\hline PERLND & 343 & SNOW & SNOWE & 49.64167 & COPY & 1 & INPUT & MEAN \\
\hline PERLND & 347 & PWATER & SURO & 173.32500 & COPY & 1 & INPUT & MEAN \\
\hline PERLND & 347 & PWATER & IFWO & 173.32500 & COPY & 1 & INPUT & MEAN \\
\hline PERLND & 347 & PWATER & AGWI & 173.32500 & COPY & 1 & INPUT & MEAN \\
\hline PERLND & 347 & PWATER & TAET & 173.32500 & COPY & 1 & INPUT & MEAN \\
\hline PERLND & 347 & SNOW & SNOWE & 173.32500 & COPY & 1 & INPUT & MEAN \\
\hline PERLND & 349 & PWATER & SURO & 100.06667 & COPY & 1 & INPUT & MEAN \\
\hline PERLND & 349 & PWATER & IFWO & 100.06667 & COPY & 1 & INPUT & MEAN \\
\hline PERLND & 349 & PWATER & AGWI & 100.06667 & COPY & 1 & INPUT & MEAN \\
\hline PERLND & 349 & PWATER & TAET & 100.06667 & COPY & 1 & INPUT & MEAN \\
\hline PERLND & 349 & SNOW & SNOWE & 100.06667 & COPY & 1 & INPUT & MEAN \\
\hline PERLND & 361 & PWATER & SURO & 77.14167 & COPY & 1 & INPUT & MEAN \\
\hline PERLND & 361 & PWATER & IFWO & 77.14167 & COPY & 1 & INPUT & MEAN \\
\hline PERLND & 361 & PWATER & AGWI & 77.14167 & COPY & 1 & INPUT & MEAN \\
\hline PERLND & 361 & PWATER & TAET & 77.14167 & COPY & 1 & INPUT & MEAN \\
\hline PERLND & 361 & SNOW & SNOWE & 77.14167 & COPY & 1 & INPUT & MEAN \\
\hline PERLND & 363 & PWATER & SURO & 9.26667 & COPY & 1 & INPUT & MEAN \\
\hline PERLND & 363 & PWATER & IFWO & 9.26667 & COPY & 1 & INPUT & MEAN \\
\hline PERLND & 363 & PWATER & AGWI & 9.26667 & COPY & 1 & INPUT & MEAN \\
\hline PERLND & 363 & PWATER & TAET & 9.26667 & COPY & 1 & INPUT & MEAN \\
\hline PERLND & 363 & SNOW & SNOWE & 9.26667 & COPY & 1 & INPUT & MEAN \\
\hline PERLND & 367 & PWATER & SURO & 19.40833 & COPY & 1 & INPUT & MEAN \\
\hline PERLND & 367 & PWATER & IFWO & 19.40833 & COPY & 1 & INPUT & MEAN \\
\hline PERLND & 367 & PWATER & AGWI & 19.40833 & COPY & 1 & INPUT & MEAN \\
\hline PERLND & 367 & PWATER & TAET & 19.40833 & COPY & 1 & INPUT & MEAN \\
\hline PERLND & 367 & SNOW & SNOWE & 19.40833 & COPY & 1 & INPUT & MEAN \\
\hline PERLND & 381 & PWATER & SURO & 55.98333 & COPY & 1 & INPUT & MEAN \\
\hline PERLND & 381 & PWATER & IFWO & 55.98333 & COPY & 1 & INPUT & MEAN \\
\hline PERLND & 381 & PWATER & AGWI & 55.98333 & COPY & 1 & INPUT & MEAN \\
\hline PERLND & 381 & PWATER & TAET & 55.98333 & COPY & 1 & INPUT & MEAN \\
\hline PERLND & 381 & SNOW & SNOWE & 55.98333 & COPY & 1 & INPUT & MEAN \\
\hline PERLND & 383 & PWATER & SURO & 16.18333 & COPY & 1 & INPUT & MEAN \\
\hline PERLND & 383 & PWATER & IFWO & 16.18333 & COPY & 1 & INPUT & MEAN \\
\hline PERLND & 383 & PWATER & AGWI & 16.18333 & COPY & 1 & INPUT & MEAN \\
\hline
\end{tabular}




\begin{tabular}{|c|c|c|c|c|c|c|c|c|c|c|}
\hline PERLND & 383 & PWATER & TAET & & 16.18333 & COPY & 1 & INPUT & MEAN & 3 \\
\hline PERLND & 383 & SNOW & SNOWE & & 16.18333 & COPY & 1 & INPUT & MEAN & 3 \\
\hline PERLND & 387 & PWATER & SURO & & 69.16666 & COPY & 1 & INPUT & MEAN & 1 \\
\hline PERLND & 387 & PWATER & IFWO & & 69.16666 & COPY & 1 & INPUT & MEAN & 1 \\
\hline PERLND & 387 & PWATER & AGWI & & 69.16666 & COPY & 1 & INPUT & MEAN & 2 \\
\hline PERLND & 387 & PWATER & TAET & & 69.16666 & COPY & 1 & INPUT & MEAN & 3 \\
\hline PERLND & 387 & SNOW & SNOWE & & 69.16666 & COPY & 1 & INPUT & MEAN & 3 \\
\hline PERLND & 389 & PWATER & SURO & & 28.42500 & COPY & 1 & INPUT & MEAN & 1 \\
\hline PERLND & 389 & PWATER & IFWO & & 28.42500 & COPY & 1 & INPUT & MEAN & 1 \\
\hline PERLND & 389 & PWATER & AGWI & & 28.42500 & COPY & 1 & INPUT & MEAN & 2 \\
\hline PERLND & 389 & PWATER & TAET & & 28.42500 & COPY & 1 & INPUT & MEAN & 3 \\
\hline PERLND & 389 & SNOW & SNOWE & & 28.42500 & COPY & 1 & INPUT & MEAN & 3 \\
\hline PERLND & 441 & PWATER & SURO & & 10.71667 & COPY & 1 & INPUT & MEAN & 1 \\
\hline PERLND & 441 & PWATER & IFWO & & 10.71667 & COPY & 1 & INPUT & MEAN & 1 \\
\hline PERLND & 441 & PWATER & AGWI & & 10.71667 & COPY & 1 & INPUT & MEAN & 2 \\
\hline PERLND & 441 & PWATER & TAET & & 10.71667 & COPY & 1 & INPUT & MEAN & 3 \\
\hline PERLND & 441 & SNOW & SNOWE & & 10.71667 & COPY & 1 & INPUT & MEAN & 3 \\
\hline PERLND & 447 & PWATER & SURO & & 16.18333 & COPY & 1 & INPUT & MEAN & 1 \\
\hline PERLND & 447 & PWATER & IFWO & & 16.18333 & COPY & 1 & INPUT & MEAN & 1 \\
\hline PERLND & 447 & PWATER & AGWI & & 16.18333 & COPY & 1 & INPUT & MEAN & 2 \\
\hline PERLND & 447 & PWATER & TAET & & 16.18333 & COPY & 1 & INPUT & MEAN & 3 \\
\hline PERLND & 447 & SNOW & SNOWE & & 16.18333 & COPY & 1 & INPUT & MEAN & 3 \\
\hline PERLND & 481 & PWATER & SURO & & 28.66667 & COPY & 1 & INPUT & MEAN & 1 \\
\hline PERLND & 481 & PWATER & IFWO & & 28.66667 & COPY & 1 & INPUT & MEAN & 1 \\
\hline PERLND & 481 & PWATER & AGWI & & 28.66667 & COPY & 1 & INPUT & MEAN & 2 \\
\hline PERLND & 481 & PWATER & TAET & & 28.66667 & COPY & 1 & INPUT & MEAN & 3 \\
\hline PERLND & 481 & SNOW & SNOWE & & 28.66667 & COPY & 1 & INPUT & MEAN & 3 \\
\hline PERLND & 487 & PWATER & SURO & & 44.05000 & COPY & 1 & INPUT & MEAN & 1 \\
\hline PERLND & 487 & PWATER & IFWO & & 44.05000 & COPY & 1 & INPUT & MEAN & 1 \\
\hline PERLND & 487 & PWATER & AGWI & & 44.05000 & COPY & 1 & INPUT & MEAN & 2 \\
\hline PERLND & 487 & PWATER & TAET & & 44.05000 & COPY & 1 & INPUT & MEAN & 3 \\
\hline PERLND & 487 & SNOW & SNOWE & & 44.05000 & COPY & 1 & INPUT & MEAN & 3 \\
\hline \multicolumn{11}{|c|}{$\star \star \star$ Basin water balance information } \\
\hline \multicolumn{11}{|c|}{$\star * *$ Total ppt. Mfact is fractic } \\
\hline PERLND & 201 & SNOW & RAINF & & .683 & COPY & 1 & INPUT & MEAN & 4 \\
\hline PERLND & 201 & SNOW & SNOWF & & .683 & COPY & 1 & INPUT & MEAN & 4 \\
\hline PERLND & 301 & SNOW & RAINF & & .284 & COPY & 1 & INPUT & MEAN & 4 \\
\hline PERLND & 301 & SNOW & SNOWF & & .284 & COPY & 1 & INPUT & MEAN & 4 \\
\hline PERLND & 441 & SNOW & RAINF & & .033 & COPY & 1 & INPUT & MEAN & 4 \\
\hline PERLND & 441 & SNOW & SNOWF & & .033 & COPY & 1 & INPUT & MEAN & 4 \\
\hline \multicolumn{11}{|c|}{$\star * *$ Basin water-balance displays (runoff) } \\
\hline COPY & 1 & OUTPUT & MEAN & 1 & & DISPLY & 1 & INPUT & TIMSER 1 & 1 \\
\hline \multicolumn{11}{|c|}{$\begin{array}{l}\text { END NETWORK } \\
\star \star \star\end{array}$} \\
\hline \multicolumn{11}{|c|}{ EXT TARGETS } \\
\hline \multicolumn{2}{|c|}{$\begin{array}{l}<- \text { Volume }-> \\
\star \star \star\end{array}$} & $<-\mathrm{Grp}>$ & $<-$ Membe & er- & $><--$ Mult-- $>$ Tran & $<-$ Volume & $e->$ & $<$ Member $>\mathrm{T}$ & Tsys Tgap & Amd \\
\hline 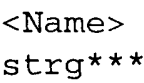 & \# & & $<$ Name $>$ & $\#$ & $\#<-$ factor->strg & $<$ Name $>$ & \# & $<$ Name $>$ & tem strg & \\
\hline COPY & 1 & OUTPUT & MEAN & 1 & SAME & WDM & 436 & $\mathrm{RO} 4$ & ENGL & REPL \\
\hline COPY & 1 & OUTPUT & MEAN & 3 & SAME & WDM & 437 & ET4 & ENGL & REPL \\
\hline COPY & 1 & OUTPUT & MEAN & 2 & SAME & WDM & 438 & DP4 & ENGL & REPL \\
\hline COPY & 1 & OUTPUT & MEAN & 4 & SAME & WDM & 439 & PT4 & ENGL & REPL \\
\hline
\end{tabular}

END EXT TARGETS 
DISPLY

DISPLY-INFO1

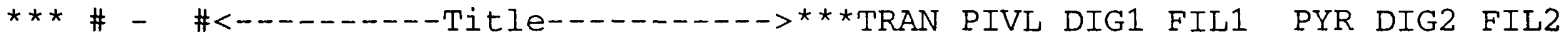

YRND

1 Dry4 -Runoff (ac-ft ) SUM $\quad 1$

509

END DISPLY-INFO1

END DISPLY

COPY

TIMESERIES

\# - \# NPT NMN

14

END TIMESERIES

END COPY

$\star \star$

SPEC-ACTIONS (Not shown)

END SPEC-ACTIONS

END RUN 
Appendix 5.--Final HSPF input file for Middle Dry Creek model. For brevity, the "SPECIAL ACTIONS" portion of the model input, where the dates of soil freezing and thawing are represented by changes in the INFILT parameter values, is not included. Complete input files may be obtained by contacting the District Chief at the address shown on page ii of this report

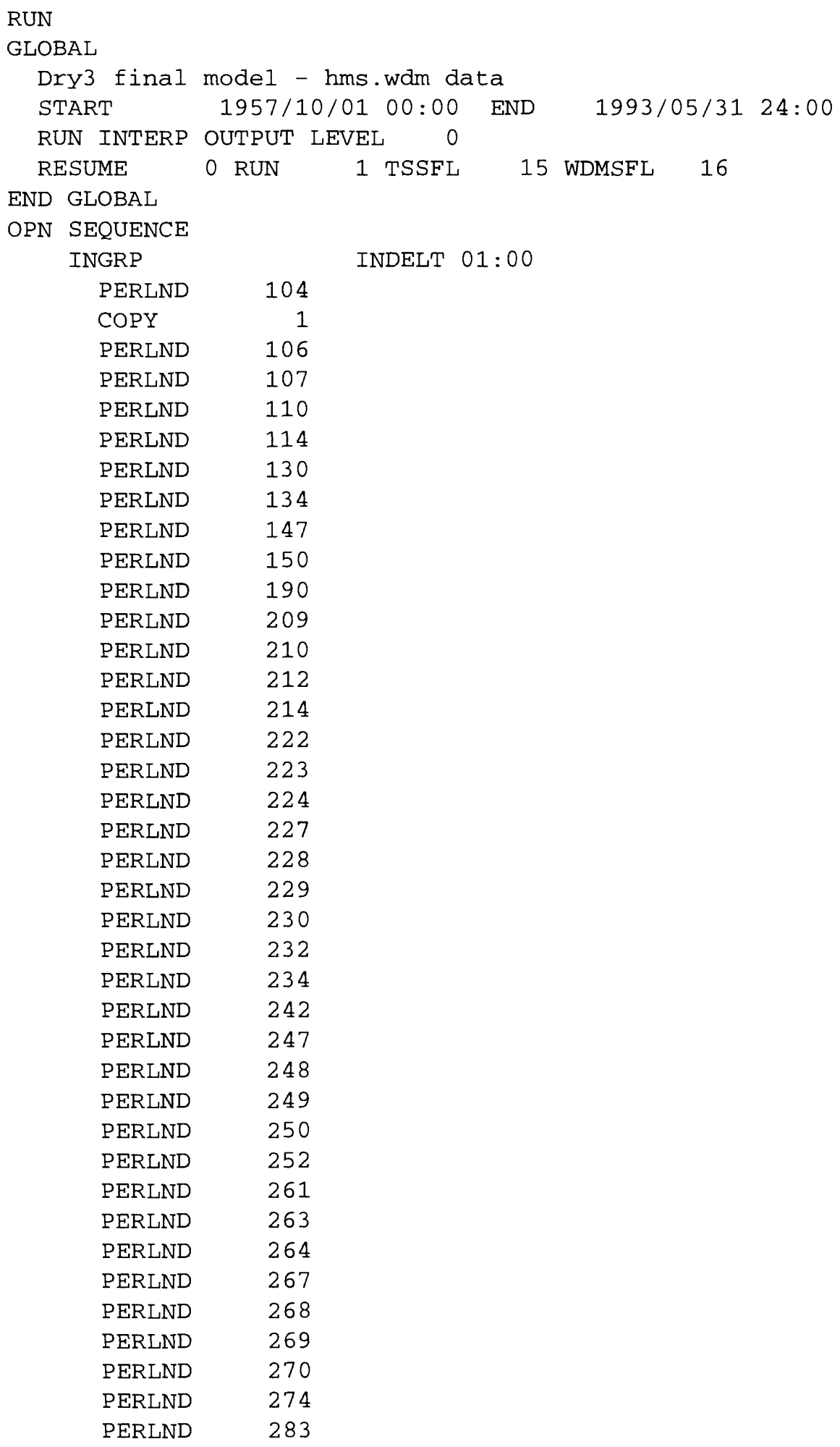




$\begin{array}{lr}\text { PERLND } & 287 \\ \text { PERLND } & 288 \\ \text { PERLND } & 289 \\ \text { PERLND } & 290 \\ \text { PERLND } & 307 \\ \text { PERLND } & 321 \\ \text { PERLND } & 327 \\ \text { PERLND } & 328 \\ \text { PERLND } & 343 \\ \text { PERLND } & 347 \\ \text { PERLND } & 361 \\ \text { PERLND } & 363 \\ \text { PERLND } & 364 \\ \text { PERLND } & 367 \\ \text { PERLND } & 370 \\ \text { PERLND } & 387 \\ \text { PERLND } & 388 \\ \text { PERLND } & 421 \\ \text { PERLND } & 427 \\ \text { COPY } & 2 \\ \text { COPY } & 3 \\ \text { DISPLY } & 2 \\ \text { END INGRP } & \\ \text { PN }\end{array}$

END OPN SEQUENCE

PERIND

ACTIVITY

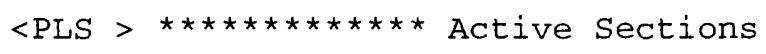

\# - \# ATMP SNOW PWAT SED PST PWG PQAL MSTL PEST NITR PHOS TRAC $\star \star \star$

$\begin{array}{lllllllllllll}104 & 427 & 0 & 1 & 1 & 0 & 0 & 0 & 0 & 0 & 0 & 0 & 0\end{array}$

END ACTIVITY

PRINT-INFO

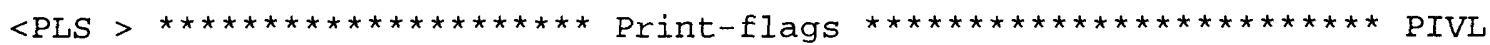

PYR

\# - \# ATMP SNOW PWAT SED PST PWG PQAL MSTL PEST NITR PHOS TRAC

\section{$\star \star \star \star * * * *$
104}

6 $106 \quad 427$

6

END PRINT-INFO

GEN-INFO

$<$ PLS $><-\ldots$ NAME- $-\cdots$ Unit-systems Printer

$\star \star \star *-\#$

User $t$-series Engl Metr

in out

$\star \star \star$ Grouped by elevation zone $* \star *$

$\begin{array}{llllllll}104 & \text { sage, soil1, flat } & 1 & 1 & 1 & 1 & 6 & 0 \\ 106 & \text { irri, soil4, flat } & 1 & 1 & 1 & 1 & 6 & 0 \\ 107 & \text { gras, soil1, flat } & 1 & 1 & 1 & 1 & 6 & 0 \\ 110 & \text { gras, soil4, flat } & 1 & 1 & 1 & 1 & 6 & 0 \\ 114 & \text { dryw, soil4, flat } & 1 & 1 & 1 & 1 & 6 & 0\end{array}$




\begin{tabular}{|c|c|c|c|c|c|c|}
\hline 130 & gras, soil4, mod.N & 1 & 1 & 1 & 1 & 6 \\
\hline 134 & dryw, soil4, mod.N & 1 & 1 & 1 & 1 & 6 \\
\hline 147 & gras, soil1, mod.s & 1 & 1 & 1 & 1 & 6 \\
\hline 150 & gras, soil4, mod.s & 1 & 1 & 1 & 1 & 6 \\
\hline 190 & gras, soil4, stp.s & 1 & 1 & 1 & 1 & 6 \\
\hline 209 & gras, soil3, flat & 1 & 1 & 1 & 1 & 6 \\
\hline 210 & gras, soil4, flat & 1 & 1 & 1 & 1 & 6 \\
\hline 212 & dryw, soil $2, \bmod . \mathrm{N}$ & 1 & 1 & 1 & 1 & 6 \\
\hline 214 & dryw, soil $4, \bmod . \mathrm{N}$ & 1 & 1 & 1 & 1 & 6 \\
\hline 222 & sage, soil2, mod.N & 1 & 1 & 1 & 1 & 6 \\
\hline 223 & sage, soil3, mod.N & 1 & 1 & 1 & 1 & 6 \\
\hline 224 & sage, soil4, mod.N & 1 & 1 & 1 & 1 & 6 \\
\hline 227 & gras, soil1, mod.N & 1 & 1 & 1 & 1 & 6 \\
\hline 228 & gras, soil2, $\bmod . \mathrm{N}$ & 1 & 1 & 1 & 1 & 6 \\
\hline 229 & gras, soil3, mod.N & 1 & 1 & 1 & 1 & 6 \\
\hline 230 & gras, soil4, mod.N & 1 & 1 & 1 & 1 & 6 \\
\hline 232 & dryw, soil2, mod.N & 1 & 1 & 1 & 1 & 6 \\
\hline 234 & dryw, soil4, mod.N & 1 & 1 & 1 & 1 & 6 \\
\hline 242 & sage, soil2, mod.s & 1 & 1 & 1 & 1 & 6 \\
\hline 247 & gras, soill, mod.s & 1 & 1 & 1 & 1 & 6 \\
\hline 248 & gras, soill,mod.s & 1 & 1 & 1 & 1 & 6 \\
\hline 249 & gras, soil3, mod.s & 1 & 1 & 1 & 1 & 6 \\
\hline 250 & gras, soil4, mod.s & 1 & 1 & 1 & 1 & 6 \\
\hline 252 & dryw, soil2, mod.s & 1 & 1 & 1 & 1 & 6 \\
\hline 261 & sage, soil1, stp.N & 1 & 1 & 1 & 1 & 6 \\
\hline 263 & sage, soil3, stp.N & 1 & 1 & 1 & 1 & 6 \\
\hline 264 & sage, soil4, stp.N & 1 & 1 & 1 & 1 & 6 \\
\hline 267 & gras, soil1, stp.N & 1 & 1 & 1 & 1 & 6 \\
\hline 268 & gras, soil2, stp.N & 1 & 1 & 1 & 1 & 6 \\
\hline 269 & gras, soil3, stp.N & 1 & 1 & 1 & 1 & 6 \\
\hline 270 & gras, soil4, stp.N & 1 & 1 & 1 & 1 & 6 \\
\hline 274 & dryw, soil4, stp.N & 1 & 1 & 1 & 1 & 6 \\
\hline 283 & sage, soil3, stp.S & 1 & 1 & 1 & 1 & 6 \\
\hline 287 & gras, soil1, stp.s & 1 & 1 & 1 & 1 & 6 \\
\hline 288 & gras, soil1, stp.s & 1 & 1 & 1 & 1 & 6 \\
\hline 289 & gras, soil3, stp.s & 1 & 1 & 1 & 1 & 6 \\
\hline 290 & gras, soil4, stp.s & 1 & 1 & 1 & 1 & 6 \\
\hline 307 & gras, soill, flat & 1 & 1 & 1 & 1 & 6 \\
\hline 321 & sage, soill, mod.N & 1 & 1 & 1 & 1 & 6 \\
\hline 327 & gras, soill, mod.N & 1 & 1 & 1 & 1 & 6 \\
\hline 328 & gras, soil1, mod.N & 1 & 1 & 1 & 1 & 6 \\
\hline 343 & sage, soil3, mod.s & 1 & 1 & 1 & 1 & 6 \\
\hline 347 & gras, soil1, mod.s & 1 & 1 & 1 & 1 & 6 \\
\hline 361 & sage, soill, stp.N & 1 & 1 & 1 & 1 & 6 \\
\hline 363 & sage, soil3, stp.N & 1 & 1 & 1 & 1 & 6 \\
\hline 364 & sage, soil4, stp.N & 1 & 1 & 1 & 1 & 6 \\
\hline 367 & gras, soill, stp.N & 1 & 1 & 1 & 1 & 6 \\
\hline 370 & dryw, soil4, stp.N & 1 & 1 & 1 & 1 & 6 \\
\hline 387 & gras, soil1, stp.s & 1 & 1 & 1 & 1 & 6 \\
\hline 388 & gras, soil2, stp, s & 1 & 1 & 1 & 1 & 6 \\
\hline 421 & sage, soil1, mod.N & 1 & 1 & 1 & 1 & 6 \\
\hline 427 & gras, soill, mod.N & 1 & 1 & 1 & 1 & 6 \\
\hline
\end{tabular}


$<$ PLS > Value of 1 means ice will be simulated, 0 means not simulated

\# - \#ICEFG

$104 \quad 427 \quad 1$

END ICE-FLAG

SNOW-PARM1

perlnd perlnd shaded gage-catch snow w.eq. needed for

\begin{tabular}{|c|c|c|c|c|c|c|}
\hline$\star \star \star$ & FLS & latitude & altitude & fraction & adjustment & complet \\
\hline \# & - & LAT & MELEV & SHADE & SNOWCF & COVIND \\
\hline$\star \star \star$ & & & & & & \\
\hline 104 & 190 & 46.6 & 820 . & 0.0 & 1.25 & 0.5 \\
\hline 209 & 290 & 46.6 & 1805. & 0.0 & 1.25 & 0.5 \\
\hline 307 & 388 & 46.6 & 2789 . & 0.0 & 1.25 & 0.5 \\
\hline 421 & 427 & 46.6 & 3609 & 0.0 & 1.25 & 0.5 \\
\hline
\end{tabular}

END SNOW-PARM1

SNOW-PARM2

\begin{tabular}{|c|c|c|c|c|c|c|c|}
\hline$\star \star \star$ & & new snow & rain vs & sublim. & latent ht. & $\max$ AWC & ground \\
\hline$\star \star \star *$ & PLS > & density & snow & adjust & adjust & of pack & melt \\
\hline$\star * *$ & $-\quad \#$ & RDCSN & TSNOW & SNOEVP & CCFACT & MWATER & MGMELT \\
\hline $\begin{array}{l}104 \\
\text { END } \\
\text { SNOI }\end{array}$ & $\begin{array}{r}427 \\
\text { SNOW } \\
W-I N I\end{array}$ & $\begin{array}{l}0.05 \\
\text { PARM2 } \\
1\end{array}$ & 32 . & 0.85 & 1.5 & 0.08 & 0.02 \\
\hline 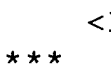 & PLS > & SNOW initia & al condit & ions & & & \\
\hline$\star \star *$ & - \# & PACKSNOW & PACKICE & PACKWATER & RDENPF & DULL & PAKTMP \\
\hline $\begin{array}{l}104 \\
\text { END } \\
\text { SNO }\end{array}$ & $\begin{array}{r}427 \\
\text { SNOW } \\
W-I N I\end{array}$ & $\begin{array}{ll} & 0.0 \\
\text { INIT1 } & \end{array}$ & 0.0 & 0.0 & 0.2 & 400 & 32.0 \\
\hline$\star * *$ & PLS > & SNOW initia & al condit & ions & & & \\
\hline$\star \star \star * ~ \#$ & $-\quad \#$ & COVINX & XLNMELT & SKYCLR & & & \\
\hline $\begin{array}{l}104 \\
\text { END }\end{array}$ & $\begin{array}{r}427 \\
\text { SNOW }\end{array}$ & ${ }^{0.50}$ & 0.0 & 1.0 & & & \\
\hline
\end{tabular}

PWAT-PARM1

$<$ PLS > PWATER variable monthly parameter value flags

Snow cepsc uzns nsur intew irc lzetp

\# - \# CSNO RTOP UZFG VCS VUZ VNN VIFW VIRC VLE

$\begin{array}{llllllllll}104 & 427 & 1 & 0 & 0 & 1 & 0 & 0 & 0 & 0\end{array}$

END PWAT-PARM1

PWAT-PARM2

$\langle\mathrm{PLS}>* * *$

$\#-\# * * *$ FOREST LZSN INFILT ISUR SLSUR KVARY

AGWRC 


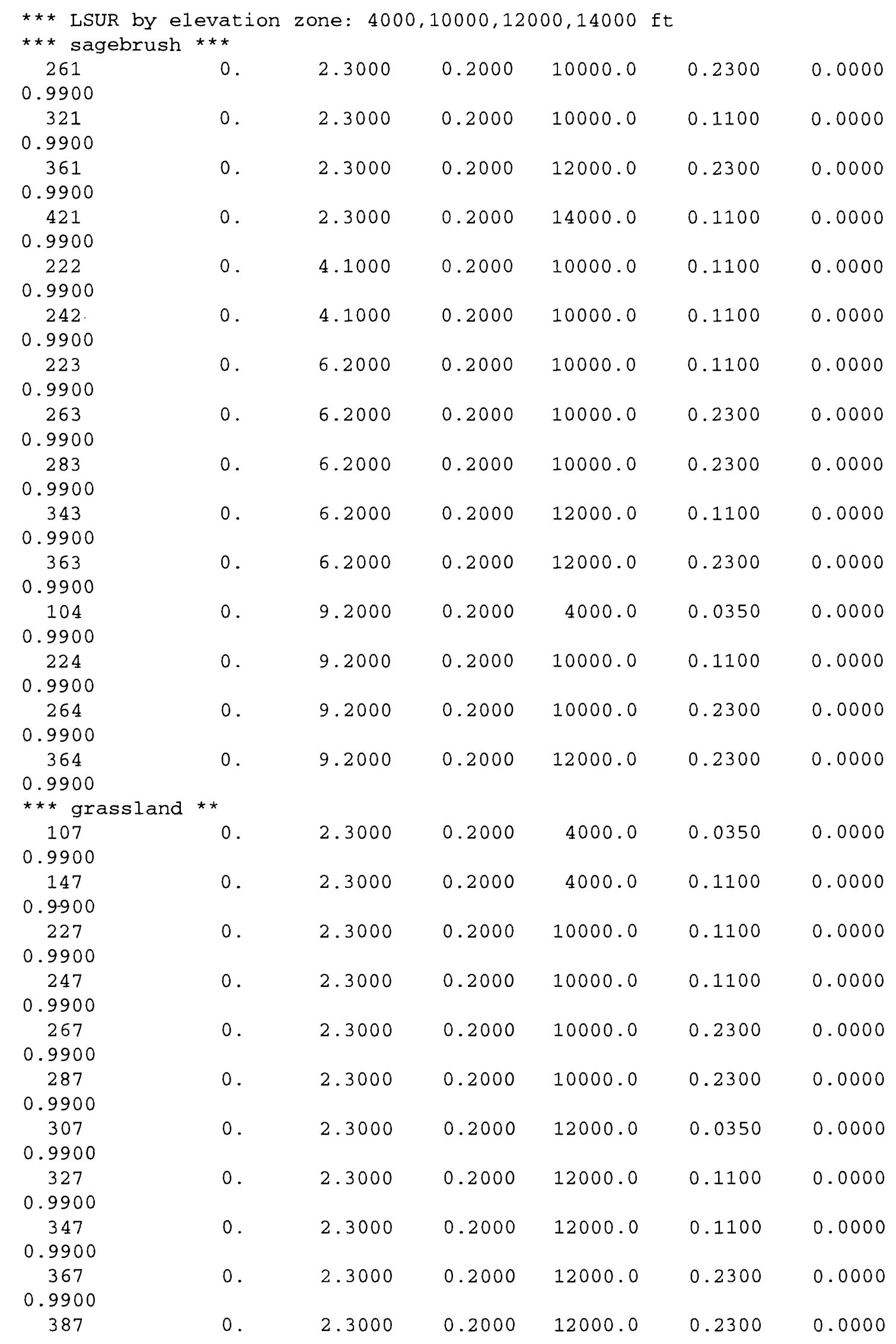




\begin{tabular}{|c|c|c|c|c|c|c|}
\hline 0.9900 & & & & & & \\
\hline 427 & 0. & 2.3000 & 0.2000 & 14000.0 & 0.1100 & 0.0000 \\
\hline 0.9900 & & & & & & \\
\hline 228 & 0 . & 4.1000 & 0.2000 & 10000.0 & 0.1100 & 0.0000 \\
\hline 0.9900 & & & & & & \\
\hline 248 & 0 . & 4.1000 & 0.2000 & 10000.0 & 0.1100 & 0.0000 \\
\hline 0.9900 & & & & & & \\
\hline 268 & 0 . & 4.1000 & 0.2000 & 10000.0 & 0.2300 & 0.0000 \\
\hline 0.9900 & & & & & & \\
\hline 288 & 0 . & 4.1000 & 0.2000 & 10000.0 & 0.2300 & 0.0000 \\
\hline 0.9900 & & & & & & \\
\hline 328 & 0. & 4.1000 & 0.2000 & 12000.0 & 0.1100 & 0.0000 \\
\hline 0.9900 & & & & & & \\
\hline 388 & 0 . & 4.1000 & 0.2000 & 12000.0 & 0.2300 & 0.0000 \\
\hline 0.9900 & & & & & & \\
\hline 209 & 0 . & 2.9000 & 0.2000 & 10000.0 & 0.0350 & 0.0000 \\
\hline 0.9900 & & & & & & \\
\hline 229 & 0 . & 2.9000 & 0.2000 & 10000.0 & 0.1100 & 0.0000 \\
\hline 0.9900 & & & & & & \\
\hline 249 & 0 . & 2.9000 & 0.2000 & 10000.0 & 0.1100 & 0.0000 \\
\hline 0.9900 & & & & & & \\
\hline 269 & 0. & 2.9000 & 0.2000 & 10000.0 & 0.2300 & 0.0000 \\
\hline 0.9900 & & & & & & \\
\hline 289 & 0 . & 2.9000 & 0.2000 & 10000.0 & 0.2300 & 0.0000 \\
\hline 0.9900 & & & & & & \\
\hline 110 & 0. & 4.6000 & 0.2000 & 4000.0 & 0.0350 & 0.0000 \\
\hline 0.9900 & & & & & & \\
\hline 130 & 0 & 4.6000 & 0.2000 & 4000.0 & 0.1100 & 0.0000 \\
\hline 0.9900 & & & & & & \\
\hline 150 & 0. & 4.6000 & 0.2000 & 4000.0 & 0.1100 & 0.0000 \\
\hline 0.9900 & & & & & & \\
\hline 190 & 0. & 4.6000 & 0.2000 & 4000.0 & 0.2300 & 0.0000 \\
\hline 0.9900 & & & & & & \\
\hline 210 & 0 & 4.6000 & 0.2000 & 10000.0 & 0.1100 & 0.0000 \\
\hline 0.9900 & & & & & & \\
\hline 230 & 0 . & 4.6000 & 0.2000 & 10000.0 & 0.1100 & 0.0000 \\
\hline 0.9900 & & & & & & \\
\hline 250 & 0. & 4.6000 & 0.2000 & 10000.0 & 0.1100 & 0.0000 \\
\hline 0.9900 & & & & & & \\
\hline 270 & 0. & 4.6000 & 0.2000 & 10000.0 & 0.2300 & 0.0000 \\
\hline 0.9900 & & & & & & \\
\hline 290 & 0. & 4.6000 & 0.2000 & 10000.0 & 0.2300 & 0.0000 \\
\hline 0.9900 & & & & & & \\
\hline 370 & 0 . & 4.6000 & 0.2000 & 12000.0 & 0.2300 & 0.0000 \\
\hline 0.9900 & & & & & & \\
\hline$\star \star \star$ dry. wheat & $\star \star \star$ & & & & & \\
\hline 212 & 0 & 4.1000 & 0.2000 & 10000.0 & 0.0350 & 0.0000 \\
\hline 0.9900 & & & & & & \\
\hline 232 & 0 . & 4.1000 & 0.2000 & 10000.0 & 0.0350 & 0.0000 \\
\hline 0.9900 & & & & & & \\
\hline 252 & 0. & 4.1000 & 0.2000 & 10000.0 & 0.1100 & 0.0000 \\
\hline 0.9900 & & & & & & \\
\hline 114 & 0 . & 9.2000 & 0.2000 & 4000.0 & 0.0350 & 0.0000 \\
\hline 0.9900 & & & & & & \\
\hline
\end{tabular}




\begin{tabular}{|c|c|c|c|c|c|c|}
\hline 134 & 0. & 9.2000 & 0.2000 & 4000.0 & 0.1100 & 0.0000 \\
\hline $\begin{array}{l}.9900 \\
214\end{array}$ & 0 & 92000 & ח 200 & 0 & 00350 & \\
\hline 0.9900 & & & & & טתנט. & \\
\hline $\begin{array}{r}234 \\
0.9900\end{array}$ & 0 . & 9.2000 & 0.2000 & 10000.0 & 0.1100 & 0.0000 \\
\hline $\begin{array}{c}274 \\
0.9900 \\
\star \star \star * i r r * \star *\end{array}$ & 0. & 9.2000 & 0.2000 & 10000.0 & 0.2300 & 0.0000 \\
\hline 106 & 0. & 9.2000 & 0.2000 & 4000.0 & 0.0350 & 0.0000 \\
\hline
\end{tabular}

END PWAT-PARM2

PWAT-PARM3

$<$ PLS $>* \star *$

\# - \#*** PETMAX

PETMIN INFEXP

INFILD

DEEPFR

BASETP

AGWETP

$104 \quad 427$

35.

0.2500

2.0000

.00

0 .

END PWAT-PARM3

PWAT-PARM4

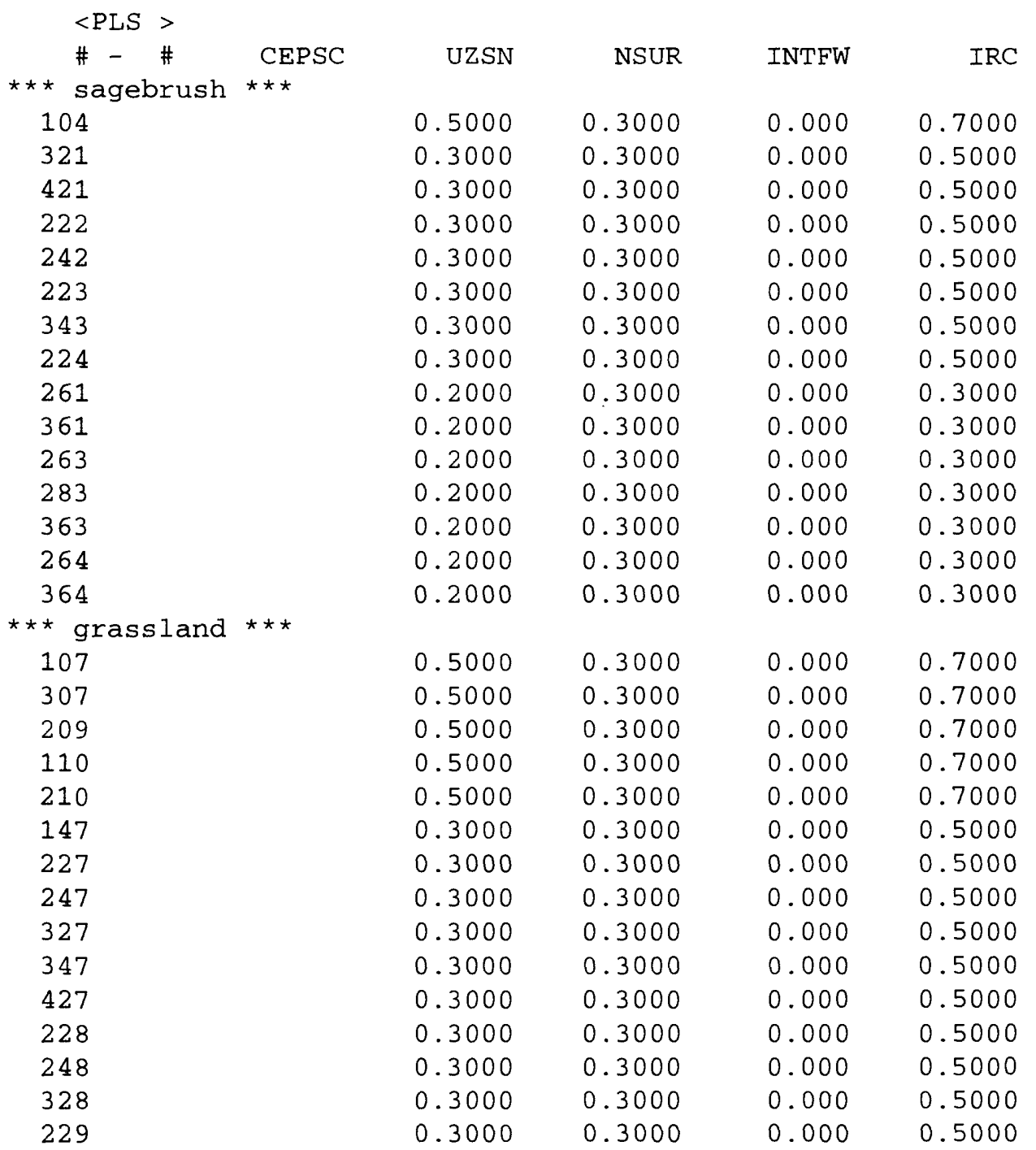




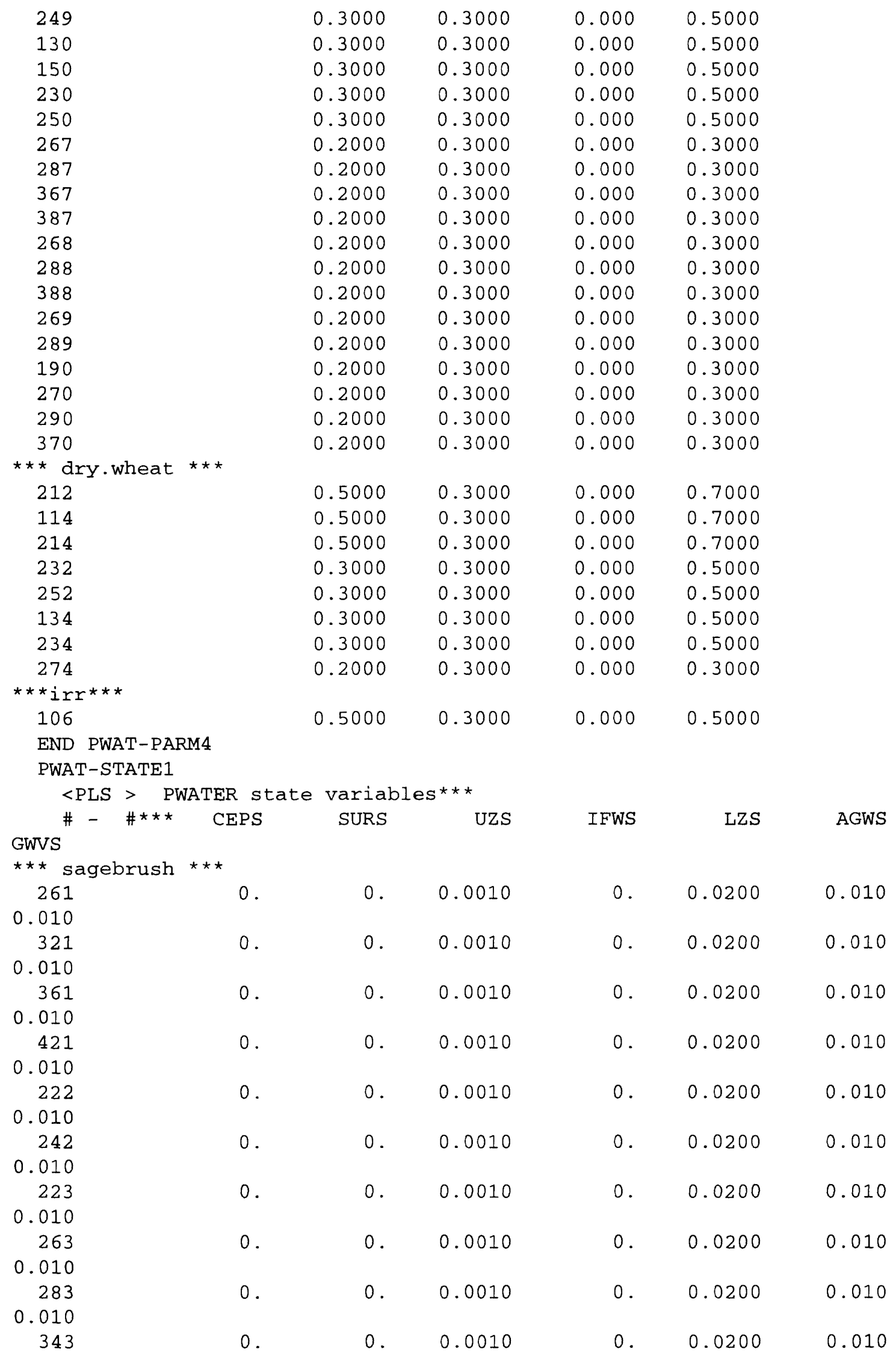




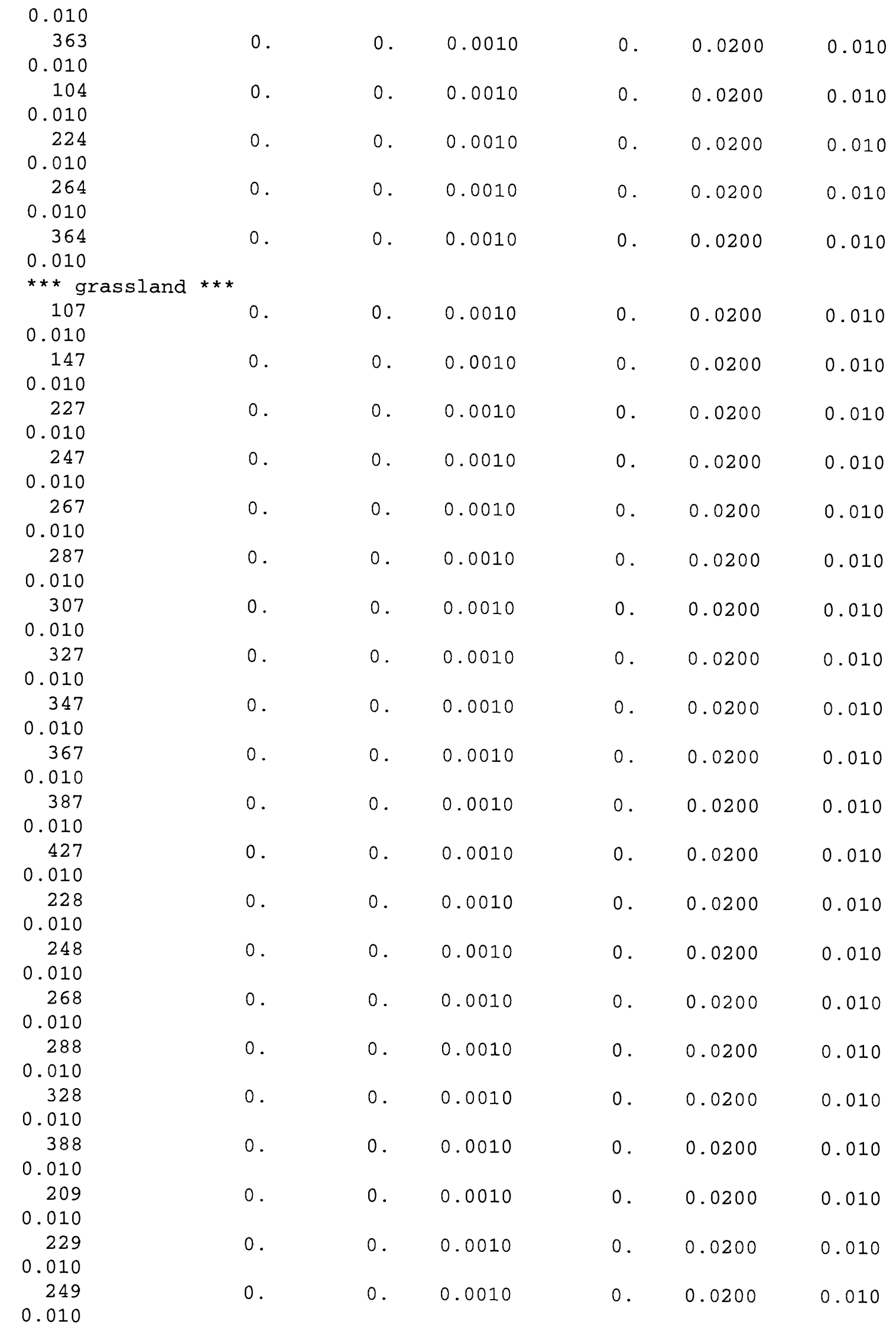




\begin{tabular}{|c|c|c|c|c|c|c|}
\hline \multirow{2}{*}{\multicolumn{7}{|c|}{$\begin{array}{r}269 \\
0.010\end{array}$}} \\
\hline & & & & & & \\
\hline 289 & 0 . & 0 . & 0.0010 & 0 . & 0.0200 & 0.010 \\
\hline \multicolumn{7}{|l|}{0.010} \\
\hline 110 & 0 . & 0 . & 0.0010 & 0 . & 0.0200 & 0.010 \\
\hline \multicolumn{7}{|l|}{0.010} \\
\hline 130 & 0 . & 0 . & 0.0010 & 0 . & 0.0200 & 0.010 \\
\hline \multicolumn{7}{|l|}{0.010} \\
\hline 150 & 0 . & 0 . & 0.0010 & 0 . & 0.0200 & 0.010 \\
\hline \multicolumn{7}{|l|}{0.010} \\
\hline 190 & 0 . & 0 . & 0.0010 & 0 . & 0.0200 & 0.010 \\
\hline \multicolumn{7}{|l|}{0.010} \\
\hline 210 & 0 . & 0 . & 0.0010 & 0 . & 0.0200 & 0.010 \\
\hline \multicolumn{7}{|l|}{0.010} \\
\hline 230 & 0 . & 0 . & 0.0010 & 0 . & 0.0200 & 0.010 \\
\hline \multicolumn{7}{|l|}{0.010} \\
\hline 250 & 0 . & 0 . & 0.0010 & 0 . & 0.0200 & 0.010 \\
\hline \multicolumn{7}{|l|}{0.010} \\
\hline 270 & 0 . & 0 . & 0.0010 & 0 . & 0.0200 & 0.010 \\
\hline \multicolumn{7}{|l|}{0.010} \\
\hline 290 & 0 . & 0 . & 0.0010 & 0 . & 0.0200 & 0.010 \\
\hline \multicolumn{7}{|l|}{0.010} \\
\hline 370 & 0 . & 0 . & 0.0010 & 0 . & 0.0200 & 0.010 \\
\hline \multicolumn{7}{|l|}{0.010} \\
\hline \multicolumn{7}{|l|}{$\star \star \star$ dry. wheat $* \star *$} \\
\hline 212 & 0 . & 0 . & 0.0010 & 0. & 0.0200 & 0.010 \\
\hline \multicolumn{7}{|l|}{0.010} \\
\hline 232 & 0 . & 0 . & 0.0010 & 0 . & 0.0200 & 0.010 \\
\hline \multicolumn{7}{|l|}{0.010} \\
\hline 252 & 0 . & 0 . & 0.0010 & 0 . & 0.0200 & 0.010 \\
\hline \multicolumn{7}{|l|}{0.010} \\
\hline 114 & 0. & 0 . & 0.0010 & 0 . & 0.0200 & 0.010 \\
\hline \multicolumn{7}{|l|}{0.010} \\
\hline 134 & 0 . & 0 . & 0.0010 & 0. & 0.0200 & 0.010 \\
\hline \multicolumn{7}{|l|}{0.010} \\
\hline 214 & 0. & 0 . & 0.0010 & 0 . & 0.0200 & 0.010 \\
\hline \multicolumn{7}{|l|}{0.010} \\
\hline 234 & 0 . & 0 . & 0.0010 & 0 . & 0.0200 & 0.010 \\
\hline \multicolumn{7}{|l|}{0.010} \\
\hline 274 & 0 . & 0 . & 0.0010 & 0 . & 0.0200 & 0.010 \\
\hline \multicolumn{7}{|l|}{0.010} \\
\hline$\star \star \star * i r r * \star *$ & & & & & & \\
\hline 106 & 0 . & 0 . & 0.0010 & 0 . & 0.0200 & 0.010 \\
\hline
\end{tabular}

END PWAT-STATE1

MON-INTERCEP

$<$ PLS> Only required if $\mathrm{VCSFG}=1$ in PWAT-PARM1

\# - \# Interception storage capacity at start of each month JAN FEB MAR APR MAY JUN JUL AUG SEP OCT NOV DEC ***

*** sagebrush $* * *$

$\begin{array}{lllllllllllllll}261 & 0.04 & 0.06 & 0.06 & 0.06 & 0.05 & 0.05 & 0.04 & 0.04 & 0.04 & 0.05 & 0.04 & 0.04\end{array}$

$\begin{array}{llllllllllllll}321 & 0.04 & 0.06 & 0.06 & 0.06 & 0.05 & 0.05 & 0.04 & 0.04 & 0.04 & 0.05 & 0.04 & 0.04\end{array}$

$\begin{array}{llllllllllllll}361 & 0.04 & 0.06 & 0.06 & 0.06 & 0.05 & 0.05 & 0.04 & 0.04 & 0.04 & 0.05 & 0.04 & 0.04\end{array}$

$\begin{array}{llllllllllllll}421 & 0.04 & 0.06 & 0.06 & 0.06 & 0.05 & 0.05 & 0.04 & 0.04 & 0.04 & 0.05 & 0.04 & 0.04\end{array}$ 


\begin{tabular}{|c|c|c|c|c|c|c|c|c|c|c|c|c|}
\hline & & & & & & & 0.04 & & 0.04 & & & \\
\hline 242 & .04 & 0.06 & .06 & 0.06 & 0.05 & 0.05 & 0.04 & 0.04 & 0.04 & 0.05 & 0.04 & .04 \\
\hline 23 & .04 & 0.06 & .06 & .06 & 0.05 & .05 & 0.04 & 0.04 & 0.04 & 0.05 & 0.04 & 04 \\
\hline 53 & 04 & 0.06 & .06 & 0.06 & 0.05 & .05 & 0.04 & 0.04 & 0.04 & 0.05 & 0.04 & 0,0 \\
\hline 33 & & .06 & .06 & 0.06 & 0.05 & .05 & 0.04 & 0.04 & 0.04 & 0.05 & 0.04 & 00 \\
\hline 3 & & .06 & .06 & 0.06 & 0.05 & .05 & 0.04 & 0.04 & 0.04 & 0.05 & 0.04 & 0 \\
\hline 3 & & .06 & .06 & 0.06 & 0.05 & & 0.04 & 0.04 & 0.04 & 0.05 & 0.04 & 0 \\
\hline 104 & & 0.06 & .06 & 0.06 & 0.05 & 0.05 & 0.04 & 0.04 & 0.04 & 0.05 & 0.04 & 0 \\
\hline 224 & & 0.06 & & 0.06 & & & 0.04 & 0.04 & 0.04 & 0.05 & 0.04 & .0 \\
\hline 264 & & 0.06 & .06 & 0.06 & 0.05 & 0.05 & 0.04 & 0.04 & 0.04 & 0.05 & 0.04 & 0.0 \\
\hline 364 & & 0.06 & .06 & 0.06 & 0.05 & 0.05 & 0.04 & 0.04 & 0.04 & 0.05 & 0.04 & 0.0 \\
\hline * gras & $\star \star \star$ & & & & & & & & & & & \\
\hline 107 & 0.03 & .04 & .05 & 0.06 & 0.06 & 0.06 & 0.06 & 0.06 & 0.06 & & 0.04 & 0.0 \\
\hline 147 & 3 & 0.04 & .05 & 0.06 & 0.06 & 06 & 0.06 & 0.06 & 0.06 & 0. & 04 & 0.0 \\
\hline 227 & 0.03 & 0.04 & .05 & 0.06 & 0.06 & 0.06 & 0.06 & 0.06 & 0.06 & 0. & 0.04 & \\
\hline 247 & 0.03 & 0.04 & .05 & 0.06 & 0.06 & 0.06 & 0.06 & 0.06 & 0.06 & 0. & & \\
\hline 267 & 0.03 & 0.04 & .05 & 0.06 & 0.06 & 0.06 & 0.06 & 0.06 & 0.06 & & & \\
\hline 287 & 0.03 & 0.04 & .05 & 0.06 & 0.06 & 0.06 & 0.06 & 0.06 & 0.06 & & & \\
\hline 307 & 0.0 & 0.04 & .05 & 0.06 & 0. & 0.06 & 0.06 & 0.06 & 0.06 & & 0.04 & \\
\hline 327 & .03 & 0.04 & .05 & 0.06 & 0.06 & .06 & 0.06 & 0.06 & 0.06 & 0.05 & .04 & \\
\hline 347 & 3 & 0.04 & .05 & 0.06 & 0.06 & .06 & 0.06 & 0.06 & 0.06 & 0.05 & .04 & .0 \\
\hline $36^{\circ}$ & 03 & 0.04 & .05 & 0.06 & 0.06 & .06 & 0.06 & 0.06 & 0.06 & 0.05 & .04 & .0 \\
\hline $38^{\circ}$ & 03 & 0.04 & .05 & 0.06 & 0.06 & .06 & 0.06 & 0.06 & 0.06 & 0.05 & .04 & .0 \\
\hline 42 & & 0.04 & .05 & 0.06 & 0.06 & .06 & 0.06 & 0.06 & 0.06 & 05 & 4 & \\
\hline 228 & & 0.04 & .05 & 0.06 & 0.06 & 6 & 0.06 & 0.06 & 0.06 & 05 & 4 & \\
\hline 248 & .03 & 0.04 & .05 & 0.06 & 0.06 & 0.06 & 0.06 & 0 . & 0.06 & 0. & 04 & \\
\hline 268 & .03 & 0.04 & .05 & 0.06 & 0.06 & .06 & 0.06 & 0.06 & 0.06 & 0. & 0.04 & \\
\hline 288 & .03 & 0.04 & .05 & 0.06 & 0.06 & 0.06 & 0.06 & 6 & 0.06 & 0. & 0.04 & \\
\hline 328 & & 0.04 & .05 & 0.06 & 0.0 & 0.06 & 0.06 & 0.06 & 06 & 05 & 04 & \\
\hline 388 & & 0.04 & .05 & 0.06 & 0.06 & 0.06 & 0.06 & 0.06 & 0.06 & 0. & 0.04 & 0.04 \\
\hline 209 & .03 & 0.04 & .05 & 0.06 & 0.06 & 0.06 & 0.06 & 0.06 & 0.06 & 0. & 0.04 & 0.04 \\
\hline 29 & .03 & 0.04 & .05 & 0.06 & 0.06 & 0.06 & 0.06 & 0.06 & 0.06 & 0. & 04 & 0.04 \\
\hline 249 & & 0.04 & .05 & 0.06 & $0 . c$ & 0.06 & 0.06 & 0.06 & 0.06 & & & 0.04 \\
\hline 269 & & 0.04 & .05 & 0.06 & 0.0 & & 0.06 & & 0.06 & & & 0.04 \\
\hline 289 & 3 & 0.04 & 5 & 0.06 & 0.06 & 0.06 & 0.06 & 0.06 & 0.06 & 0. & & 0.04 \\
\hline 110 & & 0.04 & & 0.06 & 0.06 & 0.06 & 0.06 & 0.06 & 0.06 & 0 . & 04 & .0 \\
\hline & & 0.04 & & 0.06 & 0.06 & & 0.06 & & 06 & 0.05 & & ( \\
\hline 15 & & 0.04 & .05 & 0.06 & 0.06 & & 0.06 & & & & & .0 \\
\hline 90 & & .04 & .05 & 0.06 & 0.06 & .06 & 0.06 & 0.06 & 0.06 & & & 0 \\
\hline & & .04 & & 0.06 & $0 . c$ & .06 & 0.06 & 0.06 & 0.06 & 0. & & \\
\hline 2 & & .04 & & 0.06 & 0. & & 0.06 & & 06 & & & \\
\hline 2 & & .04 & & 0.06 & & & 0.06 & & & & & 0 \\
\hline 2 & & & & 0. & & & 0. & & & & & 0 \\
\hline 290 & & & & 0. & & & 6 & & & & & 0 \\
\hline 370 & 0.03 & & & 0.06 & & & 0.06 & & & & 0.04 & 0.0 \\
\hline & & & & & & & & & & & & \\
\hline 212 & 0.16 & 0.16 & & & & & 0.00 & & & 16 & & \\
\hline 232 & & 0.16 & .16 & 0.16 & 0.16 & 0.08 & 0.00 & 0.00 & 0.06 & 0.16 & 0.16 & 0.16 \\
\hline 252 & .16 & 0.16 & 0.16 & 0.16 & 0.16 & 0.08 & 0.00 & 0.00 & 0.06 & 0.16 & 0.16 & 0.16 \\
\hline 114 & 0.16 & 0.16 & 0.16 & 0.16 & 0.16 & 0.08 & 0.00 & 0.00 & 0.06 & 0.16 & 0.16 & 0.16 \\
\hline 134 & 0.16 & 0.16 & 0.16 & 0.16 & 0.16 & 0.08 & 0.00 & 0.00 & 0.06 & 0.16 & 0.16 & 0.16 \\
\hline & 0.16 & 0.16 & 0.16 & 0.16 & 0.16 & 0.08 & 0.00 & 0.00 & 0.06 & 0.16 & 0.16 & 0.16 \\
\hline & & 0.16 & 0.16 & 0.16 & 0.16 & 0.08 & 0.00 & 0.00 & 0.06 & 0.16 & 0.16 & 0.16 \\
\hline 74 & 0.16 & 0.16 & 0.16 & 0.16 & 0.16 & 0.08 & 0.00 & 0.00 & 0.06 & 0.16 & 0.16 & 0.1 \\
\hline
\end{tabular}




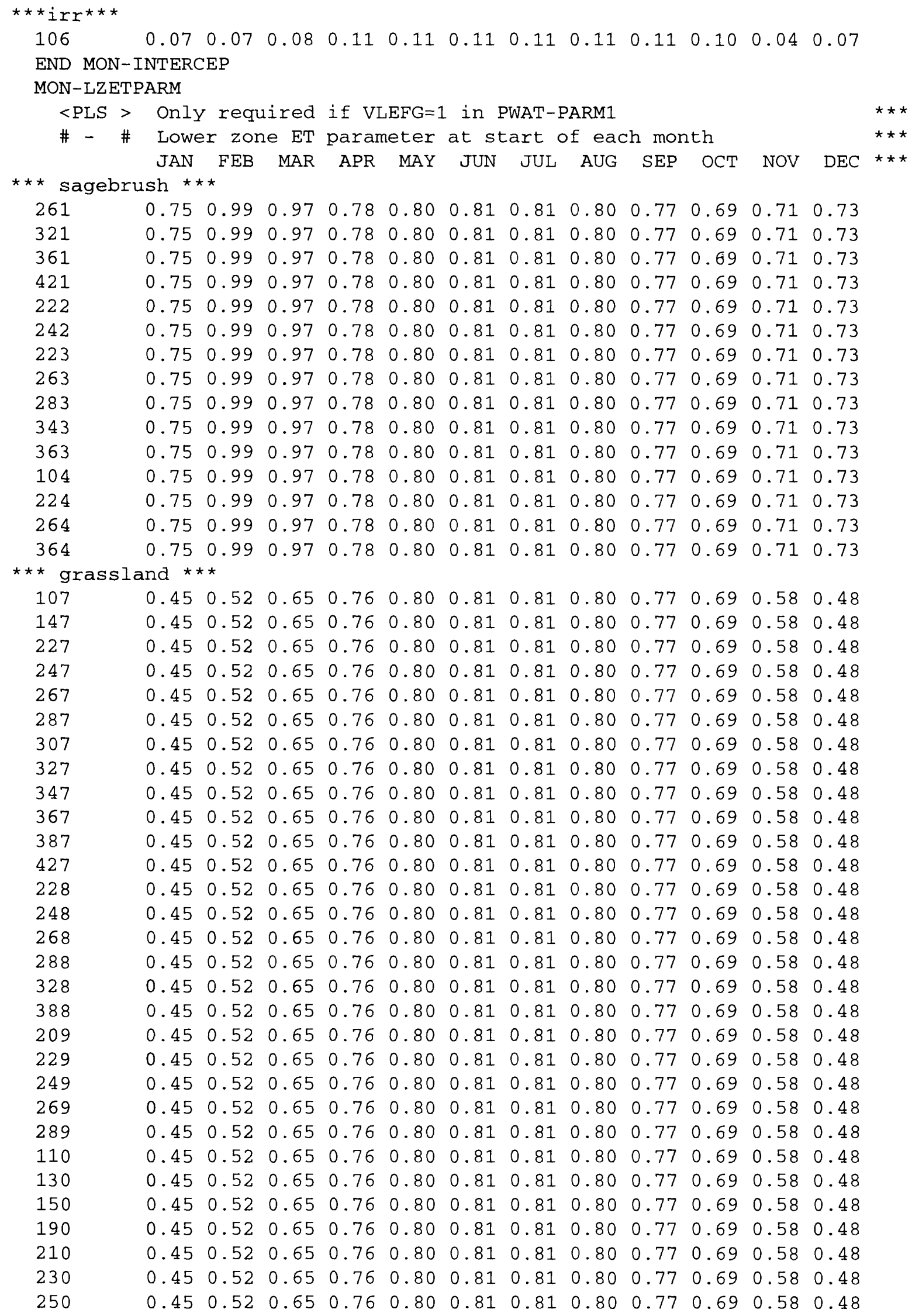




$\begin{array}{llllllllllllll}270 & 0.45 & 0.52 & 0.65 & 0.76 & 0.80 & 0.81 & 0.81 & 0.80 & 0.77 & 0.69 & 0.58 & 0.48 \\ 290 & 0.45 & 0.52 & 0.65 & 0.76 & 0.80 & 0.81 & 0.81 & 0.80 & 0.77 & 0.69 & 0.58 & 0.48 \\ 370 & 0.45 & 0.52 & 0.65 & 0.76 & 0.80 & 0.81 & 0.81 & 0.80 & 0.77 & 0.69 & 0.58 & 0.48 \\ * * * & \text { dry.wheat *** } & & & & & & & & & & \\ 212 & 0.99 & 0.99 & 0.99 & 0.99 & 0.99 & 0.50 & 0.00 & 0.00 & 0.37 & 0.99 & 0.99 & 0.99 \\ 232 & 0.99 & 0.99 & 0.99 & 0.99 & 0.99 & 0.50 & 0.00 & 0.00 & 0.37 & 0.99 & 0.99 & 0.99 \\ 252 & 0.99 & 0.99 & 0.99 & 0.99 & 0.99 & 0.50 & 0.00 & 0.00 & 0.37 & 0.99 & 0.99 & 0.99 \\ 114 & 0.99 & 0.99 & 0.99 & 0.99 & 0.99 & 0.50 & 0.00 & 0.00 & 0.37 & 0.99 & 0.99 & 0.99 \\ 134 & 0.99 & 0.99 & 0.99 & 0.99 & 0.99 & 0.50 & 0.00 & 0.00 & 0.37 & 0.99 & 0.99 & 0.99 \\ 214 & 0.99 & 0.99 & 0.99 & 0.99 & 0.99 & 0.50 & 0.00 & 0.00 & 0.37 & 0.99 & 0.99 & 0.99 \\ 234 & 0.99 & 0.99 & 0.99 & 0.99 & 0.99 & 0.50 & 0.00 & 0.00 & 0.37 & 0.99 & 0.99 & 0.99 \\ 274 & 0.99 & 0.99 & 0.99 & 0.99 & 0.99 & 0.50 & 0.00 & 0.00 & 0.37 & 0.99 & 0.99 & 0.99 \\ * * * \text { irr*** } & & & & & & & & & & & & \\ 106 & 0.63 & 0.70 & 0.99 & 0.99 & 0.99 & 0.99 & 0.99 & 0.99 & 0.90 & 0.77 & 0.67 & 0.62 \\ \text { END MON-LZETPARM } & & & & & & & & & & & & \end{array}$

END PERLND

EXT SOURCES

<-Volume-> <Member> SsysSgap<--Mult-->Tran <-Target vols> <-Grp> <-Member->

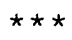

$<$ Name> \# $\quad$ Name> \# tem strg<-factor->strg <Name> \# \# <Name> \# \#

$\star \star \star *$

\begin{tabular}{|c|c|c|c|c|c|c|c|c|c|}
\hline WDM & 4 & PREC & ENGL & 0.920 & COPY & 1 & & INPUT & MEAN \\
\hline WDM & 100 & IRRI & ENGL & & COPY & 1 & & INPUT & MEAN \\
\hline WDM & 4 & PREC & ENGL & 0.920 & PERLND & 104 & & EXTNL & PREC \\
\hline WDM & 4 & PREC & ENGL & 0.920 & PERLND & 107 & 190 & EXTNL & PREC \\
\hline WDM & 4 & PREC & ENGL & 1.270 & PERLND & 209 & 290 & EXTNL & PREC \\
\hline WDM & 4 & PREC & ENGL & 1.540 & PERLND & 307 & 388 & EXTNL & PREC \\
\hline WDM & 4 & PREC & ENGL & 1.770 & PERLND & 421 & 427 & EXTNL & PREC \\
\hline WDM & 5 & WIND & ENGL & & PERLND & 104 & 427 & EXTNL & WINMOV \\
\hline WDM & 6 & SOLR & ENGL & & PERLND & 104 & 114 & EXTNL & SOLRAD \\
\hline WDM & 7 & SOLR & ENGL & & PERLND & 130 & 134 & EXTNL & SOLRAD \\
\hline WDM & 8 & SOLR & ENGL & & PERLND & 147 & 150 & EXTNL & SOLRAD \\
\hline WDM & 10 & SOLR & ENGL & & PERLND & 190 & & EXTNL & SOLRAD \\
\hline WDM & 6 & SOLR & ENGL & & PERLND & 209 & 214 & EXTNL & SOLRAD \\
\hline WDM & 7 & SOLR & ENGL & & PERLND & 222 & 234 & EXTNL & SOLRAD \\
\hline WDM & 8 & SOLR & ENGL & & PERLND & 242 & 252 & EXTNL & SOLRAD \\
\hline WDM & 9 & SOLR & ENGL & & PERLND & 261 & 274 & EXTNL & SOLRAD \\
\hline WDM & 10 & SOLR & ENGL & & PERLND & 283 & 290 & EXTNL & SOLRAD \\
\hline WDM & 6 & SOLR & ENGL & & PERLND & 307 & & EXTNL & SOLRAD \\
\hline WDM & 7 & SOLR & ENGL & & PERLND & 321 & 328 & EXTNL & SOLRAD \\
\hline WDM & 8 & SOLR & ENGL & & PERLND & 343 & 347 & EXTNL & SOLRAD \\
\hline WDM & 9 & SOLR & ENGL & & PERLND & 361 & 370 & EXTNL & SOLRAD \\
\hline WDM & 10 & SOLR & ENGL & & PERLND & 387 & 388 & EXTNL & SOLRAD \\
\hline WDM & 7 & SOLR & ENGL & & PERLND & 421 & 427 & EXTNL & SOLRAD \\
\hline WDM & 12 & TEMP & ENGL & & PERLND & 104 & 190 & ATEMP & AIRTMP \\
\hline WDM & 22 & DEWP & ENGL & & PERLND & 104 & 190 & EXTNL & DTMPG \\
\hline WDM & 15 & TEMP & ENGL & & PERLND & 209 & 290 & ATEMP & AIRTMP \\
\hline WDM & 25 & DEWP & ENGL & & PERLND & 209 & 290 & EXTNL & DTMPG \\
\hline WDM & 18 & TEMP & ENGL & & PERLND & 307 & 388 & ATEMP & AIRTMP \\
\hline WDM & 28 & DEWP & ENGL & & PERLND & 307 & 388 & EXTNL & DTMPG \\
\hline WDM & 20 & TEMP & ENGL & & PERLND & 421 & 427 & ATEMP & AIRTMP \\
\hline WDM & 30 & DEWP & ENGL & & PERLND & 421 & 427 & EXTNL & DTMPG \\
\hline WDM & 32 & PET & ENGL & & PERLND & 104 & 114 & EXTNL & PETINP \\
\hline WDM & 42 & PET & ENGL & & PERLND & 130 & 134 & EXTNL & PETINP \\
\hline
\end{tabular}




$\begin{array}{llllllll}\text { WDM } & 52 & \text { PET } & \text { ENGL } & \text { PERLND } 147 & 150 & \text { EXTNL } & \text { PETINP } \\ \text { WDM } & 72 & \text { PET } & \text { ENGL } & \text { PERLND } 190 & & \text { EXTNL } & \text { PETINP } \\ \text { WDM } & 35 & \text { PET } & \text { ENGL } & \text { PERLND } 209 & 214 & \text { EXTNL } & \text { PETINP } \\ \text { WDM } & 45 & \text { PET } & \text { ENGL } & \text { PERLND } 222 & 234 & \text { EXTNL } & \text { PETINP } \\ \text { WDM } & 55 & \text { PET } & \text { ENGL } & \text { PERLND } 242 & 252 & \text { EXTNL } & \text { PETINP } \\ \text { WDM } & 65 & \text { PET } & \text { ENGL } & \text { PERLND } 261 & 274 & \text { EXTNL } & \text { PETINP } \\ \text { WDM } & 75 & \text { PET } & \text { ENGL } & \text { PERLND } 283 & 290 & \text { EXTNL } & \text { PETINP } \\ \text { WDM } & 38 & \text { PET } & \text { ENGL } & \text { PERLND } 307 & & \text { EXTNL } & \text { PETINP } \\ \text { WDM } & 48 & \text { PET } & \text { ENGL } & \text { PERLND } 321 & 328 & \text { EXTNL } & \text { PETINP } \\ \text { WDM } & 58 & \text { PET } & \text { ENGL } & \text { PERLND } 343 & 347 & \text { EXTNL } & \text { PETINP } \\ \text { WDM } & 68 & \text { PET } & \text { ENGL } & \text { PERLND } 361 & 370 & \text { EXTNL } & \text { PETINP } \\ \text { WDM } & 78 & \text { PET } & \text { ENGL } & \text { PERLND } 387 & 388 & \text { EXTNL } & \text { PETINP } \\ \text { WDM } & 50 & \text { PET } & \text { ENGL } & \text { PERLND } 421 & 427 & \text { EXTNL } & \text { PETINP } \\ \text { END EXT } & \text { SOURCES } & & & & & \end{array}$

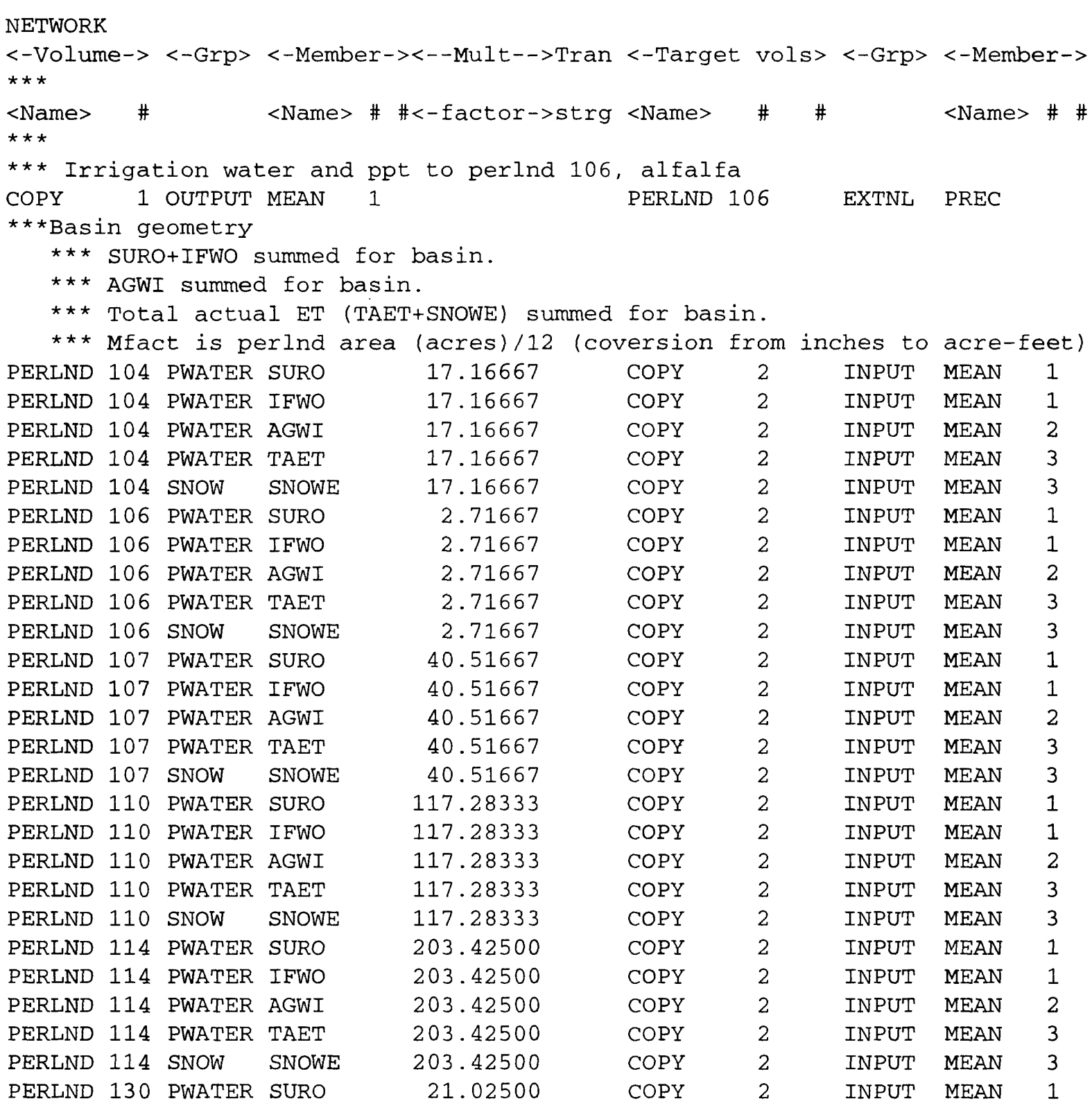




\begin{tabular}{|c|c|c|c|c|c|c|c|c|}
\hline PERLND & 130 & PWATER & IFWO & 21.02500 & COPY & 2 & INPUT & MEAN \\
\hline PERLND & 130 & PWATER & AGWI & 21.02500 & COPY & 2 & INPUT & MEAN \\
\hline PERLND & 130 & PWATER & TAET & 21.02500 & COPY & 2 & INPUT & MEAN \\
\hline PERLND & 130 & SNOW & SNOWE & 21.02500 & COPY & 2 & INPUT & MEAN \\
\hline PERLND & 134 & PWATER & SURO & 19.16667 & COPY & 2 & INPUT & MEAN \\
\hline PERLND & 134 & PWATER & IFWO & 19.16667 & COPY & 2 & INPUT & MEAN \\
\hline PERLND & 134 & PWATER & AGWI & 19.16667 & COPY & 2 & INPUT & MEAN \\
\hline PERLND & 134 & PWATER & TAET & 19.16667 & COPY & 2 & INPUT & MEAN \\
\hline PERLND & 134 & SNOW & SNOWE & 19.16667 & COPY & 2 & INPUT & MEAN \\
\hline PERLND & 147 & PWATER & SURO & 22.65000 & COPY & 2 & INPUT & MEAN \\
\hline PERLND & 147 & PWATER & IFWO & 22.65000 & COPY & 2 & INPUT & MEAN \\
\hline PERLND & 147 & PWATER & AGWI & 22.65000 & COPY & 2 & INPUT & MEAN \\
\hline PERLND & 147 & PWATER & TAET & 22.65000 & COPY & 2 & INPUT & MEAN \\
\hline PERLND & 147 & SNOW & SNOWE & 22.65000 & COPY & 2 & INPUT & MEAN \\
\hline PERLND & 150 & PWATER & SURO & 40.04167 & COPY & 2 & INPUT & MEAN \\
\hline PERLND & 150 & PWATER & IFWO & 40.04167 & COPY & 2 & INPUT & MEAN \\
\hline PERLND & 150 & PWATER & AGWI & 40.04167 & COPY & 2 & INPUT & MEAN \\
\hline PERLND & 150 & PWATER & TAET & 40.04167 & COPY & 2 & INPUT & MEAN \\
\hline PERLND & 150 & SNOW & SNOWE & 40.04167 & COPY & 2 & INPUT & MEAN \\
\hline PERLND & 190 & PWATER & SURO & 18.76667 & COPY & 2 & INPUT & MEAN \\
\hline PERLND & 190 & PWATER & IFWO & 18.76667 & COPY & 2 & INPUT & MEAN \\
\hline PERLND & 190 & PWATER & AGWI & 18.76667 & COPY & 2 & INPUT & MEAN \\
\hline PERLND & 190 & PWATER & TAET & 18.76667 & COPY & 2 & INPUT & MEAN \\
\hline PERLND & 190 & SNOW & SNOWE & 18.76667 & COPY & 2 & INPUT & MEAN \\
\hline PERLND & 209 & PWATER & SURO & 13.15000 & COPY & 2 & INPUT & MEAN \\
\hline PERLND & 209 & PWATER & IFWO & 13.15000 & COPY & 2 & INPUT & MEAN \\
\hline PERLND & 209 & PWATER & AGWI & 13.15000 & COPY & 2 & INPUT & MEAN \\
\hline PERLND & 209 & PWATER & TAET & 13.15000 & COPY & 2 & INPUT & MEAN \\
\hline PERLND & 209 & SNOW & SNOWE & 13.15000 & COPY & 2 & INPUT & MEAN \\
\hline PERLND & 210 & PWATER & SURO & 32.63334 & COPY & 2 & INPUT & MEAN \\
\hline PERLND & 210 & PWATER & IFWO & 32.63334 & COPY & 2 & INPUT & MEAN \\
\hline PERLND & 210 & PWATER & AGWI & 32.63334 & COPY & 2 & INPUT & MEAN \\
\hline PERLND & 210 & PWATER & TAET & 32.63334 & COPY & 2 & INPUT & MEAN \\
\hline PERLND & 210 & SNOW & SNOWE & 32.63334 & COPY & 2 & INPUT & MEAN \\
\hline PERLND & 212 & PWATER & SURO & 11.24167 & COPY & 2 & INPUT & MEAN \\
\hline PERLND & 212 & PWATER & IFWO & 11.24167 & COPY & 2 & INPUT & MEAN \\
\hline PERLND & 212 & PWATER & AGWI & 11.24167 & COPY & 2 & INPUT & MEAN \\
\hline PERLND & 212 & PWATER & TAET & 11.24167 & COPY & 2 & INPUT & MEAN \\
\hline PERLND & 212 & SNOW & SNOWE & 11.24167 & COPY & 2 & INPUT & MEAN \\
\hline PERLND & 214 & PWATER & SURO & 14.65000 & COPY & 2 & INPUT. & MEAN \\
\hline PERLND & 214 & PWATER & IFWO & 14.65000 & COPY & 2 & INPUT & MEAN \\
\hline PERLND & 214 & PWATER & AGWI & 14.65000 & COPY & 2 & INPUT & MEAN \\
\hline PERLND & 214 & PWATER & TAET & 14.65000 & COPY & 2 & INPUT & MEAN \\
\hline PERLND & 214 & SNOW & SNOWE & 14.65000 & COPY & 2 & INPUT & MEAN \\
\hline PERLND & 222 & PWATER & SURO & 12.83333 & COPY & 2 & INPUT & MEAN \\
\hline PERLND & 222 & PWATER & IFWO & 12.83333 & COPY & 2 & INPUT & MEAN \\
\hline PERLND & 222 & PWATER & AGWI & 12.83333 & COPY & 2 & INPUT & MEAN \\
\hline PERLND & 222 & PWATER & TAET & 12.83333 & COPY & 2 & INPUT & MEAN \\
\hline PERLND & 222 & SNOW & SNOWE & 12.83333 & COPY & 2 & INPUT & MEAN \\
\hline PERLND & 223 & PWATER & SURO & 9.29167 & COPY & 2 & INPUT & MEAN \\
\hline PERLND & 223 & PWATER & IFWO & 9.29167 & COPY & 2 & INPUT & MEAN \\
\hline PERLND & 223 & PWATER & AGWI & 9.29167 & COPY & 2 & INPUT & MEAN \\
\hline PERLND & 223 & PWATER & TAET & 9.29167 & COPY & 2 & INPUT & MEAN \\
\hline PERLND & 223 & SNOW & SNOWE & 9.29167 & COPY & 2 & INPUT & MEAN \\
\hline
\end{tabular}




\begin{tabular}{|c|c|c|c|c|c|c|c|c|}
\hline PERLND & 224 & PWATER & SURO & 15.58333 & COPY & 2 & INPUT & MEAN \\
\hline PERLND & 224 & PWATER & IFWO & 15.58333 & COPY & 2 & INPUT & MEAN \\
\hline PERLND & 224 & PWATER & AGWI & 15.58333 & COPY & 2 & INPUT & MEAN \\
\hline PERLND & 224 & PWATER & TAET & 15.58333 & COPY & 2 & INPUT & MEAN \\
\hline PERLND & 224 & SNOW & SNOWE & 15.58333 & COPY & 2 & INPUT & MEAN \\
\hline PERLND & 227 & PWATER & SURO & 19.42500 & COPY & 2 & INPUT & MEAN \\
\hline PERLND & 227 & PWATER & IFWO & 19.42500 & COPY & 2 & INPUT & MEAN \\
\hline PERLND & 227 & PWATER & AGWI & 19.42500 & COPY & 2 & INPUT & MEAN \\
\hline PERLND & 227 & PWATER & TAET & 19.42500 & COPY & 2 & INPUT & MEAN \\
\hline PERLND & 227 & SNOW & SNOWE & 19.42500 & COPY & 2 & INPUT & MEAN \\
\hline PERLND & 228 & PWATER & SURO & 15.92500 & COPY & 2 & INPUT & MEAN \\
\hline PERLND & 228 & PWATER & IFWO & 15.92500 & COPY & 2 & INPUT & MEAN \\
\hline PERLND & 228 & PWATER & AGWI & 15.92500 & COPY & 2 & INPUT & MEAN \\
\hline PERLND & 228 & PWATER & TAET & 15.92500 & COPY & 2 & INPUT & MEAN \\
\hline PERLND & 228 & SNOW & SNOWE & 15.92500 & COPY & 2 & INPUT & MEAN \\
\hline PERLND & 229 & PWATER & SURO & 27.78333 & COPY & 2 & INPUT & MEAN \\
\hline PERLND & 229 & PWATER & IFWO & 27.78333 & COPY & 2 & INPUT & MEAN \\
\hline PERLND & 229 & PWATER & AGWI & 27.78333 & COPY & 2 & INPUT & MEAN \\
\hline PERLND & 229 & PWATER & TAET & 27.78333 & COPY & 2 & INPUT & MEAN \\
\hline PERLND & 229 & SNOW & SNOWE & 27.78333 & COPY & 2 & INPUT & MEAN \\
\hline PERLND & 230 & PWATER & SURO & 78.85833 & COPY & 2 & INPUT & MEAN \\
\hline PERLND & 230 & PWATER & IFWO & 78.85833 & COPY & 2 & INPUT & MEAN \\
\hline PERLND & 230 & PWATER & AGWI & 78.85833 & COPY & 2 & INPUT & MEAN \\
\hline PERLND & 230 & PWATER & TAET & 78.85833 & COPY & 2 & INPUT & MEAN \\
\hline PERLND & 230 & SNOW & SNOWE & 78.85833 & COPY & 2 & INPUT & MEAN \\
\hline PERLND & 232 & PWATER & SURO & 10.56667 & COPY & 2 & INPUT & MEAN \\
\hline PERLND & 232 & PWATER & IFWO & 10.56667 & COPY & 2 & INPUT & MEAN \\
\hline PERLND & 232 & PWATER & AGWI & 10.56667 & COPY & 2 & INPUT & MEAN \\
\hline PERLND & 232 & PWATER & TAET & 10.56667 & COPY & 2 & INPUT & MEAN \\
\hline PERLND & 232 & SNOW & SNOWE & 10.56667 & COPY & 2 & INPUT & MEAN \\
\hline PERLND & 234 & PWATER & SURO & 25.77500 & COPY & 2 & INPUT & MEAN \\
\hline PERLND & 234 & PWATER & IFWO & 25.77500 & COPY & 2 & INPUT & MEAN \\
\hline PERLND & 234 & PWATER & AGWI & 25.77500 & COPY & 2 & INPUT & MEAN \\
\hline PERLND & 234 & PWATER & TAET & 25.77500 & COPY & 2 & INPUT & MEAN \\
\hline PERLND & 234 & SNOW & SNOWE & 25.77500 & COPY & 2 & INPUT & MEAN \\
\hline PERLND & 242 & PWATER & SURO & 17.78333 & COPY & 2 & INPUT & MEAN \\
\hline PERLND & 242 & PWATER & IFWO & 17.78333 & COPY & 2 & INPUT & MEAN \\
\hline PERLND & 242 & PWATER & AGWI & 17.78333 & COPY & 2 & INPUT & MEAN \\
\hline PERLND & 242 & PWATER & TAET & 17.78333 & COPY & 2 & INPUT & MEAN \\
\hline PERLND & 242 & SNOW & SNOWE & 17.78333 & COPY & 2 & INPUT & MEAN \\
\hline PERLND & 247 & PWATER & SURO & 21.55833 & COPY & 2 & INPUT & MEAN \\
\hline PERLND & 247 & PWATER & IFWO & 21.55833 & COPY & 2 & INPUT & MEAN \\
\hline PERLND & 247 & PWATER & AGWI & 21.55833 & COPY & 2 & INPUT & MEAN \\
\hline PERLND & 247 & PWATER & TAET & 21.55833 & COPY & 2 & INPUT & MEAN \\
\hline PERLND & 247 & SNOW & SNOWE & 21.55833 & COPY & 2 & INPUT & MEAN \\
\hline PERLND & 248 & PWATER & SURO & 44.92500 & COPY & 2 & INPUT & MEAN \\
\hline PERLND & 248 & PWATER & IFWO & 44.92500 & COPY & 2 & INPUT & MEAN \\
\hline PERLND & 248 & PWATER & AGWI & 44.92500 & COPY & 2 & INPUT & MEAN \\
\hline PERLND & 248 & PWATER & TAET & 44.92500 & COPY & 2 & INPUT & MEAN \\
\hline PERLND & 248 & SNOW & SNOWE & 44.92500 & COPY & 2 & INPUT & MEAN \\
\hline PERLND & 249 & PWATER & SURO & 9.66667 & COPY & 2 & INPUT & MEAN \\
\hline PERLND & 249 & PWATER & IFWO & 9.66667 & COPY & 2 & INPUT & MEAN \\
\hline PERLND & 249 & PWATER & AGWI & 9.66667 & COPY & 2 & INPUT & MEAN \\
\hline PERLND & 249 & PWATER & TAET & 9.66667 & COPY & 2 & INPUT & MEAN \\
\hline
\end{tabular}




\begin{tabular}{|c|c|c|c|c|c|c|c|c|}
\hline PERLND & 249 & SNOW & SNOWE & 9.66667 & COPY & 2 & INPUT & MEAN \\
\hline PERLND & 250 & PWATER & SURO & 24.07500 & COPY & 2 & INPUT & MEAN \\
\hline PERLND & 250 & PWATER & IFWO & 24.07500 & COPY & 2 & INPUT & MEAN \\
\hline PERLND & 250 & PWATER & AGWI & 24.07500 & COPY & 2 & INPUT & MEAN \\
\hline PERLND & 250 & PWATER & TAET & 24.07500 & COPY & 2 & INPUT & MEAN \\
\hline PERLND & 250 & SNOW & SNOWE & 24.07500 & COPY & 2 & INPUT & MEAN \\
\hline PERLND & 252 & PWATER & SURO & 17.55000 & COPY & 2 & INPUT & MEAN \\
\hline PERLND & 252 & PWATER & IFWO & 17.55000 & COPY & 2 & INPUT & MEAN \\
\hline PERLND & 252 & PWATER & AGWI & 17.55000 & COPY & 2 & INPUT & MEAN \\
\hline PERLND & 252 & PWATER & TAET & 17.55000 & COPY & 2 & INPUT & MEAN \\
\hline PERLND & 252 & SNOW & SNOWE & 17.55000 & COPY & 2 & INPUT & MEAN \\
\hline PERLND & 261 & PWATER & SURO & 24.33333 & COPY & 2 & INPUT & MEAN \\
\hline PERLND & 261 & PWATER & IFWO & 24.33333 & COPY & 2 & INPUT & MEAN \\
\hline PERLND & 261 & PWATER & AGWI & 24.33333 & COPY & 2 & INPUT & MEAN \\
\hline PERLND & 261 & PWATER & TAET & 24.33333 & COPY & 2 & INPUT & MEAN \\
\hline PERLND & 261 & SNOW & SNOWE & 24.33333 & COPY & 2 & INPUT & MEAN \\
\hline PERLND & 263 & PWATER & SURO & 13.00833 & COPY & 2 & INPUT & MEAN \\
\hline PERLND & 263 & PWATER & IFWO & 13.00833 & COPY & 2 & INPUT & MEAN \\
\hline PERLND & 263 & PWATER & AGWI & 13.00833 & COPY & 2 & INPUT & MEAN \\
\hline PERLND & 263 & PWATER & TAET & 13.00833 & COPY & 2 & INPUT & MEAN \\
\hline PERLND & 263 & SNOW & SNOWE & 13.00833 & COPY & 2 & INPUT & MEAN \\
\hline PERLND & 264 & PWATER & SURO & 23.95833 & COPY & 2 & INPUT & MEAN \\
\hline PERLND & 264 & PWATER & IFWO & 23.95833 & COPY & 2 & INPUT & MEAN \\
\hline PERLND & 264 & PWATER & AGWI & 23.95833 & COPY & 2 & INPUT & MEAN \\
\hline PERLND & 264 & PWATER & TAET & 23.95833 & COPY & 2 & INPUT & MEAN \\
\hline PERLND & 264 & SNOW & SNOWE & 23.95833 & COPY & 2 & INPUT & MEAN \\
\hline PERLND & 267 & PWATER & SURO & 31.50833 & COPY & 2 & INPUT & MEAN \\
\hline PERLND & 267 & PWATER & IFWO & 31.50833 & COPY & 2 & INPUT & MEAN \\
\hline PERLND & 267 & PWATER & AGWI & 31.50833 & COPY & 2 & INPUT & MEAN \\
\hline PERLND & 267 & PWATER & TAET & 31.50833 & COPY & 2 & INPUT & MEAN \\
\hline PERLND & 267 & SNOW & SNOWE & 31.50833 & COPY & 2 & INPUT & MEAN \\
\hline PERLND & 268 & PWATER & SURO & 10.54167 & COPY & 2 & INPUT & MEAN \\
\hline PERLND & 268 & PWATER & IFWO & 10.54167 & COPY & 2 & INPUT & MEAN \\
\hline PERLND & 268 & PWATER & AGWI & 10.54167 & COPY & 2 & INPUT & MEAN \\
\hline PERLND & 268 & PWATER & TAET & 10.54167 & COPY & 2 & INPUT & MEAN \\
\hline PERLND & 268 & SNOW & SNOWE & 10.54167 & COPY & 2 & INPUT & MEAN \\
\hline PERLND & 269 & PWATER & SURO & 22.73333 & COPY & 2 & INPUT & MEAN \\
\hline PERLND & 269 & PWATER & IFWO & 22.73333 & COPY & 2 & INPUT & MEAN \\
\hline PERLND & 269 & PWATER & AGWI & 22.73333 & COPY & 2 & INPUT & MEAN \\
\hline PERLND & 269 & PWATER & TAET & 22.73333 & COPY & 2 & INPUT & MEAN \\
\hline PERLND & 269 & SNOW & SNOWE & 22.73333 & COPY & 2 & INPUT & MEAN \\
\hline PERLND & 270 & PWATER & SURO & 45.75000 & COPY & 2 & INPUT & MEAN \\
\hline PERLND & 270 & PWATER & IFWO & 45.75000 & COPY & 2 & INPUT & MEAN \\
\hline PERLND & 270 & PWATER & AGWI & 45.75000 & COPY & 2 & INPUT & MEAN \\
\hline PERLND & 270 & PWATER & TAET & 45.75000 & COPY & 2 & INPUT & MEAN \\
\hline PERLND & 270 & SNOW & SNOWE & 45.75000 & COPY & 2 & INPUT & MEAN \\
\hline PERLND & 274 & PWATER & SURO & 8.35000 & COPY & 2 & INPUT & MEAN \\
\hline PERLND & 274 & PWATER & IFWO & 8.35000 & COPY & 2 & INPUT & MEAN \\
\hline PERLND & 274 & PWATER & AGWI & 8.35000 & COPY & 2 & INPUT & MEAN \\
\hline PERLND & 274 & PWATER & TAET & 8.35000 & COPY & 2 & INPUT & MEAN \\
\hline PERLND & 274 & SNOW & SNOWE & 8.35000 & COPY & 2 & INPUT & MEAN \\
\hline PERLND & 283 & PWATER & SURO & 19.75833 & COPY & 2 & INPUT & MEAN \\
\hline PERLND & 283 & PWATER & IFWO & 19.75833 & COPY & 2 & INPUT & MEAN \\
\hline PERLND & 283 & PWATER & AGWI & 19.75833 & COPY & 2 & INPUT & MEAN \\
\hline
\end{tabular}




\begin{tabular}{|c|c|c|c|c|c|c|c|c|}
\hline PERLND & 283 & PWATER & TAET & 19.75833 & COPY & 2 & INPUT & MEAN \\
\hline PERLND & 283 & SNOW & SNOWE & 19.75833 & COPY & 2 & INPUT & MEAN \\
\hline PERLND & 287 & PWATER & SURO & 22.84167 & COPY & 2 & INPUT & MEAN \\
\hline PERLND & 287 & PWATER & IFWO & 22.84167 & COPY & 2 & INPUT & MEAN \\
\hline PERLND & 287 & PWATER & AGWI & 22.84167 & COPY & 2 & INPUT & MEAN \\
\hline PERLND & 287 & PWATER & TAET & 22.84167 & COPY & 2 & INPUT & MEAN \\
\hline PERLND & 287 & SNOW & SNOWE & 22.84167 & COPY & 2 & INPUT & MEAN \\
\hline PERLND & 288 & PWATER & SURO & 21.02500 & COPY & 2 & INPUT & MEAN \\
\hline PERLND & 288 & PWATER & IFWO & 21.02500 & COPY & 2 & INPUT & MEAN \\
\hline PERLND & 288 & PWATER & AGWI & 21.02500 & COPY & 2 & INPUT & MEAN \\
\hline PERLND & 288 & PWATER & TAET & 21.02500 & COPY & 2 & INPUT & MEAN \\
\hline PERLND & 288 & SNOW & SNOWE & 21.02500 & COPY & 2 & INPUT & MEAN \\
\hline PERLND & 289 & PWATER & SURO & 13.18333 & COPY & 2 & INPUT & MEAN \\
\hline PERLND & 289 & PWATER & IFWO & 13.18333 & COPY & 2 & INPUT & MEAN \\
\hline PERLND & 289 & PWATER & AGWI & 13.18333 & COPY & 2 & INPUT & MEAN \\
\hline PERLND & 289 & PWATER & TAET & 13.18333 & COPY & 2 & INPUT & MEAN \\
\hline PERLND & 289 & SNOW & SNOWE & 13.18333 & COPY & 2 & INPUT & MEAN \\
\hline PERLND & 290 & PWATER & SURO & 14.81667 & COPY & 2 & INPUT & MEAN \\
\hline PERLND & 290 & PWATER & IFWO & 14.81667 & COPY & 2 & INPUT & MEAN \\
\hline PERLND & 290 & PWATER & AGWI & 14.81667 & COPY & 2 & INPUT & MEAN \\
\hline PERLND & 290 & PWATER & TAET & 14.81667 & COPY & 2 & INPUT & MEAN \\
\hline PERLND & 290 & SNOW & SNOWE & 14.81667 & COPY & 2 & INPUT & MEAN \\
\hline PERLND & 307 & PWATER & SURO & 13.79167 & COPY & 2 & INPUT & MEAN \\
\hline PERLND & 307 & PWATER & IFWO & 13.79167 & COPY & 2 & INPUT & MEAN \\
\hline PERLND & 307 & PWATER & AGWI & 13.79167 & COPY & 2 & INPUT & MEAN \\
\hline PERLND & 307 & PWATER & TAET & 13.79167 & COPY & 2 & INPUT & MEAN \\
\hline PERLND & 307 & SNOW & SNOWE & 13.79167 & COPY & 2 & INPUT & MEAN \\
\hline PERLND & 321 & PWATER & SURO & 24.76667 & COPY & 2 & INPUT & MEAN \\
\hline PERLND & 321 & PWATER & IFWO & 24.76667 & COPY & 2 & INPUT & MEAN \\
\hline PERLND & 321 & PWATER & AGWI & 24.76667 & COPY & 2 & INPUT & MEAN \\
\hline PERLND & 321 & PWATER & TAET & 24.76667 & COPY & 2 & INPUT & MEAN \\
\hline PERLND & 321 & SNOW & SNOWE & 24.76667 & COPY & 2 & INPUT & MEAN \\
\hline PERLND & 327 & PWATER & SURO & 28.80833 & COPY & 2 & INPUT & MEAN \\
\hline PERLND & 327 & PWATER & IFWO & 28.80833 & COPY & 2 & INPUT & MEAN \\
\hline PERLND & 327 & PWATER & AGWI & 28.80833 & COPY & 2 & INPUT & MEAN \\
\hline PERLND & 327 & PWATER & TAET & 28.80833 & $\mathrm{COPY}$ & 2 & INPUT & MEAN \\
\hline PERLND & 327 & SNOW & SNOWE & 28.80833 & COPY & 2 & INPUT & MEAN \\
\hline PERLND & 328 & PWATER & SURO & 9.10833 & COPY & 2 & INPUT & MEAN \\
\hline PERLND & 328 & PWATER & IFWO & 9.10833 & COPY & 2 & INPUT & MEAN \\
\hline PERLND & 328 & PWATER & AGWI & 9.10833 & COPY & 2 & INPUT & MEAN \\
\hline PERLND & 328 & PWATER & TAET & 9.10833 & COPY & 2 & INPUT & MEAN \\
\hline PERLND & 328 & SNOW & SNOWE & 9.10833 & COPY & 2 & INPUT & MEAN \\
\hline PERLND & 347 & PWATER & SURO & 12.91667 & COPY & 2 & INPUT & MEAN \\
\hline PERLND & 347 & PWATER & IFWO & 12.91667 & COPY & 2 & INPUT & MEAN \\
\hline PERLND & 347 & PWATER & AGWI & 12.91667 & COPY & 2 & INPUT & MEAN \\
\hline PERLND & 347 & PWATER & TAET & 12.91667 & COPY & 2 & INPUT & MEAN \\
\hline PERLND & 347 & SNOW & SNOWE & 12.91667 & COPY & 2 & INPUT & MEAN \\
\hline PERLND & 343 & PWATER & SURO & 7.06667 & COPY & 2 & INPUT & MEAN \\
\hline PERLND & 343 & PWATER & IFWO & 7.06667 & COPY & 2 & INPUT & MEAN \\
\hline PERLND & 343 & PWATER & AGWI & 7.06667 & COPY & 2 & INPUT & MEAN \\
\hline PERLND & 343 & PWATER & TAET & 7.06667 & COPY & 2 & INPUT & MEAN \\
\hline PERLND & 343 & SNOW & SNOWE & 7.06667 & COPY & 2 & INPUT & MEAN \\
\hline PERLND & 361 & PWATER & SURO & 97.37500 & COPY & 2 & INPUT & MEAN \\
\hline PERLND & 361 & PWATER & IFWO & 97.37500 & COPY & 2 & INPUT & MEAN \\
\hline
\end{tabular}




\begin{tabular}{|c|c|c|c|c|c|c|c|c|c|}
\hline PERLND & 361 & PWATER & AGWI & 97.37500 & COPY & 2 & INPUT & MEAN & 2 \\
\hline PERLND & 361 & PWATER & TAET & 97.37500 & COPY & 2 & INPUT & MEAN & 3 \\
\hline PERLND & 361 & SNOW & SNOWE & 97.37500 & COPY & 2 & INPUT & MEAN & 3 \\
\hline PERLND & 363 & PWATER & SURO & 10.65000 & COPY & 2 & INPUT & MEAN & 1 \\
\hline PERLND & 363 & PWATER & IFWO & 10.65000 & COPY & 2 & INPUT & MEAN & 1 \\
\hline PERLND & 363 & PWATER & AGWI & 10.65000 & COPY & 2 & INPUT & MEAN & 2 \\
\hline PERLND & 363 & PWATER & TAET & 10.65000 & COPY & 2 & INPUT & MEAN & 3 \\
\hline PERLND & 363 & SNOW & SNOWE & 10.65000 & COPY & 2 & INPUT & MEAN & 3 \\
\hline PERLND & 364 & PWATER & SURO & 14.95833 & COPY & 2 & INPUT & MEAN & 1 \\
\hline PERLND & 364 & PWATER & IFWO & 14.95833 & COPY & 2 & INPUT & MEAN & 1 \\
\hline PERLND & 364 & PWATER & AGWI & 14.95833 & COPY & 2 & INPUT & MEAN & 2 \\
\hline PERLND & 364 & PWATER & TAET & 14.95833 & COPY & 2 & INPUT & MEAN & 3 \\
\hline PERLND & 364 & SNOW & SNOWE & 14.95833 & COPY & 2 & INPUT & MEAN & 3 \\
\hline PERLND & 367 & PWATER & SURO & 62.94167 & COPY & 2 & INPUT & MEAN & 1 \\
\hline PERLND & 367 & PWATER & IFWO & 62.94167 & COPY & 2 & INPUT & MEAN & 1 \\
\hline PERLND & 367 & PWATER & AGWI & 62.94167 & COPY & 2 & INPUT & MEAN & 2 \\
\hline PERLND & 367 & PWATER & TAET & 62.94167 & COPY & 2 & INPUT & MEAN & 3 \\
\hline PERLND & 367 & SNOW & SNOWE & 62.94167 & COPY & 2 & INPUT & MEAN & 3 \\
\hline PERLND & 370 & PWATER & SURO & 26.40000 & COPY & 2 & INPUT & MEAN & 1 \\
\hline PERLND & 370 & PWATER & IFWO & 26.40000 & COPY & 2 & INPUT & MEAN & 1 \\
\hline PERLND & 370 & PWATER & AGWI & 26.40000 & COPY & 2 & INPUT & MEAN & 2 \\
\hline PERLND & 370 & PWATER & TAET & 26.40000 & COPY & 2 & INPUT & MEAN & 3 \\
\hline PERLND & 370 & SNOW & SNOWE & 26.40000 & COPY & 2 & INPUT & MEAN & 3 \\
\hline PERLND & 387 & PWATER & SURO & 17.28333 & COPY & 2 & INPUT & MEAN & 1 \\
\hline PERLND & 387 & PWATER & IFWO & 17.28333 & COPY & 2 & INPUT & MEAN & 1 \\
\hline PERLND & 387 & PWATER & AGWI & 17.28333 & COPY & 2 & INPUT & MEAN & 2 \\
\hline PERLND & 387 & PWATER & TAET & 17.28333 & COPY & 2 & INPUT & MEAN & 3 \\
\hline PERLND & 387 & SNOW & SNOWE & 17.28333 & COPY & 2 & INPUT & MEAN & 3 \\
\hline PERLND & 388 & PWATER & SURO & 8.99167 & COPY & 2 & INPUT & MEAN & 1 \\
\hline PERLND & 388 & PWATER & IFWO & 8.99167 & COPY & 2 & INPUT & MEAN & 1 \\
\hline PERLND & 388 & PWATER & AGWI & 8.99167 & COPY & 2 & INPUT & MEAN & 2 \\
\hline PERLND & 388 & PWATER & TAET & 8.99167 & COPY & 2 & INPUT & MEAN & 3 \\
\hline PERLND & 388 & SNOW & SNOWE & 8.99167 & COPY & 2 & INPUT & MEAN & 3 \\
\hline PERLND & 421 & PWATER & SURO & 26.37500 & COPY & 2 & INPUT & MEAN & 1 \\
\hline PERLND & 421 & PWATER & IFWO & 26.37500 & COPY & 2 & INPUT & MEAN & 1 \\
\hline PERLND & 421 & PWATER & AGWI & 26.37500 & COPY & 2 & INPUT & MEAN & 2 \\
\hline PERLND & 421 & PWATER & TAET & 26.37500 & COPY & 2 & INPUT & MEAN & 3 \\
\hline PERLND & 421 & SNOW & SNOWE & 26.37500 & COPY & 2 & INPUT & MEAN & 3 \\
\hline PERLND & 427 & PWATER & SURO & 18.35833 & COPY & 2 & INPUT & MEAN & 1 \\
\hline PERLND & 427 & PWATER & IFWO & 18.35833 & COPY & 2 & INPUT & MEAN & 1 \\
\hline PERLND & 427 & PWATER & AGWI & 18.35833 & COPY & 2 & INPUT & MEAN & 2 \\
\hline PERLND & 427 & PWATER & TAET & 18.35833 & COPY & 2 & INPUT & MEAN & 3 \\
\hline PERLND & 427 & SNOW & SNOWE & 18.35833 & COPY & 2 & INPUT & MEAN & 3 \\
\hline \multicolumn{10}{|c|}{ ***Basin water balance information } \\
\hline$\star \star$ & * To & tal ppt. & - Mfact & fraction & & for & ch elev & ation & \\
\hline PERLND & 106 & SNOW & RAINF & .0017 & COPY & 3 & INPUT & MEAN & 1 \\
\hline PERLND & 106 & SNOW & SNOWF & .0017 & COPY & 3 & INPUT & MEAN & 1 \\
\hline PERLND & 104 & SNOW & RAINF & .3170 & COPY & 3 & INPUT & MEAN & 1 \\
\hline PERLND & 104 & SNOW & SNOWF & .3170 & COPY & 3 & INPUT & MEAN & 1 \\
\hline PERLND & 209 & SNOW & RAINF & .4406 & COPY & 3 & INPUT & MEAN & 1 \\
\hline PERLND & 209 & SNOW & SNOWF & .4406 & COPY & 3 & INPUT & MEAN & 1 \\
\hline PERLND & 307 & SNOW & RAINF & .2124 & COPY & 3 & INPUT & MEAN & 1 \\
\hline PERLND & 307 & SNOW & SNOWF & .2124 & COPY & 3 & INPUT & MEAN & 1 \\
\hline PERLND & 421 & SNOW & RAINF & .0284 & COPY & 3 & INPUT & MEAN & 1 \\
\hline
\end{tabular}




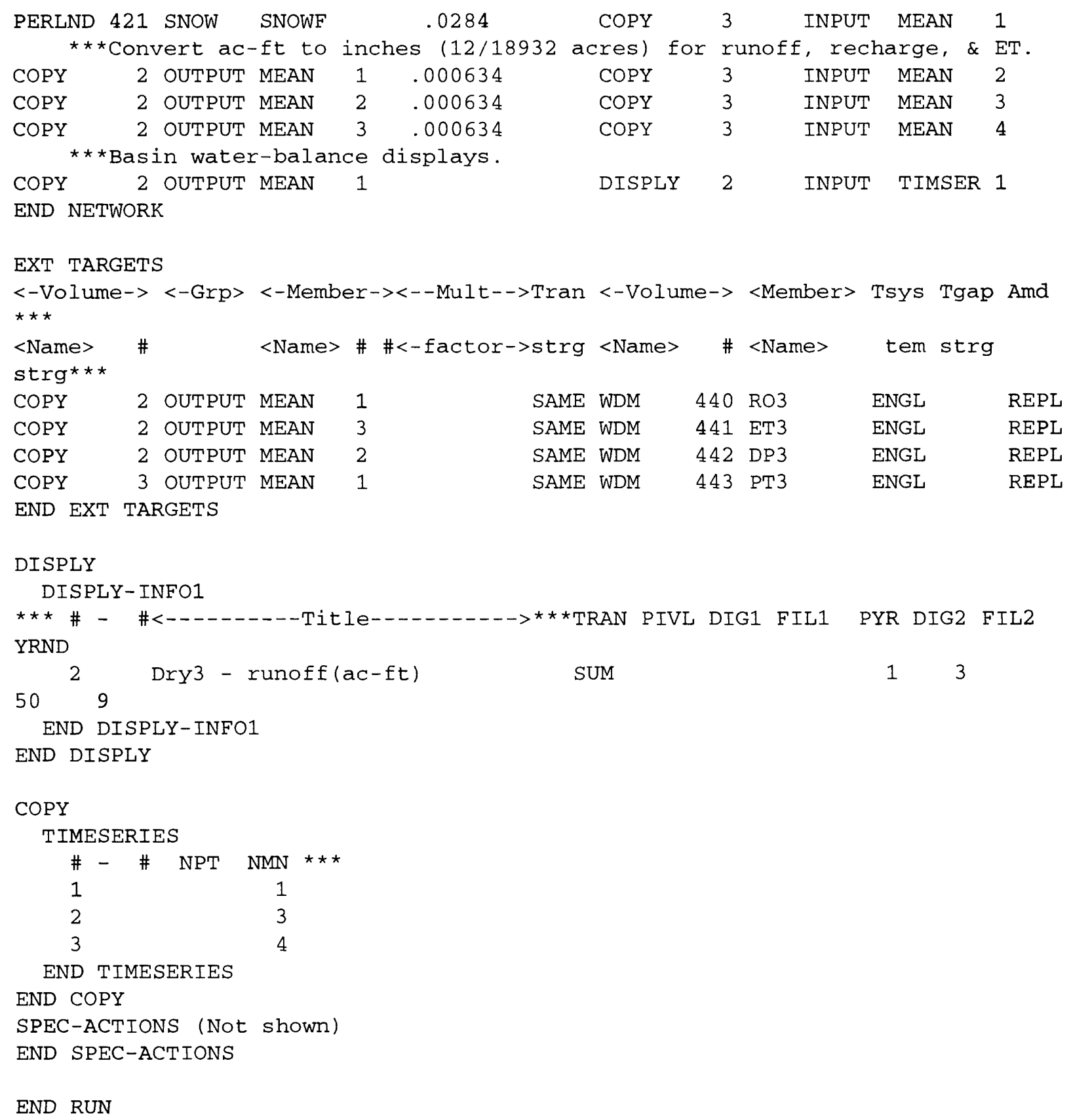


Appendix 6.--Final HSPF input file for Lower Dry Creek model. For brevity, the "SPECIAL ACTIONS" portion of the model input, where the dates of soil freezing and thawing are represented by changes in the INFILT parameter values, is not included. Complete input files may be obtained by contacting the District Chief at the address shown on page ii of this report

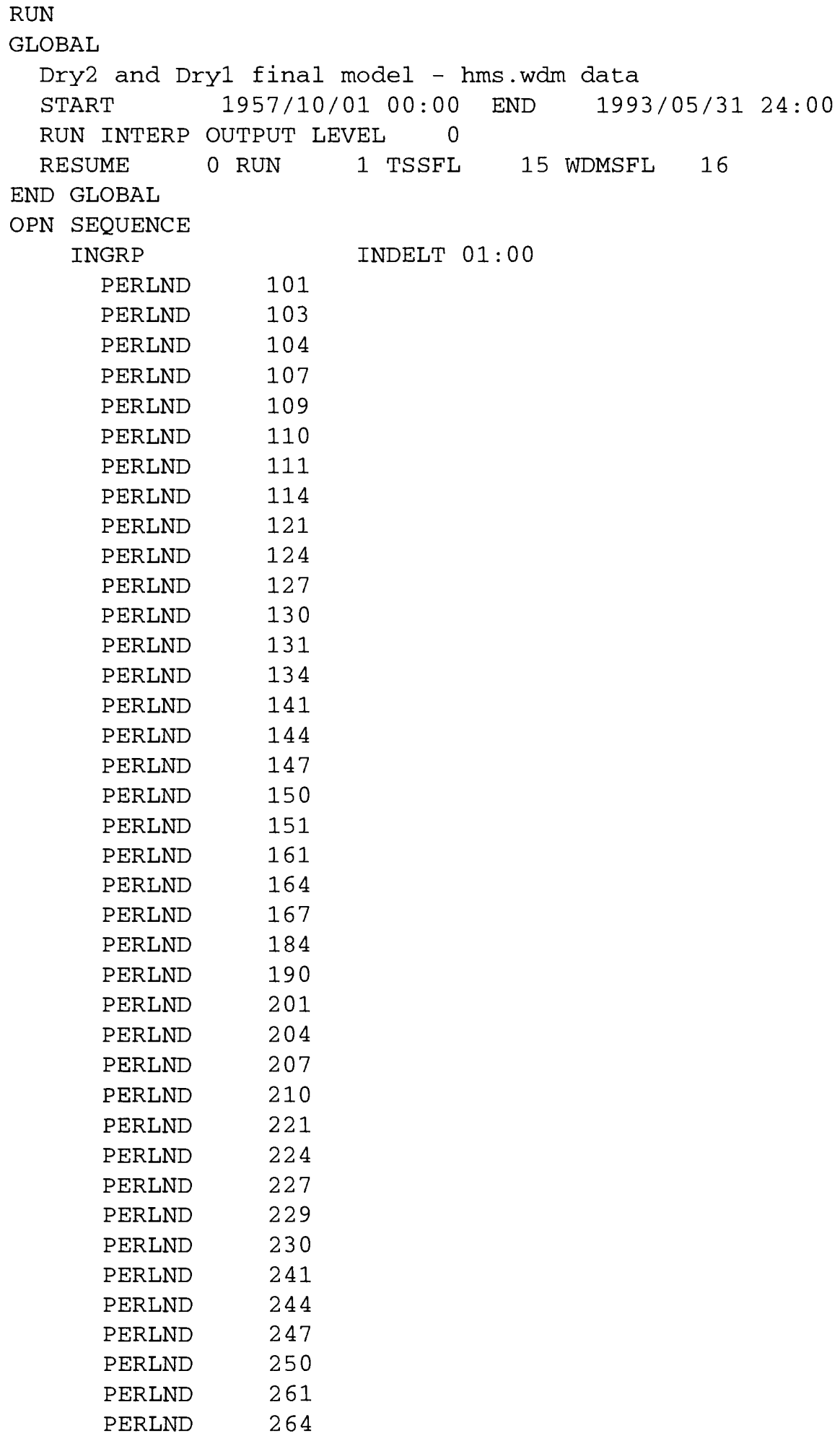




$\begin{array}{lr}\text { PERLND } & 267 \\ \text { PERLND } & 269 \\ \text { PERLND } & 270 \\ \text { PERLND } & 281 \\ \text { PERLND } & 284 \\ \text { PERLND } & 287 \\ \text { PERLND } & 290 \\ \text { PERLND } & 304 \\ \text { PERLND } & 314 \\ \text { PERLND } & 321 \\ \text { PERLND } & 324 \\ \text { PERLND } & 327 \\ \text { PERLND } & 330 \\ \text { PERLND } & 334 \\ \text { PERLND } & 344 \\ \text { PERLND } & 361 \\ \text { PERLND } & 364 \\ \text { PERLND } & 367 \\ \text { PERLND } & 370 \\ \text { PERLND } & 390 \\ \text { COPY } & 1 \\ \text { COPY } & 2 \\ \text { DISPLY } & 2 \\ \text { DISPLY } & 6\end{array}$

END INGRP

END OPN SEQUENCE

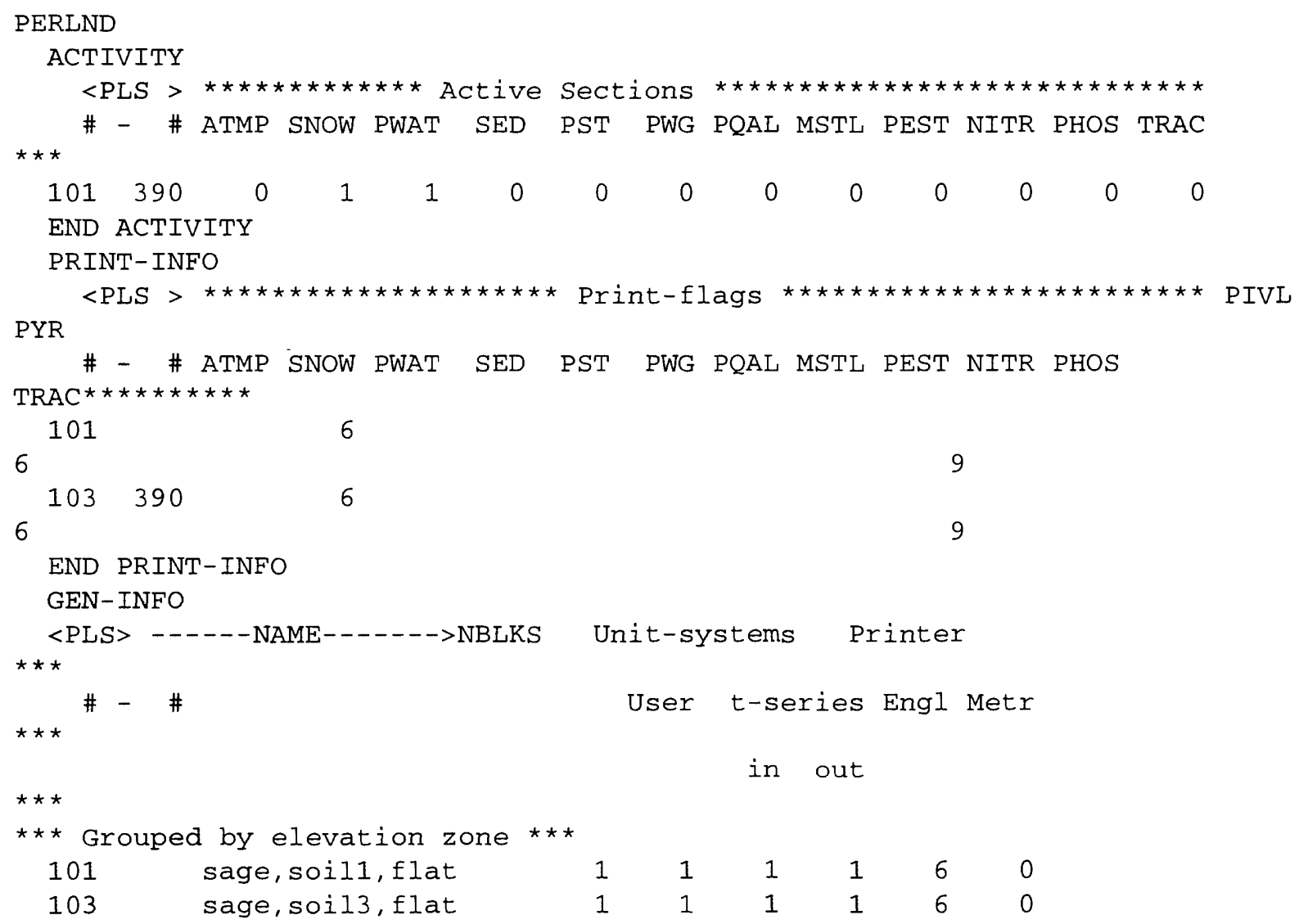




\begin{tabular}{|c|c|c|c|c|c|c|}
\hline 104 & sage, soil4, flat & 1 & 1 & 1 & 1 & 6 \\
\hline 107 & gras, soill, flat & 1 & 1 & 1 & 1 & 6 \\
\hline 109 & gras, soil3, flat & 1 & 1 & 1 & 1 & 6 \\
\hline 110 & gras, soil4, flat & 1 & 1 & 1 & 1 & 6 \\
\hline 111 & dryw, soill, flat & 1 & 1 & 1 & 1 & 6 \\
\hline 114 & dryw, soil4, flat & 1 & 1 & 1 & 1 & 6 \\
\hline 121 & sage, soill, mod.N & 1 & 1 & 1 & 1 & 6 \\
\hline 124 & sage, soil4, mod.N & 1 & 1 & 1 & 1 & 6 \\
\hline 127 & gras, soil1, mod.N & 1 & 1 & 1 & 1 & 6 \\
\hline 130 & gras, soil4, mod.N & 1 & 1 & 1 & 1 & 6 \\
\hline 131 & dryw, soil4, mod.N & 1 & 1 & 1 & 1 & 6 \\
\hline 134 & dryw, soil4, mod. N & 1 & 1 & 1 & 1 & 6 \\
\hline 141 & sage, soil1, mod.s & 1 & 1 & 1 & 1 & 6 \\
\hline 144 & sage, soil4, mod.S & 1 & 1 & 1 & 1 & 6 \\
\hline 147 & gras, soil1, mod.s & 1 & 1 & 1 & 1 & 6 \\
\hline 150 & gras, soil4, mod.s & 1 & 1 & 1 & 1 & 6 \\
\hline 151 & dryw, soil1, mod.s & 1 & 1 & 1 & 1 & 6 \\
\hline 161 & sage, soill, stp.N & 1 & 1 & 1 & 1 & 6 \\
\hline 164 & sage, soill, stp.N & 1 & 1 & 1 & 1 & 6 \\
\hline 167 & gras, soill, stp.N & 1 & 1 & 1 & 1 & 6 \\
\hline 184 & sage, soil4, stp.s & 1 & 1 & 1 & 1 & 6 \\
\hline 190 & gras, soil4, stp.s & 1 & 1 & 1 & 1 & 6 \\
\hline 201 & sage, soill, flat & 1 & 1 & 1 & 1 & 6 \\
\hline 204 & sage, soil4, flat & 1 & 1 & 1 & 1 & 6 \\
\hline 207 & gras,soill, flat & 1 & 1 & 1 & 1 & 6 \\
\hline 210 & gras, soil4, flat & 1 & 1 & 1 & 1 & 6 \\
\hline 221 & sage, soill, mod. N & 1 & 1 & 1 & 1 & 6 \\
\hline 224 & sage, soil4, mod. N & 1 & 1 & 1 & 1 & 6 \\
\hline 227 & gras, soil1, mod.N & 1 & 1 & 1 & 1 & 6 \\
\hline 229 & gras, soil3, mod.N & 1 & 1 & 1 & 1 & 6 \\
\hline 230 & gras, soil4, mod.N & 1 & 1 & 1 & 1 & 6 \\
\hline 241 & sage, soil1, mod.s & 1 & 1 & 1 & 1 & 6 \\
\hline 244 & sage, soil 14 , mod.s & 1 & 1 & 1 & 1 & 6 \\
\hline 247 & gras, soil1,mod.s & 1 & 1 & 1 & 1 & 6 \\
\hline 250 & gras, soil4,mod.s & 1 & 1 & 1 & 1 & 6 \\
\hline 261 & sage, soill, stp.N & 1 & 1 & 1 & 1 & 6 \\
\hline 264 & sage, soil4, stp.N & 1 & 1 & 1 & 1 & 6 \\
\hline 267 & gras, soil1, stp.N & 1 & 1 & 1 & 1 & 6 \\
\hline 269 & gras, soil3, stp.N & 1 & 1 & 1 & 1 & 6 \\
\hline 270 & gras, soil4, stp.N & 1 & 1 & 1 & 1 & 6 \\
\hline 281 & sage, soil1, stp.N & 1 & 1 & 1 & 1 & 6 \\
\hline 284 & sage, soil4, stp.s & 1 & 1 & 1 & 1 & 6 \\
\hline 287 & gras, soil1, stp.s & 1 & 1 & 1 & 1 & 6 \\
\hline 290 & gras, soil4, stp.s & 1 & 1 & 1 & 1 & 6 \\
\hline 304 & sage, soil4, flat & 1 & 1 & 1 & 1 & 6 \\
\hline 314 & aryw, soil4, flat & 1 & 1 & 1 & 1 & 6 \\
\hline 321 & sage, soil1, mod.N & 1 & 1 & 1 & 1 & 6 \\
\hline 324 & sage, soil4, mod.N & 1 & 1 & 1 & 1 & 6 \\
\hline 327 & gras, soill, mod.N & 1 & 1 & 1 & 1 & 6 \\
\hline 330 & gras, soil4, mod.N & 1 & 1 & 1 & 1 & 6 \\
\hline 334 & dryw, soil4, mod.N & 1 & 1 & 1 & 1 & 6 \\
\hline 344 & sage, soil4, mod.S & 1 & 1 & 1 & 1 & 6 \\
\hline 361 & sage, soil1, stp.N & 1 & 1 & 1 & 1 & 6 \\
\hline 364 & sage, soil4, stp.N & 1 & 1 & 1 & 1 & 6 \\
\hline
\end{tabular}




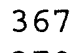

$$
\begin{array}{lllllll}
\text { gras, soil1, stp.N } & 1 & 1 & 1 & 1 & 6 & 0 \\
\text { gras, soil4, stp.N } & 1 & 1 & 1 & 1 & 6 & 0 \\
\text { gras, soil4, stp.S } & 1 & 1 & 1 & 1 & 6 & 0
\end{array}
$$

ICE-FLAG

$<$ PLS > Value of 1 means ice will be simulated, 0 means not simulated

$\#-\quad$ ICEFG

$$
\star \star *
$$

$101390 \quad 1$

END ICE-FLAG

SNOW-PARM1

perlnd perlnd shaded gage-catch snow w.eq. needed for $<$ PLS $>$ latitude altitude fraction adjustment complete snowcover

$\star * *$

\#- \# LAT MELEV SHADE SNOWCF COVIND

$101 \quad 190$ 201290

$$
46.6
$$

820 .

0.0

1.25

0.0

1.25

0.0

1.25

0.5

$46.6 \quad 1805$.

2789 .

END SNOW-PARMI

SNOW-PARM2

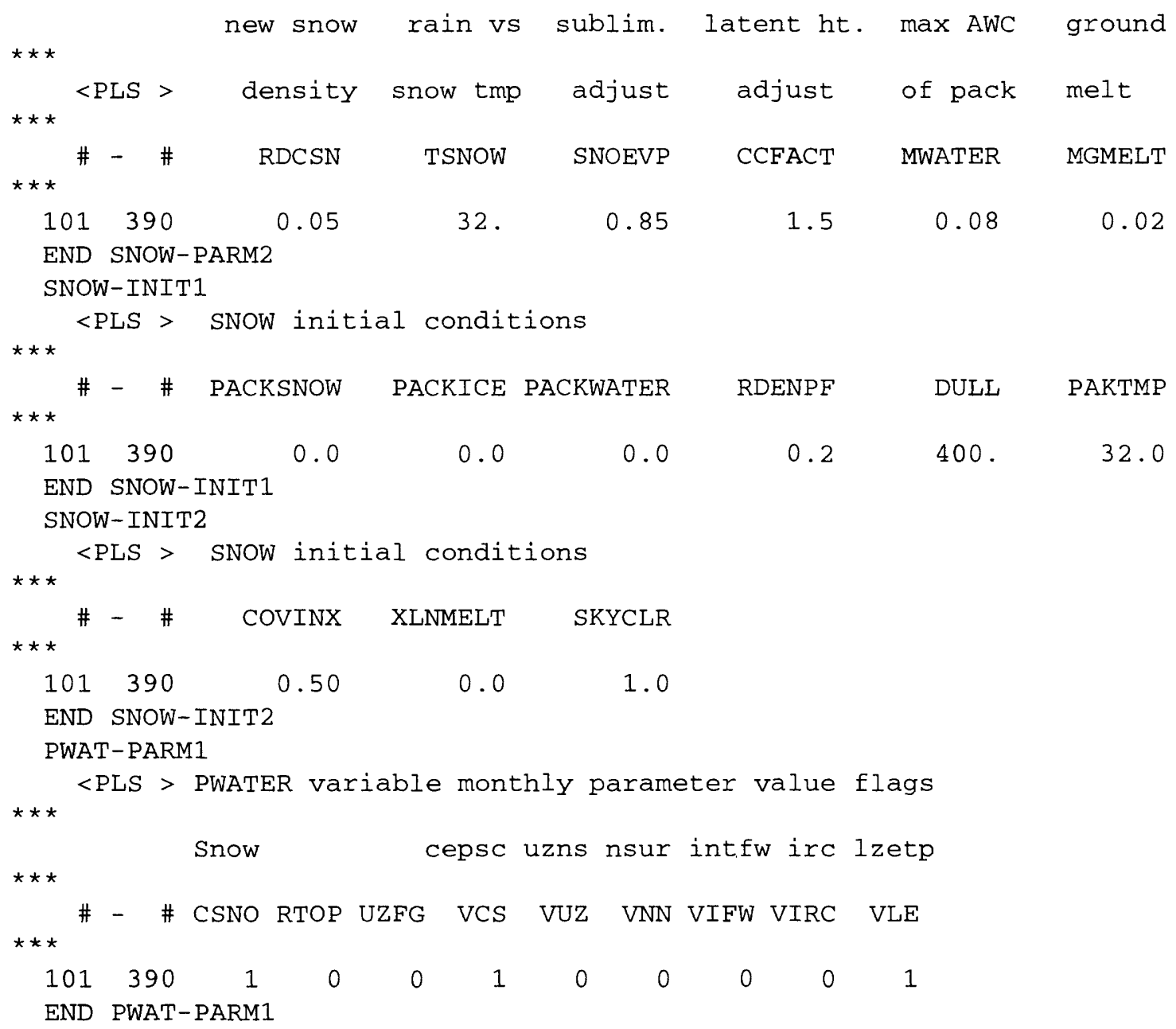




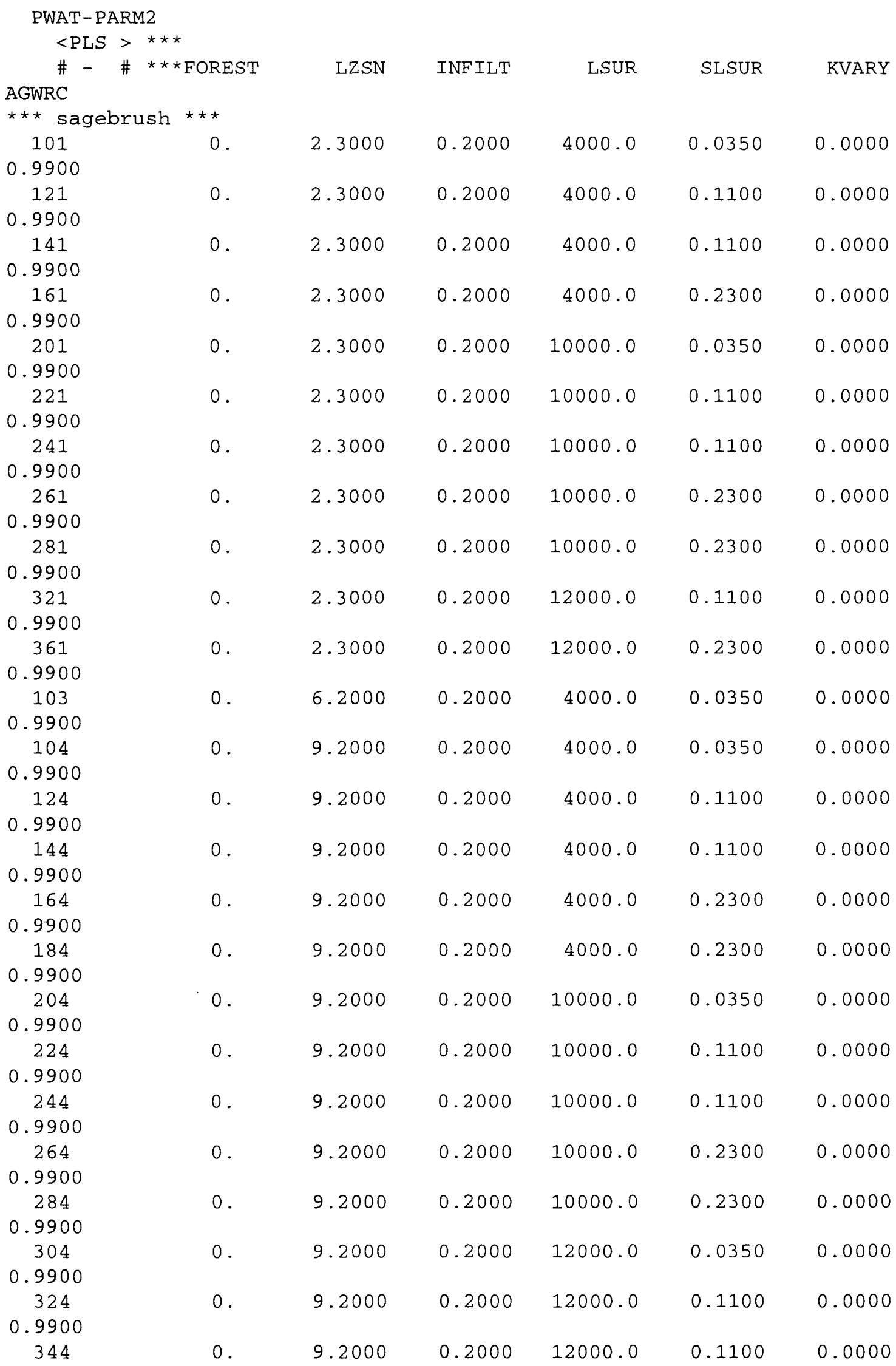




\begin{tabular}{|c|c|c|c|c|c|c|}
\hline \multicolumn{7}{|l|}{0.9900} \\
\hline 364 & 0 . & 9.2000 & 0.2000 & 12000.0 & 0.2300 & 0.0000 \\
\hline \multicolumn{7}{|c|}{0.9900} \\
\hline \multicolumn{7}{|c|}{$\star \star \star$ grassland $\star \star \star$} \\
\hline 107 & 0 & 2.3000 & 0.2000 & 4000.0 & 0.0350 & 0.0000 \\
\hline \multicolumn{7}{|l|}{0.9900} \\
\hline 127 & 0 . & 2.3000 & 0.2000 & 4000.0 & 0.1100 & 0.0000 \\
\hline \multicolumn{7}{|l|}{0.9900} \\
\hline 147 & 0 . & 2.3000 & 0.2000 & 4000.0 & 0.1100 & 0.0000 \\
\hline \multicolumn{7}{|l|}{0.9900} \\
\hline 167 & 0. & 2.3000 & 0.2000 & 4000.0 & 0.2300 & 0.0000 \\
\hline \multicolumn{7}{|l|}{0.9900} \\
\hline 207 & 0 . & 2.3000 & 0.2000 & 10000.0 & 0.0350 & 0.0000 \\
\hline \multicolumn{7}{|l|}{0.9900} \\
\hline 227 & 0 . & 2.3000 & 0.2000 & 10000.0 & 0.1100 & 0.0000 \\
\hline \multicolumn{7}{|l|}{0.9900} \\
\hline \multirow{2}{*}{\multicolumn{7}{|c|}{0.9900}} \\
\hline & & & & & & \\
\hline 267 & 0 . & 2.3000 & 0.2000 & 10000.0 & 0.2300 & 0.0000 \\
\hline \multicolumn{7}{|l|}{0.9900} \\
\hline 287 & 0 . & 2.3000 & 0.2000 & 10000.0 & 0.2300 & 0.0000 \\
\hline \multicolumn{7}{|l|}{0.9900} \\
\hline 327 & 0 . & 2.3000 & 0.2000 & 12000.0 & 0.1100 & 0.0000 \\
\hline \multicolumn{7}{|l|}{0.9900} \\
\hline 367 & 0 . & 2.3000 & 0.2000 & 12000.0 & 0.2300 & 0.0000 \\
\hline \multicolumn{7}{|l|}{0.9900} \\
\hline 109 & 0. & 2.9000 & 0.2000 & 4000.0 & 0.0350 & 0.0000 \\
\hline \multicolumn{7}{|l|}{0.9900} \\
\hline 229 & 0 & 2.9000 & 0.2000 & 10000.0 & 0.1100 & 0.0000 \\
\hline \multicolumn{7}{|l|}{0.9900} \\
\hline 269 & 0 & 2.9000 & 0.2000 & 10000.0 & 0.2300 & 0.0000 \\
\hline \multicolumn{7}{|l|}{0.9900} \\
\hline 110 & 0 . & 4.6000 & 0.2000 & 4000.0 & 0.0350 & 0.0000 \\
\hline \multicolumn{7}{|l|}{0.9900} \\
\hline 130 & 0 . & 4.6000 & 0.2000 & 4000.0 & 0.1100 & 0.0000 \\
\hline \multicolumn{7}{|l|}{0.9900} \\
\hline 150 & 0 . & 4.6000 & 0.2000 & 4000.0 & 0.1100 & 0.0000 \\
\hline 0.9900 & & & & & & \\
\hline 190 & 0 & 4.6000 & 0.2000 & 4000.0 & 0.2300 & 0.0000 \\
\hline 0.9900 & & & & & & \\
\hline 210 & 0 . & 4.6000 & 0.2000 & 10000.0 & 0.0350 & 0.0000 \\
\hline 0.9900 & & & & & & \\
\hline 230 & 0. & 4.6000 & 0.2000 & 10000.0 & 0.1100 & 0.0000 \\
\hline 0.9900 & & & & & & \\
\hline 250 & 0 . & 4.6000 & 0.2000 & 10000.0 & 0.1100 & 0.0000 \\
\hline 0.9900 & & & & & & \\
\hline 270 & 0 . & 4.6000 & 0.2000 & 10000.0 & 0.2300 & 0.0000 \\
\hline 0.9900 & & & & & & \\
\hline 290 & 0. & 4.6000 & 0.2000 & 10000.0 & 0.2300 & 0.0000 \\
\hline 0.9900 & & & & & & \\
\hline 330 & 0 . & 4.6000 & 0.2000 & 12000.0 & 0.1100 & 0.0000 \\
\hline 0.9900 & & & & & & \\
\hline 370 & 0 . & 4.6000 & 0.2000 & 12000.0 & 0.2300 & 0.0000 \\
\hline 0.9900 & & & & & & \\
\hline
\end{tabular}




\begin{tabular}{|c|c|c|c|c|c|c|}
\hline $\begin{array}{r}390 \\
0.9900\end{array}$ & 0 . & 4.6000 & 0.2000 & 12000.0 & 0.2300 & 0.0000 \\
\hline$\star \star \star$ dry. wheat & $* * *$ & & & & & \\
\hline 111 & 0 . & 2.3000 & 0.2000 & 4000.0 & 0.0350 & 0.0000 \\
\hline \multicolumn{7}{|l|}{0.9900} \\
\hline 131 & 0 & 2.3000 & 0.2000 & 4000.0 & 0.1100 & 0.0000 \\
\hline \multicolumn{7}{|l|}{0.9900} \\
\hline 151 & 0 & 2.3000 & 0.2000 & 4000.0 & 0.1100 & 0.0000 \\
\hline \multicolumn{7}{|l|}{0.9900} \\
\hline 114 & 0 & 9.2000 & 0.2000 & 4000.0 & 0.0350 & 0.0000 \\
\hline \multicolumn{7}{|l|}{0.9900} \\
\hline 134 & 0 & 9.2000 & 0.2000 & 4000.0 & 0.1100 & 0.0000 \\
\hline \multicolumn{7}{|l|}{0.9900} \\
\hline 314 & 0 & 9.2000 & 0.2000 & 12000.0 & 0.0350 & 0.0000 \\
\hline \multicolumn{7}{|l|}{0.9900} \\
\hline 334 & 0 & 9.2000 & 0.2000 & 12000.0 & 0.1100 & 0.0000 \\
\hline \multicolumn{7}{|c|}{0.9900} \\
\hline \multicolumn{7}{|c|}{ END PWAT-PARM2 } \\
\hline \multicolumn{7}{|c|}{ PWAT-PARM3 } \\
\hline \multicolumn{7}{|l|}{$<\mathrm{PLS}>\star \star \star *$} \\
\hline$\#-\# \star \star \star *$ & PETMAX & PETMIN & INFEXP & INFILD & DEEPFR & BASETP \\
\hline \multicolumn{7}{|l|}{ AGWETP } \\
\hline 101390 & 40 & 35. & 0.2500 & 2.0000 & .00 & \\
\hline \\
\hline \multicolumn{7}{|c|}{ END PWAT-PARM3 } \\
\hline \multicolumn{7}{|c|}{ PWAT-PARM4 } \\
\hline$<\mathrm{PLS}>$ & & & & & & $\star \star \star$ \\
\hline$\#-\quad \#$ & CEPSC & UZSN & NSUR & INTFW & IRC & LZETP *** \\
\hline$\star \star \star$ sagebrush & $\star \star \star$ & & & & & \\
\hline 101 & & 0.5000 & 0.3000 & 0.000 & 0.7000 & \\
\hline 201 & & 0.5000 & 0.3000 & 0.000 & 0.7000 & \\
\hline 103 & & 0.5000 & 0.3000 & 0.000 & 0.7000 & \\
\hline 104 & & 0.5000 & 0.3000 & 0.000 & 0.7000 & \\
\hline 204 & & 0.5000 & 0.3000 & 0.000 & 0.7000 & \\
\hline 304 & & 0.5000 & 0.3000 & 0.000 & 0.7000 & \\
\hline 121 & & 0.3000 & 0.3000 & 0.000 & 0.5000 & \\
\hline 141 & & 0.3000 & 0.3000 & 0.000 & 0.5000 & \\
\hline 221 & & 0.3000 & 0.3000 & 0.000 & 0.7000 & \\
\hline 241 & & 0.3000 & 0.3000 & 0.000 & 0.5000 & \\
\hline 321 & & 0.3000 & 0.3000 & 0.000 & 0.5000 & \\
\hline 124 & & 0.3000 & 0.3000 & 0.000 & 0.5000 & \\
\hline 144 & & 0.3000 & 0.3000 & 0.000 & 0.5000 & \\
\hline 224 & & 0.3000 & 0.3000 & 0.000 & 0.5000 & \\
\hline 244 & & 0.3000 & 0.3000 & 0.000 & 0.5000 & \\
\hline 324 & & 0.3000 & 0.3000 & 0.000 & 0.5000 & \\
\hline 344 & & 0.3000 & 0.3000 & 0.000 & 0.5000 & \\
\hline 161 & & 0.2000 & 0.3000 & 0.000 & 0.3000 & \\
\hline 261 & & 0.2000 & 0.3000 & 0.000 & 0.3000 & \\
\hline 281 & & 0.2000 & 0.3000 & 0.000 & 0.3000 & \\
\hline 361 & & 0.2000 & 0.3000 & 0.000 & 0.3000 & \\
\hline 164 & & 0.2000 & 0.3000 & 0.000 & 0.3000 & \\
\hline 184 & & 0.2000 & 0.3000 & 0.000 & 0.3000 & \\
\hline 264 & & 0.2000 & 0.3000 & 0.000 & 0.3000 & \\
\hline 284 & & 0.2000 & 0.3000 & 0.000 & 0.3000 & \\
\hline
\end{tabular}




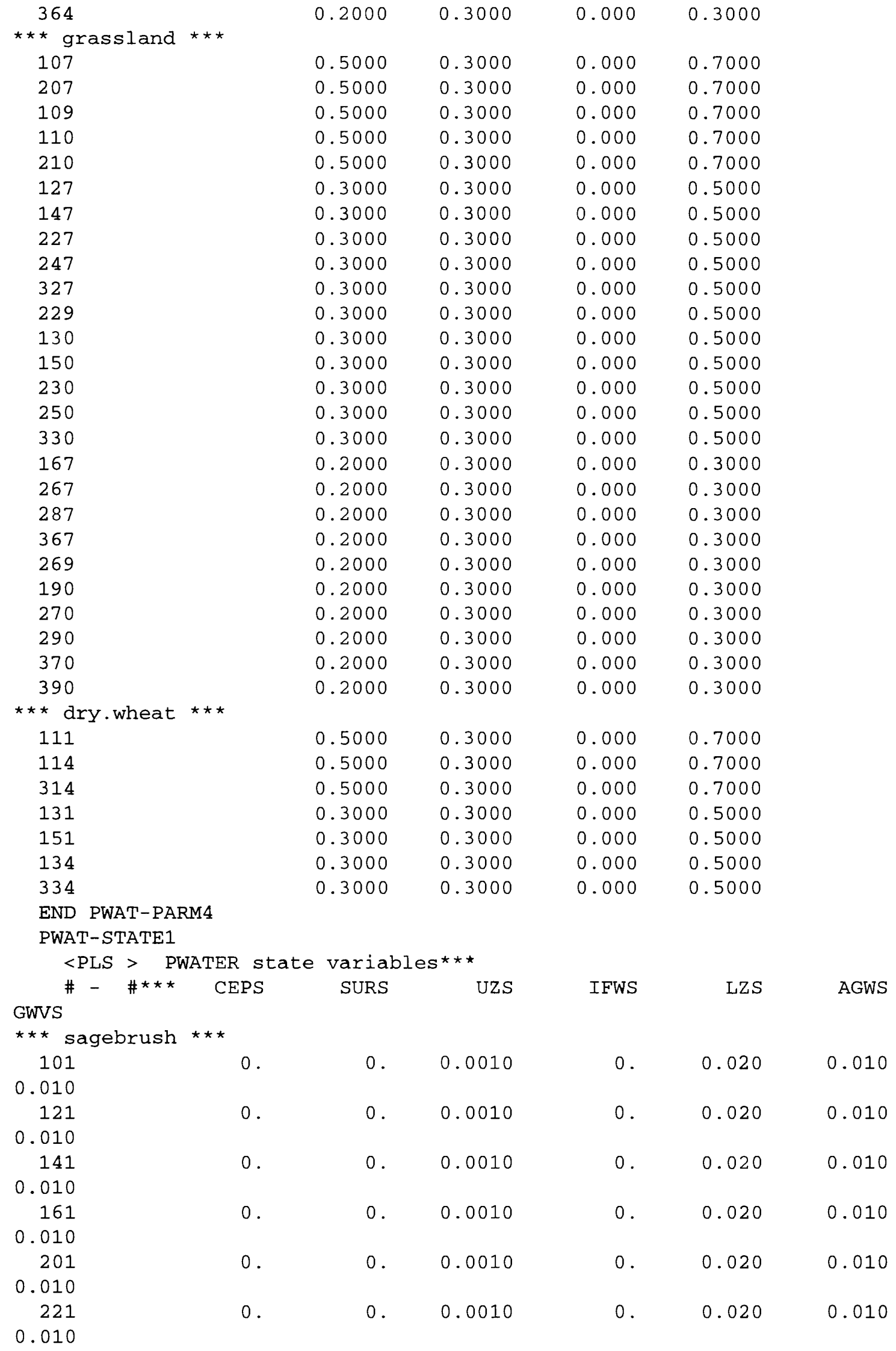




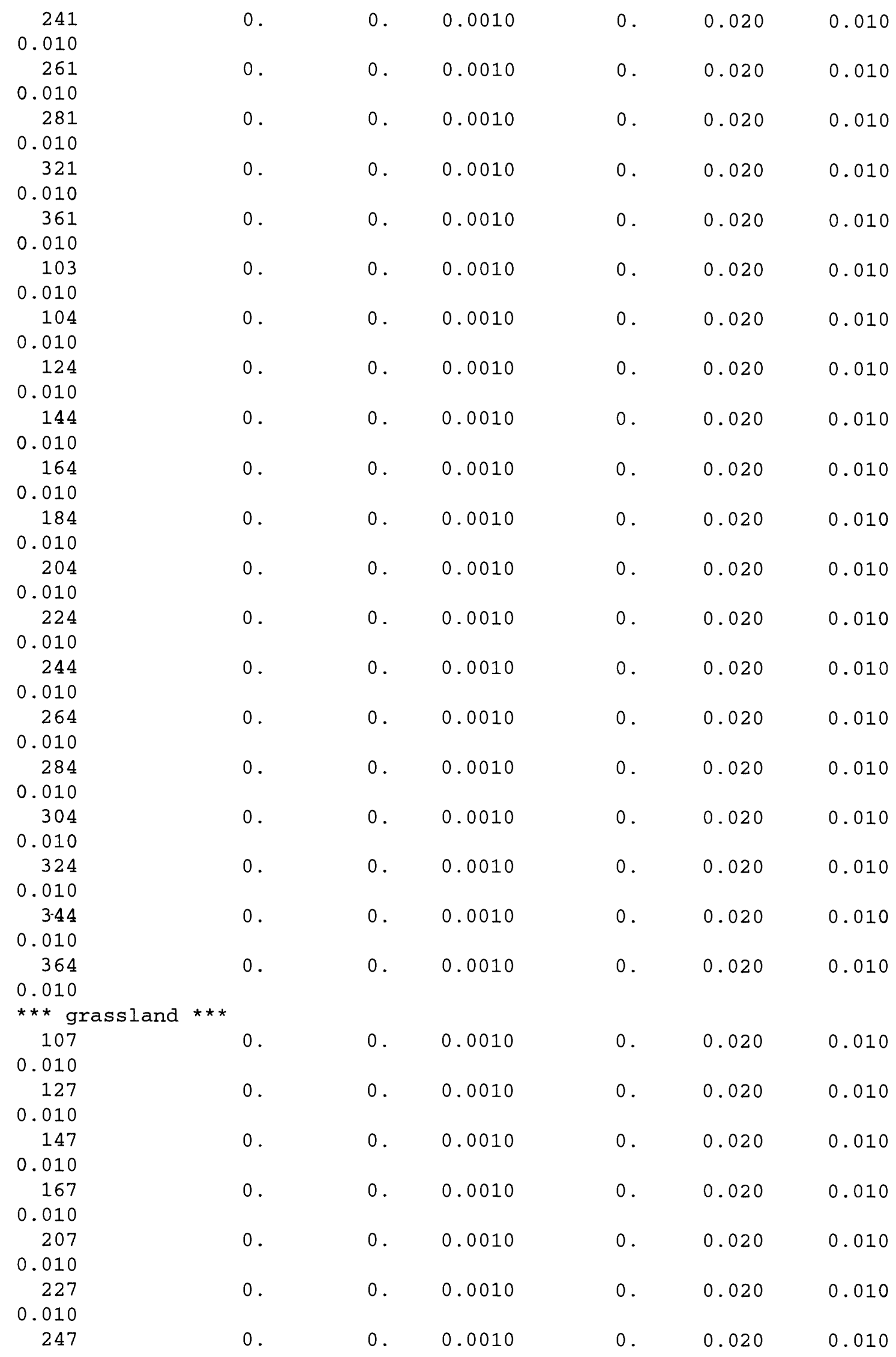




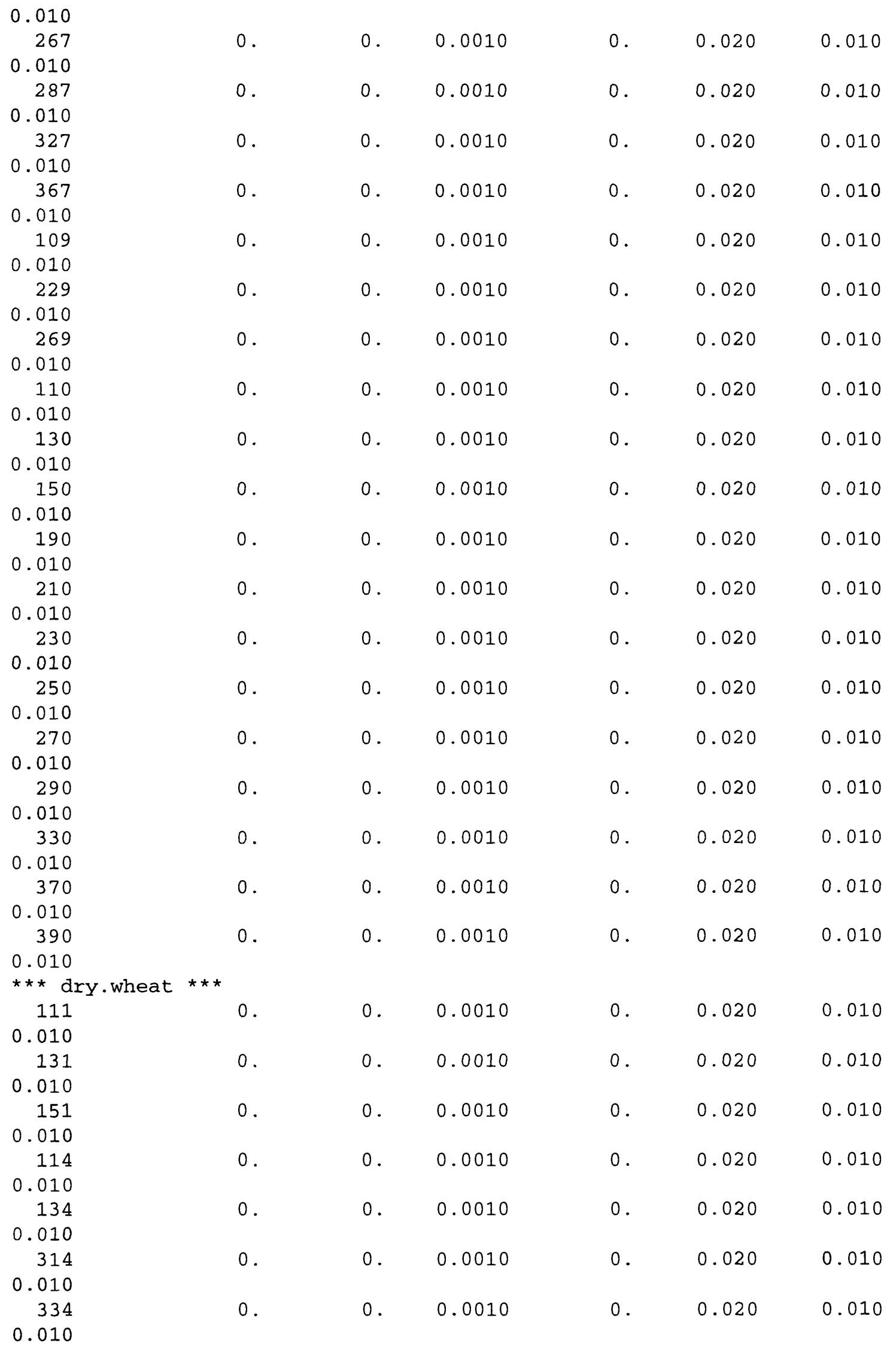


END PWAT-STATE1

MON-INTERCEP

<PLS> Only required if VCSFG=1 in PWAT-PARM1

\# - \# Interception storage capacity at start of each month JAN FEB MAR APR MAY JUN JUL AUG SEP OCT NOV DEC $* * *$

*** sagebrush ***

$\begin{array}{lllllllllllllll}101 & 0.04 & 0.06 & 0.06 & 0.06 & 0.05 & 0.05 & 0.04 & 0.04 & 0.04 & 0.05 & 0.04 & 0.04\end{array}$

$\begin{array}{lllllllllllllll}121 & 0.04 & 0.06 & 0.06 & 0.06 & 0.05 & 0.05 & 0.04 & 0.04 & 0.04 & 0.05 & 0.04 & 0.04\end{array}$

$\begin{array}{llllllllllllllll}141 & 0.04 & 0.06 & 0.06 & 0.06 & 0.05 & 0.05 & 0.04 & 0.04 & 0.04 & 0.05 & 0.04 & 0.04\end{array}$

$\begin{array}{llllllllllllllll}161 & 0.04 & 0.06 & 0.06 & 0.06 & 0.05 & 0.05 & 0.04 & 0.04 & 0.04 & 0.05 & 0.04 & 0.04\end{array}$

$\begin{array}{lllllllllllllllll}201 & 0.04 & 0.06 & 0.06 & 0.06 & 0.05 & 0.05 & 0.04 & 0.04 & 0.04 & 0.05 & 0.04 & 0.04\end{array}$

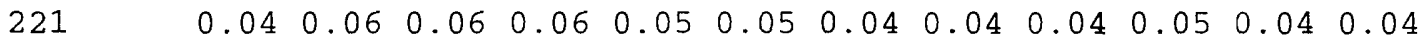

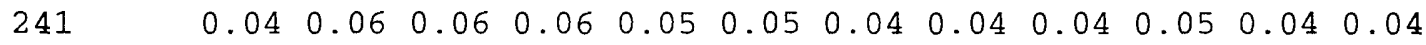

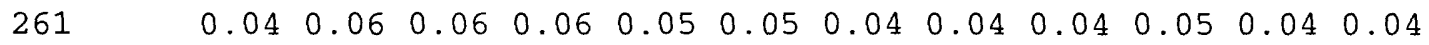

$\begin{array}{lllllllllllllll}281 & 0.04 & 0.06 & 0.06 & 0.06 & 0.05 & 0.05 & 0.04 & 0.04 & 0.04 & 0.05 & 0.04 & 0.04\end{array}$

$\begin{array}{lllllllllllllll}321 & 0.04 & 0.06 & 0.06 & 0.06 & 0.05 & 0.05 & 0.04 & 0.04 & 0.04 & 0.05 & 0.04 & 0.04\end{array}$

$\begin{array}{lllllllllllllll}361 & 0.04 & 0.06 & 0.06 & 0.06 & 0.05 & 0.05 & 0.04 & 0.04 & 0.04 & 0.05 & 0.04 & 0.04\end{array}$

$\begin{array}{llllllllllllllll}103 & 0.04 & 0.06 & 0.06 & 0.06 & 0.05 & 0.05 & 0.04 & 0.04 & 0.04 & 0.05 & 0.04 & 0.04\end{array}$

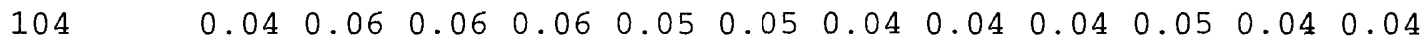

$\begin{array}{llllllllllllllll}124 & 0.04 & 0.06 & 0.06 & 0.06 & 0.05 & 0.05 & 0.04 & 0.04 & 0.04 & 0.05 & 0.04 & 0.04\end{array}$

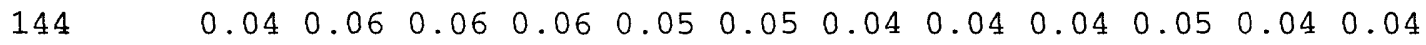

$\begin{array}{llllllllllllllll}164 & 0.04 & 0.06 & 0.06 & 0.06 & 0.05 & 0.05 & 0.04 & 0.04 & 0.04 & 0.05 & 0.04 & 0.04\end{array}$

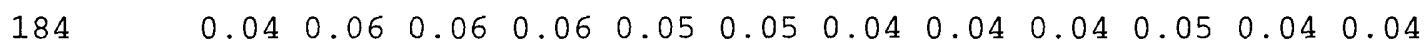

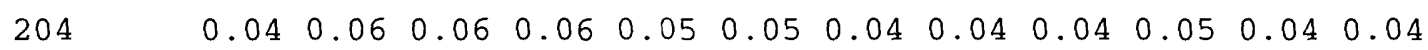

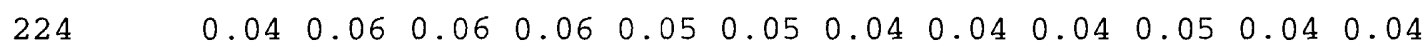

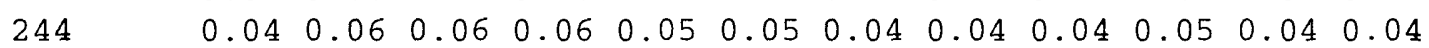

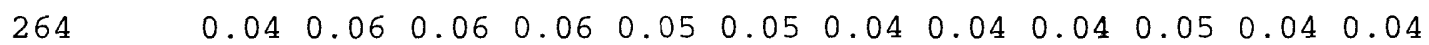

$\begin{array}{llllllllllllllll}284 & 0.04 & 0.06 & 0.06 & 0.06 & 0.05 & 0.05 & 0.04 & 0.04 & 0.04 & 0.05 & 0.04 & 0.04\end{array}$

$\begin{array}{lllllllllllllll}304 & 0.04 & 0.06 & 0.06 & 0.06 & 0.05 & 0.05 & 0.04 & 0.04 & 0.04 & 0.05 & 0.04 & 0.04\end{array}$

$\begin{array}{lllllllllllllll}324 & 0.04 & 0.06 & 0.06 & 0.06 & 0.05 & 0.05 & 0.04 & 0.04 & 0.04 & 0.05 & 0.04 & 0.04\end{array}$

$\begin{array}{lllllllllllllll}344 & 0.04 & 0.06 & 0.06 & 0.06 & 0.05 & 0.05 & 0.04 & 0.04 & 0.04 & 0.05 & 0.04 & 0.04\end{array}$

$\begin{array}{lllllllllllllll}364 & 0.04 & 0.06 & 0.06 & 0.06 & 0.05 & 0.05 & 0.04 & 0.04 & 0.04 & 0.05 & 0.04 & 0.04\end{array}$

*** grassland $* * *$

$\begin{array}{llllllllllllll}107 & 0.03 & 0.04 & 0.05 & 0.06 & 0.06 & 0.06 & 0.06 & 0.06 & 0.06 & 0.05 & 0.04 & 0.04\end{array}$

$\begin{array}{llllllllllllllll}127 & 0.03 & 0.04 & 0.05 & 0.06 & 0.06 & 0.06 & 0.06 & 0.06 & 0.06 & 0.05 & 0.04 & 0.04\end{array}$

$\begin{array}{lllllllllllllll}147 & 0.03 & 0.04 & 0.05 & 0.06 & 0.06 & 0.06 & 0.06 & 0.06 & 0.06 & 0.05 & 0.04 & 0.04\end{array}$

$\begin{array}{llllllllllllllll}167 & 0.03 & 0.04 & 0.05 & 0.06 & 0.06 & 0.06 & 0.06 & 0.06 & 0.06 & 0.05 & 0.04 & 0.04\end{array}$

$\begin{array}{lllllllllllllll}207 & 0.03 & 0.04 & 0.05 & 0.06 & 0.06 & 0.06 & 0.06 & 0.06 & 0.06 & 0.05 & 0.04 & 0.04\end{array}$

$\begin{array}{lllllllllllllll}227 & 0.03 & 0.04 & 0.05 & 0.06 & 0.06 & 0.06 & 0.06 & 0.06 & 0.06 & 0.05 & 0.04 & 0.04\end{array}$

$\begin{array}{lllllllllllllll}247 & 0.03 & 0.04 & 0.05 & 0.06 & 0.06 & 0.06 & 0.06 & 0.06 & 0.06 & 0.05 & 0.04 & 0.04\end{array}$

$\begin{array}{llllllllllllllll}267 & 0.03 & 0.04 & 0.05 & 0.06 & 0.06 & 0.06 & 0.06 & 0.06 & 0.06 & 0.05 & 0.04 & 0.04\end{array}$

$\begin{array}{lllllllllllllll}287 & 0.03 & 0.04 & 0.05 & 0.06 & 0.06 & 0.06 & 0.06 & 0.06 & 0.06 & 0.05 & 0.04 & 0.04\end{array}$

327

367

109 $\begin{array}{lllllllllllllll}0.03 & 0.04 & 0.05 & 0.06 & 0.06 & 0.06 & 0.06 & 0.06 & 0.06 & 0.05 & 0.04 & 0.04\end{array}$ $\begin{array}{llllllllllllll}0.03 & 0.04 & 0.05 & 0.06 & 0.06 & 0.06 & 0.06 & 0.06 & 0.06 & 0.05 & 0.04 & 0.04\end{array}$ $\begin{array}{llllllllllllll}0.03 & 0.04 & 0.05 & 0.06 & 0.06 & 0.06 & 0.06 & 0.06 & 0.06 & 0.05 & 0.04 & 0.04\end{array}$ $\begin{array}{llllllllllllll}0.03 & 0.04 & 0.05 & 0.06 & 0.06 & 0.06 & 0.06 & 0.06 & 0.06 & 0.05 & 0.04 & 0.04\end{array}$ $\begin{array}{llllllllllllll}0.03 & 0.04 & 0.05 & 0.06 & 0.06 & 0.06 & 0.06 & 0.06 & 0.06 & 0.05 & 0.04 & 0.04\end{array}$ $\begin{array}{lllllllllllllll}0.03 & 0.04 & 0.05 & 0.06 & 0.06 & 0.06 & 0.06 & 0.06 & 0.06 & 0.05 & 0.04 & 0.04\end{array}$ $\begin{array}{lllllllllllllll}0.03 & 0.04 & 0.05 & 0.06 & 0.06 & 0.06 & 0.06 & 0.06 & 0.06 & 0.05 & 0.04 & 0.04\end{array}$ $\begin{array}{lllllllllllllll}0.03 & 0.04 & 0.05 & 0.06 & 0.06 & 0.06 & 0.06 & 0.06 & 0.06 & 0.05 & 0.04 & 0.04\end{array}$ $\begin{array}{lllllllllllllll}0.03 & 0.04 & 0.05 & 0.06 & 0.06 & 0.06 & 0.06 & 0.06 & 0.06 & 0.05 & 0.04 & 0.04\end{array}$ $\begin{array}{llllllllllllll}0.03 & 0.04 & 0.05 & 0.06 & 0.06 & 0.06 & 0.06 & 0.06 & 0.06 & 0.05 & 0.04 & 0.04\end{array}$ $\begin{array}{llllllllllllll}0.03 & 0.04 & 0.05 & 0.06 & 0.06 & 0.06 & 0.06 & 0.06 & 0.06 & 0.05 & 0.04 & 0.04\end{array}$

230

250 $\begin{array}{llllllllllllll}0.03 & 0.04 & 0.05 & 0.06 & 0.06 & 0.06 & 0.06 & 0.06 & 0.06 & 0.05 & 0.04 & 0.04\end{array}$ 
$\begin{array}{lllllllllllll}0.03 & 0.04 & 0.05 & 0.06 & 0.06 & 0.06 & 0.06 & 0.06 & 0.06 & 0.05 & 0.04 & 0.04\end{array}$

290 $\begin{array}{llllllllllll}0.03 & 0.04 & 0.05 & 0.06 & 0.06 & 0.06 & 0.06 & 0.06 & 0.06 & 0.05 & 0.04 & 0.04\end{array}$

330 $\begin{array}{lllllllllllll}0.03 & 0.04 & 0.05 & 0.06 & 0.06 & 0.06 & 0.06 & 0.06 & 0.06 & 0.05 & 0.04 & 0.04\end{array}$

370 $\begin{array}{llllllllllll}0.03 & 0.04 & 0.05 & 0.06 & 0.06 & 0.06 & 0.06 & 0.06 & 0.06 & 0.05 & 0.04 & 0.04\end{array}$ 390 $\star \star \star$ dry. wheat $*$ $\begin{array}{lllllllllllll}0.03 & 0.04 & 0.05 & 0.06 & 0.06 & 0.06 & 0.06 & 0.06 & 0.06 & 0.05 & 0.04 & 0.04\end{array}$

$\begin{array}{lllllllllllllll}111 & 0.16 & 0.16 & 0.16 & 0.16 & 0.16 & 0.08 & 0.00 & 0.00 & 0.06 & 0.16 & 0.16 & 0.16\end{array}$ $\begin{array}{lllllllllllll}131 & 0.16 & 0.16 & 0.16 & 0.16 & 0.16 & 0.08 & 0.00 & 0.00 & 0.06 & 0.16 & 0.16 & 0.16\end{array}$ $\begin{array}{lllllllllllll}151 & 0.16 & 0.16 & 0.16 & 0.16 & 0.16 & 0.08 & 0.00 & 0.00 & 0.06 & 0.16 & 0.16 & 0.16\end{array}$ $\begin{array}{llllllllllllll}114 & 0.16 & 0.16 & 0.16 & 0.16 & 0.16 & 0.08 & 0.00 & 0.00 & 0.06 & 0.16 & 0.16 & 0.16\end{array}$ $\begin{array}{lllllllllllll}134 & 0.16 & 0.16 & 0.16 & 0.16 & 0.16 & 0.08 & 0.00 & 0.00 & 0.06 & 0.16 & 0.16 & 0.16\end{array}$ $\begin{array}{lllllllllllll}314 & 0.16 & 0.16 & 0.16 & 0.16 & 0.16 & 0.08 & 0.00 & 0.00 & 0.06 & 0.16 & 0.16 & 0.16\end{array}$ $\begin{array}{lllllllllllll}334 & 0.16 & 0.16 & 0.16 & 0.16 & 0.16 & 0.08 & 0.00 & 0.00 & 0.06 & 0.16 & 0.16 & 0.16\end{array}$ END MON-INTERCEP

MON-LZETPARM

$<$ PLS > Only required if VLEFG=1 in PWAT-PARM1

\# - \# Lower zone ET parameter at start of each month JAN FEB MAR APR MAY JUN JUL AUG SEP OCT NOV DEC *** *** sagebrush

$\begin{array}{llllllllllllll}101 & 0.75 & 0.99 & 0.97 & 0.78 & 0.80 & 0.81 & 0.81 & 0.80 & 0.77 & 0.69 & 0.71 & 0.73\end{array}$

$\begin{array}{llllllllllllll}103 & 0.75 & 0.99 & 0.97 & 0.78 & 0.80 & 0.81 & 0.81 & 0.80 & 0.77 & 0.69 & 0.71 & 0.73\end{array}$

$\begin{array}{lllllllllllll}104 & 0.75 & 0.99 & 0.97 & 0.78 & 0.80 & 0.81 & 0.81 & 0.80 & 0.77 & 0.69 & 0.71 & 0.73\end{array}$

$\begin{array}{llllllllllllll}121 & 0.75 & 0.99 & 0.97 & 0.78 & 0.80 & 0.81 & 0.81 & 0.80 & 0.77 & 0.69 & 0.71 & 0.73\end{array}$

$124 \quad \begin{array}{lllllllllllll}0.75 & 0.99 & 0.97 & 0.78 & 0.80 & 0.81 & 0.81 & 0.80 & 0.77 & 0.69 & 0.71 & 0.73\end{array}$

$\begin{array}{lllllllllllll}141 & 0.75 & 0.99 & 0.97 & 0.78 & 0.80 & 0.81 & 0.81 & 0.80 & 0.77 & 0.69 & 0.71 & 0.73\end{array}$

$144 \quad \begin{array}{lllllllllllll}0.75 & 0.99 & 0.97 & 0.78 & 0.80 & 0.81 & 0.81 & 0.80 & 0.77 & 0.69 & 0.71 & 0.73\end{array}$

$\begin{array}{llllllllllllll}161 & 0.75 & 0.99 & 0.97 & 0.78 & 0.80 & 0.81 & 0.81 & 0.80 & 0.77 & 0.69 & 0.71 & 0.73\end{array}$

$\begin{array}{lllllllllllll}164 & 0.75 & 0.99 & 0.97 & 0.78 & 0.80 & 0.81 & 0.81 & 0.80 & 0.77 & 0.69 & 0.71 & 0.73\end{array}$

$\begin{array}{lllllllllllll}184 & 0.75 & 0.99 & 0.97 & 0.78 & 0.80 & 0.81 & 0.81 & 0.80 & 0.77 & 0.69 & 0.71 & 0.73\end{array}$

$\begin{array}{llllllllllllll}201 & 0.75 & 0.99 & 0.97 & 0.78 & 0.80 & 0.81 & 0.81 & 0.80 & 0.77 & 0.69 & 0.71 & 0.73\end{array}$

$\begin{array}{lllllllllllll}204 & 0.75 & 0.99 & 0.97 & 0.78 & 0.80 & 0.81 & 0.81 & 0.80 & 0.77 & 0.69 & 0.71 & 0.73\end{array}$

$\begin{array}{llllllllllllll}221 & 0.75 & 0.99 & 0.97 & 0.78 & 0.80 & 0.81 & 0.81 & 0.80 & 0.77 & 0.69 & 0.71 & 0.73\end{array}$

$\begin{array}{lllllllllllll}224 & 0.75 & 0.99 & 0.97 & 0.78 & 0.80 & 0.81 & 0.81 & 0.80 & 0.77 & 0.69 & 0.71 & 0.73\end{array}$

$\begin{array}{llllllllllllll}241 & 0.75 & 0.99 & 0.97 & 0.78 & 0.80 & 0.81 & 0.81 & 0.80 & 0.77 & 0.69 & 0.71 & 0.73\end{array}$

$\begin{array}{lllllllllllll}244 & 0.75 & 0.99 & 0.97 & 0.78 & 0.80 & 0.81 & 0.81 & 0.80 & 0.77 & 0.69 & 0.71 & 0.73\end{array}$

$\begin{array}{llllllllllllll}261 & 0.75 & 0.99 & 0.97 & 0.78 & 0.80 & 0.81 & 0.81 & 0.80 & 0.77 & 0.69 & 0.71 & 0.73\end{array}$

$\begin{array}{llllllllllllll}264 & 0.75 & 0.99 & 0.97 & 0.78 & 0.80 & 0.81 & 0.81 & 0.80 & 0.77 & 0.69 & 0.71 & 0.73\end{array}$

$\begin{array}{llllllllllllll}281 & 0.75 & 0.99 & 0.97 & 0.78 & 0.80 & 0.81 & 0.81 & 0.80 & 0.77 & 0.69 & 0.71 & 0.73\end{array}$

$\begin{array}{lllllllllllll}284 & 0.75 & 0.99 & 0.97 & 0.78 & 0.80 & 0.81 & 0.81 & 0.80 & 0.77 & 0.69 & 0.71 & 0.73\end{array}$

$\begin{array}{lllllllllllll}304 & 0.75 & 0.99 & 0.97 & 0.78 & 0.80 & 0.81 & 0.81 & 0.80 & 0.77 & 0.69 & 0.71 & 0.73\end{array}$

$\begin{array}{llllllllllllll}321 & 0.75 & 0.99 & 0.97 & 0.78 & 0.80 & 0.81 & 0.81 & 0.80 & 0.77 & 0.69 & 0.71 & 0.73\end{array}$

$\begin{array}{lllllllllllllll}324 & 0.75 & 0.99 & 0.97 & 0.78 & 0.80 & 0.81 & 0.81 & 0.80 & 0.77 & 0.69 & 0.71 & 0.73\end{array}$

$\begin{array}{lllllllllllll}344 & 0.75 & 0.99 & 0.97 & 0.78 & 0.80 & 0.81 & 0.81 & 0.80 & 0.77 & 0.69 & 0.71 & 0.73\end{array}$

$\begin{array}{llllllllllllll}361 & 0.75 & 0.99 & 0.97 & 0.78 & 0.80 & 0.81 & 0.81 & 0.80 & 0.77 & 0.69 & 0.71 & 0.73\end{array}$

$\begin{array}{lllllllllllllll}364 & 0.75 & 0.99 & 0.97 & 0.78 & 0.80 & 0.81 & 0.81 & 0.80 & 0.77 & 0.69 & 0.71 & 0.73\end{array}$ *** grassland $* \star *$

$\begin{array}{llllllllllllll}107 & 0.45 & 0.52 & 0.65 & 0.76 & 0.80 & 0.81 & 0.81 & 0.80 & 0.77 & 0.69 & 0.58 & 0.48\end{array}$ $\begin{array}{lllllllllllll}109 & 0.45 & 0.52 & 0.65 & 0.76 & 0.80 & 0.81 & 0.81 & 0.80 & 0.77 & 0.69 & 0.58 & 0.48\end{array}$ $\begin{array}{lllllllllllll}110 & 0.45 & 0.52 & 0.65 & 0.76 & 0.80 & 0.81 & 0.81 & 0.80 & 0.77 & 0.69 & 0.58 & 0.48\end{array}$ $\begin{array}{lllllllllllll}127 & 0.45 & 0.52 & 0.65 & 0.76 & 0.80 & 0.81 & 0.81 & 0.80 & 0.77 & 0.69 & 0.58 & 0.48\end{array}$ $\begin{array}{lllllllllllll}130 & 0.45 & 0.52 & 0.65 & 0.76 & 0.80 & 0.81 & 0.81 & 0.80 & 0.77 & 0.69 & 0.58 & 0.48\end{array}$ $\begin{array}{llllllllllllll}147 & 0.45 & 0.52 & 0.65 & 0.76 & 0.80 & 0.81 & 0.81 & 0.80 & 0.77 & 0.69 & 0.58 & 0.48\end{array}$ $\begin{array}{llllllllllllll}150 & 0.45 & 0.52 & 0.65 & 0.76 & 0.80 & 0.81 & 0.81 & 0.80 & 0.77 & 0.69 & 0.58 & 0.48\end{array}$ $\begin{array}{llllllllllllll}167 & 0.45 & 0.52 & 0.65 & 0.76 & 0.80 & 0.81 & 0.81 & 0.80 & 0.77 & 0.69 & 0.58 & 0.48\end{array}$ 


$\begin{array}{lllllllllllll}190 & 0.45 & 0.52 & 0.65 & 0.76 & 0.80 & 0.81 & 0.81 & 0.80 & 0.77 & 0.69 & 0.58 & 0.48 \\ 207 & 0.45 & 0.52 & 0.65 & 0.76 & 0.80 & 0.81 & 0.81 & 0.80 & 0.77 & 0.69 & 0.58 & 0.48 \\ 210 & 0.45 & 0.52 & 0.65 & 0.76 & 0.80 & 0.81 & 0.81 & 0.80 & 0.77 & 0.69 & 0.58 & 0.48 \\ 227 & 0.45 & 0.52 & 0.65 & 0.76 & 0.80 & 0.81 & 0.81 & 0.80 & 0.77 & 0.69 & 0.58 & 0.48 \\ 229 & 0.45 & 0.52 & 0.65 & 0.76 & 0.80 & 0.81 & 0.81 & 0.80 & 0.77 & 0.69 & 0.58 & 0.48 \\ 230 & 0.45 & 0.52 & 0.65 & 0.76 & 0.80 & 0.81 & 0.81 & 0.80 & 0.77 & 0.69 & 0.58 & 0.48 \\ 247 & 0.45 & 0.52 & 0.65 & 0.76 & 0.80 & 0.81 & 0.81 & 0.80 & 0.77 & 0.69 & 0.58 & 0.48 \\ 250 & 0.45 & 0.52 & 0.65 & 0.76 & 0.80 & 0.81 & 0.81 & 0.80 & 0.77 & 0.69 & 0.58 & 0.48 \\ 267 & 0.45 & 0.52 & 0.65 & 0.76 & 0.80 & 0.81 & 0.81 & 0.80 & 0.77 & 0.69 & 0.58 & 0.48 \\ 269 & 0.45 & 0.52 & 0.65 & 0.76 & 0.80 & 0.81 & 0.81 & 0.80 & 0.77 & 0.69 & 0.58 & 0.48 \\ 270 & 0.45 & 0.52 & 0.65 & 0.76 & 0.80 & 0.81 & 0.81 & 0.80 & 0.77 & 0.69 & 0.58 & 0.48 \\ 287 & 0.45 & 0.52 & 0.65 & 0.76 & 0.80 & 0.81 & 0.81 & 0.80 & 0.77 & 0.69 & 0.58 & 0.48 \\ 290 & 0.45 & 0.52 & 0.65 & 0.76 & 0.80 & 0.81 & 0.81 & 0.80 & 0.77 & 0.69 & 0.58 & 0.48 \\ 327 & 0.45 & 0.52 & 0.65 & 0.76 & 0.80 & 0.81 & 0.81 & 0.80 & 0.77 & 0.69 & 0.58 & 0.48 \\ 330 & 0.45 & 0.52 & 0.65 & 0.76 & 0.80 & 0.81 & 0.81 & 0.80 & 0.77 & 0.69 & 0.58 & 0.48 \\ 367 & 0.45 & 0.52 & 0.65 & 0.76 & 0.80 & 0.81 & 0.81 & 0.80 & 0.77 & 0.69 & 0.58 & 0.48 \\ 370 & 0.45 & 0.52 & 0.65 & 0.76 & 0.80 & 0.81 & 0.81 & 0.80 & 0.77 & 0.69 & 0.58 & 0.48 \\ 390 & 0.45 & 0.52 & 0.65 & 0.76 & 0.80 & 0.81 & 0.81 & 0.80 & 0.77 & 0.69 & 0.58 & 0.48 \\ \star * \star & \text { dry.wheat } & \star * \star & & & & & & & & & & \end{array}$

\section{END PERLND}

EXT SOURCES

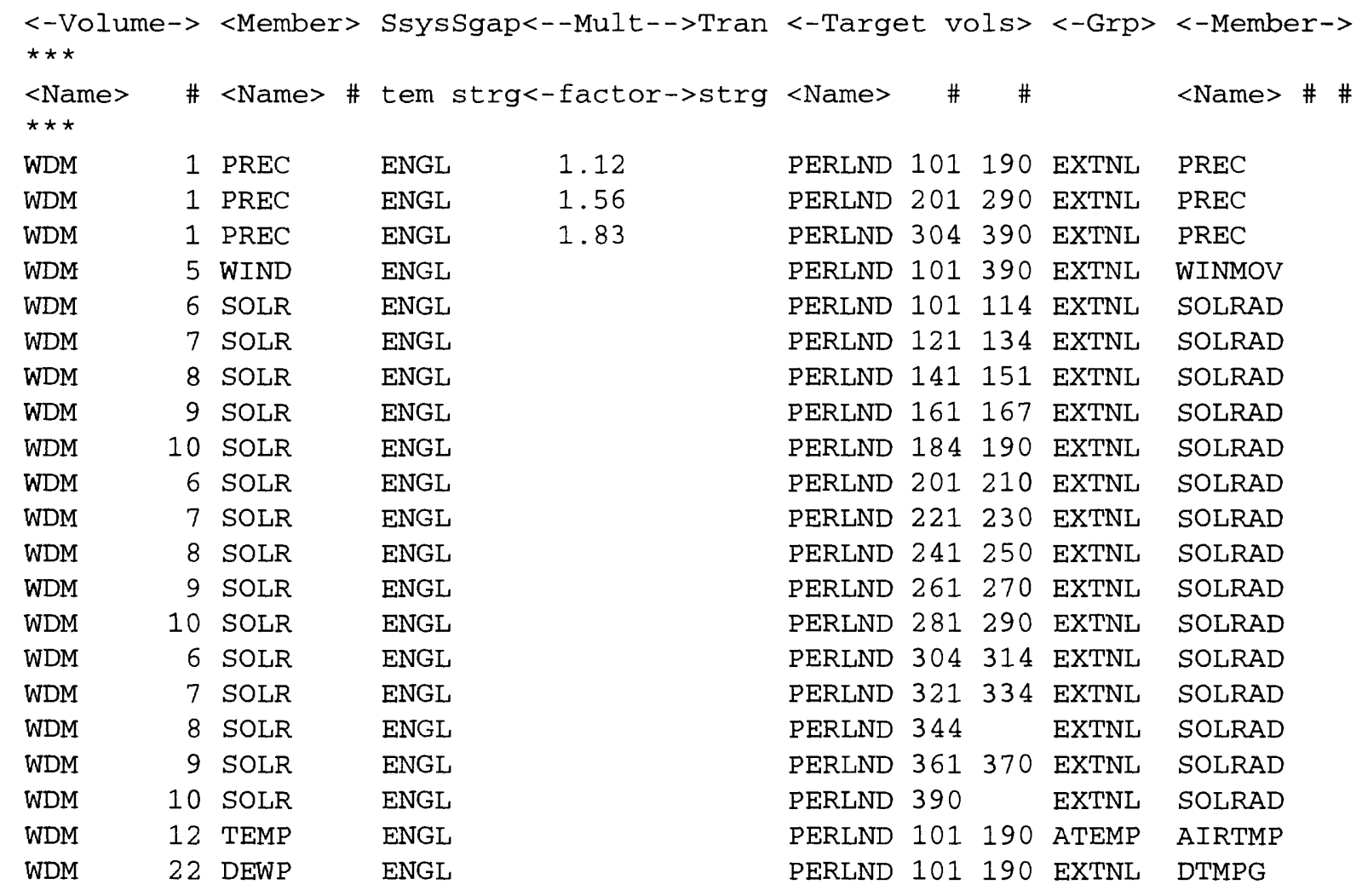




$\begin{array}{llllllll}\text { WDM } & 15 & \text { TEMP } & \text { ENGL } & \text { PERLND } 201 & 290 & \text { ATEMP } & \text { AIRTMP } \\ \text { WDM } & 25 & \text { DEWP } & \text { ENGL } & \text { PERLND } 201 & 290 & \text { EXTNL } & \text { DTMPG } \\ \text { WDM } & 18 & \text { TEMP } & \text { ENGL } & \text { PERLND } 304 & 390 & \text { ATEMP } & \text { AIRTMP } \\ \text { WDM } & 28 & \text { DEWP } & \text { ENGL } & \text { PERLND } 304 & 390 & \text { EXTNL } & \text { DTMPG } \\ \text { WDM } & 32 & \text { PET } & \text { ENGL } & \text { PERLND } 101 & 114 & \text { EXTNL } & \text { PETINP } \\ \text { WDM } & 42 & \text { PET } & \text { ENGL } & \text { PERLND } 121 & 134 & \text { EXTNL } & \text { PETINP } \\ \text { WDM } & 52 & \text { PET } & \text { ENGL } & \text { PERLND } 141 & 151 & \text { EXTNL } & \text { PETINP } \\ \text { WDM } & 62 & \text { PET } & \text { ENGL } & \text { PERLND } 161 & 167 & \text { EXTNL } & \text { PETINP } \\ \text { WDM } & 72 & \text { PET } & \text { ENGL } & \text { PERLND } 184 & 190 & \text { EXTNL } & \text { PETINP } \\ \text { WDM } & 35 & \text { PET } & \text { ENGL } & \text { PERLND } 201 & 210 & \text { EXTNL } & \text { PETINP } \\ \text { WDM } & 45 & \text { PET } & \text { ENGL } & \text { PERLND } 221 & 230 & \text { EXTNL } & \text { PETINP } \\ \text { WDM } & 55 & \text { PET } & \text { ENGL } & \text { PERLND } 241 & 250 & \text { EXTNL } & \text { PETINP } \\ \text { WDM } & 65 & \text { PET } & \text { ENGL } & \text { PERLND } 261 & 270 & \text { EXTNL } & \text { PETINP } \\ \text { WDM } & 75 & \text { PET } & \text { ENGL } & \text { PERLND } 281 & 290 & \text { EXTNL } & \text { PETINP } \\ \text { WDM } & 38 & \text { PET } & \text { ENGL } & \text { PERLND } 304 & 314 & \text { EXTNL } & \text { PETINP } \\ \text { WDM } & 48 & \text { PET } & \text { ENGL } & \text { PERLND } 321 & 334 & \text { EXTNL } & \text { PETINP } \\ \text { WDM } & 58 & \text { PET } & \text { ENGL } & \text { PERLND } 344 & \text { EXTNL } & \text { PETINP } \\ \text { WDM } & 68 & \text { PET } & \text { ENGL } & \text { PERLND } 361 & 370 & \text { EXTNL } & \text { PETINP } \\ \text { WDM } & 78 & \text { PET } & \text { ENGL } & \text { PERLND } 390 & \text { EXTNL } & \text { PETINP } \\ \text { END EXT } & \text { SOURCES } & & & & & \end{array}$

NETWORK $<-$ Volume-> <-Grp> <-Member-><--Mult-->Tran <-Target vols> <-Grp> <-Member->
$\star \star \star$

$<$ Name $>\quad$ <Name $\# \#$ \#-factor->strg $<$ Name $>\# \#$ \# $\#$ - Name $\# \#$

$\star \star \star$

$\star \star \star$ Basin geometry

*** SURO+IFWO summed for dry2 and dry1 subbasins.

*** AGWI summed for dry2 and dry1 subbasins.

*** Total actual ET (TAET+SNOWE) summed for dry1 and dry2 subbasins.

*** Mfact is perlnd area (acres)/12 (coversion from inches to acre-feet)

$* \star$ dry2 subbasin***

PERLND 101 PWATER SURO

PERLND 101 PWATER IFWO

PERLND 101 PWATER AGWI

PERLND 101 PWATER TAET

PERLND 101 SNOW SNOWE

PERLND 104 PWATER SURO

66.06667

PERLND 104 PWATER IFWO

66.06667

66.06667

66.06667

66.06667

228.53333

228.53333

PERLND 104 PWATER AGWI

228.53333

PERLND 104 PWATER TAET

228.53333

PERLND 104 SNOW SNOWE

228.53333

PERLND 107 PWATER SURO

18.29167

PERLND 107 PWATER IFWO

18.29167

PERLND 107 PWATER AGWI

18.29167

PERLND 107 PWATER TAET

18.29167

PERLND 107 SNOW SNOWE

18.29167

PERLND 110 PWATER SURO

67.55833

PERLND 110 PWATER IFWO

67.55833

PERLND 110 PWATER AGWI

67.55833

67.55833

PERLND 110 PWATER TAET

67.55833

PERLND 110 SNOW SNOWE

12.36667

$\begin{array}{lllll}\text { COPY } & 1 & \text { INPUT } & \text { MEAN } & 1 \\ \text { COPY } & 1 & \text { INPUT } & \text { MEAN } & 1 \\ \text { COPY } & 1 & \text { INPUT } & \text { MEAN } & 2 \\ \text { COPY } & 1 & \text { INPUT } & \text { MEAN } & 3 \\ \text { COPY } & 1 & \text { INPUT } & \text { MEAN } & 3 \\ \text { COPY } & 1 & \text { INPUT } & \text { MEAN } & 1 \\ \text { COPY } & 1 & \text { INPUT } & \text { MEAN } & 1 \\ \text { COPY } & 1 & \text { INPUT } & \text { MEAN } & 2 \\ \text { COPY } & 1 & \text { INPUT } & \text { MEAN } & 3 \\ \text { COPY } & 1 & \text { INPUT } & \text { MEAN } & 3 \\ \text { COPY } & 1 & \text { INPUT } & \text { MEAN } & 1 \\ \text { COPY } & 1 & \text { INPUT } & \text { MEAN } & 1 \\ \text { COPY } & 1 & \text { INPUT } & \text { MEAN } & 2 \\ \text { COPY } & 1 & \text { INPUT } & \text { MEAN } & 3 \\ \text { COPY } & 1 & \text { INPUT } & \text { MEAN } & 3 \\ \text { COPY } & 1 & \text { INPUT } & \text { MEAN } & 1 \\ \text { COPY } & 1 & \text { INPUT } & \text { MEAN } & 1 \\ \text { COPY } & 1 & \text { INPUT } & \text { MEAN } & 2 \\ \text { COPY } & 1 & \text { INPUT } & \text { MEAN } & 3 \\ \text { COPY } & 1 & \text { INPUT } & \text { MEAN } & 3 \\ \text { COPY } & 1 & \text { INPUT } & \text { MEAN } & 1\end{array}$




\begin{tabular}{|c|c|c|c|c|c|c|c|c|}
\hline PERLND & 111 & PWATER & IFWO & 12.36667 & COPY & 1 & INPUT & MEAN \\
\hline PERLND & 111 & PWATER & AGWI & 12.36667 & COPY & 1 & INPUT & MEAN \\
\hline PERLND & 111 & PWATER & TAET & 12.36667 & COPY & 1 & INPUT & MEAN \\
\hline PERLND & 111 & SNOW & SNOWE & 12.36667 & COPY & 1 & INPUT & MEAN \\
\hline PERLND & 114 & PWATER & SURO & 52.62500 & COPY & 1 & INPUT & MEAN \\
\hline PERLND & 114 & PWATER & IFWO & 52.62500 & COPY & 1 & INPUT & MEAN \\
\hline PERLND & 114 & PWATER & AGWI & 52.62500 & COPY & 1 & INPUT & MEAN \\
\hline PERLND & 114 & PWATER & TAET & 52.62500 & COPY & 1 & INPUT & MEAN \\
\hline PERLND & 114 & SNOW & SNOWE & 52.62500 & COPY & 1 & INPUT & MEAN \\
\hline PERLND & 121 & PWATER & SURO & 35.76667 & COPY & 1 & INPUT & MEAN \\
\hline PERLND & 121 & PWATER & IFWO & 35.76667 & COPY & 1 & INPUT & MEAN \\
\hline PERLND & 121 & PWATER & AGWI & 35.76667 & COPY & 1 & INPUT & MEAN \\
\hline PERLND & 121 & PWATER & TAET & 35.76667 & COPY & 1 & INPUT & MEAN \\
\hline PERLND & 121 & SNOW & SNOWE & 35.76667 & COPY & 1 & INPUT & MEAN \\
\hline PERLND & 124 & PWATER & SURO & 106.93333 & COPY & 1 & INPUT & MEAN \\
\hline PERLND & 124 & PWATER & IFWO & 106.93333 & COPY & 1 & INPUT & MEAN \\
\hline PERLND & 124 & PWATER & AGWI & 106.93333 & COPY & 1 & INPUT & MEAN \\
\hline PERLND & 124 & PWATER & TAET & 106.93333 & COPY & 1 & INPUT & MEAN \\
\hline PERLND & 124 & SNOW & SNOWE & 106.93333 & COPY & 1 & INPUT & MEAN \\
\hline PERLND & 127 & PWATER & SURO & 21.61667 & COPY & 1 & INPUT & MEAN \\
\hline PERLND & 127 & PWATER & IFWO & 21.61667 & COPY & 1 & INPUT & MEAN \\
\hline PERLND & 127 & PWATER & AGWI & 21.61667 & COPY & 1 & INPUT & MEAN \\
\hline PERLND & 127 & PWATER & TAET & 21.61667 & COPY & 1 & INPUT & MEAN \\
\hline PERLND & 127 & SNOW & SNOWE & 21.61667 & COPY & 1 & INPUT & MEAN \\
\hline PERLND & 130 & PWATER & SURO & 23.42500 & COPY & 1 & INPUT & MEAN \\
\hline PERLND & 130 & PWATER & IFWO & 23.42500 & COPY & 1 & INPUT & MEAN \\
\hline PERLND & 130 & PWATER & AGWI & 23.42500 & COPY & 1 & INPUT & MEAN \\
\hline PERLND & 130 & PWATER & TAET & 23.42500 & COPY & 1 & INPUT & MEAN \\
\hline PERLND & 130 & SNOW & SNOWE & 23.42500 & COPY & 1 & INPUT & MEAN \\
\hline PERLND & 131 & PWATER & SURO & 16.65000 & COPY & 1 & INPUT & MEAN \\
\hline PERLND & 131 & PWATER & IFWO & 16.65000 & COPY & 1 & INPUT & MEAN \\
\hline PERLND & 131 & PWATER & AGWI & 16.65000 & COPY & 1 & INPUT & MEAN \\
\hline PERLND & 131 & PWATER & TAET & 16.65000 & COPY & 1 & INPUT & MEAN \\
\hline PERLND & 131 & SNOW & SNOWE & 16.65000 & COPY & 1 & INPUT & MEAN \\
\hline PERLND & 134 & PWATER & SURO & 17.13333 & COPY & 1 & INPUT & MEAN \\
\hline PERLND & 134 & PWATER & IFWO & 17.13333 & COPY & 1 & INPUT & MEAN \\
\hline PERLND & 134 & PWATER & AGWI & 17.13333 & COPY & 1 & INPUT & MEAN \\
\hline PERLND & 134 & PWATER & TAET & 17.13333 & COPY & 1 & INPUT & MEAN \\
\hline PERLND & 134 & SNOW & SNOWE & 17.13333 & COPY & 1 & INPUT & MEAN \\
\hline PERLND & 141 & PWATER & SURO & 33.12500 & COPY & 1 & INPUT & MEAN \\
\hline PERLND & 141 & PWATER & IFWO & 33.12500 & COPY & 1 & INPUT & MEAN \\
\hline PERLND & 141 & PWATER & AGWI & 33.12500 & COPY & 1 & INPUT & MEAN \\
\hline PERLND & 141 & PWATER & TAET & 33.12500 & COPY & 1 & INPUT & MEAN \\
\hline PERLND & 141 & SNOW & SNOWE & 33.12500 & COPY & 1 & INPUT & MEAN \\
\hline PERLND & 144 & PWATER & SURO & 49.20833 & COPY & 1 & INPUT & MEAN \\
\hline PERLND & 144 & PWATER & IFWO & 49.20833 & COPY & 1 & INPUT & MEAN \\
\hline PERLND & 144 & PWATER & AGWI & 49.20833 & COPY & 1 & INPUT & MEAN \\
\hline PERLND & 144 & PWATER & TAET & 49.20833 & COPY & 1 & INPUT & MEAN \\
\hline PERLND & 144 & SNOW & SNOWE & 49.20833 & COPY & 1 & INPUT & MEAN \\
\hline PERLND & 147 & PWATER & SURO & 15.33333 & COPY & 1 & INPUT & MEAN \\
\hline PERLND & 147 & PWATER & IFWO & 15.33333 & COPY & 1 & INPUT & MEAN \\
\hline PERLND & 147 & PWATER & AGWI & 15.33333 & COPY & 1 & INPUT & MEAN \\
\hline PERLND & 147 & PWATER & TAET & 15.33333 & COPY & 1 & INPUT & MEAN \\
\hline PERLND & 147 & SNOW & SNOWE & 15.33333 & COPY & 1 & INPUT & MEAN \\
\hline
\end{tabular}




\begin{tabular}{|c|c|c|c|c|c|c|c|c|}
\hline PERLND & 150 & PWATER & SURO & 27.42500 & COPY & 1 & INPUT & MEAN \\
\hline PERLND & 150 & PWATER & IFWO & 27.42500 & COPY & 1 & INPUT & MEAN \\
\hline PERLND & 150 & PWATER & AGWI & 27.42500 & COPY & 1 & INPUT & MEAN \\
\hline PERLND & 150 & PWATER & TAET & 27.42500 & COPY & 1 & INPUT & MEAN \\
\hline PERLND & 150 & SNOW & SNOWE & 27.42500 & COPY & 1 & INPUT & MEAN \\
\hline PERLND & 151 & PWATER & SURO & 8.60000 & COPY & 1 & INPUT & MEAN \\
\hline PERLND & 151 & PWATER & IFWO & 8.60000 & COPY & 1 & INPUT & MEAN \\
\hline PERLND & 151 & PWATER & AGWI & 8.60000 & COPY & 1 & INPUT & MEAN \\
\hline PERLND & 151 & PWATER & TAET & 8.60000 & COPY & 1 & INPUT & MEAN \\
\hline PERLND & 151 & SNOW & SNOWE & 8.60000 & COPY & 1 & INPUT & MEAN \\
\hline PERLND & 161 & PWATER & SURO & 3.02500 & COPY & 1 & INPUT & MEAN \\
\hline PERLND & 161 & PWATER & IFWO & 3.02500 & COPY & 1 & INPUT & MEAN \\
\hline PERLND & 161 & PWATER & AGWI & 3.02500 & COPY & 1 & INPUT & MEAN \\
\hline PERLND & 161 & PWATER & TAET & 3.02500 & COPY & 1 & INPUT & MEAN \\
\hline PERLND & 161 & SNOW & SNOWE & 3.02500 & COPY & 1 & INPUT & MEAN \\
\hline PERLND & 164 & PWATER & SURO & 16.56667 & COPY & 1 & INPUT & MEAN \\
\hline PERLND & 164 & PWATER & IFWO & 16.56667 & COPY & 1 & INPUT & MEAN \\
\hline PERLND & 164 & PWATER & AGWI & 16.56667 & COPY & 1 & INPUT & MEAN \\
\hline PERLND & 164 & PWATER & TAET & 16.56667 & COPY & 1 & INPUT & MEAN \\
\hline PERLND & 164 & SNOW & SNOWE & 16.56667 & COPY & 1 & INPUT & MEAN \\
\hline PERLND & 167 & PWATER & SURO & 6.99167 & COPY & 1 & INPUT & MEAN \\
\hline PERLND & 167 & PWATER & IFWO & 6.99167 & COPY & 1 & INPUT & MEAN \\
\hline PERLND & 167 & PWATER & AGWI & 6.99167 & COPY & 1 & INPUT & MEAN \\
\hline PERLND & 167 & PWATER & TAET & 6.99167 & COPY & 1 & INPUT & MEAN \\
\hline PERLND & 167 & SNOW & SNOWE & 6.99167 & COPY & 1 & INPUT & MEAN \\
\hline PERLND & 184 & PWATER & SURO & 18.45833 & COPY & 1 & INPUT & MEAN \\
\hline PERLND & 184 & PWATER. & IFWO & 18.45833 & COPY & 1 & INPUT & MEAN \\
\hline PERLND & 184 & PWATER & AGWI & 18.45833 & COPY & 1 & INPUT & MEAN \\
\hline PERLND & 184 & PWATER & TAET & 18.45833 & COPY & 1 & INPUT & MEAN \\
\hline PERLND & 184 & SNOW & SNOWE & 18.45833 & COPY & 1 & INPUT & MEAN \\
\hline PERLND & 190 & PWATER & SURO & 24.14167 & COPY & 1 & INPUT & MEAN \\
\hline PERLND & 190 & PWATER & IFWO & 24.14167 & COPY & 1 & INPUT & MEAN \\
\hline PERLND & 190 & PWATER & AGWI & 24.14167 & COPY & 1 & INPUT & MEAN \\
\hline PERLND & 190 & PWATER & TAET & 24.14167 & COPY & 1 & INPUT & MEAN \\
\hline PERLND & 190 & SNOW & SNOWE & 24.14167 & COPY & 1 & INPUT & MEAN \\
\hline PERLND & 201 & PWATER & SURO & 13.99167 & COPY & 1 & INPUT & MEAN \\
\hline PERLND & 201 & PWATER & IFWO & 13.99167 & COPY & 1 & INPUT & MEAN \\
\hline PERLND & 201 & PWATER & AGWI & 13.99167 & COPY & 1 & INPUT & MEAN \\
\hline PERLND & 201 & PWATER & TAET & 13.99167 & COPY & 1 & INPUT & MEAN \\
\hline PERLND & 201 & SNOW & SNOWE & 13.99167 & COPY & 1 & INPUT & MEAN \\
\hline PERLND & 204 & PWATER & SURO & 11.75833 & COPY & 1 & INPUT & MEAN \\
\hline PERLND & 204 & PWATER & IFWO & 11.75833 & COPY & 1 & INPUT & MEAN \\
\hline PERLND & 204 & PWATER & AGWI & 11.75833 & COPY & 1 & INPUT & MEAN \\
\hline PERLND & 204 & PWATER & TAET & 11.75833 & COPY & 1 & INPUT & MEAN \\
\hline PERLND & 204 & SNOW & SNOWE & 11.75833 & COPY & 1 & INPUT & MEAN \\
\hline PERLND & 207 & PWATER & SURO & 35.94167 & COPY & 1 & INPUT & MEAN \\
\hline PERLND & 207 & PWATER & IFWO & 35.94167 & COPY & 1 & INPUT & MEAN \\
\hline PERLND & 207 & PWATER & AGWI & 35.94167 & COPY & 1 & INPUT & MEAN \\
\hline PERLND & 207 & PWATER & TAET & 35.94167 & COPY & 1 & INPUT & MEAN \\
\hline PERLND & 207 & SNOW & SNOWE & 35.94167 & COPY & 1 & INPUT & MEAN \\
\hline PERLND & 210 & PWATER & SURO & 15.40833 & COPY & 1 & INPUT & MEAN \\
\hline PERLND & 210 & PWATER & IFWO & 15.40833 & COPY & 1 & INPUT & MEAN \\
\hline PERLND & 210 & PWATER & AGWI & 15.40833 & COPY & 1 & INPUT & MEAN \\
\hline PERLND & 210 & PWATER & TAET & 15.40833 & COPY & 1 & INPUT & MEAN \\
\hline
\end{tabular}




\begin{tabular}{|c|c|c|c|c|c|c|c|c|}
\hline PERLND & 210 & SNOW & SNOWE & 15.40833 & COPY & 1 & INPUT & MEAN \\
\hline PERLND & 221 & PWATER & SURO & 44.55000 & COPY & 1 & INPUT & MEAN \\
\hline PERLND & 221 & PWATER & IFWO & 44.55000 & COPY & 1 & INPUT & MEAN \\
\hline PERLND & 221 & PWATER & AGWI & 44.55000 & COPY & 1 & INPUT & MEAN \\
\hline PERLND & 221 & PWATER & TAET & 44.55000 & COPY & 1 & INPUT & MEAN \\
\hline PERLND & 221 & SNOW & SNOWE & 44.55000 & COPY & 1 & INPUT & MEAN \\
\hline PERLND & 224 & PWATER & SURO & 24.31667 & COPY & 1 & INPUT & MEAN \\
\hline PERLND & 224 & PWATER & IFWO & 24.31667 & COPY & 1 & INPUT & MEAN \\
\hline PERLND & 224 & PWATER & AGWI & 24.31667 & COPY & 1 & INPUT & MEAN \\
\hline PERLND & 224 & PWATER & TAET & 24.31667 & COPY & 1 & INPUT & MEAN \\
\hline PERLND & 224 & SNOW & SNOWE & 24.31667 & COPY & 1 & INPUT & MEAN \\
\hline PERLND & 227 & PWATER & SURO & 110.52500 & COPY & 1 & INPUT & MEAN \\
\hline PERLND & 227 & PWATER & IFWO & 110.52500 & COPY & 1 & INPUT & MEAN \\
\hline PERLND & 227 & PWATER & AGWI & 110.52500 & COPY & 1 & INPUT & MEAN \\
\hline PERLND & 227 & PWATER & TAET & 110.52500 & COPY & 1 & INPUT & MEAN \\
\hline PERLND & 227 & SNOW & SNOWE & 110.52500 & COPY & 1 & INPUT & MEAN \\
\hline PERLND & 229 & PWATER & SURO & 8.70000 & COPY & 1 & INPUT & MEAN \\
\hline PERLND & 229 & PWATER & IFWO & 8.70000 & COPY & 1 & INPUT & MEAN \\
\hline PERLND & 229 & PWATER & AGWI & 8.70000 & COPY & 1 & INPUT & MEAN \\
\hline PERLND & 229 & PWATER & TAET & 8.70000 & COPY & 1 & INPUT & MEAN \\
\hline PERLND & 229 & SNOW & SNOWE & 8.70000 & COPY & 1 & INPUT & MEAN \\
\hline PERLND & 230 & PWATER & SURO & 51.82500 & COPY & 1 & INPUT & MEAN \\
\hline PERLND & 230 & PWATER & IFWO & 51.82500 & COPY & 1 & INPUT & MEAN \\
\hline PERLND & 230 & PWATER & AGWI & 51.82500 & COPY & 1 & INPUT & MEAN \\
\hline PERLND & 230 & PWATER & TAET & 51.82500 & COPY & 1 & INPUT & MEAN \\
\hline PERLND & 230 & SNOW & SNOWE & 51.82500 & COPY & 1 & INPUT & MEAN \\
\hline PERLND & 241 & PWATER & SURO & 14.90000 & COPY & 1 & INPUT & MEAN \\
\hline PERLND & 241 & PWATER & IFWO & 14.90000 & COPY & 1 & INPUT & MEAN \\
\hline PERLND & 241 & PWATER & AGWI & 14.90000 & COPY & 1 & INPUT & MEAN \\
\hline PERLND & 241 & PWATER & TAET & 14.90000 & COPY & 1 & INPUT & MEAN \\
\hline PERLND & 241 & SNOW & SNOWE & 14.90000 & COPY & 1 & INPUT & MEAN \\
\hline PERLND & 244 & PWATER & SURO & 10.23333 & COPY & 1 & INPUT & MEAN \\
\hline PERLND & 244 & PWATER & IFWO & 10.23333 & COPY & 1 & INPUT & MEAN \\
\hline PERLND & 244 & PWATER & AGWI & 10.23333 & COPY & 1 & INPUT & MEAN \\
\hline PERLND & 244 & PWATER & TAET & 10.23333 & COPY & 1 & INPUT & MEAN \\
\hline PERLND & 244 & SNOW & SNOWE & 10.23333 & COPY & 1 & INPUT & MEAN \\
\hline PEREND & 247 & PWATER & SURO & 35.37500 & COPY & 1 & INPUT & MEAN \\
\hline PERLND & 247 & PWATER & IFWO & 35.37500 & COPY & 1 & INPUT & MEAN \\
\hline PERLND & 247 & PWATER & AGWI & 35.37500 & COPY & 1 & INPUT & MEAN \\
\hline PERLND & 247 & PWATER & TAET & 35.37500 & COPY & 1 & INPUT & MEAN \\
\hline PERLND & 247 & SNOW & SNOWE & 35.37500 & COPY & 1 & INPUT & MEAN \\
\hline PERLND & 250 & PWATER & SURO & 14.44167 & COPY & 1 & INPUT & MEAN \\
\hline PERLND & 250 & PWATER & IFWO & 14.44167 & COPY & 1 & INPUT & MEAN \\
\hline PERLND & 250 & PWATER & AGWI & 14.44167 & COPY & 1 & INPUT & MEAN \\
\hline PERLND & 250 & PWATER & TAET & 14.44167 & COPY & 1 & INPUT & MEAN \\
\hline PERLND & 250 & SNOW & SNOWE & 14.44167 & COPY & 1 & INPUT & MEAN \\
\hline PERLND & 261 & PWATER & SURO & 51.40000 & COPY & 1 & INPUT & MEAN \\
\hline PERLND & 261 & PWATER & IFWO & 51.40000 & COPY & 1 & INPUT & MEAN \\
\hline PERLND & 261 & PWATER & AGWI & 51.40000 & COPY & 1 & INPUT & MEAN \\
\hline PERLND & 261 & PWATER & TAET & 51.40000 & COPY & 1 & INPUT & MEAN \\
\hline PERLND & 261 & SNOW & SNOWE & 51.40000 & COPY & 1 & INPUT & MEAN \\
\hline PERLND & 264 & PWATER & SURO & 35.40833 & COPY & 1 & INPUT & MEAN \\
\hline PERLND & 264 & PWATER & IFWO & 35.40833 & COPY & 1 & INPUT & MEAN \\
\hline PERLND & 264 & PWATER & AGWI & 35.40833 & COPY & 1 & INPUT & MEAN \\
\hline
\end{tabular}




\begin{tabular}{|c|c|c|c|c|c|c|c|c|}
\hline PERLND & 264 & PWATER & TAET & 35.40833 & COPY & 1 & INPUT & MEAN \\
\hline PERLND & 264 & SNOW & SNOWE & 35.40833 & COPY & 1 & INPUT & MEAN \\
\hline PERLND & 267 & PWATER & SURO & 69.73333 & COPY & 1 & INPUT & MEAN \\
\hline PERLND & 267 & PWATER & IFWO & 69.73333 & COPY & 1 & INPUT & MEAN \\
\hline PERLND & 267 & PWATER & AGWI & 69.73333 & COPY & 1 & INPUT & MEAN \\
\hline PERLND & 267 & PWATER & TAET & 69.73333 & COPY & 1 & INPUT & MEAN \\
\hline PERLND & 267 & SNOW & SNOWE & 69.73333 & COPY & 1 & INPUT & MEAN \\
\hline PERLND & 269 & PWATER & SURO & 16.10833 & COPY & 1 & INPUT & MEAN \\
\hline PERLND & 269 & PWATER & IFWO & 16.10833 & COPY & 1 & INPUT & MEAN \\
\hline PERLND & 269 & PWATER & AGWI & 16.10833 & COPY & 1 & INPUT & MEAN \\
\hline PERLND & 269 & PWATER & TAET & 16.10833 & COPY & 1 & INPUT & MEAN \\
\hline PERLND & 269 & SNOW & SNOWE & 16.10833 & COPY & 1 & INPUT & MEAN \\
\hline PERLND & 270 & PWATER & SURO & 42.90834 & COPY & 1 & INPUT & MEAN \\
\hline PERLND & 270 & PWATER & IFWO & 42.90834 & COPY & 1 & INPUT & MEAN \\
\hline PERLND & 270 & PWATER & AGWI & 42.90834 & COPY & 1 & INPUT & MEAN \\
\hline PERLND & 270 & PWATER & TAET & 42.90834 & COPY & 1 & INPUT & MEAN \\
\hline PERLND & 270 & SNOW & SNOWE & 42.90834 & COPY & 1 & INPUT & MEAN \\
\hline PERLND & 281 & PWATER & SURO & 11.66667 & COPY & 1 & INPUT & MEAN \\
\hline PERLND & 281 & PWATER & IFWO & 11.66667 & COPY & 1 & INPUT & MEAN \\
\hline PERLND & 281 & PWATER & AGWI & 11.66667 & COPY & 1 & INPUT & MEAN \\
\hline PERLND & 281 & PWATER & TAET & 11.66667 & COPY & 1 & INPUT & MEAN \\
\hline PERLND & 281 & SNOW & SNOWE & 11.66667 & COPY & 1 & INPUT & MEAN \\
\hline PERLND & 284 & PWATER & SURO & 10.60000 & COPY & 1 & INPUT & MEAN \\
\hline PERLND & 284 & PWATER & IFWO & 10.60000 & COPY & 1 & INPUT & MEAN \\
\hline PERLND & 284 & PWATER & AGWI & 10.60000 & COPY & 1 & INPUT & MEAN \\
\hline PERLND & 284 & PWATER & TAET & 10.60000 & COPY & 1 & INPUT & MEAN \\
\hline PERLND & 284 & SNOW & SNOWE & 10.60000 & COPY & 1 & INPUT & MEAN \\
\hline PERLND & 287 & PWATER & SURO & 14.55000 & COPY & 1 & INPUT & MEAN \\
\hline PERLND & 287 & PWATER & IFWO & 14.55000 & COPY & 1 & INPUT & MEAN \\
\hline PERLND & 287 & PWATER & AGWI & 14.55000 & COPY & 1 & INPUT & MEAN \\
\hline PERLND & 287 & PWATER & TAET & 14.55000 & COPY & 1 & INPUT & MEAN \\
\hline PERLND & 287 & SNOW & SNOWE & 14.55000 & COPY & 1 & INPUT & MEAN \\
\hline PERLND & 290 & PWATER & SURO & 9.94167 & COPY & 1 & INPUT & MEAN \\
\hline PERLND & 290 & PWATER & IFWO & 9.94167 & COPY & 1 & INPUT & MEAN \\
\hline PERLND & 290 & PWATER & AGWI & 9.94167 & COPY & 1 & INPUT & MEAN \\
\hline PERLND & 290 & PWATER & TAET & 9.94167 & COPY & 1 & INPUT & MEAN \\
\hline PERLND & 290 & SNOW & SNOWE & 9.94167 & COPY & 1 & INPUT & MEAN \\
\hline PERLND & 304 & PWATER & SURO & 9.02500 & COPY & 1 & INPUT & MEAN \\
\hline PERLND & 304 & PWATER & IFWO & 9.02500 & COPY & 1 & INPUT & MEAN \\
\hline PERLND & 304 & PWATER & AGWI & 9.02500 & COPY & 1 & INPUT & MEAN \\
\hline PERLND & 304 & PWATER & TAET & 9.02500 & COPY & 1 & INPUT & MEAN \\
\hline PERLND & 304 & SNOW & SNOWE & 9.02500 & COPY & 1 & INPUT & MEAN \\
\hline PERLND & 314 & PWATER & SURO & 20.72500 & COPY & 1 & INPUT & MEAN \\
\hline PERLND & 314 & PWATER & IFWO & 20.72500 & COPY & 1 & INPUT & MEAN \\
\hline PERLND & 314 & PWATER & AGWI & 20.72500 & COPY & 1 & INPUT & MEAN \\
\hline PERLND & 314 & PWATER & TAET & 20.72500 & COPY & 1 & INPUT & MEAN \\
\hline PERLND & 314 & SNOW & SNOWE & 20.72500 & COPY & 1 & INPUT & MEAN \\
\hline PERLND & 321 & PWATER & SURO & 11.70833 & COPY & 1 & INPUT & MEAN \\
\hline PERLND & 321 & PWATER & IFWO & 11.70833 & COPY & 1 & INPUT & MEAN \\
\hline PERLND & 321 & PWATER & AGWI & 11.70833 & COPY & 1 & INPUT & MEAN \\
\hline PERLND & 321 & PWATER & TAET & 11.70833 & COPY & 1 & INPUT & MEAN \\
\hline PERLND & 321 & SNOW & SNOWE & 11.70833 & COPY & 1 & INPUT & MEAN \\
\hline PERLND & 324 & PWATER & SURO & 28.75000 & COPY & 1 & INPUT & MEAN \\
\hline PERLND & 324 & PWATER & IFWO & 28.75000 & COPY & 1 & INPUT & MEAN \\
\hline
\end{tabular}




\begin{tabular}{|c|c|c|c|c|c|c|c|c|}
\hline PERLND & 324 & PWATER & AGWI & 28.75000 & COPY & 1 & INPUT & MEAN \\
\hline PERLND & 324 & PWATER & TAET & 28.75000 & COPY & 1 & INPUT & MEAN \\
\hline PERLND & 324 & SNOW & SNOWE & 28.75000 & COPY & 1 & INPUT & MEAN \\
\hline PERLND & 327 & PWATER & SURO & 6.55833 & COPY & 1 & INPUT & MEAN \\
\hline PERLND & 327 & PWATER & IFWO & 6.55833 & COPY & 1 & INPUT & MEAN \\
\hline PERLND & 327 & PWATER & AGWI & 6.55833 & COPY & 1 & INPUT & MEAN \\
\hline PERLND & 327 & PWATER & TAET & 6.55833 & COPY & 1 & INPUT & MEAN \\
\hline PERLND & 327 & SNOW & SNOWE & 6.55833 & COPY & 1 & INPUT & MEAN \\
\hline PERLND & 330 & PWATER & SURO & 17.99167 & COPY & 1 & INPUT & MEAN \\
\hline PERLND & 330 & PWATER & IFWO & 17.99167 & COPY & 1 & INPUT & MEAN \\
\hline PERLND & 330 & PWATER & AGWI & 17.99167 & COPY & 1 & INPUT & MEAN \\
\hline PERLND & 330 & PWATER & TAET & 17.99167 & COPY & 1 & INPUT & MEAN \\
\hline PERLND & 330 & SNOW & SNOWE & 17.99167 & COPY & 1 & INPUT & MEAN \\
\hline PERLND & 334 & PWATER & SURO & 12.10000 & COPY & 1 & INPUT & MEAN \\
\hline PERLND & 334 & PWATER & IFWO & 12.10000 & COPY & 1 & INPUT & MEAN \\
\hline PERLND & 334 & PWATER & AGWI & 12.10000 & COPY & 1 & INPUT & MEAN \\
\hline PERLND & 334 & PWATER & TAET & 12.10000 & COPY & 1 & INPUT & MEAN \\
\hline PERLND & 334 & SNOW & SNOWE & 12.10000 & COPY & 1 & INPUT & MEAN \\
\hline PERLND & 344 & PWATER & SURO & 8.12500 & COPY & 1 & INPUT & MEAN \\
\hline PERLND & 344 & PWATER & IFWO & 8.12500 & COPY & 1 & INPUT & MEAN \\
\hline PERLND & 344 & PWATER & AGWI & 8.12500 & COPY & 1 & INPUT & MEAN \\
\hline PERLND & 344 & PWATER & TAET & 8.12500 & COPY & 1 & INPUT & MEAN \\
\hline PERLND & 344 & SNOW & SNOWE & 8.12500 & COPY & 1 & INPUT & MEAN \\
\hline PERLND & 361 & PWATER & SURO & 43.27500 & COPY & 1 & INPUT & MEAN \\
\hline PERLND & 361 & PWATER & IFWO & 43.27500 & COPY & 1 & INPUT & MEAN \\
\hline PERLND & 361 & PWATER & AGWI & 43.27500 & COPY & 1 & INPUT & MEAN \\
\hline PERLND & 361 & PWATER & TAET & 43.27500 & COPY & 1 & INPUT & MEAN \\
\hline PERLND & 361 & SNOW & SNOWE & 43.27500 & COPY & 1 & INPUT & MEAN \\
\hline PERLND & 364 & PWATER & SURO & 78.15000 & COPY & 1 & INPUT & MEAN \\
\hline PERLND & 364 & PWATER & IFWO & 78.15000 & COPY & 1 & INPUT & MEAN \\
\hline PERLND & 364 & PWATER & AGWI & 78.15000 & COPY & 1 & INPUT & MEAN \\
\hline PERLND & 364 & PWATER & TAET & 78.15000 & COPY & 1 & INPUT & MEAN \\
\hline PERLND & 364 & SNOW & SNOWE & 78.15000 & COPY & 1 & INPUT & MEAN \\
\hline PERLND & 367 & PWATER & SURO & 37.23333 & COPY & 1 & INPUT & MEAN \\
\hline PERLND & 367 & PWATER & IFWO & 37.23333 & COPY & 1 & INPUT & MEAN \\
\hline PERLND & 367 & PWATER & AGWI & 37.23333 & COPY & 1 & INPUT & MEAN \\
\hline PERLND & 367 & PWATER & TAET & 37.23333 & COPY & 1 & INPUT & MEAN \\
\hline PERLND & 367 & SNOW & SNOWE & 37.23333 & COPY & 1 & INPUT & MEAN \\
\hline PERLND & 370 & PWATER & SURO & 41.80000 & COPY & 1 & INPUT & MEAN \\
\hline PERLND & 370 & PWATER & IFWO & 41.80000 & COPY & 1 & INPUT & MEAN \\
\hline PERLND & 370 & PWATER & AGWI & 41.80000 & COPY & 1 & INPUT & MEAN \\
\hline PERLND & 370 & PWATER & TAET & 41.80000 & COPY & 1 & INPUT & MEAN \\
\hline PERLND & 370 & SNOW & SNOWE & 41.80000 & COPY & 1 & INPUT & MEAN \\
\hline PERLND & 390 & PWATER & SURO & 13.55000 & COPY & 1 & INPUT & MEAN \\
\hline PERLND & 390 & PWATER & IFWO & 13.55000 & COPY & 1 & INPUT & MEAN \\
\hline PERLND & 390 & PWATER & AGWI & 13.55000 & COPY & 1 & INPUT & MEAN \\
\hline PERLND & 390 & PWATER & TAET & 13.55000 & COPY & 1 & INPUT & MEAN \\
\hline $\begin{array}{l}\text { PERLND } \\
\star \star \star d r y\end{array}$ & $\begin{array}{l}390 \\
1 \mathrm{si}\end{array}$ & $\begin{array}{l}\text { SNOW } \\
\text { bbasin }\end{array}$ & SNOWE & 13.55000 & COPY & 1 & INPUT & MEAN \\
\hline PERLND & 101 & PWATER & SURO & 61.03334 & COPY & 1 & INPUT & MEAN \\
\hline PERLND & 101 & PWATER & IFWO & 61.03334 & COPY & 1 & INPUT & MEAN \\
\hline PERLND & 101 & PWATER & AGWI & 61.03334 & COPY & 1 & INPUT & MEAN \\
\hline PERLND & 101 & PWATER & TAET & 61.03334 & COPY & 1 & INPUT & MEAN \\
\hline PERLND & 101 & SNOW & SNOWE & 61.03334 & COPY & 1 & INPUT & MEAN \\
\hline
\end{tabular}




\begin{tabular}{|c|c|c|c|c|c|c|c|c|}
\hline PERLND & 103 & PWATER & SURO & 86.65000 & COPY & 1 & INPUT & MEAN \\
\hline PERLND & 103 & PWATER & IFWO & 86.65000 & COPY & 1 & INPUT & MEAN \\
\hline PERLND & 103 & PWATER & AGWI & 86.65000 & COPY & 1 & INPUT & MEAN \\
\hline PERLND & 103 & PWATER & TAET & 86.65000 & COPY & 1 & INPUT & MEAN \\
\hline PERLND & 103 & SNOW & SNOWE & 86.65000 & COPY & 1 & INPUT & MEAN \\
\hline PERLND & 104 & PWATER & SURO & 431.17500 & COPY & 1 & INPUT & MEAN \\
\hline PERLND & 104 & PWATER & IFWO & 431.17500 & COPY & 1 & INPUT & MEAN \\
\hline PERLND & 104 & PWATER & AGWI & 431.17500 & COPY & 1 & INPUT & MEAN \\
\hline PERLND & 104 & PWATER & TAET & 431.17500 & COPY & 1 & INPUT & MEAN \\
\hline PERLND & 104 & SNOW & SNOWE & 431.17500 & COPY & 1 & INPUT & MEAN \\
\hline PERLND & 107 & PWATER & SURO & 35.00834 & COPY & 1 & INPUT & MEAN \\
\hline PERLND & 107 & PWATER & IEWO & 35.00834 & COPY & 1 & INPUT & MEAN \\
\hline PERLND & 107 & PWATER & AGWI & 35.00834 & COPY & 1 & INPUT & MEAN \\
\hline PERLND & 107 & PWATER & TAET & 35.00834 & COPY & 1 & INPUT & MEAN \\
\hline PERLND & 107 & SNOW & SNOWE & 35.00834 & COPY & 1 & INPUT & MEAN \\
\hline PERLND & 109 & PWATER & SURO & 44.71666 & COPY & 1 & INPUT & MEAN \\
\hline PERLND & 109 & PWATER & IFWO & 44.71666 & COPY & 1 & INPUT & MEAN \\
\hline PERLND & 109 & PWATER & AGWI & 44.71666 & COPY & 1 & INPUT & MEAN \\
\hline PERLND & 109 & PWATER & TAET & 44.71666 & COPY & 1 & INPUT & MEAN \\
\hline PERLND & 109 & SNOW & SNOWE & 44.71666 & COPY & 1 & INPUT & MEAN \\
\hline PERLND & 110 & PWATER & SURO & 220.95833 & COPY & 1 & INPUT & MEAN \\
\hline PERLND & 110 & PWATER & IFWO & 220.95833 & COPY & 1 & INPUT & MEAN \\
\hline PERLND & 110 & PWATER & AGWI & 220.95833 & COPY & 1 & INPUT & MEAN \\
\hline PERLND & 110 & PWATER & TAET & 220.95833 & COPY & 1 & INPUT & MEAN \\
\hline PERLND & 110 & SNOW & SNOWE & 220.95833 & COPY & 1 & INPUT & MEAN \\
\hline PERLND & 114 & PWATER & SURO & 2.58830 & COPY & 1 & INPUT & MEAN \\
\hline PERLND & 114 & PWATER & IEWO & 2.58830 & COPY & 1 & INPUT & MEAN \\
\hline PERLND & 114 & PWATER & AGWI & 2.58830 & COPY & 1 & INPUT & MEAN \\
\hline PERLND & 114 & PWATER & TAET & 2.58830 & COPY & 1 & INPUT & MEAN \\
\hline PERLND & 114 & SNOW & SNOWE & 2.58830 & COPY & 1 & INPUT & MEAN \\
\hline PERLND & 121 & PWATER & SURO & 40.64167 & COPY & 1 & INPUT & MEAN \\
\hline PERLND & 121 & PWATER & IFWO & 40.64167 & COPY & 1 & INPUT & MEAN \\
\hline PERLND & 121 & PWATER & AGWI & 40.64167 & COPY & 1 & INPUT & MEAN \\
\hline PERLND & 121 & PWATER & TAET & 40.64167 & COPY & 1 & INPUT & MEAN \\
\hline PERLND & 121 & SNOW & SNOWE & 40.64167 & COPY & 1 & INPUT & MEAN \\
\hline PERLND & 124 & PWATER & SURO & 57.95833 & COPY & 1 & INPUT & MEAN \\
\hline PERLND & 124 & PWATER & IFWO & 57.95833 & COPY & 1 & INPUT & MEAN \\
\hline PERLND & 124 & PWATER & AGWI & 57.95833 & COPY & 1 & INPUT & MEAN \\
\hline PERLND & 124 & PWATER & TAET & 57.95833 & COPY & 1 & INPUT & MEAN \\
\hline PERLND & 124 & SNOW & SNOWE & 57.95833 & COPY & 1 & INPUT & MEAN \\
\hline PERLND & 127 & PWATER & SURO & 35.30833 & COPY & 1 & INPUT & MEAN \\
\hline PERLND & 127 & PWATER & IFWO & 35.30833 & COPY & 1 & INPUT & MEAN \\
\hline PERLND & 127 & PWATER & AGWI & 35.30833 & COPY & 1 & INPUT & MEAN \\
\hline PERLND & 127 & PWATER & TAET & 35.30833 & COPY & 1 & INPUT & MEAN \\
\hline PERLND & 127 & SNOW & SNOWE & 35.30833 & COPY & 1 & INPUT & MEAN \\
\hline PERLND & 130 & PWATER & SURO & 18.61667 & COPY & 1 & INPUT & MEAN \\
\hline PERLND & 130 & PWATER & IFWO & 18.61667 & COPY & 1 & INPUT & MEAN \\
\hline PERLND & 130 & PWATER & AGWI & 18.61667 & COPY & 1 & INPUT & MEAN \\
\hline PERLND & 130 & PWATER & TAET & 18.61667 & COPY & 1 & INPUT & MEAN \\
\hline PERLND & 130 & SNOW & SNOWE & 18.61667 & COPY & 1 & INPUT & MEAN \\
\hline PERLND & 144 & PWATER & SURO & 7.00000 & COPY & 1 & INPUT & MEAN \\
\hline PERLND & 144 & PWATER & IFWO & 7.00000 & COPY & 1 & INPUT & MEAN \\
\hline PERLND & 144 & PWATER & AGWI & 7.00000 & COPY & 1 & INPUT & MEAN \\
\hline PERLND & 144 & PWATER & TAET & 7.00000 & COPY & 1 & INPUT & MEAN \\
\hline
\end{tabular}




\begin{tabular}{|c|c|c|c|c|c|c|c|c|}
\hline PERLND & 144 & SNOW & SNOWE & 7.00000 & COPY & 1 & INPUT & MEAN \\
\hline PERLND & 150 & PWATER & SURO & 2.01667 & COPY & 1 & INPUT & MEAN \\
\hline PERLND & 150 & PWATER & IFWO & 2.01667 & COPY & 1 & INPUT & MEAN \\
\hline PERLND & 150 & PWATER & AGWI & 2.01667 & COPY & 1 & INPUT & MEAN \\
\hline PERLND & 150 & PWATER & TAET & 2.01667 & COPY & 1 & INPUT & MEAN \\
\hline PERLND & 150 & SNOW & SNOWE & 2.01667 & COPY & 1 & INPUT & MEAN \\
\hline PERLND & 161 & PWATER & SURO & 8.57500 & COPY & 1 & INPUT & MEAN \\
\hline PERLND & 161 & PWATER & IFWO & 8.57500 & COPY & 1 & INPUT & MEAN \\
\hline PERLND & 161 & PWATER & AGWI & 8.57500 & COPY & 1 & INPUT & MEAN \\
\hline PERLND & 161 & PWATER & TAET & 8.57500 & COPY & 1 & INPUT & MEAN \\
\hline PERLND & 161 & SNOW & SNOWE & 8.57500 & COPY & 1 & INPUT & MEAN \\
\hline PERLND & 164 & PWATER & SURO & 2.51667 & COPY & 1 & INPUT & MEAN \\
\hline PERLND & 164 & PWATER & IFWO & 2.51667 & COPY & 1 & INPUT & MEAN \\
\hline PERLND & 164 & PWATER & AGWI & 2.51667 & COPY & 1 & INPUT & MEAN \\
\hline PERLND & 164 & PWATER & TAET & 2.51667 & COPY & 1 & INPUT & MEAN \\
\hline PERLND & 164 & SNOW & SNOWE & 2.51667 & COPY & 1 & INPUT & MEAN \\
\hline PERLND & 167 & PWATER & SURO & 27.10000 & COPY & 1 & INPUT & MEAN \\
\hline PERLND & 167 & PWATER & IFWO & 27.10000 & COPY & 1 & INPUT & MEAN \\
\hline PERLND & 167 & PWATER & AGWI & 27.10000 & COPY & 1 & INPUT & MEAN \\
\hline PERLND & 167 & PWATER & TAET & 27.10000 & COPY & 1 & INPUT & MEAN \\
\hline PERLND & 167 & SNOW & SNOWE & 27.10000 & COPY & 1 & INPUT & MEAN \\
\hline PERLND & 201 & PWATER & SURO & 3.84167 & COPY & 1 & INPUT & MEAN \\
\hline PERLND & 201 & PWATER & IFWO & 3.84167 & COPY & 1 & INPUT & MEAN \\
\hline PERLND & 201 & PWATER & $A G W I$ & 3.84167 & COPY & 1 & INPUT & MEAN \\
\hline PERLND & 201 & PWATER & TAET & 3.84167 & COPY & 1 & INPUT & MEAN \\
\hline PERLND & 201 & SNOW & SNOWE & 3.84167 & COPY & 1 & INPUT & MEAN \\
\hline PERLND & 207 & PWATER & SURO & 12.93333 & COPY & 1 & INPUT & MEAN \\
\hline PERLND & 207 & PWATER & IFWO & 12.93333 & COPY & 1 & INPUT & MEAN \\
\hline PERLND & 207 & PWATER & AGWI & 12.93333 & COPY & 1 & INPUT & MEAN \\
\hline PERLND & 207 & PWATER & TAET & 12.93333 & COPY & 1 & INPUT & MEAN \\
\hline PERLND & 207 & SNOW & SNOWE & 12.93333 & COPY & 1 & INPUT & MEAN \\
\hline PERLND & 221 & PWATER & SURO & 19.90000 & COPY & 1 & INPUT & MEAN \\
\hline PERLND & 221 & PWATER & IFWO & 19.90000 & COPY & 1 & INPUT & MEAN \\
\hline PERLND & 221 & PWATER & AGWI & 19.90000 & COPY & 1 & INPUT & MEAN \\
\hline PERLND & 221 & PWATER & TAET & 19.90000 & COPY & 1 & INPUT & MEAN \\
\hline PERLND & 221 & SNOW & SNOWE & 19.90000 & COPY & 1 & INPUT & MEAN \\
\hline PER:LND & 224 & PWATER & SURO & 3.40833 & COPY & 1 & INPUT & MEAN \\
\hline PERLND & 224 & PWATER & IFWO & 3.40833 & COPY & 1 & INPUT & MEAN \\
\hline PERLND & 224 & PWATER & AGWI & 3.40833 & COPY & 1 & INPUT & MEAN \\
\hline PERLND & 224 & PWATER & TAET & 3.40833 & COPY & 1 & INPUT & MEAN \\
\hline PERLND & 224 & SNOW & SNOWE & 3.40833 & COPY & 1 & INPUT & MEAN \\
\hline PERLND & 227 & PWATER & SURO & 51.65000 & COPY & 1 & INPUT & MEAN \\
\hline PERLND & 227 & PWATER & IFWO & 51.65000 & COPY & 1 & INPUT & MEAN \\
\hline PERLND & 227 & PWATER & AGWI & 51.65000 & COPY & 1 & INPUT & MEAN \\
\hline PERLND & 227 & PWATER & TAET & 51.65000 & COPY & 1 & INPUT & MEAN \\
\hline PERLND & 227 & SNOW & SNOWE & 51.65000 & COPY & 1 & INPUT & MEAN \\
\hline PERLND & 230 & PWATER & SURO & 3.10000 & COPY & 1 & INPUT & MEAN \\
\hline PERLND & 230 & PWATER & IFWO & 3.10000 & COPY & 1 & INPUT & MEAN \\
\hline PERLND & 230 & PWATER & AGWI & 3.10000 & COPY & 1 & INPUT & MEAN \\
\hline PERLND & 230 & PWATER & TAET & 3.10000 & COPY & 1 & INPUT & MEAN \\
\hline PERLND & 230 & SNOW & SNOWE & 3.10000 & COPY & 1 & INPUT & MEAN \\
\hline PERLND & 241 & PWATER & SURO & 3.12500 & COPY & 1 & INPUT & MEAN \\
\hline PERLND & 241 & PWATER & IFWO & 3.12500 & COPY & 1 & INPUT & MEAN \\
\hline PERLND & 241 & PWATER & AGWI & 3.12500 & COPY & 1 & INPUT & MEAN \\
\hline
\end{tabular}




\begin{tabular}{|c|c|c|c|c|c|c|c|c|}
\hline PERLND & 241 & PWATER & TAET & 3.12500 & COPY & 1 & INPUT & MEAN \\
\hline PERLND & 241 & SNOW & SNOWE & 3.12500 & COPY & 1 & INPUT & MEAN \\
\hline PERLND & 247 & PWATER & SURO & 16.55000 & COPY & 1 & INPUT & MEAN \\
\hline PERLND & 247 & PWATER & IFWO & 16.55000 & COPY & 1 & INPUT & MEAN \\
\hline PERLND & 247 & PWATER & AGWI & 16.55000 & COPY & 1 & INPUT & MEAN \\
\hline PERLND & 247 & PWATER & TAET & 16.55000 & COPY & 1 & INPUT & MEAN \\
\hline PERLND & 247 & SNOW & SNOWE & 16.55000 & COPY & 1 & INPUT & MEAN \\
\hline PERLND & 261 & PWATER & SURO & 39.96667 & COPY & 1 & INPUT & MEAN \\
\hline PERLND & 261 & PWATER & IFWO & 39.96667 & COPY & 1 & INPUT & MEAN \\
\hline PERLND & 261 & PWATER & AGWI & 39.96667 & COPY & 1 & INPUT & MEAN \\
\hline PERLND & 261 & PWATER & TAET & 39.96667 & COPY & 1 & INPUT & MEAN \\
\hline PERLND & 261 & SNOW & SNOWE & 39.96667 & COPY & 1 & INPUT & MEAN \\
\hline PERLND & 264 & PWATER & SURO & 9.14167 & COPY & 1 & INPUT & MEAN \\
\hline PERLND & 264 & PWATER & IFWO & 9.14167 & COPY & 1 & INPUT & MEAN \\
\hline PERLND & 264 & PWATER & AGWI & 9.14167 & COPY & 1 & INPUT & MEAN \\
\hline PERLND & 264 & PWATER & TAET & 9.14167 & COPY & 1 & INPUT & MEAN \\
\hline PERLND & 264 & SNOW & SNOWE & 9.14167 & COPY & 1 & INPUT & MEAN \\
\hline PERLND & 267 & PWATER & SURO & 55.40833 & COPY & 1 & INPUT & MEAN \\
\hline PERLND & 267 & PWATER & IFWO & 55.40833 & COPY & 1 & INPUT & MEAN \\
\hline PERLND & 267 & PWATER & AGWI & 55.40833 & COPY & 1 & INPUT & MEAN \\
\hline PERLND & 267 & PWATER & TAET & 55.40833 & COPY & 1 & INPUT & MEAN \\
\hline PERLND & 267 & SNOW & SNOWE & 55.40833 & COPY & 1 & INPUT & MEAN \\
\hline PERLND & 270 & PWATER & SURO & 11.50000 & COPY & 1 & INPUT & MEAN \\
\hline PERLND & 270 & PWATER & IFWO & 11.50000 & COPY & 1 & INPUT & MEAN \\
\hline PERLND & 270 & PWATER & AGWI & 11.50000 & COPY & 1 & INPUT & MEAN \\
\hline PERLND & 270 & PWATER & TAET & 11.50000 & COPY & 1 & INPUT & MEAN \\
\hline PERLND & 270 & SNOW & SNOWE & 11.50000 & COPY & 1 & INPUT & MEAN \\
\hline PERLND & 281 & PWATER & SURO & 3.19167 & COPY & 1 & INPUT & MEAN \\
\hline PERLND & 281 & PWATER & IFWO & 3.19167 & COPY & 1 & INPUT & MEAN \\
\hline PERLND & 281 & PWATER & AGWI & 3.19167 & COPY & 1 & INPUT & MEAN \\
\hline PERLND & 281 & PWATER & TAET & 3.19167 & COPY & 1 & INPUT & MEAN \\
\hline PERLND & 281 & SNOW & SNOWE & 3.19167 & COPY & 1 & INPUT & MEAN \\
\hline PERLND & 287 & PWATER & SURO & 8.71667 & COPY & 1 & INPUT & MEAN \\
\hline PERLND & 287 & PWATER & IFWO & 8.71667 & COPY & 1 & INPUT & MEAN \\
\hline PERLND & 287 & PWATER & AGWI & 8.71667 & COPY & 1 & INPUT & MEAN \\
\hline PERLND & 287 & PWATER & TAET & 8.71667 & COPY & 1 & INPUT & MEAN \\
\hline PERLND & 287 & SNOW & SNOWE & 8.71667 & COPY & 1 & INPUT & MEAN \\
\hline PERLND & 304 & PWATER & SURO & 1.10833 & COPY & 1 & INPUT & MEAN \\
\hline PERLND & 304 & PWATER & IFWO & 1.10833 & COPY & 1 & INPUT & MEAN \\
\hline PERLND & 304 & PWATER & AGWI & 1.10833 & COPY & 1 & INPUT & MEAN \\
\hline PERLND & 304 & PWATER & TAET & 1.10833 & COPY & 1 & INPUT & MEAN \\
\hline PERLND & 304 & SNOW & SNOWE & 1.10833 & COPY & 1 & INPUT & MEAN \\
\hline PERLND & 314 & PWATER & SURO & 1.81667 & COPY & 1 & INPUT & MEAN \\
\hline PERLND & 314 & PWATER & IFWO & 1.81667 & $\mathrm{COPY}$ & 1 & INPUT & MEAN \\
\hline PERLND & 314 & PWATER & AGWI & 1.81667 & COPY & 1 & INPUT & MEAN \\
\hline PERLND & 314 & PWATER & TAET & 1.81667 & COPY & 1 & INPUT & MEAN \\
\hline PERLND & 314 & SNOW & SNOWE & 1.81667 & COPY & 1 & INPUT & MEAN \\
\hline PERLND & 321 & PWATER & SURO & 8.47500 & COPY & 1 & INPUT & MEAN \\
\hline PERLND & 321 & PWATER & IFWO & 8.47500 & COPY & 1 & INPUT & MEAN \\
\hline PERLND & 321 & PWATER & AGWI & 8.47500 & COPY & 1 & INPUT & MEAN \\
\hline PERLND & 321 & PWATER & TAET & 8.47500 & COPY & 1 & INPUT & MEAN \\
\hline PERLND & 321 & SNOW & SNOWE & 8.47500 & COPY & 1 & INPUT & MEAN \\
\hline PERLND & 324 & PWATER & SURO & 14.19167 & COPY & 1 & INPUT & MEAN \\
\hline PERLND & 324 & PWATER & IFWO & 14.19167 & COPY & 1 & INPUT & MEAN \\
\hline
\end{tabular}




\begin{tabular}{|c|c|c|c|c|c|c|c|c|}
\hline PERLND & 324 & PWATER & AGWI & 14.19167 & COPY & 1 & INPUT & MEAN \\
\hline PERLND & 324 & PWATER & TAET & 14.19167 & COPY & 1 & INPUT & MEAN \\
\hline PERLND & 324 & SNOW & SNOWE & 14.19167 & COPY & 1 & INPUT & MEAN \\
\hline PERLND & 327 & PWATER & SURO & 2.85833 & COPY & 1 & INPUT & MEAN \\
\hline PERLND & 327 & PWATER & IFWO & 2.85833 & COPY & 1 & INPUT & MEAN \\
\hline PERLND & 327 & PWATER & AGWI & 2.85833 & COPY & 1 & INPUT & MEAN \\
\hline PERLND & 327 & PWATER & TAET & 2.85833 & COPY & 1 & INPUT & MEAN \\
\hline PERLND & 327 & SNOW & SNOWE & 2.85833 & COPY & 1 & INPUT & MEAN \\
\hline PERLND & 330 & PWATER & SURO & 9.45833 & COPY & 1 & INPUT & MEAN \\
\hline PERLND & 330 & PWATER & IFWO & 9.45833 & COPY & 1 & INPUT & MEAN \\
\hline PERLND & 330 & PWATER & AGWI & 9.45833 & COPY & 1 & INPUT & MEAN \\
\hline PERLND & 330 & PWATER & TAET & 9.45833 & COPY & 1 & INPUT & MEAN \\
\hline PERLND & 330 & SNOW & SNOWE & 9.45833 & COPY & 1 & INPUT & MEAN \\
\hline PERLND & 334 & PWATER & SURO & 2.55833 & COPY & 1 & INPUT & MEAN \\
\hline PERLND & 334 & PWATER & IFWO & 2.55833 & COPY & 1 & INPUT & MEAN \\
\hline PERLND & 334 & PWATER & AGWI & 2.55833 & COPY & 1 & INPUT & MEAN \\
\hline PERLND & 334 & PWATER & TAET & 2.55833 & COPY & 1 & INPUT & MEAN \\
\hline PERLND & 334 & SNOW & SNOWE & 2.55833 & COPY & 1 & INPUT & MEAN \\
\hline PERLND & 344 & PWATER & SURO & 0.96667 & COPY & 1 & INPUT & MEAN \\
\hline PERLND & 344 & PWATER & IFWO & 0.96667 & COPY & 1 & INPUT & MEAN \\
\hline PERLND & 344 & PWATER & AGWI & 0.96667 & COPY & 1 & INPUT & MEAN \\
\hline PERLND & 344 & PWATER & TAET & 0.96667 & COPY & 1 & INPUT & MEAN \\
\hline PERLND & 344 & SNOW & SNOWE & 0.96667 & COPY & 1 & INPUT & MEAN \\
\hline PERLND & 361 & PWATER & SURO & 14.50833 & COPY & 1 & INPUT & MEAN \\
\hline PERLND & 361 & PWATER & IFWO & 14.50833 & COPY & 1 & INPUT & MEAN \\
\hline PERLND & 361 & PWATER & AGWI & 14.50833 & COPY & 1 & INPUT & MEAN \\
\hline PERLND & 361 & PWATER & TAET & 14.50833 & COPY & 1 & INPUT & MEAN \\
\hline PERLND & 361 & SNOW & SNOWE & 14.50833 & COPY & 1 & INPUT & MEAN \\
\hline PERLND & 364 & PWATER & SURO & 15.11667 & COPY & 1 & INPUT & MEAN \\
\hline PERLND & 364 & PWATER & IFWO & 15.11667 & COPY & 1 & INPUT & MEAN \\
\hline PERLND & 364 & PWATER & AGWI & 15.11667 & COPY & 1 & INPUT & MEAN \\
\hline PERLND & 364 & PWATER & TAET & 15.11667 & COPY & 1 & INPUT & MEAN \\
\hline PERLND & 364 & SNOW & SNOWE & 15.11667 & COPY & 1 & INPUT & MEAN \\
\hline PERLND & 367 & PWATER & SURO & 5.53333 & COPY & 1 & INPUT & MEAN \\
\hline PERLND & 367 & PWATER & IFWO & 5.53333 & COPY & 1 & INPUT & MEAN \\
\hline PERLND & 367 & PWATER & AGWI & 5.53333 & COPY & 1 & INPUT & MEAN \\
\hline PERLND & 367 & PWATER & TAET & 5.53333 & COPY & 1 & INPUT & MEAN \\
\hline PERLND & 367 & SNOW & SNOWE & 5.53333 & COPY & 1 & INPUT & MEAN \\
\hline PERLND & 370 & PWATER & SURO & 9.19167 & COPY & 1 & INPUT & MEAN \\
\hline PERLND & 370 & PWATER & IFWO & 9.19167 & COPY & 1 & INPUT & MEAN \\
\hline PERLND & 370 & PWATER & AGWI & 9.19167 & COPY & 1 & INPUT & MEAN \\
\hline PERLND & 370 & PWATER & TAET & 9.19167 & COPY & 1 & INPUT & MEAN \\
\hline PERLND & 370 & SNOW & SNOWE & 9.19167 & COPY & 1 & INPUT & MEAN \\
\hline
\end{tabular}

$* * *$ Basin water balance information

$\star * *$ Total ppt. Mfact is fraction of basin area for each elevation zone. $* \star \star \operatorname{dry} 2$

$\begin{array}{lllllllll}\text { PERLND 101 SNOW } & \text { RAINF } & .469 & \text { COPY } & 1 & \text { INPUT } & \text { MEAN } & 7 \\ \text { PERLND 101 SNOW } & \text { SNOWF } & .469 & \text { COPY } & 1 & \text { INPUT } & \text { MEAN } & 7 \\ \text { PERLND 201 SNOW } & \text { RAINF } & .353 & \text { COPY } & 1 & \text { INPUT } & \text { MEAN } & 7 \\ \text { PERLND 201 SNOW } & \text { SNOWF } & .353 & \text { COPY } & 1 & \text { INPUT } & \text { MEAN } & 7 \\ \text { PERLND 304 SNOW } & \text { RAINF } & .178 & \text { COPY } & 1 & \text { INPUT } & \text { MEAN } & 7 \\ \text { PERLND 304 SNOW } & \text { SNOWF } & .178 & \text { COPY } & 1 & \text { INPUT } & \text { MEAN } & 7 \\ \text { ** drY1 } & & & & & & & & \\ \text { PERLND 101 SNOW } & \text { RAINF } & .769 & \text { COPY } & 1 & \text { INPUT } & \text { MEAN } & 8\end{array}$




\begin{tabular}{|c|c|c|c|c|c|c|c|c|c|c|}
\hline PERLND & 101 & SNOW & SNOWF & & & .769 & COPY & 1 & INPUT & MEAN \\
\hline PERLND & 201 & SNOW & RAINF & & & .171 & COPY & 1 & INPUT & MEAN \\
\hline PERLND & 201 & SNOW & SNOWF & & & .171 & COPY & 1 & INPUT & MEAN \\
\hline PERLND & 304 & SNOW & RAINF & & & .060 & COPY & 1 & INPUT & MEAN \\
\hline PERLND & 304 & SNOW & SNOWF & & & .060 & COPY & 1 & INPUT & MEAN \\
\hline \multicolumn{2}{|c|}{$\begin{array}{l}\star \star \star \\
\star \star \star \\
* \star\end{array}$} & $\begin{array}{l}\text { vert ac- } \\
\text { mfact }=\end{array}$ & $\begin{array}{l}\text { - ft to } \\
=\quad 112\end{array}$ & inc & $\begin{array}{l}\text { hes } \\
37 \text { a }\end{array}$ & $\begin{array}{l}\text { for ru } \\
\text { acres) }\end{array}$ & recharg & $\delta$ & & \\
\hline COPY & 1 & OUTPUT & MEAN & 1 & & .000540 & COPY & 2 & INPUT & MEAN \\
\hline COPY & 1 & OUTPUT & MEAN & 2 & & .000540 & COPY & 2 & INPUT & MEAN \\
\hline COPY & 1 & OUTPUT & MEAN & 3 & & .000540 & COPY & 2 & INPUT & MEAN \\
\hline \multicolumn{11}{|c|}{$\star \star \star \operatorname{dry} 1$, mfact $=(12 / 17059$ acres $)$} \\
\hline COPY & 1 & OUTPUT & MEAN & 4 & & .000703 & COPY & 2 & INPUT & MEAN \\
\hline COPY & 1 & OUTPUT & MEAN & 5 & & .000703 & COPY & 2 & INPUT & MEAN \\
\hline COPY & 1 & OUTPUT & MEAN & 6 & & .000703 & COPY & 2 & INPUT & MEAN \\
\hline \multicolumn{11}{|c|}{$\star \star \star$ Basin water-balance displays. } \\
\hline COPY & 1 & OUTPUT & MEAN & 7 & $\star \star \star$ & & DISPLY & 1 & INPUT & TIMSER \\
\hline COPY & 1 & OUTPUT & MEAN & 1 & & & DISPLY & 2 & INPUT & TIMSER \\
\hline COPY & 2 & OUTPUT & MEAN & 2 & $\star \star \star$ & & DISPLY & 3 & INPUT & TIMSER \\
\hline COPY & 2 & OUTPUT & MEAN & 3 & $\star \star \star$ & & DISPLY & 4 & INPUT & TIMSER \\
\hline COPY & 1 & OUTPUT & MEAN & 8 & $\star \star \star$ & & DISPLY & 5 & INPUT & TIMSER \\
\hline COPY & 1 & OUTPUT & MEAN & 4 & & & DISPLY & 6 & INPUT & TIMSER \\
\hline COPY & 2 & OUTPUT & MEAN & 5 & 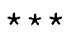 & & DISPLY & 7 & INPUT & TIMSER \\
\hline COPY & 2 & OUTPUT & MEAN & 6 & 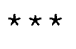 & & DISPLY & 8 & INPUT & TIMSER \\
\hline
\end{tabular}

END NETWORK

EXT TARGETS

$\begin{aligned} & <- \text { Volume-> } \\ & \star * \star\end{aligned}$
$\begin{aligned} & \text { <Name> } \\ & \text { strg*** }\end{aligned}$

END EXT TARGETS

DISPLY

DISPLY - INFO1

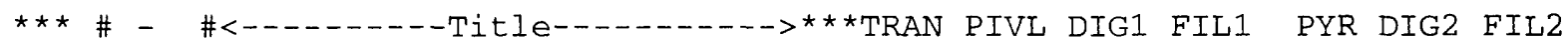

YRND

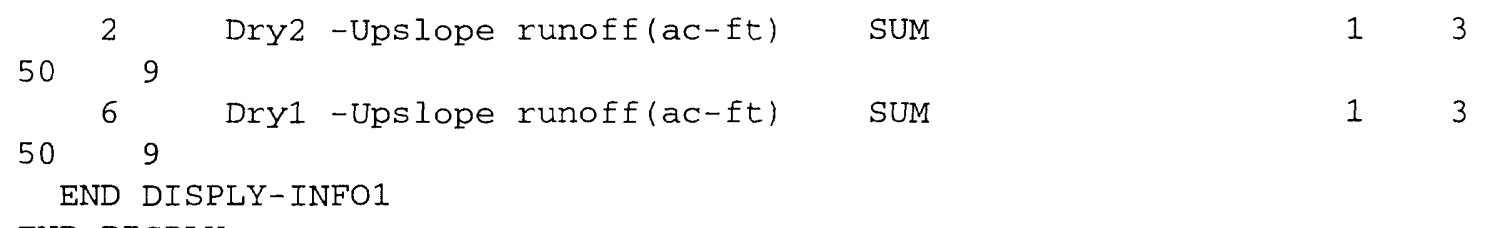

END DISPLY

COPY

TIMESERIES

\#-\# NPT NMN ** * 
1

8

2

END TIMESERIES

END COPY

SPEC-ACTIONS (Not shown)

END SPEC-ACTIONS

END RUN 
Appendix 7.--Final HSPF input file for combined Dry Creek model

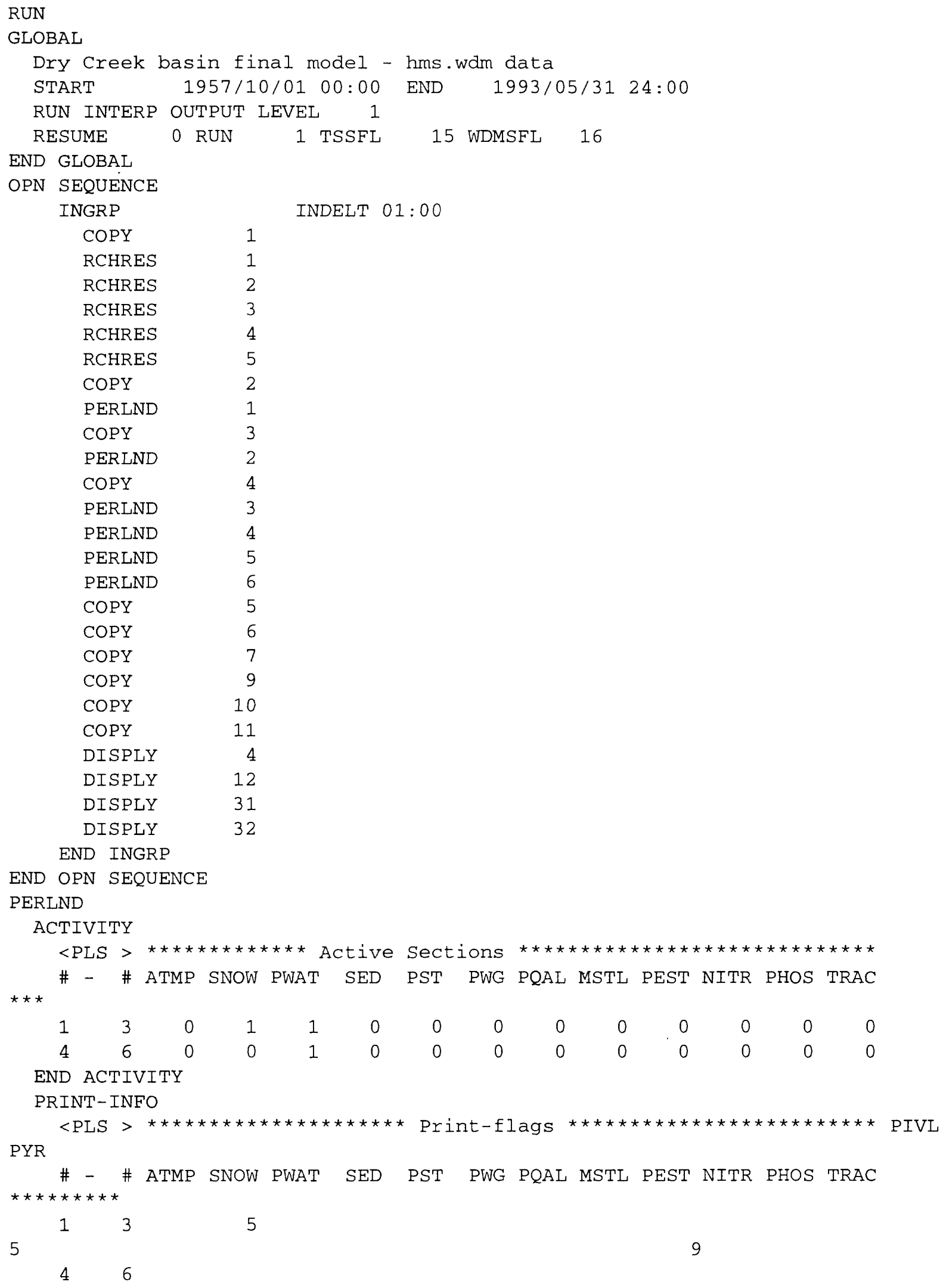

1
1
2
3
4
5
2
1
3
2
4
3
4
5
6
5
6
7
9
10
11
4
12
31
32


END PRINT-INFO

GEN-INFO

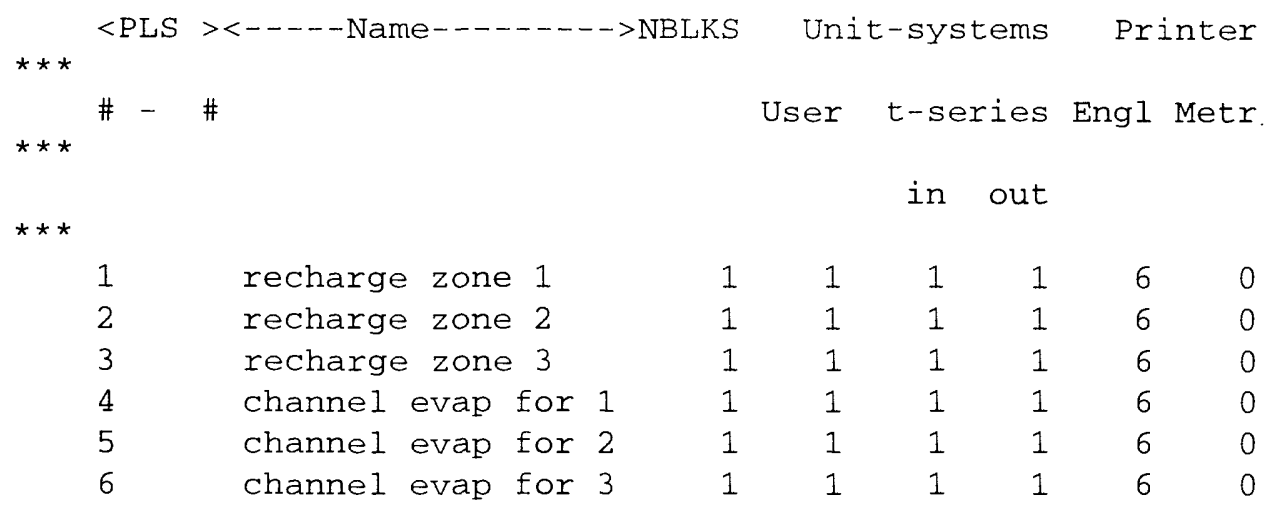

END GEN-INFO

ICE-FLAG

$<$ PLS > Value of 1 means ice will be simulated, 0 means not simulated

*** \#- \#ICEFG

$\star \star \star$

130

END ICE-FLAG

SNOW-PARM1

perlnd perlnd shaded gage-catch snow w.eq. needed for

\begin{tabular}{|c|c|c|c|c|c|c|c|}
\hline & $<$ PLS & $>$ & latitude & altitude & fraction & adjustment & complete snowcover \\
\hline & $\#-$ & \# & LAT & MELEV & SHADE & SNOWCF & COVIND \\
\hline
\end{tabular}

$\begin{array}{lllllll}* * * & & & & & & \\ & 3 & 46.6 & 820 . & 0.0 & 1.25 & 0.5\end{array}$

END SNOW-PARM1

SNOW-PARM2

\begin{tabular}{|c|c|c|c|c|c|c|c|c|}
\hline$\star \star \star$ & & & new snow & rain vs & sublim. & latent ht. & $\max$ AWC & ground \\
\hline & $<$ PLS & $>$ & density & snow tmp & adjust & adjust & of pack & melt \\
\hline$\star \star \star$ & & & & & & & & \\
\hline & \# & \# & RDCSN & TSNOW & SNOEVP & CCFACT & MWATER & MGMELT \\
\hline & 1 & 3 & 0.05 & 32. & 0.85 & 1.5 & 0.08 & 0.02 \\
\hline
\end{tabular}

END SNOW-PARM2

SNOW-INIT1

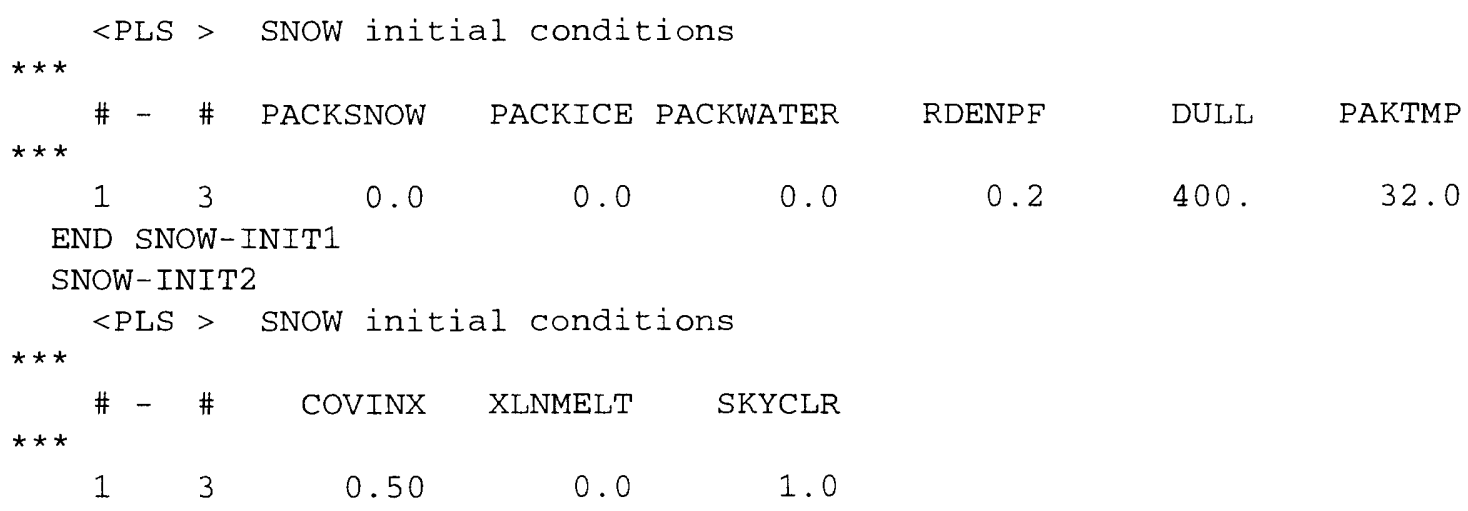


END SNOW-INIT2

PWAT-PARM1

$<$ PLS > PWATER variable monthly parameter value flags

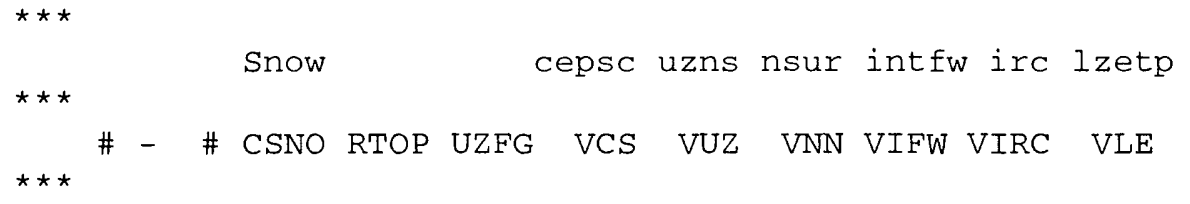

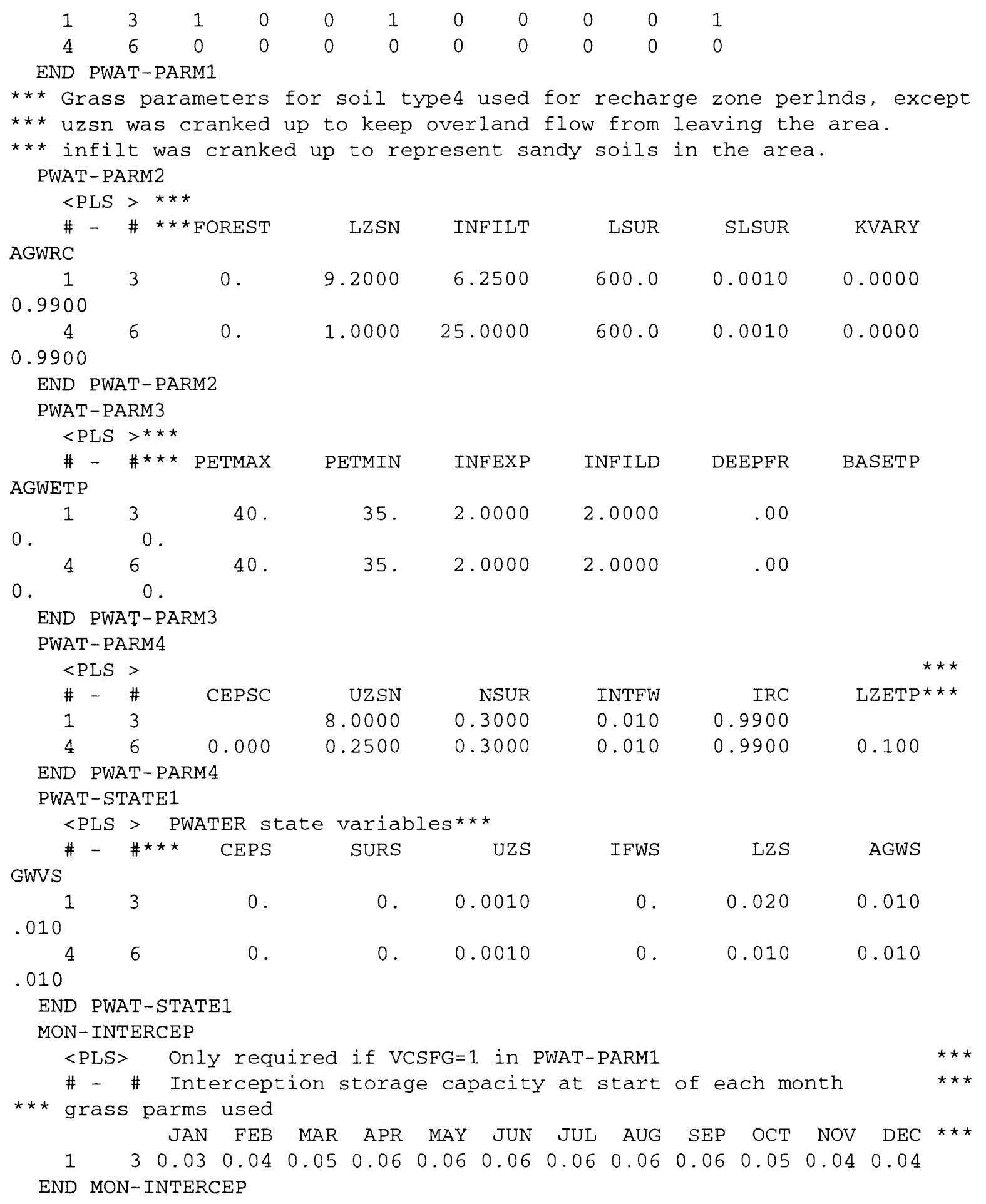




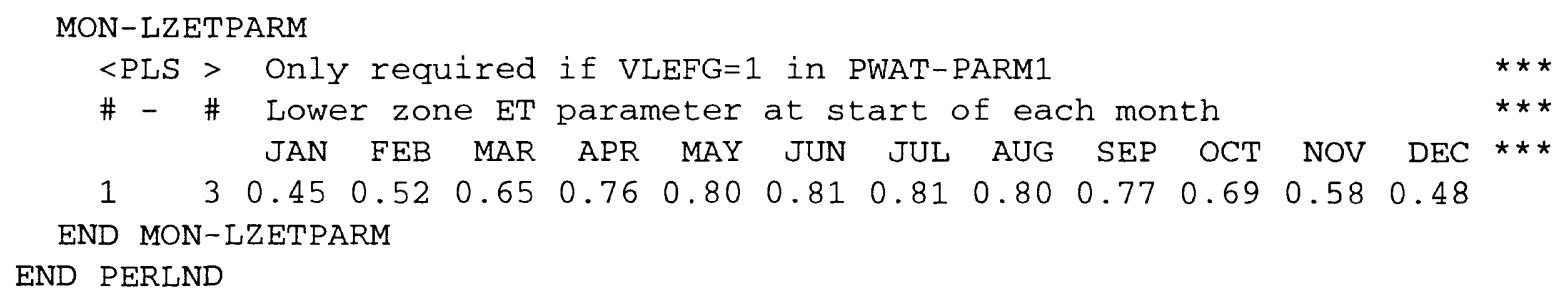




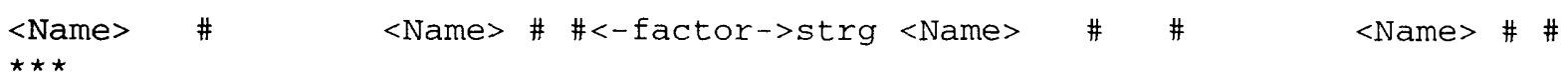

$\star \star \star$ Basin geometry (a11 units are ac-ft)

** Channel inflows from direct runoff in cold4,cold3; cold2, cold1

\begin{tabular}{|c|c|c|c|}
\hline COPY & 1 & OUTPUT & MEAN \\
\hline COPY & 1 & OUTPUT & MEAN \\
\hline COPY & 1 & OUTPUT & MEAN \\
\hline COPY & 1 & OUTPUT & MEAN \\
\hline
\end{tabular}

RCHRES 1 INFLOW IVOL 1

RCHRES 2 INFLOW IVOL 1

RCHRES 3 INFLOW IVOL 1

COPY 1 OUTPUT MEAN 4

RCHRES 5 INFLOW IVOL 1

*** Channel connections-ary4 to ary3 to dry2a to ary2b to dry 1

$\begin{array}{lllllllll}\text { RCHRES } & 1 & \text { HYDR } & \text { OVOL } & 2 & \text { RCHRES } & 2 & \text { INFLOW IVOL } & 1 \\ \text { RCHRES } & 2 & \text { HYDR } & \text { OVOL } & 2 & \text { RCHRES } & 3 & \text { INFLOW IVOL } \\ \text { RCHRES } & 3 & \text { HYDR } & \text { OVOL } & 2 & \text { RCHRES } & 4 & \text { INFLOW IVOL } 1 \\ \text { RCHRES } & 4 \text { HYDR } & \text { ROVOL } & & \text { RCHRES } & 5 & \text { INFLOW IVOL }\end{array}$

** Channel discharge+ppt to recharge zone perlnds

*** mfact for ovol to copy converts acft to inches

$\star \star \star$ mfact for suro to copy is the ratio of source area to target area

$\star \star \star$ Recharge zone perlnd areas are $34.4,68.9$, and 34.4 acres.

$\star \star \star$ Channel discharge to subsurface perlnds for channel et losses applied

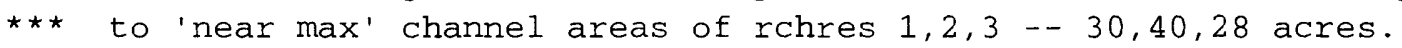

$\begin{array}{llllllllll}\text { RCHRES } & 5 & \text { HYDR } & \text { OVOL } & 2 & 0.34884 & \text { COPY } & 2 & \text { INPUT } & \text { MEAN } \\ \text { COPY } & 2 \text { OUTPUT MEAN } & 1 & & \text { PERLND } & 1 & \text { EXTNL } & \text { PREC } \\ \text { PERLND } & 1 & \text { PWATER SURO } & & 0.5 & \text { COPY } & 3 & \text { INPUT } & \text { MEAN } & 1 \\ \text { COPY } & 3 & \text { OUTPUT MEAN } & 1 & & \text { PERLND } & 2 & \text { EXTNL } & \text { PREC } \\ \text { PERLND } & 2 & \text { PWATER SURO } & & 2.0 & \text { COPY } & 4 & \text { INPUT } & \text { MEAN } & 1 \\ \text { COPY } & 4 & \text { OUTPUT MEAN } & 1 & & \text { PERLND } & 3 & \text { EXTNL } & \text { PREC } \\ \text { RCHRES } & 1 \text { HYDR } & \text { OVOL } & 1 & 0.40000 & \text { PERLND } & 4 & \text { EXTNL } & \text { PREC } \\ \text { RCHRES } & 2 \text { HYDR } & \text { OVOL } & 1 & 0.30000 & \text { PERLND } & 5 & \text { EXTNL } & \text { PREC } \\ \text { RCHRES } & 3 \text { HYDR } & \text { OVOL } & 1 & 0.42857 & \text { PERLND } & 6 & \text { EXTNL } & \text { PREC }\end{array}$

$\star \star \star$ End Basin Geometry

$\star \star \star$ Dry 4 water balance (ac-ft and inches). Area $=36,446$ acres.

$\star \star \star$ Precip (converts inches to ac-ft)

$\begin{array}{lllllllll}\text { COPY } 6 & 6 \text { OUTPUT MEAN } 1 & 3037.2 & \text { COPY } & 7 & \text { INPUT } & \text { MEAN }\end{array}$

$\star \star \star$ ET losses (converts inches to acre-feet)

\begin{tabular}{|c|c|c|c|c|c|c|c|}
\hline COPY & 5 OUTPUT & MEAN & 1 & COPY & 7 & INPUT & MEAN \\
\hline PERLND & 4 PWATER & TAET & 2.500000 & COPY & 7 & INPUT & MEAN \\
\hline$\star \star \star$ & Recharge ( & Conve & inches to a & eet) & & & \\
\hline COPY & 5 OUTPUT & MEAN & 5 & COPY & 7 & INPUT & MEAN \\
\hline PERLND & 4 PWATER & SURO & 2.500000 & COPY & 7 & INPUT & MEAN \\
\hline PERLND & 4 PWATER & IFWO & 2.500000 & COPY & 7 & INPUT & MEAN \\
\hline PERLND & PWATER & AGWI & 2.500000 & COPY & 7 & INPUT & MEAN \\
\hline$\star \star \star$ & Streamflow & & & & & & \\
\hline
\end{tabular}

$\begin{array}{llllllll}\text { RCHRES } & 1 \text { HYDR OVOL } 2 & \text { COPY } & 7 & \text { INPUT } & \text { MEAN } & 4\end{array}$

$\star \star \star \operatorname{Dry} 4+\mathrm{dry} 3$ water balance (ac-ft and inches). Area $=55,378$ acres.

$\star \star \star$ Precip (converts inches to ac-ft) - ary $3=18932$ ac

\begin{tabular}{|c|c|c|c|c|c|c|c|c|c|}
\hline COPY & 6 & OUTPUT & MEAN & 1 & 3037.2 & COPY & 7 & INPUT & MEAN \\
\hline COPY & 6 & OUTPUT & MEAN & 2 & 1577.7 & COPY & 7 & INPUT & MEAN \\
\hline$\star \star \star$ & ET & losses & (conver & ts & ac-ft to inches & or $\mathrm{vj}$ & versa) & & \\
\hline COPY & 5 & OUTPUT & MEAN & 1 & & COPY & 7 & INPUT & MEAN \\
\hline OPY & 5 & OUTPUT & MEAN & 2 & & COPY & 7 & INPUT & MEAN \\
\hline ERLND & 4 & PWATER & TAET & & 2.500000 & COPY & 7 & INPUT & MEAN \\
\hline ERLND & 5 & PWATER & TAET & & 3.333333 & COPY & 7 & INPUT & MEAN \\
\hline
\end{tabular}




\begin{tabular}{|c|c|c|c|c|c|c|c|c|}
\hline COPY & 5 OUTPUT & MEAN & 5 & & COPY & 7 & INPUT & MEAN \\
\hline COPY & 5 OUTPUT & MEAN & 6 & & COPY & 7 & INPUT & MEAN \\
\hline PERLND & 4 PWATER & SURO & & 2.500000 & COPY & 7 & INPUT & MEAN \\
\hline PERLND & 4 PWATER & IFWO & & 2.500000 & COPY & 7 & INPUT & MEAN \\
\hline PERLND & 4 PWATER & AGWI & & 2.500000 & COPY & 7 & INPUT & MEAN \\
\hline PERLND & 5 PWATER & SURO & & 3.333333 & COPY & 7 & INPUT & MEAN \\
\hline PERLND & 5 PWATER & IFWO & & 3.333333 & COPY & 7 & INPUT & MEAN \\
\hline $\begin{array}{r}\text { PERLND } \\
\star \star \star\end{array}$ & $\begin{array}{r}5 \text { PWATER } \\
\text { Streamflow }\end{array}$ & \multicolumn{6}{|c|}{ Streamflow } & MEAN \\
\hline RCHRES & 2 HYDR & OVOL & \multicolumn{2}{|l|}{2} & COPY & 7 & INPUT & MEAN \\
\hline $\begin{array}{c}* * \operatorname{Dry}^{4} \\
\star \star \star\end{array}$ & $\begin{array}{l}y+d r y 3+d r y 2 \\
\text { Precip (cor }\end{array}$ & $\begin{array}{r}\text { water } \\
\text { nverts }\end{array}$ & \multicolumn{2}{|c|}{$\begin{array}{l}\text { balance }(\mathrm{ac}-\mathrm{ft} \text { and } \\
\text { inches to } \mathrm{ac}-\mathrm{ft}) \text { - }\end{array}$} & $\begin{array}{l}\text { inche } \\
\text { dry } 2=\end{array}$ & $\begin{array}{l}\text { Area } \\
37 \text { ac }\end{array}$ & \multicolumn{2}{|c|}{$=77,615$ acres } \\
\hline COPY & 7 OUTPUT & MEAN & 5 & & $\mathrm{COPY}$ & 9 & INPUT & MEAN \\
\hline COPY & 6 OUTPUT & MEAN & 3 & 1853.1 & COPY & 9 & INPUT & MEAN \\
\hline \multicolumn{9}{|c|}{ *** ET losses (converts ac-ft to inches) } \\
\hline COPY & 7 OUTPUT & MEAN & 6 & & COPY & 9 & INPUT & MEAN \\
\hline COPY & 5 OUTPUT & MEAN & 3 & & COPY & 9 & INPUT & MEAN \\
\hline PERLND & 6 PWATER & TAET & & 2.333333 & COPY & 9 & INPUT & MEAN \\
\hline RCHRES & 4 HYDR & VOLEV & & & COPY & 9 & INPUT & MEAN \\
\hline$\star \star \star$ & \multicolumn{8}{|c|}{ Recharge (converts ac-ft to inches) } \\
\hline COPY & 7 OUTPUT & MEAN & 7 & & COPY & 9 & INPUT & MEAN \\
\hline COPY & 5 OUTPUT & MEAN & 7 & & COPY & 9 & INPUT & MEAN \\
\hline PERLND & 6 PWATER & SURO & & 2.333333 & COPY & 9 & INPUT & MEAN \\
\hline PERLND & 6 PWATER & IFWO & & 2.333333 & COPY & 9 & INPUT & MEAN \\
\hline PERLND & 6 PWATER & AGWI & & 2.333333 & COPY & 9 & INPUT & MEAN \\
\hline \multicolumn{9}{|c|}{$* * *$ subtract springflow } \\
\hline COPY & 1 OUTPUT & MEAN & 5 & & COPY & 9 & INPUT & MEAN \\
\hline & \multicolumn{8}{|c|}{ Streamflow (converts ac-ft to inches) } \\
\hline RCHRES & 4 HYDR & ROVOL & & & COPY & 9 & INPUT & MEAN \\
\hline
\end{tabular}

$* * *$ Whole basin water balance (ac-ft and inches). Area $=94,674$ acres.

$* * *$ Recharge zone perlnd areas are $34.4,68.9$, and 34.4 acres.

$\star * *$ Precip (converts inches to ac-ft) - dry $1=17059$ ac

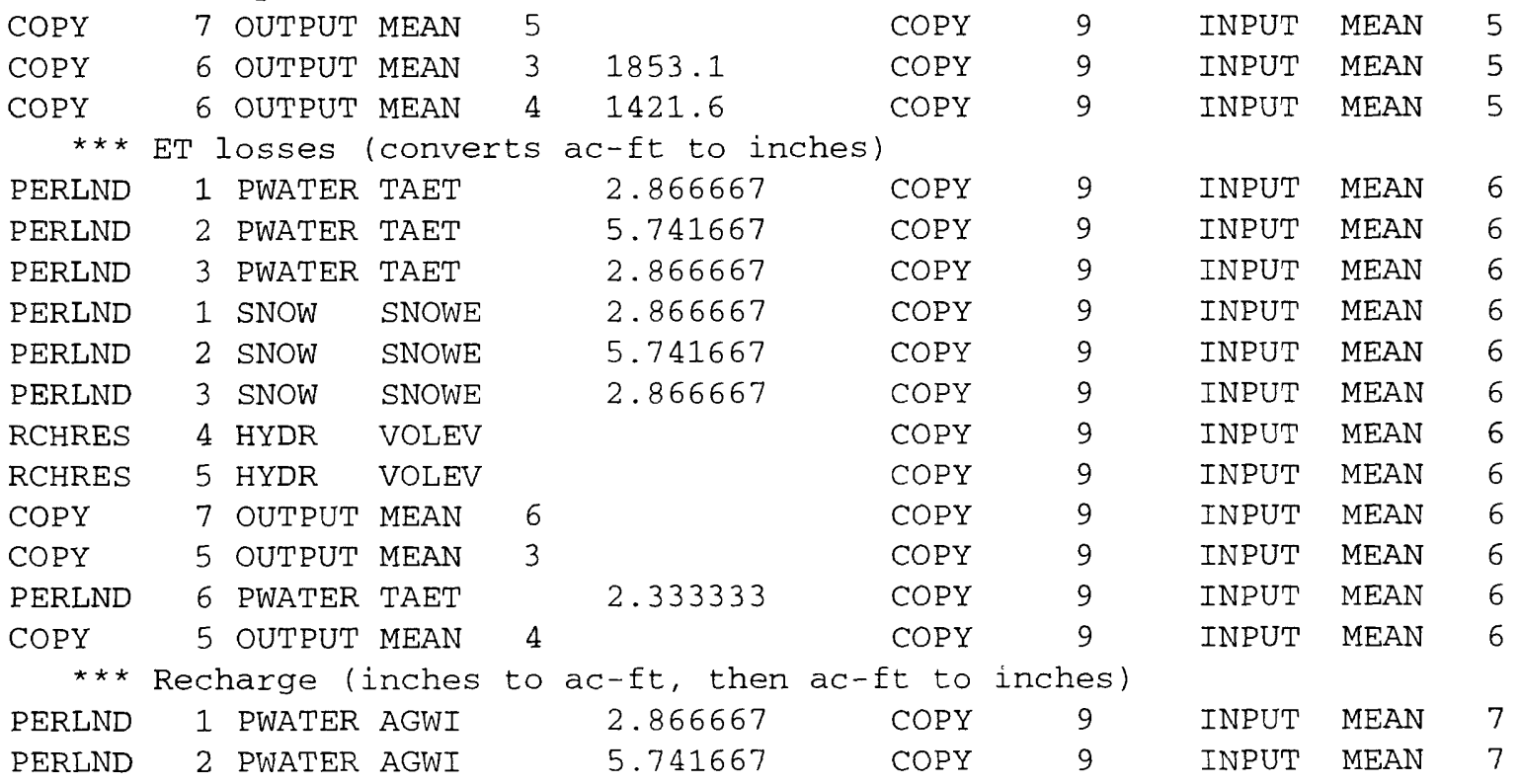




\begin{tabular}{|c|c|c|c|c|c|c|c|c|c|c|}
\hline PERLND & 3 & PWATER & AGWI & & 2.866667 & COPY & 9 & INPUT & MEAN & 7 \\
\hline PERLND & 3 & PWATER & SURO & & 2.866667 & COPY & 9 & INPUT & MEAN & 7 \\
\hline \multirow[t]{2}{*}{ PERLND } & 3 & PWATER & IFWO & & 2.866667 & COPY & 9 & INPUT & MEAN & 7 \\
\hline & & $\star \star \star \quad$ abo & bve ass & igns & any runoff $f$ & Erom final & recha & ge per 1 & nd to & ech \\
\hline COPY & 7 & OUTPUT & MEAN & 7 & & COPY & 9 & INPUT & MEAN & 7 \\
\hline COPY & 5 & OUTPUT & MEAN & 7 & & COPY & 9 & INPUT & MEAN & 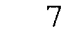 \\
\hline COPY & 5 & OUTPUT & MEAN & 8 & & COPY & 9 & INPUT & MEAN & \\
\hline COPY & 1 & OUTPUT & MEAN & 5 & & COPY & 9 & INPUT & MEAN & \\
\hline PERLND & 6 & PWATER & PERO & & 2.333333 & COPY & 9 & INPUT & MEAN & \\
\hline RCHRES & 5 & HYDR & OVOL & 1 & & COPY & 9 & INPUT & MEAN & \\
\hline \multicolumn{3}{|c|}{ *** Simulated flow } & at gac & & afs) and from & n recharge & zone & inches) & & \\
\hline RCHRES & 1 & HYDR & OVOL & 2 & 12.1 & COPY & 9 & INPUT & MEAN & 8 \\
\hline RCHRES & 4 & HYDR & ROVOL & & 12.1 & COPY & 10 & INPUT & MEAN & \\
\hline \multicolumn{11}{|c|}{ *** Recharge from runoff } \\
\hline PERLND & 4 & PWATER & SURO & & 2.50000 & COPY & 11 & INPUT & MEAN & 1 \\
\hline PERLND & 4 & PWATER & IFWO & & 2.50000 & COPY & 11 & INPUT & MEAN & \\
\hline PERLND & 4 & PWATER & AGWI & & 2.50000 & COPY & 11 & INPUT & MEAN & \\
\hline PERLND & 5 & PWATER & SURO & & 3.33333 & COPY & 11 & INPUT & MEAN & 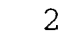 \\
\hline PERLND & 5 & PWATER & IFWO & & 3.33333 & COPY & 11 & INPUT & MEAN & 2 \\
\hline PERLND & 5 & PWATER & AGWI & & 3.33333 & COPY & 11 & INPUT & MEAN & 2 \\
\hline PERLND & 6 & PWATER & SURO & & 2.33333 & COPY & 11 & INPUT & MEAN & 3 \\
\hline PERLND & 6 & PWATER & IFWO & & 2.33333 & COPY & 11 & INPUT & MEAN & 3 \\
\hline PERLND & 6 & PWATER & AGWI & & 2.33333 & COPY & 11 & INPUT & MEAN & 3 \\
\hline RCHRES & 5 & HYDR & OVOL & 1 & & COPY & 11 & INPUT & MEAN & 4 \\
\hline PERLND & 1 & PWATER & AGWI & & 2.866667 & COPY & 11 & INPUT & MEAN & 4 \\
\hline PERLND & 2 & PWATER & AGWI & & 5.741667 & COPY & 11 & INPUT & MEAN & 4 \\
\hline PERLND & 3 & PWATER & AGWI & & 2.866667 & COPY & 11 & INPUT & MEAN & 4 \\
\hline PERLND & 3 & PWATER & SURO & & 2.866667 & COPY & 11 & INPUT & MEAN & 4 \\
\hline $\begin{array}{l}\text { PERLND } \\
\star * \quad \mathrm{Dr}\end{array}$ & $\begin{array}{c}3 \\
4+c\end{array}$ & $\begin{array}{l}\text { PWATER } \\
\text { Ary3 }\end{array}$ & \multicolumn{7}{|c|}{$\star \star \operatorname{Dry} 4+\operatorname{dry} 3$} & 4 \\
\hline PERLND & 4 & PWATER & SURO & & 2.50000 & COPY & 11 & INPUT & MEAN & 5 \\
\hline PERLND & 4 & PWATER & IFWO & & 2.50000 & COPY & 11 & INPUT & MEAN & 5 \\
\hline PERLND & 4 & PWATER & AGWI & & 2.50000 & COPY & 11 & INPUT & MEAN & 5 \\
\hline PERLND & 5 & PWATER & SURO & & 3.33333 & COPY & 11 & INPUT & MEAN & 5 \\
\hline PERLND & 5 & PWATER & IFWO & & 3.33333 & COPY & 11 & INPUT & MEAN & 5 \\
\hline PERLND & 5 & PWATER & AGWI & & 3.33333 & COPY & 11 & INPUT & MEAN & 5 \\
\hline \multicolumn{11}{|c|}{ ** Dry $4+d r y 3+d r y 2$} \\
\hline PERLND & 4 & PWATER & SURO & & 2.50000 & COPY & 11 & INPUT & MEAN & 6 \\
\hline PERLND & 4 & PWATER & IFWO & & 2.50000 & COPY & 11 & INPUT & MEAN & 6 \\
\hline PERLND & 4 & PWATER & $A G W I$ & & 2.50000 & COPY & 11 & INPUT & MEAN & 6 \\
\hline PERLND & 5 & PWATER & SURO & & 3.33333 & COPY & 11 & INPUT & MEAN & 6 \\
\hline PERLND & 5 & PWATER & IFWO & & 3.33333 & COPY & 11 & INPUT & MEAN & 6 \\
\hline PERLND & 5 & PWATER & AGWI & & 3.33333 & COPY & 11 & INPUT & MEAN & 6 \\
\hline PERLND & 6 & PWATER & SURO & & 2.33333 & COPY & 11 & INPUT & MEAN & 6 \\
\hline PERLND & 6 & PWATER & IFWO & & 2.33333 & COPY & 11 & INPUT & MEAN & 6 \\
\hline \multicolumn{11}{|c|}{ ** Dry $4+d r y 3+d r y 2+d r y 1$} \\
\hline PERLND & 4 & PWATER & SURO & & 2.50000 & COPY & 11 & INPUT & MEAN & 7 \\
\hline PERLND & 4 & PWATER & IFWO & & 2.50000 & COPY & 11 & INPUT & MEAN & 7 \\
\hline PERLND & 4 & PWATER & AGWI & & 2.50000 & COPY & 11 & INPUT & MEAN & 7 \\
\hline PERLND & 5 & PWATER & SURO & & 3.33333 & COPY & 11 & INPUT & MEAN & \\
\hline
\end{tabular}




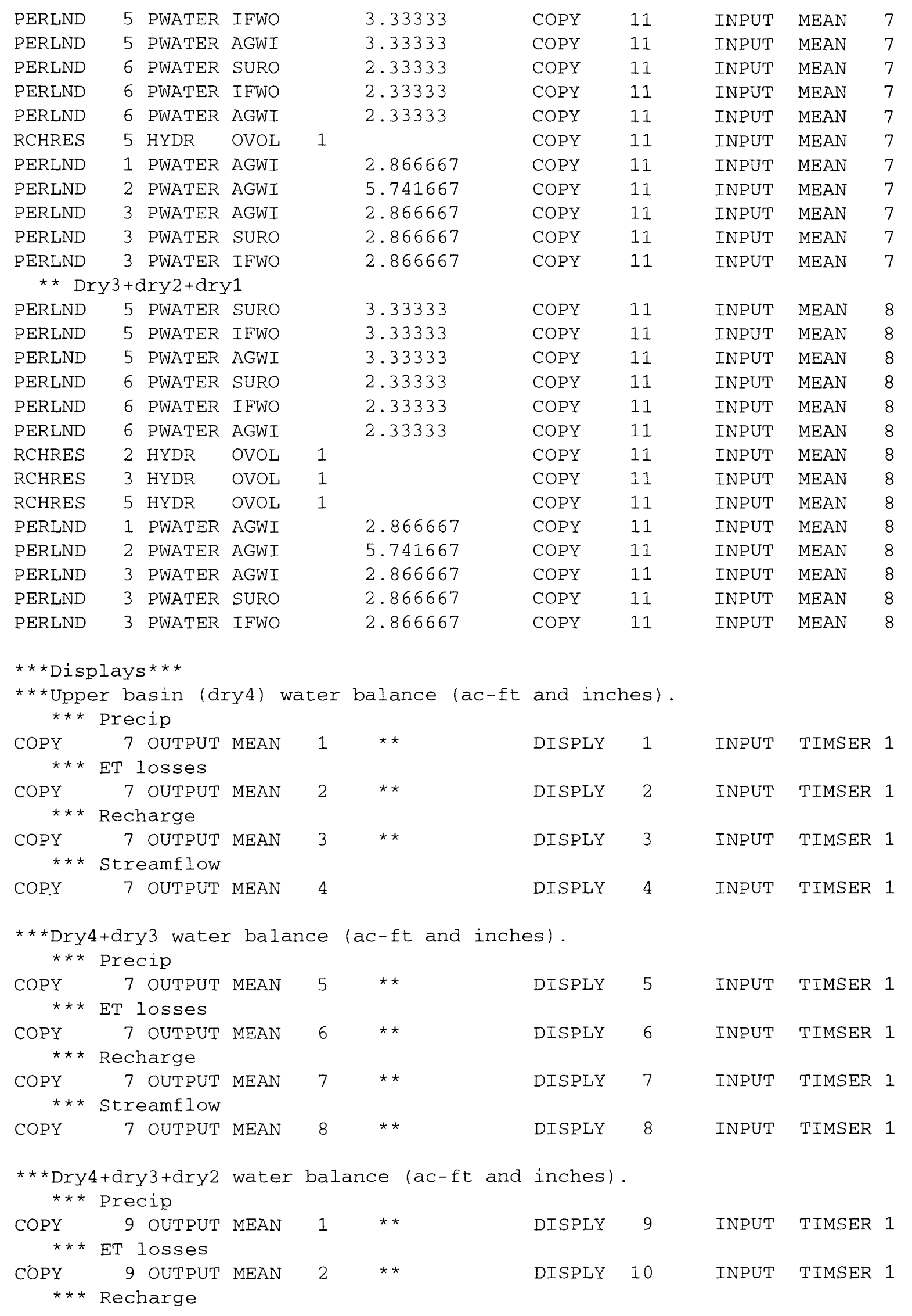




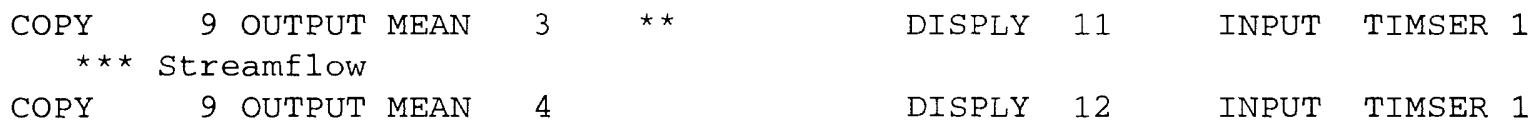

***Whole basin (dry4-dryl and recharge zone) water balance (ac-ft and inches)

$\star \star \star$ Precip

\begin{tabular}{|c|c|c|c|c|c|c|c|}
\hline COPY & 9 OUTPUT & MEAN & $\star \star$ & DISPLY & 13 & INPUT & TIMSER \\
\hline \multicolumn{8}{|c|}{$\star \star \star$ ET losses } \\
\hline COPY & 9 OUTPUT & MEAN & $\star \star$ & DISPLY & 14 & INPUT & TIMSER \\
\hline \multicolumn{8}{|c|}{$\star \star \star$ Recharge } \\
\hline COPY & 9 OUTPUT & MEAN & $\star \star$ & DISPLY & 15 & INPUT & TIMSER \\
\hline \multicolumn{8}{|c|}{ Streamflow - none } \\
\hline \multicolumn{8}{|c|}{ ***Simulated flow at gages (cfs) } \\
\hline COPY & 9 OUTPUT & MEAN & 8 & DISPLY & 31 & INPUT & TIMSER \\
\hline DPY & 10 OUTPUT & MEAN & 1 & DISPLY & 32 & INPUT & TIMSER \\
\hline
\end{tabular}

END NETWORK

EXT TARGETS

$<-$ Volume-> <-Grp> <-Member-><--Mult-->Tran <-Volume-> <Member $>$ Tsys Tgap Amd

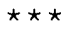

$<$ Name $>\quad$ <Name $\# \#<-$ factor-strg $<$ Name $\quad \#<$ Name $>$ tem strg

strg***

$\star \star \star$ Upper basin (ary4) water balance (ac-ft and inches).

$\star \star \star$ Precip

COPY 7 OUTPUT MEAN

$\star \star \star$ ET losses

COPY 7 OUTPUT MEAN 2

$\star \star \star$ Recharge

COPY 7 OUTPUT MEAN 3

$\star \star \star$ Streamflow

COPY 7 OUTPUT MEAN 4

SAME WDM 453 PT4

ENGL

REPL

SAME WDM 455 ET4A ENGL REPL

SAME WDM 457 DP4A ENGL REPL

SAME WDM 459 Q4A ENGL REPL

$* \star \star \operatorname{Dry} 4+$ dry 3 water balance (ac-ft and inches).

$\star \star \star$ Precip

COPY 7 OUTPUT MEAN

$\star \star \star \mathrm{ET}$ losses

COPY 7 OUTPUT MEAN 6

SAME WDM

461 P34A

ENGL

REPL

*** Recharge

SAME WDM 463 E34A ENGL REPL

COPY 7 OUTPUT MEAN 7

SAME WDM 465 D34A ENGL REPL

$\star \star \star$ Streamflow

COPY 7 OUTPUT MEAN 8

SAME WDM 467 Q34A ENGL

REPL

$\star \star \star \operatorname{Dry} 4+\operatorname{dry} 3+\operatorname{dry} 2$ water balance (ac-ft and inches).

$\star \star \star$ Precip

COPY 9 OUTPUT MEAN 1

$\star \star \star$ ET losses

COPY 9 OUTPUT MEAN 2

$\star \star \star$ Recharge

COPY 9 OUTPUT MEAN 3

$* \star *$ Streamflow

COPY 9 OUTPUT MEAN 4

SAME WDM 469 P24A ENGI

REPL

SAME WDM 471 E24A ENGL REPL

SAME WDM 473 D2 4A ENGL REPL

SAME WDM 475 Q24A ENGL REPL 


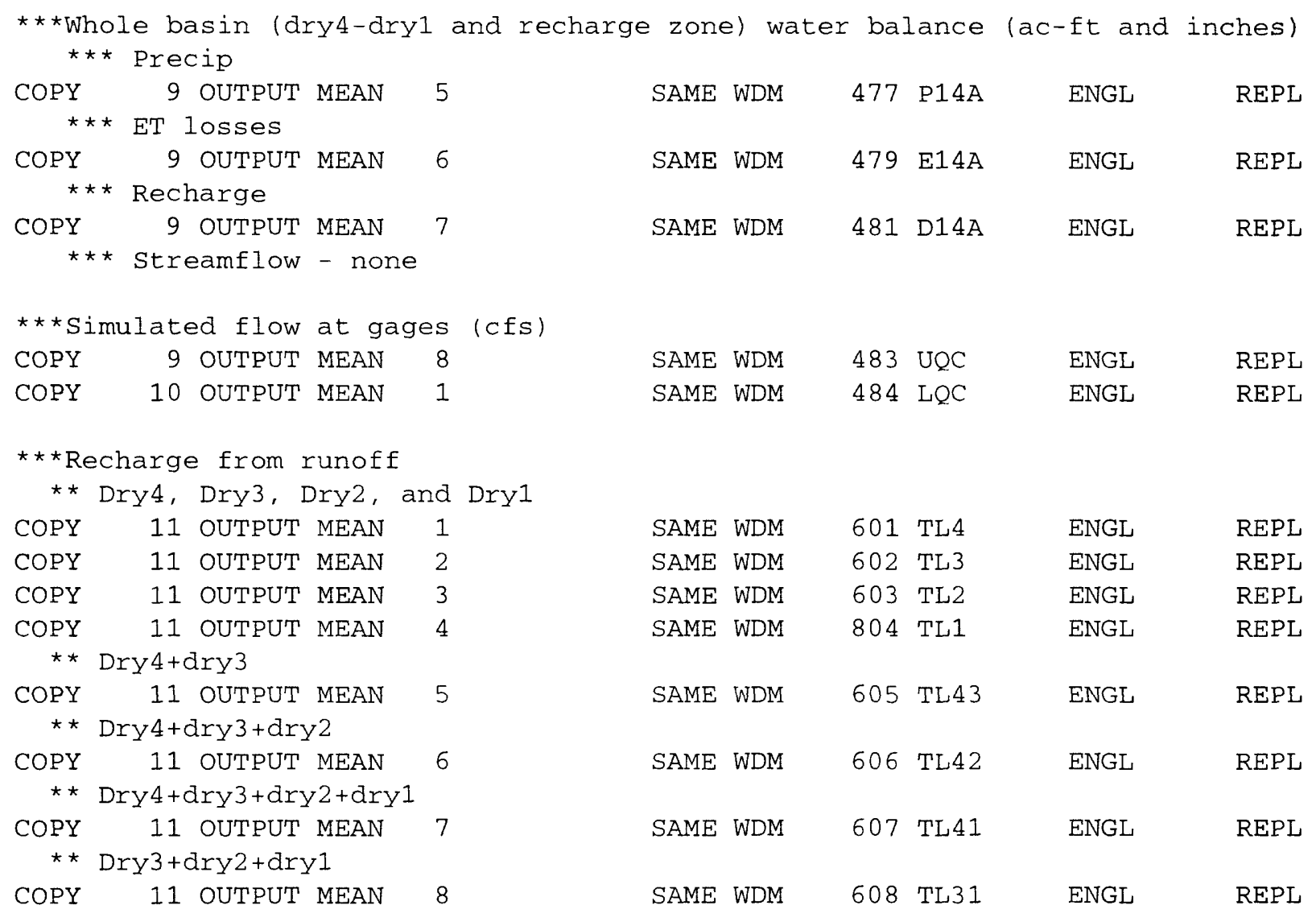

\section{END EXT TARGETS}

\section{RCHRES}

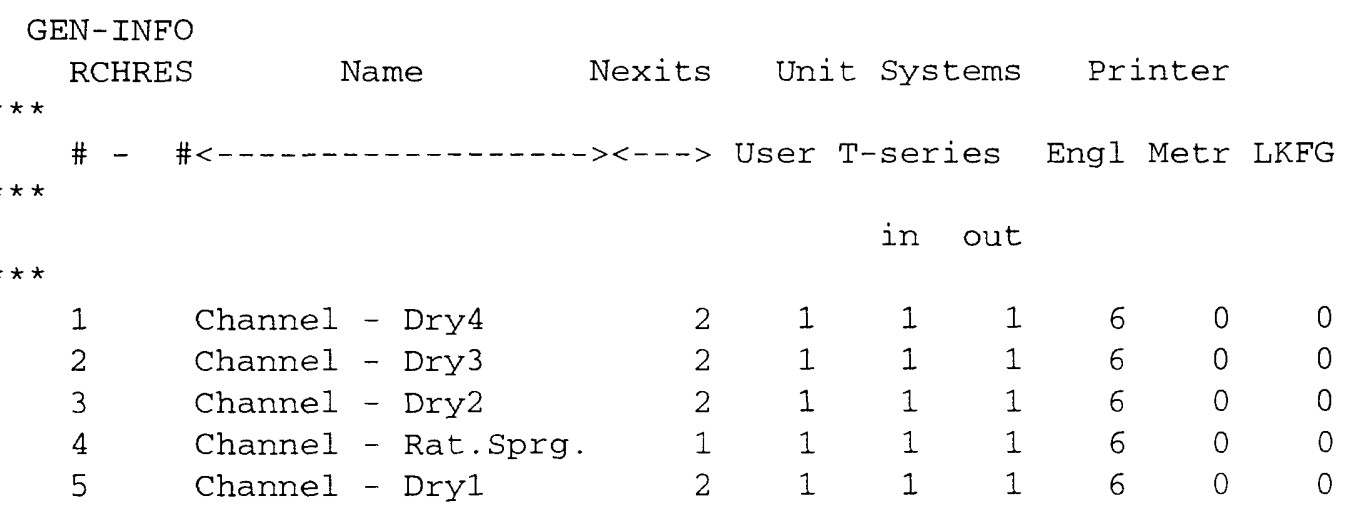

END GEN-INFO

ACTIVITY

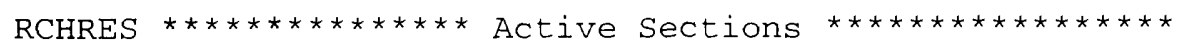

\#- \# HYFG ADFG CNFG HTFG SDFG GQFG OXFG NUFG PKFG PHFG $\star \star \star$

$\begin{array}{ccc}1 & 5 & 1 \\ \text { END } & \text { ACTIVITY }\end{array}$

PRINT-INFO

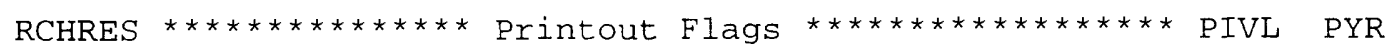

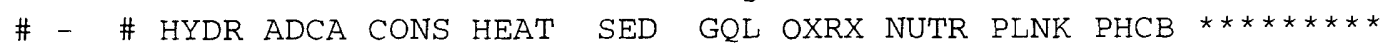

$\begin{array}{llllllllllllll}1 & 5 & 5 & 0 & 0 & 0 & 0 & 0 & 0 & 0 & 0 & 0 & 1 & 9\end{array}$ 
END PRINT-INFO

HYDR-PARM1

RCHRES Flags for each HYDR Section

\#- \# VC A1 A2 A3 ODFVFG for each *** ODGTFG for each FUNCT for each

exit FG FG FG FG possible exit $\star \star \star$ possible exit possible

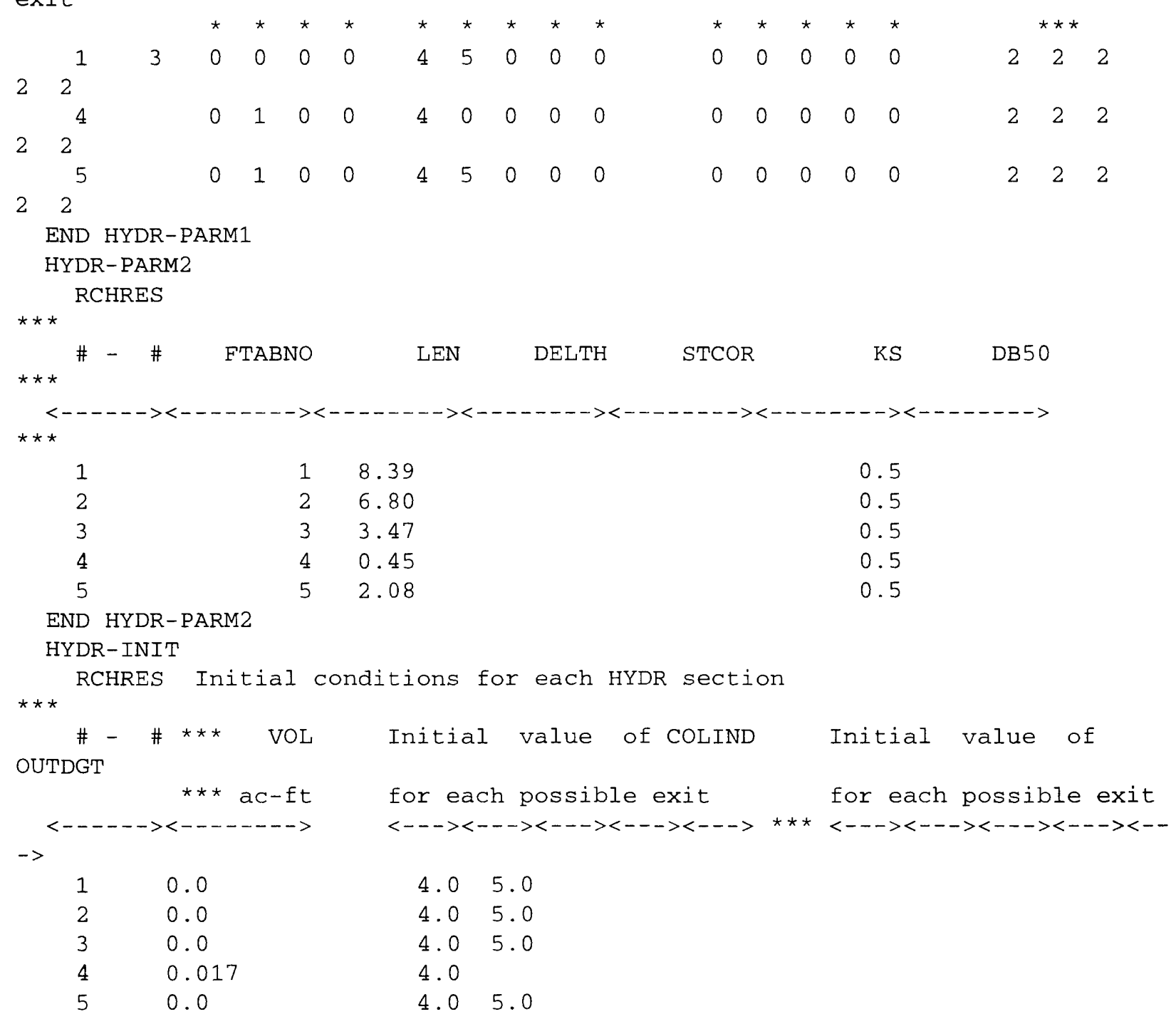

END HYDR-INIT

END RCHRES

FTABLES

FTABLE 1

Rows Cols (Dry4 reach - headwaters to upstream gage @ hwy 241 $12510650) * * \star$

65

$\star * *$ Outflow 1 is channel loss ( $4 \mathrm{cfs}$ per acre $=4 \mathrm{in} / \mathrm{hr}$ channel infilt rate)

$* * *$ Reach length $=44,300 \mathrm{ft}$ - last row extrapolated

Depth Area Volume Outflow1 Outflow2 


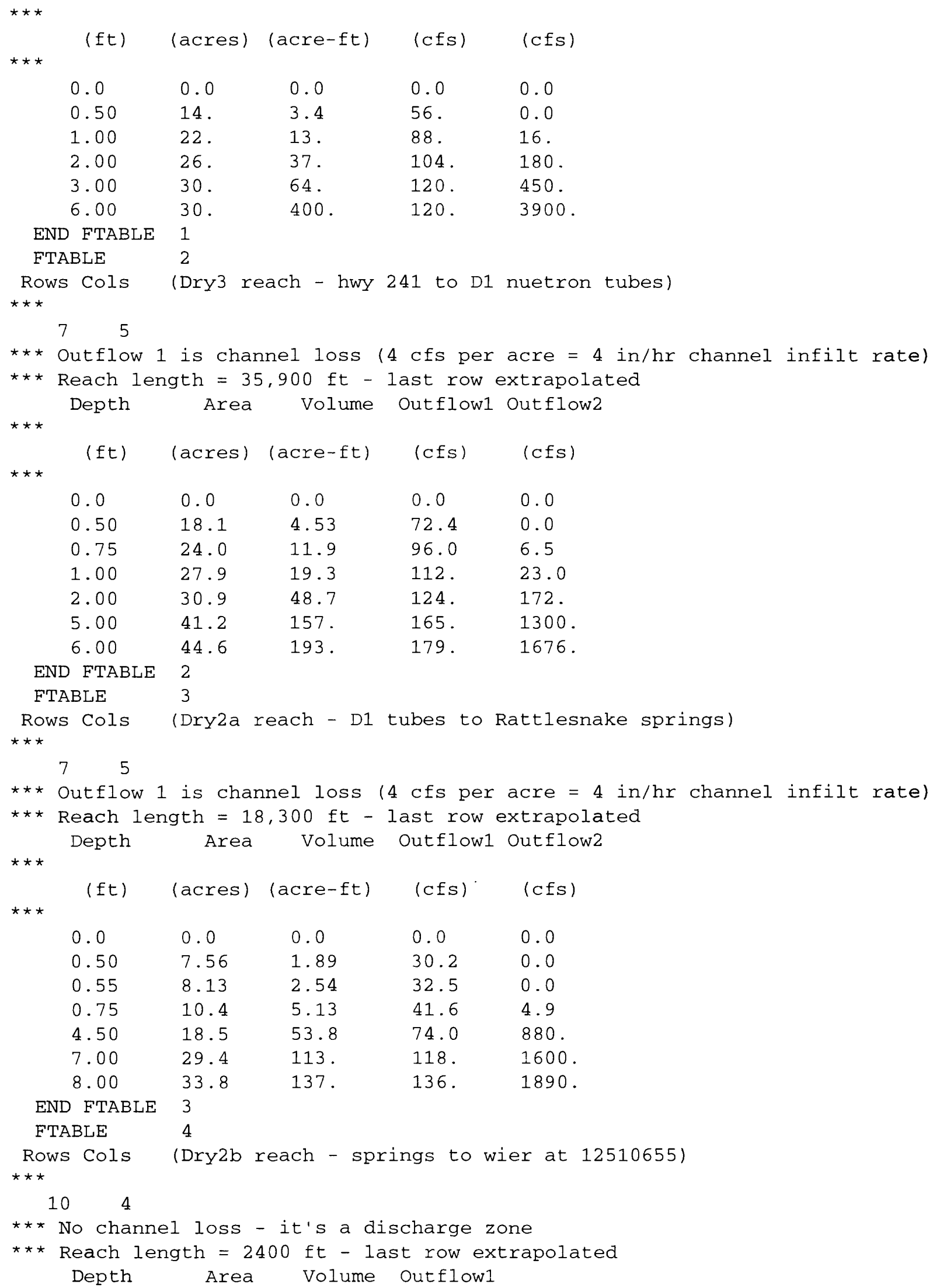




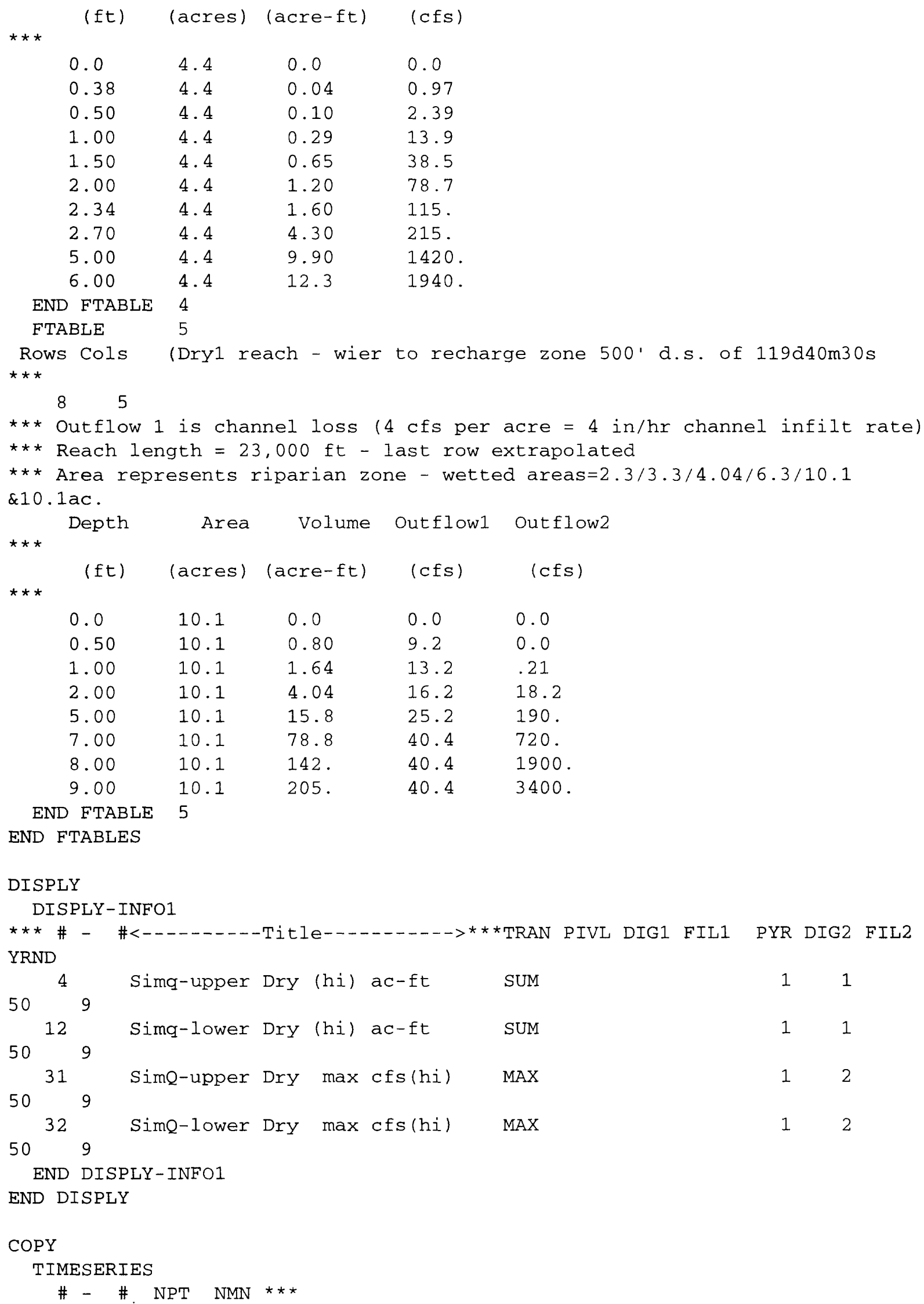




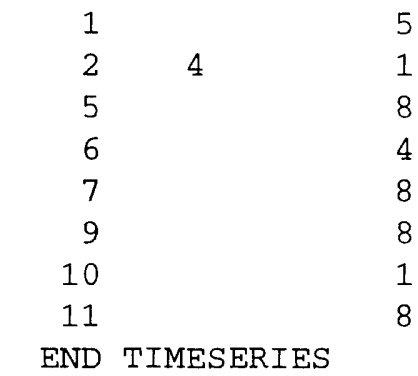

END COPY

END RUN 